Luiz Russo Neto

\title{
INTERPRETAÇÃO DE DEFORMAÇÃO E RECALQUE NA FASE DE MONTAGEM DE ESTRUTURA DE CONCRETO COM FUNDAÇÃO EM ESTACA CRAVADA
}

Orientador: Prof. Dr. Nelson Aoki 
Russo Neto, Luiz

Interpretação de deformação e recalque na fase de montagem de estrutura de concreto com fundação em estaca cravada / Luiz Russo Neto. -- São Carlos, 2005.

Tese (Doutorado) -- Escola de Engenharia de São Carlos-Universidade de São Paulo, 2005.

Área: Geotecnia.

Orientador: Prof. Dr. Nelson Aoki.

1. Interação solo-estrutura. 2. Instrumentação de campo. 3. Estrutura de concreto pré-moldado.

4. Recalque. 5. Fluência. 6. Fundação profunda.

I. Título. 
Candidato: Engenheiro LUIZ RUSSO NETO

Dissertação defendida e julgada em 22-03-2005 perante a Comissão Julgadora:

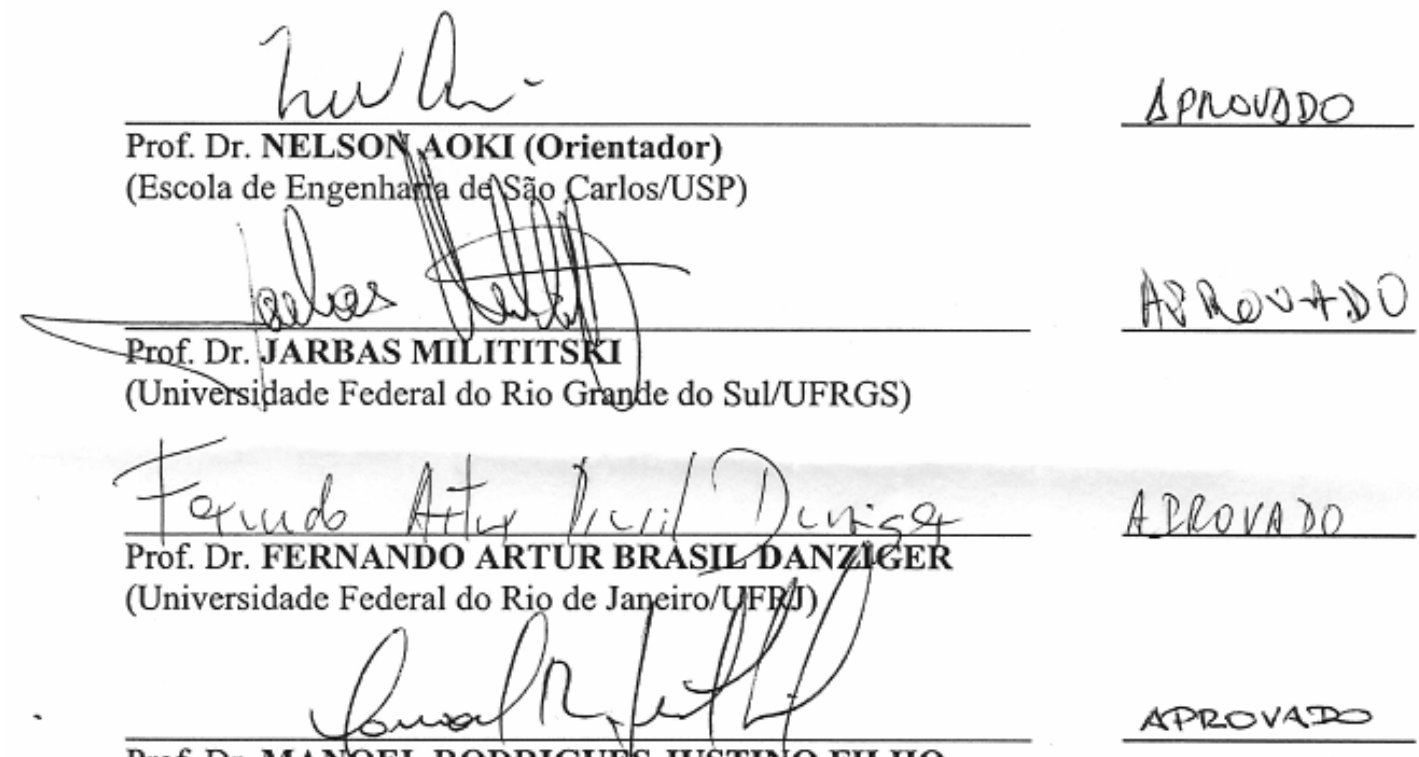

Prof. Dr. MANGEL RODRIGUES JUSTINO FILHO

(Pontificia Universidade Católica do Paraná/PUCPR)

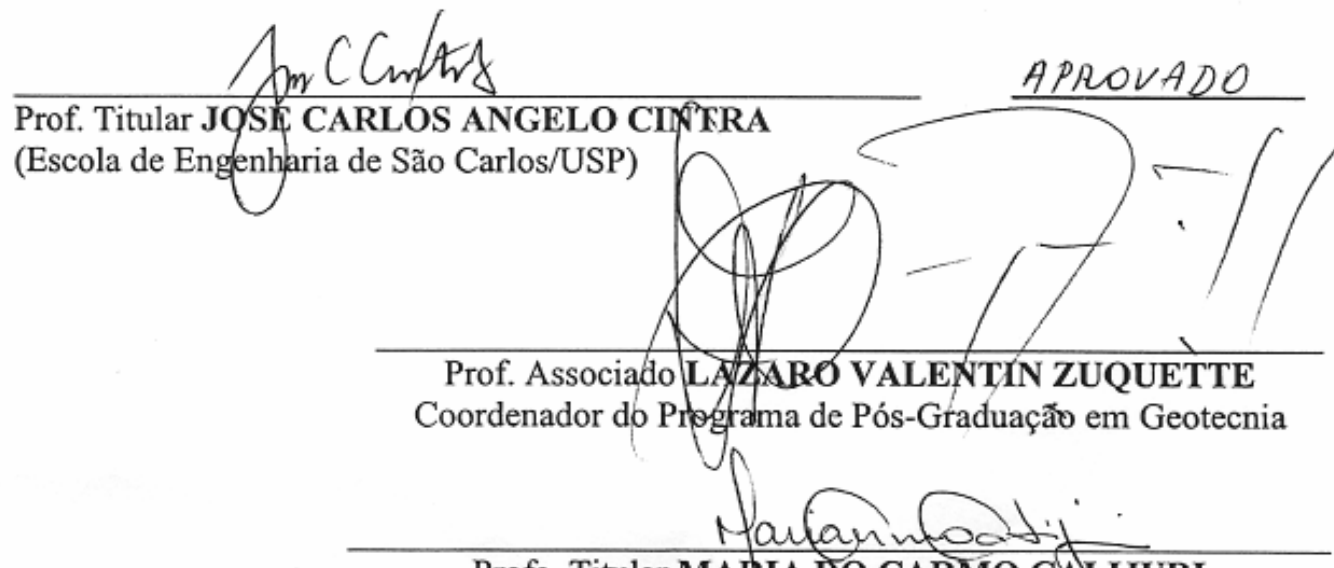

Profa. Titular MARIA DO CARMO CAJIJURI

Presidente da Comissão de Pós-Graduação 

À minha família, célula mãe de nossa sociedade, razão principal para o desenvolvimento desse trabalho. 



\section{AGRADECIMENTOS}

À Pontifícia Universidade Católica do Paraná, através de seu Curso de Engenharia Civil e seus Diretores Prof. Dr. Orlando Maciel Strobel, Prof. M. Sc. Ricardo José Bertin e Prof. Dr. Manoel Rodrigues Justino Filho, pelo total apoio recebido e liberação das atividades acadêmicas, com vencimentos.

Ao Prof. Dr. Nelson Aoki pela orientação fraterna, desafiadora e estimulante. A convivência com o Prof. Aoki nesse período foi ímpar, repleta de sabedoria e vivência profissional.

Aos colegas do Programa de Pós-graduação do Departamento de Geotecnia da EESC-USP, especialmente a Carlos José Marques da Costa Branco, Célio Roberto Piedade Jr. e Karla Maria Wingler Rebelo pela amizade, contribuições, sugestões e apoio recebidos.

Aos Professores e funcionários do Departamento de Geotecnia da EESC-USP, em particular ao Técnico de Laboratório Silvio Roberto Wick pelo suporte na fase de ensaios de validação do equipamento em laboratório.

À Prefeitura do Campus Curitiba da PUCPR pela permissão e facilitação de acesso à obra.

Às empresas de engenharia envolvidas na obra investigada, nominalmente DM Construtora de Obras Ltda., Escoll Engenharia de Solos e Fundações Ltda. e In Situ Geotecnia Ltda., e pela cessão de direitos para reprodução e disponibilização de todas as informações solicitadas.

Ao Professor Victor F. B. de Mello pelo envio de material bibliográfico.

Ao Técnico de Laboratório Edgar Pedroso Reis pelo seu inestimável auxílio na fase das medidas de campo.

A Alexandre Martin, na época acadêmico e estagiário do Curso de Engenharia Civil da PUCPR, pelo seu auxílio nos serviços de campo e na digitação dos dados.

À Professora Dra. Maria Ignez Marins pela cuidadosa e competente revisão gramatical. 

"O mal neste mundo é que os estúpidos vivem cheios de si e os inteligentes cheios de dúvidas." Bertrand Russel (1872-1970) 



\section{SUMÁRIO}

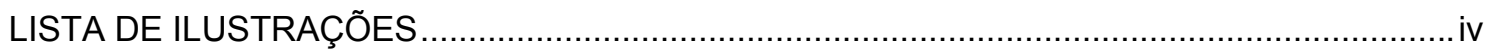

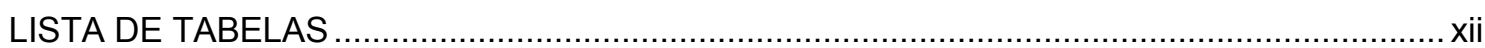

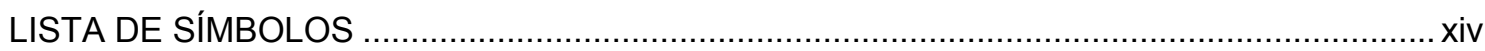

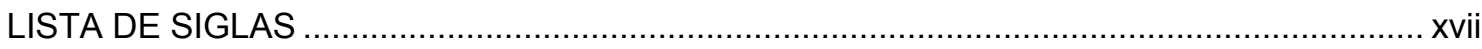

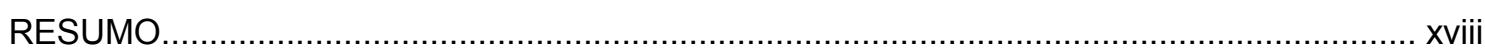

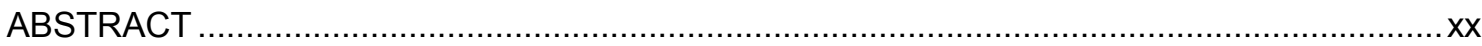

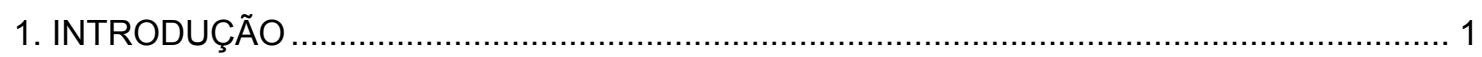

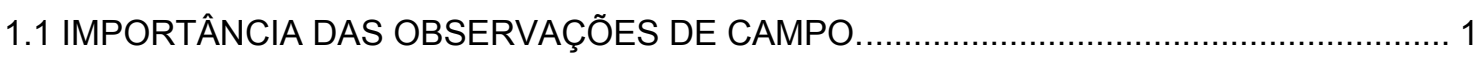

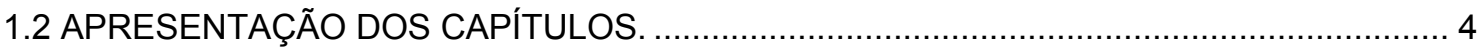

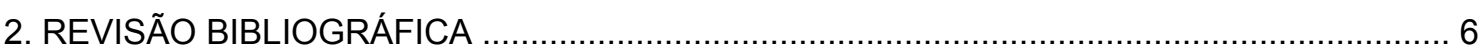

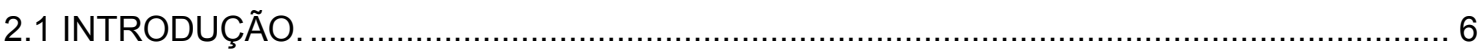

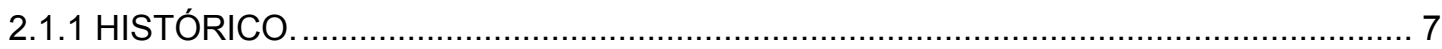

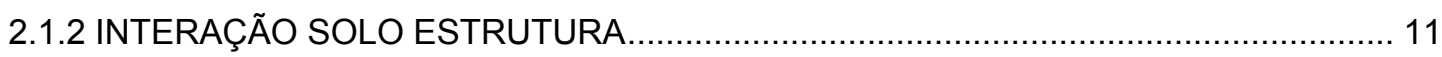

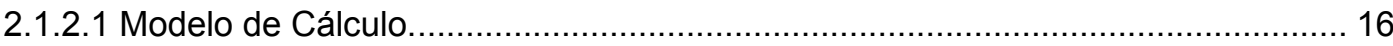

2.1.2.2 Efeitos da Interação Solo Estrutura. ............................................................ 18

2.1.2.3 Influência da Seqüência de Construção. .......................................................... 19

2.1.2.4 Influência do Comportamento Visco-Elástico dos Materiais................................. 21

2.2. AVALIAÇÃO DE DESEMPENHO

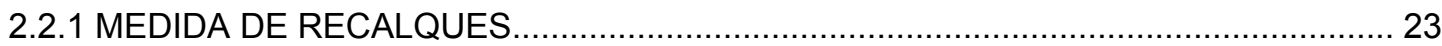

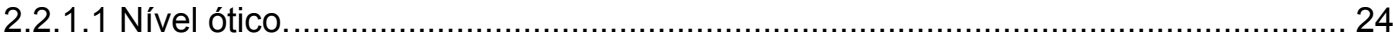

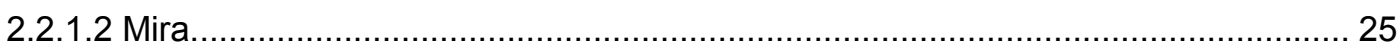

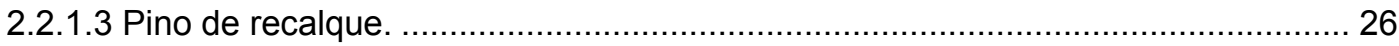

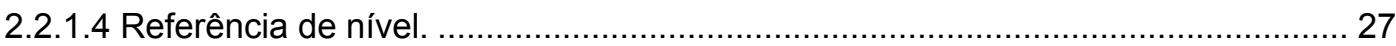

2.2.2 MEDIDAS DE SOLICITAÇÕES EM PEÇAS ESTRUTURAIS. ................................... 28

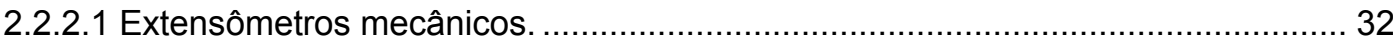

2.2.2.2 Extensômetros Elétricos de Resistência................................................................ 33

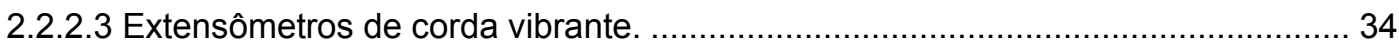

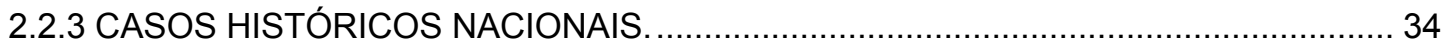

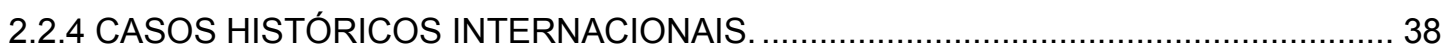

2.3. MÉTODOS DE PREVISÃO DE RECALQUES EM ESTACAS ISOLADAS......................... 43

2.3.1 MÉTODOS BASEADOS NA TEORIA DA ELASTICIDADE.......................................... 43

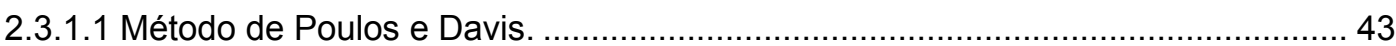




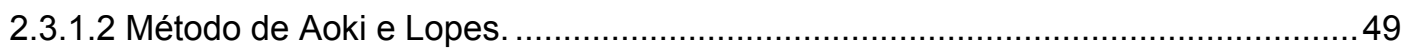

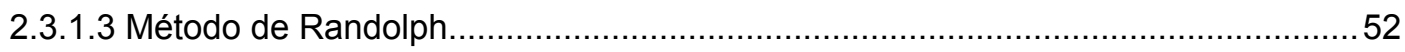

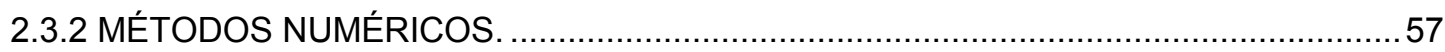

2.4. MÉTODOS DE PREVISÃO DE RECALQUES DE GRUPO DE ESTACAS. ........................58

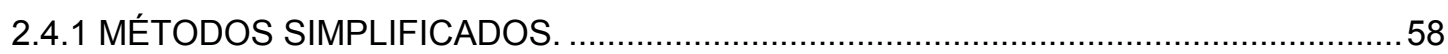

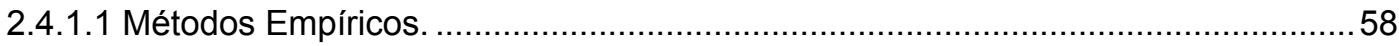

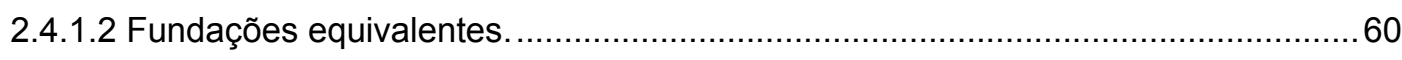

2.4.2 MÉTODOS BASEADOS NA TEORIA DA ELASTICIDADE..........................................63

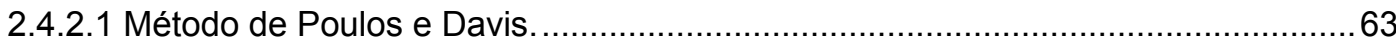

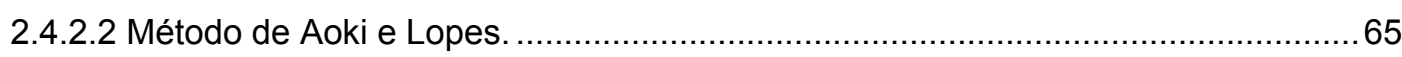

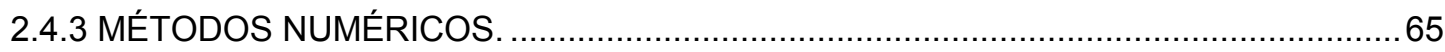

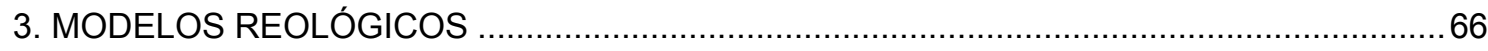

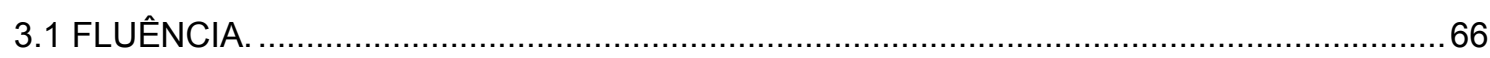

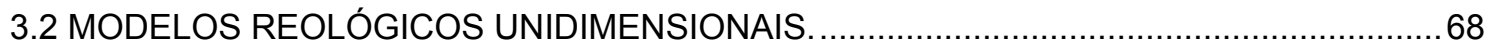

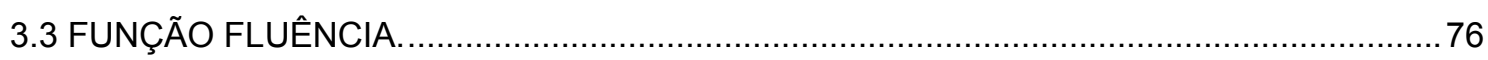

3.3.1 Representação integral das funções de fluência e relaxação....................................77

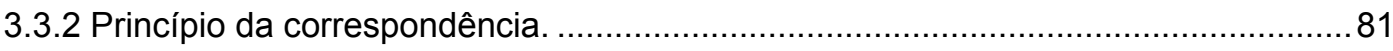

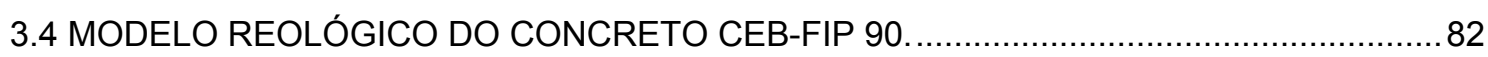

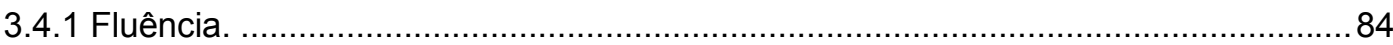

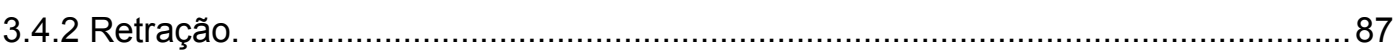

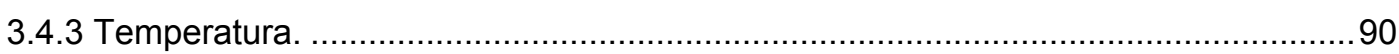

3.4.4 Determinação do coeficiente de dilatação térmica do concreto................................91

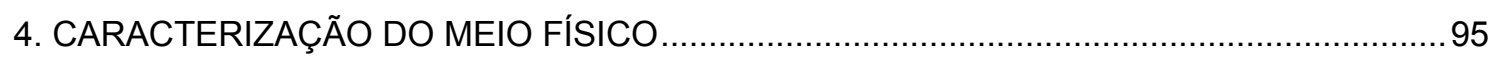

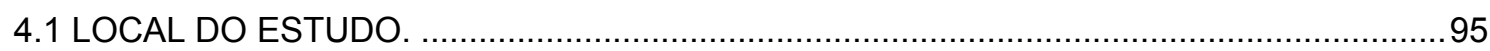

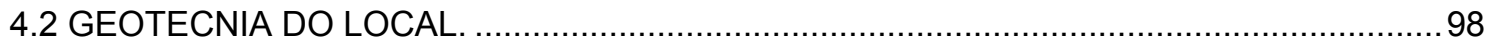

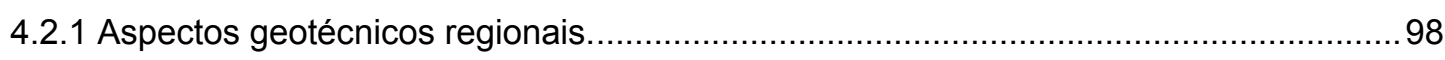

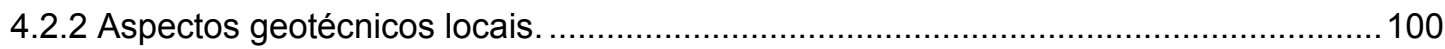

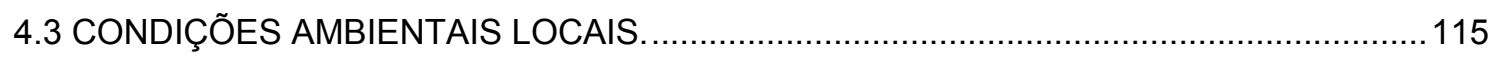

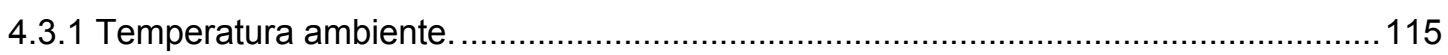

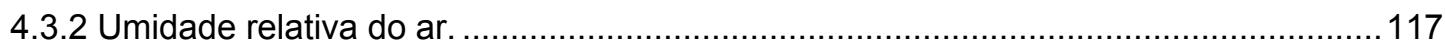

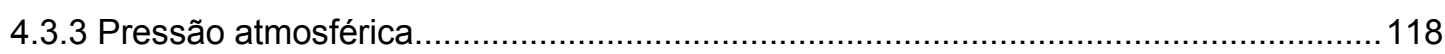

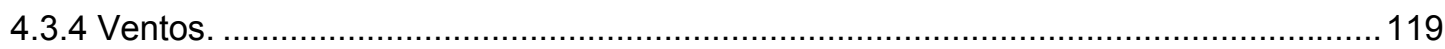

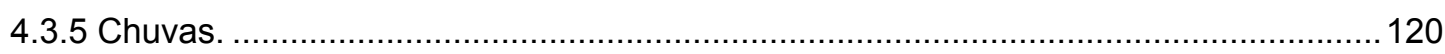

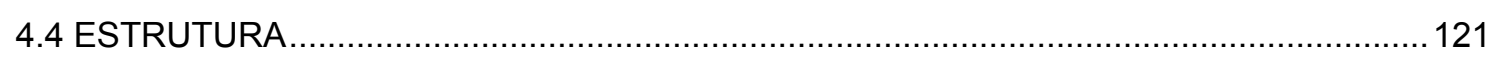

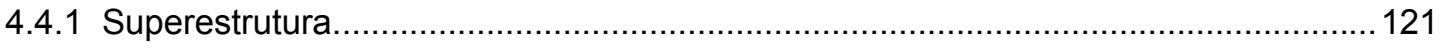

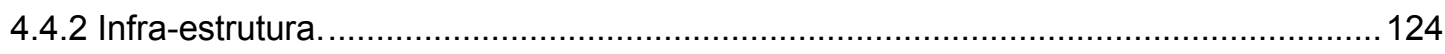

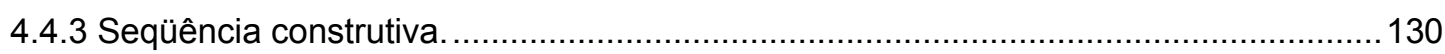

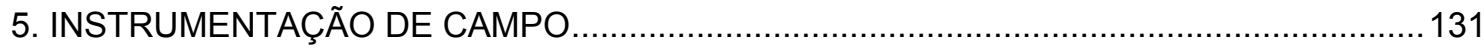

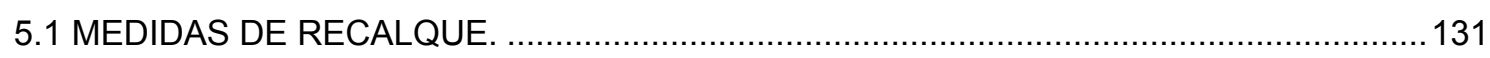

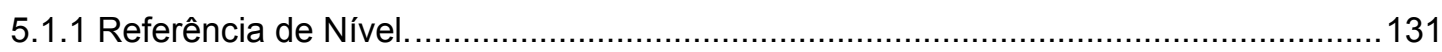




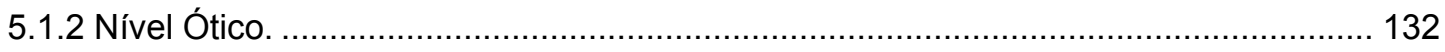

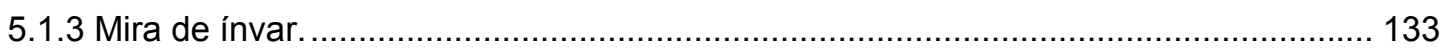

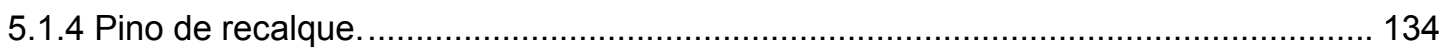

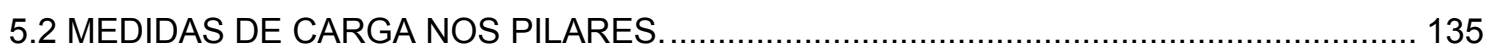

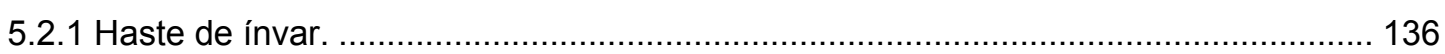

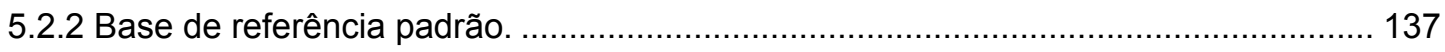

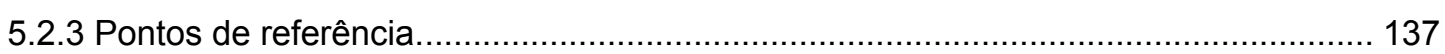

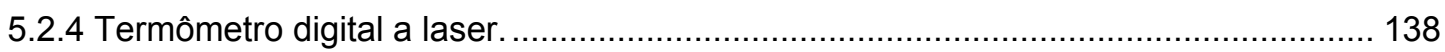

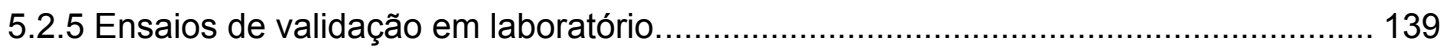

5.2.6 Procedimentos adotados durante as medidas de campo. ........................................ 145

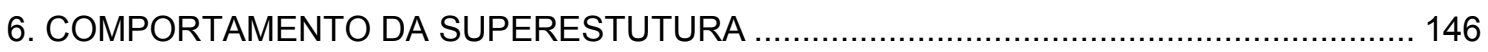

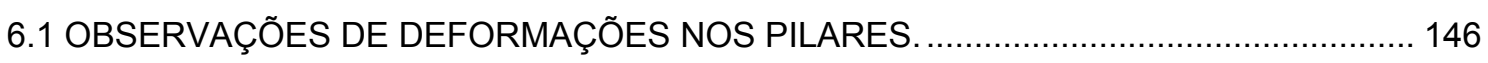

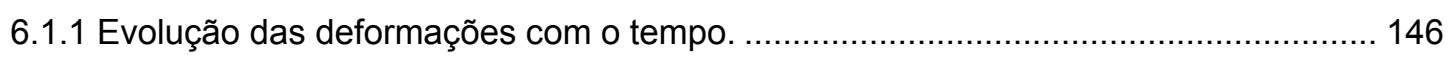

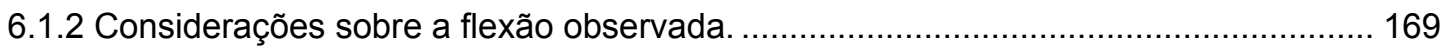

6.1.3 Deformações sob carga constante - fluência e retração da superestrutura................ 171

6.2 AVALIAÇÃO DA SOLICITAÇÃO NORMAL NOS PILARES........................................... 175

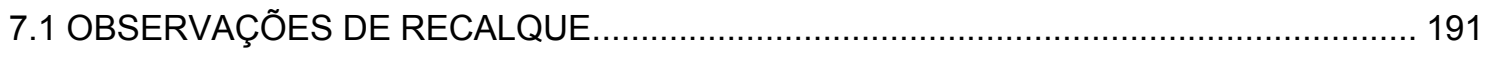

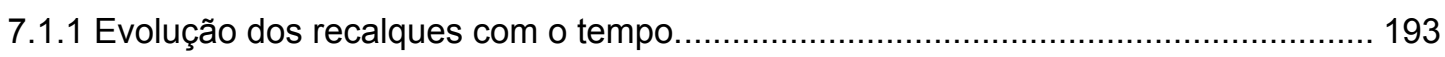

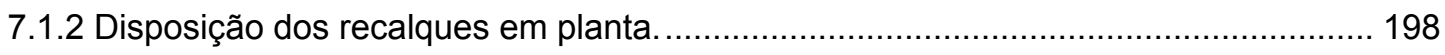

7.1.3 Recalques sob carga constante - fluência da fundação.......................................... 208

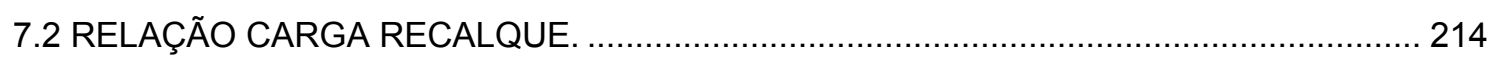

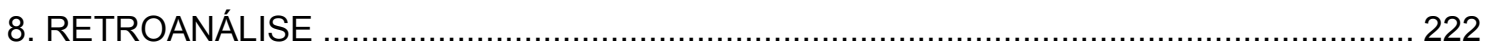

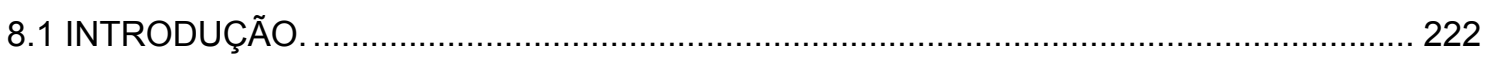

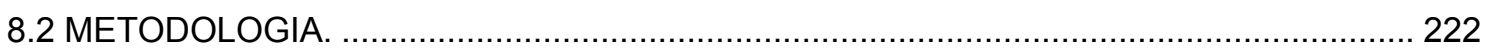

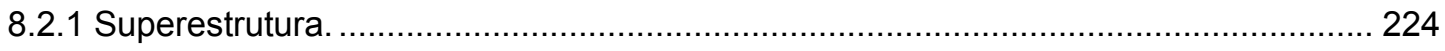

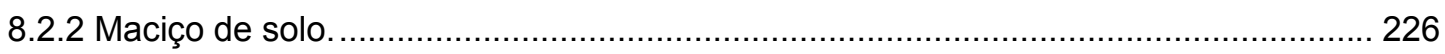

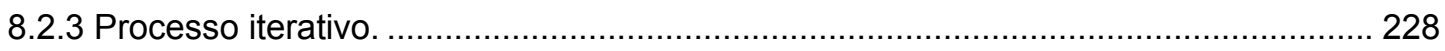

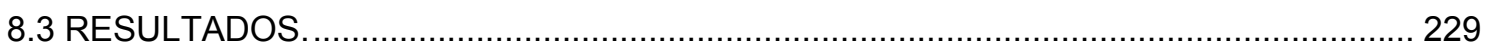

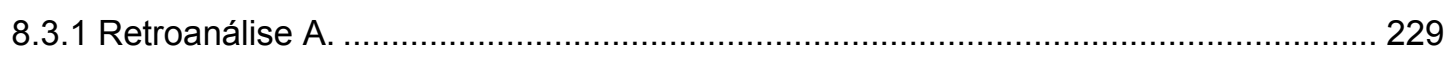

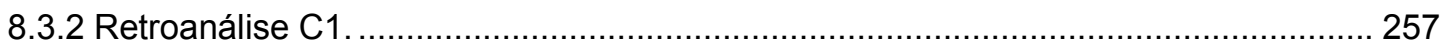

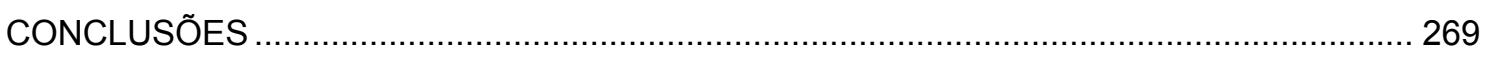

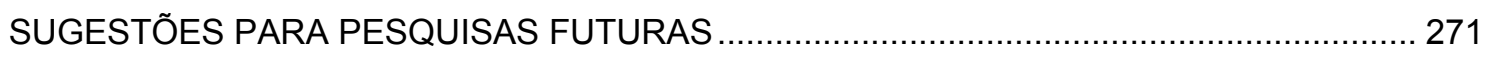

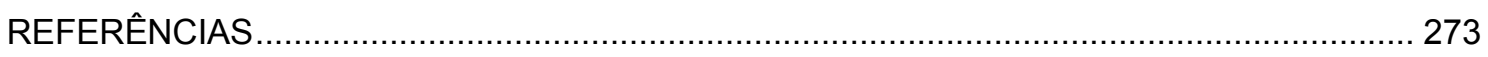




\section{LISTA DE ILUSTRAÇÕES}

Figura 2.1 - Condição de equilíbrio de um elemento isolado de fundação. .................................13

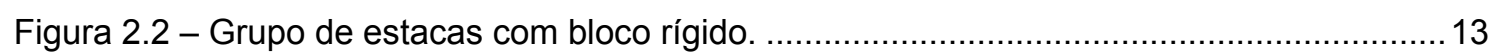

Figura 2.3 - Pórtico sobre grupo de estacas - equilíbrio do sistema global. ............................. 14

Figura 2.4 - Pórtico sobre grupo de estacas - equilíbrio da superestrutura e da fundação. ....... 15

Figura 2.5 - Pórtico sobre grupo de estacas - equilíbrio da estrutura e do maciço de solo ....... 16

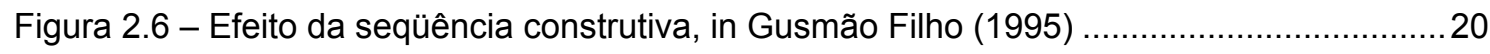

Figura 2.7 - Definição de acurácia e precisão, Dunnicliff, 1993...............................................23

Figura 2.8 - Arranjo esquemático de medida de recalques com uso de nivelamento ótico.......23

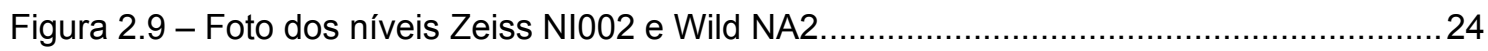

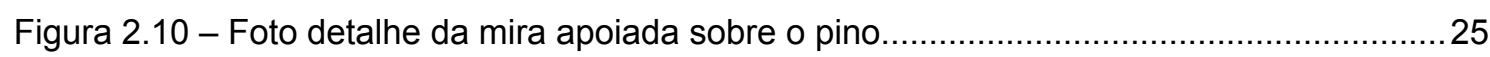

Figura 2.11 - Detalhe da visada, mostrando a coincidência de traços e o micrômetro interno. 26

Figura 2.12 - Foto detalhe de resina epóxi, tampa, pino fêmea, pino macho e chave de fenda

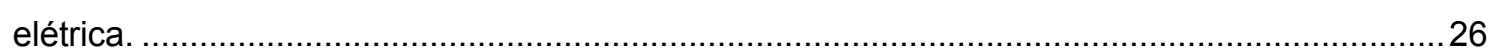

Figura 2.13 - Representação esquemática de "bench-mark", in Taylor (1948).......................27

Figura 2.14 - Foto referência de nível profunda. ............................................................. 28

Figura 2.15 - Extensômetro mecânico Tensotast, in Takeya (2000).......................................... 32

Figura 2.16 - Extensômetro de condutor livre tipo Carlson, in Takeya (2000) ...........................33

Figura 2.17 - Arranjo esquemático do extensômetro de corda vibrante, in Takeya (2000).......34

Figura 2.18 - Evolução dos recalques com o tempo, in Lobo et al. (1994)................................ 35

Figura 2.19 - Gráfico tempo x recalque em sete edifícios durante dezoito meses de construção,

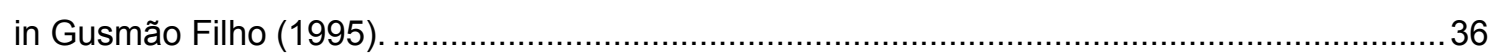

Figura 2.20 - Commerzbank Tower in Frankfurt am Main, in Katzenbach et al. (1997). ........... 39

Figura 2.21 - Curvas carga $x$ recalque em diferentes posições do radier estaqueado, in

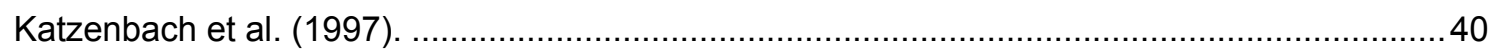

Figura 2.22 - Distribuição de esforços entre estacas, in Viggiani (1997) ................................. 41

Figura 2.23 - Disposição em planta estacas, in Van Inpe (1999)............................................ 42

Figura 2.24 - Comparativo entre valores medidos e calculados da carga nas estacas, in Van

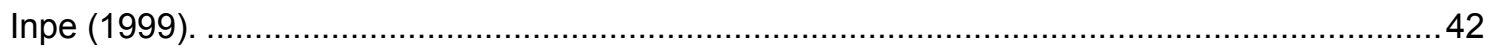

Figura 2.25 - Geometria do problema e condições de contorno - método de Poulos e Davis (1980), in Velloso e Lopes (2000).

Figura 2.26 - Fatores para o cálculo de recalque de estacas, método de Poulos e Davis (1980), in Velloso e Lopes (2002). 46 
Figura 2.27 - Fator de influência "R $\mathrm{R}_{\mathrm{b}}$ "Poulos e Davis (1980).

Figura 2.28 - Solução de Mindlin, geometria do problema, in Reis (2000).............................. 50

Figura 2.29 - Aplicação do procedimento de Steinbrenner para o caso de meio heterogêneo, in

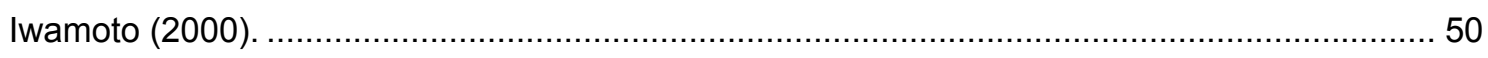

Figura 2.30 - Diagramas de transferência de carga, in: Aoki (1989)............................... 51

Figura 2.31 - Distribuição dos deslocamentos ao longo da estaca, in: Aoki (1989)................ 52

Figura 2.32 -Modelo de análise, método de Randolph in Velloso e Lopes (2002)................. 54

Figura 2.33 - Radier equivalente - proposição de Randolph (1994) .....................................61 61

Figura 2.34 - Determinação do diâmetro do tubulão equivalente, caso de estacas "flutuantes",

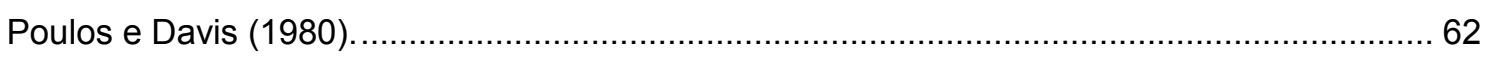

Figura 2.35 - Fator de interação $(\alpha)$ entre duas estacas, in Velloso e Lopes (2002)..............63 63

Figura 2.36 - Correções ao fator de interação, in Velloso e Lopes (2002)............................64

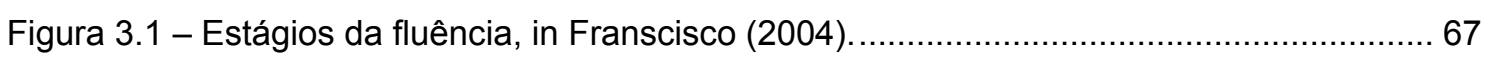

Figura 3.2 - Representação física para o modelo Hookeano. ........................................6 68

Figura 3.3 - Comportamento tensão deformação tempo - modelo elástico linear. ..................69

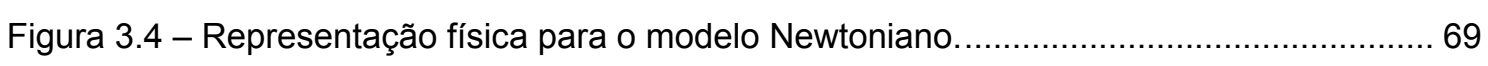

Figura 3.5 - Comportamento tensão deformação tempo - material viscoso perfeito................70

Figura 3.6 - Representação física para o modelo plástico............................................ 70

Figura 3.7 - Comportamento tensão deformação tempo - material rígido plástico.................. 71

Figura 3.8 - Representação física para o modelo elasto-plástico.................................... 71

Figura 3.9 - Comportamento tensão deformação tempo - material elasto-plástico perfeito..... 72

Figura 3.10 - Representação física para o modelo de Maxwell......................................... 72

Figura 3.11 - Comportamento tensão deformação tempo - modelo de Maxwell..................... 73

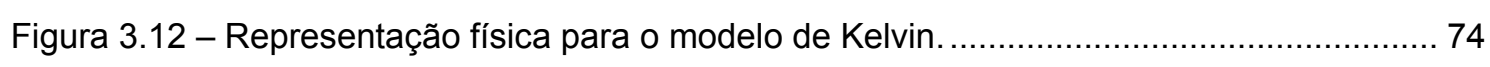

Figura 3.13 - Comportamento tensão deformação tempo - modelo de Kelvin. ...................... 75

Figura 3.14 - Representação física para o modelo de Boltzmann...................................... 75

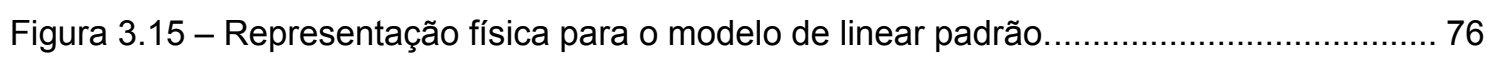

Figura 3.16 - Representação física para o modelo de Bingham........................................ 76

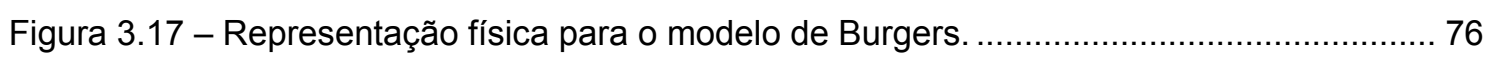

Figura 3.18 - Curva deformação em função do tempo - fluência...................................... 77

Figura 3.19 - Solução do problema visco-elástico via transformada de Laplace. ................... 82

Figura 3.20 - Leitura micrômetro x temperatura na face - pilar 26........................................ 93

Figura 3.21 - Leitura micrômetro $x$ temperatura na face - pilar $10 \ldots \ldots \ldots \ldots \ldots \ldots \ldots \ldots \ldots \ldots \ldots \ldots . \ldots \ldots$

Figura 3.22 - Disposição em planta do coeficiente de dilatação térmica (valores em $\mu \varepsilon /{ }^{\circ} \mathrm{C}$ ) $\ldots 94$

Figura 4.1 - Município de Curitiba - bairros (fonte IPPUC) . ......................................... 95

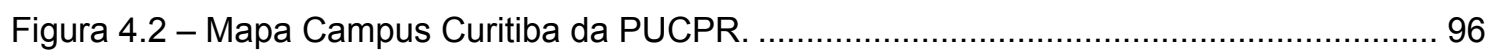

Figura 4.3 - Planta de locação da estrutura (medidas em $\mathrm{cm}$ ) . .................................... 97

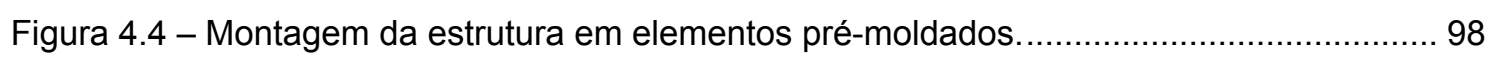

Figura 4.5 - Carta Geológica Folha Curitiba - CPRM................................................ 99 
Figura 4.6 - Mapa geotécnico orientativo para ocupação do espaço subterrâneo (Talamini, 2001). 100

Figura 4.7 - Superfície de contato entre a base da camada de argila mole e o topo do estrato arenoso 102

Figura 4.8 - Superfície de contato entre a base da camada arenosa e o topo do estrato silto arenoso 103

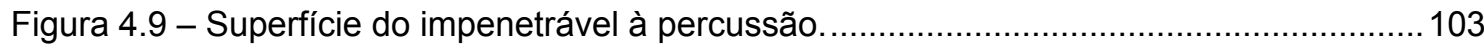

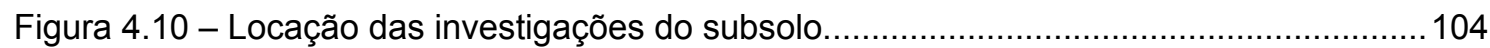

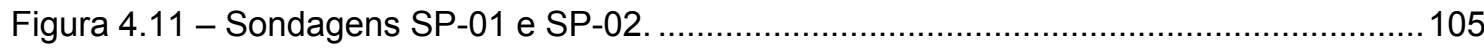

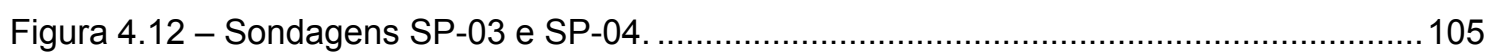

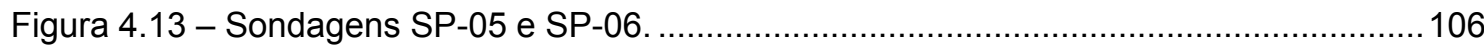

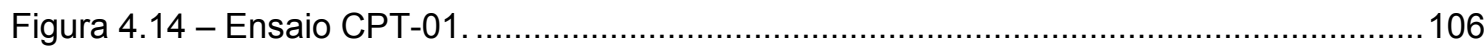

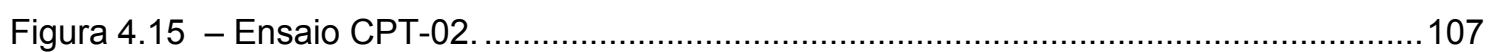

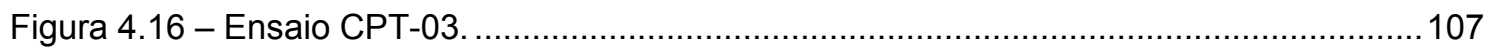

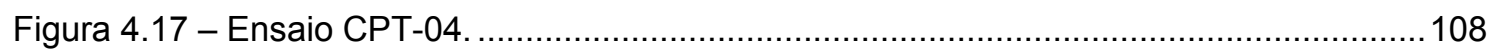

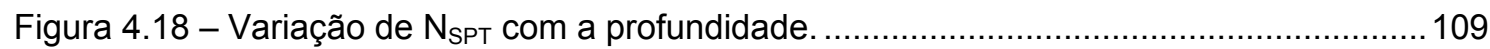

Figura 4.19 - Superfície de contato entre a camada de argila mole e o estrato arenoso. .......110

Figura 4.20 - Superfície de contato entre a base do estrato arenoso e o topo da camada silto-

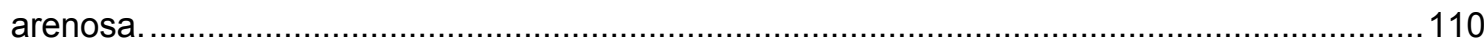

Figura 4.21 - Superfície do impenetrável à percussão.........................................................111

Figura 4.22 - Perfil geotécnico - seção transversal SP-01 a SP-03.........................................111

Figura 4.23 - Perfil geotécnico - seção transversal SP-04 a SP-06..................................... 112

Figura 4.24 - Variação da resistência de ponta do cone $\left(q_{c}\right)$ com a profundidade. ..................113

Figura 4.25 - Perfil de solo residual, in Aoki (1985).............................................................. 113

Figura 4.26 - Variação horária da temperatura ambiente................................................. 115

Figura 4.27 - Temperatura ambiente máxima, mínima, média e variação diária......................116

Figura 4.28 - Relação entre temperatura medida nas faces dos pilares e a temperatura

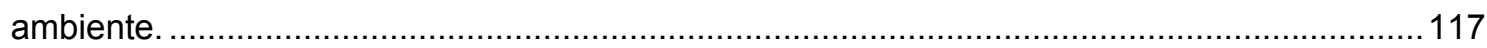

Figura 4.29 - Variação horária da umidade relativa do ar. .................................................117

Figura 4.30 - Umidade relativa do ar, máximo, mínimo, média e variação diária. ...................118

Figura 4.31 - Variação horária da pressão atmosférica ao longo do período de observações.

Figura 4.32 - Pressão atmosférica valores máximo, mínimo e médio diários..........................119

Figura 4.33 - Variação horária da velocidade dos ventos ao longo do período de observação.

Figura 4.34 - Velocidade dos ventos valores máximo, mínimo e médio diários. ......................120

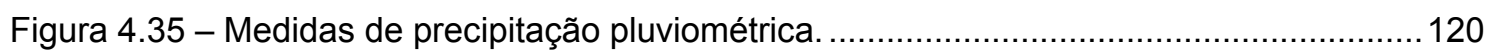

Figura 4.36 - Seção transversal típica dos elementos pré-moldados tipo laje, dimensões em

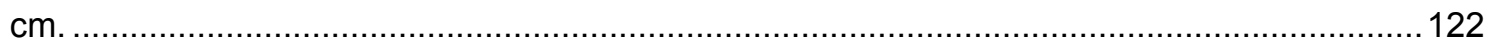

Figura 4.37 - Viga típica (elevação), dimensões em cm. …................................................... 122 
Figura 4.38 - Seção transversal viga típica, dimensões em $\mathrm{cm}$.

Figura 4.39 - Seção transversal mostrando painel de fechamento externo fixado à viga,

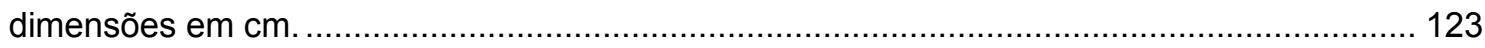

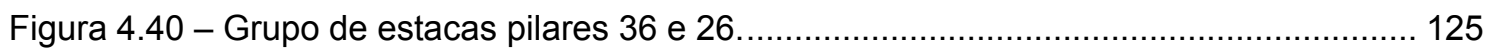

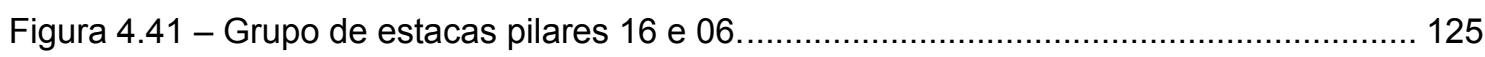

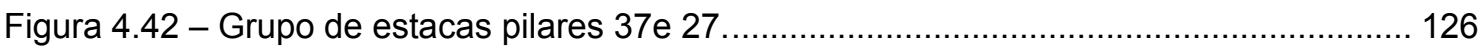

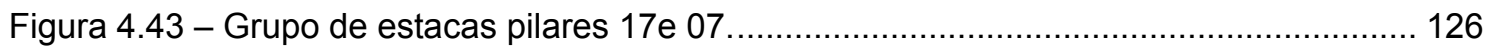

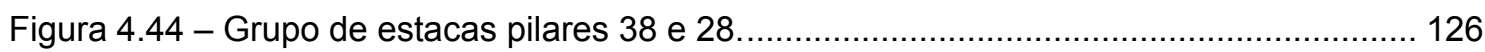

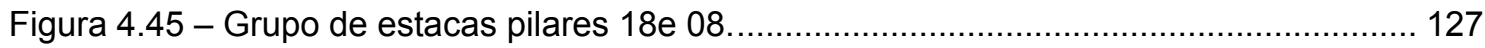

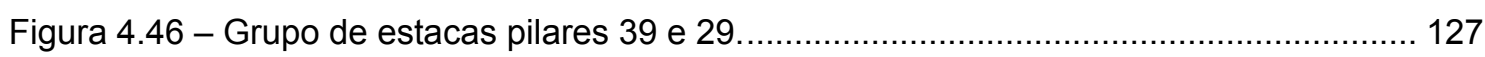

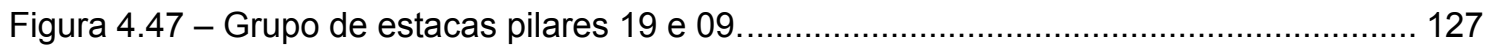

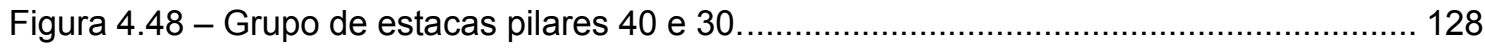

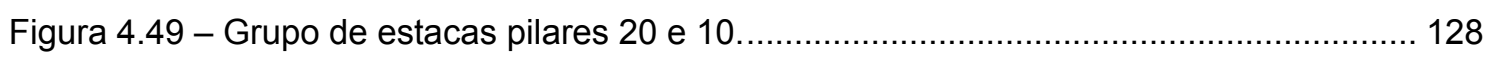

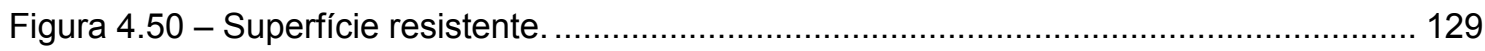

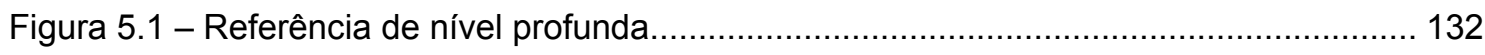

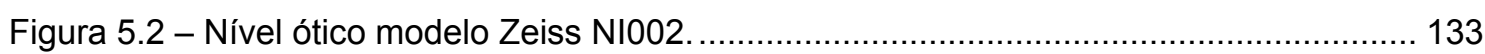

Figura 5.3 - Detalhe do pino de recalque instalado no pilar. .............................................. 134

Figura 5.4 - Locação em planta dos pilares instrumentados (dimensões em cm). ................. 135

Figura 5.5 - Detalhe da extremidade superior da haste, com relógio comparador digital fixado.

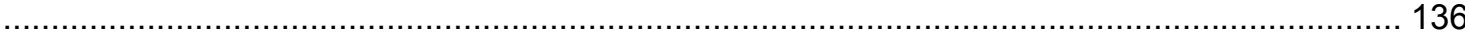

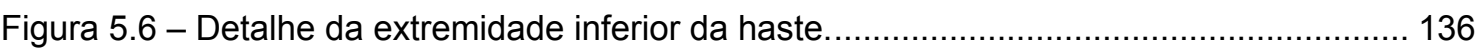

Figura 5.7 - Detalhe das cantoneiras utilizadas como ponto de referência das medidas. ...... 138

Figura 5.8 - Detalhe do posicionamento da haste nos pontos de referência. .......................... 138

Figura 5.9 - Detalhe do termômetro digital a laser........................................................... 138

Figura 5.10 - Planta de localização dos pontos de medida de deformação nos pilares. ......... 139

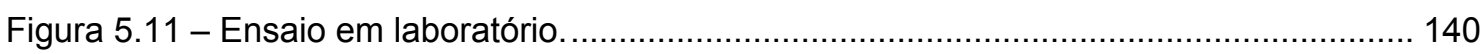

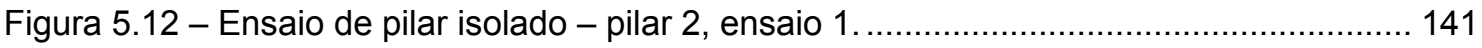

Figura 5.13 - Regressão linear, pilar isolado, média faces paralelas - pilar 1 ensaio 2 ........ 142

Figura 5.14 - Ensaio de montagem em pórtico - pilar 1, ensaio 3. ...................................... 143

Figura 5.15 - Regressão linear, montagem em pórtico, média faces paralelas - pilar 1, ensaio

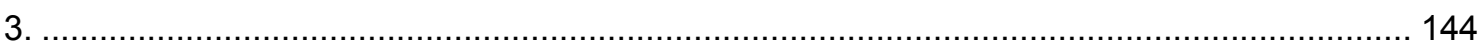

Figura 6.1 - Planta de localização dos pontos de medida de deformação nos pilares. .......... 148

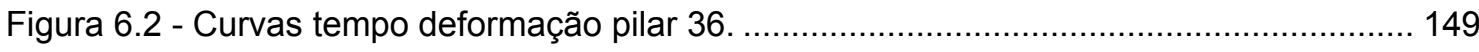

Figura 6.3 - Curvas tempo deformação Pilar 26 .............................................................. 150

Figura 6.4 - Curvas tempo deformação pilar 16. …........................................................ 151

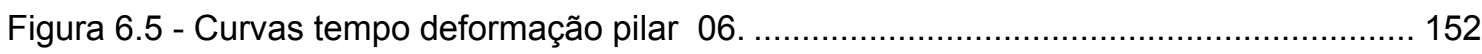

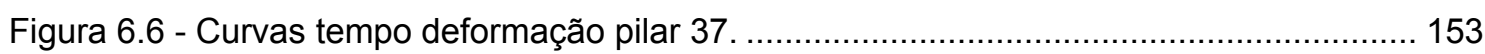

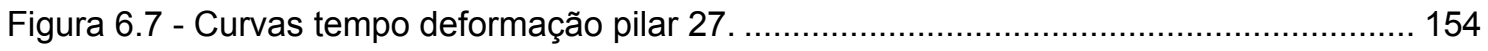

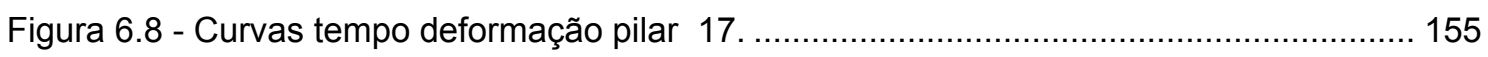

Figura 6.9 - Curvas tempo deformação pilar 07. ................................................................. 156 


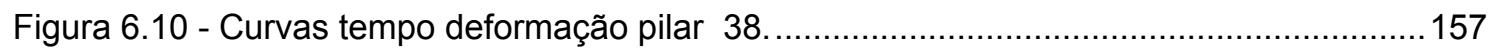

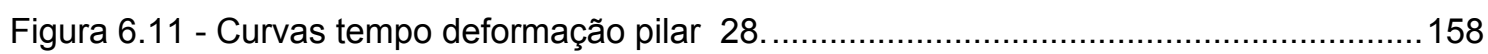

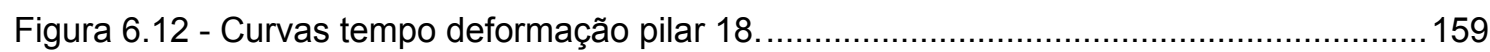

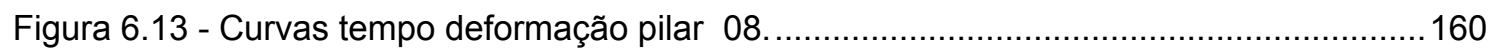

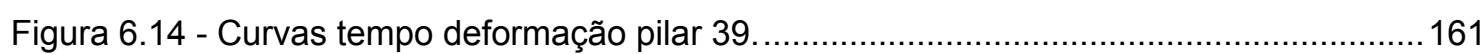

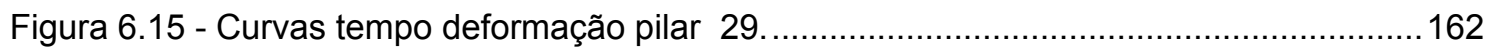

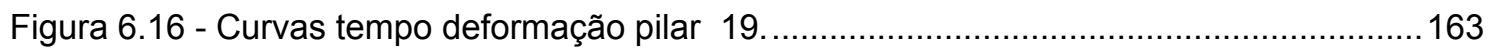

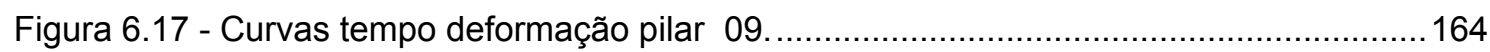

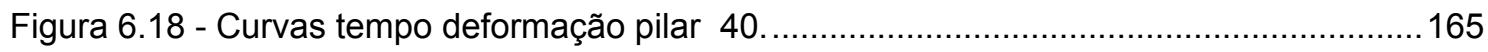

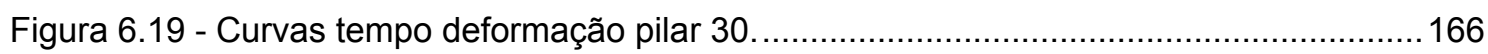

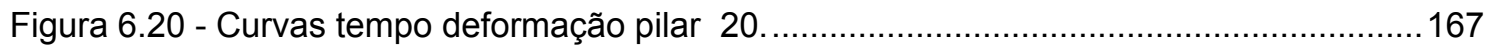

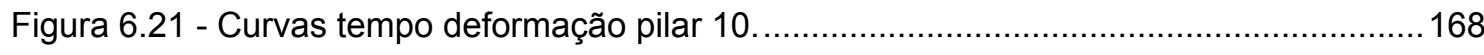

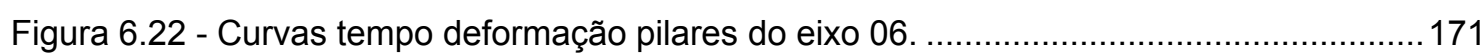

Figura 6.23 - Curvas tempo deformação pilares do eixo 07.................................................... 172

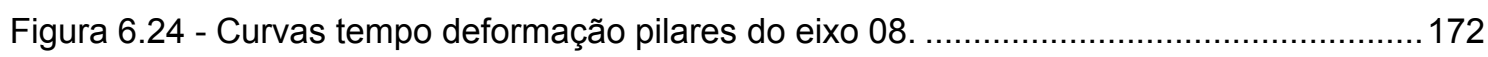

Figura 6.25 - Curvas tempo deformação pilares do eixo 09. ...................................................173

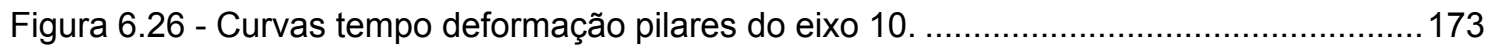

Figura 6.27 - Carga aplicada x somatório das deformações medidas.......................................176

Figura 6.28 - Relação tensão deformação dos pilares do eixo 06...........................................177

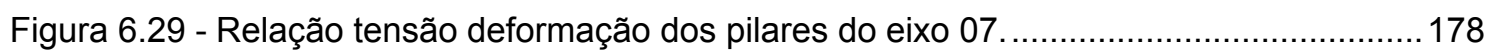

Figura 6.30 - Relação tensão deformação dos pilares do eixo 08 ............................................ 178

Figura 6.31 - Relação tensão deformação dos pilares do eixo 09.........................................179

Figura 6.32 - Relação tensão deformação dos pilares do eixo 10 .......................................... 179

Figura 6.33 - Montagem parcial dos eixos 6 a 7 (10/09) ....................................................... 183

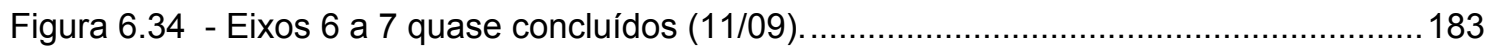

Figura 6.35 - Montagem dos elementos entre os eixos 7 e 8 (13/09) ...................................... 184

Figura 6.36 - Fase final da montagem entre os eixos 7 e 8 (14/09). ..................................... 184

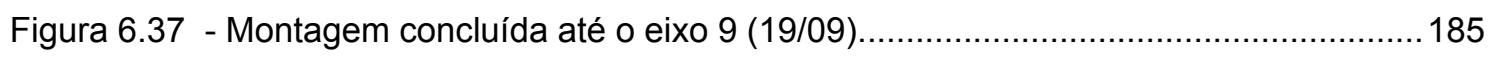

Figura 6.38 - Montagem da estrutura pré-moldada concluída (23/09) .................................. 185

Figura 6.39 - Solicitação normal - comparativo medido x cálculo estrutural - pilares do eixo 06.

Figura 6.40 - Solicitação normal - comparativo medido x cálculo estrutural - pilares do eixo 07.

Figura 6.41 - Solicitação normal - comparativo medido x cálculo estrutural - pilares do eixo 08.

Figura 6.42 - Solicitação normal - comparativo medido x cálculo estrutural - pilares do eixo 09.

Figura 6.43 - Solicitação normal - comparativo medido x cálculo estrutural - pilares do eixo10.

Figura 7.1 - Planta de localização dos pontos de monitoramento dos recalques. 192 
Figura 7.2 - Curvas tempo $\mathrm{x}$ recalque, pilares do eixo 6 . 193

Figura 7.3 - Curvas tempo $x$ recalque, pilares do eixo 7 193

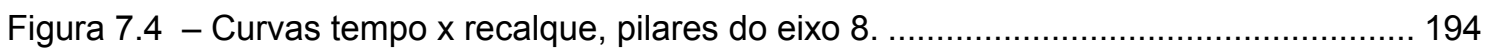

Figura 7.5 - Curvas tempo x recalque, pilares do eixo 9. .................................................... 194

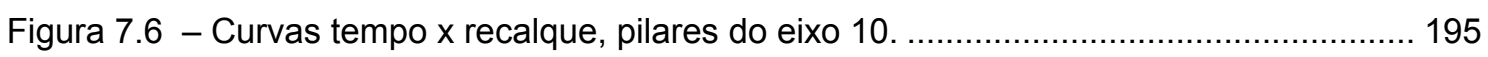

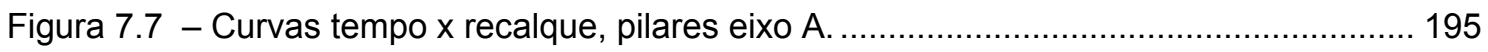

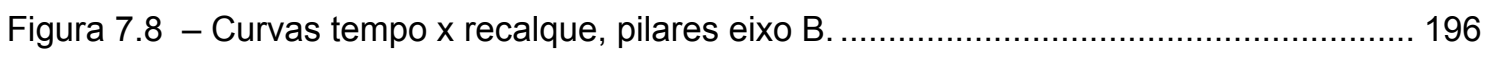

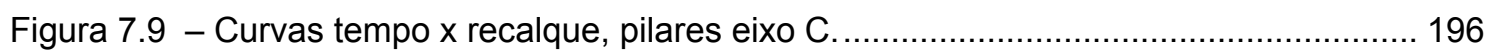

Figura 7.10 - Curvas tempo x recalque, pilares eixo D..................................................... 197

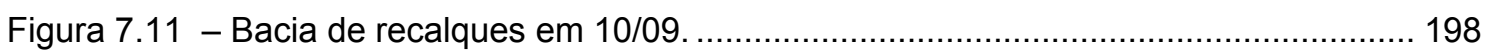

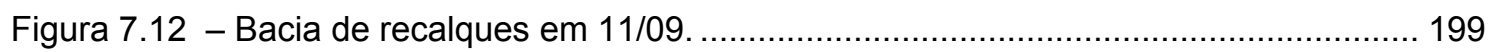

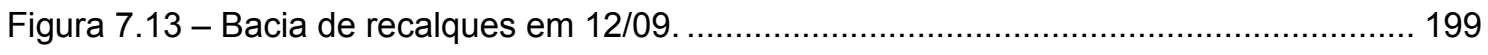

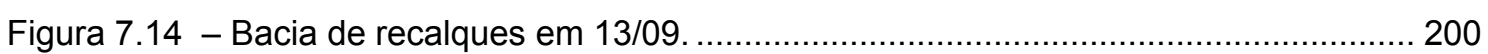

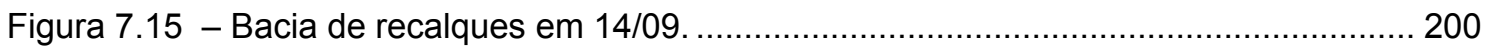

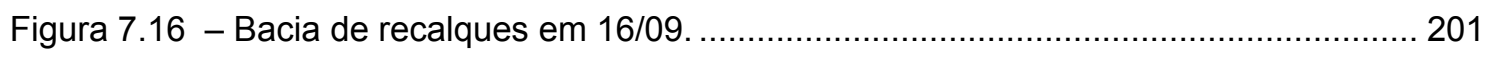

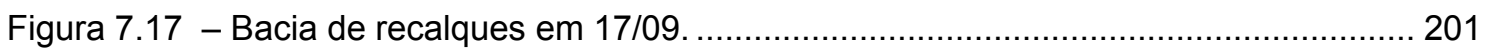

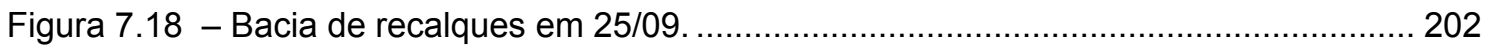

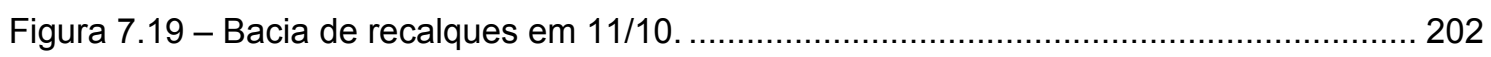

Figura 7.20 - Bacia de recalques em 17/10 (máximo recalque observado). .......................... 203

Figura 7.21 - Deformada de recalques, pilares 06 a 10 ...................................................... 203

Figura 7.22 - Deformada de recalques, pilares 16 a 20 ....................................................... 204

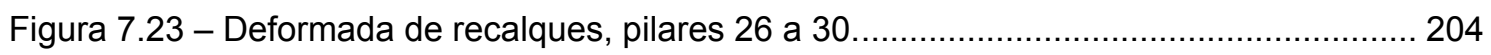

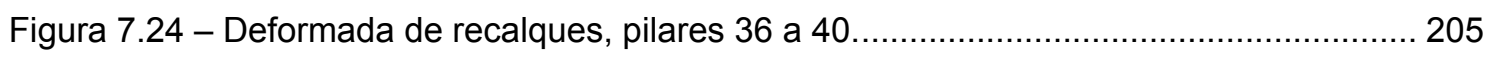

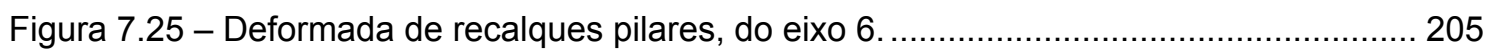

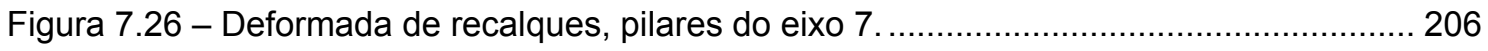

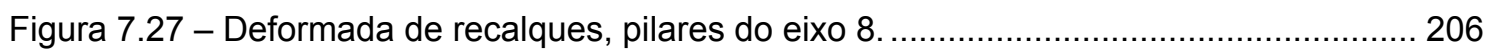

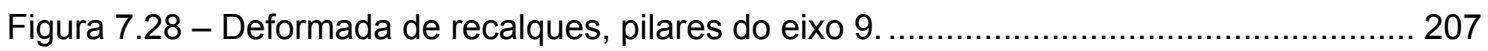

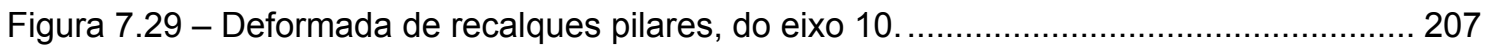

Figura 7.30 - Curva tempo recalque - pilares do eixo 06 ................................................... 208

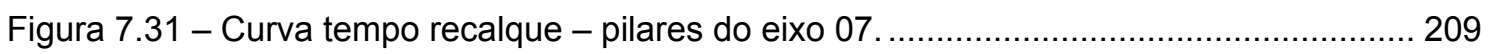

Figura 7.32 - Curva tempo recalque - pilares do eixo 08.................................................. 209

Figura 7.33 - Curva tempo recalque pilares do eixo 09................................................. 210

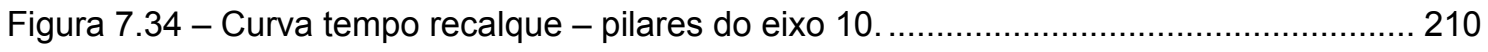

Figura 7.35 -Variação da velocidade de recalque com o tempo, sob carga constante........... 213

Figura 7.36 - Curvas tempo x carga e recalque, pilares do eixo A....................................... 214

Figura 7.37 - Curvas tempo $x$ carga e recalque, pilares do eixo B...................................... 215

Figura 7.38 - Curvas tempo $x$ carga e recalque, pilares do eixo C........................................... 215

Figura 7.39 - Curvas tempo $x$ carga e recalque, pilares do eixo D....................................... 216

Figura 7.40 - Curvas de igual coeficiente de mola............................................................. 218

Figura 7.41 - Relação carga recalque, pilares do eixo 06.................................................. 219 


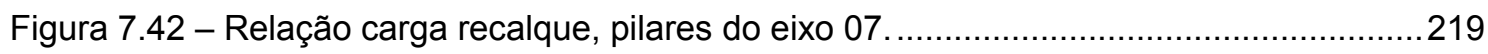

Figura 7.43 - Relação carga recalque, pilares do eixo 08..................................................220

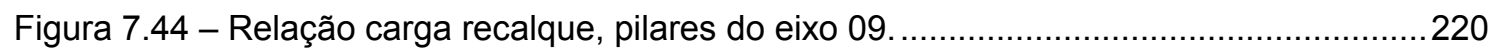

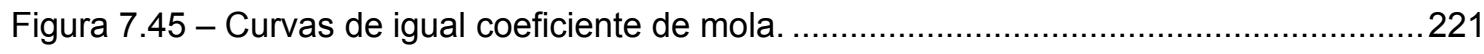

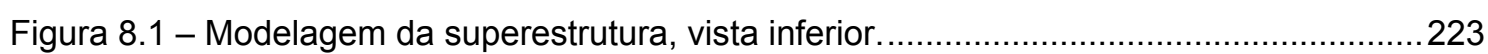

Figura 8.2 - Discretização da superestrutura por meio de elementos de barra e placa. ..........225

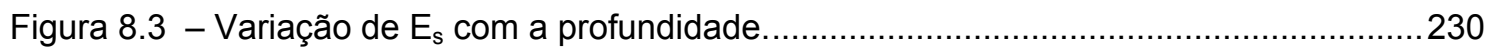

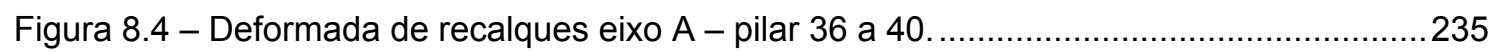

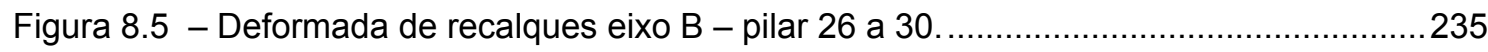

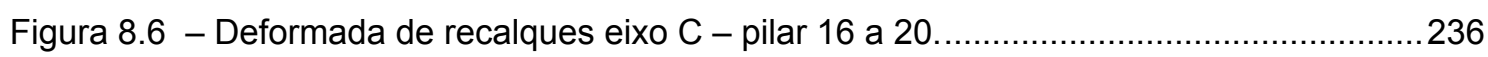

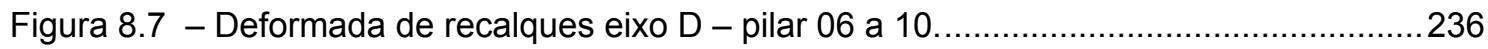

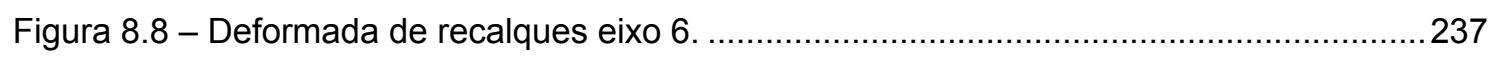

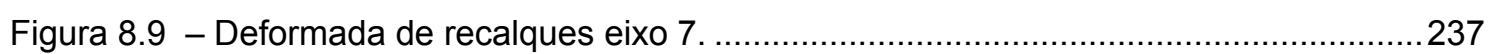

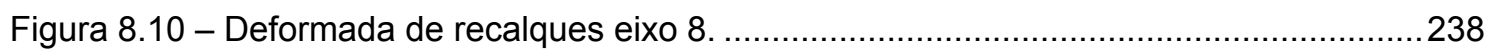

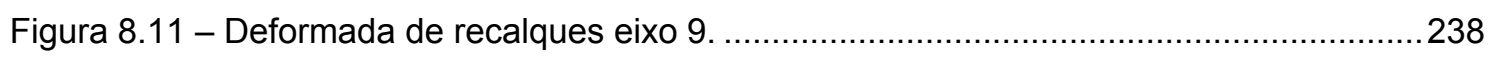

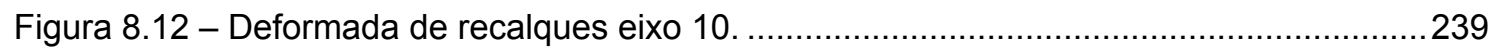

Figura 8.13 - Diagrama de solicitação normal nas estacas - pilares do eixo 6 . ......................240

Figura 8.14 - Diagrama de solicitação normal nas estacas - pilares do eixo 7 . .......................241

Figura 8.15 - Diagrama de solicitação normal nas estacas - pilares do eixo 8 . .....................242

Figura 8.16 - Diagrama de solicitação normal nas estacas - pilares do eixo 9......................243

Figura 8.17 - Diagrama de solicitação normal nas estacas - pilares do eixo 10 ….................244

Figura 8.18 - Curvas de igual solicitação no topo das estacas (valores em MPa). ................247

Figura 8.19 - Curvas de igual coeficiente de mola (valores em kN/m) ...............................2. 247

Figura 8.20 - Curvas de igual deformação - profundidade 5,5 m (valores em $\mathrm{m} \varepsilon$ ) .................249

Figura 8.21 - Curvas de igual deformação - profundidade $6,5 \mathrm{~m}$ (valores em me). .................249

Figura 8.22 - Curvas de igual deformação - profundidade $7,5 \mathrm{~m}$ (valores em $\mathrm{m} \varepsilon$ ). ................220

Figura 8.23 - Curvas de igual deformação - profundidade $8,5 \mathrm{~m}$ (valores em $\mathrm{m \varepsilon}$ ) . ................250

Figura 8.24 - Curvas de igual deformação - eixo $A$ (valores em $m \varepsilon$ ). .....................................251

Figura 8.25 - Curvas de igual deformação - eixo $B$ (valores em $\mathrm{m} \varepsilon$ ). .....................................251

Figura 8.26 - Curvas de igual deformação - eixo C (valores em $\mathrm{m} \varepsilon$ ) ......................................251

Figura 8.27 - Curvas de igual deformação - eixo $D$ (valores em $m \varepsilon$ ) . .....................................251

Figura 8.28 - Curvas de igual acréscimo de tensão - profundidade 5,5 m (valores em kPa). 253

Figura 8.29 - Curvas de igual acréscimo de tensão - profundidade 6,5 m (valores em kPa). 254

Figura 8.30 - Curvas de igual acréscimo de tensão - profundidade 7,5 m (valores em kPa). 254

Figura 8.31 - Curvas de igual acréscimo de tensão - profundidade $8,5 \mathrm{~m}$ (valores em kPa). 255

Figura 8.32 - Curvas de igual acréscimo de tensão - profundidade 9,5 m (valores em kPa). 255

Figura 8.33 - Curvas de igual acréscimo de tensão - eixo A (valores em kPa).......................2.256

Figura 8.34 - Curvas de igual acréscimo de tensão - eixo $\mathrm{B}$ (valores em $\mathrm{kPa}$ ).........................256

Figura 8.35 - Curvas de igual acréscimo de tensão - eixo C (valores em kPa). .....................256

Figura 8.36 - Curvas de igual acréscimo de tensão - eixo D (valores em kPa). ......................256 
Figura 8.37 - Curvas de igual relação $\mathrm{E} / \mathrm{q}_{\mathrm{c}}$.

Figura 8.38 - Variação do módulo de deformabilidade do solo $\left(E_{s}\right)$ com a profundidade -

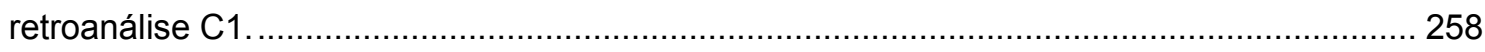

Figura 8.39 - Diagrama de solicitação normal nas estacas - pilares do eixo 6....................... 262

Figura 8.40 - Diagrama de solicitação normal nas estacas - pilares do eixo 7 ....................... 263

Figura 8.41 - Diagrama de solicitação normal nas estacas - pilares do eixo 8....................... 264

Figura 8.42 - Diagrama de solicitação normal nas estacas - pilares do eixo 9....................... 265

Figura 8.43 - Diagrama de solicitação normal nas estacas - pilares do eixo 10..................... 266

Figura 8.44 - Curvas de igual solicitação no topo das estacas (valores em MPa) .................. 267

Figura 8.45 - Curvas de igual coeficiente de mola das estacas (valores em kN/m)............... 267 


\section{LISTA DE TABELAS}

Tabela 2.1 - Efeitos da interação solo estrutura em edifícios, in Gusmão (2000). ................... 19

Tabela 2.2 - Principais características dos extensômetros mecânicos, in Dunnicliff (1993).....30

Tabela 2.3 - Coeficiente de dilatação térmica para diversos materiais, in Dunnicliff (1993)...... 31

Tabela 2.4 - Recalques medidos em sete edifícios após dezoito meses de construção, in

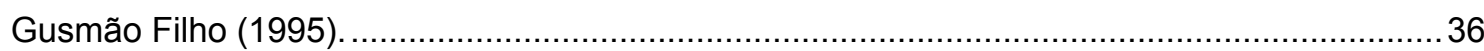

Tabela 2.5 - Recalques medidos nos pilares de maior carga, in Danziger et al. (1997)............37

Tabela 2.6 - Deformações medidas em pilares, in Danziger et al. (1997). ................................37

Tabela 3.1 - Função fluência para modelos reológicos compostos elementares. .......................77

Tabela 3.2 - Variação do coeficiente de dilatação térmica do concreto com o tipo do agregado,

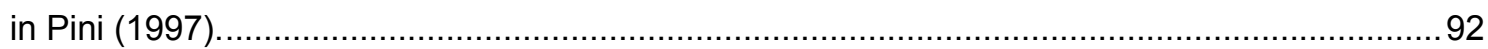

Tabela 3.3 - Coeficiente de dilatação térmica dos pilares.........................................................94

Tabela 4.1 - Localização das sondagens Campus Curitiba PUCPR. .................................... 101

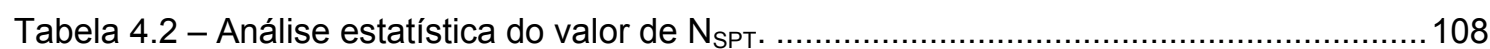

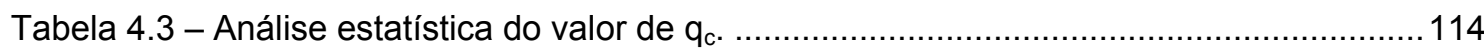

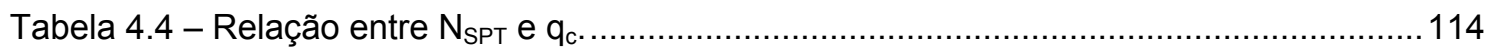

Tabela 4.5 - Controle tecnológico das peças pré-moldadas.................................................... 123

Tabela 4.6 - Controle tecnológico do concreto dos pilares monitorados. ............................... 124

Tabela 4.7 - Controle tecnológico do concreto aplicado nas estacas.....................................130

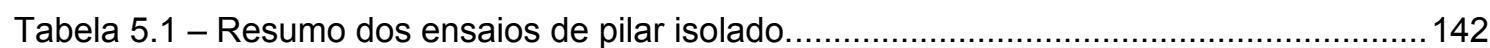

Tabela 5.2 - Resumo dos ensaios de montagem em pórtico .................................................... 144

Tabela 6.1 - Avaliação da excentricidade (e) da solicitação normal, valores em cm................170

Tabela 6.2 - Regressão logarítmica deformação/deslocamento $\mathrm{x}$ tempo período de carga

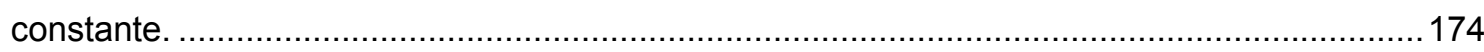

Tabela 6.3 - Relação tensão deformação no concreto armado dos pilares................................180

Tabela 6.4 - Avaliação do módulo de elasticidade concreto simples...................................... 181

Tabela 6.5 - Comparativo cálculo estrutural x valores obtidos pela instrumentação. ...............186

Tabela 6.6 - Comparativo entre a solicitação normal nos pilares cálculo estrutural $\mathrm{x}$ medido -

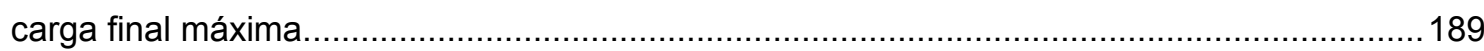

Tabela 6.7 - Comparativo do coeficiente de variação (\%) deformação média medida $\mathrm{x}$

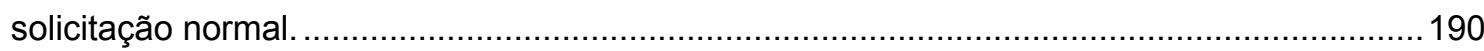

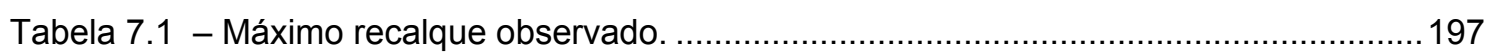

Tabela 7.2 - Regressão logarítmica recalque $\mathrm{x}$ tempo, período de carga constante...............211 
Tabela 7.3 - Tempo (dias) para atingir determinada velocidade de recalques.

Tabela 7.4 - Características geométricas do grupo de estacas, resumo dos valores medidos e

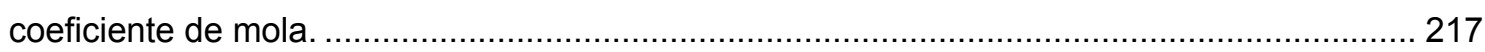

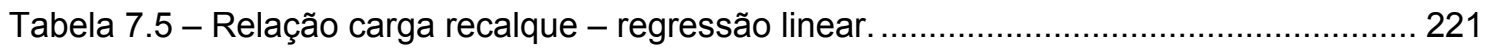

Tabela 8.1 - Determinação do atrito lateral, método Aoki Velloso, sondagem SP-06............. 227

Tabela 8.2 - Variação de $\mathrm{E}_{\mathrm{s}}$ com a profundidade - retroanálise A ...................................... 230

Tabela 8.3 - Relação entre módulo de cisalhamento secante e inicial tangente..................... 232

Tabela 8.4 - Resultados da análise interação solo estrutura - retroanálise A. ......................... 233

Tabela 8.5 - Comparativo entre recalques medidos e calculados - retroanálise A.................. 235

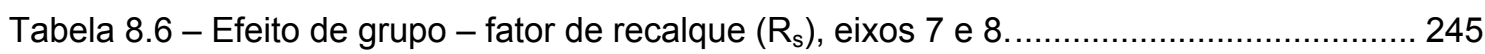

Tabela 8.7 - Aspectos importantes relacionados com o nível de deformação, in Correa et al.

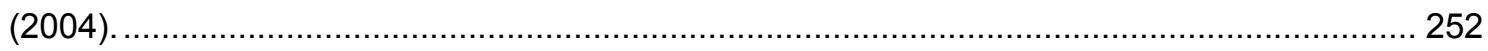

Tabela 8.8 - Valores limite superior e inferior de $E_{s}$ - retroanálise $C 1$. ................................ 258

Tabela 8.9 - Resultados análise interação solo estrutura - retroanálise C1 ........................... 259 


\section{LISTA DE SÍMBOLOS}

\section{Romanos}

a lado da seção transversal do pilar quadrado

a lado da seção transversal da estaca pré-moldada

A área da seção transversal do pilar

$\mathrm{A}_{\mathrm{g}} \quad$ área da figura plana que inscreve o grupo de estacas, método de Poulos

$A_{p}$ área da seção transversal da estaca, método de Poulos e Davis

$A_{s} \quad$ área da armadura do pilar

B largura do grupo de estacas

C profundidade do ponto de aplicação da carga concentrada, solução de Mindlin

C relação entre espaçamento entre estacas e diâmetro método de Meyerhof

CV coeficiente de variação

$\mathrm{C}_{\alpha} \quad$ taxa de deslocamento sob carga constante

D diâmetro da estaca, método de Poulos e Davis

D diâmetro da estaca, método de Meyerhof

$\mathrm{d}_{\mathrm{e}} \quad$ diâmetro do tubulão equivalente, método de Poulos

E excentricidade

$E(t) \quad$ função de deformabilidade

$E_{b} \quad$ módulo de elasticidade do solo, baixo da ponta da estaca, método de Poulos e Davis

$\mathrm{E}_{\mathrm{c}} \quad$ módulo de elasticidade do concreto

$\mathrm{E}_{\mathrm{c}}(\mathrm{t})$ módulo de elasticidade para uma idade de $\mathrm{t}$ dias

$\mathrm{E}_{\mathrm{ca}} \quad$ módulo de elasticidade do concreto armado

$E_{c m}$ módulo de elasticidade médio do concreto armado

$\mathrm{E}_{\mathrm{p}} \quad$ característica elástica da estaca

$\mathrm{E}_{\mathrm{s}} \quad$ módulo de deformabilidade do solo

$\mathrm{F}_{1} \quad$ coeficiente fator de instalação da ponta, método Aoki Velloso

$\mathrm{F}_{2} \quad$ coeficiente fator de instalação lateral, método Aoki Velloso

$\mathrm{f}_{\mathrm{c} 28}$ resistência à compressão do concreto na idade de 28 dias

$\mathrm{f}_{\mathrm{cj}}$ resistência à compressão média do concreto na idade de j dias

$\mathrm{f}_{\mathrm{ck}} \quad$ resistência característica do concreto

$\mathrm{f}_{\mathrm{cm}} \quad$ resistência à compressão média do concreto na idade de 28 dias

[FM] matriz de flexibilidade da fundação

$G$ módulo de deformabilidade transversal do solo

h dimensão teórica da peça

$H(t) \quad$ função de Heaviside ou função degrau

I momento de inércia

$\mathrm{I}_{0} \quad$ fator de influência para estacas incompressíveis em meio semi-infinito, método de Poulos e Davis

[l] a matriz identidade

$\mathrm{J}(\mathrm{t})$ função de fluência

$\mathrm{k}_{\text {mola }}$ coeficiente de rigidez da mola, modelo Hookeano

$\mathrm{K}$ coeficiente de rigidez da estaca, método de Poulos e Davis

$\mathrm{k}$ coeficiente função da textura do solo, método Aoki Velloso

$\mathrm{k}_{\text {mola }}$ constante de mola

L comprimento da estaca

$\mathrm{L}_{\mathrm{e}} \quad$ comprimento da estaca efetivamente executado

$L_{p} \quad$ comprimento da estaca previsto no projeto 


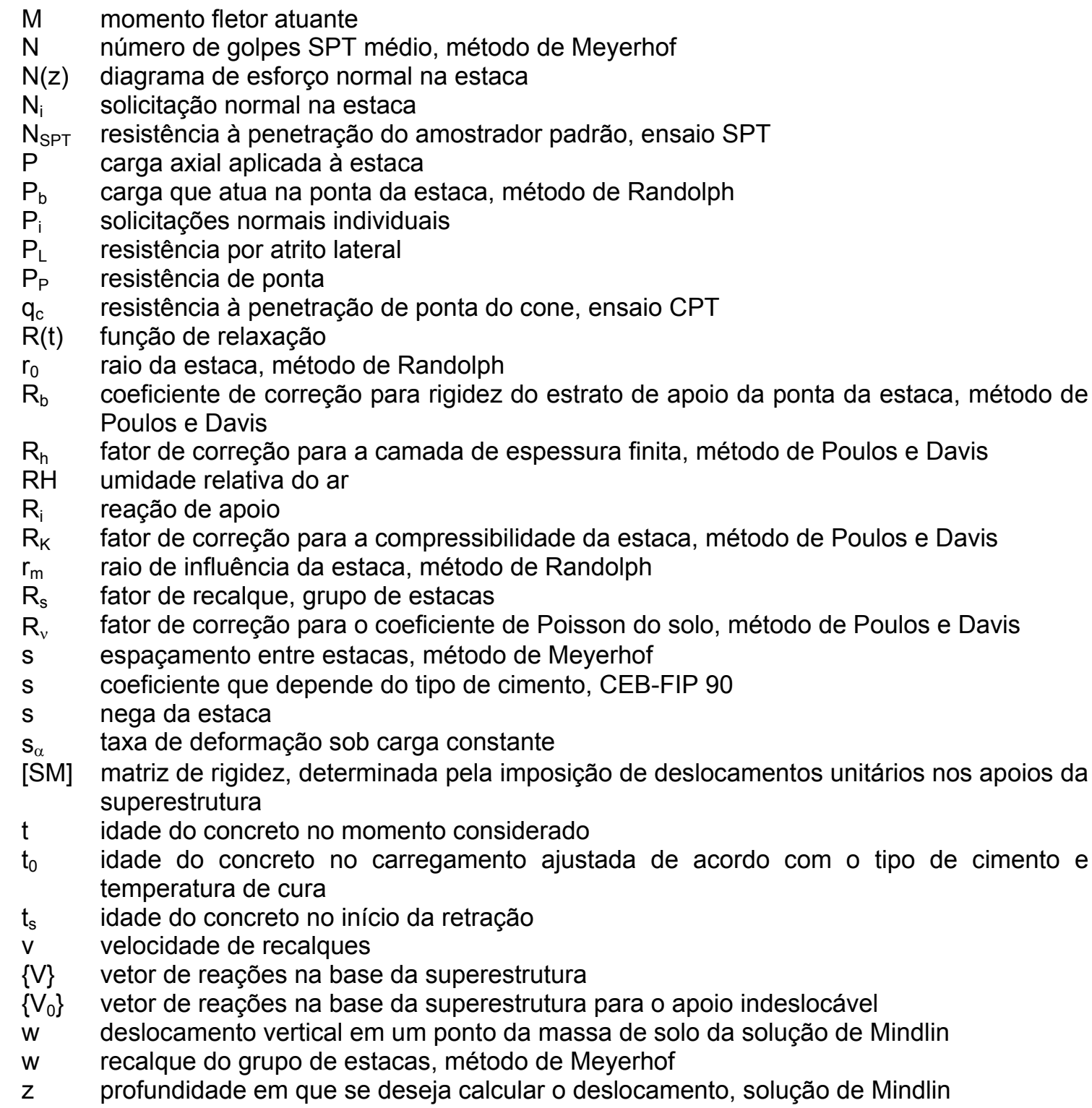

\section{Gregos}

$\alpha \quad$ fator de interação em termos de recalque, método de Poulos

$\alpha \quad$ coeficiente de ajuste da idade do concreto, CEB FIP-90

$\alpha_{T} \quad$ coeficiente de dilatação térmica do concreto

$\alpha \quad$ coeficientes função da textura do solo, método Aoki Velloso

$\beta_{c} \quad$ coeficiente que descreve o desenvolvimento do fluência com o tempo

$\beta_{E}(t) \quad$ coeficiente que depende da idade do concreto

$\beta_{\mathrm{s}} \quad$ coeficiente que descreve o desenvolvimento da retração com o tempo

$\beta_{\mathrm{sc}} \quad$ coeficiente que depende do tipo do cimento

$\delta_{\text {calculado }}$ recalque calculado

$\delta_{\mathrm{f}} \quad$ recalque em um tempo t após a aplicação da carga máxima

$\delta_{\text {final }} \quad$ recalque ao final da aplicação do carregamento máximo

$\delta_{\text {máx }} \quad$ máximo recalque

$\delta_{\text {medido }}$ recalque medido

$\delta_{\mathrm{p}} \quad$ encurtamento elástico da estaca

$\delta_{\mathrm{s}} \quad$ deslocamento da ponta da estaca

$\delta_{\mathrm{t}} \quad$ deslocamento do topo da estaca

$\delta_{\mathrm{zi}} \quad$ deslocamento do maciço de solo a uma profundidade $\mathrm{z}$ 
$\{\delta\} \quad$ vetor de recalques na base da superestrutura

$\Delta \mathrm{T} \quad$ variação de temperatura

$\varepsilon_{c} \quad$ deformação no concreto total ou medida

$\varepsilon_{c c} \quad$ deformações no concreto devidas à fluência

$\varepsilon_{\mathrm{ci}} \quad$ deformação no concreto instantânea ou "elástica"

$\varepsilon_{\mathrm{cn}} \quad$ parcela da deformação independente da tensão

$\varepsilon_{\mathrm{cs}} \quad$ deformações no concreto devidas à retração

$\varepsilon_{\text {cso }} \quad$ coeficiente de retração teórico

$\varepsilon_{C T}$ deformações no concreto devidas à variação de temperatura

$\varepsilon_{\mathrm{c \sigma} \sigma} \quad$ parcela da deformação dependente da tensão

$\varepsilon_{\text {med }} \quad$ deformação média medida

$\varepsilon_{\min } \quad$ menor deformação medida

$\varepsilon_{\mathrm{zi}} \quad$ deformação do maciço de solo na profundidade $\mathrm{z}$

$\varepsilon_{\alpha} \quad$ coeficiente angular da regressão logarítmica

$\phi_{0} \quad$ coeficiente teórico de fluência

$\eta \quad$ coeficiente de viscosidade do material

$\eta \quad$ constante de proporcionalidade entre $E_{s}$ e $q_{c}$

$\lambda \quad$ rigidez relativa, método de Randolph

$v_{\mathrm{s}} \quad$ coeficiente de Poisson do solo, método de Poulos e Davis

$\rho \quad$ recalque no topo da estaca, método de Poulos e Davis

$\sigma \quad$ tensão normal

$\sigma_{\text {med }} \quad$ tensão normal média

$\sigma_{\min } \quad$ tensão normal mínima

$\sigma_{\mathrm{zi}} \quad$ acréscimo de tensão na profundidade $\mathrm{z}$

$\Sigma \mathrm{A}_{\mathrm{i}} \quad$ somatória das seções transversais dos elementos

$\Sigma P_{i} \quad$ ação externa total aplicada

$\Sigma \varepsilon_{i} \quad$ somatória das deformações medidas

$\tau_{0} \quad$ tensão cisalhante no fuste da estaca, método de Randolph 


\title{
LISTA DE SIGLAS
}

\author{
ABNT Associação Brasileira de Normas Técnicas \\ CPRM Companhia de Pesquisa e Recursos Minerais \\ IPPUC Instituto de Pesquisa e Planejamento Urbano de Curitiba \\ PUCPR Pontifícia Universidade Católica do Paraná \\ SIMEPAR Instituto Tecnológico SIMEPAR \\ USP Universidade de São Paulo
}




\section{RESUMO}

RUSSO NETO, L. (2005). Interpretação de deformação e recalque na fase de montagem de estrutura de concreto com fundações em estaca cravada. Tese (Doutorado) - Escola de Engenharia de São Carlos, Universidade de São Paulo, 2005.

Relatos da observação do comportamento de obras de engenharia em escala natural, especialmente no caso de edifícios apoiados em fundações profundas, são pouco freqüentes em nossa literatura, embora estimulados por vários autores e pela Norma Brasileira de Projeto e Execução de Fundações. Este trabalho apresenta resultados de medidas de carga e recalque em 20 pilares contíguos de uma estrutura em concreto armado pré-moldada, apoiada em fundações do tipo estaca cravada. Os recalques foram medidos por meio de nivelamento ótico de precisão, tendo sido determinado valores máximos variáveis entre 1,1 e $4,3 \mathrm{~mm}$. Foram observados deslocamentos sob carga constante, fluência da fundação, com taxa variável entre 0,8 e $3,2 \mathrm{~mm} / \log \mathrm{t}$. As solicitações normais nos pilares foram avaliadas indiretamente por meio da variação de seu comprimento, utilizando-se um extensômetro mecânico removível. Apresenta-se a metodologia para interpretação das medidas efetuadas pelo extensômetro mecânico, levando em conta as variações dos fatores ambientais e a reologia do concreto, a qual conduz a uma boa concordância entre os valores medidos e os fornecidos pelo cálculo estrutural. Os dados coletados são retroanalisados sob o enfoque da interação solo estrutura pela modelagem da superestrutura por meio de pórtico espacial apoiado em molas representativas das fundações por estacas. No cálculo das molas foi utilizada a integração numérica da solução de Mindlin para a modelagem do efeito de grupo do sistema formado pelas estacas e o maciço de solo. Verificou-se que a elevada variabilidade dos solos da formação geológica do local foi refletida no comportamento da obra, como mostra o resultado da retroanálise efetuada. Conclui-se que as variabilidades da formação geotécnica devem ser consideradas para que previsões de comportamento sejam mais realistas.

PALAVRAS-CHAVES: interação solo estrutura; instrumentação de campo; estrutura de concreto pré-moldado;recalque; fluência; fundação profunda. 


\section{ABSTRACT}

RUSSO NETO, L. (2005). Strain and settlement interpretation in the assembly of a concrete structure supported by driven piles. Tese (Doutorado) - Escola de Engenharia de São Carlos, Universidade de São Paulo, 2005.

Although encouraged by several authors and by the Brazilian Foundation Code, reports of actual column loads measurement in natural scale are not frequent in our technical literature, especially in the case of buildings supported by deep foundations. Results of load and settlement measurements at 20 contiguous columns of a structure built in pre-cast reinforced concrete and supported by driven piles are presented. Settlements were measured by means of optical level and a range of values between 1.1 to $4.3 \mathrm{~mm}$ were observed. Settlement under constant load were observed under variable creep rates from 0.8 to 3.2 $\mathrm{mm} / \log$ t. Loads over columns were indirectly evaluated through column length variation, using a demountable mechanical extensometer. The methodology for interpretation of measurements made with the mechanical extensometer is described, considering corrections due to the variation of environmental conditions and to the concrete's rheology; this methodology leads to a good agreement between measured values and those supplied by conventional structural design. The collected data is back analysed taking into account the soil structure interaction. The superstructure was modelled as a spatial frame supported by springs with the same rigidity of the pile foundation element. The equivalent spring parameter for each column support has considered the settlement group effect for all piles embedded in soil, using the numerical integration of Mindlin's equations. Results of this back analysis show a high variability, reflecting the high degree of variability of local subsoil conditions. Therefore, one can conclude that predictions, in order to be reliable, must consider these soil variations.

KEYWORDS: soil structure interaction; field instrumentation; concrete pre-cast structure; settlement; creep; deep foundation. 

1. INTRODUÇÃO

Relatos de observação do comportamento de obras de engenharia em escala natural, especialmente no caso de edifícios apoiados em fundações profundas, são pouco freqüentes em nossa literatura, embora estimulados por vários autores e pela Norma Brasileira de Projeto e Execução de Fundações (ABNT, 1996).

A previsão e a observação do comportamento real de obras de engenharia são o objeto final das pesquisas e investigações no campo da Geotecnia e, em particular, na Engenharia de Fundações. Assim sendo, a observação do comportamento de uma determinada obra de engenharia em escala natural, ou escala 1:1, permitirá avaliar e aferir modelos ou códigos de obras empregados na prática corrente da Engenharia Civil.

Uma visão atual desse problema, conforme proposto, por exemplo, por Aoki (2002), deve contemplar uma análise de confiabilidade das obras civis, tanto para o caso de análises no estado limite último (ELU) como para o caso do estado de limite de serviço (ELS). Esse tipo de análise requer 0 conhecimento prévio das solicitações atuantes e resistências disponíveis nos elementos envolvidos dentro do sistema em questão. Assim sendo, a confiabilidade real de uma determinada obra de engenharia somente pode ser determinada se as variáveis envolvidas forem efetivamente medidas e comprovadas.

\subsection{IMPORTÂNCIA DAS OBSERVAÇÕES DE CAMPO.}

Em seu discurso de abertura no $1^{0}$. Congresso Internacional de Mecânica dos Solos, Terzaghi (1936) afirmou que as teorias empregadas até aquela data seriam superadas por outras melhores, mas os resultados de boas observações de campo permaneceriam sendo de inestimável valor para a 
profissão. Considerou urgente a necessidade de observação de estruturas em escala natural em todo o mundo e a comparação entre os fatos observados com aquilo que fora previsto a partir das investigações do solo.

Lambe (1973), em sua conhecida "Rankine Lecture" a respeito de previsões em Engenharia Geotécnica, afirma que a publicação de resultados de observações de campo constitui-se em importante contribuição para a profissão. Prossegue o autor afirmando que a simples apresentação da evolução dos recalques ao longo do tempo pode ser de pouco valor. Contudo, a publicação de caso, indicando a magnitude e a direção das deformações em vários locais da fundação, pode ser de valor inestimável. Sobre a necessidade da medida das solicitações impostas às fundações, o autor considera que casos envolvendo edifícios são de difícil interpretação, porque raramente é conhecida a magnitude, ou quase nada sobre a distribuição das cargas aplicadas ao subsolo. Expressa sua opinião, ainda, afirmando que existem poucos casos de medidas de recalques de fundações e nossa profissão sofre em particular com a falta de casos nos quais foram avaliadas as tensões totais na fundação.

Vaughan (1975) considera dois fatores para explicar o pouco uso de instrumentação em Engenharia de Fundações. O primeiro refere-se ao fato de que fundações de edifícios são pequenos projetos ("done in a hurry"), sendo difícil agregar custo adicional da instrumentação a eles. Como segundo fator, o mesmo autor considera que os projetos de fundação são geralmente elaborados por engenheiros estruturais, os quais no seu entendimento, não possuem conhecimento detalhado de problemas especiais de Mecânica dos Solos. Complementa, ainda, reconhecendo que o uso de instrumentação intensiva é mais freqüente para o caso da análise do comportamento de estacas isoladas. Segue afirmando que o problema a ser resolvido para fins de projeto de fundações é referente aos recalques ou, mais particularmente, aos recalques diferenciais. $O$ uso de instrumentação para examinar o mecanismo desse problema tem sido muito restrito e são raros os casos de registro desse tipo.

Danziger et al. (1997) relatam que a prática brasileira de medida de recalques ocorre somente nos casos em que existem indícios de dano estrutural, ou quando são executadas escavações muito profundas, próximas 
às estruturas. Reconhecem os autores que existem na literatura nacional notáveis casos históricos de medidas de recalque desde o início da construção, mas são poucos. Consideram, também, que o número de casos publicados na literatura internacional é pequeno.

Em artigo sobre o desempenho de edifícios com fundações sob solos compressíveis, de Mello (2003) afirma que o caminho promissor para a resolução de problemas profissionais referentes a extrapolações para o futuro é o monitoramento de protótipos. Também considera que um alarmante obstáculo, no caso de edifícios, é o fato de ter sido regra apenas o monitoramento e a publicação de registros de deslocamento da base dos pilares, conduzindo à necessidade da introdução de considerações complexas de distribuição de tensões na estrutura. Entretanto, para elucidação do problema, sob o ponto de vista geotécnico, seria desejável o conhecimento das cargas efetivas e por meio delas verificar seus reflexos nos recalques do maciço de solo.

Mais recentemente foram publicados alguns casos em que a medida de recalque foi efetuada em conjunto com medidas de tensões totais na fundação. Pode-se citar o experimento de Katzenbach et al. (1997), no qual são apresentados resultados de instrumentação em um edifício comercial de $300 \mathrm{~m}$ de altura, localizado na cidade de Frankfurt. Viggiani (1997) apresenta resultado da instrumentação da fundação do pilar central de uma ponte localizada no sul da Itália, sobre o Rio Gargliano. Van Impe (1999) relata caso de observação de um edifício comercial de três andares, no qual todas as estacas componentes da fundação foram monitoradas continuamente por meio de células de carga desde o início da construção.

Visando a contribuir para o melhor entendimento do comportamento de obras de engenharia em face das condições impostas pelos processos executivos, apresentam-se, neste trabalho, resultados de medidas, interpretação e análise da carga e do recalque em vinte pilares contíguos de uma superestrutura isostática em concreto armado pré-moldada, apoiada em fundações do tipo estaca pré-moldada de concreto armado com seção quadrada. O estudo foi desenvolvido durante a execução da estrutura de uma edificação composta por quatro pavimentos, localizada no Campus Curitiba da Pontifícia Universidade Católica do Paraná, na cidade de Curitiba/PR. 


\subsection{APRESENTAÇÃO DOS CAPÍTULOS.}

Este trabalho é composto por nove capítulos. No próximo capítulo, apresenta-se revisão da bibliografia existente sobre o tema em questão. São descritos equipamentos e procedimentos já utilizados em instrumentação de campo para o caso de estruturas de edifícios. Atenção especial é dada ao problema da interação solo estrutura e à previsão de recalques para o caso de fundações profundas.

O capítulo 3 trata da formulação teórica sobre o comportamento reológico dos materiais, tendo em vista que as medidas efetuadas permitiram quantificar componentes de deformações visco-elásticas tanto na superestrutura de concreto como na fundação. Além disso, Santa Maria et al. (1999) alertam que a não consideração do comportamento visco-elástico nas análises de interação solo estrutura pode conduzir a erros contra a segurança.

A caracterização do meio físico em que foi desenvolvido esse estudo experimental é descrita no capítulo 4, o qual pretende fornecer informações sobre a localização do estudo, da geotecnia do local, das condições ambientais em que foram realizadas as observações e das características da obra de engenharia.

O detalhamento dos equipamentos e procedimentos adotados para a realização das medidas de campo é descrito no capítulo Instrumentação de Campo. Os recalques foram medidos utilizando-se nivelamento ótico de precisão. Um extensômetro mecânico removível foi especialmente desenvolvido para esta pesquisa, visando a avaliação indireta da solicitação normal nos pilares. As medidas foram realizadas desde o momento do posicionamento de cada pilar em sua base até a conclusão da montagem da estrutura pré-moldada, seguido de um período de cerca de 15 dias no qual nenhum carregamento adicional foi aplicado à obra.

Os resultados das medidas de deformação efetuadas no conjunto de pilares do pavimento térreo são apresentados e interpretados no capítulo 6, no qual se verifica que a solicitação normal nos pilares pode ser avaliada indiretamente pela metodologia proposta. As solicitações normais nos pilares são avaliadas pela variação de seu comprimento, utilizando-se um extensômetro mecânico removível. Apresenta-se a metodologia para 
interpretação das medidas efetuadas pelo extensômetro mecânico, levando em conta as variações dos fatores ambientais e a reologia do concreto, a qual conduz a uma boa concordância entre os valores medidos e os fornecidos pelo cálculo estrutural

No capítulo 7 apresenta-se o comportamento da fundação de acordo com as medidas de deslocamento vertical efetuadas próximas às bases do pilares. Os recalques máximos observados variaram entre 1,1 e 4,3 mm. Também foi possível observar fluência da fundação profunda.

O conjunto de dados coletados é retroanalisado no capítulo seguinte sob o enfoque da interação solo estrutura, o qual permite definir parâmetros de deformabilidade do maciço de solo do local estudado. A superestrutura é modelada como pórtico isostático espacial apoiado em molas representativas das fundações por estacas. No cálculo das molas utilizou-se a integração numérica da solução de Mindlin, apresentada por Aoki e Lopes (1975) para a modelagem do efeito de grupo do sistema formado pelas estacas e o maciço de solo.

As conclusões deste trabalho e as sugestões para novas pesquisas são apresentadas no capítulo 9 . 


\section{REVISÃO BIBLIOGRÁFICA}

\subsection{INTRODUÇÃO.}

O termo interação solo estrutura é extremamente amplo e envolve uma gama de situações de obras de engenharia que se encontram em contato ou fazem uso do solo. Assim, por exemplo, a interação solo estrutura se dá em edifícios, pontes e viadutos, estruturas de contenção, dutos enterrados, túneis, barragens, etc.

Este trabalho apresenta revisão bibliográfica do tema interação solo estrutura, envolvendo obras de engenharia de estruturas de edifícios. O tema será restrito também para o caso de solução de fundação do tipo profunda, com uso de estacas ou tubulões. Somente serão consideradas as situações em que o desempenho da estrutura é satisfatório, não sendo contemplados os casos em que se verificou qualquer tipo de dano na estrutura devido ao desempenho insatisfatório da obra de engenharia.

Na prática atual, as estruturas de edifícios são projetadas e executadas considerando-se que os apoios das estruturas aporticadas (interface infra e superestrutura) são indeslocáveis. São pouco freqüentes os casos em que uma estimativa de recalques é efetuada, embora a NBR 6122 - ABNT (1996) "Projeto e execução de fundações", em seu item 5.6.2, estabeleça condições de verificação de um determinado projeto pelo estado limite de utilização ou análise de deformações.

O aspecto que apresenta maior dificuldade na interação solo estrutura refere-se à definição da flexibilidade (ou rigidez) da fundação, a qual permitirá estimar os deslocamentos verticais (recalques) a que os pontos de apoio da superestrutura irão estar submetidos. Essa dificuldade reside no fato de que o equilíbrio estático dos elementos da subestrutura apresenta elevado grau de 
hiperestaticidade ou geotécnicamente hiperestático, conforme Nunes et al. (1980).

Como será visto a seguir, esses deslocamentos não dependem apenas da rigidez da subestrutura, mas são dependentes também da rigidez da superestrutura.

Assim sendo, atenção especial será dada neste trabalho à estimativa de recalques, bem como à medida desses deslocamentos.

\subsubsection{HISTÓRICO.}

O reconhecimento do fato de que obras de engenharia recalcam é fundamental para o processo de interação solo estrutura. Caso fosse possível executar uma fundação de rigidez infinita (sem recalques), os efeitos da interação solo estrutura não existiriam.

Assim, pode-se atribuir o início dos estudos de interação solo-estrutura a Terzaghi (1936) em seu discurso de abertura no I Congresso Internacional de Mecânica dos Solos e Engenharia de Fundações, realizado na Universidade de Harvard, em junho de 1936. Naquele discurso, encontram-se relatos de sua experiência relativa a recalques de estruturas. Como será mostrado neste trabalho, os recalques são os fenômenos geradores do processo de interação solo estrutura.

Trecho da tradução daquela apresentação em que é citada a experiência e opinião de Terzaghi sobre o assunto é transcrito a seguir:

....Um observador pode garantir que um edifício não apresenta quaisquer sinais de recalque, e, no entanto, a estrutura pode ter recalcado de um décimo de polegada até quatro polegadas, desde que o recalque tenha sido uniforme e a distância das estruturas vizinhas apreciável.....Entre os casos que tive sob observação, houve o de um edifício que recalcou mais de $30 \mathrm{~cm}$ devido ao adensamento de uma camada de argila, situada entre 30 e $39 \mathrm{~m}$ de profundidade abaixo da superfície do terreno.

....Durante a minha carreira profissional, encontrei grande número de engenheiros práticos e empreiteiros que acreditavam honestamente que o recalque de uma fundação por estacas, sob uma carga de 20 toneladas por estaca, seria aproximadamente igual ao recalque de uma das estacas durante uma prova de carga de 20 toneladas. Importantes decisões eram baseadas nessa hipótese simples. Entretanto, se medirmos realmente os recalques - e eu tenho medido muitas vezes - veremos que o recalque da fundação por estacas pode atingir um valor compreendido entre 5 e 500 vezes o de uma estaca individual. A falta de conhecimento desse fato banal por parte dos engenheiros só podia ser devida a uma idiossincrasia 
contra medidas, aliada ao hábito de confundir a ausência de quaisquer sinais visíveis de recalque com a ausência total de recalque.

....Há bem uns oito anos, uma fábrica muito cara foi construída sobre uma floresta inteira de estacas de 18 a $24 \mathrm{~m}$ de comprimento. A maquinaria instalada nessa fábrica era extremamente sensível a recalques desiguais. A capacidade de carga individual das estacas era muito satisfatória. Segundo todos os manuais e compêndios sobre o assunto, a carga de trabalho das estacas era igual à metade da capacidade de carga admissível. Apesar disso, o proprietário da fábrica recusou-se a aceitar essa opinião, porque algumas partes da sua fábrica sofreram recalques de $30 \mathrm{~cm}$. Na Áustria Ocidental existe um edifício de Correios cujas fundações consistem de sapatas contínuas, assentes sobre um leito muito compacto de areia e pedregulho de 7 metros de espessura. A pressão sobre o terreno é de 2,5 quilos por centímetro quadrado. Todos os códigos de construção e compêndios que conheço especificam valores muito mais altos para a capacidade de carga de tal tipo de terreno. Contudo, o recalque do edifício atingiu de 60 a $90 \mathrm{~cm}$.

Também é importante ressaltar a opinião de Terzaghi naqueles idos, relativa à necessidade de uma efetiva comprovação dos fenômenos físicos que envolvem a Mecânica dos Solos e a Engenharia de Fundações.

....A experimentação intensiva com os solos conduziu à descoberta de um grande número de fatores físicos de importância vital que tinham escapado à atenção dos investigadores das gerações precedentes. Entre esses fatores figuram, em primeira linha, os que determinam o aumento gradual dos recalques sob carga constante. O conhecimento da existência desses novos fatores tornou necessário reconstruir as teorias, de acordo com o nosso conhecimento evoluído das propriedades do material. No desenvolvimento dessas teorias não se perdeu de vista as aproximações que foram necessárias fazer, nem tampouco as imperfeições que delas resultaram. A sua aplicabilidade prática ficou dependente pois, do confronto de seus resultados com observações paralelas cuidadosas do comportamento de estruturas de tamanho natural.

....A segunda forte impressão que recebi quando fazia os extratos das revistas de engenharia, há dezoito anos, resultou da descoberta que fiz da ausência completa, nos escritos, daquilo que se chama prova suficiente. Com o correr dos anos, aparecia fórmula após fórmula e anunciava-se regra após regra, porém, quando procurei provas empíricas em que as afirmações deviam estar baseadas, descobri que não ou quase não existiam. Esse fato paradoxal levanos a uma das mais importantes tarefas que têm de ser cumpridas, se é que desejamos melhorar o padrão profissional. Ela consiste em rever a nossa atitude com relação à prova (evidência).

Mais recentemente, em 1971, no $4^{\circ}$ Congresso Pan-Americano de Mecânica dos Solos e Engenharia de Fundações, Golder (1971) apresenta um relato do estado da arte sobre recalque admissível de estruturas. Nesse 
trabalho o autor reconhece que até os anos 1930 a 40 não se imaginava que as estruturas recalcavam. Tradução livre de parte desse trabalho é apresentada a seguir, de modo a ressaltar a importância dos recalques na interação solo estrutura.

... Estruturas recalcam?

Trinta anos atrás, os engenheiros deveriam responder "Não". As pessoas não acreditavam que os edifícios recalcavam. Permita-me contar uma parábola.

Parábola.

Era uma vez um engenheiro muito cuidadoso e consciente. Ele também era muito jovem. Um dia seu chefe pediu para que procedesse ao nivelamento, em relação a uma referência de nível, de um edifício sujeito a elevadas cargas, apoiado em argila rija.

$O$ cuidadoso e consciente engenheiro procedeu ao nivelamento e disse ao chefe: 'Senhor o edifício afundou $3,2 \mathrm{~cm}$, ou então a referência de nível elevou-se na mesma quantidade.' O chefe disse: 'Não pode ser. Meus edifícios não afundam. Você provavelmente cometeu um erro da ordem de $3 \mathrm{~cm}$ em seus cálculos. Volte ao local e refaça o serviço e traga correto.' Assim, o cuidadoso e consciente engenheiro refez o serviço. Embora ele fosse muito jovem, era também muito inteligente, retornou dizendo: 'O senhor estava certo. Eu encontrei o meu erro. Seu edifício não afundou.' Alguns anos depois, o chefe pretendia executar um edifício com carregamento de $6 \mathrm{kgf} / \mathrm{cm}^{2}$ em toda a área e naquele tempo ele havia ouvido falar de mecânica dos solos. Assim ele chamou um engenheiro de fundações e disse: 'Teste o solo e me informe se esse projeto é seguro.' $O$ engenheiro de fundações realizou os ensaios e informou: 'O edifício com pressão de $6 \mathrm{kgf} / \mathrm{cm}^{2}$ irá recalcar cerca de $10 \mathrm{~cm}$ em poucos anos.' O chefe então perguntou: 'Quanto deve recalcar um edifício sob pressão de $4 \mathrm{kgf} / \mathrm{cm}^{2}$ ?' Cerca de $7,5 \mathrm{~cm}$ respondeu 0 engenheiro. O chefe disse: 'Aquele edifício existente está sujeito a uma pressão de $4 \mathrm{kgf} / \mathrm{cm}^{2}$ e não recalcou nada.' O engenheiro de fundações disse: 'Vamos verificar as cargas.' Assim procedeu e concluiu que embora as cargas de projeto fossem $4 \mathrm{kgf} / \mathrm{cm} 2 \mathrm{o}$ carregamento real era $2,5 \mathrm{kgf} / \mathrm{cm}^{2}$. Dessa forma o engenheiro disse: 'o edifício deve ter recalcado $3,8 \mathrm{~cm}$.' $O$ chefe quase ia dizendo que ele era um tolo quando se lembrou do cuidadoso e consciente engenheiro e não disse mais nada.

Quando o engenheiro de fundações saiu, o chefe procurou o consciente e cuidadoso engenheiro e disse: 'Você lembra-se que alguns anos atrás você disse que aquele edifício havia recalcado 3,2 $\mathrm{cm}$ ? Pode ser que você estivesse certo. Pegue seus dados de nivelamento.' O cuidadoso e consciente engenheiro, não era mais tão jovem, mas ainda era inteligente, trouxe seus dados e disse: 'Não senhor. Eu estava errado e o senhor estava certo. O edifício não recalcou, aqui estão os meus dados para provar isso.'

O chefe que hoje está aposentado ainda fica tentando imaginar o que realmente aconteceu. O cuidadoso e consciente engenheiro hoje é o chefe.

Esta parábola é baseada em um caso real.

Estruturas recalcam. No caso da Torres de Pisa, ou um lado recalcou ou alguém puxou o outro lado para cima. O Palácio das Belas Artes 
na Cidade do México recalcou 1,5 m. A Igreja de Guadalupe na Cidade do México, recalcou e inclinou.

Em resposta à questão: 'Estruturas recalcam?' Muitos irão dizer que si, mas isso não é verdade. Alguns edifícios podem sofrer levantamento.

A explicitação do processo de interação solo estrutura acontece no I Congresso Brasileiro de Mecânica dos Solos, quando Chamecki (1954) estabelece a ligação entre a rigidez da estrutura e os recalques da fundação e os procedimentos a serem adotados para a consideração da interação. A conclusão do autor é que a consideração da rigidez da estrutura conduz a menores recalques diferenciais, devido à redistribuição de esforços no sistema altamente hiperestático. Ressalta-se a propriedade com que o autor, já naquele momento, estabelecia as atribuições do Engenheiro de Estruturas e do Engenheiro Geotécnico. O sumário desse trabalho, devido a sua importância, é transcrito na íntegra, a seguir:

A hipótese, de que os apoios das estruturas hiperestáticas têm infinita facilidade de se adaptarem às deformações do solo, conduz a resultados que se afastam da realidade, mormente em casos como os de ossaturas de arranha-céus. A solidariedade entre os elementos da estrutura confere à mesma considerável rigidez, o que faz com que os recalques diferenciais fiquem bem menos acentuados do que os calculados com a hipótese referida.

A solução rigorosa e geral que o autor dá ao problema da interação estrutura-solo obedece, em tudo, ao que é ortodoxo nos dois campos interessados da engenharia.

Inicialmente indica a maneira usual de calcular os recalques, isto é, sem considerar a rigidez da estrutura, dá as expressões que fornecem as reações dos apoios, as tensões verticais de compressão e os recalques totais nas verticais dos pilares.

Com o fim de apresentar a solução geral do problema da consideração da rigidez da estrutura no cálculo dos recalques da fundação, define os coeficientes de transferência de carga $Q$, que são as reações verticais dos apoios, provenientes de recalques unitários de cada apoio em separado. As reações totais dos apoios são expressas em função dos recalques incógnitos multiplicados pelos correspondentes coeficientes $Q$, donde resulta o sistema de equações simultâneas que, resolvido, fornece os recalques dos apoios com a consideração da rigidez da estrutura.

Em seguida, define e deduz as expressões que fornecem os índices de rigidez à flexão, à torção e à translação das barras, os coeficientes de propagação dos deslocamentos e os deslocamentos primários dos nós para, pelo processo que denominou de "propagação dos deslocamentos», calcular as rotações nos nós e as rotações dos apoios, resultantes de recalques unitários, que são os próprios coeficientes de transferência de carga.

Na marcha de cálculo que o autor sistematiza, tem a preocupação de separar bem as tarefas que cabem ao engenheiro de estruturas e ao 
de solos e fundações. O engenheiro de estruturas confecciona a planta de cargas que deverá conter os coeficientes $Q$, que são constantes elásticas do conjunto estrutural; o engenheiro de solos, de posse desses dados, calcula os recalques da fundação, por correções sucessivas, o que equivale a resolver, por iteração, o sistema geral de equações que considera a rigidez da estrutura. Sendo boa a predominância da diagonal principal da matriz, atingese boa aproximação com uma ou duas correções.

Finaliza, o autor, o seu trabalho, resolvendo um exemplo de um prédio de três andares com nove sapatas, apoiadas sobre um solo que contém uma camada de argila de $9 \mathrm{~m}$ de espessura e que será a responsável pela quase totalidade do recalque.

Observa-se, perfeitamente, como os recalques diferenciais passam a ser menos acentuados quando se considera a rigidez da estrutura no seu cálculo, o que se ajusta aos resultados das medições em estruturas reais.

\subsubsection{INTERAÇÃO SOLO ESTRUTURA}

A definição mais atualizada e completa do objeto de estudo da interação solo estrutura encontra-se em Aoki (2003), a qual é transcrita a seguir.

O objeto de estudo da interação solo-estrutura é a determinação numérica das linhas de estado, nas várias seções transversais dos elementos estruturais discretos, ou dos tensores de tensão, ou deformação em pontos do contínuo maciço de solos. As reações de apoio, ou seja, as resultantes das tensões reativas em pontos indeslocáveis do sistema, surgem ao longo da superfície que delimita o maciço indeformável sob a ação das cargas atuantes. Tendo em vista que o número de pontos da superfície de contorno do maciço indeslocável é infinito, o problema é dito estaticamente indeterminado no mais alto grau, ou nas palavras do professor Costa Nunes, tratase de um sistema geotécnicamente hiperestático.

Finalmente, deve-se considerar que a construção do esqueleto da obra (a estrutura) começa pela instalação de cada elemento isolado de fundação no solo e termina após a execução da última peça estrutural da superestrutura. Portanto, as solicitações e os estados de tensão são, inicialmente, influenciados pelos efeitos de execução $e$, posteriormente, modificados devido às ações externas, num processo de interação que continua ao longo do tempo, até o término da vida útil da obra.

Sob essa visão a interação pode ser analisada segundo um grau de complexidade crescente sob três aspectos, conforme Aoki e Cintra (2003).

O modelo de análise atual denominado de modelo de interação superestrutura - fundação, a superestrutura é o subconjunto formado pelas peças estruturais que não entram em contato com o solo e que aparecem acima do nível do terreno, e a fundação pode ser definida como o subconjunto formado pela subestrutura (infra-estrutura) e pelo maciço de solos que o envolve. O maciço de solos é formado por camadas de solo de gênese e formação natural tão complexas que as tornam únicas. A variabilidade introduzida pelo processo de 
instalação modifica as características naturais e justifica, pelo grau de responsabilidade da modificação envolvido, a importância dos serviços especiais de engenharia de fundações. No método do elemento de contorno o modelo usual do maciço de solos é o do meio elástico, homogêneo, isótropo e semi - infinito.

Sob ação das ações (cargas externas ativas), a superestrutura interage com a fundação nos pontos de ligação (seção da base dos pilares). A superestrutura é normalmente modelada pelo método dos elementos finitos e programas aplicativos comerciais e de vários especialistas encontram-se disponíveis no mercado. Tudo que fica abaixo dos pontos de ligação com a superestrutura constitui a fundação. A compatibilização de deslocamentos nos pontos de contato superestrutura $x$ fundação é o elo de ligação das duas especialidades. Nesses pontos as reações de apoio variam a cada iteração/interação e as novas reações e deslocamentos devem convergir no fim do processo. Resumindo, a análise do equilíbrio das forças atuantes sobre o sistema se dá ao longo do contorno materializado por estes pontos de ligação.

Como os modelos de cálculo da interação dependem da definição do contorno onde se procede à análise do equilíbrio, deve-se recordar as noções fundamentais de forças ativas, forças reativas e reações de apoio, que podem ser encontradas no excelente livro de Resistência dos Materiais do professor Schiel. Observe-se que o termo restrito força é usado apenas para facilitar a compreensão do conceito, que envolve seis graus de liberdade. Dessas noções decorre o modelo alternativo de cálculo, onde se procede à análise do equilíbrio das forças ao longo do contorno correspondente à superfície de interface entre a subestrutura e o maciço de solos. Nessa visão, a estrutura, formada pela subestrutura mais a superestrutura, é que interage com o maciço de solos.

\section{i) Estaca isolada}

Na Figura 2.1 apresentam-se as condições de equilíbrio de um elemento isolado de fundação.

Em (a) apresenta-se a visão tradicional do problema.

Em (b) é mostrada a condição de equilíbrio geral do sistema, na qual a força externa $(P)$ é equilibrada por um sistema de forças internas ( $R$ - reações de apoio) que se desenvolve ao longo da superfície indeslocável.

No quadro (c) apresenta-se o equilíbrio do elemento estrutural de fundação, em que a força externa $(P)$ é equilibrada pela resistência lateral $\left(P_{L}\right)$ e pela ponta $\left(P_{p}\right)$.

Finalmente em (d) é apresentada a condição de equilíbrio do maciço de solo. Nela as forças reativas internas $\left(P_{L}\right)$ e $\left(P_{p}\right)$ são equilibradas pela reação de apoio (R). 


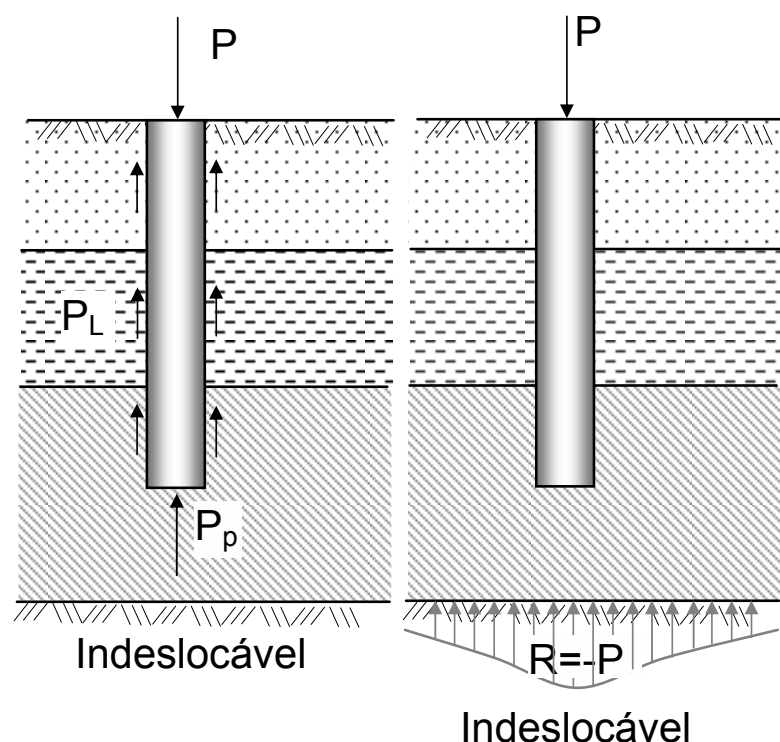

a)

b)

Figura 2.1 - Condição de equilíbrio de um elemento isolado de fundação.

ii) Grupo de estacas com bloco rígido

A condição de equilíbrio é similar à de elemento isolado.

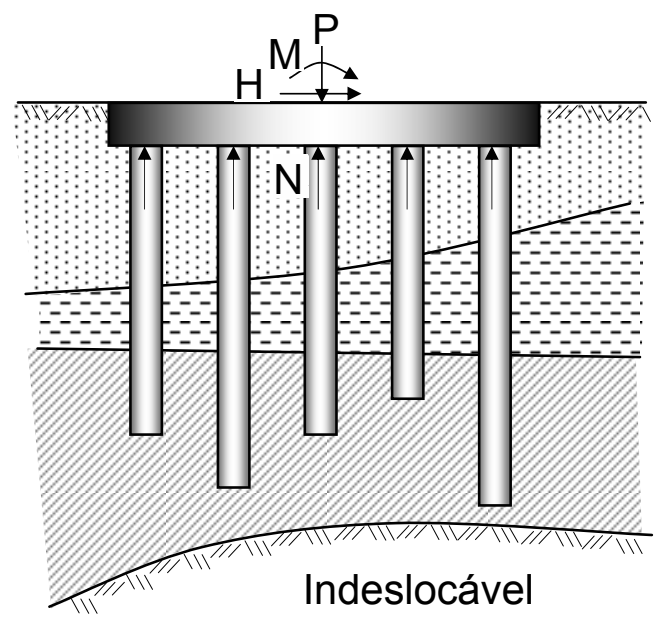

Figura 2.2 - Grupo de estacas com bloco rígido.

iii) Pórtico sobre grupo de estacas

O equilíbrio geral do sistema formado pela superestrutura e a subestrutura ou fundação (conjunto de estacas e maciço de solo) se dá entre as forças ativas externas (gravitacionais, ambientais etc.), representadas pela sua resultante $(F)$, Figura 2.3, e as forças reativas internas que se desenvolvem ao longo da superfície indeslocável, representadas por (R). 


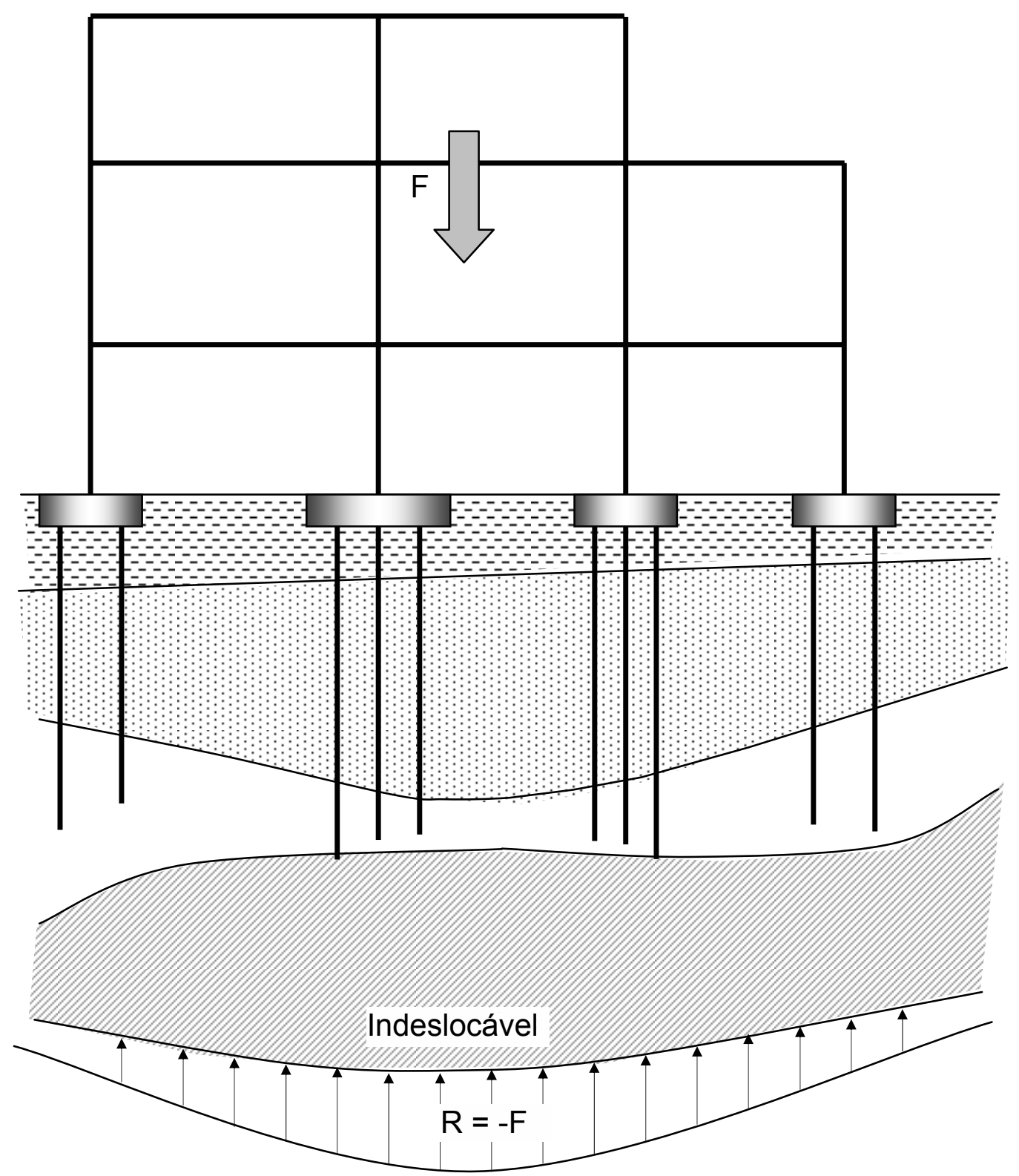

Figura 2.3 - Pórtico sobre grupo de estacas - equilíbrio do sistema global.

O sistema global pode ser subdividido em dois subsistemas (superestrutura e fundação ou subestrutura), nos quais o equilíbrio se dá conforme apresentado na Figura 2.4.

$\mathrm{Na}$ superestrutura, o equilíbrio entre as forças externas $(\mathrm{F})$ ocorre ao longo de uma superfície delimitada entre o contato do pilar e o bloco de fundação pelo conjunto de reações de apoio $(\Sigma R)$, chamadas "cargas nos pilares".

Para a fundação, o equilíbrio se dá entre as forças internas reativas $(\Sigma R)$ e a reação de apoio ao longo da superfície indeslocável (R). 

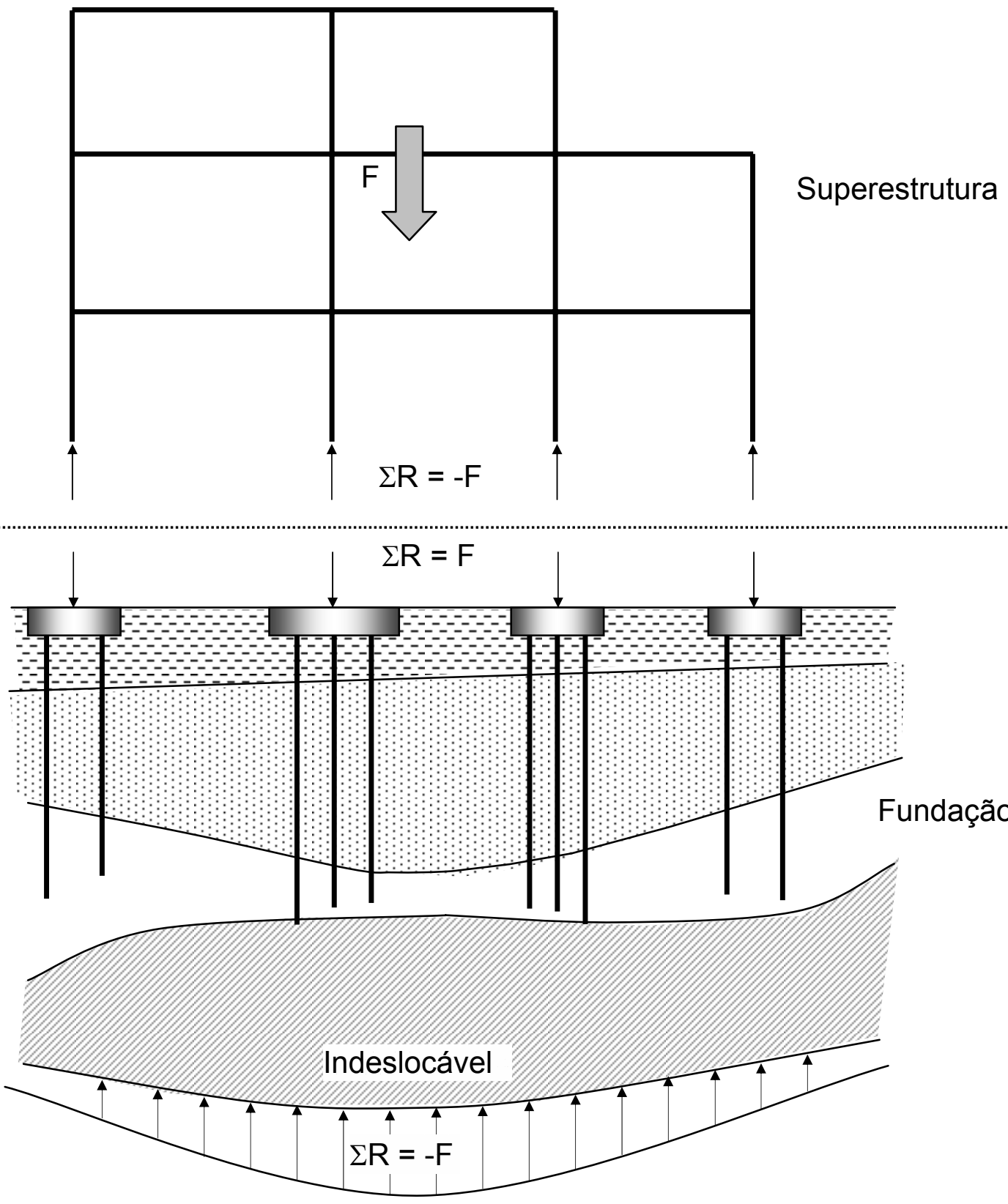

Figura 2.4 - Pórtico sobre grupo de estacas - equilibrio da superestrutura e da fundação.

Finalmente, pode-se considerar que a estrutura é delimitada pelo contorno dos elementos estruturais da subestrutura; o equilíbrio verifica-se conforme ilustrado na Figura 2.5. 

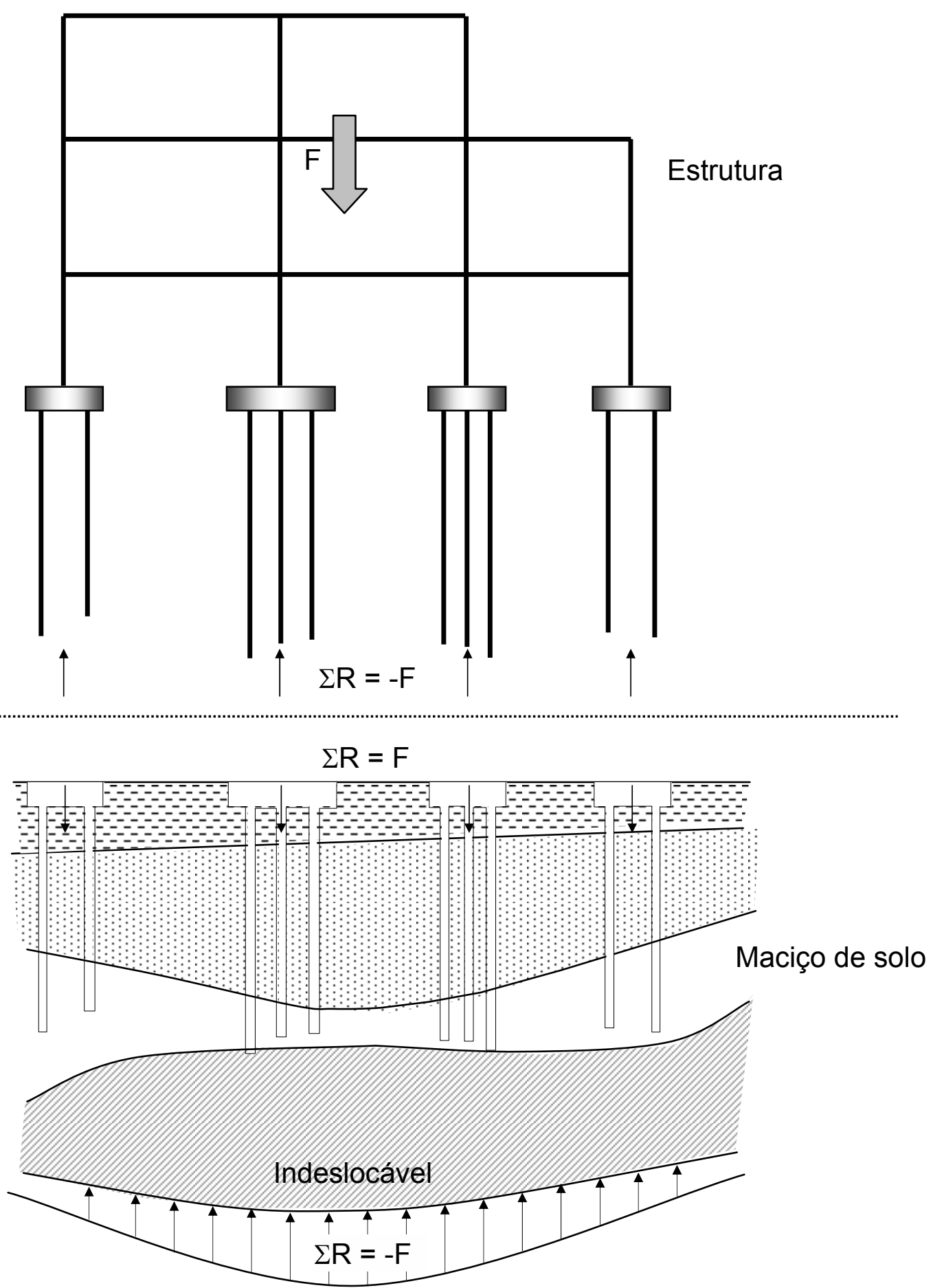

Figura 2.5 - Pórtico sobre grupo de estacas - equilíbrio da estrutura e do maciço de solo

\subsubsection{Modelo de Cálculo.}

De maneira similar à proposta inicialmente por Chamecki (1954), Aoki e Cintra (2003) sugerem adotar o seguinte roteiro: 
Trata-se do modelo de cálculo mais simples. Neste caso deve-se reconhecer a existência de duas especialidades que tratam do problema, que é o cálculo estrutural do sistema formado pela superestrutura e a fundação de uma edificação: a engenharia de estruturas e a engenharia de solos.

O ponto de convergência é o cálculo das cargas nos pilares, que deve ser o objeto da preocupação inicial de nossa análise. Isso porque sem as cargas não se pode prever a bacia de recalques e sem os recalques não se pode estimar a rigidez das molas de apoio da estrutura. Para resolver essa situação de interdependência, procede-se iterativamente do seguinte modo:

- inicialmente, o engenheiro estrutural calcula as cargas nos pilares, considerando que as fundações não recalcam;

- a partir dessas cargas o engenheiro de fundações calcula os recalques considerando que a rigidez da estrutura é nula obtendo a bacia de recalques inicial;

- o engenheiro estrutural divide as cargas pelos recalques e obtém os coeficientes de mola iniciais para cada pilar e recalcula as cargas nos pilares considerando a estrutura sobre apoios elásticos;

- a partir dessas novas cargas o engenheiro de fundações recalcula os recalques considerando que a rigidez da estrutura é nula, obtendo nova bacia de recalques;

- o engenheiro estrutural reavalia os novos coeficientes de mola a partir desta nova bacia de recalques, recalcula as cargas nos pilares e os reenvia ao geotécnico.

O processo é iterativo até que se atinja a convergência desejada. Pode-se concluir que, no mínimo, deve haver completa interação entre aquelas duas especialidades da engenharia.

Esse procedimento pode ser expresso segundo uma notação matricial, conforme proposto por Poulos (1975). Para a superestrutura é possível escrever:

$$
\{\mathrm{V}\}=\left\{\mathrm{V}_{0}\right\}+[\mathrm{SM}]\{\delta\}
$$

onde:

$\{V\}$ - vetor de reações na base da superestrutura.

$\left\{V_{0}\right\}$ - vetor de reações na base da superestrutura para o apoio indeslocável.

[SM] - matriz de rigidez, determinada pela imposição de deslocamentos unitários nos apoios da superestrutura.

$\{\delta\}$ - vetor de recalques na base da superestrutura.

Para a subestrutura (maciço de solo e elementos estruturais de fundação) a formulação matricial pode ser expressa por: 


$$
\{\delta\}=[\mathrm{FM}]\{\mathrm{V}\}
$$

onde:

[FM] - matriz de flexibilidade da fundação.

Combinando-se as equações (2.1) e (2.2), obtém-se a expressão que leva em conta a rigidez da superestrutura e a flexibilidade da subestrutura:

$$
\begin{aligned}
& \{\mathrm{V}\}=\left\{\mathrm{V}_{0}\right\}+[\mathrm{SM}][\mathrm{FM}]\{\delta\} \\
& \left\{\mathrm{V}_{0}\right\}=([\mathrm{I}]-[\mathrm{SM}][\mathrm{FM}])\{\mathrm{V}\}
\end{aligned}
$$

sendo:

[l] - a matriz identidade.

A solução da equação (2.4) fornece as incógnitas $\{\mathrm{V}\}$, reações de apoio da superestrutura e, com estas através da equação (2.2), determinam-se os recalques.

Considerando o modelo completo de cargas e deslocamentos, existirão seis componentes de reação (três forças e três momentos) e seis componentes de deslocamento (três translações e três rotações) em cada apoio. Sendo (n) o número de apoios da estrutura, os vetores acima definidos serão de ordem (6n), e as matrizes de rigidez e flexibilidade serão representadas por matrizes quadradas de dimensão ( $6 n \times 6 n)$. Como o deslocamento em um apoio pode não depender apenas de seu carregamento, mas também do carregamento dos demais apoios, implica que, em termos matriciais, os elementos fora da diagonal principal das matrizes de rigidez e flexibilidade podem não ser nulos.

\subsubsection{Efeitos da Interação Solo Estrutura.}

Segundo Gusmão (2000), a interação influencia a deformada de recalques da edificação, suavizando-a devido aos efeitos de redistribuição de cargas na superestrutura. Neste trabalho é apresentada tabela na qual são mostradas as conseqüências da interação solo estrutura em função das hipóteses de projeto. 
Tabela 2.1 - Efeitos da interação solo estrutura em edifícios, in Gusmão (2000).

HIPÓTESE

Apoios são considerados Redistribuição de cargas e esforços nos elementos indeslocáveis.

\section{CONSEQÜÊNCIAS}

estruturais, especialmente vigas e pilares.
Alívio de carga nos pilares mais carregados e sobrecarga nos pilares menos carregados.

Pode haver danos nos elementos estruturais.

Apoios podem recalcar $A$ ligação entre os elementos estruturais confere à de maneira independente estrutura uma rigidez que restringe os recalques uns dos outros.

diferenciais.

A deformada de recalques medida é mais suave que a estimada convencionalmente.

Há uma tendência de uniformização dos recalques.

O carregamento do À medida que a estrutura vai sendo construída, vai prédio só ocorre ao final havendo um aumento do seu carregamento e dos da sua construção.

Há, no entanto, um aumento da rigidez da estrutura, que faz com que haja uma tendência de uniformização dos recalques.

Há uma altura limite, correspondente aos cinco primeiros pavimentos, em que praticamente não há mais aumento da rigidez para fins de uniformização dos recalques.

Moura (1995) conclui que os momentos fletores nos pilares, introduzidos pela interação solo estrutura, são maiores nos primeiros andares e diminuem à medida que o número de andares cresce. Considera que, embora a distribuição das solicitações (momentos fletores em vigas e pilares) seja bem mais forte nos primeiros andares, pode, em alguns casos, dependendo da rigidez da superestrutura, propagar-se aos andares superiores.

Jordão (2003) desenvolve análise de interação solo estrutura no qual não apenas a rigidez vertical da fundação é levada em consideração. A análise envolve os seis graus de liberdade dos apoios, os quais são modelados por meio de molas. Conclui que a consideração da interação influi na estabilidade global da estrutura.

\subsubsection{Influência da Seqüência de Construção.}

Segundo Goshy (1978), a rigidez real da superestrutura aumenta gradualmente com o processo de construção e carregamento. Assim, para os primeiros incrementos de carga, a estrutura se comporta como viga em meio elástico. Para os estágios sucessivos há um aumento da rigidez da 
superestrutura. O autor conclui que há uma diminuição da taxa de crescimento das distorções angulares à medida que novos pavimentos são acrescentados à superestrutura.

Fonte et al. (1994) apresentam análise de um edifício de quatorze pavimentos, levando em consideração a seqüência de construção. Os resultados da análise que mais se aproximam dos recalques diferenciais medidos são aqueles determinados pelos modelos que levaram em consideração a seqüência de construção. Para aqueles autores, o modelo que considera a aplicação total do carregamento subestima os recalques diferenciais devido à consideração implícita de uma rigidez maior que a real.

Moura (1995) conclui que há grande influência do efeito construtivo incremental nos esforços normais finais decorrentes da interação solo estrutura. No caso analisado, embora o efeito incremental tenha sido pequeno na avaliação dos recalques e cargas nos pilares, mostra-se importante na avaliação dos esforços nas vigas da superestrutura.

Gusmão Filho (1995) apresenta ilustração do efeito da seqüência de construção na análise de interação, reproduzida na Figura 2.6. Afirma que, durante a construção, a carga média dos pilares cresce, tendo como conseqüência o aumento do recalque médio. No entanto, o aumento da rigidez da superestrutura faz com que haja uma tendência de uniformização dos recalques, manifestada por uma diminuição no coeficiente de variação.
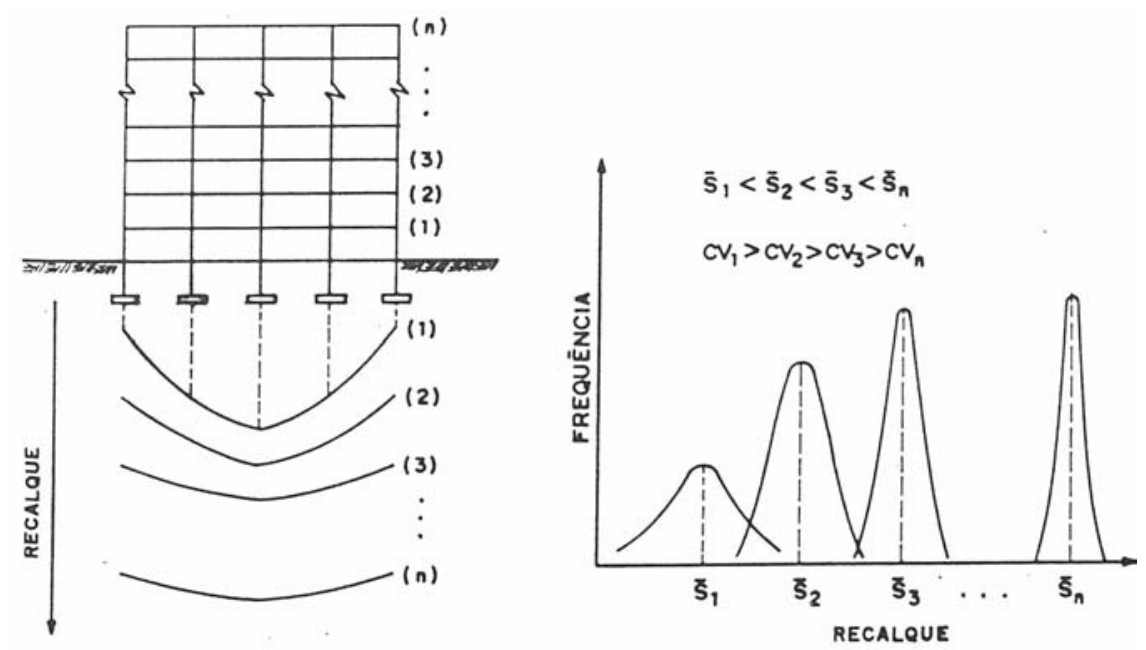

Figura 2.6 - Efeito da seqüência construtiva, in Gusmão Filho (1995) 
Iwamoto (2000) ressalta que a não consideração da seqüência construtiva na análise pode levar o projetista de estruturas à estimativa de um comportamento estrutural distinto do real. Como na prática a estrutura recebe acréscimo de cargas e aumento da rigidez para cada pavimento levantado, e eles dependem também da velocidade de construção (idade do concreto e tempo de escoramento, ou seja, a reologia do material concreto durante e depois da construção), suas conseqüências na redistribuição das reações, recalques e esforços nos elementos estruturais podem apresentar diferenças significativas em relação aos modelos com carregamento instantâneo e edifício totalmente construído.

\subsubsection{Influência do Comportamento Visco-Elástico dos Materiais.}

Santa Maria et al. (1999) apresentam metodologia para análise de vigas contínuas com apoios visco-elásticos. O método é ilustrado com dois exemplos, onde a interação solo estrutura é estudada. O primeiro considera o caso da viga apresentar comportamento elástico instantâneo, e o segundo adicionalmente leva em conta o comportamento visco-elástico da viga.

Concluem que tanto os esforços solicitantes na viga, bem como as ações e recalques nos apoios, variam ao longo do tempo. Para o caso analisado podem ocorrer erros contra a segurança, tanto no comportamento da viga como no das fundações, se o comportamento visco-elástico dos materiais envolvidos não for considerado.

\subsection{AVALIAÇÃO DE DESEMPENHO.}

A medida de recalques, como ferramenta de avaliação de desempenho de estruturas nas suas condições reais, é fator primordial no estudo e avaliação da interação solo estrutura.

A NBR 6122, ABNT (1996), recomenda em seu item 9, "Observação do comportamento e instrumentação de obras de fundação", a medida de recalques, visando:

a) acompanhar desempenho da fundação;

b) esclarecer anormalidades constatadas em obra;

c) ampliar a experiência local quanto ao desempenho da fundação; 
d) permitir a comparação de valores medidos com os calculados, visando aperfeiçoamento dos métodos de previsão de recalques.

Silveira (1975), durante a realização do Simpósio sobre Instrumentação de Campo, sugere a observação sistemática do comportamento das fundações, sobretudo das fundações profundas. Considera que uma campanha organizada de medidas de tensões no topo e na base de tubulões traria inestimável auxílio para uma estimativa mais objetiva do real significado das cargas estruturais que são fornecidas pelos engenheiros de estruturas. Conclui, afirmando que a instrumentação é um meio que, utilizado de maneira adequada, criteriosa e objetiva, pode ser muito útil à Engenharia de Solos e Fundações.

Niyama et al (1996), consideram que a medida de recalque é a verificação do desempenho global da fundação, permitindo observar o comportamento da interação solo estrutura do conjunto. Consideram os autores que o procedimento é recomendável para qualquer tipo de obra, mas que na prática tem sido pouco empregada. Complementam afirmando que existe um entendimento equivocado de que só se faz medida de recalques se a estrutura apresenta problemas ou se possa apresentá-los.

Alonso (1995) afirma que as medidas de recalques devem ser complementadas por uma estimativa de cargas atuantes nos pilares por ocasião da medição, e que essas cargas podem ser estimadas a partir do projeto estrutural da obra em questão.

O emprego dos equipamentos de instrumentação de campo, como ferramenta de avaliação de desempenho, implica na realização de uma medida e cada medida envolve um erro ou incerteza. Segundo Dunnicliff (1993), os termos associados a essas incertezas são:

a) Conformação - idealmente a presença do instrumento de medida não deve alterar o parâmetro que está sujeito à avaliação.

b) Acurácia - indica a proximidade entre o valor medido e o real valor presente nessa medida.

c) Precisão - refere-se à repetitibilidade de uma determinada medida.

O autor apresenta figura na qual a diferença entre esses dois últimos termos pode ser mais bem entendida e encontra-se reproduzida na Figura 2.7, que indica o resultado de três medidas efetuadas (pontos negros) em relação 
ao valor real presente (centro do conjunto de círculos). Na figura à esquerda, embora as três medidas indiquem um mesmo valor (são repetidas), elas se encontram afastadas em relação ao centro do alvo. Na parte central, conquanto exista dispersão nos valores medidos, esses são próximos ao valor real pela sua média. A representação à direita indica medidas com acurácia e precisão.

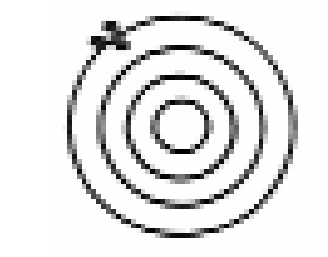

Preciso mas sem acurácia

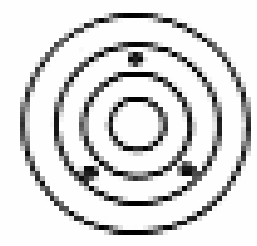

Sem precisão mas média apresenta acurácia

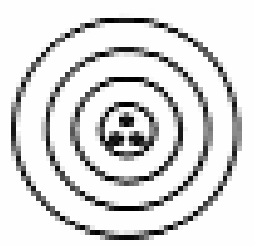

Preciso e com acurácia

Figura 2.7 - Definição de acurácia e precisão, Dunnicliff, 1993.

\subsubsection{MEDIDA DE RECALQUES.}

A prática atual de medidas de recalques, descrita por diversos autores, como, por exemplo, Danziger (1997), Danziger e Crispel (2000) e Alonso (1995), envolve a realização de um nivelamento ótico de precisão, tomando-se por base uma referência de nível profunda, efetuado em pontos fixos na estrutura na qual pretende-se medir os deslocamentos verticais.

A Figura 2.8 ilustra, esquematicamente, 0 arranjo dos elementos envolvidos no processo.

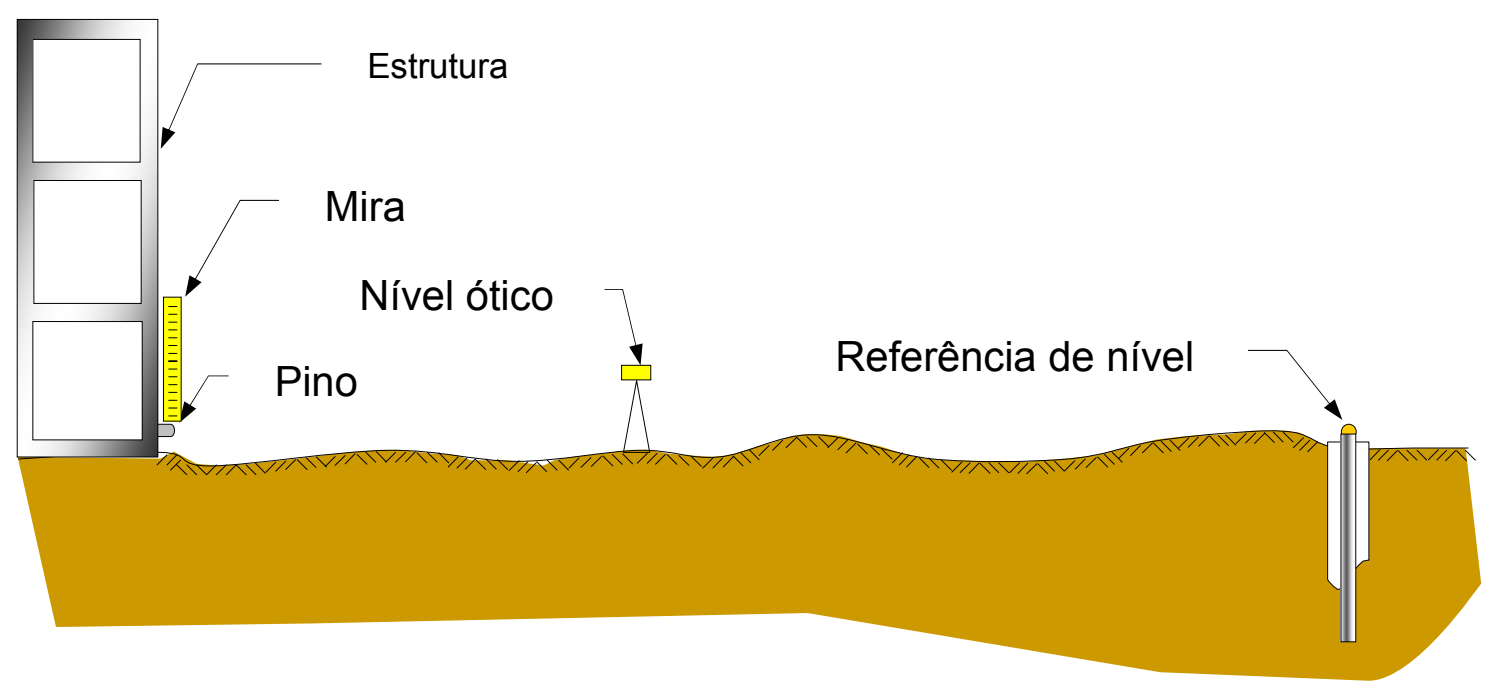

Figura 2.8 - Arranjo esquemático de medida de recalques com uso de nivelamento ótico. 
Estão envolvidos no referido processo os seguintes elementos:

a) Nível ótico.

b) Mira.

c) Pino de recalque.

d) Referência de nível profunda.

São tecidos, a seguir, comentários sobre detalhes e cuidados que devem ser observados com cada um daqueles elementos. Esses comentários são também fruto da vivência do autor iniciada, em sua pesquisa de Mestrado, Russo Neto (1980).

\subsubsection{Nível ótico.}

O nível ótico a ser empregado deve ser dotado de placa plano paralela, munida de micrômetro. Os modelos empregados normalmente são o Wild NA2/ NA3 ou o Zeiss NI002, ver Figura 2.9. Deve ser evitado qualquer tipo de choque ou queda do aparelho, pois isso provoca o desvio do eixo ótico.

Recomenda-se que o instrumento, após ser instalado e calado, seja protegido contra eventuais variações de temperatura. O uso de um guarda-sol minimiza tais efeitos.

A aferição do aparelho é efetuada por empresas especializadas com o uso de colimador, recomendando-se anualmente proceder à sua calibração.

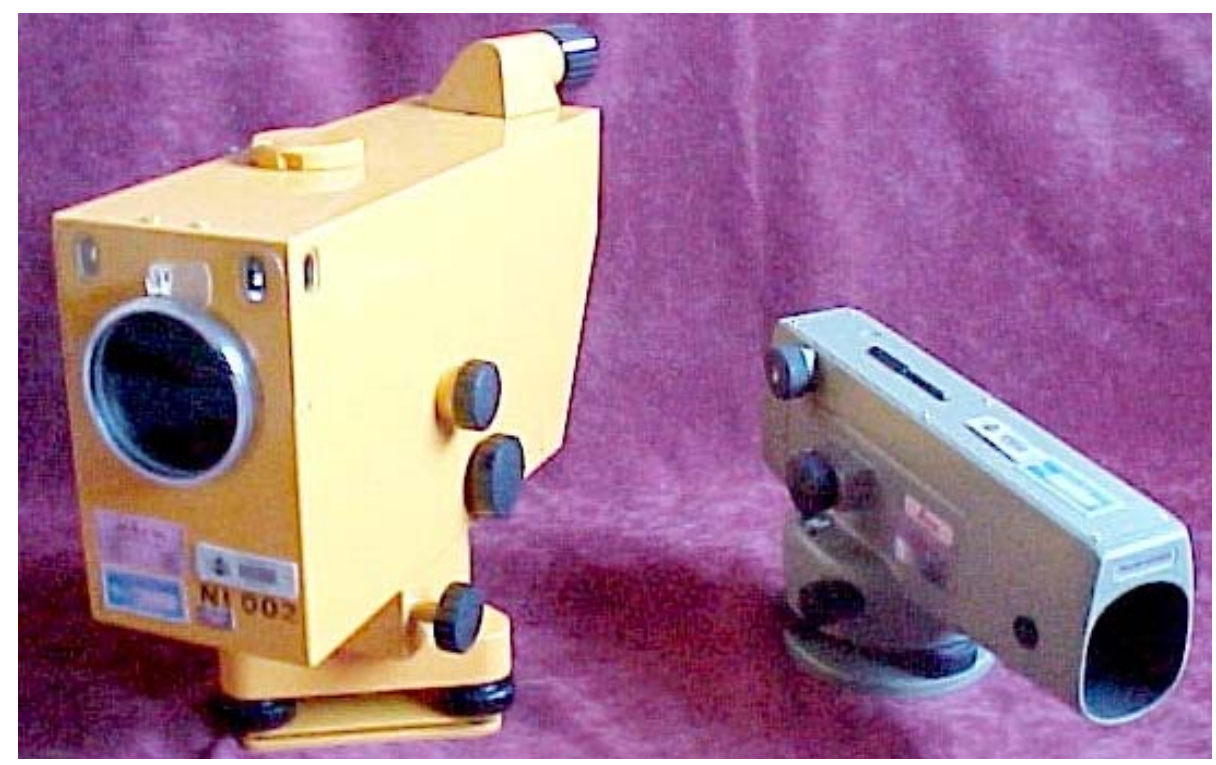

Figura 2.9 - Foto dos níveis Zeiss NI002 e Wild NA2. 
2.2.1.2 Mira.

A mira a ser utilizada deve ter sua escala graduada em chapa de ínvar, evitando efeitos de dilatação térmica. Deve ser dotada de nível tipo bolha fixo ao seu corpo. As miras podem ter graduação a cada $1 \mathrm{~cm}$ ou a cada $5 \mathrm{dm}$. Algumas miras apresentam dupla escala de graduação. No caso do uso do nível Wild NA2, com mira graduada a cada $5 \mathrm{dm}$ e dupla escala de graduação, é possível efetuar quatro leituras em cada visada. A Figura 2.10 apresenta foto da mira apoiada sobre o pino de recalque.

Recomenda-se que as leituras sejam efetuadas sempre que possível com o mesmo operador, tanto do nível como da mira. O operador deve cuidar para que a base da mira esteja sempre limpa. A calibração da mira é feita por empresas especializadas e deve ter freqüência anual.

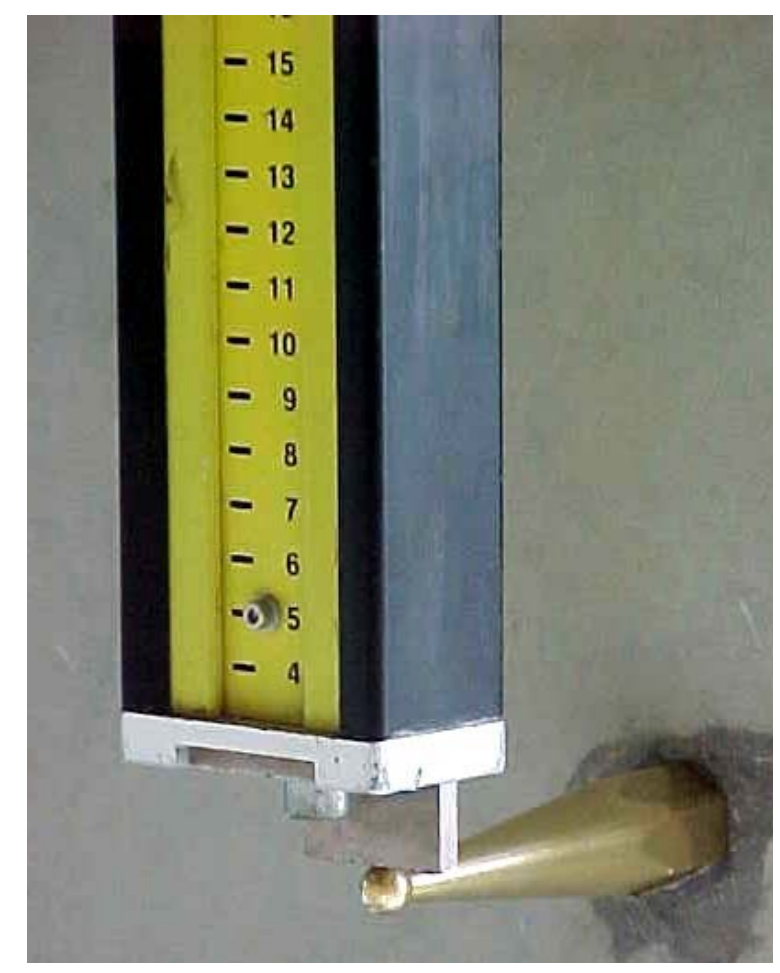

Figura 2.10 - Foto detalhe da mira apoiada sobre o pino.

A leitura é efetuada, buscando a coincidência de traços entre o fio horizontal do aparelho e a marca na mira. Obtida essa coincidência de traços, a leitura complementar é feita no micrômetro do interior do aparelho, conforme mostra a Figura 2.11. 


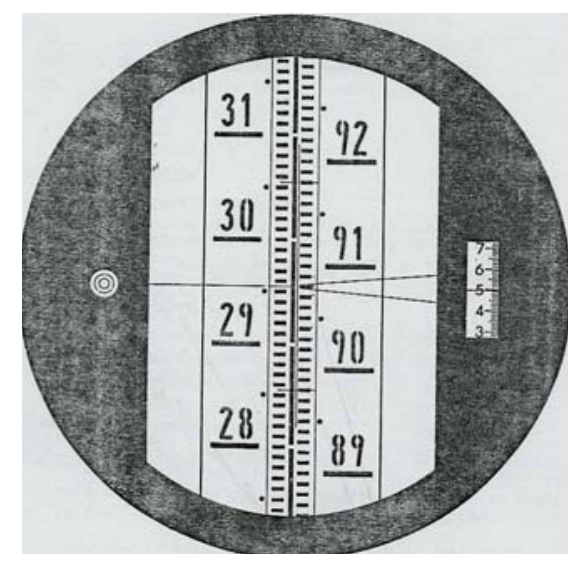

Figura 2.11 - Detalhe da visada, mostrando a coincidência de traços e o micrômetro interno.

\subsubsection{Pino de recalque.}

O pino de recalque é normalmente confeccionado em latão com uma extremidade esférica sobre a qual é apoiada a mira. É composto por dois elementos: o pino fêmea, elemento cilíndrico em latão com tampa rosqueável, que é fixado com uso de resina epóxi à estrutura em orifícios executados normalmente próximos à base do pilar; o pino macho, removível, o qual é rosqueado aos pinos fêmeas nos pontos de medida, no momento da leitura. Recomenda-se o uso de um pino macho reserva para o caso de eventual dano ao elemento removível.

Pode-se utilizar um sistema mais simples e de uso mais rápido, no qual o pino não é removível e fica fixo ao pilar por meio de resina epóxi. Embora ocorra uma maior facilidade de operação nesse arranjo ele fica muito susceptível a danos causados pelas atividades da obra.

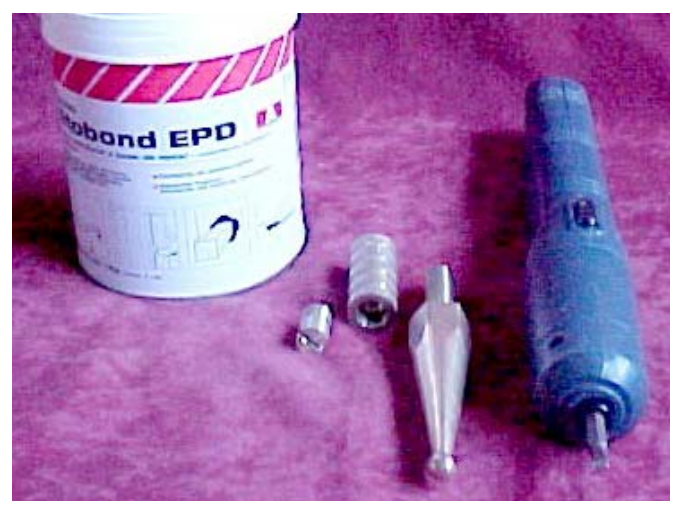

Figura 2.12 - Foto detalhe de resina epóxi, tampa, pino fêmea, pino macho e chave de fenda elétrica. 


\subsubsection{Referência de nível.}

A referência de nível recomendada para uma boa precisão e confiabilidade deve ser do tipo profunda ou "bench-mark". A Norma Brasileira Segurança de escavação a céu aberto (ABNT, 1985) apresenta arranjo esquemático para esse tipo de instrumento. Referências superficiais tipo meiofio, poste, devem ser evitadas, pois estão sujeitas a deslocamentos que não serão percebidos. É o elemento de maior custo. Recomenda-se instalar mais de uma referência de nível no local, de modo a que seja possível aferir eventuais deslocamentos e propiciar um elemento de reserva contra eventuais acidentes de obra.

A título de resgate histórico reproduz-se, a seguir, figura apresentada em Taylor (1948), na qual é mostrado esquema de uma referência de nível profunda empregada em 1927 para monitoramento de recalques de um prédio do MIT.

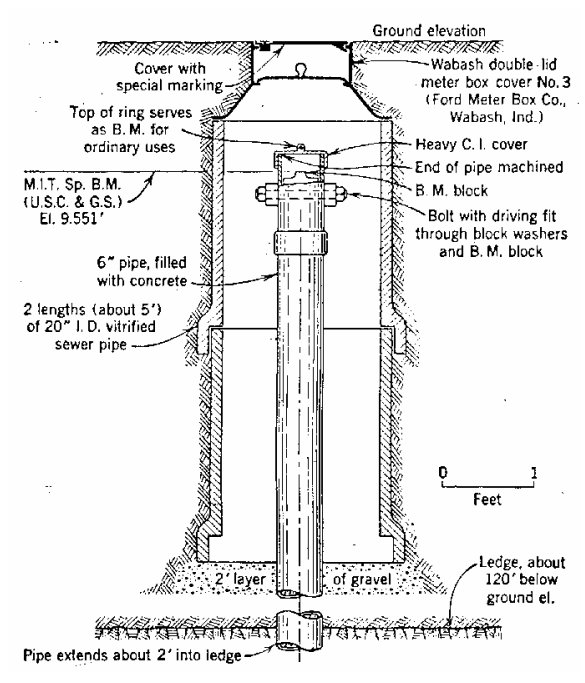

Figura 2.13 - Representação esquemática de "bench-mark", in Taylor (1948).

A referência de nível profunda é executada em furos de sondagem de diâmetro superior a três polegadas, os quais devem se estender preferencialmente até o estrato rochoso. Um tubo externo de revestimento preenchido por graxa grafitada protege uma haste central de eventuais movimentos do terreno. A haste central deve ser chumbada no estrato indeformável com uso de calda de cimento, tendo na sua extremidade superior um elemento esférico de latão, sobre o qual será apoiada a mira. É desejável 
que o topo deste instrumento seja protegido por uma caixa com tampa e chave. A Figura 2.14 apresenta visão do topo de uma referência de nível profunda.

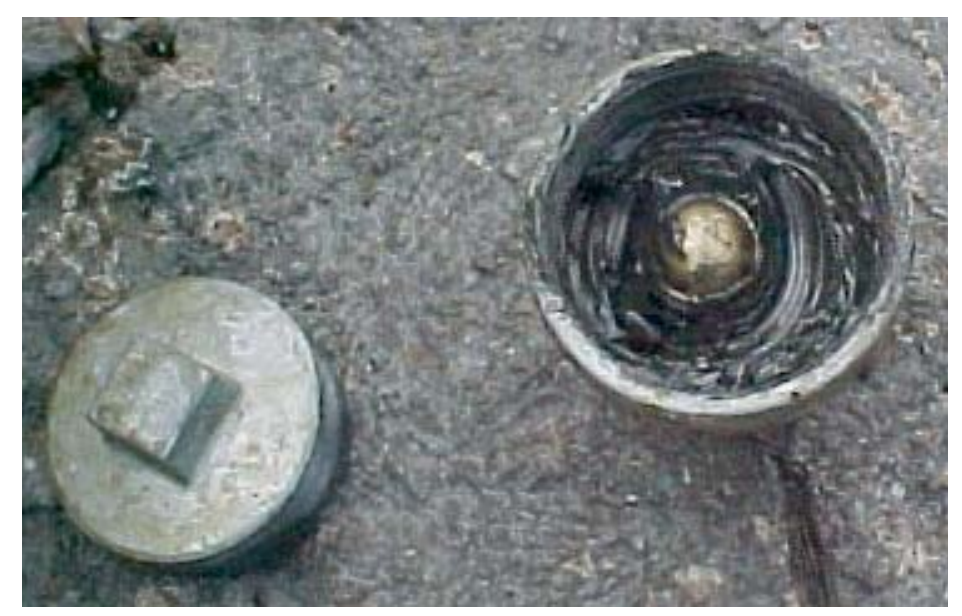

Figura 2.14 - Foto referência de nível profunda.

\subsubsection{MEDIDAS DE SOLICITAÇÕES EM PEÇAS ESTRUTURAIS.}

Outro elemento importante na interação solo estrutura é a avaliação da real solicitação a que estão submetidas as peças dos elementos da superestrutura e, em especial, a "carga nos pilares". O assunto é de domínio dos Engenheiros Estruturais o qual denominam de "Análise Experimental".

Takeya (2000) afirma que as medidas de tensão não são feitas diretamente pelos instrumentos atualmente disponíveis; o que se faz é a medida de uma deformação, a qual é posteriormente transformada em tensão, se for conhecida a relação entre tensão e deformação do material de que é constituída a estrutura em questão.

Segundo Dunniclliff (1993), medidas de cargas e deformações em elementos estruturais podem ser realizadas por meio de:

a) células de carga ("load cells") e

b) medidores de deformação ("strain gages").

As células de carga são inseridas na estrutura, de modo a que as solicitações internas "passem" através do equipamento. Os medidores de deformação podem ser fixados externamente ao elemento estrutural, ou embutidos em seu interior de modo a medir alongamentos e encurtamentos na estrutura. 
Os medidores de deformação são usados quando há impossibilidade do uso de células de carga por questões de geometria, capacidade ou economia, e quando as solicitações ou tensões podem ser calculadas adequadamente a partir do conhecimento da relação tensão deformação do sistema que compõe o elemento estrutural em questão.

Dunnicliff (1993) classifica os medidores de deformações em:

a) portáteis;

b) "scratch";

c) hastes múltiplas;

d) corda vibrante;

e) resistência elétrica.

O presente trabalho irá ater-se apenas a instrumentos do tipo medidor de deformação instalado na superfície do elemento estrutural do tipo portátil ou extensômetro mecânico de haste.

Em linhas gerais, esse equipamento é composto por uma haste de ínvar, na qual é fixado um relógio comparador ou extensômetro mecânico, sendo que esse conjunto irá medir as variações de comprimento entre dois pontos fixos do elemento estrutural. O uso do ínvar visa diminuir os efeitos de variação de temperatura no equipamento. Além da haste, uma base de referência de comprimento padrão, também em ínvar, compõe o equipamento. Exemplos de aplicação desse equipamento podem ser consultados em Base (1955), Morice e Base (1953), Cording et al. (1975), ISRM (1984), Castro (1985) e Gonçalves (2004).

A Tabela 2.2 reproduz as principais características dos extensômetros mecânicos de haste, conforme apresentado por Dunnicliff (1993).

As leituras fornecidas por um medidor de deformação são de pouco interesse. O objetivo final delas é a de determinar a solicitação ou tensão que está atuando no elemento estrutural. No caso de peças de aço, desde que seja conhecido o seu módulo de elasticidade e a temperatura no momento da medição, a transformação de deformação em tensão é direta. Já para o caso de peças em concreto armado o problema torna-se um pouco mais complicado, pois as deformações no concreto não são devidas apenas à variação de tensão ou variação da temperatura. Para esse material, as deformações também são devidas à fluência (deformação sob carga constante), contração e expansão 
(devidas à variação da umidade relativa do ar) e deformações devidas à cura do concreto.

Tabela 2.2 - Principais características dos extensômetros mecânicos, in Dunnicliff (1993).

\begin{tabular}{ll}
\hline Vantagens & - Simples \\
& - Baixo custo \\
& - Não é necessário impermeabilizar \\
& - Calibração pode ser realizada em qualquer \\
& instante \\
& - Não utiliza partes delicadas fixas à estrutura \\
& - Requer acesso à estrutura \\
Limitações & • Necessita extremo cuidado nas leituras \\
Comprimentos típicos $(\mathrm{mm})$ & 50 a 2000 \\
Faixa de medida típica $(\mu \varepsilon)$ & Até 50000 \\
Sensibilidade $(\mu \varepsilon)$ & 3 a 50 \\
Precisão aproximada $(\mu \varepsilon)$ & \pm 5 a 200 \\
\hline
\end{tabular}

As deformações devidas à variação de temperatura $\left(\varepsilon_{\mathrm{c} T}\right)$ podem ser estimadas através da expressão:

$$
\varepsilon_{c T}=\alpha \times \Delta T
$$

onde:

$\alpha$ - coeficiente de dilatação térmica do concreto armado;

$\Delta \mathrm{T}$ - variação de temperatura.

A Tabela 2.3, transcrita de Dunnicliff (1993), apresenta valores do coeficiente de dilatação térmica, $(\alpha)$ expressos em $\mu \varepsilon /{ }^{\circ} \mathrm{C}$ para diferentes materiais, na qual é possível verificar que o ínvar apresenta menores valores.

Também é necessário considerar que, para o caso do concreto armado, o estabelecimento de um módulo de elasticidade único pode conduzir a erros significativos devidos a incertezas na sua definição. O módulo do concreto armado pode variar de ponto a ponto devido a variações nas propriedades do mesmo devidas a vazios, umidade retida e ao adensamento do concreto. 
Tabela 2.3 - Coeficiente de dilatação térmica para diversos materiais, in Dunnicliff (1993).

\begin{tabular}{lclc}
\hline LIGAS E METAIS & $\alpha\left(\mu \varepsilon /{ }^{\circ} \mathrm{C}\right)$ & ROCHAS E ALVENARIA & $\alpha\left(\mu \varepsilon /{ }^{\circ} \mathrm{C}\right)$ \\
\hline Alumínio & 23,1 & Alvenaria de tijolos & 6,1 \\
Latão & 18,8 & Concreto & 10 a 13 \\
Cobre & 16 & Granito & 8,0 \\
Ínvar & 1,4 & Gesso & 7,6 \\
Ferro & 10,6 & Mármore & 8,1 \\
Aço & 12,0 & Arenito & 9,7 \\
Aço inoxidável & 17,8 & Ardósia & 8,0 \\
Super-ínvar & 0,4 & & \\
\hline
\end{tabular}

Dunnicliff (1993) sugere, como alternativa para solucionar o problema do estabelecimento de uma relação tensão deformação para as peças de concreto armado, a instalação de uma célula de carga em um dos elementos monitorados e, a partir da relação tensão deformação determinada pela célula de carga, aplicá-la aos demais elementos envolvidos.

Para o caso de monitoramento da solicitação normal em um conjunto de pilares é possível determinar uma relação tensão deformação média, desde que seja conhecido o valor total da ação externa (peso total) aplicada, conforme dado pela expressão a seguir:

$$
E_{c m}=\frac{\frac{\sum P_{i}}{\sum A_{i}}}{\sum \varepsilon_{i}}
$$

sendo

$\mathrm{E}_{\mathrm{cm}}$ - módulo de elasticidade médio do concreto armado;

$\Sigma \mathrm{P}_{\mathrm{i}}$ - ação externa total aplicada;

$\Sigma \mathrm{A}_{\mathrm{i}}$ - somatória das seções transversais dos elementos;

$\Sigma \varepsilon_{\mathrm{i}}-$ somatória das deformações medidas.

As solicitações normais individuais $\left(\mathrm{P}_{\mathrm{i}}\right)$ podem, então, ser determinadas por:

$$
P_{i}=E_{c m} \times \varepsilon_{i} \times A_{i}
$$


Dunnicliff (1993) considera que as deformações devidas à fluência e à retração não são importantes se o programa de monitoramento envolver um período de poucos dias. Já se esse programa se estender por semanas ou meses, essas deformações serão significantes. Considera, também, que podem ser avaliadas pelo uso de funções de fluência estabelecidas em diversos códigos.

Uma vez calculadas as deformações por fluência $\left(\varepsilon_{c c}\right)$, as devidas à retração $\left(\varepsilon_{\mathrm{cs}}\right)$ e as deformações devidas à variação de temperatura $\left(\varepsilon_{\mathrm{c} T}\right)$, essas são subtraídas dos valores medidos $\left(\varepsilon_{c}\right)$ de modo a determinar as deformações decorrentes apenas da variação de tensões $\left(\varepsilon_{\mathrm{ci}}\right)$.

$$
\varepsilon_{c i}=\varepsilon_{c}-\varepsilon_{c c}-\varepsilon_{c s}-\varepsilon_{c T}
$$

2.2.2.1 Extensômetros mecânicos.

Os extensômetros mecânicos permitem medida de deformação da ordem de $8 \times 10^{-5}$ a $1 \times 10^{-5}$. Um exemplo desse tipo de instrumento é o modelo Tensotast, fabricado pela Huggenberg, e apresentado na Figura 2.15.
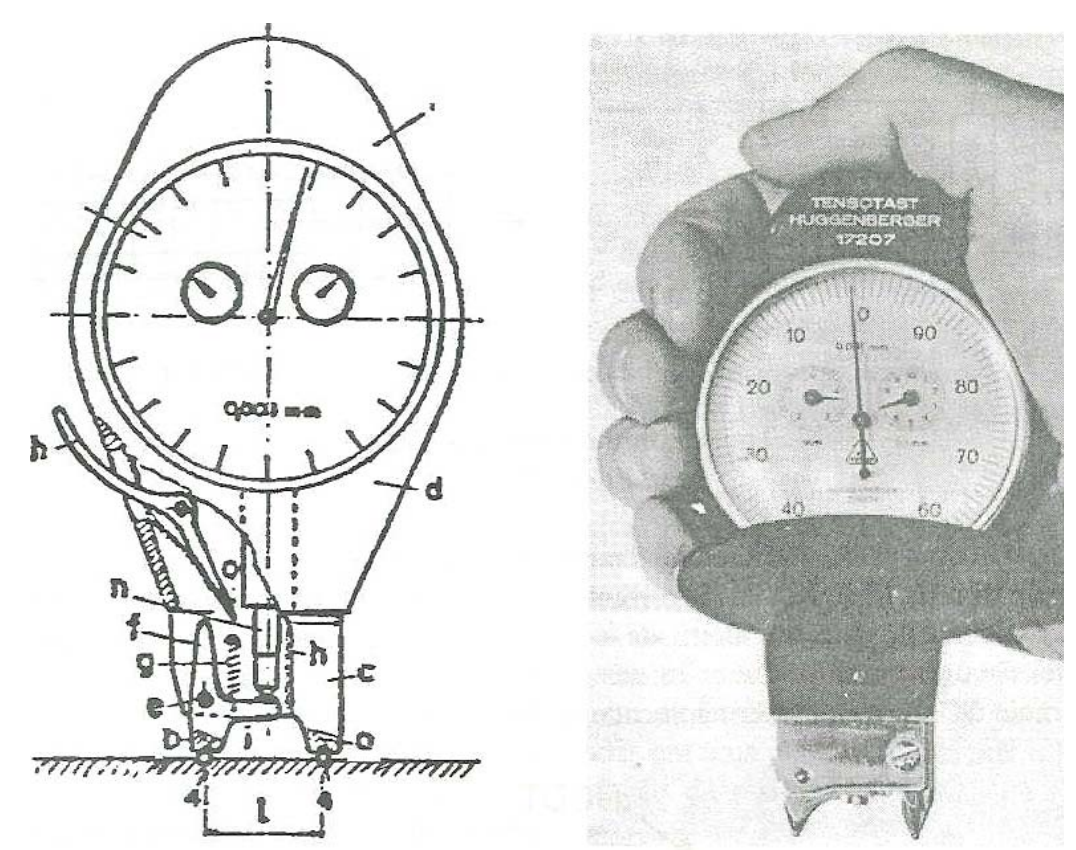

Figura 2.15 - Extensômetro mecânico Tensotast, in Takeya (2000). 
2.2.2.2 Extensômetros Elétricos de Resistência.

Os extensômetros elétricos de resistência, conhecidos como "strain gauges", são os mais empregados em análise experimental. Têm seu princípio baseado na lei que relaciona a variação da resistência elétrica de fios metálicos quando submetidos a solicitações mecânicas.

Segundo Takeya (2000), os extensômetros elétricos podem apresentar sérios problemas se não forem utilizados corretamente, principalmente porque são instrumentos muito sensíveis à umidade e às variações de temperatura.

Podem ser classificados em dois grupos: condutor livre (tipo Carlson) e condutor colado. Os do tipo Carlson são utilizados para medida de deformações no interior de peças de concreto, sendo instalados no momento da concretagem da peça de concreto. Apresentam excelente desempenho em medições de longa duração. A Figura 2.16 ilustra um extensômetro de condutor livre, tipo Carlson.

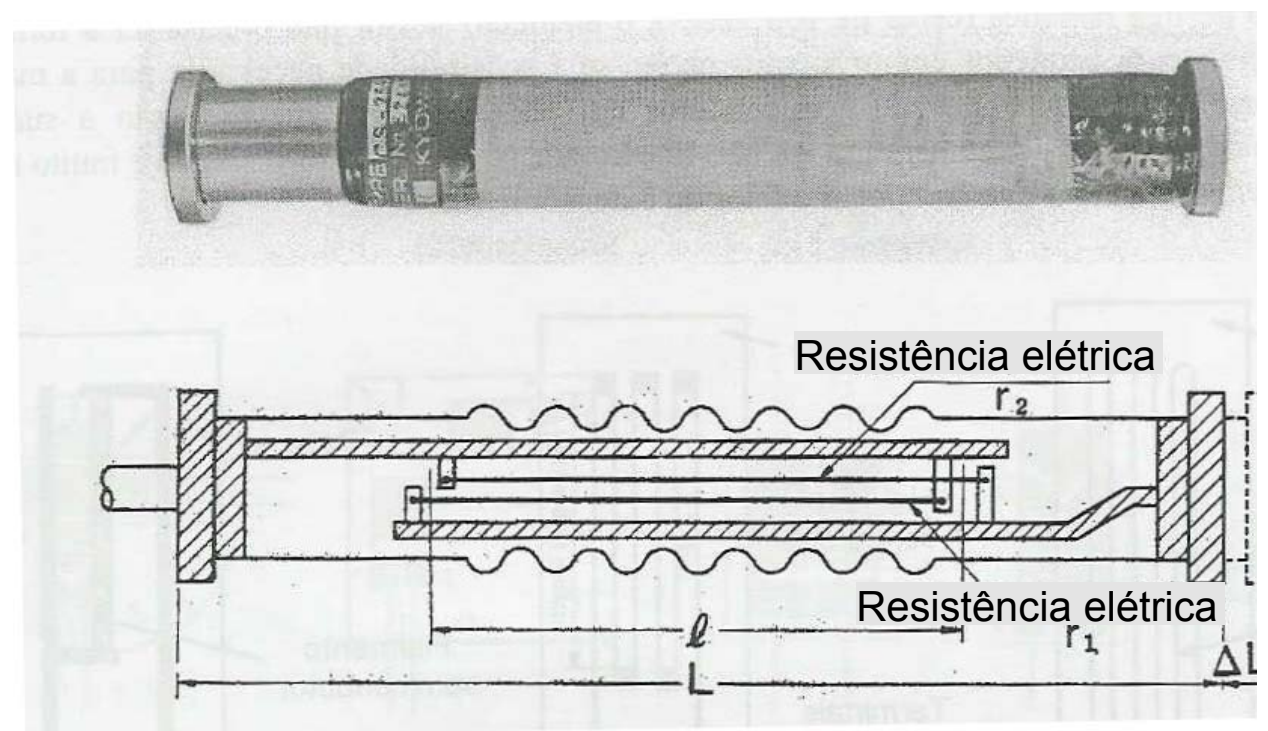

Figura 2.16 - Extensômetro de condutor livre tipo Carlson, in Takeya (2000).

Normalmente os extensômetros elétricos são fixados às barras das armaduras dos elementos estruturais em concreto armado, visto que o módulo de elasticidade do aço é bem definido e conhecido. Podem ser fixados a uma peça de aço, formando uma célula de carga que pode ser calibrada em uma prensa. 
2.2.2.3 Extensômetros de corda vibrante.

Os extensômetros de corda vibrante têm como princípio de funcionamento a relação entre a freqüência de vibração de um fio e a tensão a ele aplicada. O instrumento é constituído basicamente por um fio de aço tensionado e por dois eletroímãs. Um dos eletroímãs provoca a vibração do fio e outro capta a freqüência de vibração. O conjunto é conectado a um aparelho que aciona o eletroímã de excitação, ao mesmo tempo em que registra a freqüência de vibração captada pelo outro eletroímã.

Para realização das medidas é necessário que o extensômetro seja fixado à peça da qual se deseja conhecer as solicitações. Essa fixação pode ser efetuada por imersão, como nos extensômetros elétricos do tipo Carlson ou por meio de solda ou de parafusos. A Figura 2.17 mostra esquematicamente o equipamento.

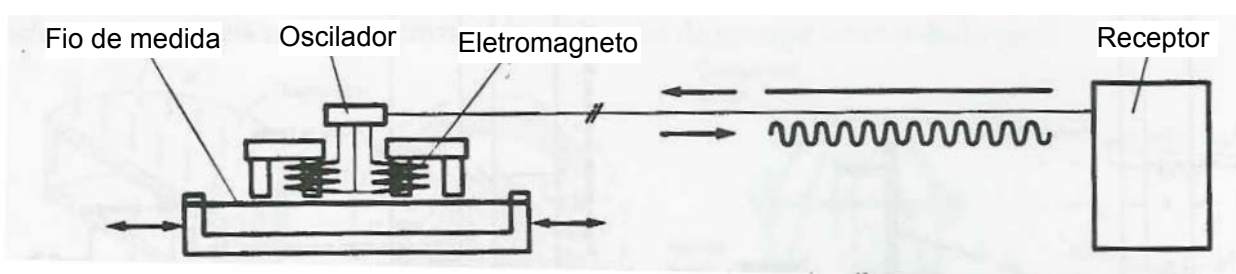

Figura 2.17 - Arranjo esquemático do extensômetro de corda vibrante, in Takeya (2000).

\subsubsection{CASOS HISTÓRICOS NACIONAIS.}

Em artigo publicado no $14^{\circ}$ Congresso Internacional, ocorrido em Hamburgo no ano de 1997, Danziger et al. (1997) relatam que a prática brasileira de medida de recalques ocorre somente nos casos em que existem indícios de dano estrutural, ou quando são executadas escavações muito profundas, próximas às estruturas. Reconhecem os autores que existem na literatura nacional notáveis casos históricos de medidas de recalque desde o início da construção, mas esses são poucos. Reconhecem, também, que o número de casos publicados na literatura internacional também é pequeno.

Neste trabalho serão omitidos todos os casos de monitoramento de recalques na cidade de Santos, visto que a grande maioria deles envolve soluções em fundações superficiais e casos em que o desempenho da obra de engenharia não foi satisfatório. 
Lobo et al. (1994) apresentam resultados de medidas de recalques efetuadas durante a construção de um edifício de 12 pavimentos, localizado na cidade de Bauru, SP. As fundações são do tipo tubulão a céu aberto, com comprimento médio de $11 \mathrm{~m}$ e bases com diâmetro variável entre 1,3 e 2,5 m. Os recalques médios medidos foram de 6,4 mm, variando entre 3,0 e 11,3 mm. A máxima distorção angular aferida por essas medições foi da ordem de 1/1600. A Figura 2.18 apresenta a evolução dos recalques com o tempo.

Iwamoto (2000) retroanalisou, por meio de programa de computador desenvolvido para análise de interação solo estrutura, no qual a superestrutura foi modelada pelo método dos elementos finitos e a infra-estrutura modelada conforme proposição de Vésic (1975), os dados observados por Lobo et al. (1994), chegando a valores de recalques muito próximos aos medidos.
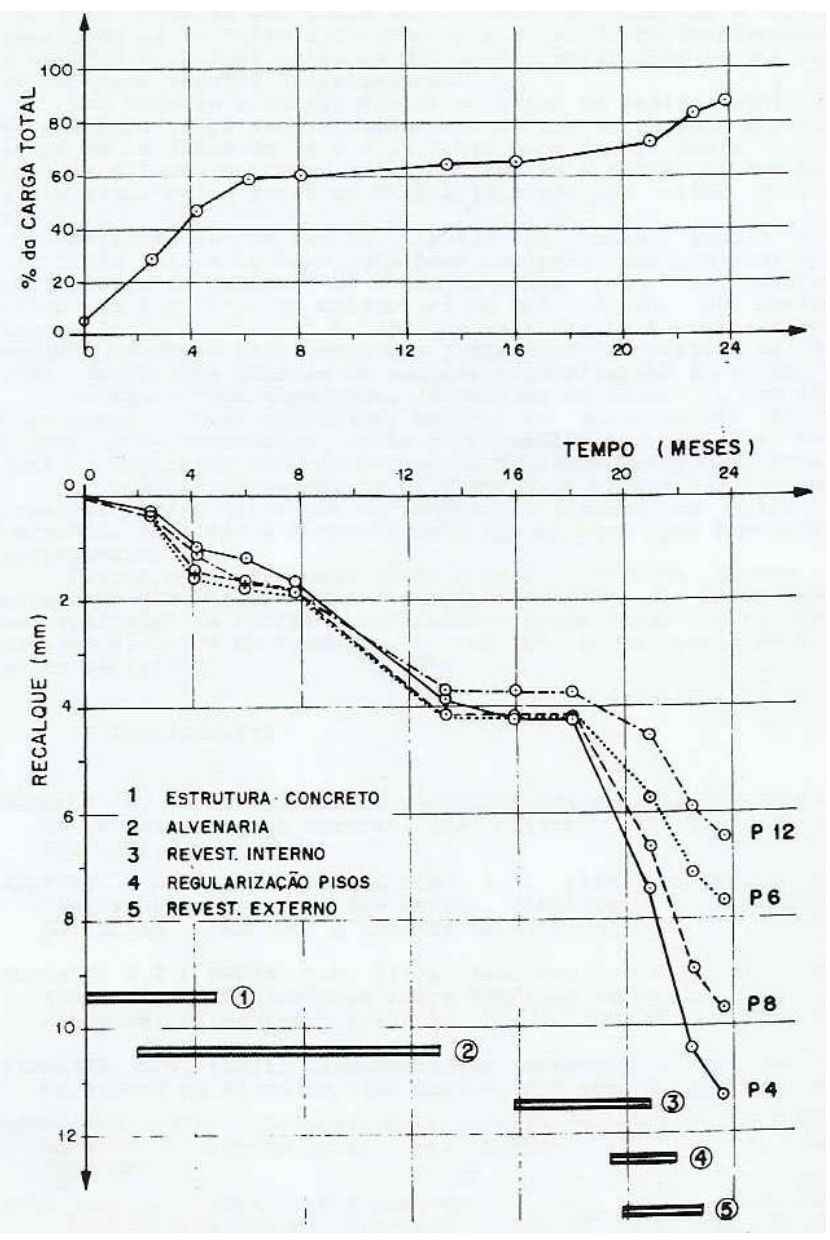

Figura 2.18 - Evolução dos recalques com o tempo, in Lobo et al. (1994). 
Gusmão Filho (1995) relata caso em que foram medidos recalques em sete edifícios idênticos de um conjunto habitacional localizado em Recife. Para a fundação dos prédios, foram executadas estacas pré-moldadas de concreto, com comprimento variando entre 30 a $42 \mathrm{~m}$. O perfil e os problemas na cravação suscitaram dúvidas sobre o desempenho das estacas, sendo feito o monitoramento dos sete edifícios para acompanhar os recalques durante a construção. Foram instalados pinos em todos os pilares e os recalques medidos quinzenalmente, durante os dezoito meses de construção. A Tabela 2.4 apresenta resultados das medidas durante o período de construção.

Tabela 2.4 - Recalques medidos em sete edifícios após dezoito meses de construção, in Gusmão Filho (1995).

\begin{tabular}{cccc}
\hline Bloco & \multicolumn{3}{c}{ Recalque $(\mathrm{mm})$} \\
& Máximo & Mínimo & Médio \\
\hline A & 33 & 10 & 23,7 \\
B & 43 & 18 & 34,3 \\
C & 29 & 2 & 16,4 \\
D & 31 & 6 & 19,0 \\
E & 36 & 4 & 23,2 \\
F & 47 & 14 & 34,4 \\
G & 33 & 14 & 25,5 \\
\hline
\end{tabular}

A evolução dos recalques ao longo do tempo é mostrada na figura a seguir. O autor afirma que os recalques praticamente cessaram em todos os sete blocos, quando a carga total da construção foi atingida.

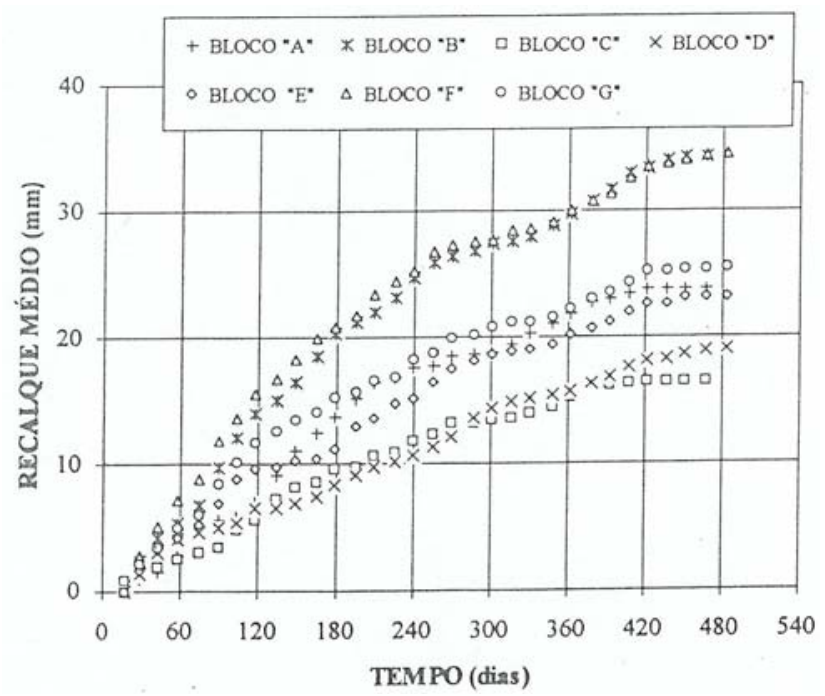

Figura 2.19 - Gráfico tempo x recalque em sete edifícios durante dezoito meses de construção, in Gusmão Filho (1995). 
Danziger et al. (1997) apresentam caso de medida de recalques em um edifício de 11 pavimentos situado no Rio de Janeiro, cuja solução de fundações foi a de uso de estacas do tipo Franki, de diâmetro 520 e 600 mm com comprimento médio de $20 \mathrm{~m}$. As medidas ocorreram entre dezembro de $1992 \mathrm{e}$ fevereiro de 1996, durante o período de construção do edifício. Os principais resultados são apresentados na Tabela 2.5 .

\begin{tabular}{|c|c|c|c|}
\hline \multirow[t]{2}{*}{ Data } & \multicolumn{2}{|c|}{ Recalque (mm) } & \multirow[t]{2}{*}{ Estágio da obra } \\
\hline & Pilar C18 & Pilar C22 & \\
\hline $23-12-92$ & 0 & 0 & Concretagem do teto do subsolo \\
\hline $12-02-93$ & 0,37 & 1,17 & Concretagem do $1^{\circ}$ andar tipo \\
\hline $05-04-93$ & 1,58 & 2,54 & Concretagem do $3^{\circ}$ andar tipo \\
\hline $17-05-93$ & 2,53 & 3,75 & Concretagem do $5^{\circ}$ andar tipo \\
\hline $17-08-93$ & 5,70 & 7,27 & $\begin{array}{l}\text { Concretagem do } 8^{\circ} \text { andar tipo. } \\
\text { Alvenaria executada até o } 3^{\circ} \text { andar. }\end{array}$ \\
\hline $26-01-94$ & 11,17 & - & $\begin{array}{l}\text { Estrutura concluída. Alvenaria } \\
\text { executada até o } 7^{\circ} \text { andar. } \\
\text { Revestimento interno executado até } \\
05^{\circ} \text { andar. }\end{array}$ \\
\hline $03-08-96$ & 21,99 & 23,78 & Conclusão do revestimento. \\
\hline 07-02-96 & - & 26,61 & Obra concluída. \\
\hline
\end{tabular}

Quanto às distorções angulares acarretadas por esses deslocamentos verticais, os autores informam que os maiores valores foram da ordem de $1 / 600$ a $1 / 700$.

Adicionalmente, esses autores apresentam resultado de medidas de deformações em cinco pilares do prédio, utilizando-se extensômetro mecânico Huggenberg. Essas medidas tinham por objetivo a estimativa de carga nos pilares e avaliação de redistribuição de esforços na superestrutura, devidos à interação. Os valores apresentados pelos autores são transcritos na tabela 2.6.

Tabela 2.6 - Deformações medidas em pilares, in Danziger et al. (1997).

\begin{tabular}{lcc}
\hline Pilar & \multicolumn{2}{c}{ Deformação $(\mu \varepsilon)$} \\
& 10/07/95 & $09 / 02 / 96$ \\
\hline 5 & 678 & - \\
9 & 646 & - \\
14 & 724 & - \\
15 & 735 & 706 \\
22 & 501 & 506 \\
\hline
\end{tabular}


Gonçalves (2004) apresenta um caso em que o comportamento de um edifício localizado no Recreio dos Bandeirantes, Rio de Janeiro, foi monitorado por meio de medidas de recalques desde o início da construção, complementado por medida de deformações nos pilares, efetuadas por meio de extensômetro mecânico Huggenberg de curso máximo 250 mm, visando à determinação indireta da carga nos pilares. Embora a solução de fundações para o caso seja a do tipo superficial, esse trabalho é pioneiro no Brasil na análise de um caso de interação solo estrutura, que envolveu a medida da carga em alguns pilares. Uma das principais conclusões desse trabalho é que a diferença entre a carga nos pilares, entre o cálculo estrutural convencional, considerando apoios indeslocáveis, e a análise com consideração da interação solo estrutura, pode ser de até $30 \%$.

\subsubsection{CASOS HISTÓRICOS INTERNACIONAIS.}

Em 1974, a Sociedade Geotécnica Inglesa BGS (1974), organizou evento denominado Recalque de Estruturas (Settlements of Structures). São apresentados cerca de 50 trabalhos, nos quais os deslocamentos verticais de estruturas são relatados.

Outro evento marcante foi organizado em 1991 na cidade de Florença, Itália, por ocasião da $10^{\mathrm{a}}$. Conferência Européia, tendo como tema Deformações nos Solos e Deslocamentos de Estruturas, AGI (1991).

Katzenbach et al. (1997) apresentam resultados de instrumentação em um edifício comercial (Commerzbank Tower II, o mais alto da Europa) de 300 $\mathrm{m}$ de altura, localizado na cidade de Frankfurt. A solução de fundação é do tipo radier estaqueado, tendo o radier espessura variável entre 4,45 e 2,25 m. Essa placa apóia-se num total de 111 estacas escavadas, com comprimento variável entre 37,6 e 45,6 m, com diâmetro $1,8 \mathrm{~m}$ até a profundidade de $23 \mathrm{~m}$, sendo que a partir dessa o diâmetro foi reduzido para 1,5 m. A Figura 2.20 apresenta uma seção transversal do edifício em questão, estando nela indicado esquematicamente a geotecnia do local e a posição das estacas. Logo abaixo, o gráfico da deformada de recalques ao longo da seção oeste-leste é apresentado em 4 datas, seguindo-se gráfico tempo $x$ recalque determinado em seis posições distintas. 
As medidas de deslocamento indicaram um máximo recalque da Torre II de 2,0 cm. A Torre I pré-existente, situada próxima ao local, recalcou entre 0,3 e $1,0 \mathrm{~cm}$. Edifícios vizinhos, apoiados em fundações superficiais, recalcaram até $2,5 \mathrm{~cm}$.

A instrumentação envolveu a medida de deslocamentos verticais em 13 pontos com uso de extensômetros. Visando a determinar o diagrama de transferência de carga, 30 estacas tiveram seu fuste instrumentado com pares de "strain gauges" em cinco diferentes profundidades.

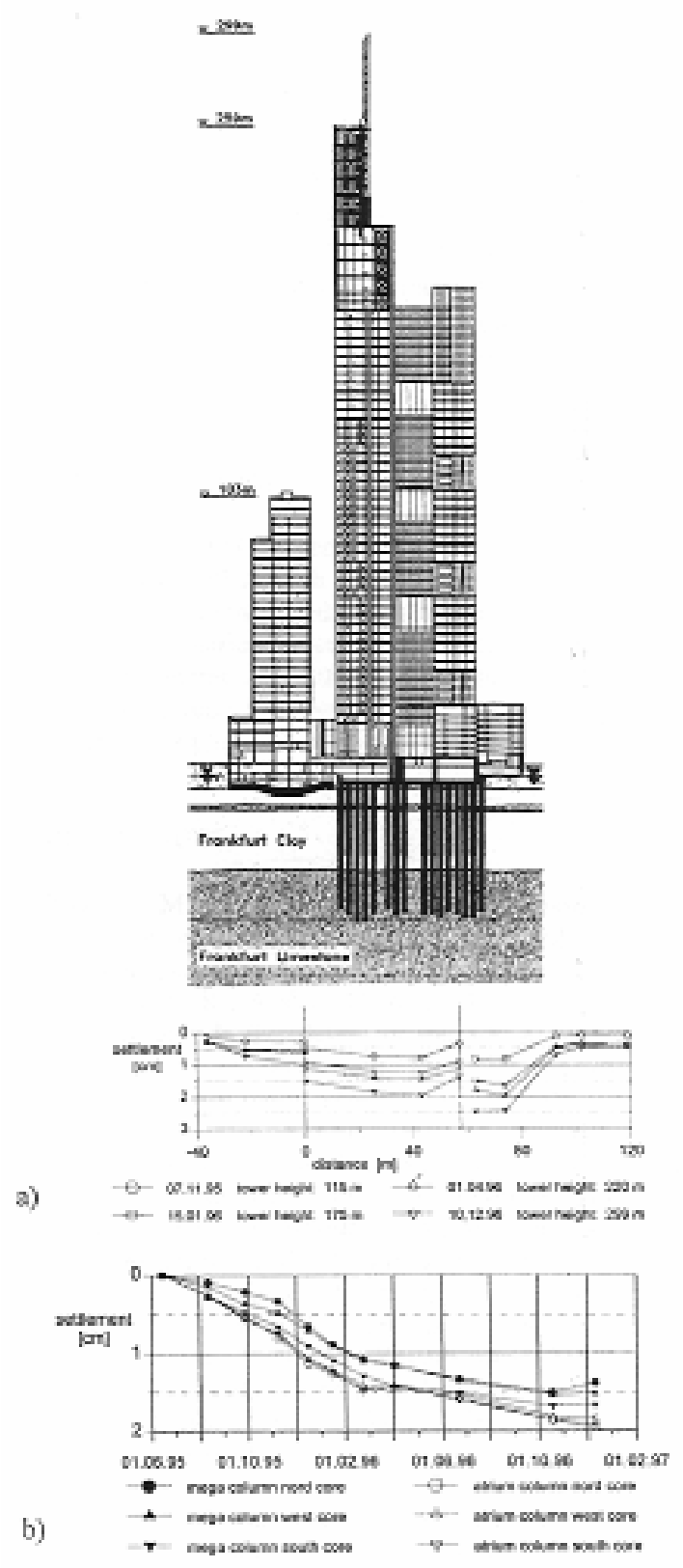

Figura 2.20 - Commerzbank Tower in Frankfurt am Main, in Katzenbach et al. (1997). 
Além disso, visando determinar a parcela de carregamento suportada pelo radier e pela ponta das estacas, em quinze elementos foram instaladas células de carga de diâmetro 1,3 m na ponta da estaca e em cinco dessas foram instaladas células de carga de diâmetro $1,5 \mathrm{~m}$ no topo.

As medidas de carga indicam que o radier absorve $5 \%$ da carga total. Do carregamento transferido às estacas, apenas $5 \%$ é absorvido pela ponta. Também indicam que, dentro de um mesmo grupo, as estacas externas recebem maior parcela de carga que as internas, conforme mostra a figura a seguir.

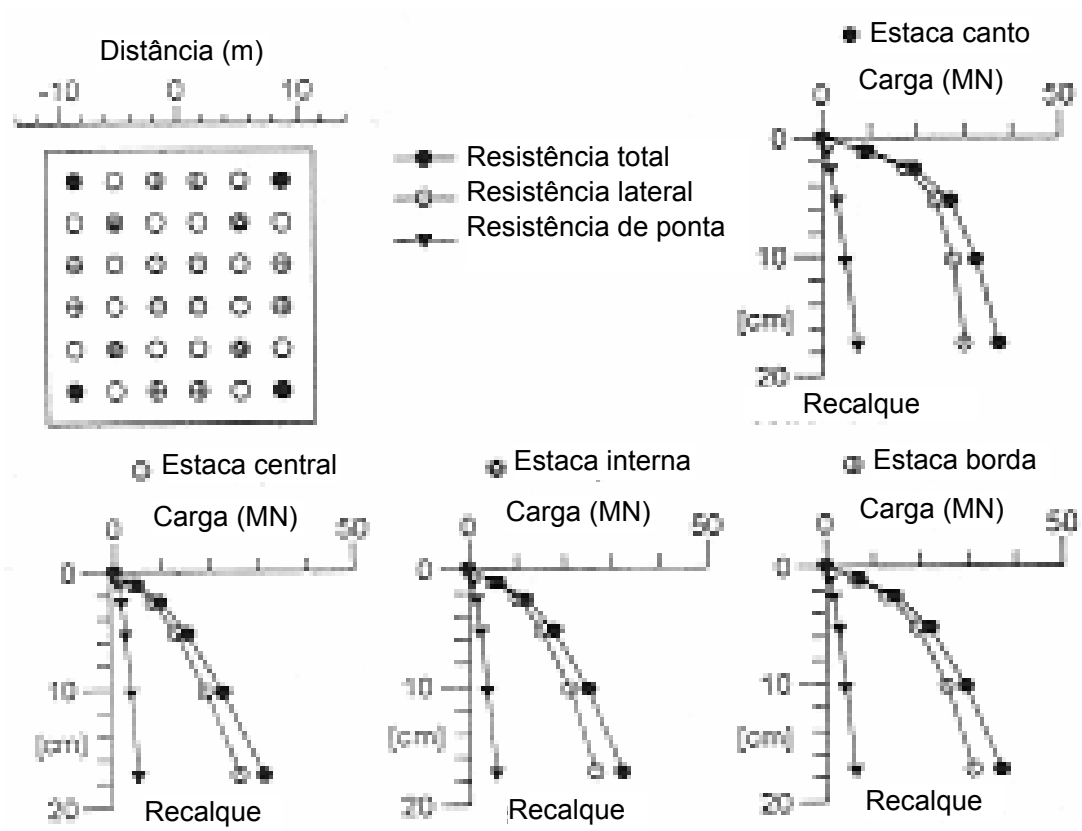

Figura 2.21 - Curvas carga x recalque em diferentes posições do radier estaqueado, in Katzenbach et al. (1997).

Viggiani (1997) apresenta resultado da instrumentação destinada a medir carga em estacas do radier estaqueado do pilar central de uma ponte localizada no sul da Itália, sobre o Rio Gargliano. A instrumentação composta por 35 células de carga localizadas no topo das estacas e 8 células de carga inseridas entre o radier e o solo, conduziu à conclusão de que $80 \%$ do carregamento total é transferido às estacas, enquanto que os restantes $20 \%$ são suportados pelo radier. Também foi observada uma distribuição de esforços no topo das estacas, conforme apresentado na Figura 2.22(a), a qual pode ser confrontada com os valores fornecidos por análise teórica, Figura 2.22 (b). 

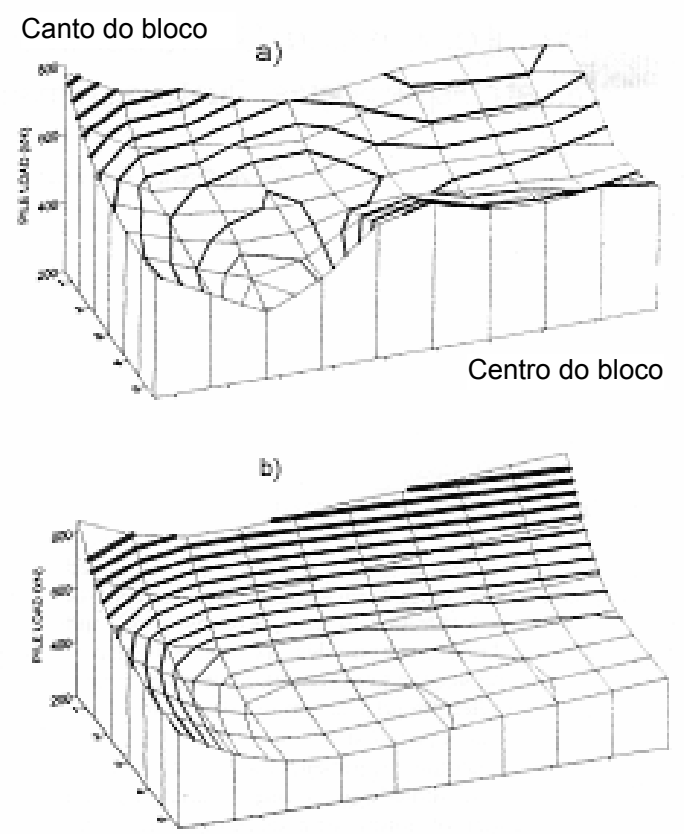

Figura 2.22 - Distribuição de esforços entre estacas, in Viggiani (1997).

Van Impe (1999) relata caso de observação de um edifício comercial de três andares, no qual todas as 55 estacas, componentes da fundação, foram monitoradas continuamente por meio de células de carga desde o início da construção e durante um ano após a conclusão e ocupação da edificação. As leituras foram efetuadas eletronicamente, sendo o intervalo de aquisição de dados de 15 minutos.

A fundação é composta por seis tipos de estacas: 15 pré-moldadas de concreto armado, 10 metálicas perfil $\mathrm{H}, 9$ tipo vibro, 10 tipo vibrex, 8 hélices contínuas, e 3 pré-moldadas em concreto protendido. Adicionalmente, é informado que as estacas hélice contínua foram cravadas cerca de $30 \mathrm{~cm}$ após a cura do concreto. Segundo aquele autor, o comprimento desses elementos é de 7,0 m, sugerindo que a metodologia de projeto é do tipo 2 , conforme classificação proposta por Aoki e Cintra (1999), na qual é fixado um comprimento para todos os elementos. A Figura 2.23 apresenta a distribuição em planta das estacas.

Todas as estacas de deslocamento foram submetidas à prova de carga dinâmica. Provas de carga estática foram realizadas em 23 estacas após a conclusão da obra, utilizando a estrutura existente como reação para esses ensaios. 


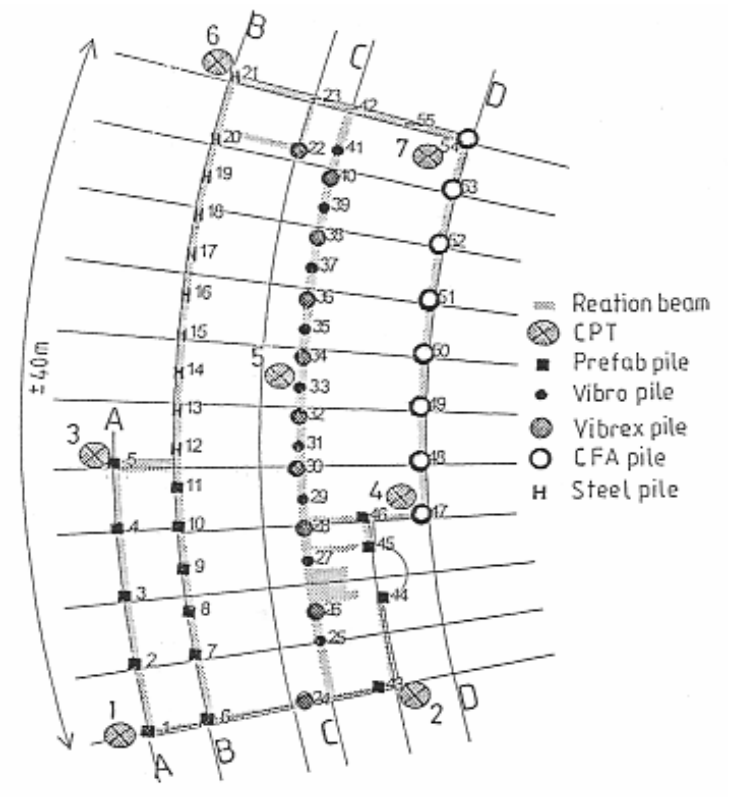

Figura 2.23 - Disposição em planta estacas, in Van Inpe (1999).

As cargas nas estacas medidas ao final da construção são comparadas com os valores fornecidos por análise de interação solo estrutura tridimensional, na qual o coeficiente de mola utilizado foi determinado a partir das provas de carga realizadas. A figura a seguir apresenta comparativo entre valores medidos e calculados ao longo das seções B e C.

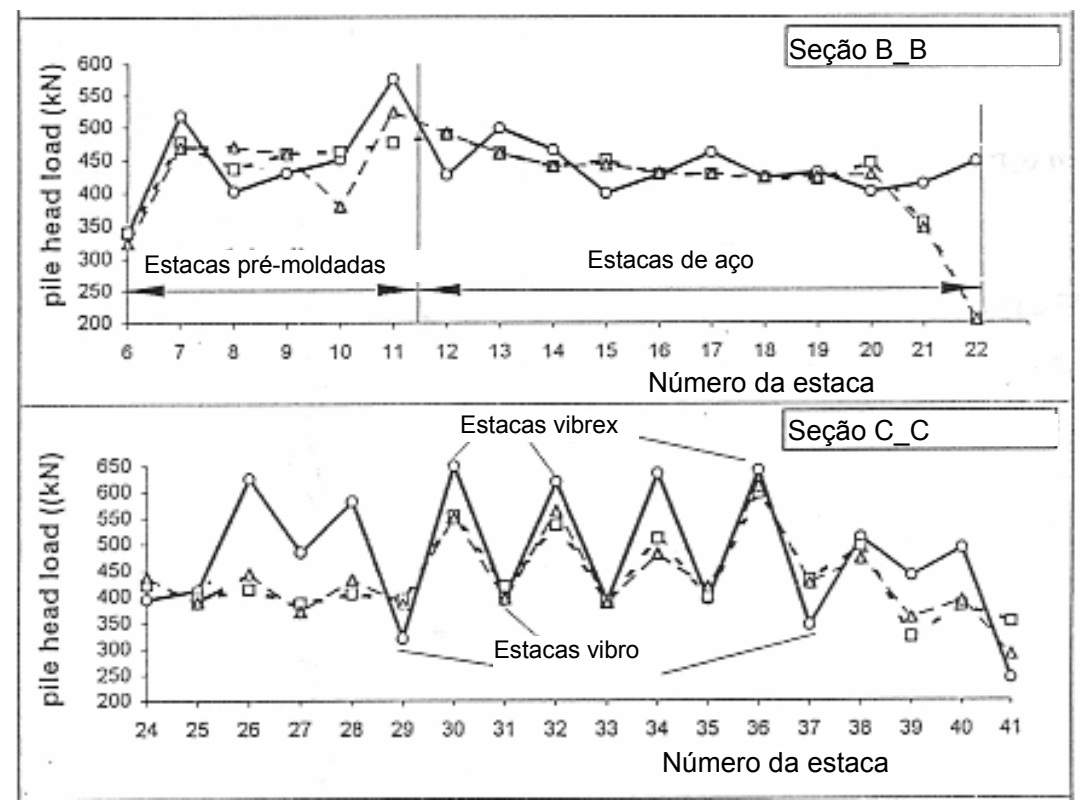

Figura 2.24 - Comparativo entre valores medidos e calculados da carga nas estacas, in Van Inpe (1999). 


\subsection{MÉTODOS DE PREVISÃO DE RECALQUES EM ESTACAS ISOLADAS.}

As seguintes considerações, extraídas de Vesic (1975), são importantes para delimitar a complexidade do problema de previsão de recalques. Os efeitos de execução no estado de tensões do sistema são salientados pelo autor como de extrema relevância.

As análises de recalques de fundações profundas apresentam certa semelhança com as de fundações superficiais, visto que são baseadas nos mesmos princípios. Existem, entretanto algumas diferenças distintas entre elas. Essas são devidas, em parte, ao amolgamento do solo adjacente à estaca e a mudanças no estado de tensão, ocasionadas pelas operações de instalação da estaca. Devido ao amolgamento o solo ao redor da estaca, mesmo que inicialmente homogêneo, pode apresentar profundas variações até em sua rigidez nas direções vertical e horizontal, pelo menos na região mais solicitada ao redor da estaca. Se o elemento for cravado, pode apresentar elevadas tensões residuais, as quais irão influenciar significativamente a resposta da estaca à aplicação das cargas e sua relação carga recalque característica. A posição exata da superfície de transferência de carga entre estaca e solo é desconhecida e normalmente varia com a intensidade do carregamento. De maneira semelhante ao problema de capacidade de carga, os efeitos de estacas adjacentes e possíveis efeitos de grupo, tornam extremamente difícil uma abordagem racional ao problema, adicionando mais complicadores ao problema. Dessa maneira, no estágio atual de conhecimento soluções aproximadas ao problema estão disponíveis e suas limitações devem ser lembradas em todas as suas aplicações.

\subsubsection{MÉTODOS BASEADOS NA TEORIA DA ELASTICIDADE.}

Estes métodos envolvem a consideração de que o maciço de solo é constituído por material que apresenta comportamento tensão deformação linear, ao qual é atribuído um módulo de elasticidade ou de deformabilidade $\left(E_{s}\right)$.

O sistema em questão a ser resolvido é o da interação entre estaca e maciço de solo, o qual por natureza é altamente hiperestático. A seguir são apresentados três métodos consagrados, os quais levantam a indeterminação do sistema de modo singular.

\subsubsection{Método de Poulos e Davis.}

O método de Poulos e Davis (1980) considera que, no caso em que não há deslizamento no contato entre a estaca e solo (domínio elástico), o 
movimento entre a estaca e o solo adjacente são iguais. A partir dessa igualdade e por meio da solução de um conjunto de equações, a indeterminação do sistema (transferência de carga) é levantada e o recalque da estaca é calculado.

A Figura 2.25 ilustra a geometria e as condições de contorno da solução de Poulos. A estaca é subdividida em ( $n$ ) elementos, mais um elemento destinado a representar as forças que atuam na ponta. A geometria do elemento isolado de fundação é seção circular de diâmetro (d) e comprimento total $(L)$, com características elásticas $\left(E_{p}\right)$. O maciço de solo é homogêneo de espessura (h) e propriedades elásticas dadas pelo seu módulo de elasticidade $\left(E_{s}\right)$ e seu coeficiente de Poisson $\left(v_{s}\right)$.

Nessa formulação é introduzido um parâmetro denominado coeficiente de rigidez da estaca $(\mathrm{K})$, dado pela expressão:

$$
K=\frac{E_{p}}{E_{s}} R_{A}
$$

sendo:

$$
R_{A}=\frac{A_{p}}{\pi \cdot d^{2} / 4}
$$

onde:

$A_{p}$ - área da seção transversal da estaca $\left(R_{A}=1\right.$ para estacas maciças $)$.

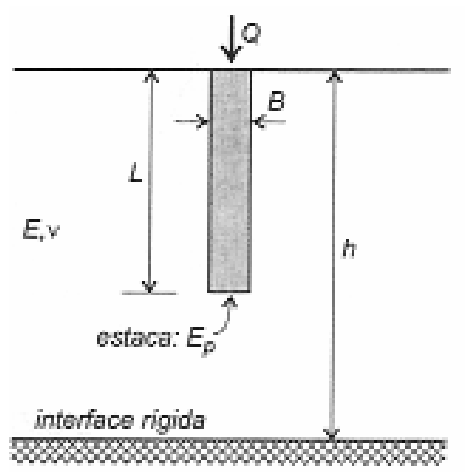

(a)

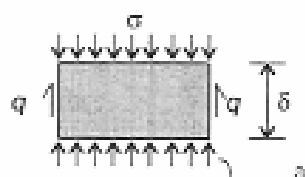

(b)

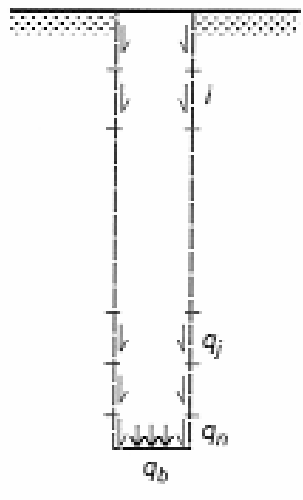

(c)

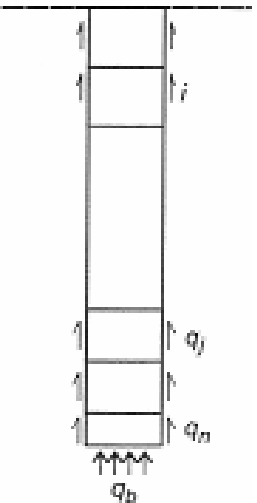

(d)

Figura 2.25 - Geometria do problema e condições de contorno - método de Poulos e Davis (1980), in Velloso e Lopes (2000). 
Para o caso de solos de espessura finita, os fatores de influência, determinados pela solução de Mindlin (1936), são ajustados empregando-se a aproximação proposta por Steinbrenner (1934).

A solução da determinação do recalque de estacas é dada com o uso de gráficos e contempla duas situações:

a) Estacas flutuantes

$$
\rho=\frac{P I}{E_{s} d}
$$

sendo:

$\rho$ - recalque no topo da estaca,

$\mathrm{P}$ - carga axial aplicada à estaca.

I - fator de influência dado pela expressão:

$$
I=I_{0} R_{K} R_{h} R_{v}
$$

onde:

$I_{0}$ - fator de influência para estacas incompressíveis em meio semi-infinito e $v_{\mathrm{s}}$ $=0,5$, gráfico da Figura 2.26 .

$R_{K}$ - fator de correção para a compressibilidade da estaca, dado pelo gráfico da Figura 2.26 .

$R_{h}$ - fator de correção para a camada de espessura finita, dado pelo gráfico da Figura 2.26.

$\mathrm{R}_{v}$ - fator de correção para o coeficiente de Poisson do solo, dado pelo gráfico da Figura 2.26. 


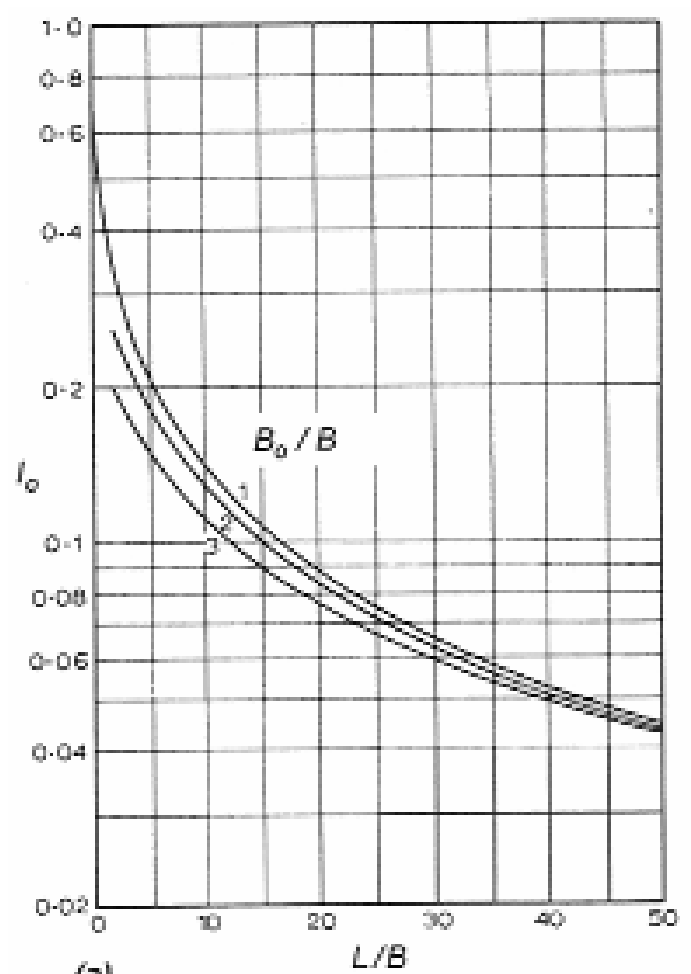

(a)

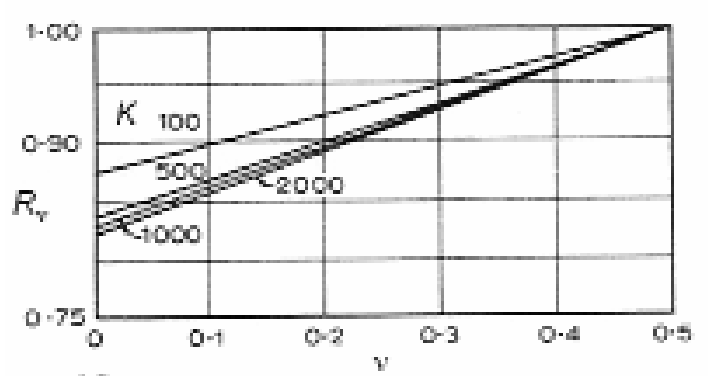

(d)

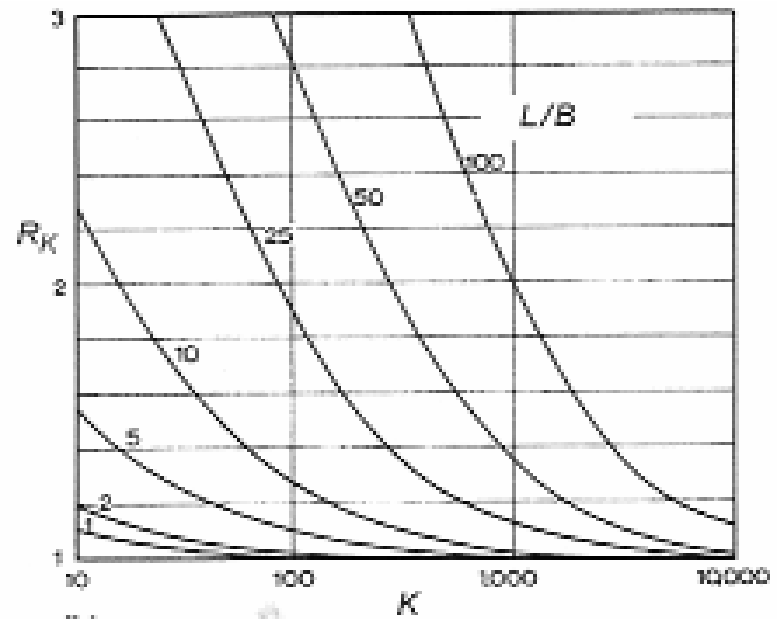

(b)

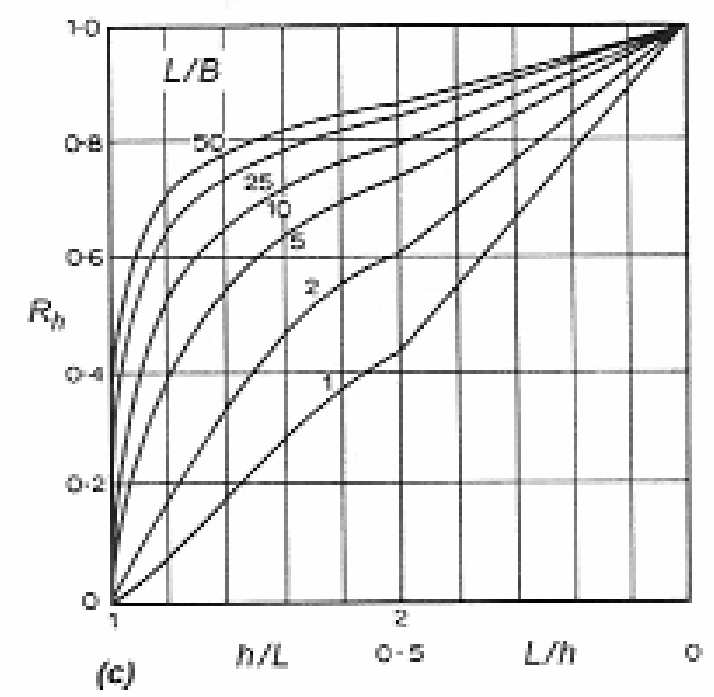

Figura 2.26 - Fatores para o cálculo de recalque de estacas, método de Poulos e Davis (1980), in Velloso e Lopes (2002).

b) Estacas onde predomina a resistência de ponta.

Para esta condição, os autores consideram que, ao longo do fuste da estaca, o módulo é $\left(E_{s}\right)$ e abaixo da ponta do elemento isolado de fundação o módulo de elasticidade do solo é $\left(E_{b}\right)$.

$$
\rho=\frac{P I}{E_{s} d}
$$

sendo:

$$
I=I_{0} R_{K} R_{b} R_{v}
$$


onde:

$I_{0}, R_{K}$ e $R_{v}$ têm igual tratamento e valor que os apresentados para estacas flutuantes e

$\mathrm{R}_{\mathrm{b}}$ - coeficiente de correção para rigidez do estrato de apoio da ponta da estaca, dado pelos gráficos da Figura 2.27.
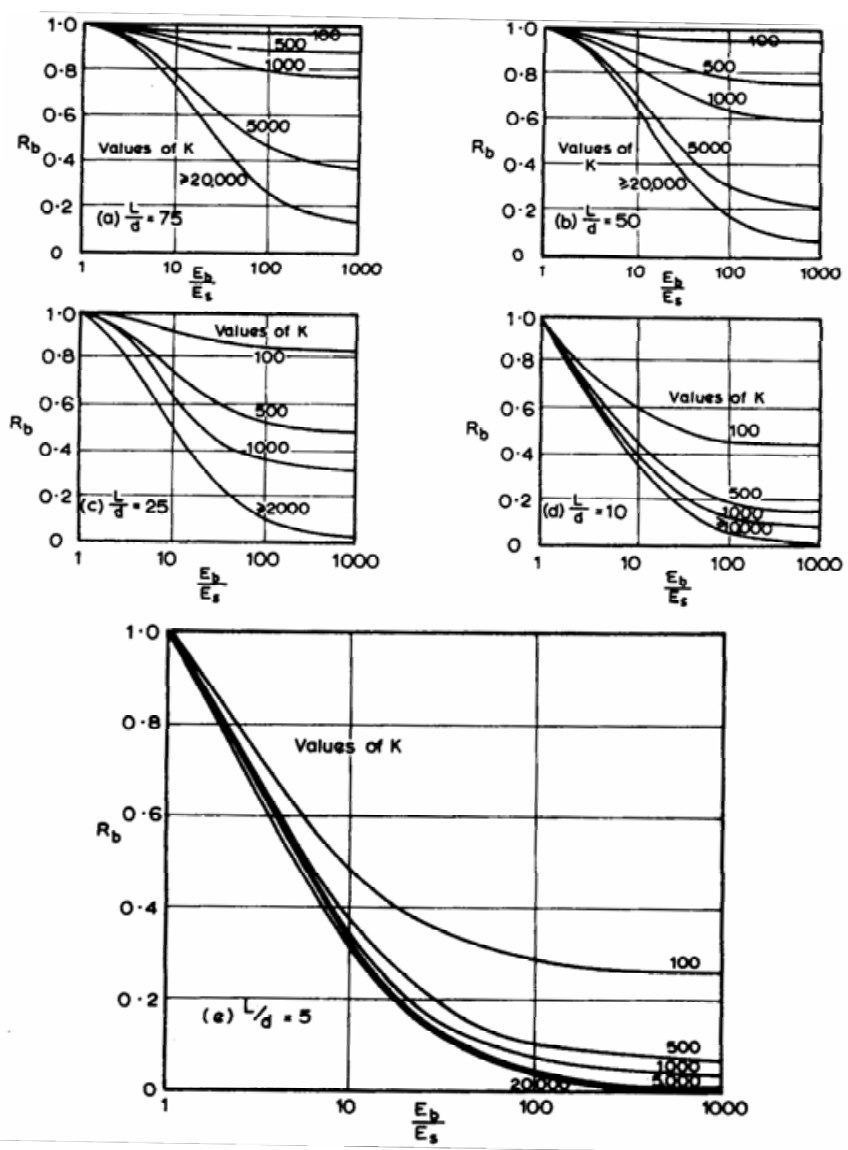

Figura 2.27 - Fator de influência " $R_{b}$ " Poulos e Davis (1980).

Vesic (1975) considera que o método de Poulos é aplicável a estacas escavadas em solos argilosos, pois sua teoria supõe que a transferência de carga entre estaca e solo é governada pelas propriedades elásticas do solo e da estaca, e desconsidera a existência de tensões residuais.

Posteriormente, Vesic (1977) apresenta algumas considerações sobre o método de Poulos, ao final das quais conclui pela não recomendação do uso do método. Pela relevância das opiniões de Vesic sobre o método de Poulos, a tradução livre do texto é apresentada a seguir. 
Embora consistente e agradável o método com enfoque sólido elástico, conforme proposto por Poulos e seus colaboradores apresenta algumas sérias deficiências.

Primeiramente, a hipótese que a resposta do solo ao carregamento pode ser adequadamente descrita por somente dois parâmetros característicos, E e v, pode ser altamente simplificadora em elevado grau, quando comparada às situações envolvendo fundações superficiais. A grande maioria dos solos apresentam resposta ao carregamento dependente da trajetória de tensões e do tempo de aplicação das solicitações. $O$ modo como as tensões são transmitidas ao maciço de solo é fortemente afetado pelas alterações de tensões e densidade produzidas pelos processos de instalação da estaca no solo. Por exemplo, um maciço arenoso não coesivo deve apresentar valor de $E$ crescente com a raiz quadrada da tensão normal média e comportamento diferente entre carregamento e descarregamento. A resposta de uma estaca instalada nesse maciço será fortemente afetada pelas tensões laterais provocadas pela sua cravação. A cravação de estaca adicionais adjacentes irá produzir alterações adicionais de tensão e densidade, totalmente desconsideradas pelo enfoque sólido elástico proposto.

Segundo, essa abordagem admite igual valor de $E$ tanto na tração como na compressão, enquanto que a maioria dos solos não resiste a solicitações de tração. A distribuição de tensões de acordo com a solução de Mindlin freqüentemente conduz a significantes esforços de tração acima do ponto de aplicação da carga. A menos que essas tensões trativas sejam compensadas por tensões compressivas decorrentes das cargas aplicadas acima do ponto em consideração, elas não serão transmitidas ao solo. Assim sendo, a real distribuição de tensões deverá ser significativamente diferente daquela suposta pelo uso cego da solução de Mindlin. Isso será particularmente verdadeiro no caso de estacas em solos não coesivos, nas quais as cargas na ponta são, pelo menos, maiores que as cargas laterais.

Terceiro, o enfoque sólido elástico supõe que a transferência de tensões no sistema estaca solo inicia-se de um estado completamente não solicitado. Assim qualquer efeito de tensões residuais nas estacas devidas a sua cravação ou a prova de carga, será desconsiderado. Atualmente está bem estabelecido que essas tensões podem contribuir de maneira significativa ao comportamento inicial da estaca quando carregada.

Finalmente, a distribuição de tensões e a análise de recalques proposta pelo enfoque de Poulos admitem que a transferência de tensões do fuste da estaca ao maciço de solo se ocorre como se o maciço fosse contínuo, incluindo dessa forma o espaço ocupado pelas estacas. Uma análise dessa hipótese mostra que ela pode resultar em erros significantes nos fatores de recalque. (Por exemplo, para uma estaca isolada em maciço homogêneo com $\mu=0.25$, o fator de recalque é $50 \%$ maior que o obtido usando a hipótese anteriormente mencionada).

Os efeitos combinados de todas as discrepâncias aqui mencionadas no comportamento de grupo de estacas podem ser apreciáveis, embora possam existir casos, tais como aqueles envolvendo grupo de estacas em argila mole, onde o efeito total no recalque calculado ou na transferência de carga pode ser menos significante. Por esses motivos, o uso geral do enfoque sólido elástico conforme proposto por Poulos não deve ser recomendado. 


\subsubsection{Método de Aoki e Lopes.}

No $5^{\text {o. }}$ Congresso Pan-Americano de Mecânica dos Solos e Engenharia de Fundações, Aoki e Lopes (1975) apresentaram trabalho destinado a estimar tensões e recalques devidos a fundações profundas pela teoria da elasticidade. Nesse trabalho, as cargas que um grupo de estacas ou tubulões transmitem ao solo são decompostas em um sistema equivalente de cargas concentradas, cujos efeitos são superpostos no ponto de estudo.

Os efeitos são calculados pela solução de Mindlin (1936), que admite ser o solo homogêneo, isotrópico, semi-infinito e apresenta comportamento elástico linear.

A expressão que fornece o deslocamento vertical (w) em um ponto da massa de solo da solução de Mindlin é dada por:

$$
w=\frac{P}{16 \pi G(1-v)}\left[\begin{array}{l}
\frac{3-4 v}{R_{1}}+\frac{8\left(1-v^{2}\right)-(3-4 v)}{R_{2}}+\frac{(z-c)^{2}}{R_{1}^{3}}+\cdots \\
\cdots \frac{(3-4 v)(z+c)^{2}-2 c z}{R_{2}^{3}}+\frac{6 c z(z+c)^{2}}{R_{2}^{5}}
\end{array}\right]
$$

onde:

$\mathrm{P}$ - carga concentrada vertical aplicada dentro do maciço de solo;

G - módulo de elasticidade transversal do solo;

$v$ - coeficiente de Poisson do solo;

z - profundidade do ponto em que se deseja calcular o deslocamento;

c - profundidade do ponto de aplicação da carga concentrada $(P)$.

$$
\begin{aligned}
& R_{1}=\sqrt{r^{2}+(z-c)^{2}} \\
& R_{2}=\sqrt{r^{2}+(z+c)^{2}}
\end{aligned}
$$




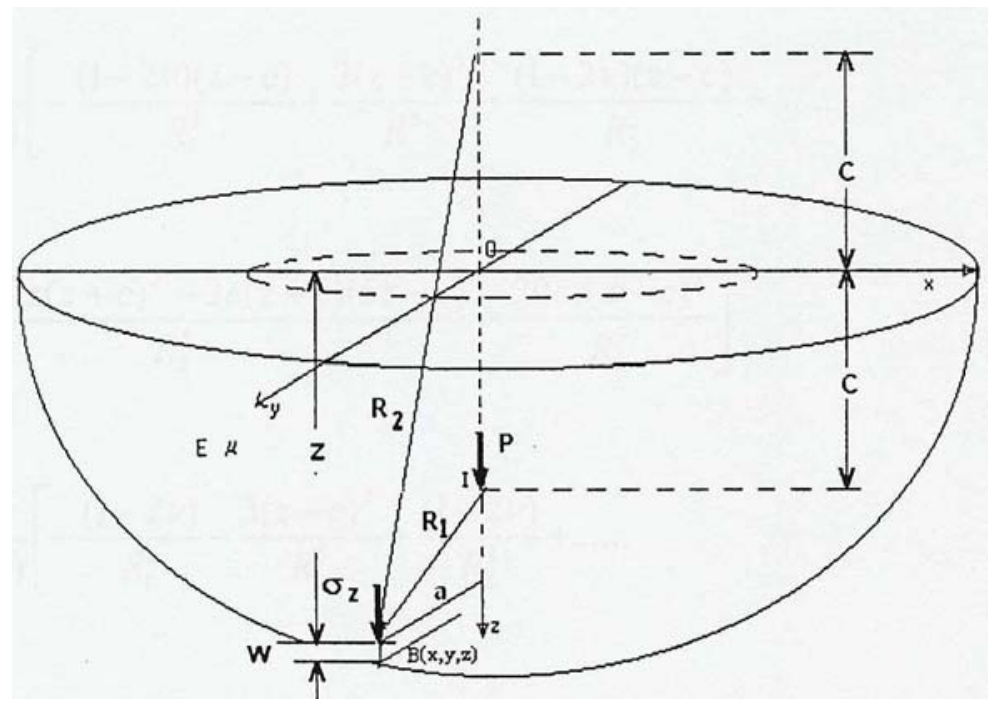

Figura 2.28 - Solução de Mindlin, geometria do problema, in Reis (2000).

Para o caso de maciços serem heterogêneos e de espessura finita, os autores sugerem adotar o procedimento de Steinbrenner (1934), no qual o recalque pode ser obtido a partir da solução de espessura infinita pela diferença entre o recalque no ponto em estudo e o ponto onde é considerada a superfície indeslocável. A Figura 2.29 ilustra a aplicação do procedimento de Steinbrenner.

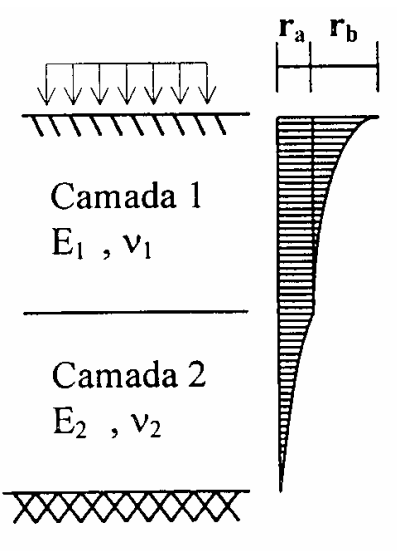

(a) Recalque final

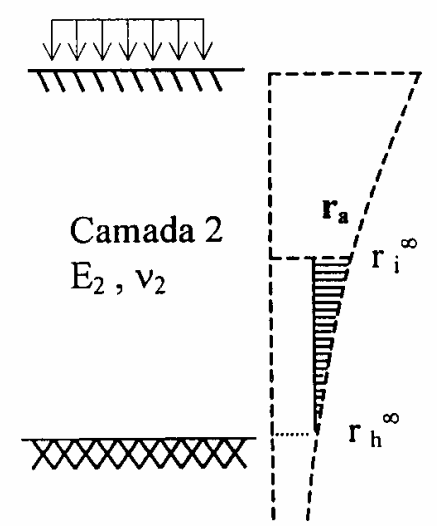

(b)

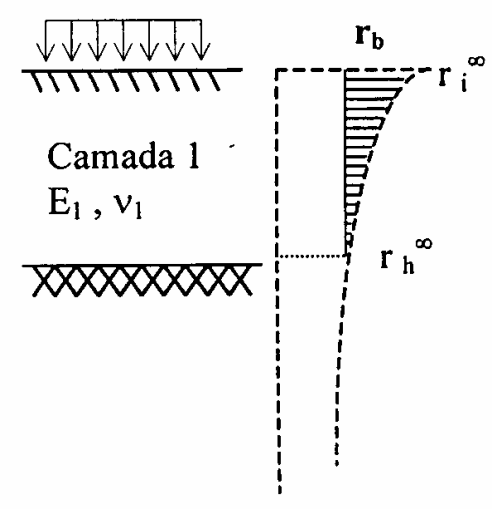

(c)

Figura 2.29 - Aplicação do procedimento de Steinbrenner para o caso de meio heterogêneo, in Iwamoto (2000).

Para o caso da aplicação do método Aoki e Lopes (1975) no cálculo do recalque do topo das estacas, são necessárias duas considerações fundamentais: 
a) Levantamento da indeterminação do problema.

A distribuição de tensões entre o elemento estrutural de fundação e o maciço de solo envolve um elevado grau de indeterminação ou hiperestaticidade. Segundo Aoki (1989), essa indeterminação pode ser levantada se for conhecido o mecanismo de transferência de carga, cujos diagramas são mostrados na Figura 2.33.

Normalmente, as parcelas de resistência de ponta $\left(P_{p}\right)$ e de atrito lateral $\left(P_{L}\right)$, bem como a distribuição deste ao longo do fuste da estaca são calculados por um método tradicional de capacidade de carga, como, por exemplo, Aoki e Velloso (1975a), Décourt e Quaresma (1979) ou qualquer outro método que permita determinar a capacidade de carga.

O diagrama de transferência de carga pode ser obtido por meio de provas de carga estática instrumentadas ou de provas de carga dinâmicas, com análises do tipo CAPWAP como, por exemplo, Balech (2000) ou Ávila (2001).

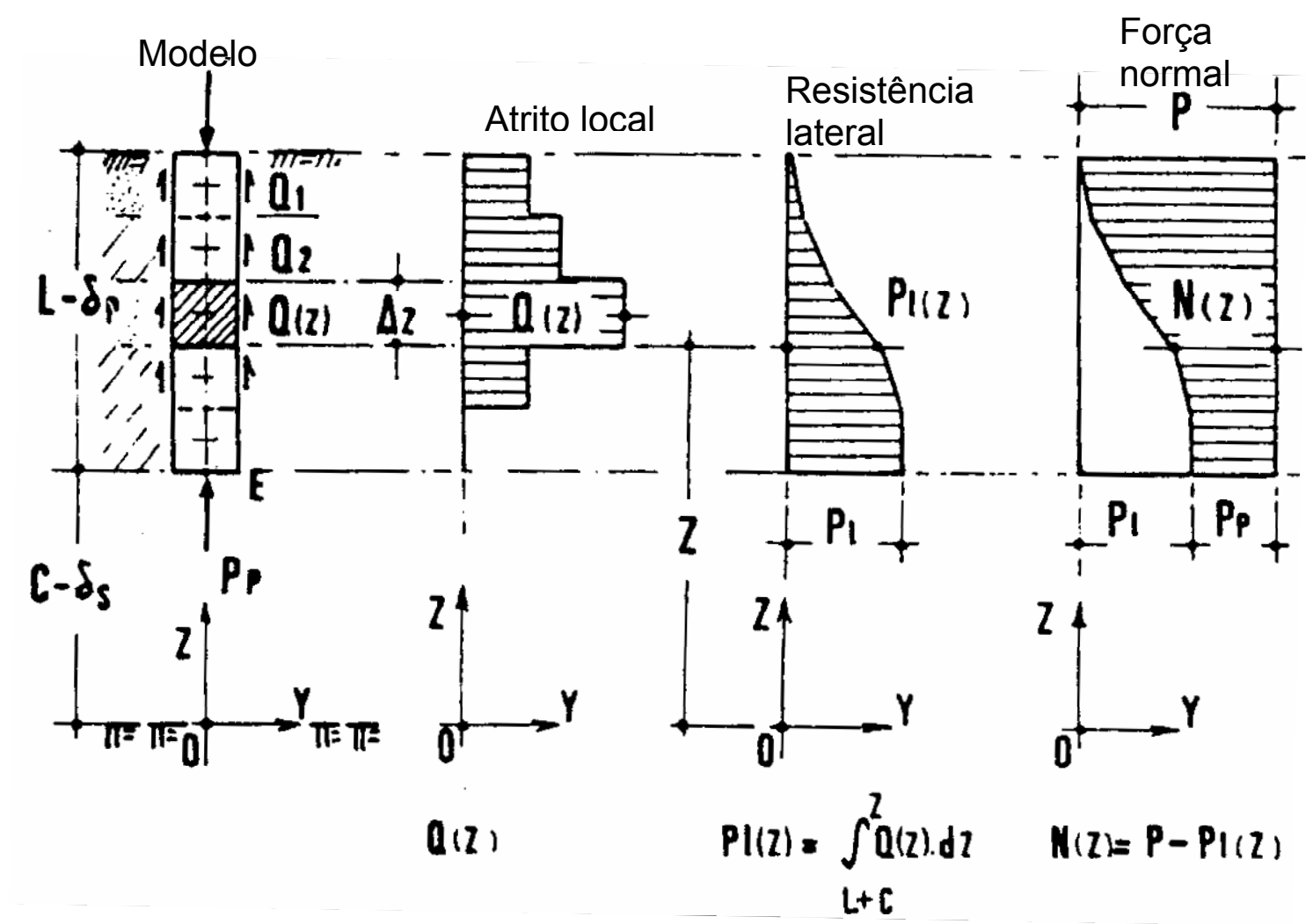

Figura 2.30 - Diagramas de transferência de carga, in: Aoki (1989).

b) Proposição de Vesic. 
Segundo Vesic, o recalque no topo da estaca é dado por duas parcelas, o deslocamento da ponta da estaca $\left(\delta_{\mathrm{s}}\right)$ determinado, por exemplo, pela integração numérica de Mindlin, apresentada por Aoki e Lopes, acrescido do encurtamento elástico da estaca $\left(\delta_{\mathrm{p}}\right)$, calculado pela lei de Hooke a partir do diagrama de esforço normal $\mathrm{N}(\mathrm{z})$ na estaca.

$$
\delta_{p}=\frac{1}{A \cdot E_{p}} \int_{c}^{c+L} N(z) \cdot d z
$$

A Figura 2.31 ilustra a distribuição dos deslocamentos verticais ao longo da estaca.

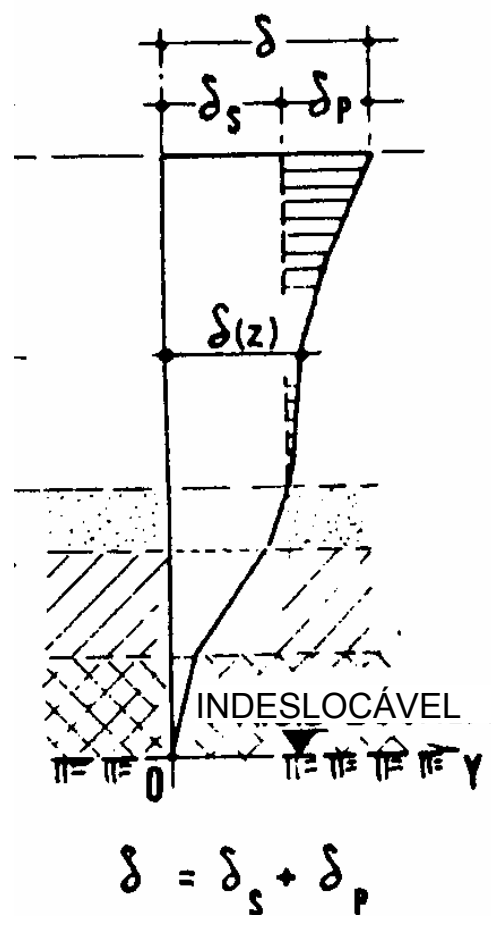

Figura 2.31 - Distribuição dos deslocamentos ao longo da estaca, in: Aoki (1989).

2.3.1.3 Método de Randolph.

Randolph (1977) e Randolph e Wroth (1978) apresentam solução para o cálculo do recalque no topo de uma estaca. Os principais aspectos envolvidos nesse método são resumidos a seguir. 
A análise é baseada em um solo de comportamento elástico, caracterizado pelo seu módulo de elasticidade transversal ou de cisalhamento (G), o qual pode variar com a profundidade, e um coeficiente de Poisson ( $v$ ). $O$ maciço de solo é dividido em duas partes por uma linha "AB", que passa pela ponta da estaca. Os autores admitem que a porção acima da linha "AB" deforma-se somente devido à ação das tensões de atrito lateral, desenvolvidas no contato entre o fuste da estaca e o solo, e que o solo abaixo da linha "AB" irá deformar-se pelas tensões desenvolvidas na ponta da estaca. A Figura 2.32 ilustra a desvinculação entre ponta e fuste proposta no Método de Randolph.

Considerando o equilíbrio vertical, verifica-se que as tensões cisalhantes ao redor do fuste da estaca decrescem numa proporção inversa com o raio da estaca, conforme Cooke (1974); Frank (1974) ou Baguelin et al. (1975).

$$
\begin{aligned}
& w_{r}=\frac{\tau_{o} r_{0}}{G} \ln \left(\frac{r_{m}}{r}\right) \quad r_{0} \leq r \leq r_{m} \\
& w_{r}=0 \quad r>r_{m}
\end{aligned}
$$

onde:

$\tau_{0}$ - tensão cisalhante no fuste da estaca,

$r_{0}$ - raio da estaca,

$r_{m}$ - raio de influência da estaca, dado pela expressão.

$$
r_{m}=2,5 L(1-v)
$$

sendo:

$\mathrm{L}$ - comprimento da estaca 


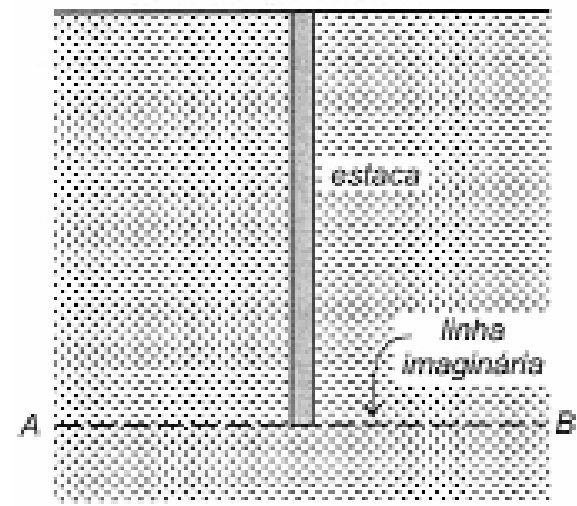

(a)

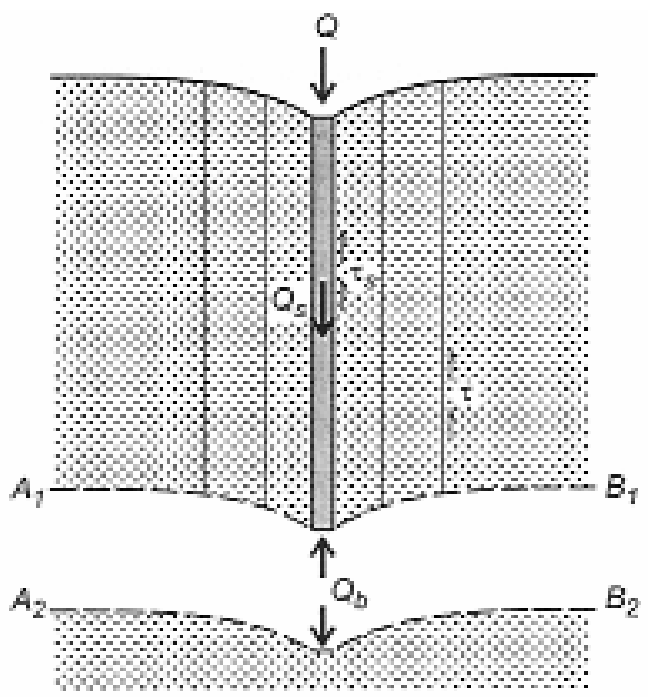

(b)

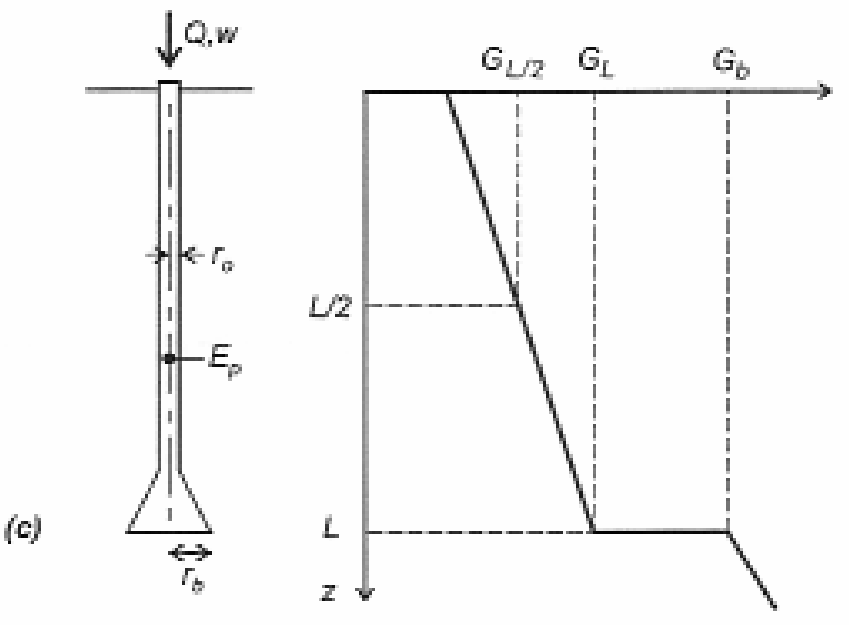

Figura 2.32 -Modelo de análise, método de Randolph in Velloso e Lopes (2002).

As deformações devidas ao atrito lateral podem ser escritas:

$$
w_{s}=\zeta \frac{\tau_{0} r_{0}}{G} \quad e \quad \zeta=\ln \left(\frac{r_{m}}{r_{o}}\right)
$$

A deformação da ponta da estaca é dada pela solução de Boussinesq. Ver, por exemplo, Timoshenko e Godier (1970):

$$
w_{p}=\frac{P_{b}(1-v)}{4 r_{0} G}
$$


sendo:

$\mathrm{P}_{\mathrm{b}}$ - a carga que atua na ponta da estaca.

Para uma estaca rígida são válidas as seguintes relações:

$$
w=w_{s}=w_{b} \quad e \quad P=P_{s}+P_{b}
$$

Essas relações, associadas às equações que definem $\left(w_{s}\right)$ e $\left(w_{p}\right)$ conduzem a expressão que fornece o recalque no topo da estaca.

$$
\frac{P}{w r_{0} G}=\frac{4}{(1-v)}+\frac{2 \pi L}{\zeta r_{0}}
$$

Para considerar a compressibilidade da estaca, Randolph introduz mais um coeficiente, chamado rigidez relativa $(\lambda)$, dado por:

$$
\lambda=\frac{E_{p}}{G}
$$

onde:

$E_{p}$ - módulo de elasticidade da estaca.

A condição de compressibilidade da estaca é expressa por:

$$
\frac{d w_{s}(z)}{d z}=\frac{P(z)}{\pi r_{0}^{2} E_{p}}
$$

Essa condição conduz a um sistema de três equações a três incógnitas que, resolvido, conduz a uma equação diferencial de segunda ordem, a qual, resolvida para as condições de contorno, resultam na expressão:

$$
\frac{P}{w r_{o} G}=\left[\frac{\frac{4}{(1-v)}+\frac{2 \pi}{\zeta} \frac{L}{r_{0}} \frac{\tanh (\mu L)}{\mu L}}{1+\frac{4}{(1-v)} \frac{1}{\pi \lambda} \frac{L}{r_{0}} \frac{\tanh (\mu L)}{\mu L}}\right]
$$


onde:

$$
\mu=\frac{1}{r_{0}\left(\frac{2}{\zeta \lambda}\right)^{1 / 2}}
$$

Essa solução é válida apenas para meio homogêneo. Os autores apresentam solução para o caso em que o módulo de elasticidade cresce linearmente com a profundidade, solo de Gibson (1967), e essa variação pode ser expressa por:

$$
G=m(b+z)
$$

Para o caso em questão, os autores consideram as condições representadas na Figura 2.32.

Nessa situação, os autores introduzem e redefinem os seguintes parâmetros:

$$
\rho=\frac{G_{L / 2}}{G_{L}} \quad \text { e } \quad r_{m} \cong 2,5 L(1-v) \rho
$$

chegando a uma nova expressão geral dada por:

$$
\frac{P}{w r_{o} G}=\left[\frac{\frac{4}{(1-v)}+\frac{2 \pi}{\zeta} \frac{L}{r_{0}} \frac{\tanh (\mu L)}{\mu L} \rho}{1+\frac{4}{(1-v)} \frac{1}{\pi \lambda} \frac{L}{r_{0}} \frac{\tanh (\mu L)}{\mu L}}\right]
$$

Para o caso em que ocorra um súbito aumento do módulo cisalhante logo abaixo da ponta da estaca, e ainda para o caso de base alargada, os autores introduzem novos coeficientes:

$$
\Omega=\frac{G_{L}}{G_{b}} \quad n=\frac{r_{b}}{r_{0}}
$$


os quais conduzem à expressão:

$$
\frac{P}{w r_{o} G}=\left[\frac{\frac{4}{(1-v) \Omega}+\frac{2 \pi}{\zeta} \frac{L}{r_{0}} \frac{\tanh (\mu L)}{\mu L} \rho}{1+\frac{4 n}{(1-v) \Omega} \frac{1}{\pi \lambda} \frac{L}{r_{0}} \frac{\tanh (\mu L)}{\mu L}}\right]
$$

\subsubsection{MÉTODOS NUMÉRICOS.}

Encontram-se nesta categoria os métodos das diferenças finitas, dos elementos finitos e dos elementos de contorno.

O método dos elementos finitos é normalmente empregado utilizando-se programas comerciais. Os elementos envolvidos no problema da determinação do recalque de uma estaca podem ser discretizados pelos elementos de barra, placa ou sólidos.

Segundo Vesic (1977), as deficiências apresentadas pelos métodos baseados na teoria da elasticidade podem ser superadas com o uso de análises pelo método dos elementos finitos, com modelos de solos mais complexos, permitindo levar em conta efeitos da seqüência de carregamento, nível de tensões e mudanças de densidade. Esse tipo de análise permite a introdução das condições de tensão e deslocamento impostas pelo método de execução das estacas e considerar que a presença da estaca altera o estado de tensões no maciço de solo. Também permite a introdução de heterogeneidades arbitrárias no maciço, tais como lentes e camadas de solos com diferentes características.

Velloso e Lopes (2002) consideram que, no método dos elementos finitos, o contínuo, maciço de solo, é representado por elementos - cujo comportamento pode ser facilmente formulado em função de sua geometria e propriedades - conectados entre si por meio de pontos pelos quais interagem entre si. A solução obtida por esse método será tão mais próxima da exata quanto maior for o número de pontos da solução numérica (ou seja, quanto mais refinada for a rede ou malha). O método dos elementos de contorno difere do de elementos finitos na medida em que apenas a fronteira dos elementos precisa ser dividida em elementos. 
Segundo estes autores as principais vantagens do método de elementos de contorno em relação ao de elementos finitos são:

a) discretização restrita ao contorno;

b) menor número de incógnitas;

c) facilidade no tratamento de domínios semi-infinitos ou com superfície livre;

d) bons resultados em regiões onde ocorrem concentração de tensões.

As desvantagens apontadas pelos mesmos autores são:

a) sistema de equações não simétrico;

b) utilizado basicamente em problemas lineares;

c) dificuldade em se determinar a solução fundamental para fenômenos novos.

O modelo de comportamento dos elementos, implementado nesses métodos, pode ser elástico, elástico não linear (hiperbólico) ou elasto-plástico.

\subsection{MÉTODOS DE PREVISÃO DE RECALQUES DE GRUPO DE ESTACAS.}

\subsubsection{MÉTODOS SIMPLIFICADOS.}

\subsubsection{Métodos Empíricos.}

Nesses métodos são apresentadas correlações normalmente expressas em função do Fator de Recalque $\left(R_{s}\right)$, que é a razão entre o recalque do grupo de estacas $\left(\delta_{\mathrm{g}}\right)$ e o recalque de uma estaca isolada $\left(\delta_{\mathrm{i}}\right)$ sob sua parcela de carga no grupo.

$$
R_{s}=\delta_{g} / \delta_{i}
$$

Tais correlações envolvem entes geométricos do arranjo do grupo de estacas e foram elaboradas a partir de condições particulares

Citam-se, a seguir, algumas correlações mencionadas na literatura.

Skempton (1953) sugeriu a seguinte equação para estimativa do recalque de grupo de estacas em areia: 


$$
R_{s}=\left(\frac{4 B+3}{B+4}\right)^{2}
$$

onde:

B - largura do grupo de estacas (em metros).

Meyerhof (1959) propôs:

$$
R_{s}=\frac{c\left(5-\frac{c}{3}\right)}{\left(1+\frac{1}{n_{r}}\right)^{2}}
$$

onde:

$c=s / D$ - relação entre espaçamento entre estacas (s) e o diâmetro (D) das estacas que compõem o bloco;

$\mathrm{n}_{\mathrm{r}}$ - número de linhas de estacas.

Posteriormente, em sua Terzaghi Lecture, Meyerhof (1976) apresentou expressão para cálculo do recalque (w expresso em polegadas) do grupo de estacas em areias e pedregulhos:

$$
w=\frac{2 q \sqrt{B}}{N}
$$

onde:

B - largura do grupo de estacas (em pés);

$\mathrm{q}$ - pressão aplicada ao solo pelo grupo de estacas (em $\left.\mathrm{kgf} / \mathrm{cm}^{2}\right)$;

$\mathrm{N}$ - número de golpes SPT médio ao longo de uma profundidade igual à largura do grupo.

Para areias siltosas, o valor calculado pela expressão anterior deve ser dobrado. Caso as estacas penetrem ( $\left.D^{\prime}\right)$ na camada suporte, o valor da expressão anterior deve ser multiplicado por: 


$$
I=1-\frac{D^{\prime}}{8 B} \geq 0,5
$$

Vesic (1969) sugeriu:

$$
R_{s}=\sqrt{\frac{B}{D}}
$$

onde:

B - largura do grupo de estacas;

D - diâmetro das estacas.

Randolph, em Fleming et al. (1985), sugere a expressão:

$$
R_{s}=n^{w}
$$

onde:

$\mathrm{n}$ - número de estacas;

w - expoente, adotado normalmente entre 0,4 e 0,6 para a maioria dos grupos.

O valor 0,5 vem sendo empregado por diversos autores, como Poulos (1993a).

Poulos e Davis (1980) apresentam uma série de tabelas para a determinação de $\left(R_{s}\right)$, considerando fatores de interação entre estacas. Os fatores de interação, além das propriedades elásticas do solo e das estacas, dependem fundamentalmente do espaçamento entre os elementos envolvidos.

\subsubsection{Fundações equivalentes.}

Diversos autores apresentam soluções simplificadas, nas quais o grupo de estacas é substituído por um elemento isolado "equivalente", sendo então o recalque calculado para esse elemento fictício.

a) Radier equivalente.

Essa proposta foi inicialmente apresentada por Terzaghi (1943), a qual considera que o grupo pode ser substituído por um radier situado acima da ponta das estacas, a uma distância de $1 / 3$ do seu comprimento. Os recalques 
podem então ser estimados utilizando-se soluções da teoria da elasticidade empregadas para o caso de fundações superficiais. Procedimento similar também é recomendado no item 7.7 da NBR 6122 (1996) a fim de avaliar o efeito do grupo de estacas.

Randolph (1994) sugere que a posição do radier equivalente situe-se a $1 / 3$ do comprimento em que efetivamente há contribuição de atrito lateral para estacas onde a parcela lateral é predominante (Figura 2.33 a). Para o caso de estacas onde predomina a resistência de ponta, sugere que $O$ radier equivalente situe-se na mesma cota da ponta das estacas (Figura $2.33 \mathrm{~b}$ ). A figura a seguir ilustra essas sugestões.

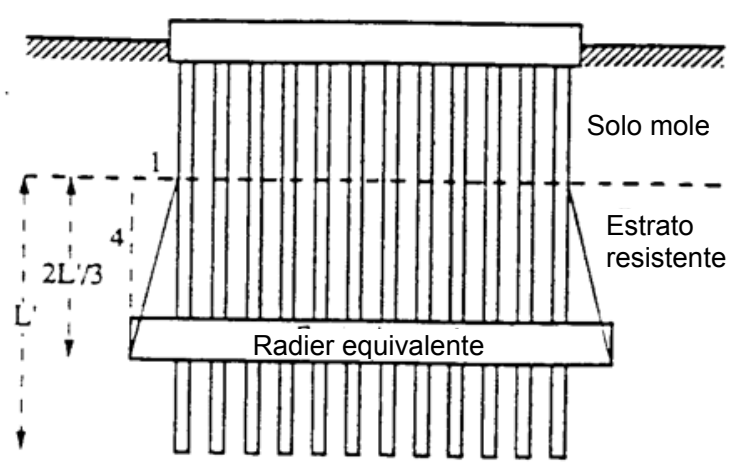

a) Estacas com atrito lateral predominante

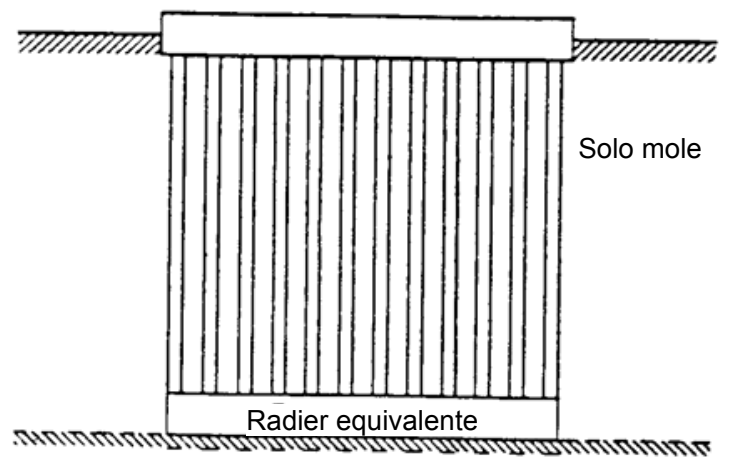

b) Estacas com resistência de ponta predominante

Figura 2.33 - Radier equivalente - proposição de Randolph (1994).

b) Tubulão equivalente.

Poulos (1980) propõe que o grupo de estacas seja substituído por um tubulão equivalente, no qual seu diâmetro $\left(\mathrm{d}_{\mathrm{e}}\right)$ é dado por:

$$
d_{e}=1,27 \sqrt{A_{g}}
$$


para estacas em que predomina a resistência de atrito lateral, e

$$
d_{e}=1,13 \sqrt{A_{g}}
$$

para estacas em que há predominância da resistência de ponta, sendo $A_{g}$ - área da figura plana que inscreve o grupo de estacas.

Poulos (1980) apresenta gráfico, reproduzido na Figura 2.34, para o caso de estacas "flutuantes", no qual é mostrada a relação da razão entre o diâmetro do tubulão equivalente e o lado do quadrado que inscreve o grupo de estacas $\left(d_{e} / B\right)$ e o espaçamento entre estacas, para diferentes valores da rigidez $\mathrm{K}$ da estaca e diferentes relações comprimento diâmetro (L/d).

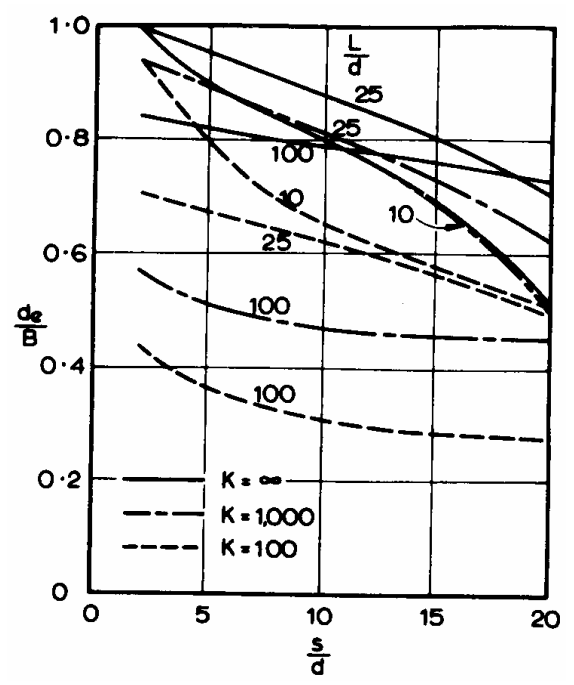

Figura 2.34 - Determinação do diâmetro do tubulão equivalente, caso de estacas "flutuantes", Poulos e Davis (1980).

Poulos (1993a) considera que a solução do tubulão equivalente seria mais aplicável para grupos com menos de 16 estacas, e que a solução em radier equivalente seria mais adequada para grupos com mais de 16 estacas. 


\subsubsection{MÉTODOS BASEADOS NA TEORIA DA ELASTICIDADE.}

\subsubsection{Método de Poulos e Davis.}

A metodologia aplicada ao caso de estaca isolada foi estendida para o caso de grupo de estacas (Poulos, 1980).

Inicialmente os autores introduzem um fator de interação em termos de recalque $(\alpha)$ entre duas estacas iguais e igualmente carregadas, definido como pela relação:

$$
\alpha=\frac{\text { recalque adicional provocado por uma estaca adjacente }}{\text { recalque de uma estaca sob sua própria carga }}
$$

Para o caso de meio elástico semi-infinito com coeficiente de Poisson igual a 0,5 , os valores de $(\alpha)$ são apresentados em gráficos em função do espaçamento entre estacas $(\mathrm{s} / \mathrm{B})$, do fator de rigidez $(\mathrm{K})$ e para diferentes valores da relação (L/B), os quais são reproduzidos a seguir.
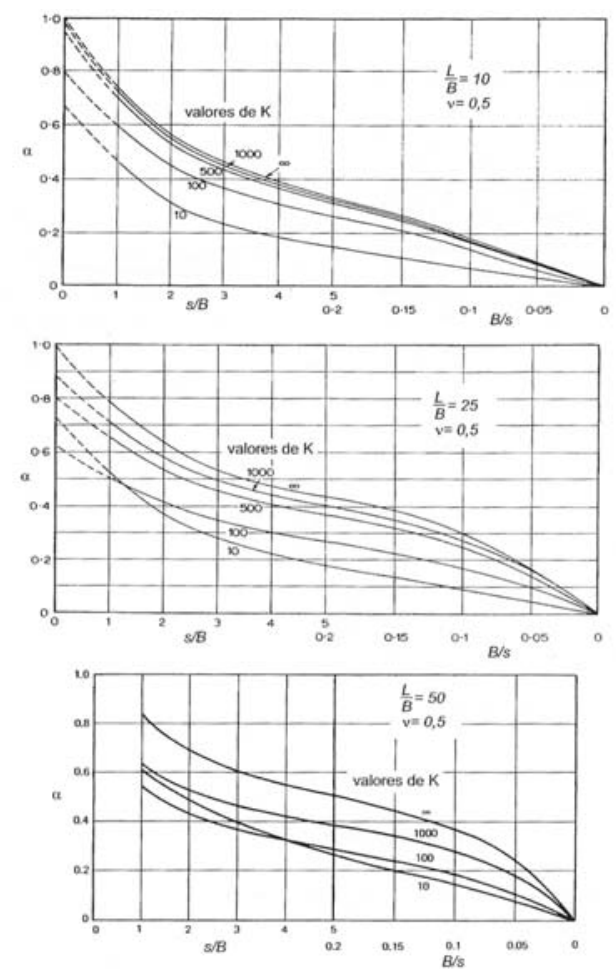

Figura 2.35 - Fator de interação $(\alpha)$ entre duas estacas, in Velloso e Lopes (2002). 
Para o caso de espessura finita do maciço de solo, coeficiente de Poisson diferente de 0,5 e alargamento da base do elemento isolado de fundação, estes autores sugerem modificar o valor do fator de interação $(\alpha)$ pela expressão:

$$
\alpha=\alpha \cdot N_{h} \cdot N_{v} \cdot N_{B}
$$

onde os fatores $N_{h}, N_{v}$ e $N_{B}$ são dados nos gráficos a seguir:
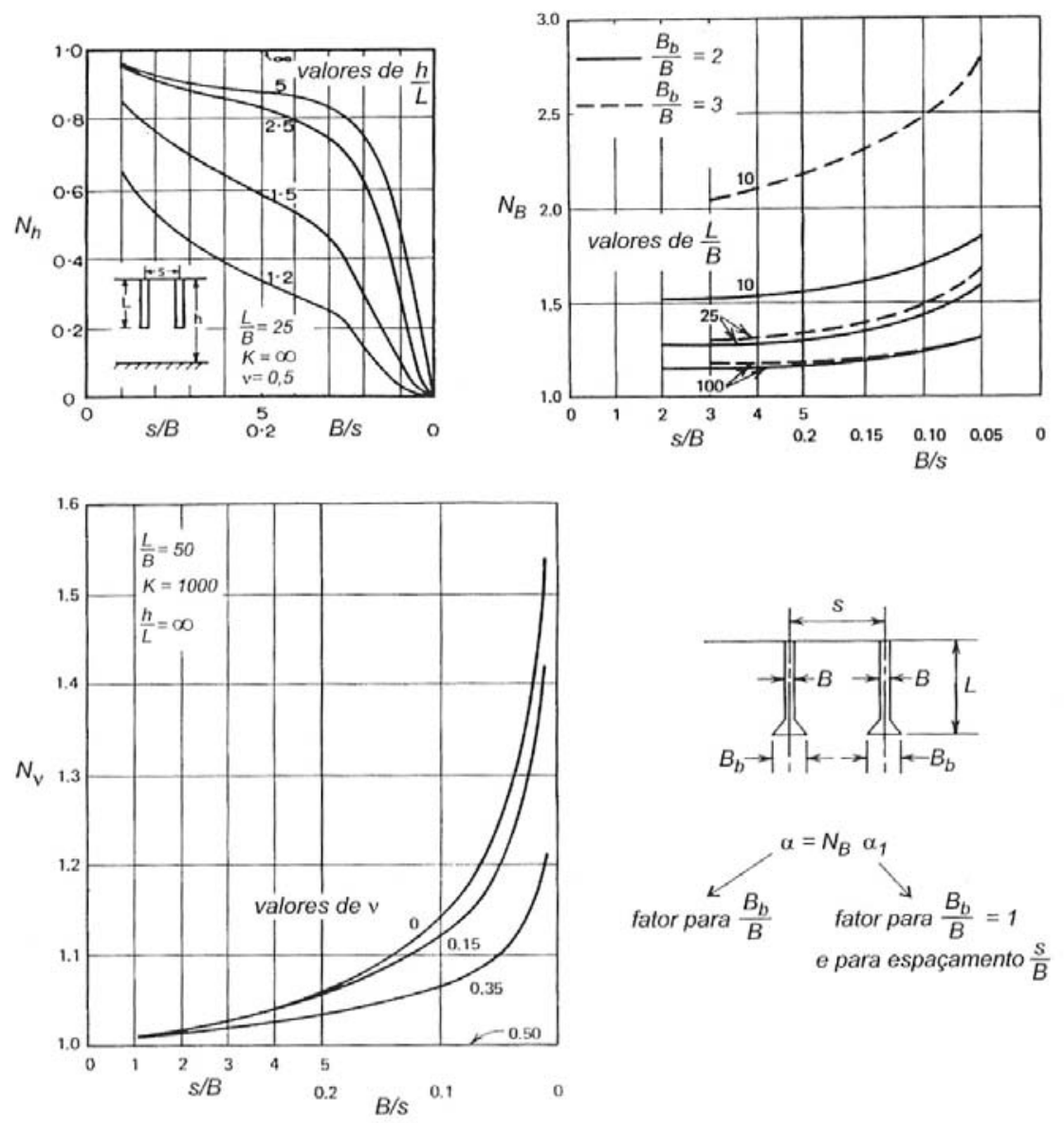

Figura 2.36 - Correções ao fator de interação, in Velloso e Lopes (2002).

Para um grupo de (n) estacas iguais e por superposição de efeitos da formulação acima, o recalque de uma estaca $\left(\mathrm{w}_{\mathrm{i}}\right)$ pode ser expresso por:

$$
w_{i}=w_{1}\left[\sum_{\substack{j=1 \\ j \neq i}}^{n}\left(Q_{j} \alpha_{i j}\right)+Q_{i}\right]
$$


onde:

$\mathrm{w}_{1}$ - recalque da estaca isolada sob carregamento unitário;

$Q_{j}$ - carga na estaca "j";

$\alpha_{i j}$ - fator de interação entre as estacas "i” e "j".

\subsubsection{Método de Aoki e Lopes.}

Não existem alterações no método proposto para o caso de elemento isolado. Há necessidade de superpor os efeitos dos elementos envolvidos no(s) ponto(s) onde o recalque está sendo avaliado.

\subsubsection{MÉTODOS NUMÉRICOS.}

Assim como no método anterior, não existem diferenças entre o caso de estaca isolada e o grupo de estacas. 


\section{MODELOS REOLÓGICOS}

\subsection{FLUÊNCIA.}

O termo fluência é empregado para definir deformações inelásticas dependentes do tempo, sob a ação de um carregamento constante. Em alguns materiais, grandes deformações plásticas podem ocorrer e causar a ruptura por fluência.

Segundo Boresi et al. (1993) as primeiras observações de fluência de materiais remontam a um passado remoto. Uma forma simples de fluência na natureza é o movimento lento, quase imperceptível de partículas de solo de um talude sob a ação da gravidade. Nossos ancestrais devem ter observado esse fenômeno nas rochas dos tetos de suas cavernas ou no gelo das paredes e teto de seus iglus.

Os primeiros estudos quantitativos sobre o assunto remontam ao ano de 1834, quando o engenheiro francês L. J. Vicat, estudando o comportamento de fios de ferro endurecidos para aplicação em cabos para pontes suspensas, observou o desenvolvimento de deformações dependentes do tempo sob a ação de carga constante. Somente no início do século 20 o completo conhecimento da curva de fluência foi determinado para fios de aço e diversos materiais.

Devido à extrema complexidade do comportamento da fluência, as análises geralmente são realizadas pelo ajuste de curvas de dados experimentais, sendo esse ajuste expresso por meio de fórmulas empíricas, as quais podem apresentar-se sob as seguintes formas:

Racional $\quad \varepsilon_{c}=\frac{a \cdot t}{1+b \cdot t}$ 
Logarítmica

$$
\varepsilon=a+b \cdot \ln (t) \quad \varepsilon=a+b \cdot \ln (1+c \cdot t)
$$

Exponencial

$$
\varepsilon=a+b \cdot t-c \cdot \exp (-d \cdot t) \quad \varepsilon_{c}=a \cdot t+b \cdot[1-\exp (-c \cdot t)]
$$

Potência

$$
\varepsilon_{c}=b \cdot t^{n}
$$

Sendo, nessas equações

$\varepsilon$ - deformação total;

$\varepsilon_{\mathrm{C}}-$ deformação por fluência;

$\mathrm{t}$ - tempo;

a, b, c, d-constantes.

A fluência caracteriza-se por três estágios distintos (primário, secundário e terciário), conforme ilustrado nos gráficos a seguir, os quais apresentam a evolução da deformação $(\varepsilon)$ e da velocidade de deformação $\left(\varepsilon^{\bullet}\right)$ com o tempo.
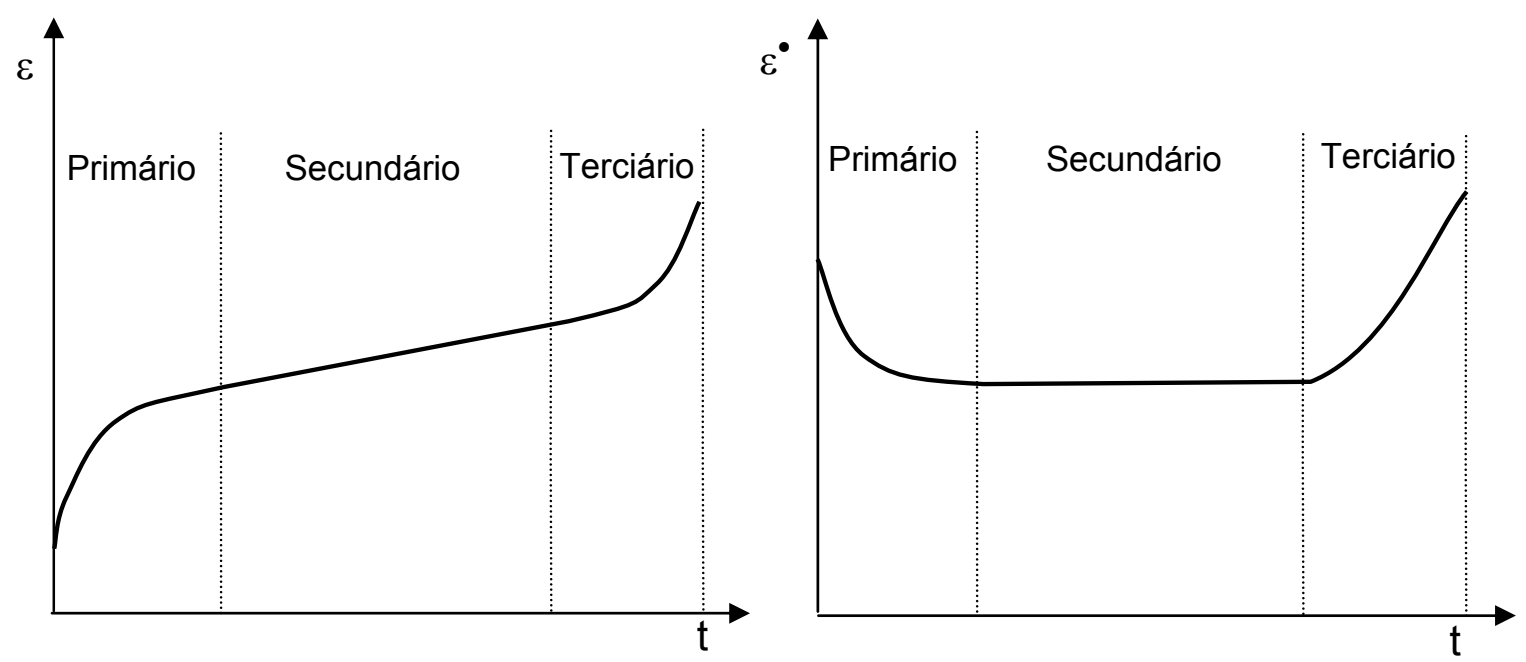

Figura 3.1 - Estágios da fluência, in Francisco (2004).

Os gráficos da Figura 3.1 indicam que ao se aplicar uma tensão constante em um corpo sólido, esse apresenta uma deformação inicial denominada deformação elástica instantânea. No estágio primário, mantido esse nível de tensão constante com o tempo, há um crescimento da deformação, sendo que a velocidade de deformação decresce. O estágio 
secundário caracteriza-se por deformações crescentes sob velocidade de deformação constante. Finalmente, no estágio terciário manifesta-se um crescimento da velocidade de deformação até a ruptura.

\subsection{MODELOS REOLÓGICOS UNIDIMENSIONAIS.}

Para melhor compreensão dos mecanismos que regem 0 comportamento de um dado material ou sistema, empregam-se analogias mecânicas, denominadas modelos reológicos. Segundo Santa Maria et al. (1999), os modelos reológicos básicos são três:

a) Modelo Hookeano, ou "modelo elástico", constituído por uma única mola de comportamento linear com resposta independente do tempo.

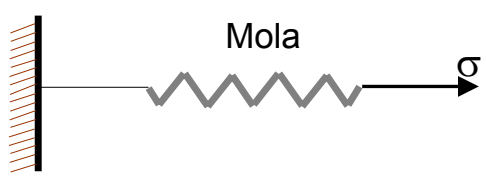

Figura 3.2 - Representação física para o modelo Hookeano.

O comportamento representado por esse modelo corresponde ao caso em que o material, sendo solicitado por uma ação externa, sofre deformações imediatas, as quais permanecem constantes enquanto durar o carregamento. Uma vez removida a ação externa, as deformações são totalmente revertidas. Para esse modelo é possível estabelecer a relação entre a tensão aplicada $(\sigma)$ e a deformação $(\varepsilon)$ :

$$
\sigma=k \cdot \varepsilon
$$

onde:

k- denominada constante de mola, ou coeficiente de rigidez da mola, a qual pode ser uma função constante, ou não, dependendo do material a ser representado. No caso da função ser representada por uma constante, o coeficiente de rigidez da mola é denominado Módulo de Elasticidade do material (E), sendo, então, a condição expressa pela Lei de Hooke para o caso unidimensional: 


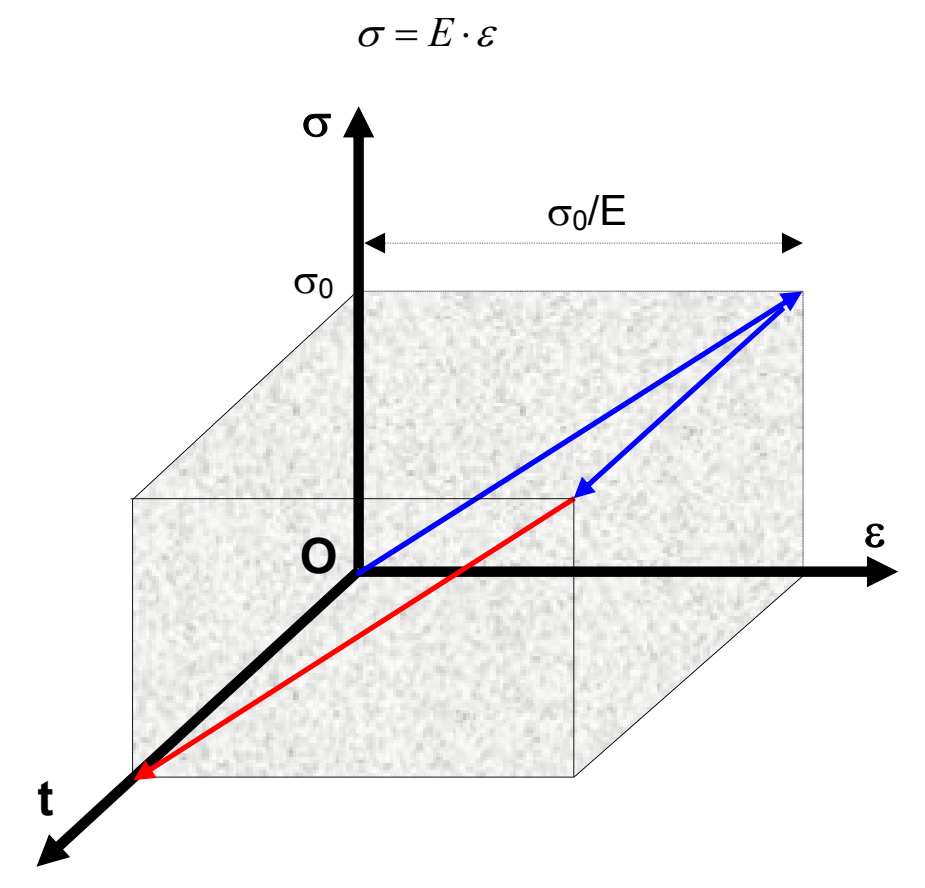

Figura 3.3 - Comportamento tensão deformação tempo - modelo elástico linear.

Obs.: As representações gráficas tridimensionais aqui mostradas são uma adaptação livre do originalmente apresentado por Hertzberg (1996).

b) Modelo Newtoniano, ou "modelo viscoso" o qual é constituído por um único amortecedor, com comportamento linear e tem resposta dependente do tempo.

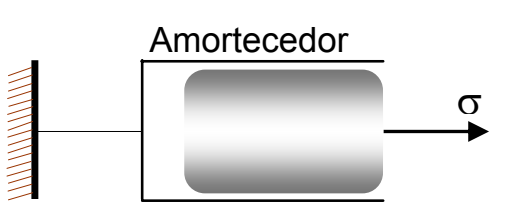

Figura 3.4 - Representação física para o modelo Newtoniano.

O comportamento representado por esse modelo indica que, ao ser solicitado por ação externa, o material sofre deformações que variam ao longo do tempo, sendo essas irreversíveis quando for removida a ação externa. Analiticamente, pode-se expressar que a tensão é proporcional à taxa de variação da deformação com o tempo:

$$
\sigma=\eta \cdot \frac{d \varepsilon}{d t}
$$

onde: 
$\eta$ - coeficiente de viscosidade do material.

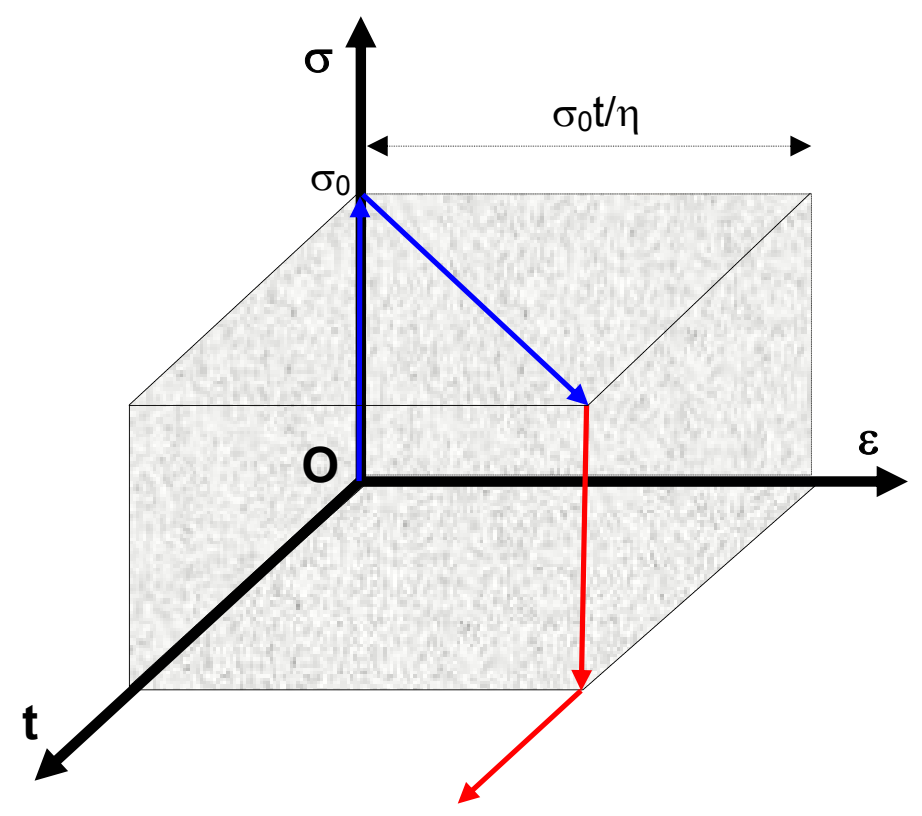

Figura 3.5 - Comportamento tensão deformação tempo - material viscoso perfeito.

c) Modelo rígido-plástico, que é constituído por um único bloco de atrito, com comportamento tensão deformação proporcional à função degrau e tem resposta independente do tempo.

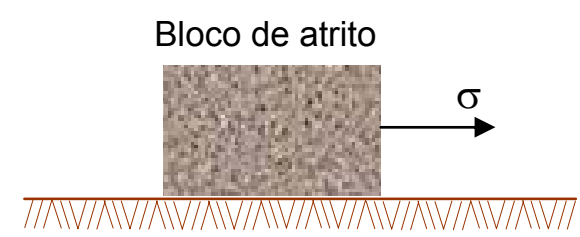

Figura 3.6 - Representação física para o modelo plástico.

No modelo plástico, aplicando-se um esforço externo a um corpo, esse não sofrerá deformações até um estado limite denominado tensão de escoamento $\left(\sigma_{y}\right)$, a partir da qual o corpo sofrerá deformações plásticas $\left(\varepsilon_{p}\right)$ que ocorrem de maneira ilimitada e irreversível. 


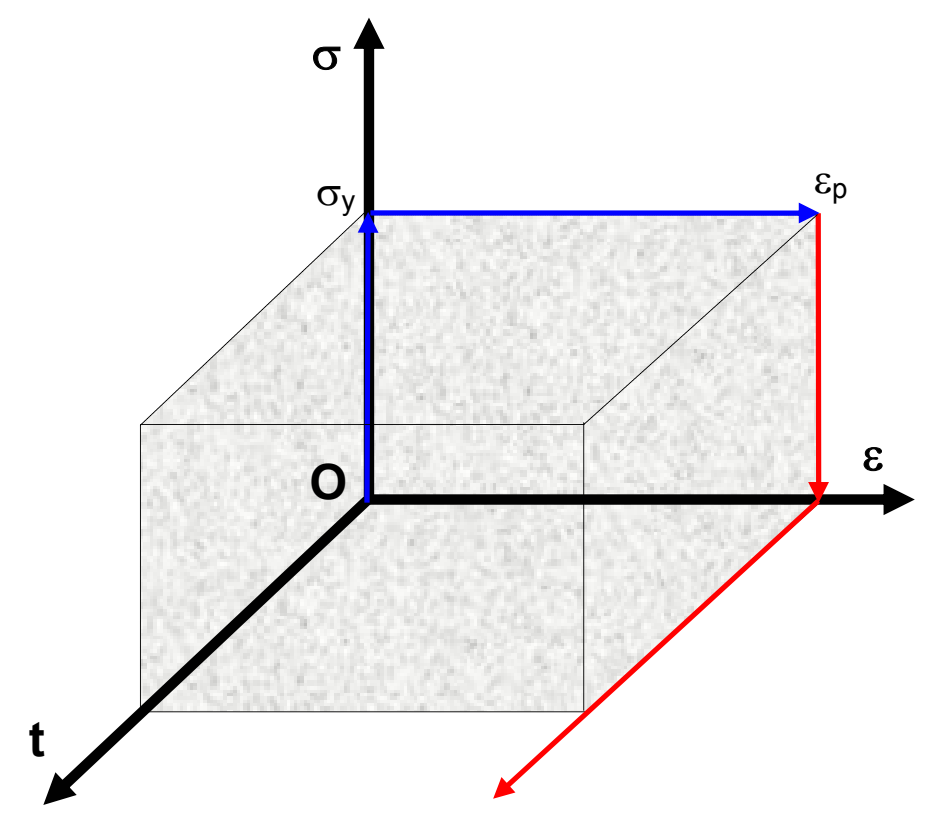

Figura 3.7 - Comportamento tensão deformação tempo - material rígido plástico.

De modo a permitir a representação do comportamento de certos materiais ou sistemas, torna-se necessário combinar os modelos elementares, os quais são denominados modelos compostos elementares, dados a seguir:

a) Modelo de Saint-Venant, ou modelo elasto-plástico, composto por uma mola e um bloco de atrito em série.

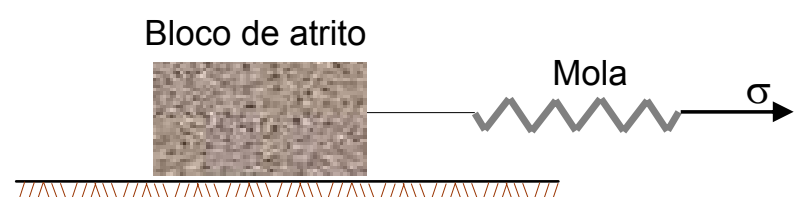

Figura 3.8 - Representação física para o modelo elasto-plástico.

Nesse modelo, as tensões agem igualmente nos dois elementos, e a deformação total é dada pela somas da deformação elástica $\left(\varepsilon_{\mathrm{e}}\right)$ proveniente da mola e da deformação plástica $\left(\varepsilon_{p}\right)$.

$$
\begin{aligned}
& \sigma<\sigma_{y} \Rightarrow \varepsilon=\varepsilon_{e} \\
& \sigma \geq \sigma_{y} \Rightarrow \varepsilon=\varepsilon_{e}+\varepsilon_{p}
\end{aligned}
$$




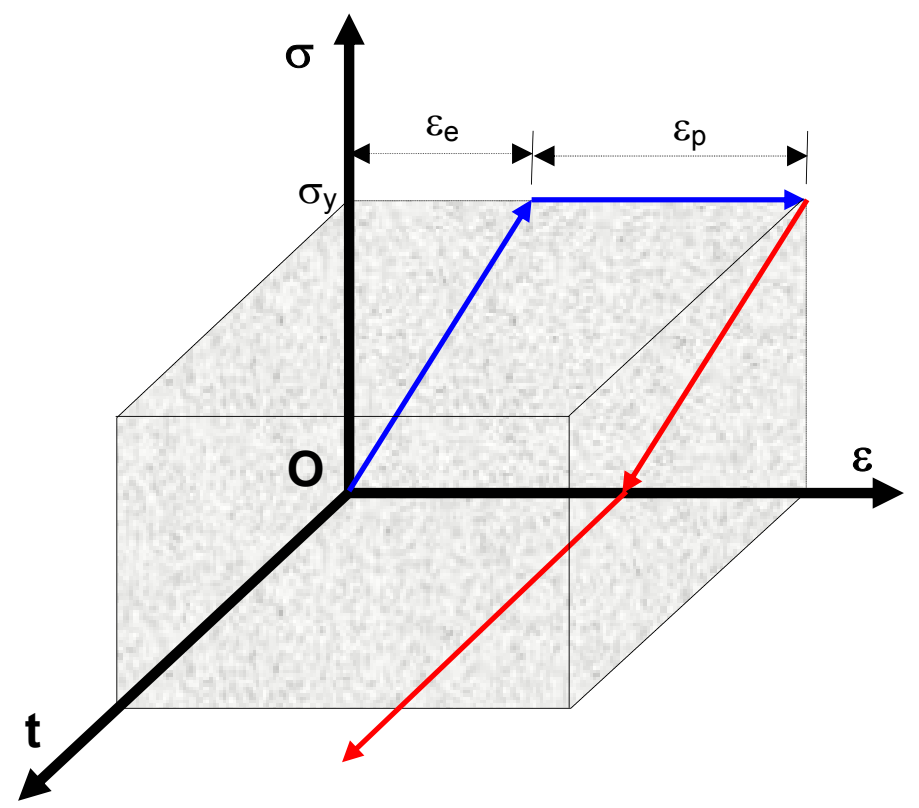

Figura 3.9 - Comportamento tensão deformação tempo - material elasto-plástico perfeito.

b) Modelo de Maxwell, formado por uma mola e um amortecedor dispostos em série.

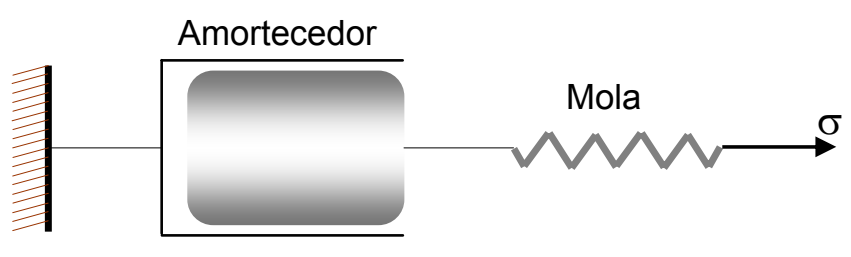

Figura 3.10 - Representação física para o modelo de Maxwell.

Nessa situação, as tensões na mola $\left(\sigma_{\mathrm{m}}\right)$ e no amortecedor $\left(\sigma_{\mathrm{t}}\right)$ são iguais:

$$
\sigma=\sigma_{m}=\sigma_{t}
$$

sendo:

$$
\sigma_{m}=E \cdot \varepsilon_{e} \quad \sigma_{t}=\eta \cdot \frac{d \varepsilon_{t}}{d t}
$$

A deformação total é obtida pela soma das duas parcelas de deformação: 


$$
\varepsilon=\varepsilon_{e}+\varepsilon_{t}
$$

A taxa de deformação em função do tempo é igual à taxa de deformação elástica somada à taxa de deformação viscosa:

$$
\frac{d \varepsilon}{d t}=\frac{d \varepsilon_{e}}{d t}+\frac{d \varepsilon_{t}}{d t}
$$

A equação (3.12), combinada com as relações apresentadas em (3.10), define a equação diferencial do modelo de Maxwell:

$$
\frac{d \varepsilon}{d t}=\frac{d \sigma}{E \cdot d t}+\frac{\sigma}{\eta}
$$

Um corpo cujo comportamento segue o modelo de Maxwell apresenta, no instante da aplicação do carregamento, uma deformação elástica instantânea $\left(\varepsilon_{\mathrm{i}}\right)$. Após esse momento inicial o corpo continua a se deformar ao longo do tempo. Uma vez removida a ação externa o corpo recupera instantaneamente as deformações elásticas, ao passo que as deformações viscosas permanecem constantes com o tempo e são irreversíveis.

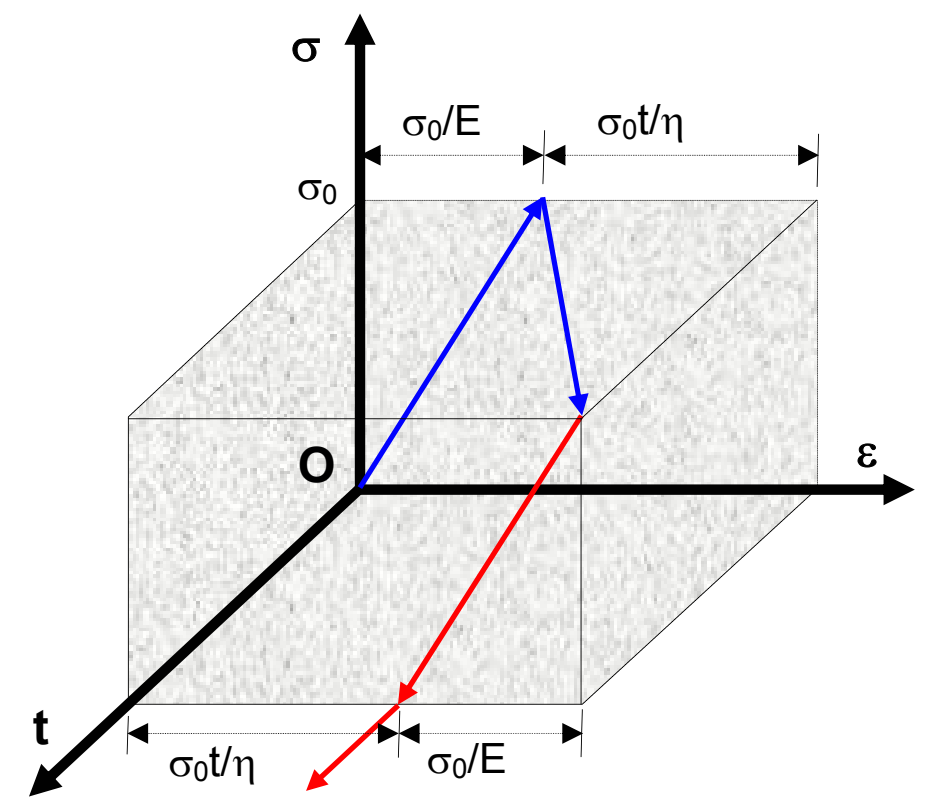

Figura 3.11 - Comportamento tensão deformação tempo - modelo de Maxwell. 
c) Modelo de Kelvin, constituído por arranjo de uma mola e um amortecedor em paralelo.

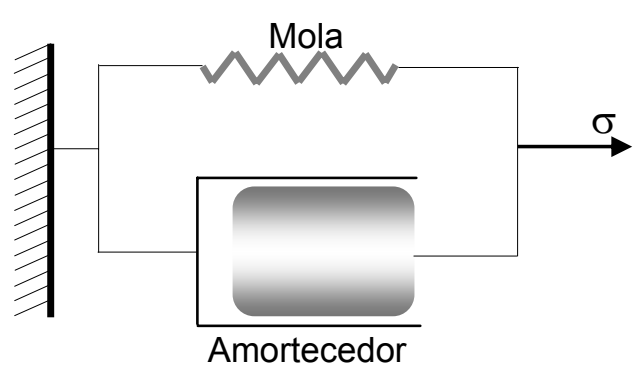

Figura 3.12 - Representação física para o modelo de Kelvin.

Nesse modelo, as deformações nos dois elementos são iguais em qualquer tempo:

$$
\varepsilon=\varepsilon_{e}+\varepsilon_{t}
$$

A tensão total é a soma da tensão atuante na mola $\left(\sigma_{e}\right)$ com a tensão que atua no amortecedor $\left(\sigma_{\mathrm{t}}\right)$ :

$$
\sigma=\sigma_{e}+\sigma_{t}
$$

onde:

$$
\sigma_{m}=E \cdot \varepsilon_{e} \quad \sigma_{t}=\eta \cdot \frac{d \varepsilon_{t}}{d t}
$$

A equação constitutiva para materiais, cujo comportamento é descrito pelo modelo de Kelvin, é obtida pela combinação das equações (3.14) e (3.15):

$$
\sigma=E \cdot \varepsilon_{e}+\eta \cdot \frac{d \varepsilon}{d t}
$$

Esse modelo representa o comportamento de um corpo que, ao ser solicitado, não sofre deformações instantâneas. As deformações desenvolvem- 
se ao longo, do tempo tendendo a um valor assintótico a tempo infinito. Quando descarregado, todas as deformações são recuperadas.

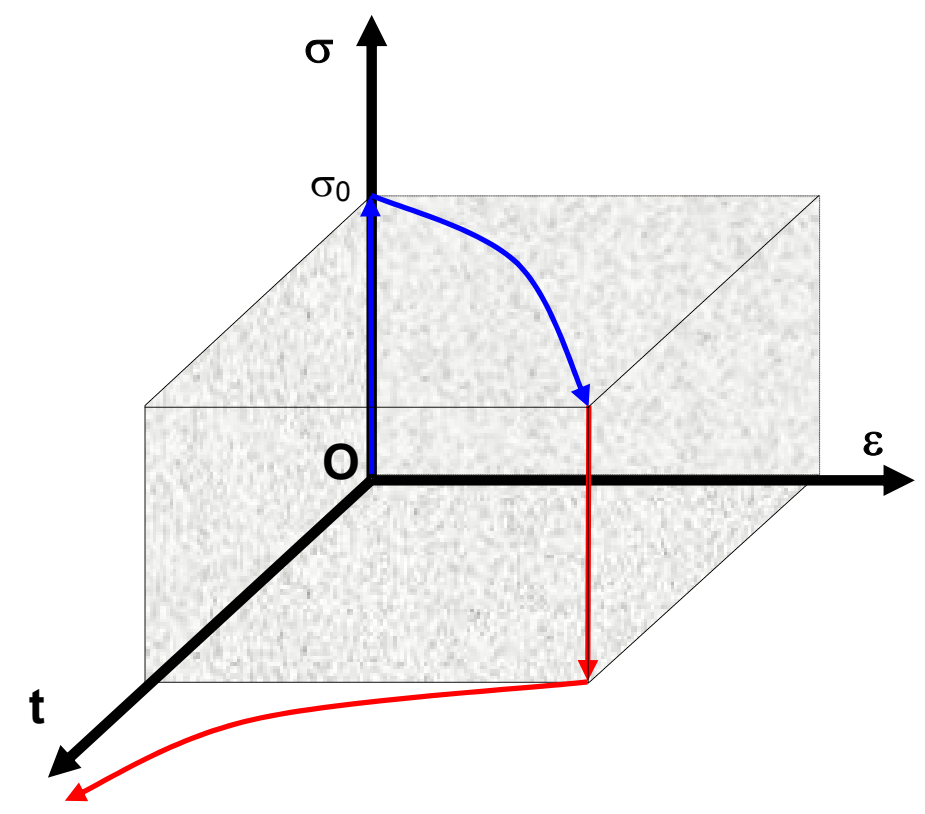

Figura 3.13 - Comportamento tensão deformação tempo - modelo de Kelvin.

Para materiais que apresentam comportamento mais complexo, os modelos reológicos elementares e compostos elementares podem ser combinados de forma a gerar modelos denominados compostos complexos. Alguns exemplos desses modelos são apresentados a seguir.

a) Modelo de Boltzmann ou sólido padrão, composto pela associação em série de um modelo de Kelvin e uma mola.

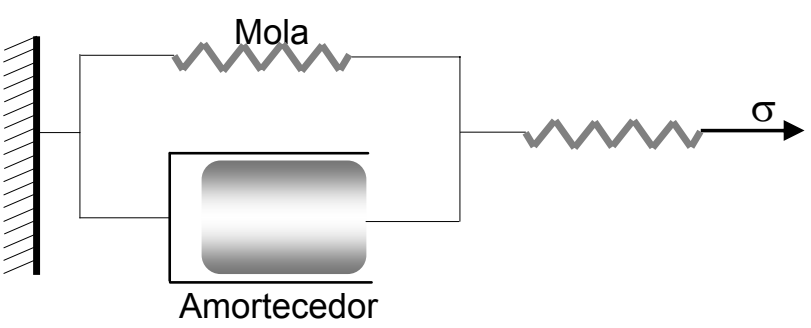

Figura 3.14 - Representação física para o modelo de Boltzmann.

b) Modelo linear padrão, formado pela associação em paralelo de um modelo de Maxwell e uma mola. 


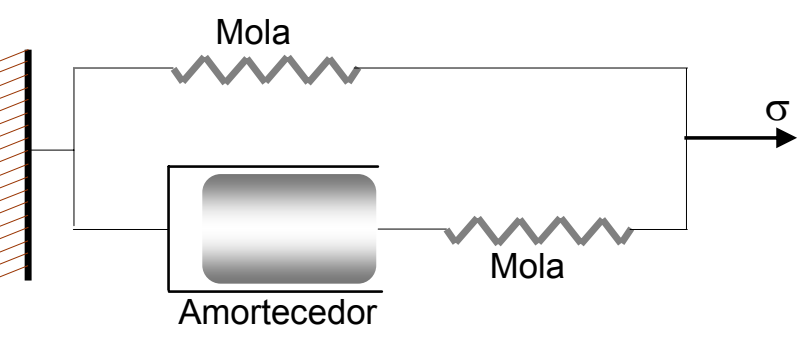

Figura 3.15 - Representação física para o modelo de linear padrão.

c) Modelo de Bingham, formado pela associação em série dos três modelos elementares.

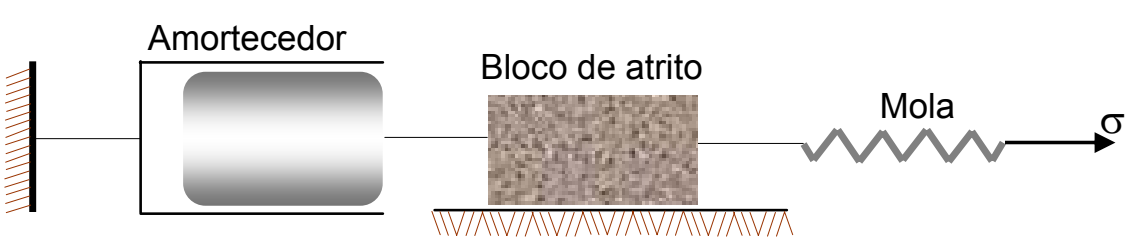

Figura 3.16 - Representação física para o modelo de Bingham.

d) Modelo de Burgers, formado pela associação em série dos modelos de Maxwell e Kelvin.

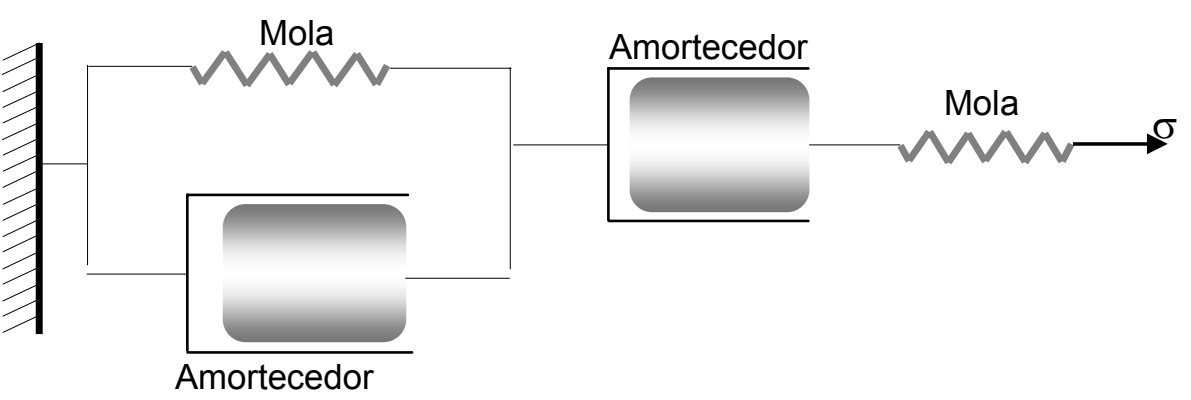

Figura 3.17 - Representação física para o modelo de Burgers.

\subsection{FUNÇÃO FLUÊNCIA.}

Os modelos denominados visco-elásticos são utilizados para modelar problemas de fluência, onde um corpo, ao ser solicitado, sofre deformações que variam ao longo do tempo. A Figura 3.18 ilustra comportamento típico de fluência. 


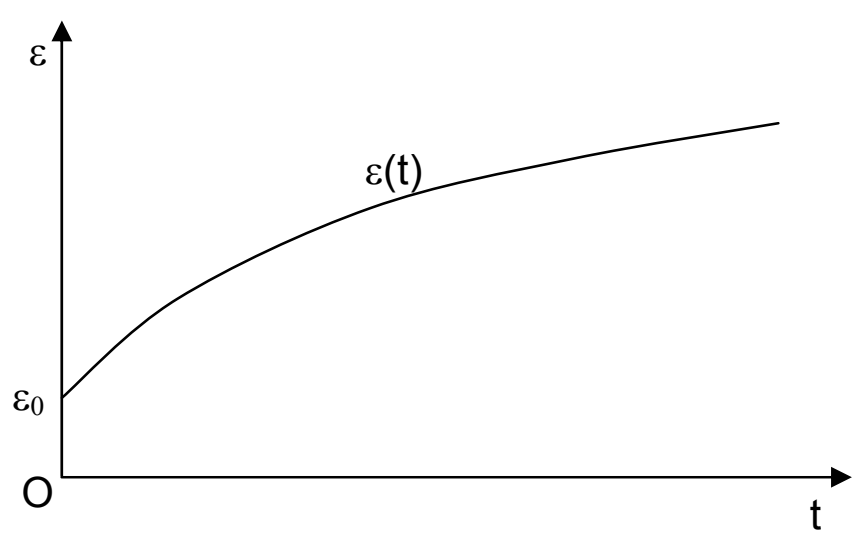

Figura 3.18 - Curva deformação em função do tempo - fluência.

Estudando o comportamento típico da curva de fluência, verifica-se que é possível definir uma função que, para qualquer instante (t), é possível estabelecer uma relação tensão deformação do tipo:

$$
\sigma(t)=\varepsilon_{0} \cdot E(t) \quad \text { ou } \quad \varepsilon(t)=\sigma_{0} \cdot J(t)
$$

onde:

$E(t)$ - função de deformabilidade;

$J(t)$ - função de fluência.

A título de ilustração, a Tabela 3.1 apresenta a função fluência para alguns dos modelos reológicos apresentados.

Tabela 3.1 - Função fluência para modelos reológicos compostos elementares.

\begin{tabular}{ccc}
\hline & Modelo de Maxwell & Modelo de Kelvin \\
\hline Função fluência & $\frac{1}{k}+\frac{t}{\eta}$ & $\frac{1}{k}\left(1-e^{\frac{k t}{\eta}}\right)$ \\
\hline
\end{tabular}

3.3.1 Representação integral das funções de fluência e relaxação.

O desenvolvimento teórico a ser apresentado em seqüência está baseado em Santa Maria (1996), conforme apresentado por Francisco (2004). 
Se a um corpo visco-elástico aplica-se uma tensão $\sigma_{1}=\sigma_{0}$ no tempo $t=$ $\tau_{1}$, as expressões a seguir fornecem a tensão atuante e a deformação resultante:

$$
\begin{aligned}
& \sigma(t)=\sigma_{1} H\left(t-\tau_{1}\right) \\
& \varepsilon(t)=\sigma_{1} J\left(t-\tau_{1}\right) H\left(t-\tau_{1}\right)
\end{aligned}
$$

onde:

$H(t-\tau)$ - função de Heaviside ou função degrau.

Para um material elástico linear, aplicando-se o princípio da superposição de Boltzmann, a uma função de tensão $\sigma(t)$ inteiramente arbitrária pode ser aproximada pela soma de incrementos de tensão, conforme a expressão:

$$
\sigma(t)=\sum_{i=1}^{r} \Delta \sigma_{i} H\left(t-\tau_{i}\right)
$$

A função de deformação associada a essa função de tensão pode se obtida pelo mesmo princípio de superposição:

$$
\varepsilon(t)=\sum_{i=1}^{r} \Delta \sigma_{i} J\left(t-\tau_{i}\right) H\left(t-\tau_{i}\right)
$$

Quando o número de incrementos tende a infinito, a expressão anterior pode ser representada por uma integral:

$$
\varepsilon(t)=\int_{0}^{t} J(t-\tau) H(t-\tau) d[\sigma(\tau)]
$$

Considerando que entre os limites de integração a função de tensões é contínua, possui derivada finita e que a variável auxiliar $(\tau)$ é sempre menor que $(\mathrm{t})$, assim $\mathrm{H}(\mathrm{t}-\tau)=1$, a expressão anterior toma a forma: 


$$
\varepsilon(t)=\int_{0}^{t} J(t-\tau) \frac{\partial \sigma(\tau)}{\partial(\tau)} d \tau
$$

onde:

$\tau$ - variável auxiliar.

A expressão (3.24) pode ser usada para representar as deformações por fluência sob qualquer história de tensões, desde seja que conhecida a função de fluência.

Admitindo que a função fluência é contínua e pode ser derivada em relação a $\tau$ e que a tensão inicial é nula $(\sigma(0)=0)$, a expressão (3.24) pode ser escrita por:

$$
\varepsilon(t)=\sigma(t) J(0)+\int_{0}^{t} \frac{\partial J(t-\tau)}{\partial \tau} \sigma(\tau) d \tau
$$

Caso a função de tensão possua um valor inicial $\sigma_{0}$, ela pode ser representada por:

$$
\sigma(t)=\sigma_{0} H(t-0)+\sum_{i=1}^{r} \Delta \sigma_{i} H\left(t-\tau_{i}\right)
$$

A deformação correspondente será:

$$
\varepsilon(t)=\sigma_{0} J(t-0) H(t-0)+\sum_{i=1}^{r} \Delta \sigma_{i} J\left(t-\tau_{i}\right) H\left(t-\tau_{i}\right)
$$

Na expressão acima, se $r \rightarrow \infty(\Delta \sigma \rightarrow 0)$ e $\sigma_{0}=\sigma(0)$, então:

$$
\varepsilon(t)=\sigma_{0} J(t)+\int_{0}^{t} J(t-\tau) \frac{\partial \sigma(\tau)}{\partial \tau} d \tau
$$


As expressões (3.24), (3.25) e (3.28) foram estabelecidas para o início do processo, ocorrendo no tempo $t=0$. Caso o tempo de início seja $t=\tau_{0}$, as expressões anteriores ficam definidas por:

Para $\sigma\left(\tau_{0}\right)=0$

$$
\begin{gathered}
\varepsilon(t)=\int_{\tau_{0}}^{t} J(t-\tau) \frac{\partial \sigma}{\partial \tau} d \tau \\
\varepsilon(t)=\sigma(t) J(0)-\int_{\tau_{0}}^{t} \frac{\partial J(t-\tau)}{\partial \tau} \sigma(\tau) d \tau
\end{gathered}
$$

Para $\sigma\left(\tau_{0}\right) \neq 0$

$$
\begin{aligned}
& \varepsilon(t)=\sigma\left(\tau_{0}\right) J\left(t-\tau_{0}\right)+\int_{\tau_{0}}^{t} J(t-\tau) \frac{\partial \sigma(\tau)}{\partial \tau} d \tau \\
& \varepsilon(t)=\sigma(t) J(0)-\int_{\tau_{0}}^{t} \frac{\partial J(t-\tau)}{\partial \tau} \sigma(\tau) d \tau
\end{aligned}
$$

A função fluência $J(t)$ pode ser determinada por ensaio de fluência sob tensão constante. Conhecida essa função, pode-se utilizar a expressão (3.23) para se encontrar a função de tensão $\sigma(t)$ a partir de uma história de deformações prescritas $\varepsilon(t)$. Mas como sua resolução costuma ser matematicamente trabalhosa, é preferível utilizar um conceito semelhante ao empregado para o estabelecimento da equação (3.23), sendo que para uma deformação imposta $\varepsilon\left(\tau_{0}\right)=0$ pode-se escrever:

$$
\sigma(t)=\int_{\tau_{0}}^{t} R(t-\tau) \frac{\partial \varepsilon(\tau)}{\partial \tau} d \tau
$$

ou

$$
\sigma(t)=\varepsilon(t) R(0)-\int_{\tau_{0}}^{t} \frac{\partial R(t-\tau)}{\partial \tau} \varepsilon(\tau) d \tau
$$


onde:

$R(t)$ - função de relaxação.

De forma análoga, para uma deformação imposta $\varepsilon\left(\tau_{0}\right) \neq 0$ tem-se:

$$
\sigma(t)=\varepsilon\left(\tau_{0}\right) R\left(t-\tau_{0}\right)+\int_{\tau_{0}}^{t} R(t-\tau) \frac{\partial \varepsilon(\tau)}{\partial \tau} d \tau
$$

ou

$$
\sigma(t)=\varepsilon(t) R(0)-\int_{\tau_{0}}^{t} \frac{\partial R(t-\tau)}{\partial \tau} \varepsilon(t) d \tau
$$

Para se determinar $\sigma(t)$ a partir de uma história de deformações prescritas $\varepsilon(t)$, é necessário que se conheça a função de relaxação $R(t)$, que pode ser obtida de um ensaio de relaxação sob deformação constante.

\subsubsection{Princípio da correspondência.}

Diversos problemas de visco-elasticidade linear podem ser resolvidos aplicando-se o Princípio da Correspondência ou Teorema da Reciprocidade a partir da solução elástica, aplicando-se a transformada de Laplace.

Por meio de um artifício algébrico, uma função não linear é transformada em uma função linear. Uma vez resolvida a função linear, opera-se a transformação inversa e obtém-se a solução do problema real. A Figura 3.19 ilustra o procedimento adotado pela aplicação da transformada de Laplace aos problemas visco-elásticos. 


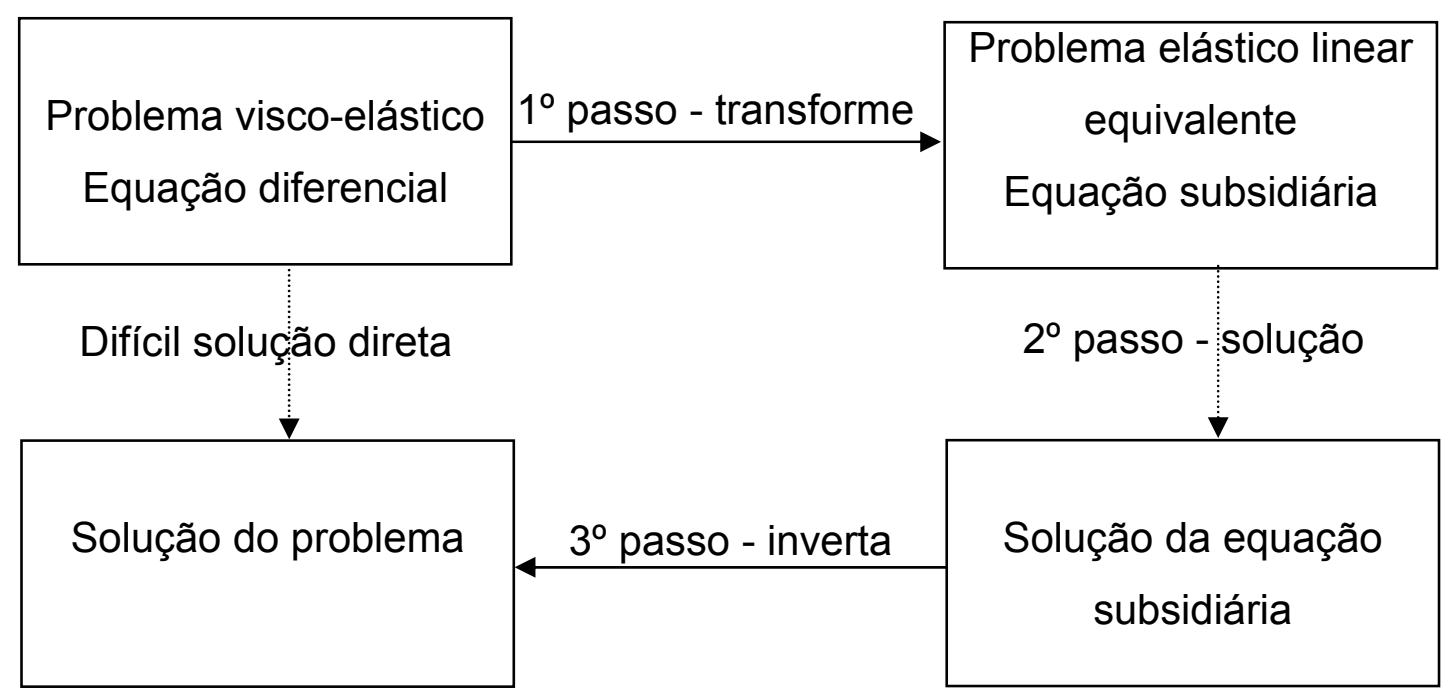

Figura 3.19 - Solução do problema visco-elástico via transformada de Laplace.

\subsection{MODELO REOLÓGICO DO CONCRETO CEB-FIP 90.}

Vários códigos e normas apresentam modelos que procuram simular o comportamento reológico do concreto, os quais de maneira geral apresentam modelos similares. A título de exemplificação cita-se a Norma Brasileira NBR$6118 \mathrm{em} \mathrm{seu}$ anexo 3 (ABNT, 2001), o código do Instituto Americano de Concreto ACl- 318-02 (ACl, 2002), o código para o Mercado Comum Europeu, Eurocode 2 e o código da Comissão Européia do Concreto e Federação Internacional de Protensão, CEB FIP (1990). Nesse trabalho optou-se por adotar o modelo do CEB para avaliação do comportamento reológico do concreto.

Segundo o CEB-FIP (1990), uma peça de concreto solicitada axialmente por uma tensão constante e uniforme $\sigma_{c}\left(t_{0}\right)$ em um instante $t_{0}$ apresenta deformação total em um tempo qualquer $t, \varepsilon_{c}(t)$, a qual pode ser subdividida conforme segue:

$$
\varepsilon_{c}(t)=\varepsilon_{c \sigma}(t)+\varepsilon_{c n}(t)
$$

onde:

$\varepsilon_{c \sigma}$ - parcela da deformação dependente da tensão;

$\varepsilon_{\mathrm{cn}}$ - parcela da deformação independente da tensão. 
A parcela dependente da tensão $\left(\varepsilon_{c \sigma}\right)$ apresenta duas componentes, deformações iniciais ou instantâneas $\left(\varepsilon_{\mathrm{ci}}\right)$ e deformações por fluência ou creep $\left(\varepsilon_{\mathrm{cc}}\right)$. A parcela independente da tensão $\left(\varepsilon_{\mathrm{cn}}\right)$ também é composta de duas parcelas, deformações devidas à temperatura $\left(\varepsilon_{c \mathrm{cT}}\right)$ e devidas à retração $\left(\varepsilon_{\mathrm{cS}}\right)$.

$$
\varepsilon_{c \sigma}(t)=\varepsilon_{c i}(t)+\varepsilon_{c c}(t) \quad \varepsilon_{c n}(t)=\varepsilon_{c T}(t)+\varepsilon_{c s}(t)
$$

Assim, a deformação total pode ser considerada como composta por quatro parcelas:

$$
\varepsilon_{c}(t)=\varepsilon_{c i}(t)+\varepsilon_{c c}(t)+\varepsilon_{c T}(t)+\varepsilon_{c s}(t)
$$

As deformações devidas à fluência são expressas por:

$$
\varepsilon_{c c}(t)=\frac{\sigma_{c}\left(t_{0}\right)}{E_{c}} \cdot \phi\left(t, t_{0}\right)
$$

As deformações dependentes da tensão podem ser expressas por:

$$
\varepsilon_{c \sigma}(t)=\sigma_{c}\left(t_{o}\right) \cdot\left[\frac{1}{E_{c}\left(t_{0}\right)}+\frac{1}{E_{c}} \cdot \phi\left(t, t_{0}\right)\right]
$$

O módulo de elasticidade $E_{c}\left(t_{0}\right)$ é expresso em função de $E_{c}$ (módulo de elasticidade para a idade de 28 dias) por:

$$
E_{c}\left(t_{0}\right)=\beta_{E}\left(t_{0}\right) \cdot E_{c}
$$

Substituindo-se (3.37) em (3.36), tem-se:

$$
\varepsilon_{c \sigma}(t)=\sigma_{c}\left(t_{o}\right) \cdot\left[\frac{1}{\beta_{E}\left(t_{0}\right) \cdot E_{c}}+\frac{1}{E_{c}} \cdot \phi\left(t, t_{0}\right)\right]=\frac{\sigma_{c}\left(t_{o}\right)}{E_{c}} \cdot\left[\frac{1}{\beta_{E}\left(t_{0}\right)}+\phi\left(t, t_{0}\right)\right]
$$


A deformação inicial é dada por:

$$
\varepsilon_{c i}=\frac{\sigma_{c}\left(t_{o}\right)}{E_{c}}
$$

Assim, a expressão (3.38) pode ser reescrita:

$$
\varepsilon_{c \sigma}(t)=\varepsilon_{c i} \cdot\left[\frac{1}{\beta_{E}\left(t_{0}\right)}+\phi\left(t, t_{0}\right)\right]
$$

onde o termo entre colchetes é denominado função fluência do concreto.

Substituindo a expressão (3.42) em (3.36), tem-se:

$$
\varepsilon_{c}(t)=\varepsilon_{c i} \cdot\left[\frac{1}{\beta_{E}\left(t_{0}\right)}+\phi\left(t, t_{0}\right)\right]+\varepsilon_{c T}(t)+\varepsilon_{c s}(t)
$$

Assim as deformações iniciais são dadas por:

$$
\varepsilon_{c i}(t)=\frac{\varepsilon_{c}(t)-\varepsilon_{c T}(t)-\varepsilon_{c s}(t)}{\frac{1}{\beta_{E}\left(t_{0}\right)}+\phi\left(t, t_{0}\right)}
$$

3.4.1 Fluência.

O coeficiente de fluência $\phi\left(t, t_{0}\right)$ pode ser calculado pela expressão:

$$
\phi\left(t, t_{0}\right)=\phi_{0} \cdot \beta_{c}\left(t-t_{0}\right)
$$

onde:

$\phi_{0}$ - coeficiente teórico de fluência;

$\beta_{c}$ - coeficiente que descreve o desenvolvimento da fluência com o tempo após o carregamento; 
$\mathrm{t}$ - idade do concreto no momento considerado;

$t_{0}$ - idade do concreto no carregamento, ajustada de acordo com o tipo de cimento e temperatura de cura.

$$
\phi_{0}=\phi_{R H} \cdot \beta\left(f_{c m}\right) \cdot \beta\left(t_{0}\right)
$$

sendo:

$$
\phi_{R H}=1+\frac{1-R H / R H_{0}}{0,46 \cdot\left(h / h_{o}\right)^{3}} \quad \beta\left(f_{c m}\right)=\frac{5,3}{\left(f_{c m} / f_{c m 0}\right)^{0,5}} \quad \beta\left(t_{0}\right)=\frac{1}{0,1+\left(t_{0} / t_{1}\right)^{0,2}}
$$

onde:

$h=\frac{2 \cdot A_{c}}{u} ;$

$\mathrm{f}_{\mathrm{cm}}$ - resistência à compressão média do concreto na idade de 28 dias;

$\mathrm{f}_{\mathrm{cm} 0}-10 \mathrm{MPa}$;

$\mathrm{RH}$ - umidade relativa do ar;

$\mathrm{RH}_{0}-100 \%$;

$\mathrm{h}$ - dimensão teórica da peça, onde $\left(A_{c}\right)$ é a área da seção transversal e $(u) \circ$ perímetro em contato com a atmosfera;

$\mathrm{h}_{0}-100 \mathrm{~mm}$;

$\mathrm{t}_{1}-1$ dia.

Para o estudo em questão, ver capítulo 4 :

$h=\frac{2 \cdot 400^{2}}{4 \cdot 400}=200 \mathrm{~mm} \quad R H=76,7 \% \quad f_{c m}=39,4 \mathrm{MPa}$

$\phi_{R H}=1+\frac{1-{ }^{76,7} / 100}{0,46 \cdot(200 / 100)^{3}}=1,063$ 


$$
\begin{aligned}
& \beta\left(f_{c m}\right)=\frac{5,3}{(39,4 / 10)^{0,5}}=2,67 \\
& \phi_{0}=\phi_{R H} \cdot \beta\left(f_{c m}\right) \cdot \beta\left(t_{0}\right)=1,063 \cdot 2,67 \cdot \beta\left(t_{0}\right)=2,84 \cdot\left[\frac{1}{0,1+t_{0}^{0,2}}\right]=\frac{2,84}{0,1+t_{0}^{0,2}}
\end{aligned}
$$

O desenvolvimento da fluência com o tempo é dado por:

$$
\beta_{c}\left(t, t_{0}\right)=\left[\frac{\left(t-t_{0}\right) / t_{1}}{\beta_{H}+\left(t-t_{0}\right) / t_{1}}\right]^{0,3}
$$

com:

$$
\beta_{H}=150 \cdot\left[1+\left(1,2 \cdot \frac{R H}{R H_{0}}\right)^{18}\right] \cdot \frac{h}{h_{0}}+250 \leq 1500
$$

que, para as condições locais (ver capítulo 4) e tempo expresso em dias, tornase:

$\beta_{H}=150 \cdot\left[1+\left(1,2 \cdot \frac{76,7}{100}\right)^{18}\right] \cdot \frac{200}{100}+250=617$

Assim,

$\beta_{c}\left(t, t_{0}\right)=\left[\frac{\left(t-t_{0}\right)}{617+\left(t-t_{0}\right)}\right]^{0,3}$

Finalmente, o coeficiente de fluência para as condições do estudo pode ser escrito pela expressão: 


$$
\phi\left(t, t_{0}\right)=\phi_{0} \cdot \beta_{c}\left(t-t_{0}\right)=\frac{2,84}{0,1+t_{0}^{0,2}} \cdot\left[\frac{\left(t-t_{0}\right)}{617+\left(t-t_{0}\right)}\right]^{0,3}
$$

Ainda há uma recomendação de ajuste da idade do concreto em função do tipo de cimento, expressa por:

$$
t_{0}=t_{o, T} \cdot\left[\frac{9}{2+\sqrt{\frac{t_{0, T}}{t_{1, T}}}}+1\right]^{\alpha} \geq 0,5 \text { dias }
$$

sendo:

$\alpha$ - coeficiente que depende do tipo de cimento e igual a -1 para cimentos de endurecimento lento (SL), 0 para cimentos de endurecimento normal ou rápido $(N, R)$ e 1 para cimentos de endurecimento rápido e de alta resistência (RS).

Para o presente trabalho, como $\alpha=0$ (cimento de alta resistência inicial), a expressão torna-se $t_{0}=t_{o, T}$.

\subsubsection{Retração.}

A retração pode ser calculada a partir da expressão:

$$
\varepsilon_{c s}\left(t, t_{s}\right)=\varepsilon_{c s 0} \cdot \beta_{s}\left(t-t_{s}\right)
$$

onde:

$\varepsilon_{\mathrm{cso}}-$ coeficiente de retração teórico;

$\beta_{\mathrm{s}}$ - coeficiente que descreve o desenvolvimento da retração com o tempo;

$\mathrm{t}$ - idade do concreto;

$t_{s}$ - idade do concreto no início da retração.

$$
\varepsilon_{c s o}=\varepsilon_{c}\left(f_{c m}\right) \cdot \beta_{R H}
$$

com: 


$$
\varepsilon_{c}\left(f_{c m}\right)=\left[160+10 \cdot \beta_{s c} \cdot\left(9-\frac{f_{c m}}{f_{c m 0}}\right)\right] \cdot 10^{-6}
$$

onde:

$\beta_{\mathrm{sc}}$ - coeficiente que depende do tipo do cimento, sendo igual a 4 para cimentos de endurecimento lento (SL), 5 para cimentos de endurecimento normal ou rápido $(\mathrm{N}, \mathrm{R})$ e 8 para cimentos de endurecimento rápido e de alta resistência (RS).

$$
\beta_{R H}=-1,55 \cdot \beta_{s R H}
$$

sendo:

$$
\beta_{s R H}=1-\left(\frac{R H}{R H_{0}}\right)^{3}
$$

Para as condições locais apresentadas no capítulo 4, essa formulação torna-se:

$$
\begin{aligned}
& \varepsilon_{c}\left(f_{c m}\right)=\left[160+10 \cdot \beta_{s c} \cdot\left(9-\frac{f_{c m}}{f_{c m 0}}\right)\right] \cdot 10^{-6}=\left[160+10 \cdot 5 \cdot\left(9-\frac{39,4}{10}\right)\right] \cdot 10^{-6}=413 \cdot 10^{-6} \\
& \beta_{s R H}=1-\left(\frac{R H}{R H_{0}}\right)^{3}=1-\left(\frac{76,7}{100}\right)^{3}=0,548 \\
& \beta_{R H}=-1,55 \cdot \beta_{s R H}=-1,55 \cdot 0,548=-0,85
\end{aligned}
$$

Assim,

$\varepsilon_{c s o}=\varepsilon_{c}\left(f_{c m}\right) \cdot \beta_{R H}=413 \cdot 10^{-6} \cdot-0,85=-351 \cdot 10^{-6}$ 


$$
\beta_{s}\left(t, t_{s}\right)=\left[\frac{\left(t-t_{s}\right) / t_{1}}{350 \cdot\left(h / h_{0}\right)^{2}+\left(t-t_{s}\right) / t_{1}}\right]^{0,5}
$$

a qual para as condições do estudo (ver capítulo 4) e tempo expresso em dias, torna-se:

$$
\beta_{s}\left(t, t_{s}\right)=\left[\frac{\left(t-t_{s}\right) / t_{1}}{350 \cdot(200 / 100)^{2}+\left(t-t_{s}\right) / t_{1}}\right]^{0,5}=\left[\frac{\left(t-t_{s}\right)}{1400+\left(t-t_{s}\right)}\right]^{0,5}
$$

Finalmente, o coeficiente de retração para as condições do estudo pode ser escrito pela expressão:

$$
\varepsilon_{c s}\left(t, t_{s}\right)=\varepsilon_{c s 0} \cdot \beta\left(t-t_{s}\right)=-351 \cdot 10^{-6} \cdot\left[\frac{\left(t-t_{s}\right)}{1400+\left(t-t_{s}\right)}\right]^{0,5}
$$

Além disso, é necessário considerar a variação do módulo de elasticidade com o tempo. O módulo de elasticidade do concreto para uma idade $\mathrm{t} \neq 28$ dias pode ser estimado pela expressão:

$$
E_{c}(t)=\beta_{E}(t) \cdot E_{c}
$$

onde:

$E_{c}(t)$ - módulo de elasticidade para uma idade de (t) dias;

$\mathrm{E}_{\mathrm{c}}$ - módulo de elasticidade do concreto a 28 dias;

$\beta_{E}(t)$ - coeficiente que depende da idade do concreto.

sendo:

$$
\beta_{E}(t)=\sqrt{\beta_{c c(t)}}
$$




$$
\beta_{c c}(t)=e^{\left.s \cdot 1-\sqrt{\frac{28}{t}}\right]}
$$

sendo:

s - coeficiente que depende do tipo de cimento e igual a 0,20 para cimentos de endurecimento rápido e de alta resistência (RS), 0,25 para cimentos normais e de rápido endurecimento $(N, R)$ e 0,38 para cimentos de endurecimento lento (SL).

Para as condições do presente estudo, ver capítulo 4:

$$
\begin{aligned}
& \beta_{c c}(t)=e^{s \cdot\left[1-\sqrt{\frac{28}{t}}\right]}=e^{0,25 \cdot\left[1-\sqrt{\frac{28}{t}}\right]} \\
& \beta_{E}(t)=\sqrt{e^{0,25 \cdot\left[1-\sqrt{\frac{28}{t}}\right]}}
\end{aligned}
$$

\subsubsection{Temperatura.}

A dilatação térmica do concreto pode ser calculada pela expressão:

$$
\varepsilon_{c T}=\alpha_{T} \cdot \Delta T
$$

onde:

$\alpha_{T}$ - coeficiente de dilatação térmica do concreto;

$\Delta_{T}-$ variação de temperatura.

O efeito de temperaturas elevadas ou reduzidas pode ser levado em consideração, ajustando-se a idade do concreto de acordo com a expressão

$$
t_{T}=\sum_{i=1}^{n} \Delta t_{i} \cdot e^{-\left[\frac{4000}{273+T\left(\Delta t_{i}\right) / T_{0}}-13,65\right]}
$$

onde: 
$t_{T}$ - idade do concreto ajustada em função da temperatura, a qual substitui ( $t$ ) nas equações correspondentes;

$\mathrm{T}\left(\Delta \mathrm{t}_{\mathrm{i}}\right)$ - temperatura durante o intervalo $\left(\Delta \mathrm{t}_{\mathrm{i}}\right)$;

$\mathrm{T}_{0}-1^{\circ} \mathrm{C}$;

$\Delta t_{i}-$ número de dias em que a temperatura $(T)$ predomina.

Para o concreto do presente estudo, tendo em vista que o mesmo é submetido à cura a vapor mantida por um período não inferior a 6 horas à temperatura de $60^{\circ} \mathrm{C}$, a expressão (3.60) torna-se:

$$
t_{T}=\sum_{i=1}^{n} \Delta t_{i} \cdot e^{-\left[\frac{4000}{273+T\left(\Delta t_{i}\right) / T_{0}}-13,65\right]}=\frac{6}{24} \cdot e^{-\left[\frac{4000}{273+60}-13,65\right]}=\frac{6}{24} \cdot 5,144=1,29 \text { dias }
$$

A deformação inicial, instantânea ou "elástica" do concreto $\varepsilon_{\mathrm{ci}}(\mathrm{t})$, levando-se em consideração as correções devidas à retração, fluência e dilatação térmica, pode ser expressa em função da idade do concreto, para as condições do presente estudo, pela expressão:

$$
\varepsilon_{c i}(t)=\frac{\varepsilon_{c}(t)-\varepsilon_{c T}(t)-\varepsilon_{c s}(t)}{\frac{1}{\beta_{E}\left(t_{0}\right)}+\phi\left(t, t_{0}\right)}=\frac{\varepsilon_{c}(t)-\alpha_{T} \cdot \Delta T-\left\{-351 \cdot 10^{-6} \cdot\left[\frac{\left(t-t_{s}\right)}{1400+\left(t-t_{s}\right)}\right]^{0,5}\right\}}{\frac{1}{\sqrt{e^{0,25 \cdot\left[1-\sqrt{\frac{28}{t_{0}}}\right]}}}+\frac{2,84}{0,1+t_{0}^{0,2}} \cdot\left[\frac{\left(t-t_{0}\right)}{617+\left(t-t_{0}\right)}\right]^{0,3}}
$$

3.4.4 Determinação do coeficiente de dilatação térmica do concreto.

A literatura específica, os códigos e normas indicam para o coeficiente de dilatação térmica do concreto o valor $10^{-5} /{ }^{\circ} \mathrm{C}$ ou $10 \mu \varepsilon /{ }^{\circ} \mathrm{C}$. Esse parâmetro é avaliado segundo a NBR-12815 ABNT (1993), a qual recomenda, para a realização de cada etapa do ensaio, a estabilização da temperatura entre o corpo de prova e a câmara de ensaio. Geralmente, o período necessário para a estabilização das leituras durante o ensaio é da ordem de 3 dias. Essa condição não é verificada na situação de campo, pois as temperaturas oscilam durante o dia e, portanto, não há um equilíbrio entre a temperatura ambiente e 
a totalidade do pilar de concreto armado. Também a posição de cada pilar, ou mesmo de cada face, participa de maneira decisiva no comportamento de dilatação térmica. Por exemplo, um pilar externo pode receber insolação direta em uma de suas faces durante determinado período do dia, enquanto que a sua face oposta ficará, durante esse período, na sombra. Já um pilar interno à obra sofrerá menos efeito da insolação direta. De qualquer forma, como as medidas foram efetuadas na fibra mais externa do pilar, ocorre um equilíbrio de temperatura mais imediato nessa região.

Segundo Pini (1997), esse coeficiente também é dependente do tipo de agregado utilizado no concreto. A Tabela 3.2 apresenta resultados de ensaios de laboratório, realizado de acordo com a NBR-12815 para concretos confeccionados com agregados de diferente origem geológica.

Tabela 3.2 - Variação do coeficiente de dilatação térmica do concreto com o tipo do agregado,

\begin{tabular}{lc}
\multicolumn{2}{c}{ in Pini (1997). } \\
\hline Tipo litológico - Procedência & $\alpha_{T}\left(\mu \varepsilon /{ }^{\circ} \mathrm{C}\right)$ \\
\hline Basalto - Itaipu & 5,0 \\
Gnaisse - Angra & 5,2 \\
Gabro - Cana-Brava & 6,2 \\
Basalto - Itumbiara & 6,6 \\
Metagrauvaca - Tucuruí & 6,8 \\
Gnaisse - Itumbiara & 8,0 \\
M. Cerâmico - Itumbiara & 8,2 \\
Granito - Serra Mesa & 9,4 \\
Quartzito - Corumbá & 9,7 \\
Cascalho - Itaparica & 11,1 \\
Siltito - Formoso & 11,3 \\
Arenito - Itaipu & 11,4 \\
\hline
\end{tabular}

De modo a superar as dificuldades acima mencionadas para a definição do valor do coeficiente de dilatação térmica do pilar em concreto armado, adotou-se uma metodologia para definição desse parâmetro. Conforme será mencionado nos capítulos seguintes, no período de 25/09/2002 a 17/10/2002 não houve variação de carregamento nos pilares.

Assim sendo, as variações nas medidas realizadas nesse período são consideradas devidas à temperatura, à retração e fluência do concreto armado do pilar. Nesse intervalo de tempo, as variações de deformações decorrentes da fluência e retração são pequenas e podem ser consideradas de ordem inferior às decorrentes da variação térmica. Dessa forma, avaliou-se por 
retroanálise o coeficiente de dilatação térmica para cada face monitorada, relacionando-se a leitura indicada no relógio comparador com a temperatura registrada pelo termômetro digital a laser, no período acima definido.

A título de exemplo, são apresentados nas Figuras 3.20 e 3.21, gráficos da variação da leitura micrométrica com a temperatura. Nesses gráficos também é apresentada, por meio de linha contínua, a regressão linear entre os dados envolvidos.
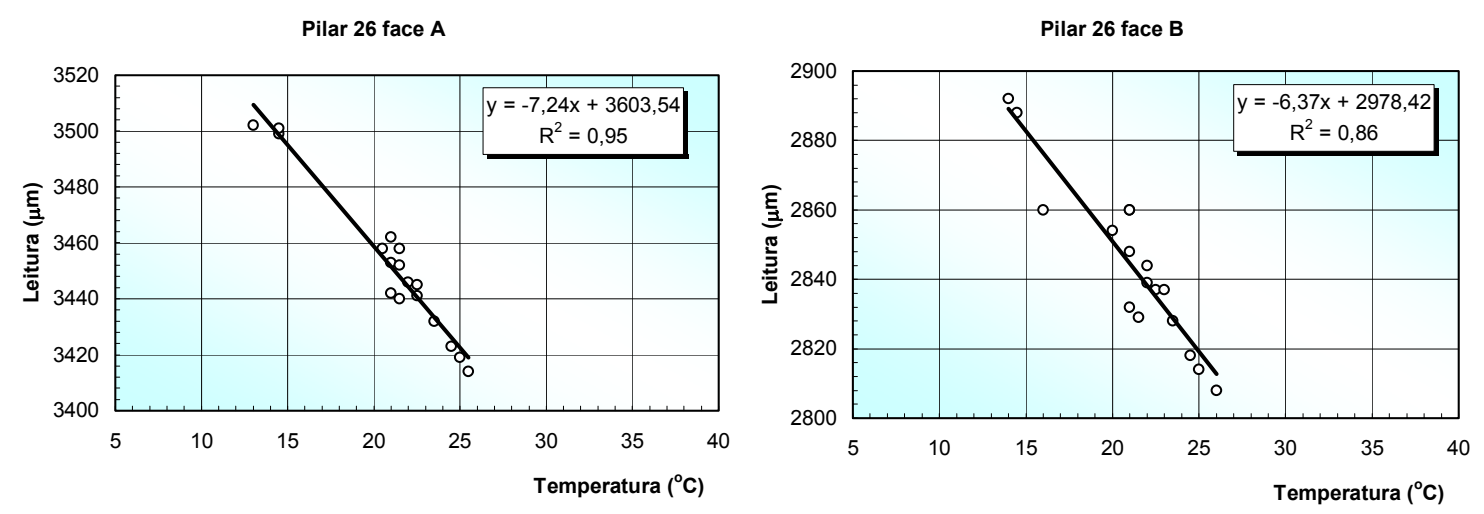

Figura 3.20 - Leitura micrômetro x temperatura na face - pilar 26.
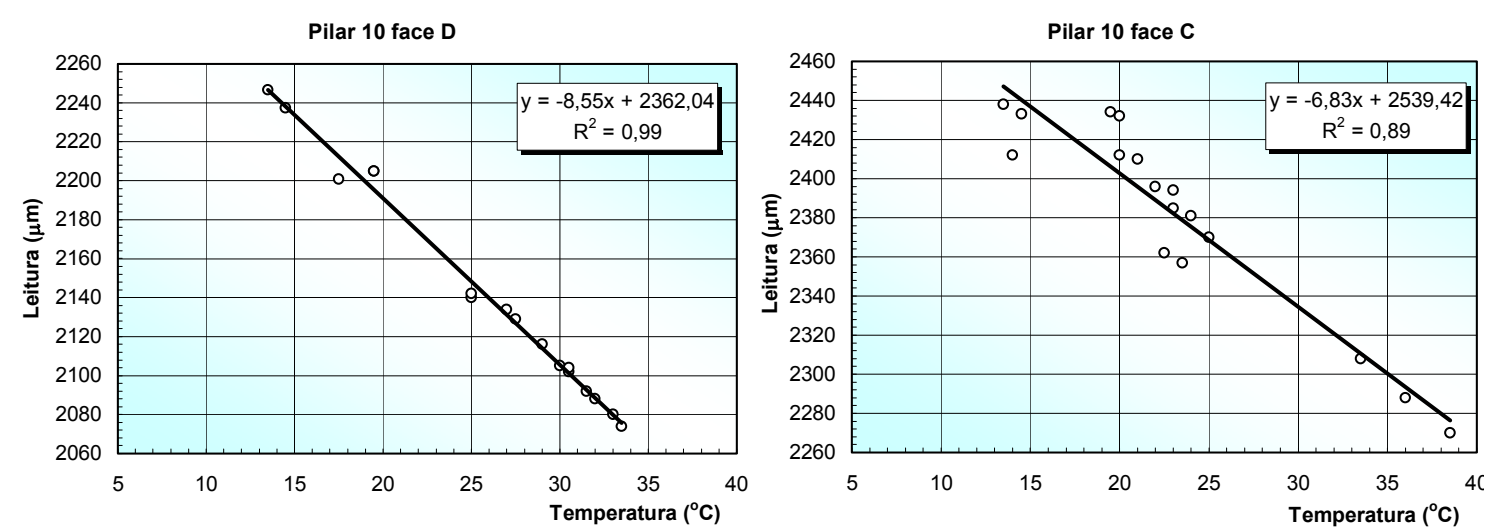

Figura 3.21 - Leitura micrômetro x temperatura na face - pilar 10.

A Tabela 3.3 sumariza os resultados obtidos por meio desse procedimento, sendo os valores determinados nela, adotados para a correção do efeito da temperatura em cada face envolvida pelo monitoramento. 
Tabela 3.3 - Coeficiente de dilatação térmica dos pilares.

\begin{tabular}{|c|c|c|c|c|c|c|c|c|c|c|c|}
\hline Pilar & Face & $\begin{array}{c}\alpha_{\mathrm{T}} \\
\left(\mu \varepsilon /{ }^{\circ} \mathrm{C}\right)\end{array}$ & $\begin{array}{l}R^{2} \\
(\%)\end{array}$ & Pilar & Face & $\begin{array}{c}\alpha_{\mathrm{T}} \\
\left(\mu \varepsilon /{ }^{\circ} \mathrm{C}\right)\end{array}$ & $\begin{array}{l}R^{2} \\
(\%) \\
\end{array}$ & Pilar & Face & $\begin{array}{c}\alpha_{\mathrm{T}} \\
\left(\mu \varepsilon /^{\circ} \mathrm{C}\right)\end{array}$ & $\begin{array}{l}\mathrm{R}^{2} \\
(\%) \\
\end{array}$ \\
\hline \multirow{2}{*}{36} & A & 4,9 & 90 & \multirow{2}{*}{37} & $A$ & 5,0 & 91 & \multirow{2}{*}{38} & $\mathrm{D}$ & 3,0 & 71 \\
\hline & B & 5,2 & 91 & & B & 3,7 & 83 & & C & 4,4 & 86 \\
\hline \multirow{2}{*}{26} & A & 4,9 & 95 & \multirow{2}{*}{27} & A & 4,5 & 80 & \multirow{2}{*}{28} & D & 3,7 & 78 \\
\hline & B & 4,3 & 86 & & B & 5,1 & 89 & & C & 4,3 & 79 \\
\hline \multirow{2}{*}{16} & A & 7,1 & 98 & \multirow{2}{*}{17} & A & 3,4 & 78 & \multirow{2}{*}{18} & D & 3,7 & 86 \\
\hline & B & 4,0 & 92 & & B & 4,3 & 81 & & C & 5,3 & 85 \\
\hline \multirow{2}{*}{06} & A & 4,6 & 98 & \multirow{2}{*}{07} & A & 4,3 & 84 & \multirow{2}{*}{08} & D & 4,1 & 75 \\
\hline & B & 5,6 & 94 & & B & 4,4 & 88 & & C & 4,6 & 94 \\
\hline
\end{tabular}

\begin{tabular}{|c|c|c|c|c|c|c|c|}
\hline Pilar & Face & $\begin{array}{c}\alpha_{\mathrm{T}} \\
\left(\mu \varepsilon /{ }^{\circ} \mathrm{C}\right)\end{array}$ & $\begin{array}{l}\mathrm{R}^{2} \\
(\%)\end{array}$ & Pilar & Face & $\begin{array}{c}\alpha_{T} \\
\left(\mu \varepsilon /{ }^{\circ} \mathrm{C}\right)\end{array}$ & $\begin{array}{l}\mathrm{R}^{2} \\
(\%)\end{array}$ \\
\hline \multirow{2}{*}{39} & D & 5,5 & 87 & \multirow{2}{*}{40} & D & 3,1 & 86 \\
\hline & C & 4,5 & 80 & & C & 6,8 & 98 \\
\hline \multirow{2}{*}{29} & D & 2,7 & 65 & \multirow{2}{*}{30} & D & 6,4 & 99 \\
\hline & C & 2,4 & 62 & & C & 6,1 & 96 \\
\hline \multirow{2}{*}{19} & D & 4,7 & 81 & \multirow{2}{*}{20} & D & 4,7 & 98 \\
\hline & C & 4,1 & 78 & & C & 5,7 & 97 \\
\hline \multirow{2}{*}{09} & D & 4,0 & 74 & \multirow{2}{*}{10} & D & 5,7 & 99 \\
\hline & C & 3,3 & 82 & & C & 4,6 & 89 \\
\hline
\end{tabular}

Os valores determinados para o coeficiente de dilatação térmica do pilar em concreto armado variam entre 2,4 e $7,1 \mu \varepsilon /{ }^{\circ} \mathrm{C}$, tendo valor central igual a $4,6 \mu \varepsilon /{ }^{\circ} \mathrm{C}$ e coeficiente de variação de $23 \%$. A Figura 3.22 apresenta a disposição em planta dos valores determinados desse coeficiente.

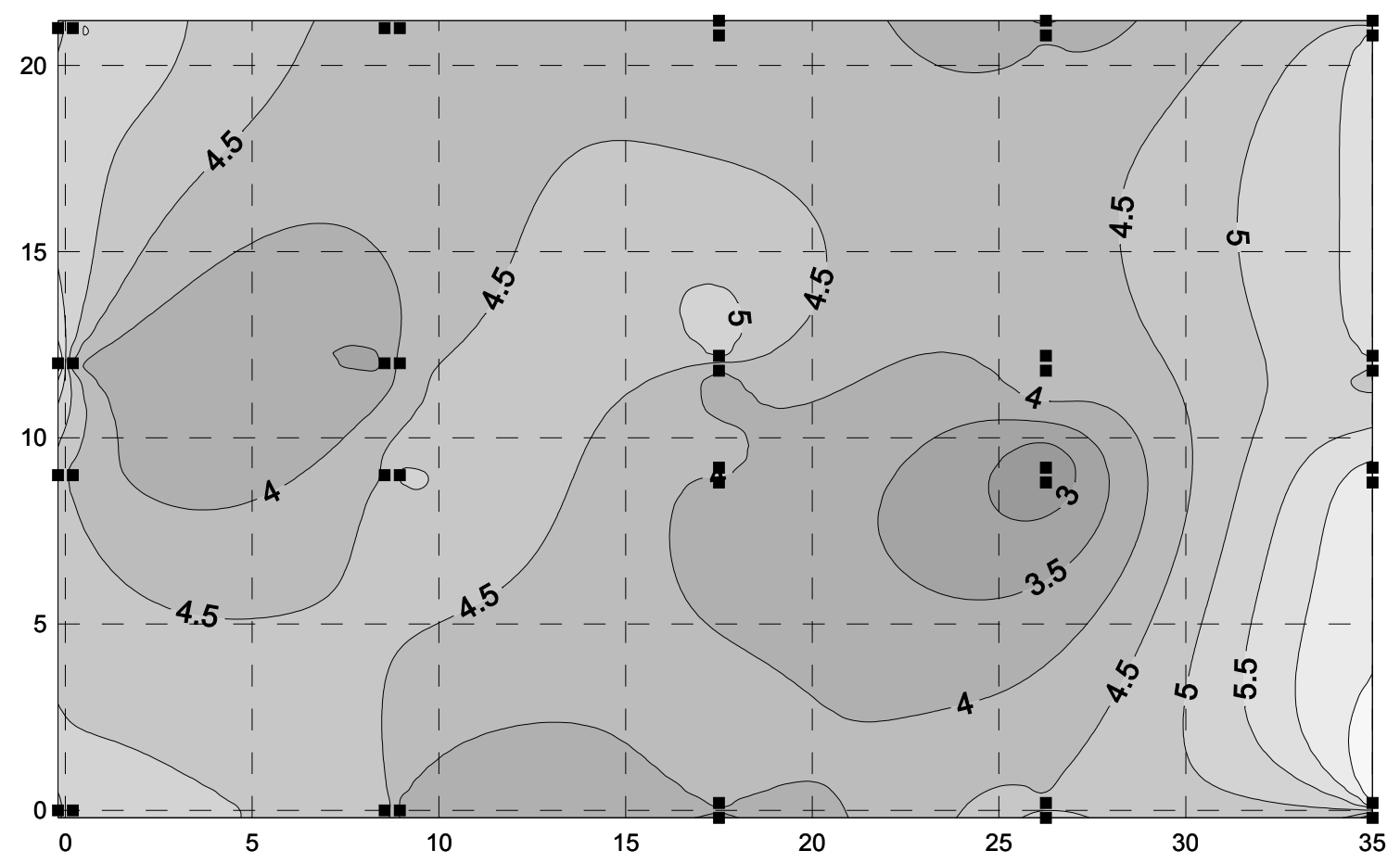

Figura 3.22 - Disposição em planta do coeficiente de dilatação térmica (valores em $\mu \varepsilon^{\varnothing} \mathrm{C}$ ). 


\section{CARACTERIZAÇÃO DO MEIO FÍSICO}

\subsection{LOCAL DO ESTUDO.}

A obra de engenharia, objeto do presente estudo, situa-se no Estado do Paraná, cidade de Curitiba, no bairro denominado Prado Velho, onde se localiza o Campus Curitiba da Pontifícia Universidade Católica do Paraná (PUCPR). As Figuras 4.1 e 4.2 apresentam a posição do local do estudo, indicada por seta vermelha, em relação aos bairros da cidade de Curitiba e em relação ao Campus Curitiba da PUCPR.

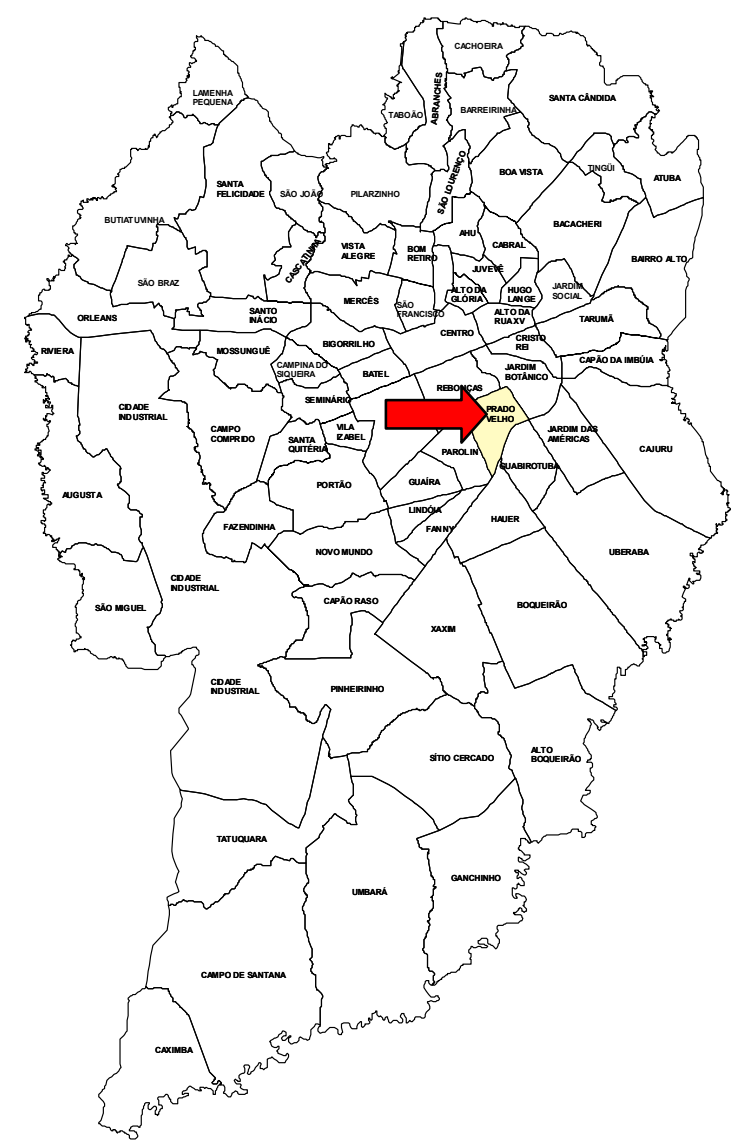

Figura 4.1 - Município de Curitiba - bairros (fonte IPPUC). 


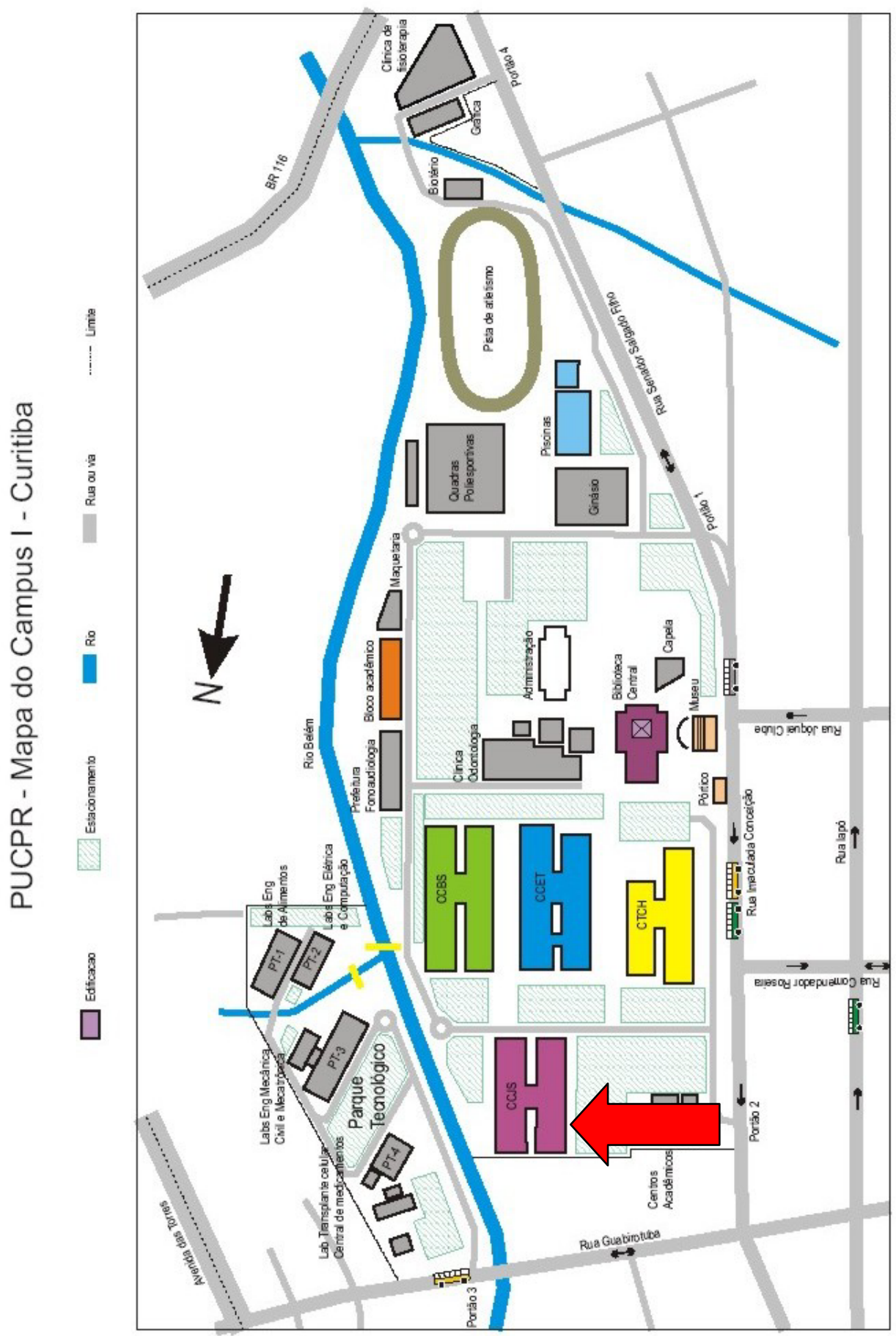

Figura 4.2 - Mapa Campus Curitiba da PUCPR.

A edificação objeto deste trabalho é denominada Bloco Didático 2 do Centro de Ciências Jurídicas e Sociais, que terá uso final predominante de salas de aula. É composta por um pavimento térreo, seguido de três pisos tipo e cobertura, os quais formam um pórtico espacial com quatro linhas de 10 pilares cada uma delas. Todos os pilares são de igual seção transversal quadrada com lado de $40 \mathrm{~cm}$. As observações de campo foram efetuadas em 
vinte pilares contígüos dessa estrutura. A projeção em planta da área de estudo é de 35,4 x 21,4 m e encontra-se apresentada na Figura 4.3.

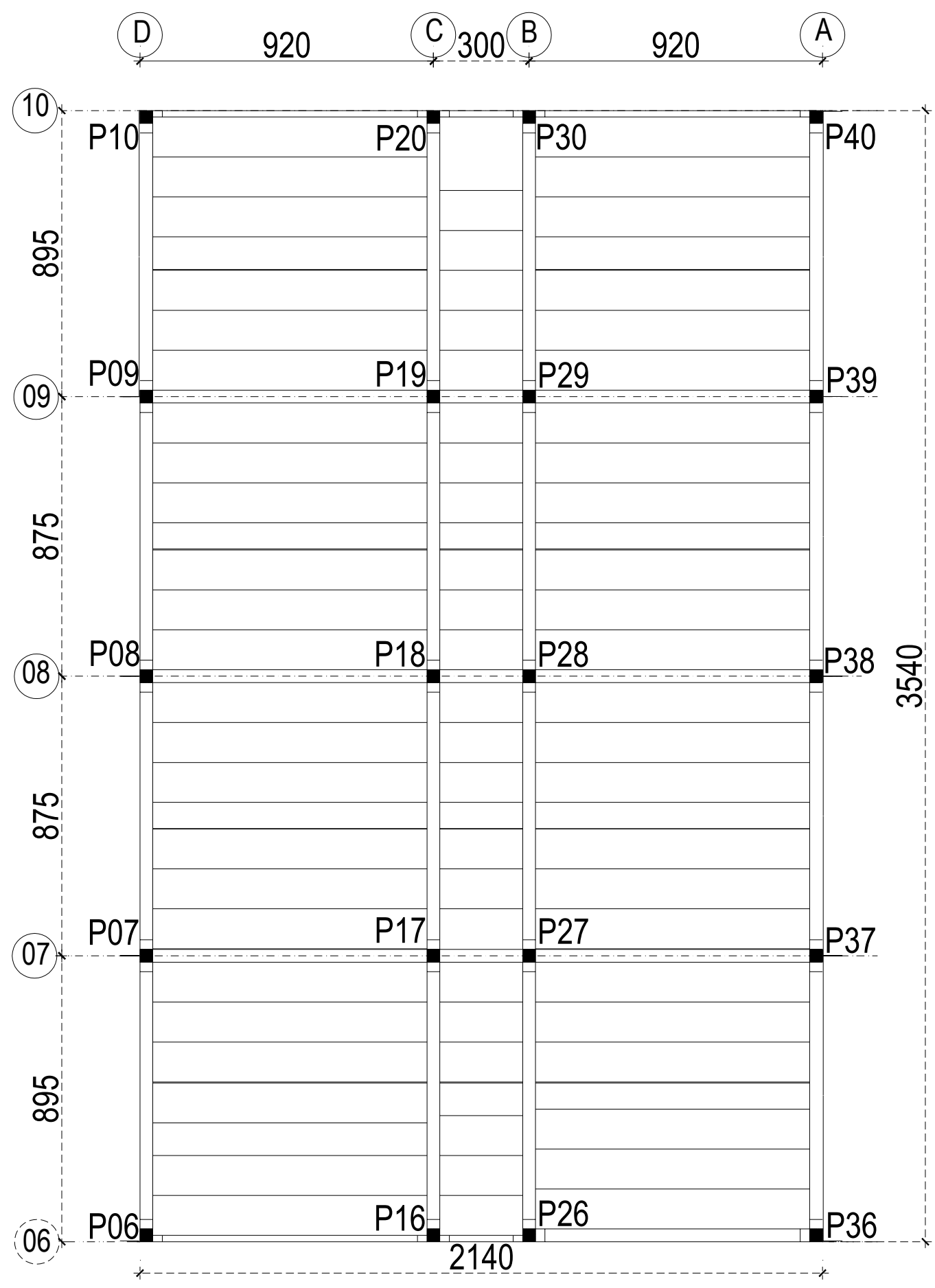

Figura 4.3 - Planta de locação da estrutura (medidas em cm).

A foto da Figura 4.4 ilustra um momento da execução da obra durante a montagem das peças pré-moldadas. Nela pode-se observar uma linha de 4 
pilares posicionados em suas bases, estando em conclusão o conjunto de peças do módulo anterior.

Ao fundo da foto pode-se visualizar o Bloco Didático 1, cuja obra encontra-se concluída e em utilização, que apresenta características arquitetônicas e estruturais idênticas às do presente estudo.

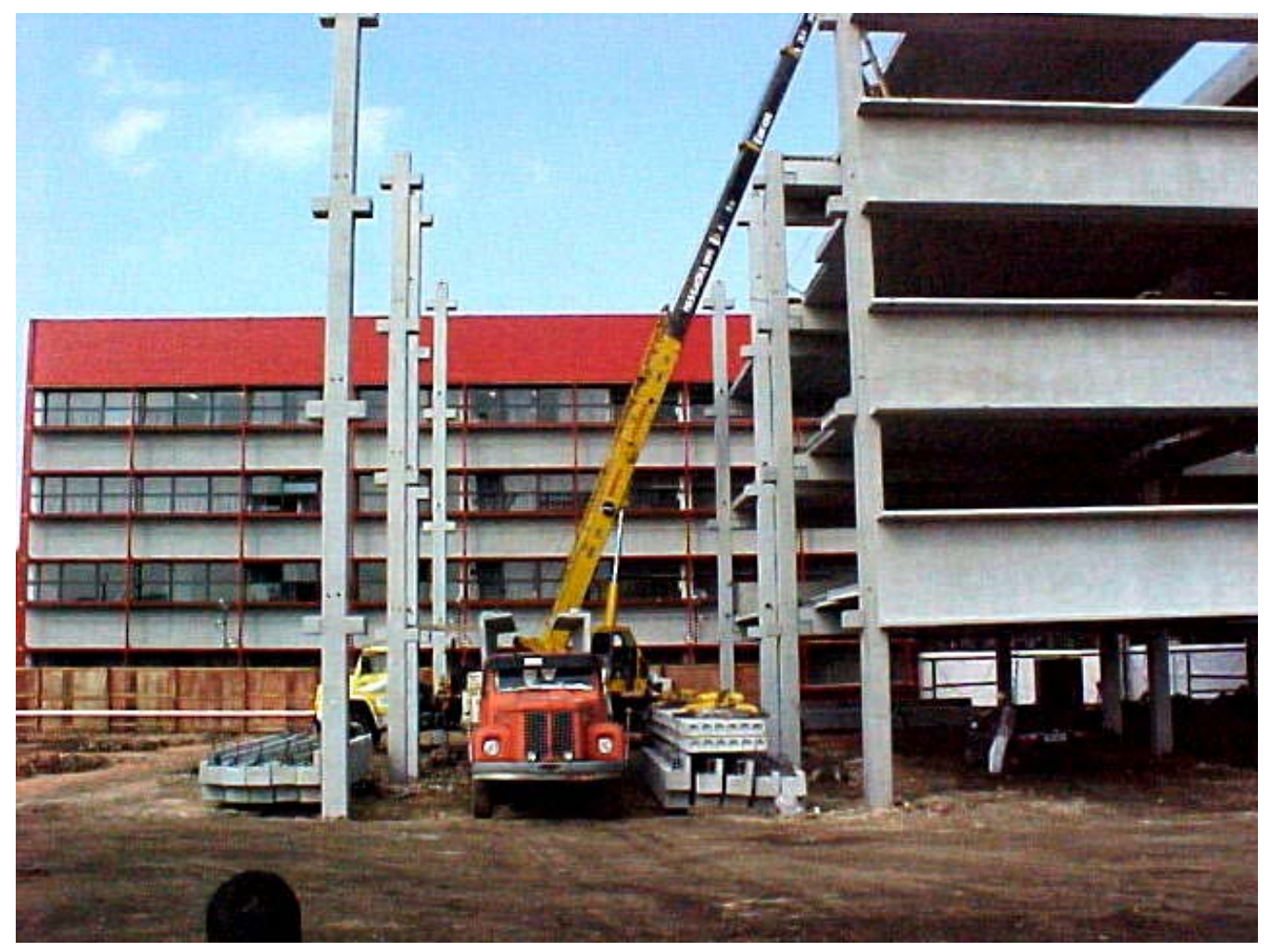

Figura 4.4 - Montagem da estrutura em elementos pré-moldados.

\subsection{GEOTECNIA DO LOCAL.}

\subsubsection{Aspectos geotécnicos regionais.}

A Região Metropolitana de Curitiba é formada, em uma grande extensão, por solos de origem sedimentar denominados Formação Guabirotuba. A Companhia de Pesquisa e Recursos Minerais - CPRM disponibiliza, em sua página na Internet, a Carta Geológica da região denominada Folha Curitiba a qual é apresentada na Figura 4.5. O local do presente estudo é indicado por uma seta vermelha. Nesse documento, na região do presente trabalho, são identificados solos formados no Holoceno, 
descritos como sedimentos aluvionares em geral, e no Pleistoceno, identificados como argilitos, arcóseos, margas, areias e cascalhos. Para as duas formações, o documento as identifica como Formação Guabirotuba.

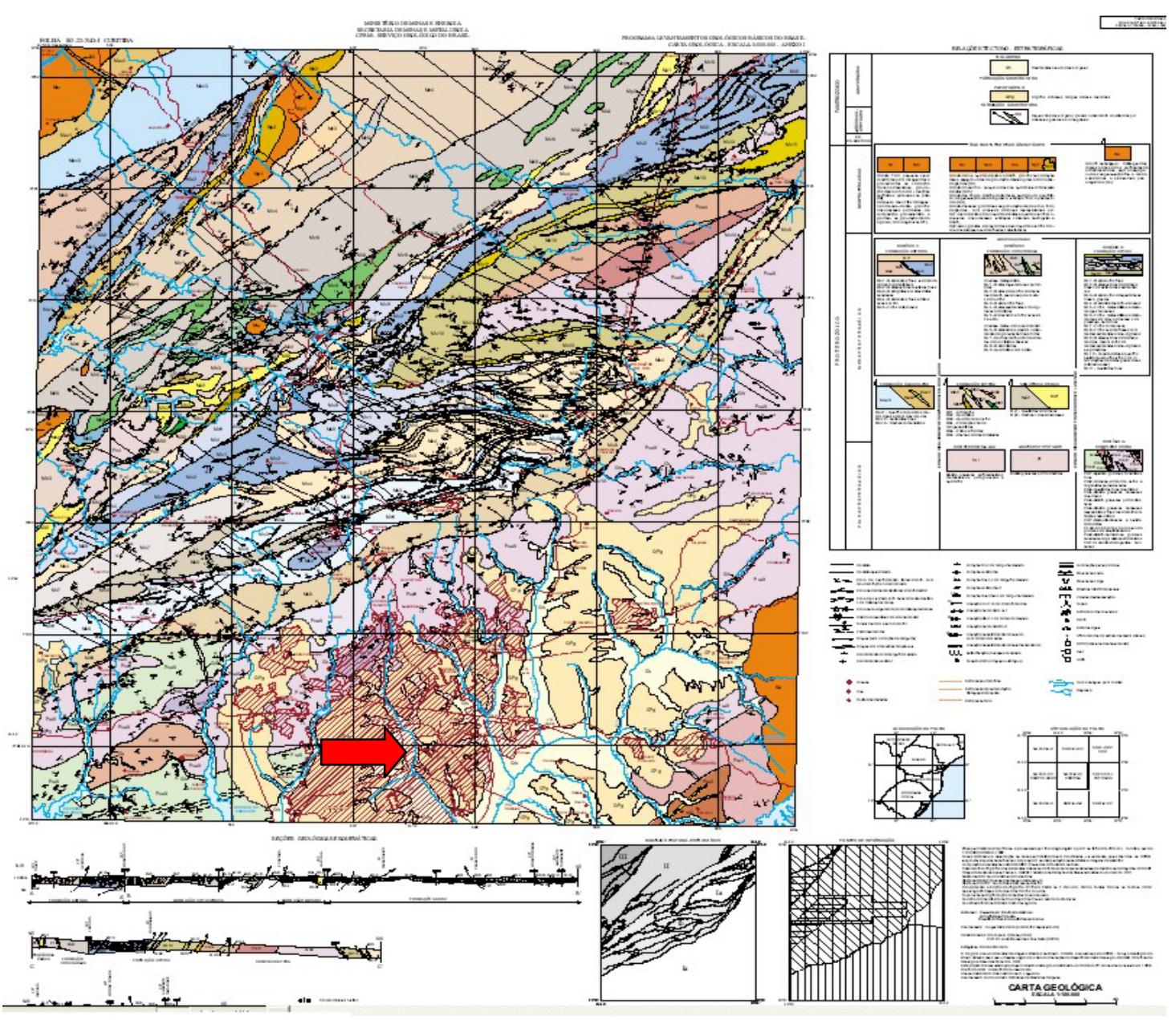

Figura 4.5 - Carta Geológica Folha Curitiba - CPRM.

Talamini (2001) apresenta mapeamento geotécnico do subsolo curitibano, buscando fornecer subsídios para o planejamento e a ocupação do espaço subterrâneo, o qual é reproduzido na Figura 4.6. Nesse trabalho os solos presentes na região são agrupados e descritos como:

- sedimentos aluviais, areias e siltes contendo camadas subordinadas de argila orgânica;

- Formação Guabirotuba, argilas rijas sobreadensadas e fraturadas com intercalações de arcósios;

- solos residuais, materiais com diferentes granulometrias; predomínio de siltes argilosos a arenosos, podendo apresentar estrutura da rocha original. 


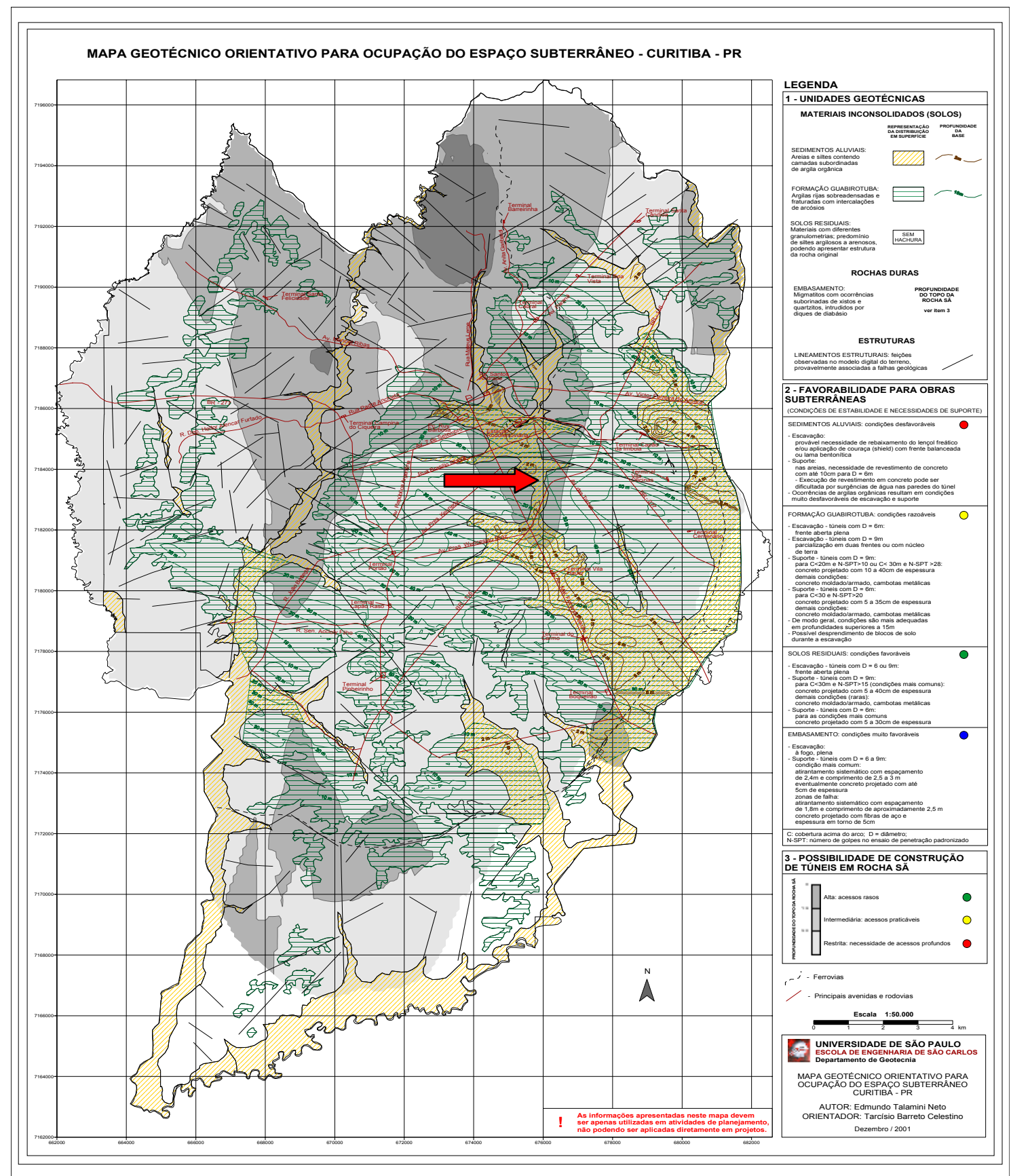

Figura 4.6 - Mapa geotécnico orientativo para ocupação do espaço subterrâneo (Talamini, 2001).

4.2.2 Aspectos geotécnicos locais.

Tendo em vista a construção dos edifícios que compõem o Campus Curitiba da PUCPR, foi possível resgatar um total de 30 furos de sondagem à percussão executados no local em diferentes momentos. A Tabela 4.1 apresenta a localização e quantidade das sondagens analisadas. 
Tabela 4.1 - Localização das sondagens Campus Curitiba PUCPR.

\begin{tabular}{|c|c|}
\hline Local & $\mathrm{N}^{\circ}$ de furos \\
\hline Jurídicas e Sociais $^{\left({ }^{*}\right)}$ & 6 \\
\hline Biblioteca & 6 \\
\hline Farmácia & 5 \\
\hline Biomédicas & 6 \\
\hline Bloco acadêmico & 3 \\
\hline Maquetaria & 2 \\
\hline Engenharia Química/Alimentos & 2 \\
\hline
\end{tabular}

$\left({ }^{*}\right)$ Local do presente estudo experimental

Essas investigações indicam que, na região, os solos enquadram-se na categoria de sedimentos aluvionares, conforme a Carta Geológica da CPRM e Talamini (2001). O Campus Curitiba da PUCPR é cortado pelo Rio Belém, importante meio de drenagem da região, conforme mostrado na Figura 4.2, tendo como decorrência disso que a geotecnia local é, em seus primeiros estratos de origem aluvionar, devida à planície de inundação daquele rio.

O horizonte mais próximo à superfície é composto por argilas orgânicas moles, com espessura média de $3 \mathrm{~m}$, seguidas de camada arenosa de espessura variável entre 1 e $4 \mathrm{~m}$. Apresentam-se eventualmente, neste horizonte granular, lentes de pedregulho. Em apenas quatro dos trinta furos de sondagens não se verifica a presença da camada arenosa.

Abaixo dos sedimentos encontram-se siltes arenosos, eventualmente argilosos ou micáceos, muito compactos, com coloração predominante cinza e amarela de origem residual, os quais se estendem até o limite das sondagens. O impenetrável à percussão se dá em profundidades entre 9 e $14 \mathrm{~m}$.

O nível de água no local é controlado pelo Rio Belém e foi determinado nas sondagens variável entre 1 a $3 \mathrm{~m}$.

De modo a analisar e a visualizar a disposição dos estratos de solos locais, procedeu-se à interpolação dos dados das 30 sondagens utilizando-se programa de computador específico (SURFER 7.0). Foram considerados nessas análises os seguintes aspectos:

a) superfície de contato entre a base da camada de argila mole e o topo da camada arenosa;

b) superfície de contato entre a base da camada arenosa (aluvião) e o topo do estrato silto arenoso (solo residual);

c) superfície indicando a posição do impenetrável à percussão. 
Os resultados são apresentados nas Figuras 4.7 a 4.9, por meio de curvas de igual profundidade, estando indicado nelas a posição das sondagens analisadas por marcadores circulares. Também se encontra delimitado, por meio de uma linha branca, a posição do local da presente pesquisa experimental.

No local do presente estudo as investigações geotécnicas do subsolo envolveram a realização de seis furos de sondagem à percussão (SPT) e quatro furos de ensaio de cone elétrico (CPT). Os furos SP-01 a SP-03 foram executados durante a fase de projeto do Bloco Didático 1, situado cerca de 20 metros do local da pesquisa. As demais sondagens à percussão foram executadas para fins de projeto do Bloco 2 .

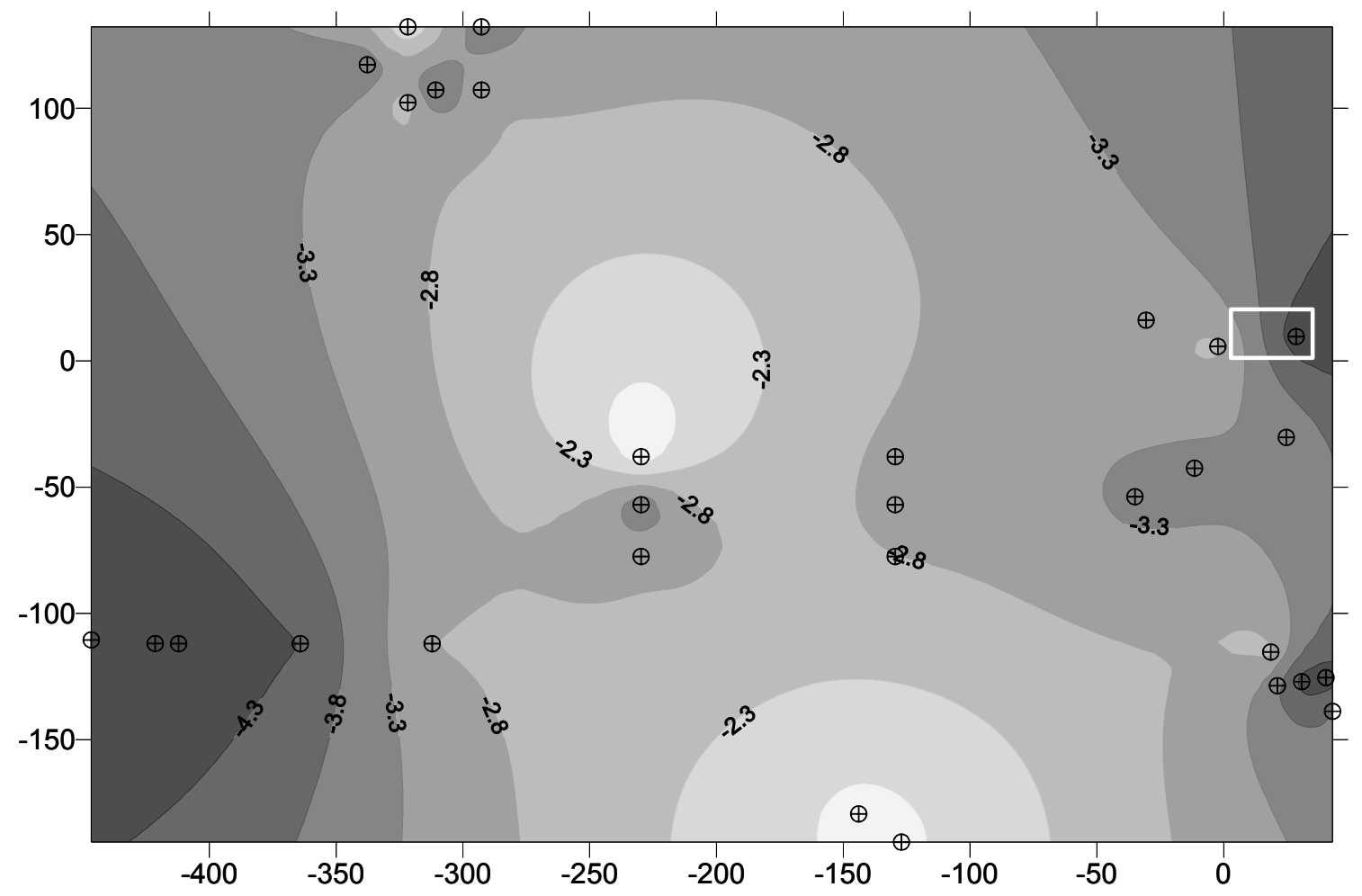

Figura 4.7 - Superfície de contato entre a base da camada de argila mole e o topo do estrato arenoso. 


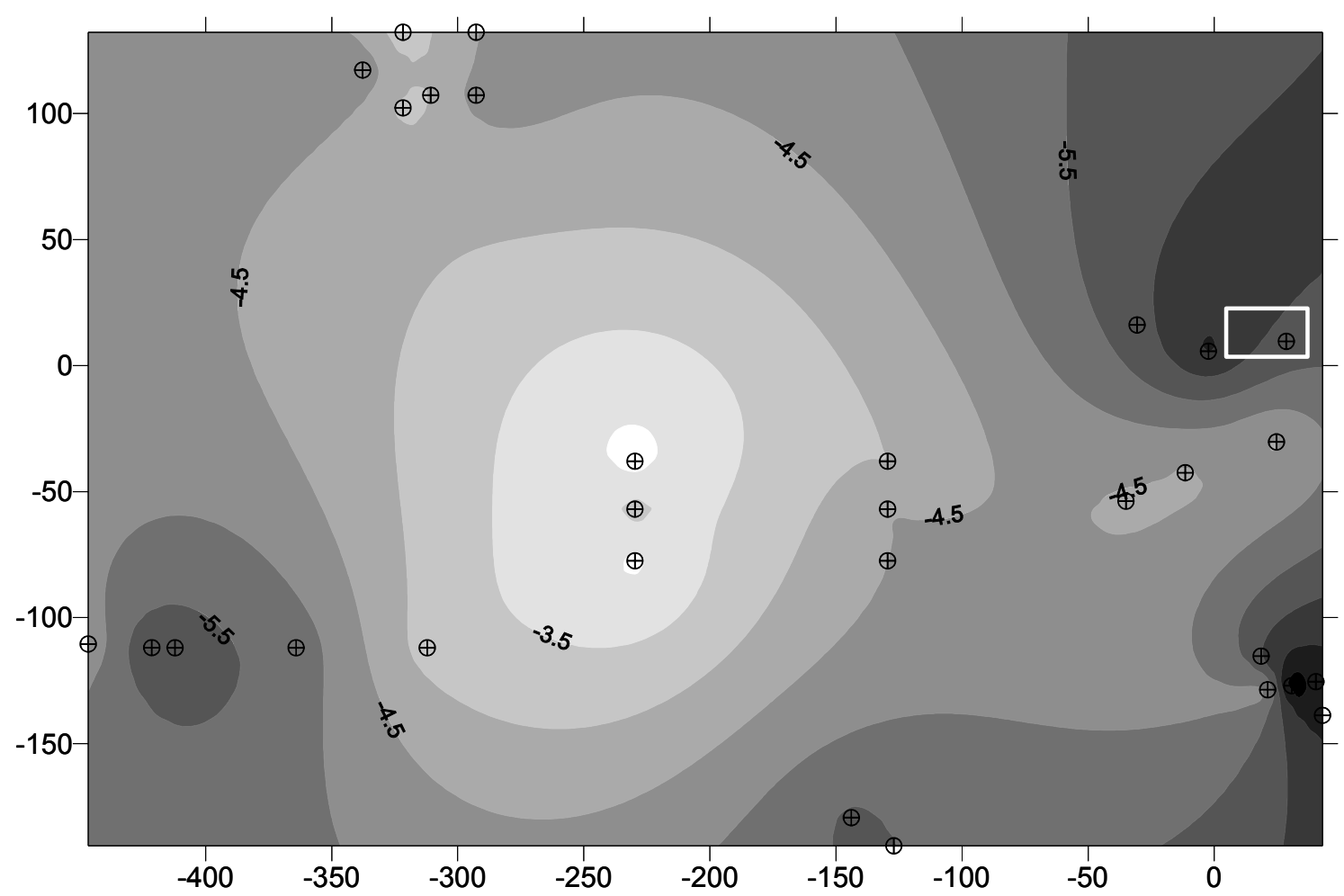

Figura 4.8 - Superfície de contato entre a base da camada arenosa e o topo do estrato silto arenoso.

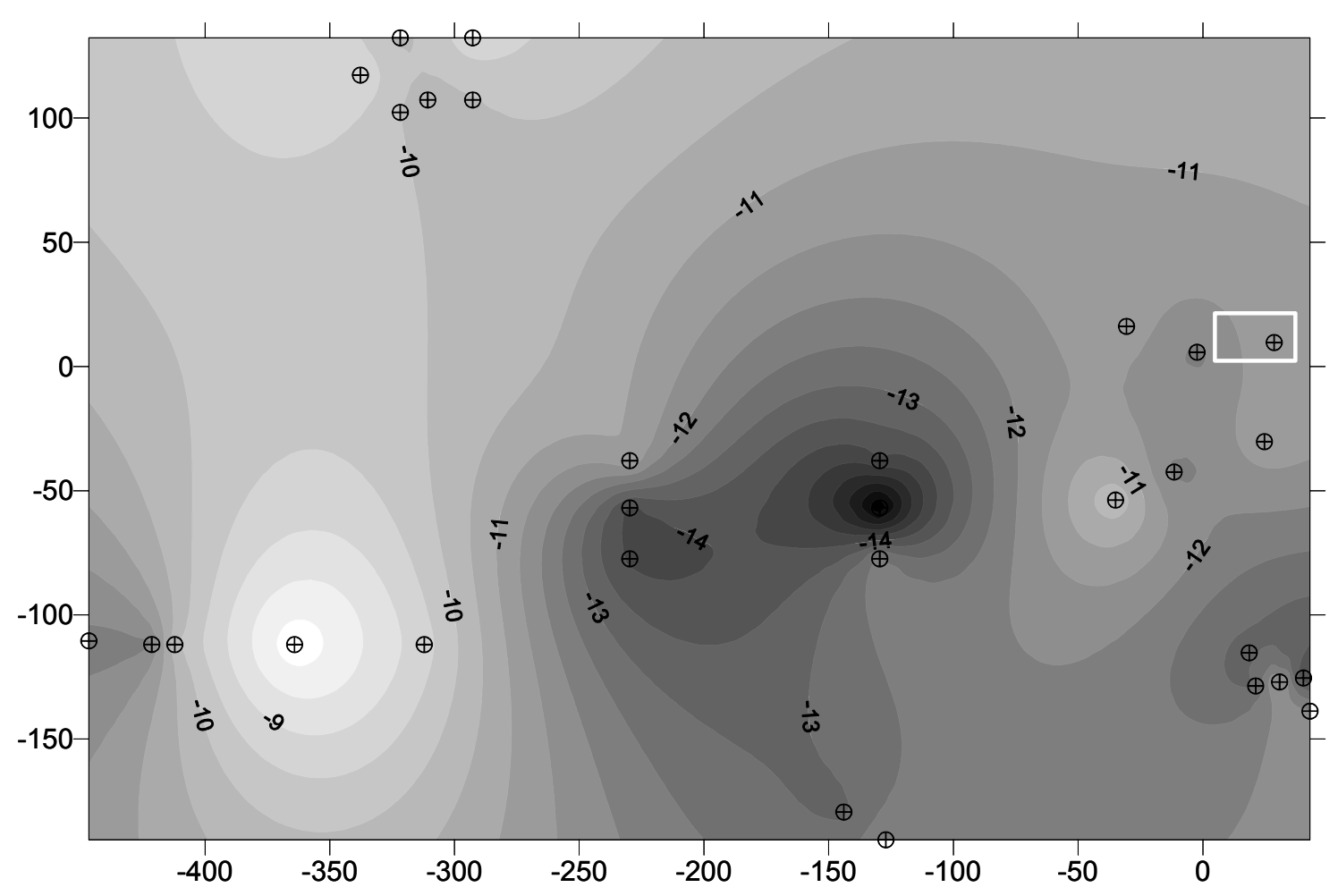

Figura 4.9 - Superfície do impenetrável à percussão. 
Cabe salientar que a área da projeção em planta tanto do Bloco 1 como do Bloco 2 é igual a $1.680 \mathrm{~m}^{2}$. Segundo a NBR-8036 (ABNT, 1983), a quantidade de furos de sondagem necessária seria de 7 furos para cada bloco.

Os ensaios de cone elétrico foram executados após a conclusão das obras, tendo sido locados o mais próximo ao local de estudo e se destinam a melhor definir propriedades mecânicas do estrato silto-arenoso.

A planta de localização das investigações e os resultados delas são apresentados nas figuras 4.10 a 4.17. O formato de apresentação das investigações é o utilizado pela empresa que realizou o respectivo serviço.

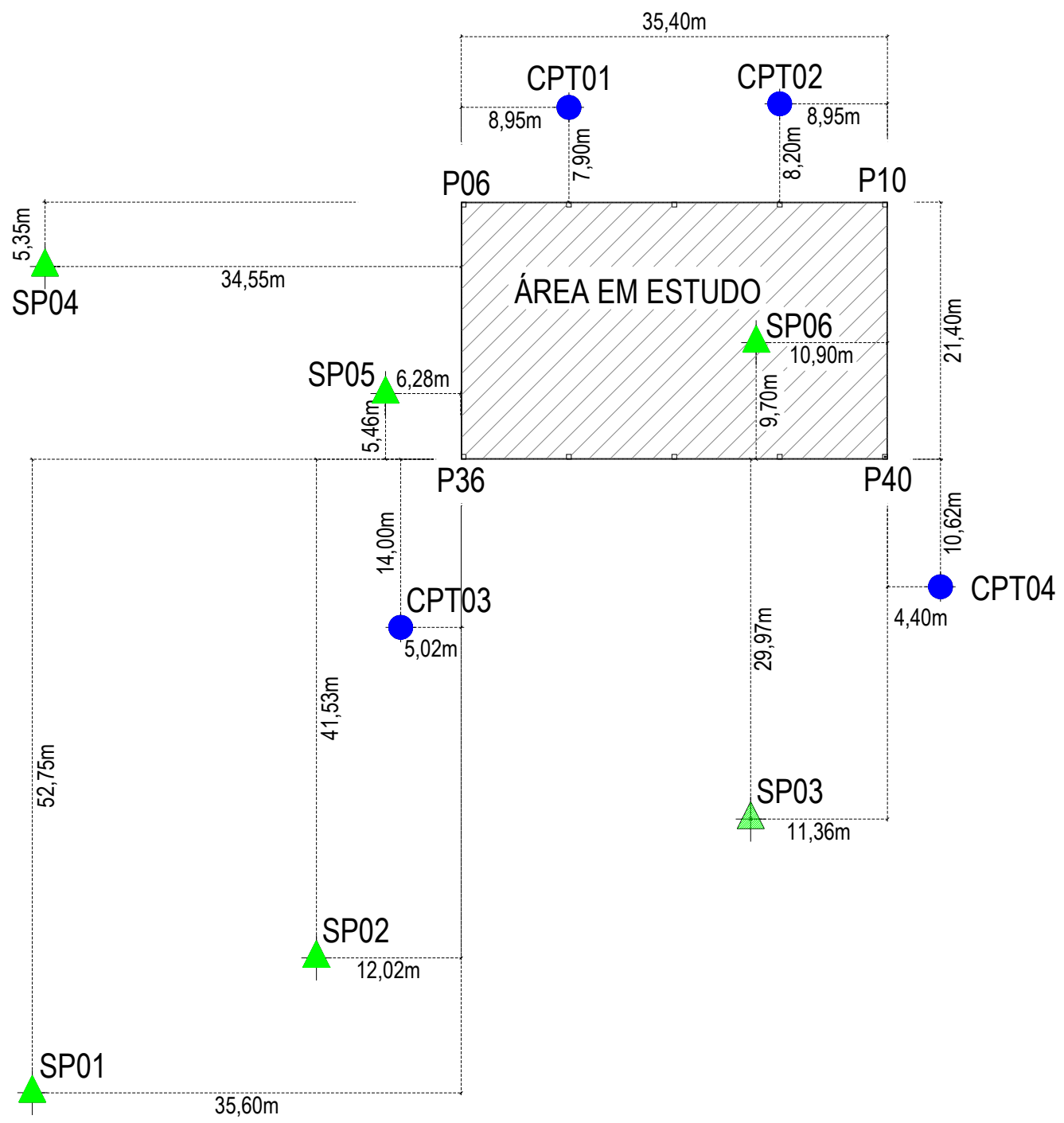

Figura 4.10 - Locação das investigações do subsolo. 
São José dos Pinhais, 18 de Setembro de 2001

CLIENTE : Pont. Univers. Católica do Paraná OBRA : R. Imaculada Conceição, 1155
São José dos Pinhais, 20 de Setembro de 2001

Cliente : Pont. Univers. Católica do Paraná

OBRA : R. Imaculada Conceição, 1155
SONDAGEM Nº 01

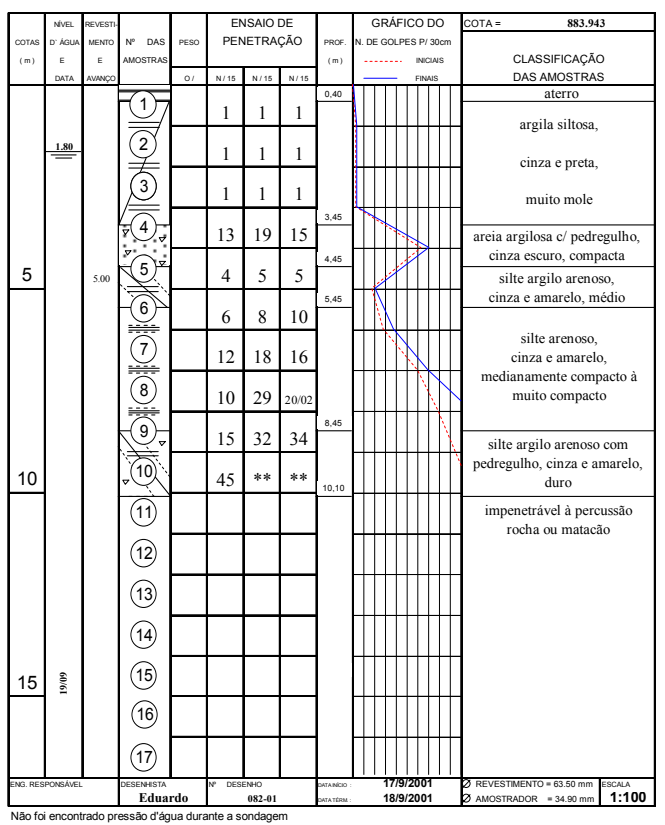

SONDAGEM N .02

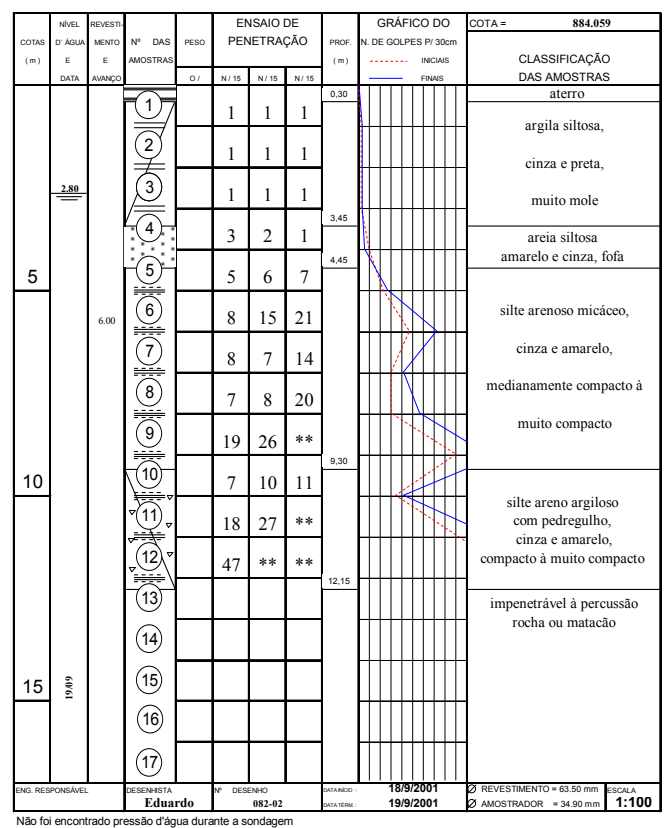

Figura 4.11 - Sondagens SP-01 e SP-02.

São José dos Pinhais, 21 de Setembro de 2001

CLIENTE : Pont. Univers. Católica do Paraná OBRA : R. Imaculada Conceição, 1155
São José dos Pinhais, 19 de Junho de 2002

CLIENTE : PUC-PR

OBRA : Bloco Didático
SONDAGEM N .03

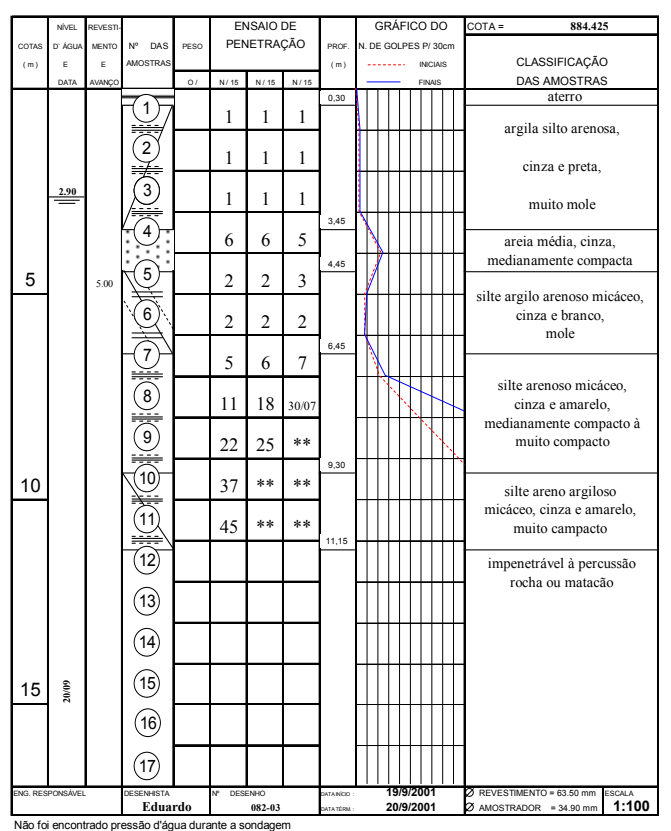

SONDAGEM N ${ }^{\circ} .04$

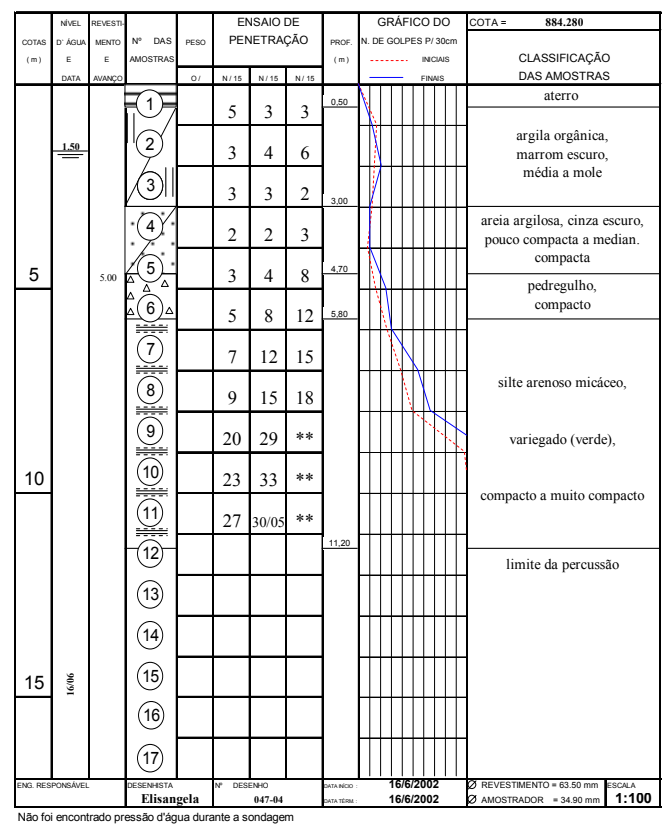

Figura 4.12 - Sondagens SP-03 e SP-04. 
São José dos Pinhais, 19 de Junho de 2002

CLIENTE : PUC-PR

OBRA : Bloco Didático

SONDAGEM $\mathrm{N}^{\circ} .05$

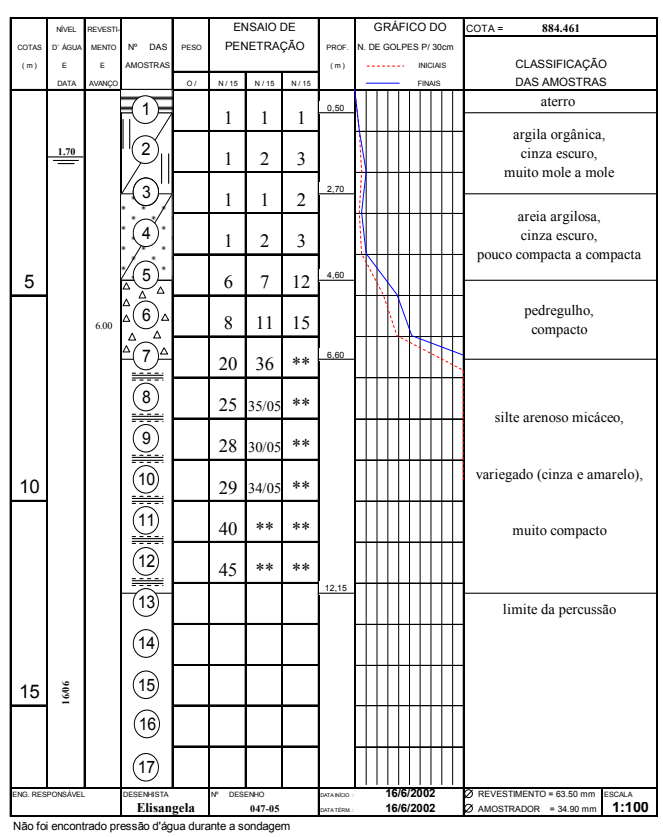

São José dos Pinhais, 19 de Junho de 2002

CLIENTE : PUC-PR

OBRA : Bloco Didático

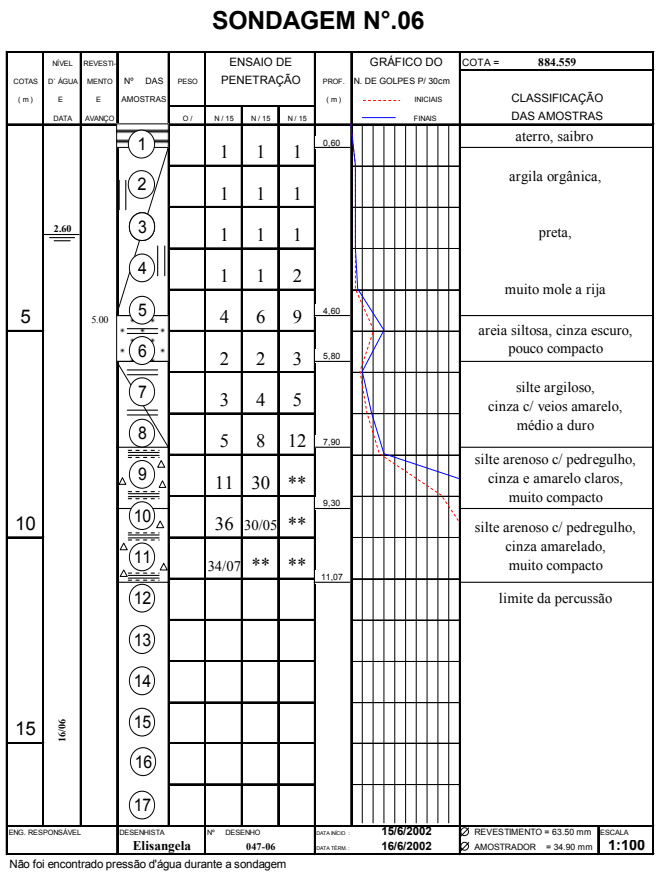

Figura 4.13 - Sondagens SP-05 e SP-06.

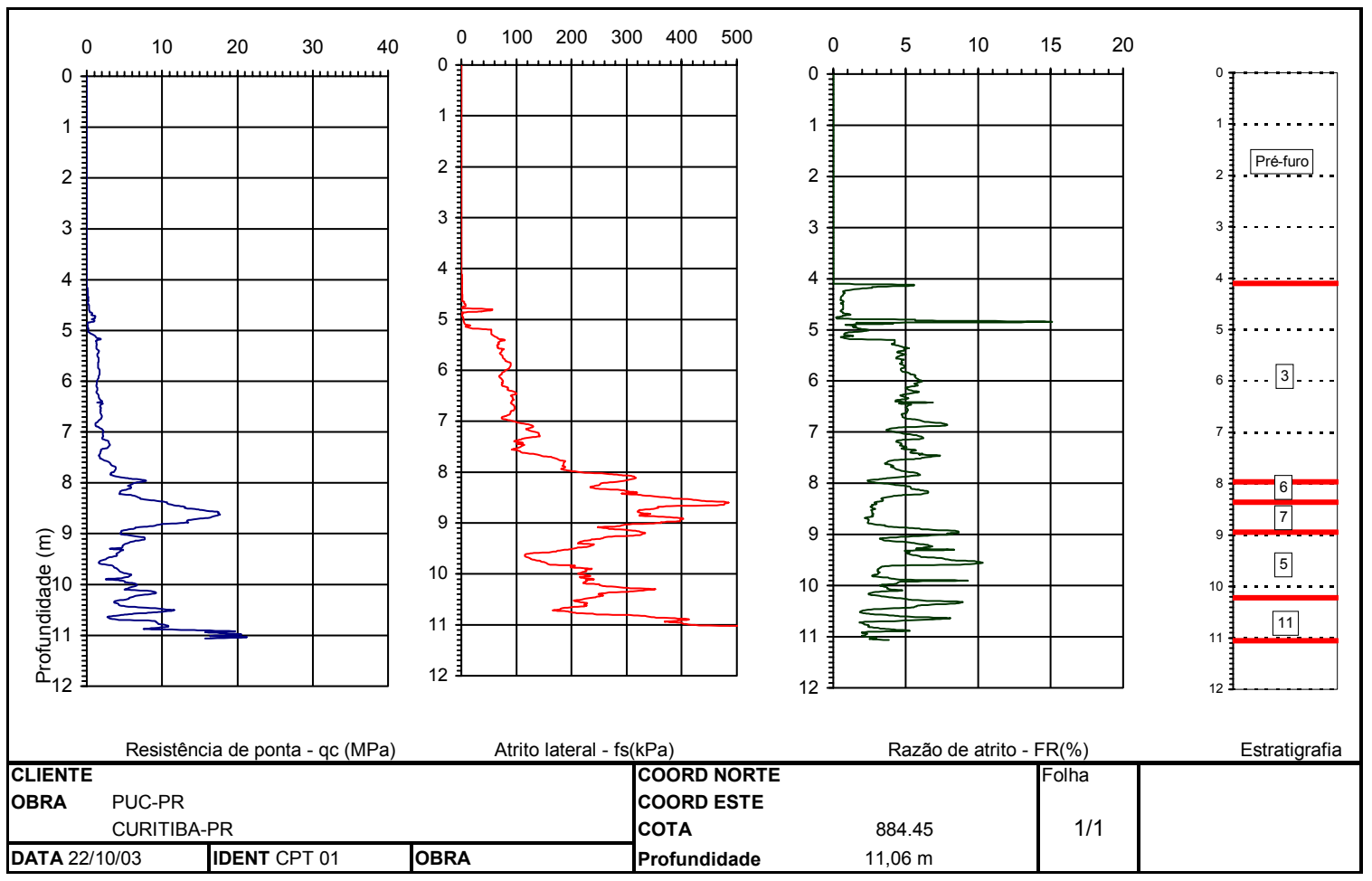

Figura 4.14 - Ensaio CPT-01. 


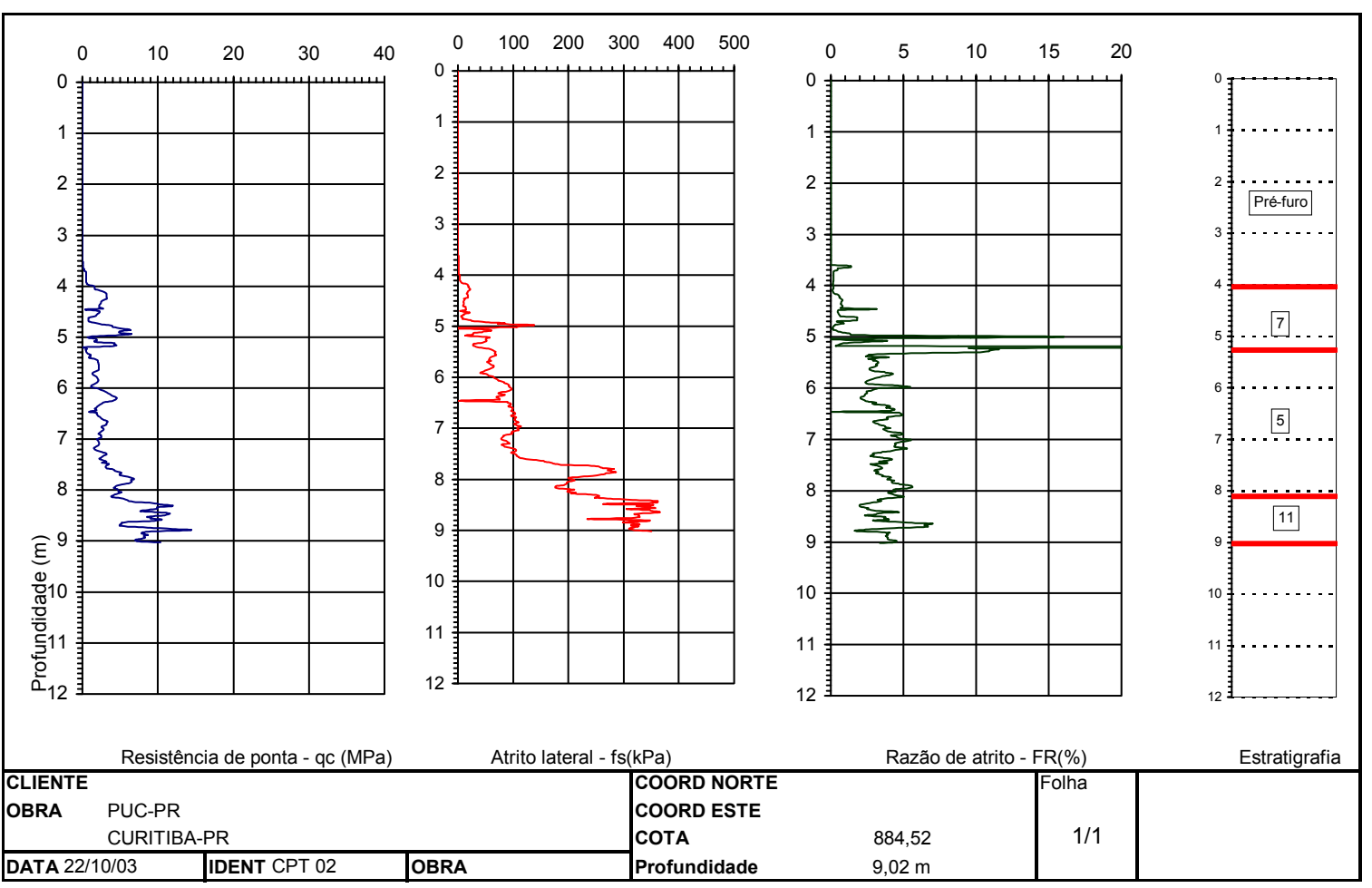

Figura 4.15 - Ensaio CPT-02.

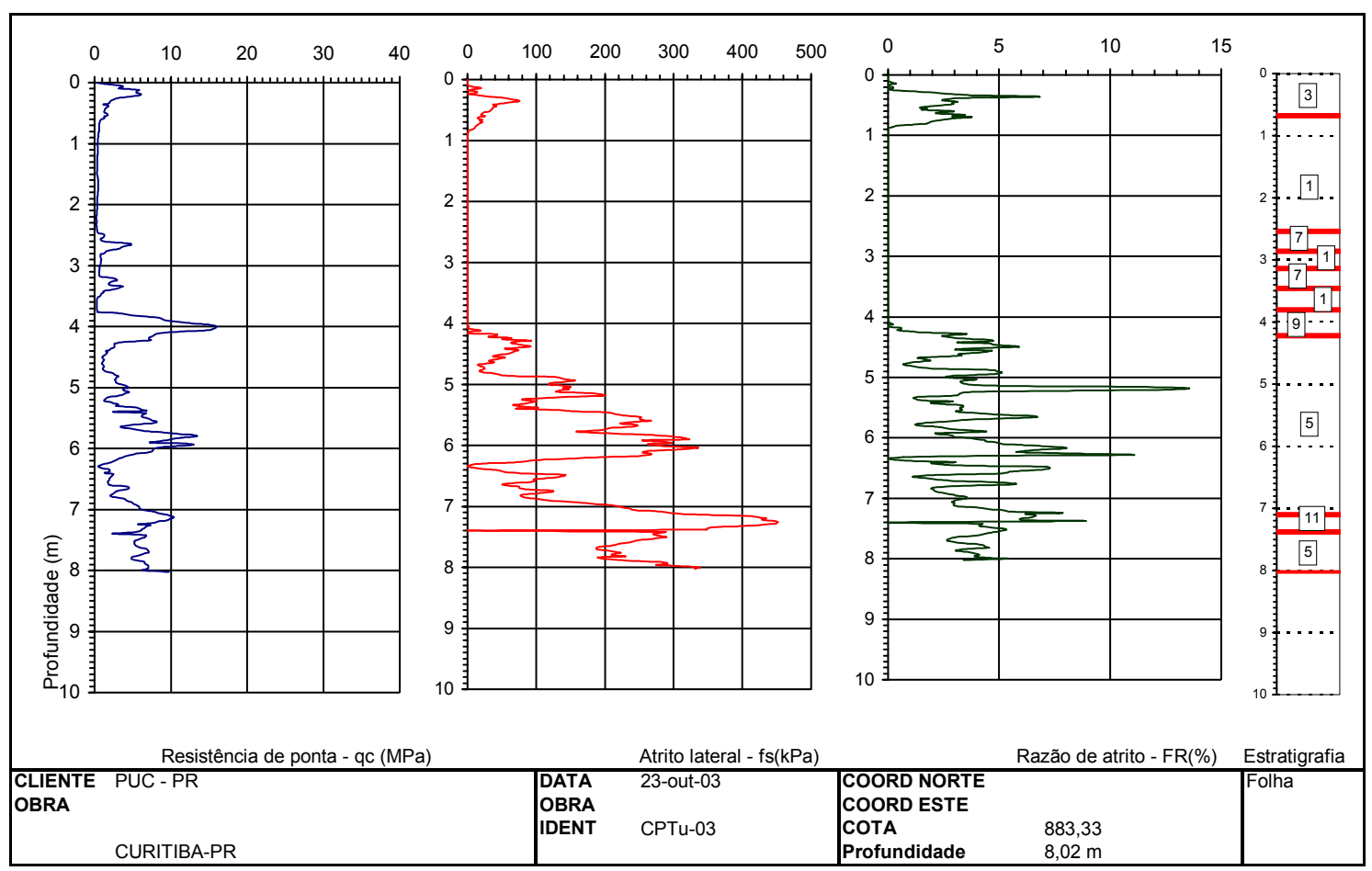

Figura 4.16 - Ensaio CPT-03. 


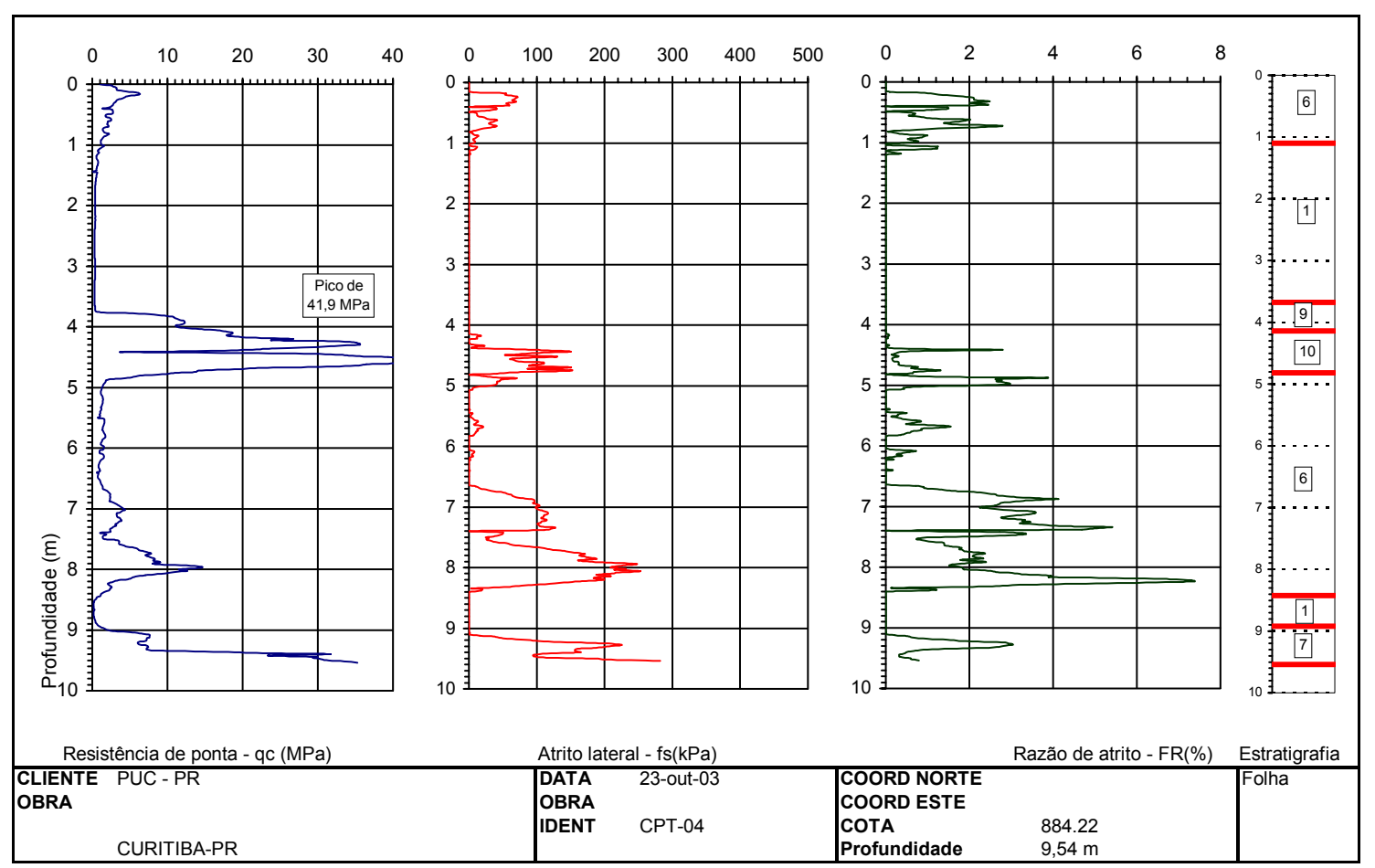

Figura 4.17 - Ensaio CPT-04.

Os resultados das sondagens à percussão permitem analisar a variabilidade dos solos locais no que diz respeito ao valor da resistência à penetração do amostrador padrão, dada pelo número de golpes ( $\left.\mathrm{N}_{\mathrm{SPT}}\right)$.

A Tabela 4.2 apresenta análise estatística dos valores do número de golpes SPT, determinados nos furos de sondagem, na qual se constata a grande variabilidade dos solos do local pelo coeficiente de variação (CV), que se apresenta na faixa entre 41 e $73 \%$.

\begin{tabular}{|c|c|c|c|c|}
\hline \multirow{2}{*}{$\begin{array}{c}\text { Cota } \\
\text { (m) }\end{array}$} & \multicolumn{3}{|c|}{$\mathrm{N}_{\mathrm{SPT}}(/ 30 \mathrm{~cm})$} & \multirow{2}{*}{$\begin{array}{l}\text { CV } \\
(\%)\end{array}$} \\
\hline & Máximo & Mínimo & Médio & \\
\hline 883 & 7,1 & 1,9 & 3,1 & $62 \%$ \\
\hline 882 & 8,6 & 2,0 & 3,4 & $70 \%$ \\
\hline 881 & 5,8 & 2,0 & 3,6 & $41 \%$ \\
\hline 880 & 32,2 & 3,6 & 12,1 & $77 \%$ \\
\hline 879 & 22,2 & 4,6 & 12,7 & $42 \%$ \\
\hline 878 & 39,8 & 7,2 & 21,6 & $58 \%$ \\
\hline 877 & 90,1 & 15,1 & 34,7 & $73 \%$ \\
\hline 876 & 124,5 & 29,0 & 49,7 & $68 \%$ \\
\hline 875 & 123,5 & 43,6 & 71,6 & $38 \%$ \\
\hline 874 & 139,2 & 22,4 & 90,2 & $44 \%$ \\
\hline 873 & 154,6 & 47,9 & 101,3 & $53 \%$ \\
\hline
\end{tabular}


O gráfico da Figura 4.18 mostra a variação do número de golpes ( $\left.\mathrm{N}_{\mathrm{SPT}}\right)$ com a profundidade para os furos de sondagem, no qual também é possível visualizar a grande variabilidade dos solos.

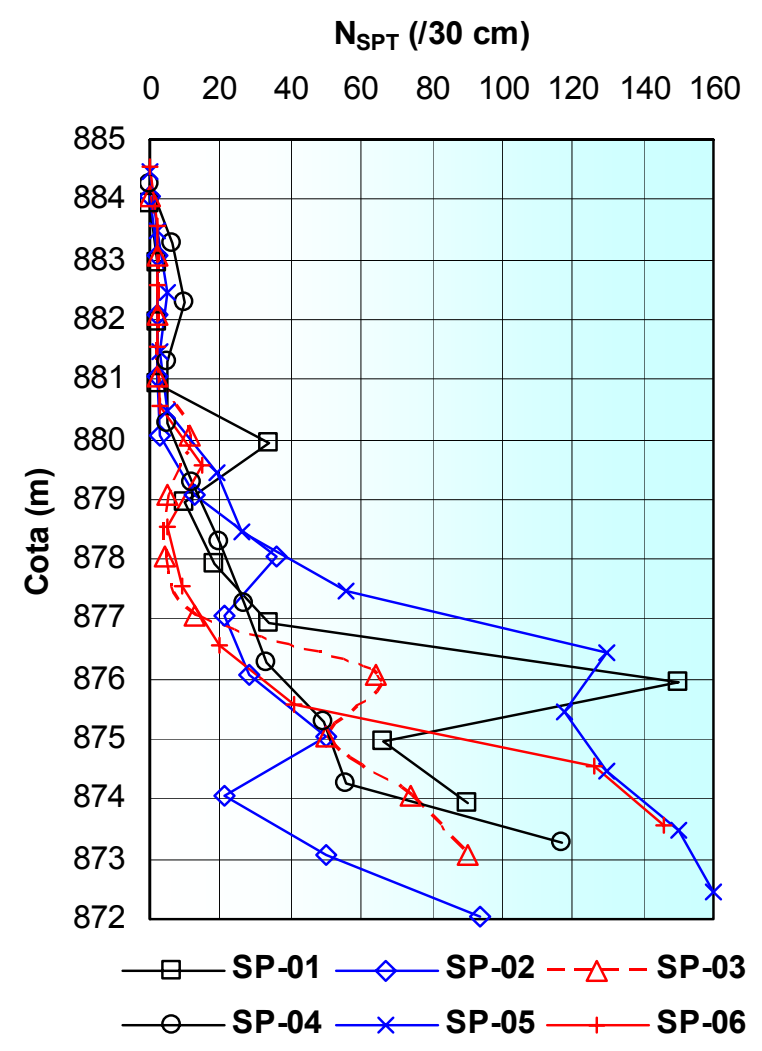

Figura 4.18 - Variação de $N_{S P T}$ com a profundidade.

De maneira idêntica à realizada anteriormente, procedeu-se à interpolação dos resultados dos seis furos de sondagem, realizados na área em estudo, cujos resultados são apresentados nas Figuras 4.19 a 4.21. Nelas são indicadas as posições das sondagens por meio de marcadores circulares, bem como a posição dos pilares monitorados pelos marcadores quadrados. Essas ilustrações indicam pequena variabilidade (entre 1,0 e 1,5 m) na disposição dos estratos que ocorrem no local.

A visualização das disposições dos estratos presentes no local é apresentada nas Figuras 4.22 e 4.23 , por meio de duas seções transversais, traçadas entre os furos de sondagem SP-01 a SP-03 e SP-04 a SP-06. 


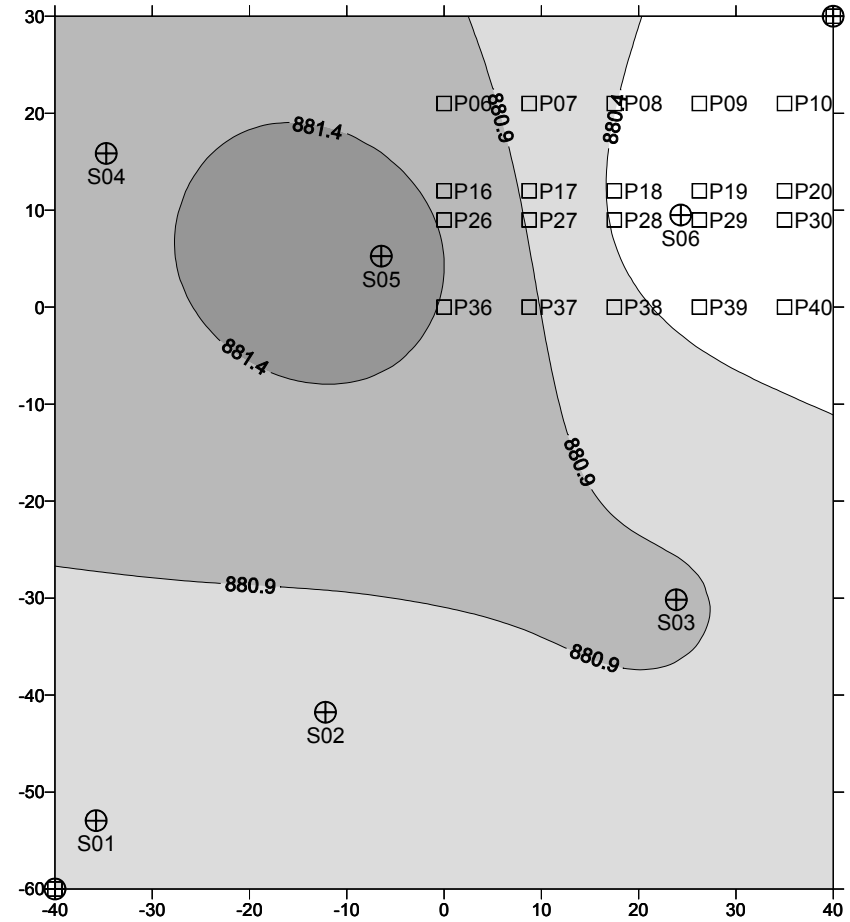

Figura 4.19 - Superfície de contato entre a camada de argila mole e o estrato arenoso.

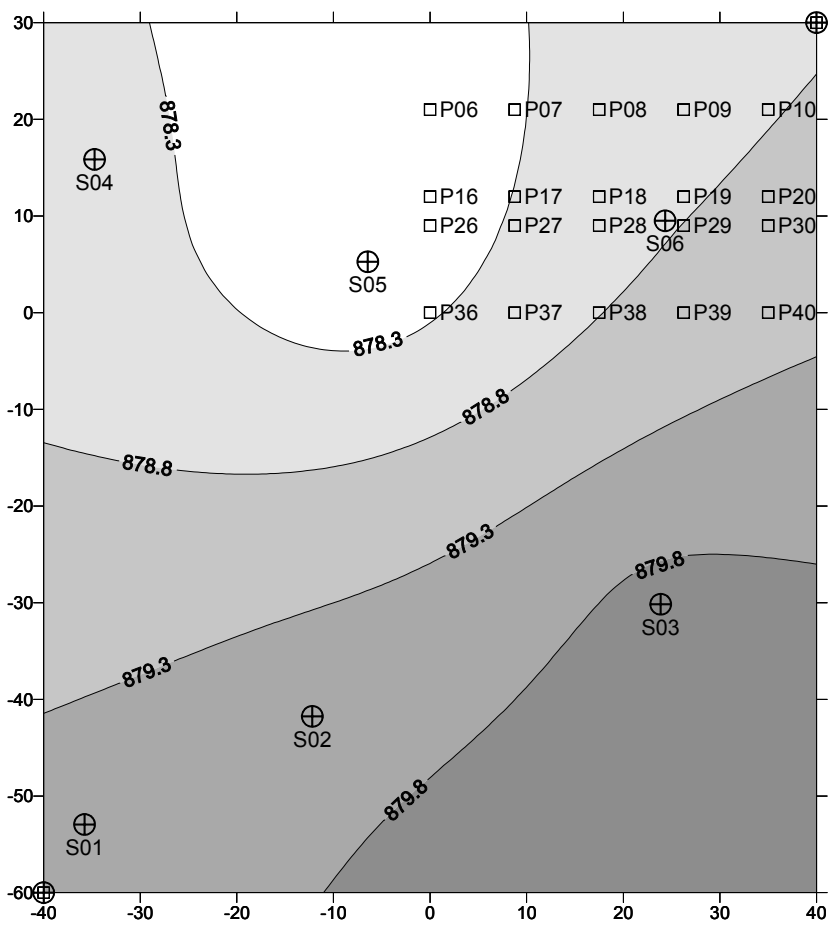

Figura 4.20 - Superfície de contato entre a base do estrato arenoso e o topo da camada siltoarenosa. 


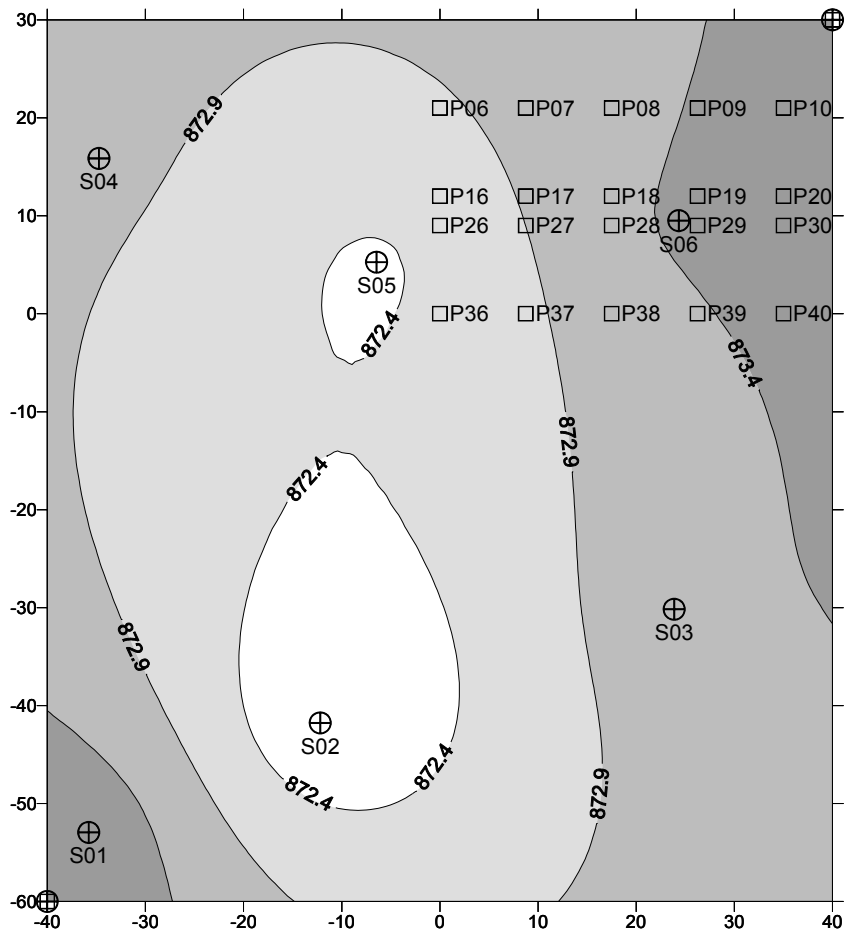

Figura 4.21 - Superfície do impenetrável à percussão.

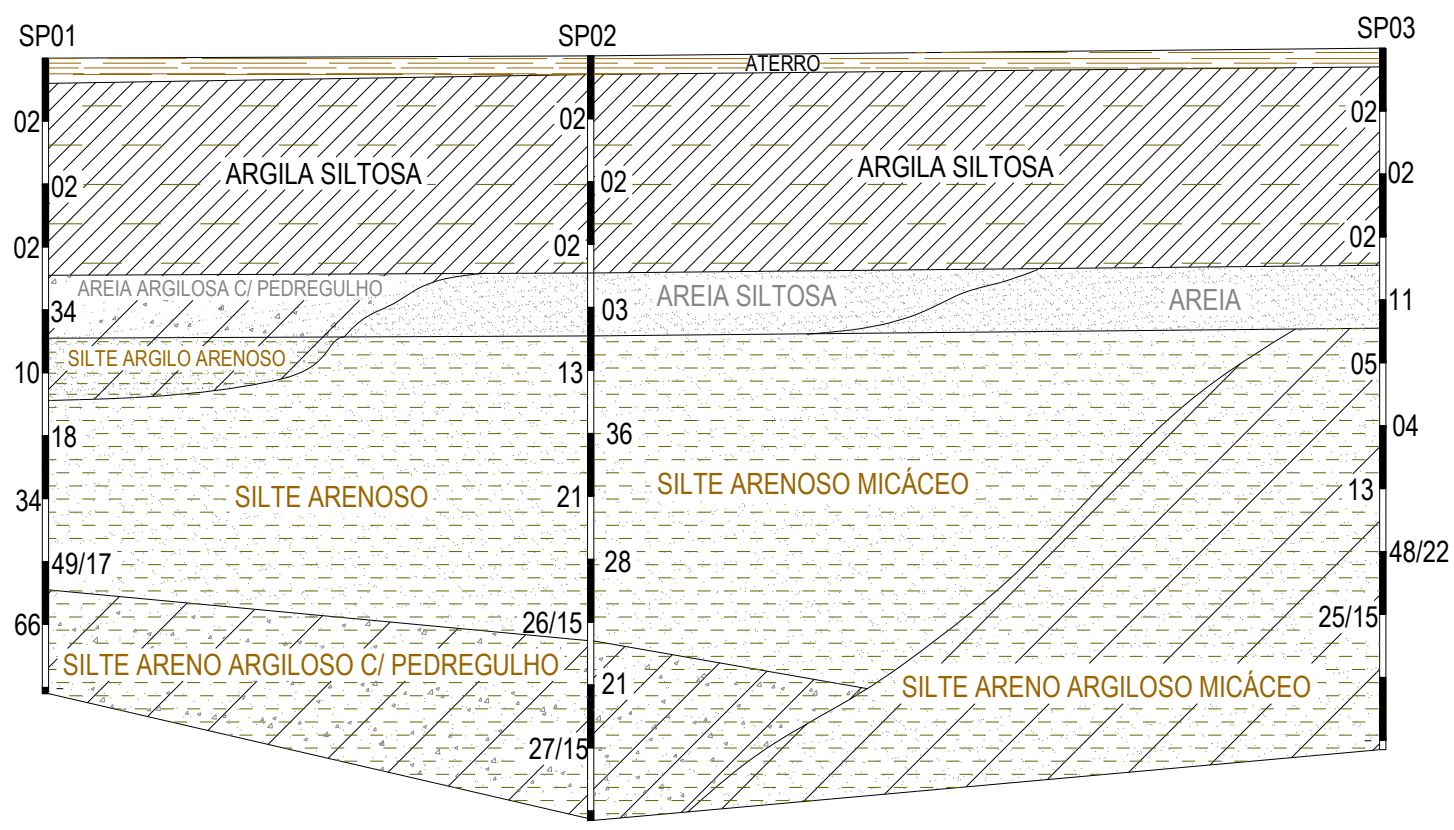

Figura 4.22 - Perfil geotécnico - seção transversal SP-01 a SP-03. 


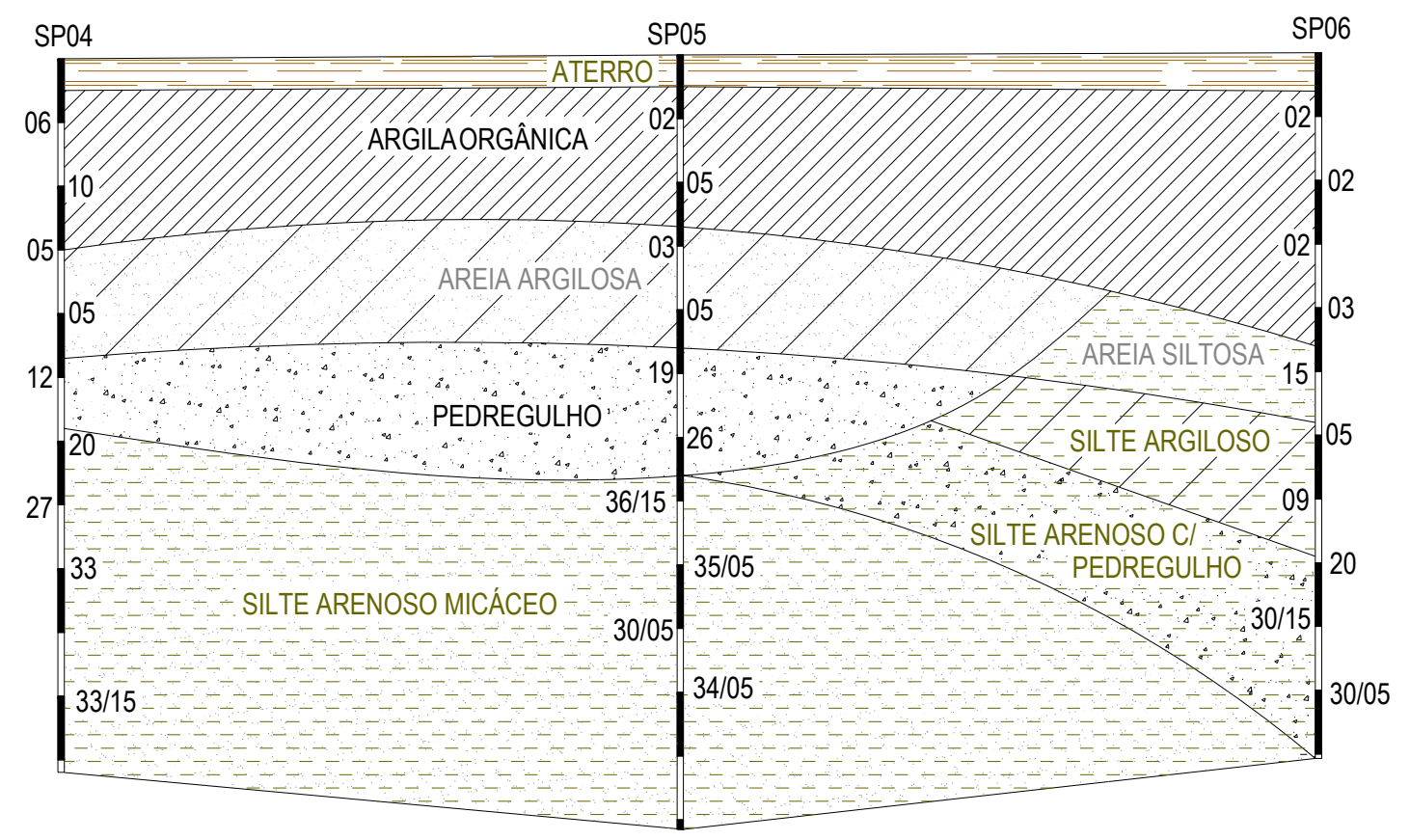

Figura 4.23 - Perfil geotécnico - seção transversal SP-04 a SP-06.

As investigações de campo do tipo cone elétrico ou CPT permitem também analisar a variabilidade dos materiais envolvidos na obra. As análises a seguir referem-se apenas à resistência à penetração de ponta do cone $\left(q_{c}\right)$ para a camada silto-arenosa. O gráfico da Figura 4.24 apresenta a variação desse valor com a profundidade nas quatro verticais investigadas. Nesse gráfico é possível observar picos de resistência em extensões da ordem de 50 $\mathrm{cm}$, seguidos de redução, indicando a presença de camadas mais resistentes inseridas no maciço de menor resistência.

Aoki (1985) apresenta representação esquemática de perfil de solo residual de gnaisse bastante esclarecedora sobre esse comportamento, a qual é reproduzida na Figura 4.25. A rocha-mãe apresenta-se com bandas de espessura variáveis, nas quais pode ocorrer a predominância de quartzo $(Q)$, feldspato $(F)$ e mica $(M)$ com atitudes subverticais. A alteração dessa matriz resultará em solos com textura predominante argilosa (A), siltosa (SS) ou arenosa (S). Dependendo da espessura do estrato residual e da atitude dos veios subverticais, uma sondagem poderá indicar a presença de camadas arenosas com a eventual presença de pedregulhos inserida entre solos argilosos ou siltosos. 


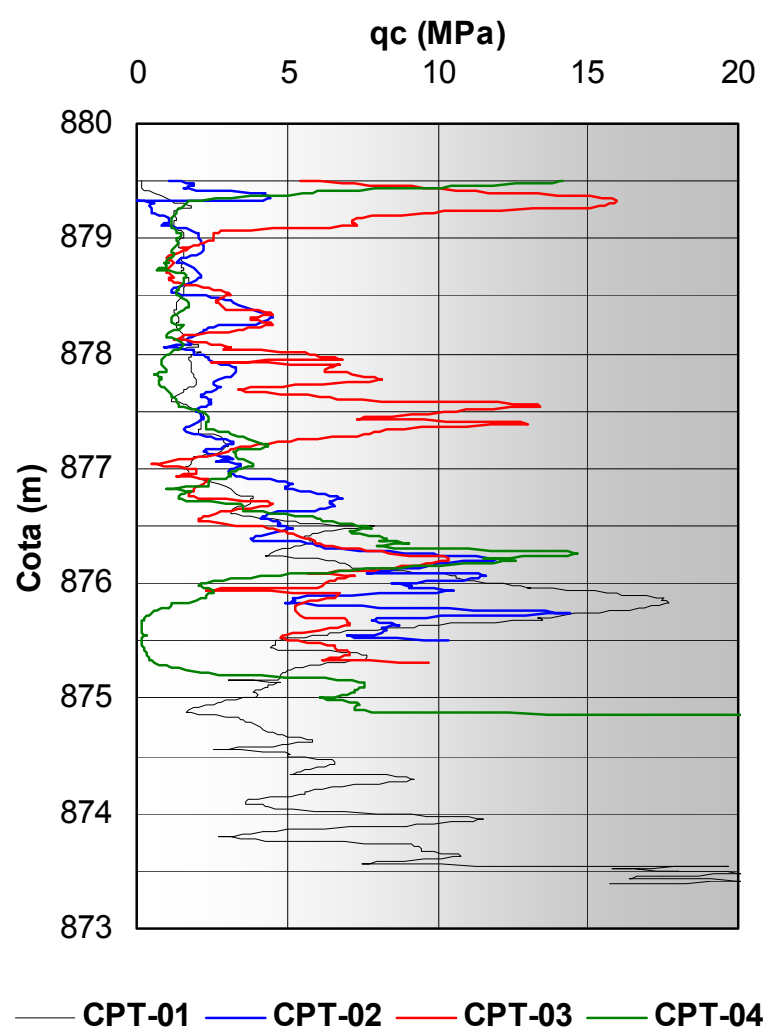

Figura 4.24 - Variação da resistência de ponta do cone $\left(q_{c}\right)$ com a profundidade.

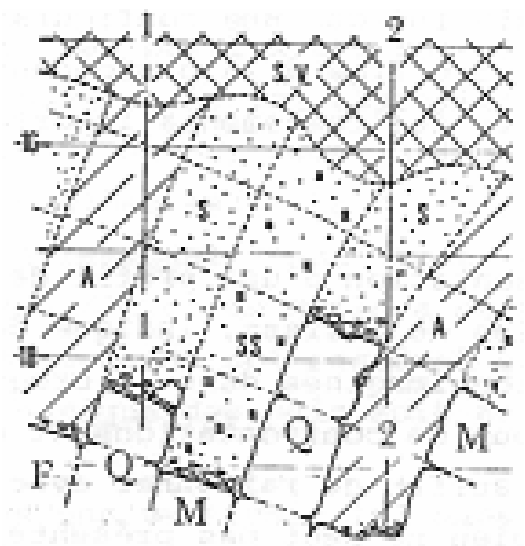

Figura 4.25 - Perfil de solo residual, in Aoki (1985).

De modo a facilitar a visualização de uma análise estatística, os valores de $q_{c}$ foram reunidos a cada $50 \mathrm{~cm}$ pelo seu valor médio, a partir da cota 879,5 $\mathrm{m}$, estando o resultado dessa análise apresentado na Tabela 4.3. 
Constata-se nessa tabela a alta variabilidade do material silto-arenoso, conforme expresso pelo coeficiente de variação $(\mathrm{CV})$ situado na faixa entre $9 \mathrm{e}$ $84 \%$.

\begin{tabular}{|c|c|c|c|c|}
\hline \multirow{2}{*}{$\begin{array}{l}\text { Prof } \\
\text { (m) }\end{array}$} & \multicolumn{3}{|c|}{$\mathrm{q}_{\mathrm{c}}(\mathrm{MPa})$} & \multirow{2}{*}{$\begin{array}{l}\text { CV } \\
(\%)\end{array}$} \\
\hline & Máximo & Mínimo & Média & \\
\hline 5,0 & 9,4 & 1,0 & 3,9 & 84 \\
\hline 5,5 & 1,8 & 1,3 & 1,6 & 12 \\
\hline 6,0 & 30 & & 2,2 & 35 \\
\hline 6,5 & 6,9 & 1,0 & 3,0 & 75 \\
\hline 7 & 6,3 & 3 & 3,5 & 45 \\
\hline 7, & 0 & & 3,4 & 27 \\
\hline 8,0 & 8,5 & 8 & 7,5 & 9 \\
\hline 8,5 & 13,0 & 1,1 & 7,0 & 61 \\
\hline 9,0 & & 3,0 & 6,3 & 42 \\
\hline 9,5 & 1 & 7 & 10,1 & 59 \\
\hline 10,0 & 19,7 & 5,9 & 10,7 & 51 \\
\hline 10 & 19,7 & 6,8 & 11,3 & 44 \\
\hline $11, \mathrm{C}$ & 19,7 & 6,8 & 13,7 & 39 \\
\hline
\end{tabular}

Os dados das investigações de subsuperfície permitem verificar a relação $(k)$ entre o valor resistência à penetração dinâmica do ensaio SPT $\left(N_{S P T}\right)$ e a resistência à penetração dinâmica da ponta do cone $\left(q_{c}\right)$ no ensaio CPT. A Tabela 4.4 apresenta os valores desta correlação determinados apenas para a camada silto-arenosa presente no local. Os valores obtidos apresentam valor médio do coeficiente $(\mathrm{k})$ igual a $144 \mathrm{kPa}$, com coeficiente de variação $41 \%$.

\begin{tabular}{|c|c|c|c|}
\hline $\begin{array}{l}\text { Prof } \\
(\mathrm{m})\end{array}$ & $\begin{array}{c}\mathrm{N}_{\mathrm{SPT}} \\
(/ 30 \mathrm{~cm})\end{array}$ & $\begin{array}{c}\mathrm{q}_{\mathrm{c}} \\
(\mathrm{MPa})\end{array}$ & $\begin{array}{c}\mathrm{k} \\
(\mathrm{kPa})\end{array}$ \\
\hline 5,0 & 12,4 & 3,94 & 318 \\
\hline 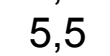 & & & 23 \\
\hline & & & 128 \\
\hline & & & 141 \\
\hline T, & & & 126 \\
\hline 7,5 & & & \\
\hline 8,0 & & & 178 \\
\hline 8,5 & & & 142 \\
\hline & & & \\
\hline 9 & & 1 & 164 \\
\hline & & & 73 \\
\hline & & & \\
\hline 11,0 & 95,7 & 17,89 & 18 \\
\hline
\end{tabular}




\subsection{CONDIÇÕES AMBIENTAIS LOCAIS.}

Tendo em vista que o presente estudo foi realizado em condições não controladas, as quais são normalmente encontradas em laboratórios, foi necessário acessar dados das condições ambientais locais para o período das observações, os quais foram cedidos pelo Instituto Tecnológico SIMEPAR, órgão oficial local de monitoramento metereológico. A estação mais próxima ao local do estudo localiza-se no Centro Politécnico da UFPR e situa-se a cerca de $1 \mathrm{~km}$ de distância. Os dados levantados referem-se a:
a) temperatura ambiente;
b) umidade relativa do ar;
c) pressão atmosférica;
d) velocidade do vento;
e) precipitação.

\subsubsection{Temperatura ambiente.}

O gráfico da Figura 4.26 apresenta a variação da temperatura ambiente no período das observações de campo (06/09/2002 a 17/10/2002). No gráfico, em linha pontilhada é apresentado o valor médio dessas medidas, sendo esse igual a $18,1^{\circ} \mathrm{C}$. A temperatura máxima no período foi de $32,9{ }^{\circ} \mathrm{C}$, verificada no dia $11 / 10 / 2002$, às $16 \mathrm{~h}$, e a mínima de $5,5^{\circ} \mathrm{C}$ registrada no dia 22/09/2002 às $6 \mathrm{~h}$.

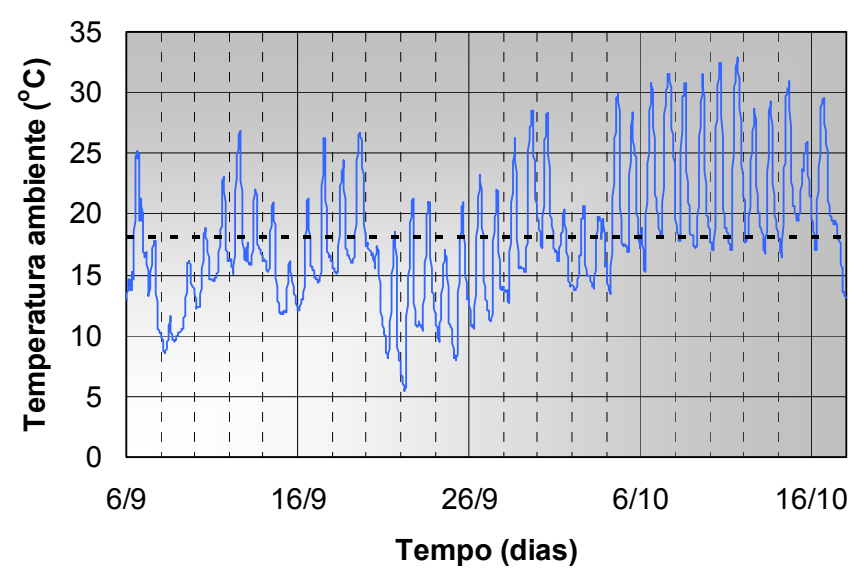

Figura 4.26 - Variação horária da temperatura ambiente. 
De modo a avaliar as variações da temperatura ambiente ao longo do dia, o gráfico da Figura 4.27 apresenta os valores máximo, médio e mínimo diários, assim como a sua variação. A maior variação ocorreu no dia 04/10/2002, sendo igual a $16,3{ }^{\circ} \mathrm{C}$, e a menor foi de $3,0^{\circ} \mathrm{C}$, acontecendo no dia 08/09/2002. Os dados indicam uma variação média diária de $10,5^{\circ} \mathrm{C}$.

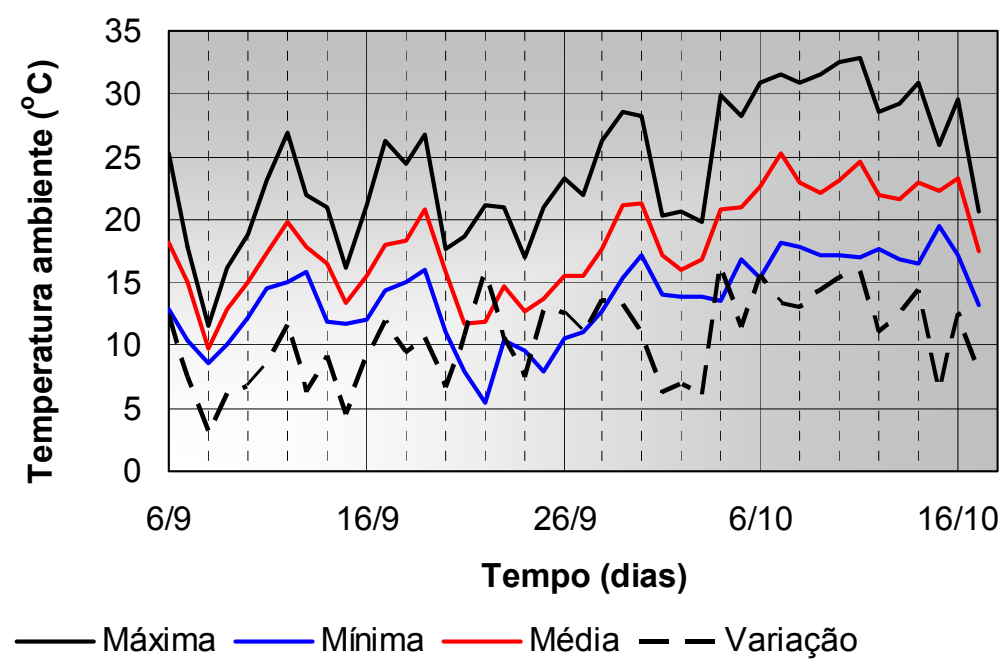

Figura 4.27 - Temperatura ambiente máxima, mínima, média e variação diária.

Os dados da estação metereológica foram então confrontados com as medidas de temperatura efetuadas nas faces dos pilares por meio de termômetro digitais laser, sendo o resultado apresentado no gráfico da Figura 4.28 .

Observa-se no gráfico uma proporcionalidade, com coeficiente angular bastante próximo à unidade, entre a temperatura ambiente medida na estação metereológica e a média das medidas efetuadas nas faces do pilares. A regressão linear conduz a um coeficiente linear também bastante próximo à unidade (distância entre a linha $45^{\circ}$ indicada por linha em vermelho e a reta da regressão indicada por linha preta). Isso indica que a temperatura na face dos elementos estruturais acompanha as variações da temperatura ambiente, com uma defasagem entre elas de aproximadamente $1^{\circ} \mathrm{C}$. 


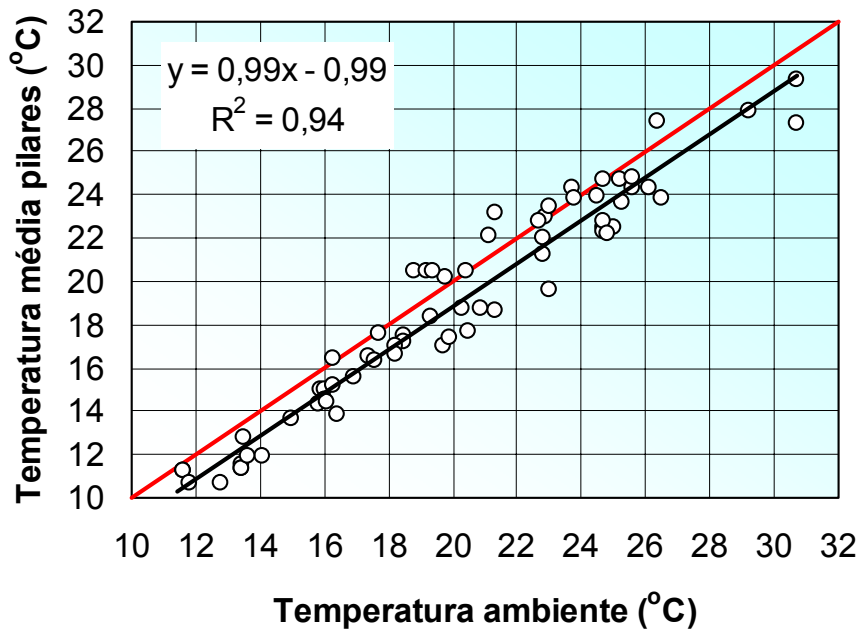

Figura 4.28 - Relação entre temperatura medida nas faces dos pilares e a temperatura ambiente.

\subsubsection{Umidade relativa do ar.}

Outra informação importante para o presente estudo refere-se às variações da umidade relativa do ar, cujos dados de variação ao longo do tempo são apresentados no gráfico da Figura 4.29, o qual indica, por meio da linha tracejada, um valor médio de $76,3 \%$. Podem ser observados valores variáveis entre $27,1 \%$ (29/09/2002, às 17 h) e 97,8\% (05/10/2002, às 08 h). Esse conjunto de dados é apresentado pelos valores diários máximo, médio, mínimo e variação no gráfico da Figura 4.30. Variações diárias entre 8,1 \% (20/09/2002) e $67,2 \%$ (10/10/2002) foram registradas.

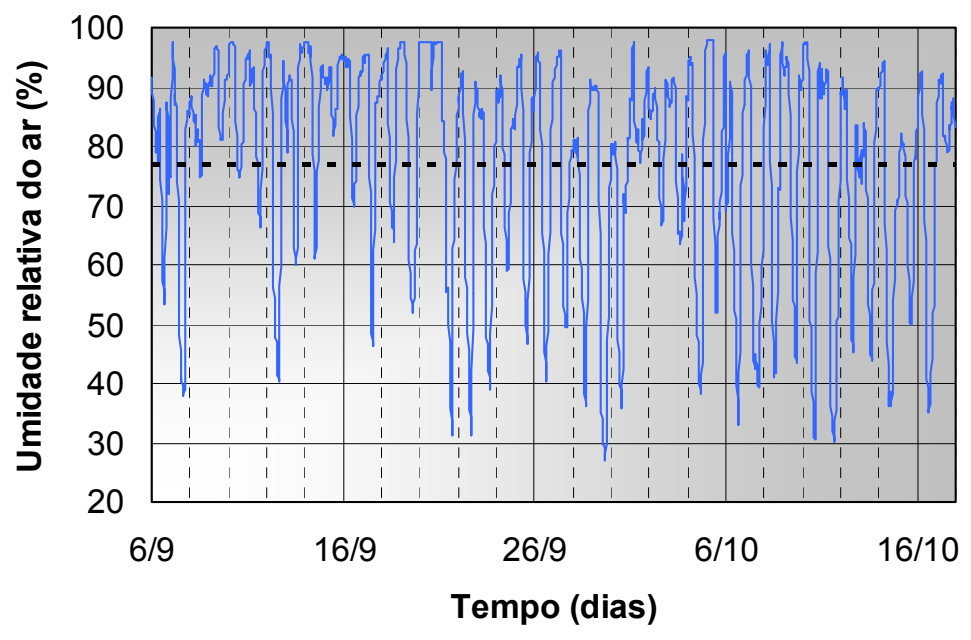

Figura 4.29 - Variação horária da umidade relativa do ar. 


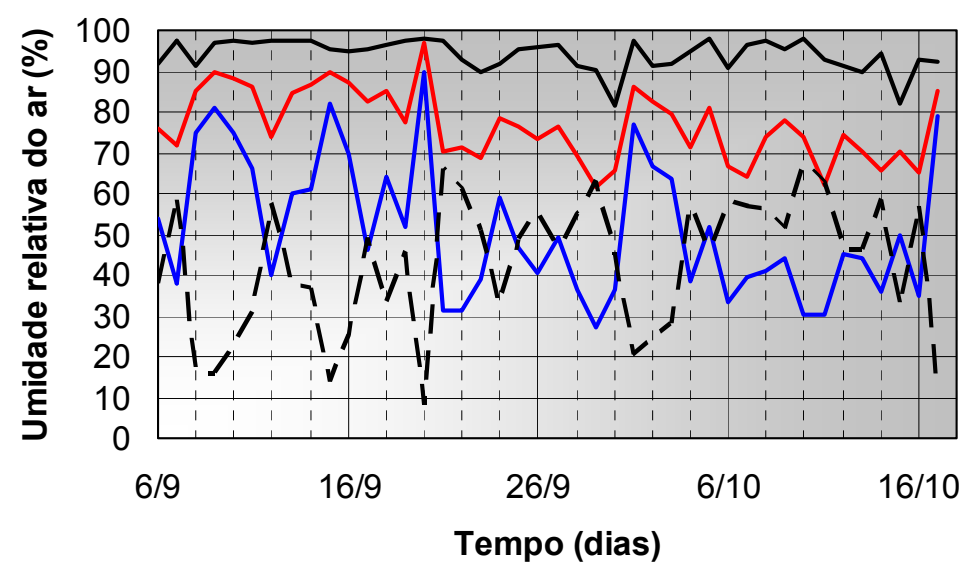

— Máxima — Mínima — Média - - Variação

Figura 4.30 - Umidade relativa do ar, máximo, mínimo, média e variação diária.

\subsubsection{Pressão atmosférica.}

As variações na pressão atmosférica apresentam pequena influência nas medidas efetuadas, embora elas envolvam deformações máximas da ordem de centenas de micro strains. Os dados fornecidos são apresentados no gráfico da Figura 4.31, o qual mostra a variação, ao longo do período de observações, da pressão atmosférica. A linha tracejada indica um valor médio de 912,9 hPa e as variações apresentam-se entre 904,3 hPa (06/09/2002, às 20 h) e 920,8 hPa (08/09/2002, às 11 h).

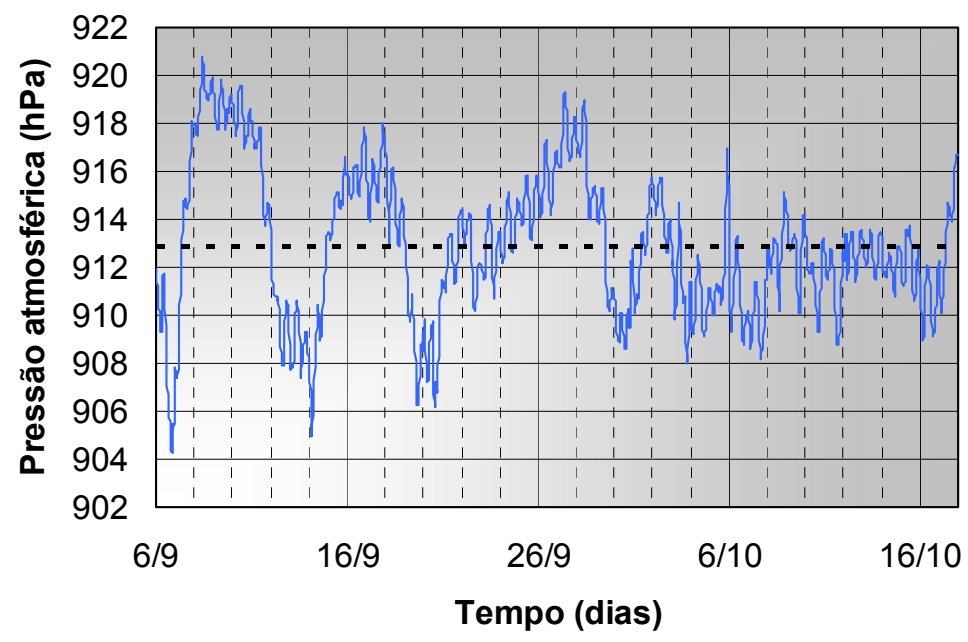

Figura 4.31 - Variação horária da pressão atmosférica ao longo do período de observações. 


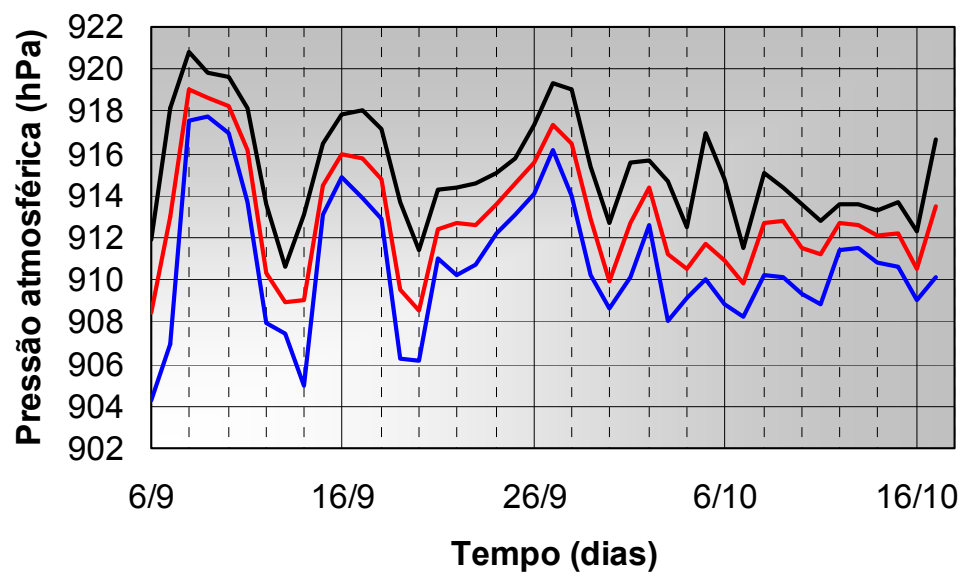

— Máxima — Mínima — Média

Figura 4.32 - Pressão atmosférica valores máximo, mínimo e médio diários.

\subsubsection{Ventos.}

Também foram disponibilizados os dados referentes à velocidade dos ventos, medida na estação metereológica. O gráfico da Figura 4.33 apresenta a variação com o tempo da velocidade dos ventos para o período de observação do presente estudo. O valor máximo de $11,2 \mathrm{~m} / \mathrm{s}$ foi observado no dia 06/09, às $21 \mathrm{~h}$. Para o período de observação o valor médio é igual a 2,2 m/s, o qual se encontra indicado no gráfico pela linha tracejada.

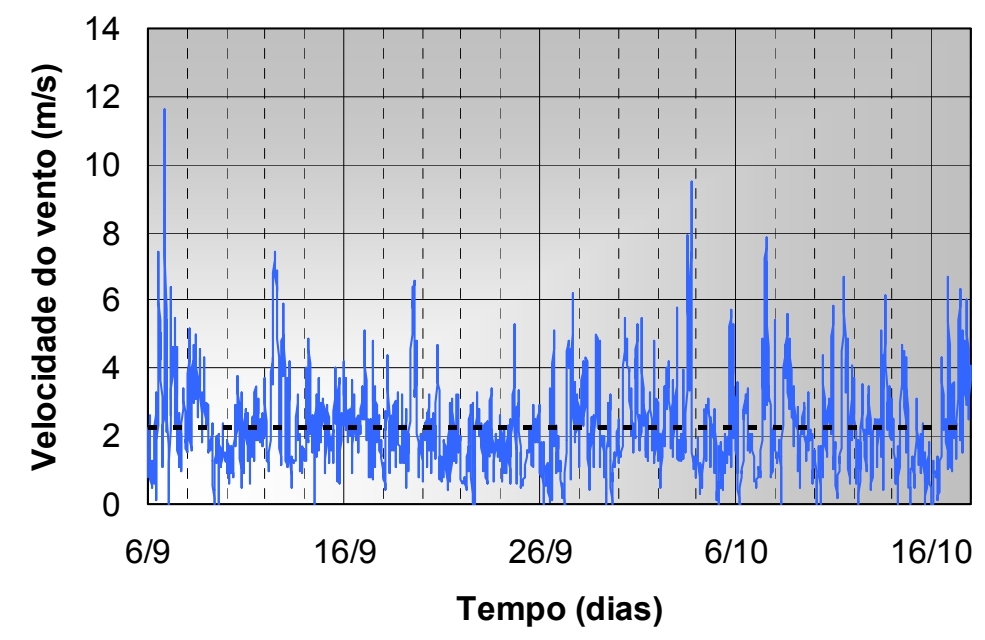

Figura 4.33 - Variação horária da velocidade dos ventos ao longo do período de observação. 
A variação diária em termos máximo, mínimo e médio foi analisada e é apresentada no gráfico da Figura 4.34.

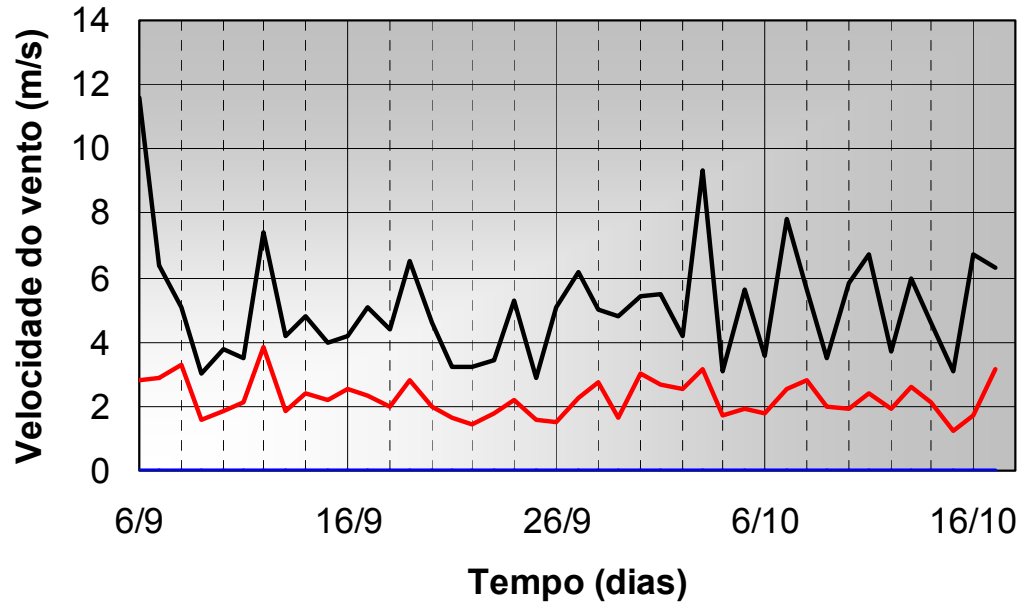

— Máxima —-Mínima —Média

Figura 4.34 - Velocidade dos ventos valores máximo, mínimo e médio diários.

\subsubsection{Chuvas.}

Os dados de precipitação são apresentados no gráfico a seguir:

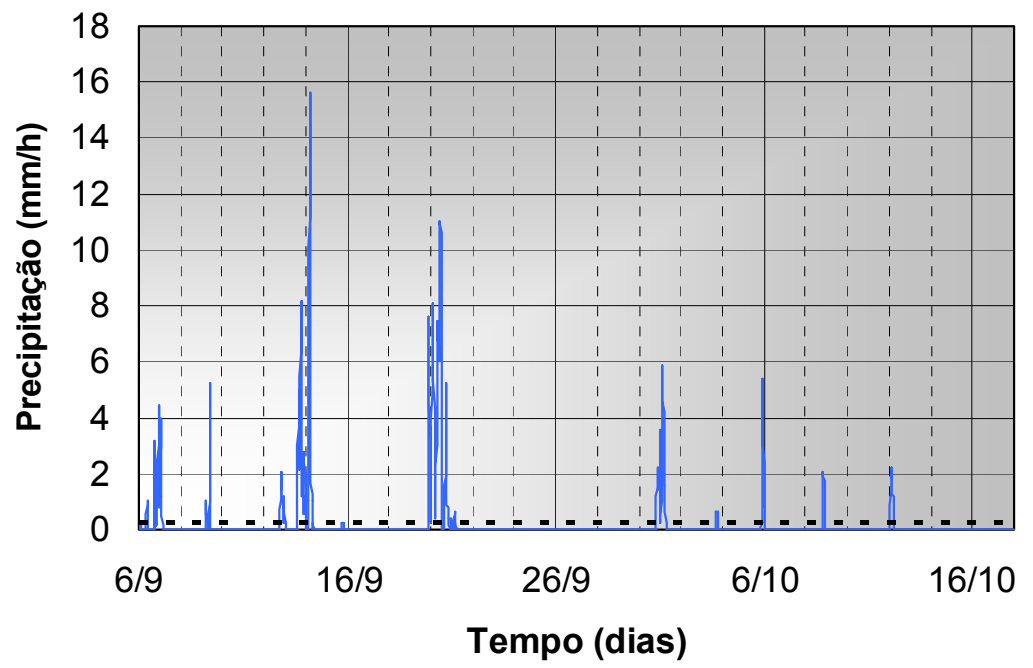

Figura 4.35 - Medidas de precipitação pluviométrica. 


\subsection{ESTRUTURA}

São apresentadas, a seguir, informações referentes aos elementos que formam a estrutura da obra de engenharia monitorada, a qual, é neste trabalho, subdividida em dois elementos: a superestrutura, composta por elementos de concreto pré-moldado, e a infra-estrutura, constituída pelos elementos estruturais de fundação (estacas) instaladas no maciço de solo.

\subsubsection{Superestrutura.}

a) Pilares.

Todos os pilares são executados em concreto armado com seção transversal quadrada de $40 \mathrm{~cm}$ de lado e comprimento total $5,4 \mathrm{~m}$. A resistência característica $\left(f_{c k}\right)$ de projeto para essas peças é de $35 \mathrm{MPa}$. São dotados de console para apoio das vigas com dimensões $40 \mathrm{~cm} \times 30 \mathrm{~cm} \times 30$ $\mathrm{cm}$.

Os pilares foram confeccionados com traço do concreto armado para resistência característica igual a $35 \mathrm{MPa}$ dado a seguir:

Cimento CPV ARI - RS Votoran.

Consumo de cimento $340 \mathrm{kgf} / \mathrm{m}^{3}$.

Areia média $-866 \mathrm{kgf} / \mathrm{m}^{3}$.

Brita $01-1031 \mathrm{kgf} / \mathrm{m}^{3}$.

Água - $180 \mathrm{l} / \mathrm{m}^{3}$ (fator água cimento 0,53 ).

Aditivo $-2,2 \mathrm{l} / \mathrm{m}^{3}$.

As peças são submetidas à cura a vapor por um período de 6 horas, com temperatura mantida constante em $60^{\circ} \mathrm{C}$. Para a retirada das formas aguarda-se a temperatura das peças equalizar com a ambiente.

b) Lajes.

As peças do tipo laje apresentam-se com duas alturas $(21,5 \mathrm{~cm}$ e 14 $\mathrm{cm}$ ), sendo as de menor dimensão aplicadas na parte central (entre eixos B e C) da obra. A armadura é protendida e são alveolares, processo esse obtido por extrusão. Para estas peças, a resistência característica de projeto é especificada em 40 MPa. A Figura 4.36 apresenta duas seções transversais típicas desses elementos. 

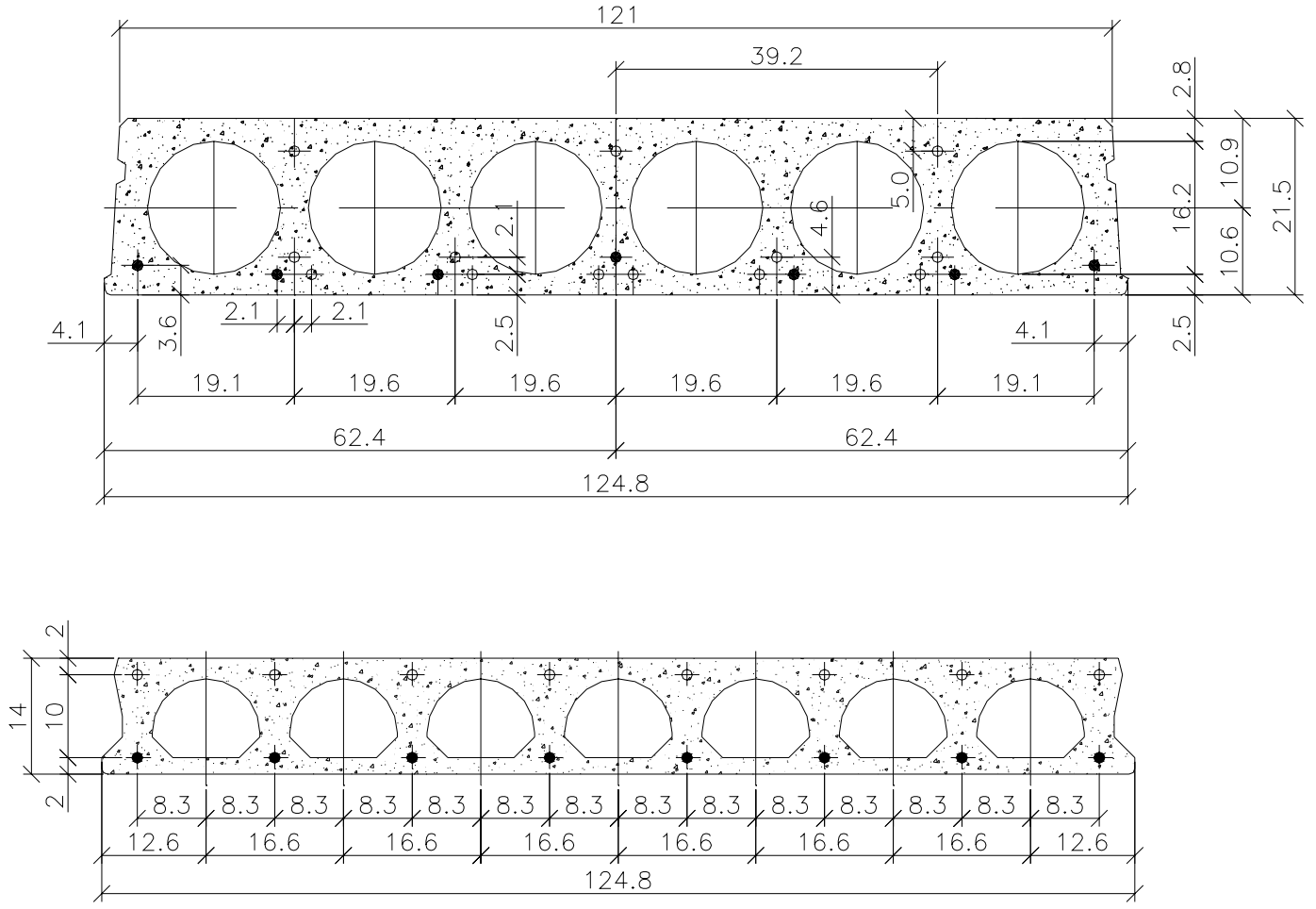

Figura 4.36 - Seção transversal típica dos elementos pré-moldados tipo laje, dimensões em $\mathrm{cm}$.

c) Vigas e painéis.

As vigas são confeccionadas em concreto armado, com seção transversal retangular $40 \times 85 \mathrm{~cm}$, conforme apresentado nas Figuras $4.37 \mathrm{e}$ 4.38. Nas faces externas da edificação, ao longo dos eixos A e D, um painel de fechamento é fixado por solda à viga, conforme ilustrado na Figura 4.39.

Figura 4.37 - Viga típica (elevação), dimensões em cm. 


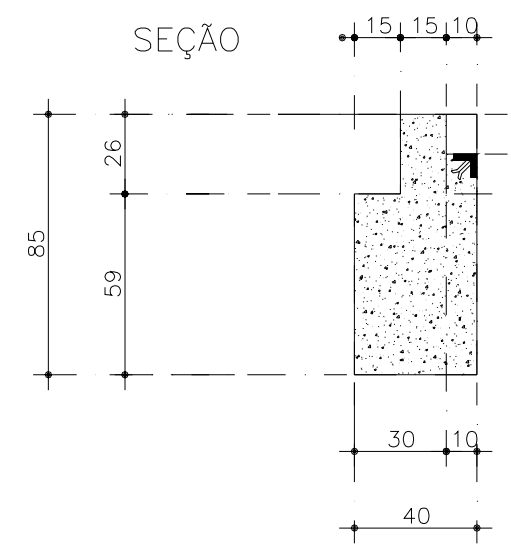

Figura 4.38 - Seção transversal viga típica, dimensões em cm.

Figura 4.39 - Seção transversal mostrando painel de fechamento externo fixado à viga, dimensões em $\mathrm{cm}$.

A Tabela 4.5 resume os resultados obtidos de resistência à ruptura aos 28 dias determinados em corpos de prova cilíndricos de $10 \mathrm{~cm} \times 20 \mathrm{~cm}$.

Tabela 4.5 - Controle tecnológico das peças pré-moldadas.

\begin{tabular}{lccc}
\hline Peça & $\begin{array}{c}\mathrm{f}_{\mathrm{c} 28} \\
(\mathrm{MPa})\end{array}$ & $\begin{array}{c}\mathrm{CV} \\
(\%)\end{array}$ & $\begin{array}{c}\mathrm{f}_{\mathrm{ck}} \\
(\mathrm{MPa})\end{array}$ \\
\hline Pilares & 39,5 & 5,4 & 36,0 \\
Vigas & 39,2 & 4,8 & 36,1 \\
Painéis & 43,5 & 7,3 & 38,3 \\
Lajes $(\mathrm{h}=21,5 \mathrm{~cm})$ & 50,9 & 6,5 & 45,5 \\
Lajes $(\mathrm{h}=14 \mathrm{~cm})$ & 56,7 & 3,3 & 53,6 \\
\hline
\end{tabular}


Como, no presente estudo, os pilares são de extrema relevância apresenta-se a seguir o resultado do controle tecnológico nessas peças. Dos vinte pilares monitorados foram ensaiados quatorze elementos.

Tabela 4.6 - Controle tecnológico do concreto dos pilares monitorados.

\begin{tabular}{cccc}
\hline Pilar & $\begin{array}{c}\mathrm{f}_{\mathrm{c} 28} \\
(\mathrm{MPa})\end{array}$ & Pilar & $\begin{array}{c}\mathrm{f}_{\mathrm{c} 28} \\
(\mathrm{MPa})\end{array}$ \\
\hline 20 & 38,2 & 07 & 38,5 \\
10 & 45,8 & 17 & 39,2 \\
09 & 38,2 & 37 & 38,2 \\
29 & 37,9 & 36 & 39,5 \\
18 & 43,5 & 26 & 39,0 \\
08 & 37,7 & 16 & 39,5 \\
28 & 38,2 & 06 & 38,2 \\
\hline
\end{tabular}

O conjunto de ensaios de resistência à compressão conduz a um valor médio de 39,4 MPa, com desvio padrão igual a 2,25 MPa, correspondendo a um coeficiente de variação de 5,7\%. A resistência característica $\left(f_{c k}\right)$ correspondente a esse grupo de ensaios é igual a 35,7 MPa.

O peso específico do concreto das peças pré-moldadas foi avaliado pela pesagem de um conjunto de 40 corpos de provas cilíndricos de concreto, obtendo-se valor médio de $24,5 \mathrm{kN} / \mathrm{m}^{3}$, com um coeficiente de variação dessas medidas igual a $1 \%$. Também foram submetidas à pesagem algumas peças pré-moldadas selecionadas aleatoriamente, obtendo-se peso específico médio igual a $24,9 \mathrm{kN} / \mathrm{m}^{3}$.

\subsubsection{Infra-estrutura.}

Apresentam-se a seguir dados referentes a características geométricas (comprimento, seção, posicionamento espacial) de resistência e deformabilidade de cada elemento estrutural que compõe a infra-estrutura.

A solução de fundação adotada foi o uso de estacas pré-moldadas de concreto armado de seção quadrada. Em apenas dois blocos foram utilizados elementos de $32 \mathrm{~cm}$ de lado; em todos os demais foram utilizados elementos de $35 \mathrm{~cm}$ de lado, perfazendo um total de 99 estacas instaladas.

De acordo com o projeto de fundações, a carga de trabalho para esses elementos é respectivamente, $735 \mathrm{kN}$ para seção de $35 \mathrm{~cm}$ e $614 \mathrm{kN}$ para a seção de $32 \mathrm{~cm}$, as quais conduzem a uma tensão máxima de $6 \mathrm{MPa}$. 
As Figuras 4.40 a 4.49 apresentam a disposição, em planta, do grupo de estacas de cada pilar, conforme projeto de fundação. Próximo a cada estaca é indicado o seu número de identificação, a data da sua execução, o comprimento previsto no projeto $\left(L_{p}\right)$, comprimento efetivamente executado $\left(L_{e}\right)$ e o valor da nega (s) ao final da cravação. Também é indicado nessas figuras o espaçamento entre estacas (dimensões em $\mathrm{cm}$ ). Essas informações foram resgatadas do relatório final emitido pela empresa executora do serviço de engenharia.

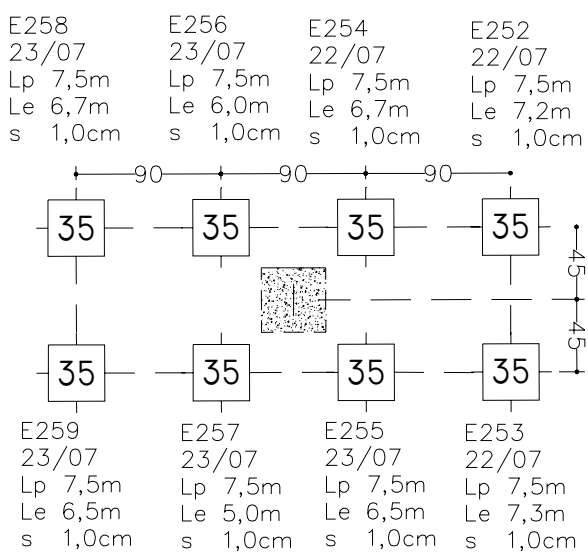

Pilar 36

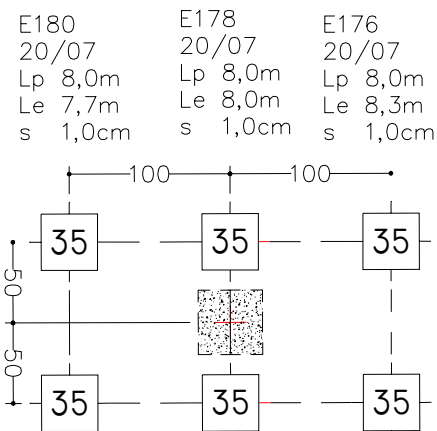

Pilar 26

Figura 4.40 - Grupo de estacas pilares 36 e 26.

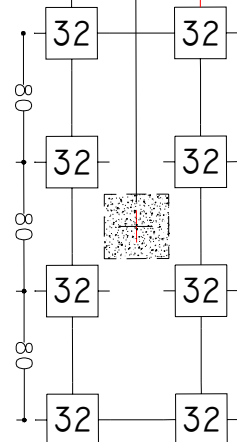

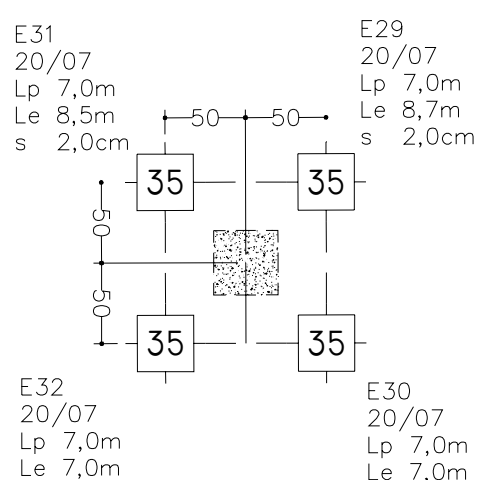

Pilar 06

Pilar 16

Figura 4.41 - Grupo de estacas pilares 16 e 06. 


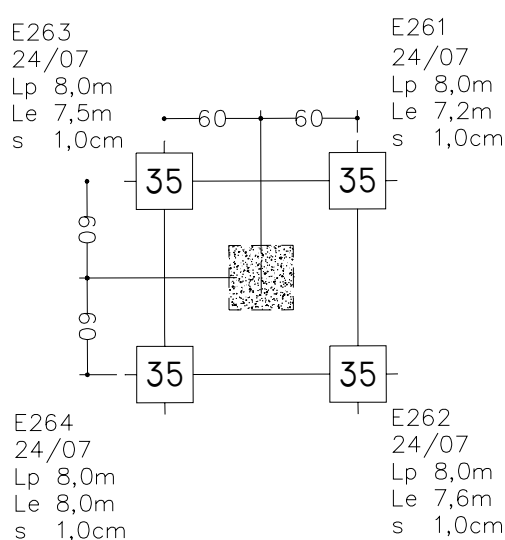

Pilar 37

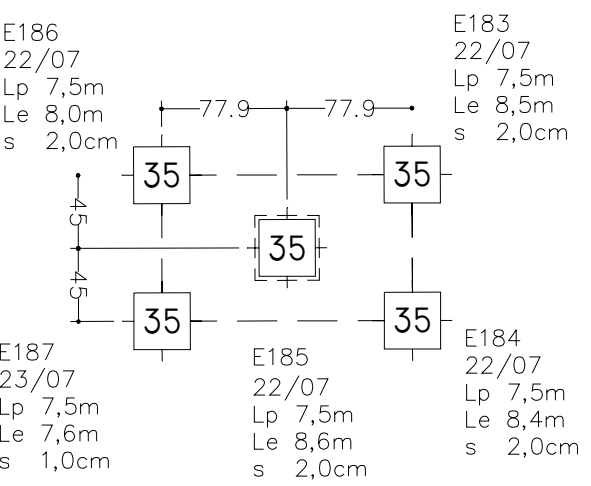

Pilar 27

Figura 4.42 - Grupo de estacas pilares 37e 27.

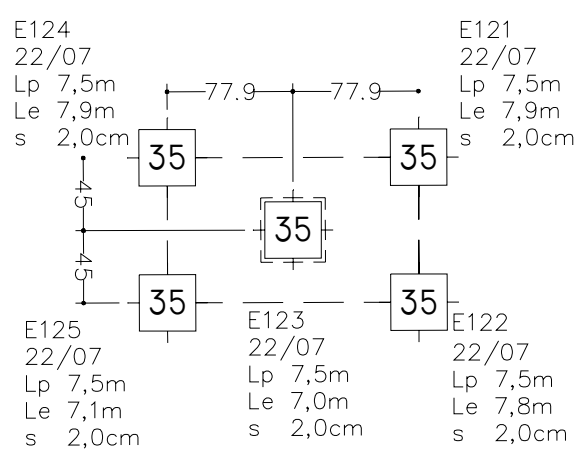

Pilar 17

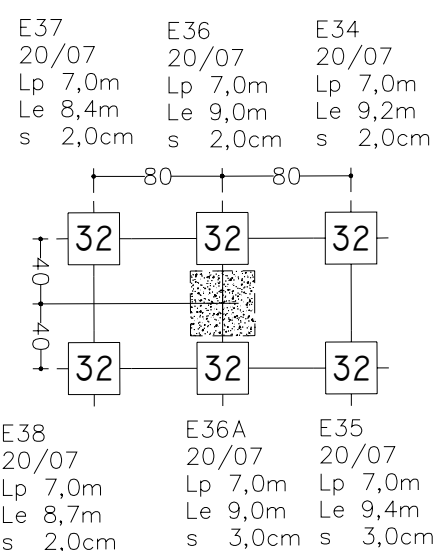

Pilar 07

Figura 4.43 - Grupo de estacas pilares 17e 07.

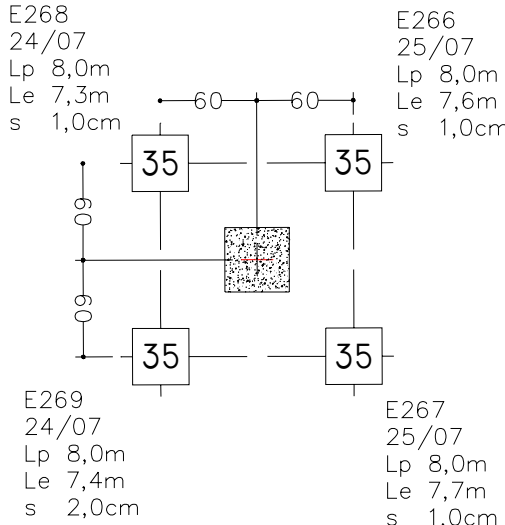

Pilar 38

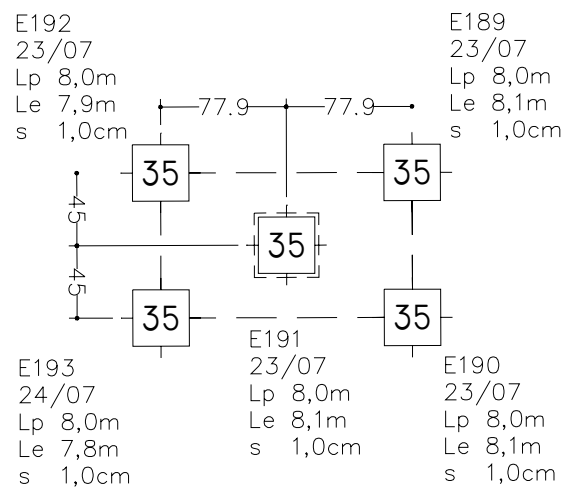

Pilar 28

Figura 4.44 - Grupo de estacas pilares 38 e 28. 


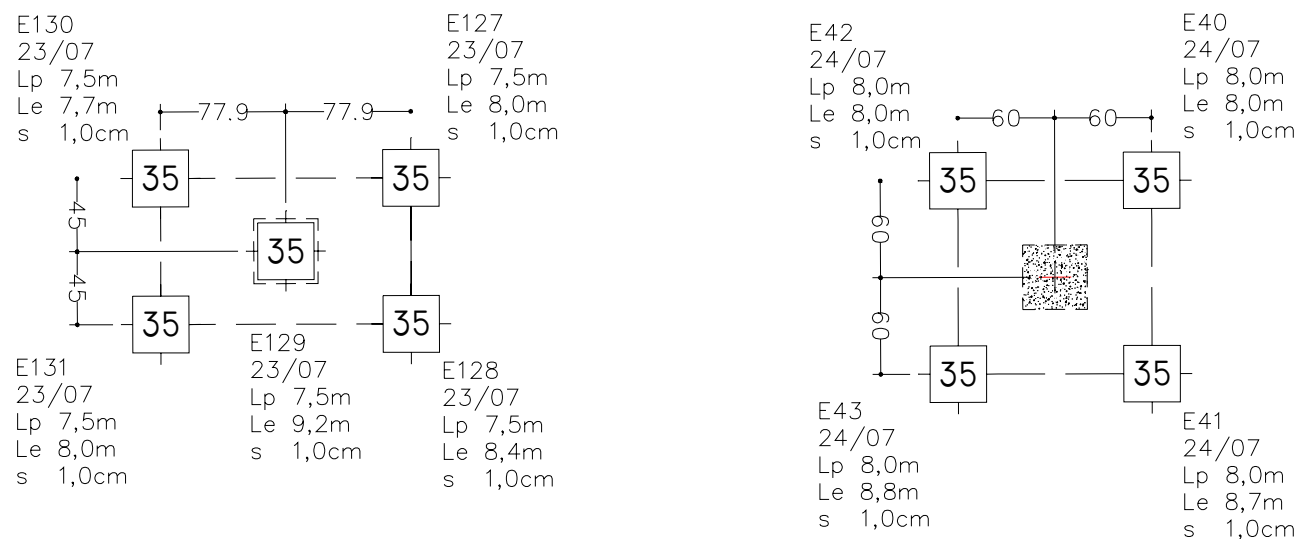

Pilar 18

Pilar 08

Figura 4.45 - Grupo de estacas pilares 18e 08.

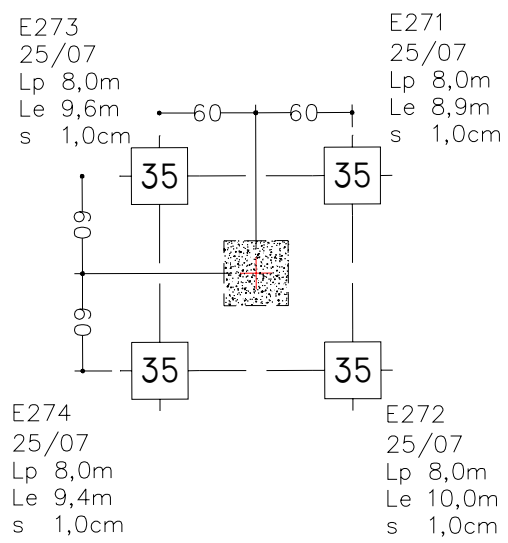

Pilar 39

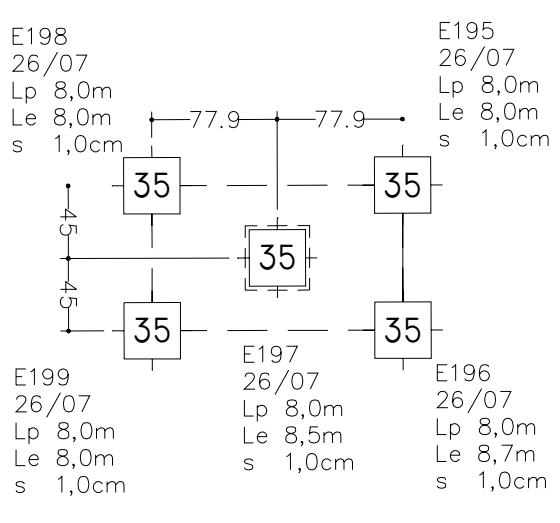

Pilar 29

Figura 4.46 - Grupo de estacas pilares 39 e 29.

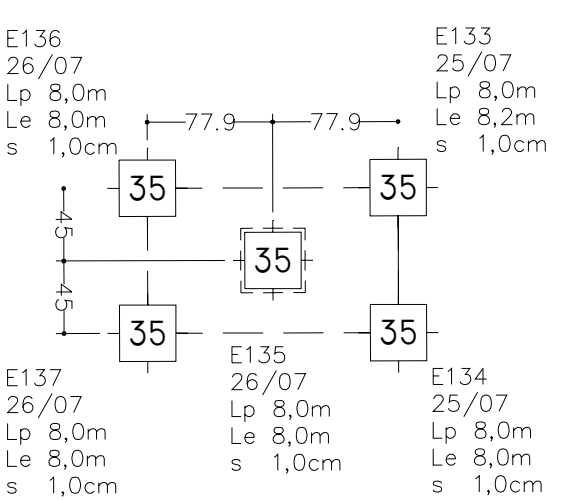

Pilar 19

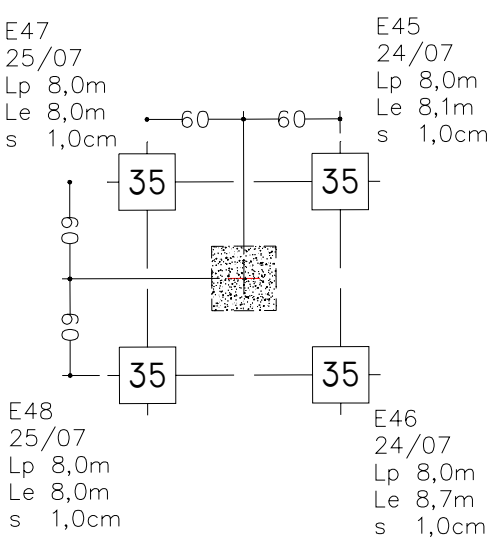

Pilar 09

Figura 4.47 - Grupo de estacas pilares 19 e 09. 


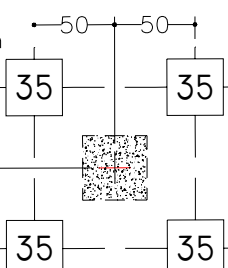

Pilar 40

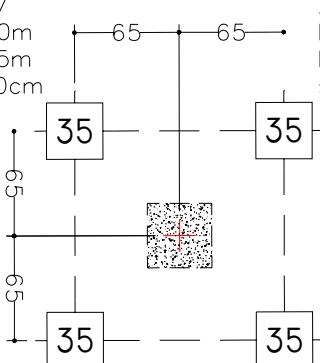

Pilar 30

Figura 4.48 - Grupo de estacas pilares 40 e 30 .

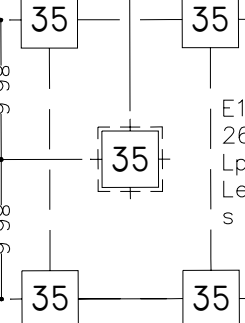

Pilar 20

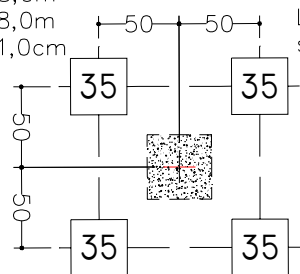

Pilar 10

Figura 4.49 - Grupo de estacas pilares 20 e 10.

De acordo com informação verbal do executor, o critério de projeto adotado para a paralisação da instalação por cravação dos elementos no terreno foi o de um valor de nega pré-fixado de $1 \mathrm{~cm} / 10$ golpes, para martelo com peso de $20 \mathrm{kN}$ e altura de queda de 1,0 $\mathrm{m}$. Verifica-se que nem todos os valores registrados da nega durante a execução de cada estaca, indicados nas figuras 4.40 a 4.49 estão de acordo com o critério informado. Por exemplo, a estaca E32 do pilar 06 apresenta um valor máximo da nega igual a $4 \mathrm{~cm} / 10$ golpes e as estacas do pilar 07 apresentam negas com valores variando entre 2 e $3 \mathrm{~cm} / 10$ golpes. O presente trabalho não teve por objetivo intervir em nenhuma etapa executiva da obra de engenharia, mas objetivou proceder à observação de comportamento sob condições usuais e correntes de execução. 
De qualquer forma, verifica-se com base nos dados disponíveis, que para alguns pilares não há homogeneidade do estaqueamento de acordo com critério de nega ao final da cravação.

Os comprimentos resultantes da execução são resumidos a seguir:

Máximo $-10,00 \mathrm{~m}$.

Mínimo $-5,00 \mathrm{~m}$.

Médio - 8,08 $\mathrm{m}$.

Desvio padrão $-0,82 \mathrm{~m}$.

Coeficiente de variação - 10,2\%.

A partir dos dados referentes ao comprimento executado de cada estaca, é possível definir uma superfície que une as pontas desses elementos, denominada superfície resistente, a qual é apresentada graficamente na Figura 4.50 .

\section{$\mathrm{P} 10$}

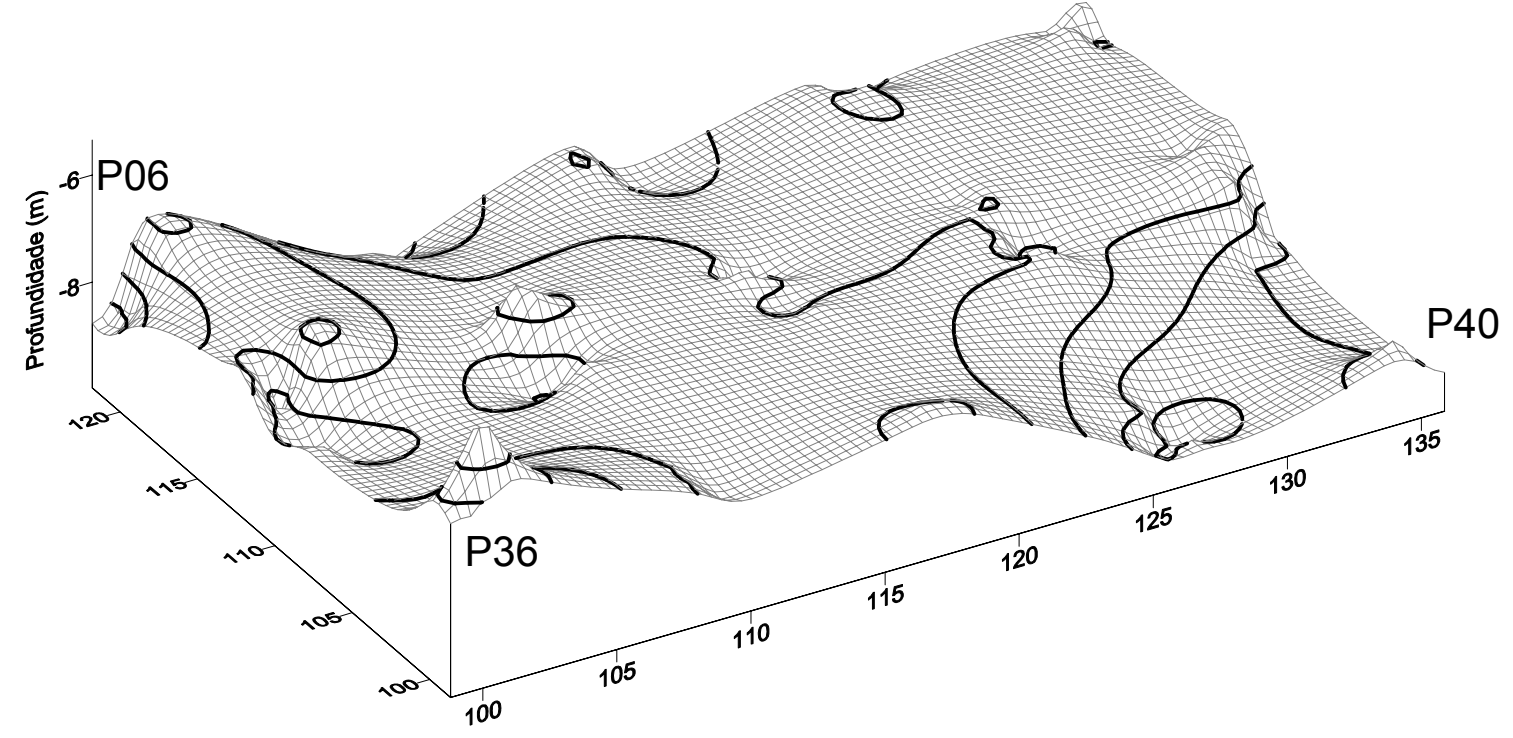

Figura 4.50 - Superfície resistente.

O traço do concreto utilizado nas estacas apresenta as seguintes características:

Cimento CPV ARI - RS.

Consumo de cimento $-380 \mathrm{kgf} / \mathrm{m}^{3}$.

Areia $-776 \mathrm{kgf} / \mathrm{m}^{3}$.

Brita $-944 \mathrm{kgf} / \mathrm{m}^{3}$.

Fator água cimento $-0,60$. 
Ensaios de controle tecnológico do concreto utilizado na moldagem das estacas apresentaram os seguintes resultados:

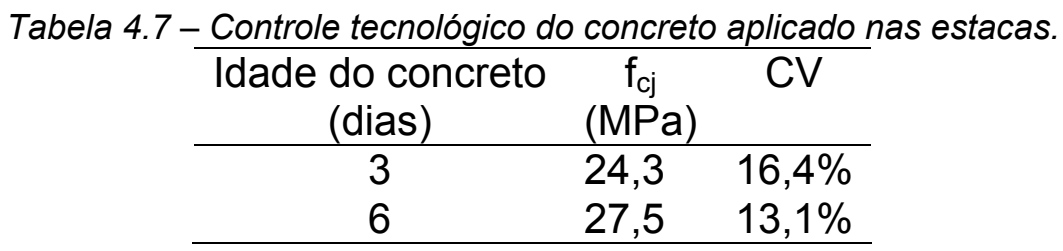

4.4.3 Seqüência construtiva.

As observações de campo foram iniciadas no dia 06/09/2002, com o posicionamento dos pilares do eixo 07 em suas bases. Nesse momento, procedeu-se ao início da instalação da instrumentação. Entre os dias 09 e 11 foi executado o módulo de pré-moldados entre os eixos 06 e 07 . O peso total dos elementos adicionados nessa etapa é de 3.059 kN.

O posicionamento dos quatro pilares do eixo 08 foi efetuado no final do dia 11. A montagem entre os eixos 07 e 08 foi realizada entre os dias 12 e 14 . A carga total aplicada nessa etapa é de $3.033 \mathrm{kN}$.

No dia 14 foram posicionados os pilares do eixo 09. A etapa de montagem entre os eixos 08 e 09 se deu entre os dias 16 e 19, a qual aplicou um carregamento adicional de $3.033 \mathrm{kN}$.

Finalmente, no dia 19 foram posicionados os pilares do eixo 10. O módulo final, localizado entre os eixos 09 e 10 foi executado entre os dias 19 e 23, aplicando um carregamento adicional de $3.258 \mathrm{kN}$. Dessa forma a carga total aplicada nesse período perfaz um total de $12.384 \mathrm{kN}$. 


\section{INSTRUMENTAÇÃO DE CAMPO}

Apresenta-se, neste capítulo, descrição dos equipamentos utilizados e procedimentos adotados na instrumentação de campo. Inicialmente, trata-se das medidas de recalque para, posteriormente, serem apresentados os detalhes das medidas visando à avaliação indireta da solicitação normal nos pilares de concreto armado.

\subsection{MEDIDAS DE RECALQUE.}

Para a realização de um acompanhamento de recalques de uma estrutura por meio de nivelamento geométrico, com precisão adequada, são utilizados os seguintes equipamentos:

a) Referência de nível.

b) Nível ótico.

c) Mira de ínvar.

d) Pino de recalque.

São apresentadas, a seguir, descrições, recomendações e detalhes de instalação destes equipamentos.

\subsubsection{Referência de Nível.}

A referência de nível recomendada para uma boa precisão e confiabilidade deve ser do tipo profunda ou "bench-mark". Referências superficiais do tipo meio-fio, poste, etc. devem ser evitadas, pois estão sujeitas a deslocamentos que podem não ser percebidos. É o elemento de maior custo. Recomenda-se instalar mais de uma referência de nível no local, de modo a que seja possível aferir eventuais deslocamentos e propiciar um elemento de reserva contra eventuais acidentes de obra. 
A referência de nível profunda é executada em furos de sondagem de diâmetro superior a três polegadas (3"), os quais devem se estender preferencialmente até o estrato rochoso. Um tubo externo de revestimento, preenchido por graxa grafitada, protege uma haste central de eventuais movimentos do terreno. A haste central deve ser chumbada no estrato indeformável com uso de calda de cimento, tendo na sua extremidade superior um elemento esférico de latão, sobre o qual será apoiada a mira. É desejável que o topo desse instrumento seja protegido por uma caixa com tampa e chave. A foto da Figura 5.1 apresenta visão do topo de uma referência de nível, profunda, instalada no local da obra.

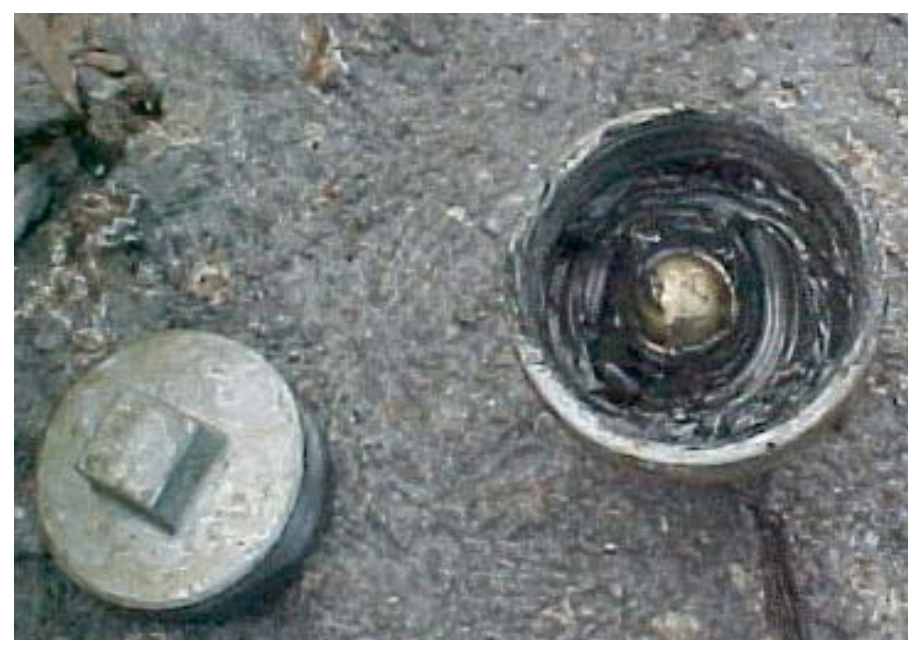

Figura 5.1 - Referência de nível profunda.

A referência de nível utilizada no presente estudo foi fixada a uma profundidade de $14 \mathrm{~m}$, tendo sido a perfuração executada com auxílio de equipamento rotativo. Nessa profundidade constatou-se a presença de rocha fraturada.

\subsubsection{Nível Ótico.}

O nível ótico a ser empregado deve ser dotado de placa plano paralela, munida de micrômetro. O modelo utilizado nesse trabalho foi o Zeiss NI002.

Deve ser evitado qualquer tipo de choque ou queda do aparelho durante o transporte e instalação no tripé, pois isso provoca o desvio do eixo ótico. Recomenda-se que o instrumento, após ser instalado e calado, seja protegido 
contra eventuais variações de temperatura. $\mathrm{O}$ uso de um guarda-sol minimiza esses efeitos. A aferição do aparelho é efetuada por empresas especializadas com o uso de colimador e recomenda-se anualmente proceder à sua calibração. A foto da Figura 5.2 mostra o equipamento adotado no presente estudo, o qual é um aparelho Zeiss NI002.

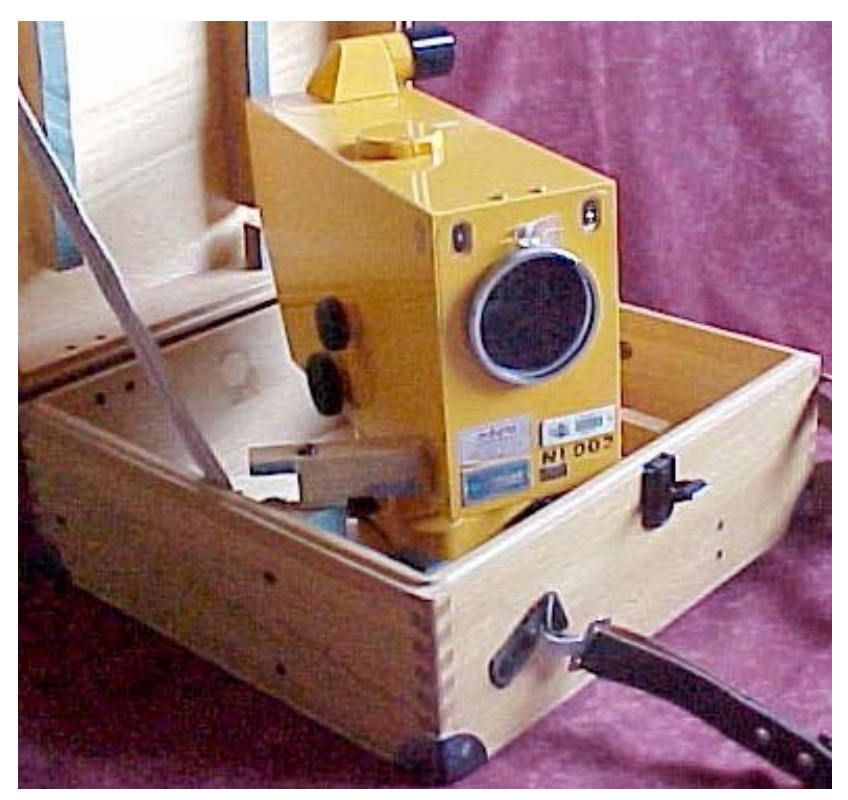

Figura 5.2 - Nível ótico modelo Zeiss NI002.

5.1.3 Mira de ínvar.

A mira a ser utilizada deve ter sua escala graduada em chapa de ínvar, evitando efeitos de dilatação térmica e dotada de nível tipo bolha fixo ao seu corpo. As miras podem ter graduação a cada $1 \mathrm{~cm}$ ou a cada $0,5 \mathrm{~cm}$. Algumas miras apresentam dupla escala de graduação. No caso do uso do nível Wild NA2, com mira graduada a cada $0,5 \mathrm{~cm}$ e dupla escala, é possível efetuar quatro leituras em cada visada.

Recomenda-se que as leituras sejam efetuadas, sempre que possível, com o mesmo operador tanto do nível como da mira. O operador deve cuidar para que a base da mira esteja sempre limpa. A calibração da mira é feita por empresas especializadas e deve ter freqüência anual. 
5.1.4 Pino de recalque.

O pino de recalque materializa uma posição fixa à estrutura do qual se pretende que se mova solidariamente com a mesma. Normalmente são instalados nos pilares, em posição próxima ao topo do bloco de coroamento das estacas. No presente estudo, foram instalados a cerca de $20 \mathrm{~cm}$ do nível do piso acabado, no ponto médio da face do pilar.

Tradicionalmente, o pino de recalque é do tipo rosqueável, formado por um conjunto de pino fêmea fixo ao pilar e um pino macho removível. Como neste estudo também estava envolvida a medida indireta da solicitação normal do pilar pelo do seu encurtamento, adotou-se um arranjo diferente daquele usado na prática corrente.

Neste caso, o pino de recalque é formado por uma cantoneira metálica de abas iguais $(5 \mathrm{~cm} \times 5 \mathrm{~cm}$ ), largura $2,5 \mathrm{~cm}$ e espessura $6,35 \mathrm{~mm}$. Para garantir a durabilidade do material quando exposta ao tempo e às condições de obra, procedeu-se à galvanização do metal. Em uma das abas é fixado um elemento semi-esférico de latão, sobre o qual será apoiada a mira de recalques. A fixação dessa cantoneira ao pilar se faz com uso de resina epóxi de alta resistência. A superfície do concreto deve ser preparada com apicoamento da camada superficial e limpeza de poeira e resíduos.

A foto da Figura 5.3 ilustra o pino fixado ao pilar e o detalhe da base da mira de ínvar para encaixe na posição correta.

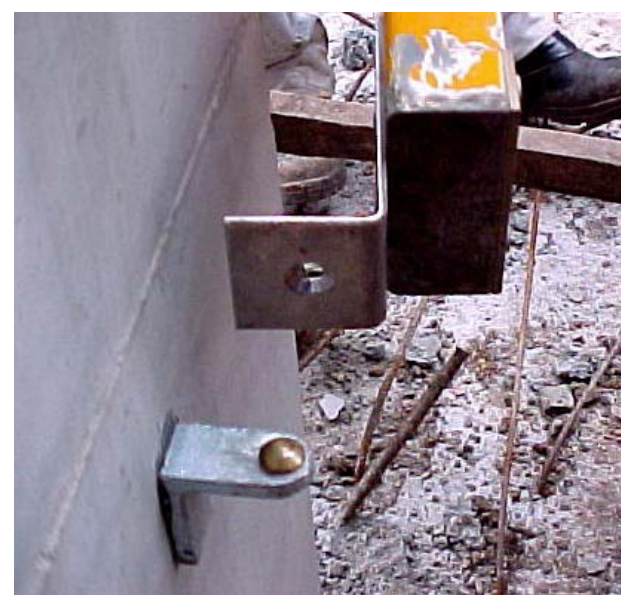

Figura 5.3 - Detalhe do pino de recalque instalado no pilar. 
Os pinos de recalque foram instalados em 20 pilares, cuja disposição em planta é apresentada na Figura 5.4. Também são indicados nessa figura a posição da referência de nível profunda ("bench-mark") e o ponto de instalação do nível ótico.

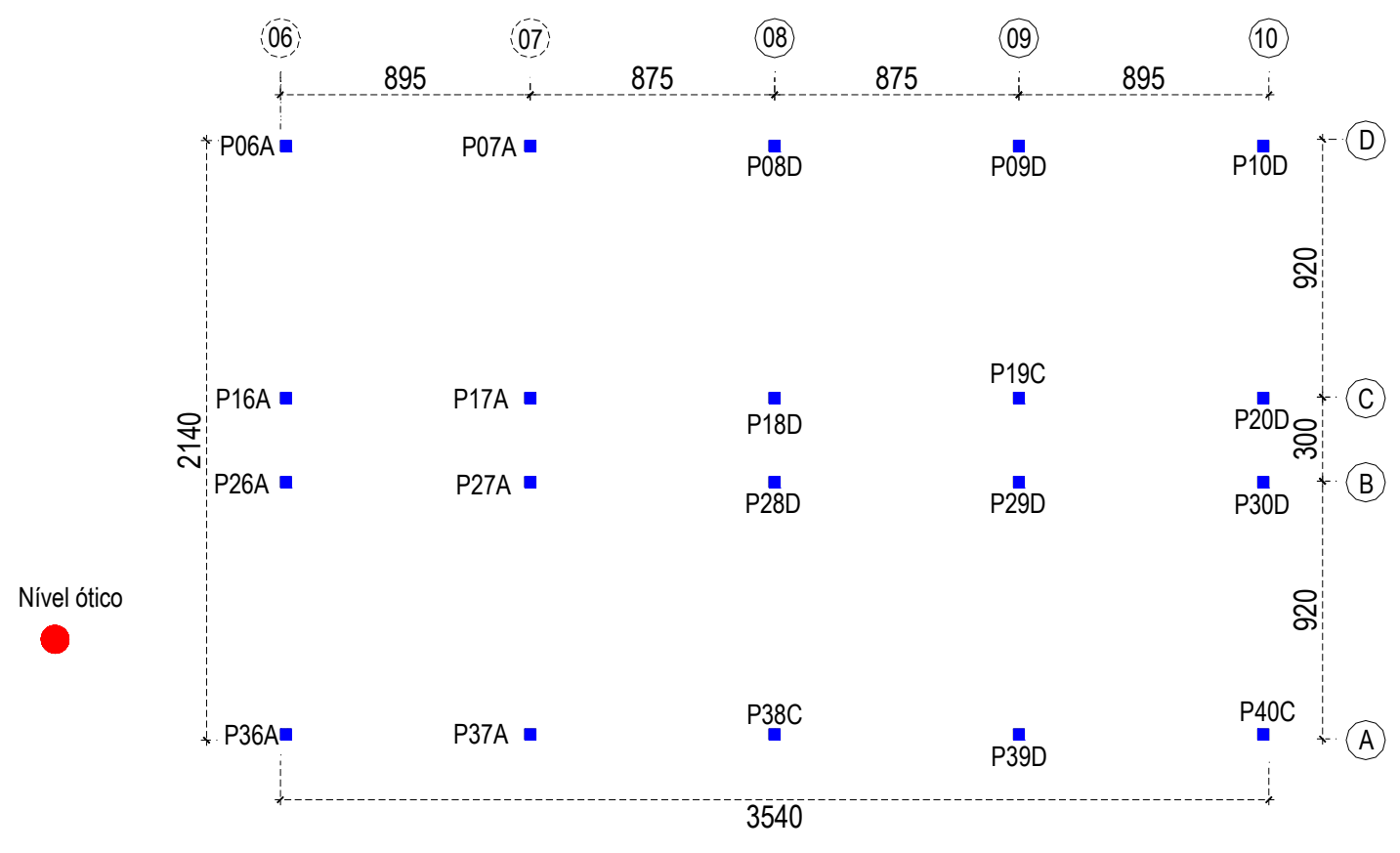

Bench-mark

0

Figura 5.4 - Locação em planta dos pilares instrumentados (dimensões em cm).

Cada conjunto de leitura envolvia nivelamento em circuito fechado, ou seja, é feita uma primeira visada, obtendo-se duas leituras (a mira utilizada era duplamente graduada) para a referência de nível profunda. Procede-se à visada a cada um dos pontos de monitoramento. Ao final, retorna-se a visada à referência de nível profunda.

\subsection{MEDIDAS DE CARGA NOS PILARES.}

Visando a desenvolver um extensômetro mecânico de haste para fins de monitoramento da solicitação normal em pilares de obras de engenharia e de modo a fornecer subsídios ao Grupo de Pesquisa de Fundações do Departamento de Geotecnia da Escola de Engenharia de São Carlos - USP, no tocante aos temas confiabilidade de fundações e interação solo estrutura, foram fabricados ou adquiridos os seguintes equipamentos: 
a) haste de ínvar;

b) base de referência padrão;

c) conjunto de pontos fixos aos pilares;

d) termômetro laser.

\subsubsection{Haste de ínvar.}

Esta peça é o extensômetro mecânico de haste propriamente dito, constituído por três barras cilíndricas de ínvar, com diâmetro $6 \mathrm{~mm}$, dispostas paralelamente de modo que a seção transversal forme um triângulo eqüilátero de lado $2 \mathrm{~cm}$, e que são ligadas em suas extremidades por elementos de aço com finalidades distintas. De modo a diminuir o comprimento de flambagem das barras de ínvar, quinze espaçadores de acrílico são igualmente distribuídos ao longo do comprimento, cujo comprimento final é igual a $149 \mathrm{~cm}$.

$\mathrm{Na}$ extremidade superior, as barras são ligadas a um elemento cilíndrico, dotado de rosca na qual é fixado o relógio comparador digital. Na extremidade inferior o elemento cilíndrico apresenta uma concavidade semi-esférica, de modo a ser apoiada no ponto de referência inferior fixo ao pilar, o qual apresenta elemento semi-esférico em latão, que se encaixa à concavidade. Os detalhes das extremidades da haste são mostrados nas Fotos das figuras $5.5 \mathrm{e}$ 5.6 .

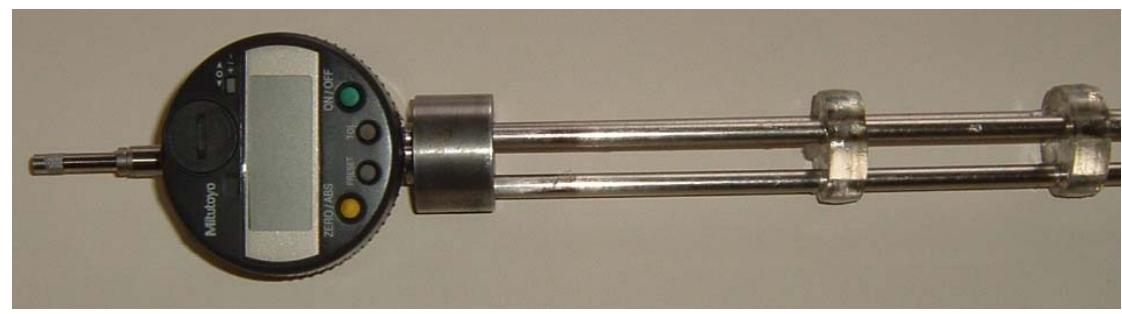

Figura 5.5-Detalhe da extremidade superior da haste, com relógio comparador digital fixado.

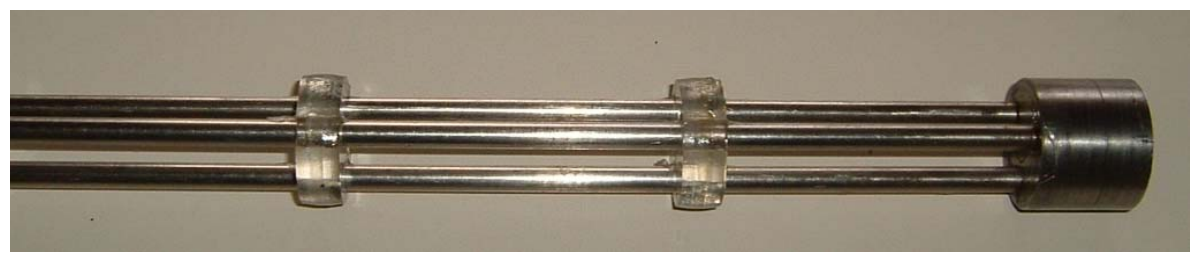

Figura 5.6 - Detalhe da extremidade inferior da haste. 
O relógio comparador digital utilizado é da marca Mitutoyo, modelo 250B. O curso total do mesmo e de $13 \mathrm{~mm}$ e segundo a especificação do fabricante, sua precisão é de $3 \mu \mathrm{m}$.

Objetivando proteger as barras de ínvar, uma capa de aço inox envolve o conjunto, sendo a mesma fixada por meio de um anel metálico apenas na extremidade superior da haste. O diâmetro dessa capa é superior ao das arruelas de acrílico, de modo a não gerar nenhum atrito entre a capa e o interior da haste. Dessa forma, deslocamentos da capa, devidos principalmente a variações de temperatura, não serão transmitidos ao grupo de hastes de ínvar.

5.2.2 Base de referência padrão.

Um conjunto de igual características às do extensômetro foi produzido e fixado a uma base para que esse fosse usado como referência das medidas efetuadas. Esse arranjo também é utilizado no extensômetro de Huggemberg e é recomendado por Dunnicliff (1993). Cada conjunto de medidas realizadas era iniciado com três leituras à base de referência padrão e concluído com um igual conjunto de medidas.

\subsubsection{Pontos de referência.}

A materialização da distância a ser medida nos pilares foi efetuada por meio de duas cantoneiras metálicas galvanizadas, as quais foram fixadas aos pilares por meio de resina epóxi de alta resistência. A fixação com esse tipo de adesivo requer apenas limpeza da superfície de concreto antes de sua aplicação. Cada conjunto de cantoneiras foi fixado no ponto médio da face do pilar, a uma distância que permitisse a realização das medidas dentro do curso do relógio comparador. Em cada pilar duas faces paralelas e opostas foram instrumentadas.

As fotos das Figuras 5.7 e 5.8 apresentam detalhe das duas cantoneiras metálicas utilizadas, o ajuste do extensômetro à cantoneira inferior e 0 posicionamento do relógio comparador na cantoneira superior. 


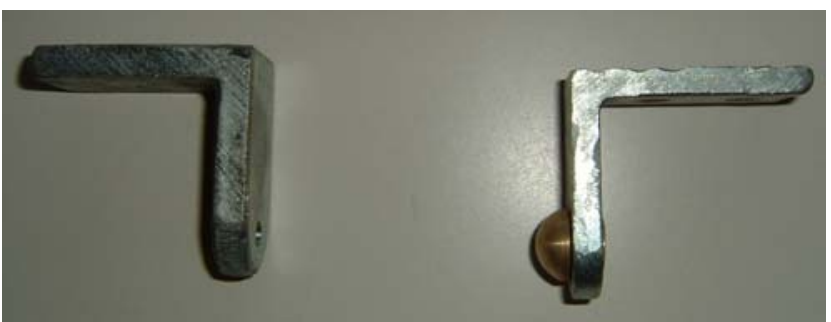

Figura 5.7 - Detalhe das cantoneiras utilizadas como ponto de referência das medidas.
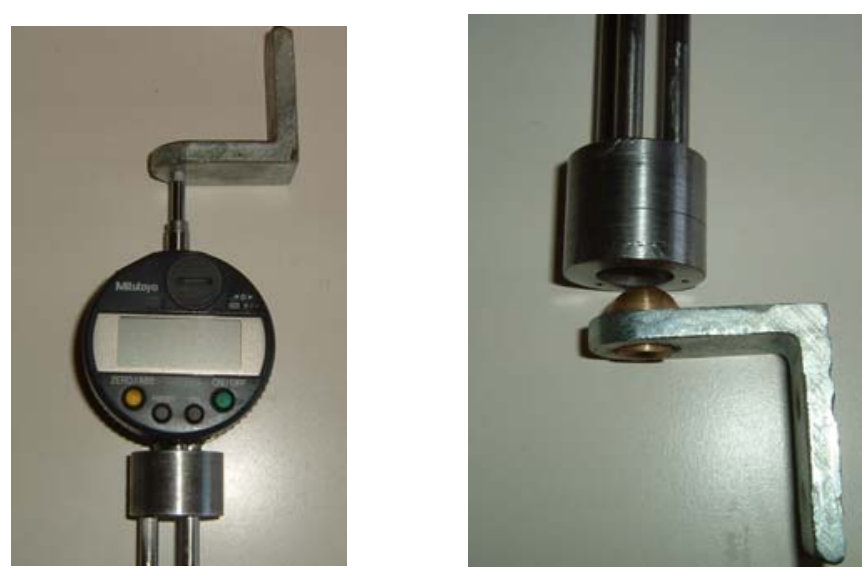

Figura 5.8 - Detalhe do posicionamento da haste nos pontos de referência.

\subsubsection{Termômetro digital a laser.}

De modo a medir a temperatura nas faces dos pilares no momento das medidas, foi disponibilizado um termômetro digital a laser, o qual é mostrado na foto da Figura 5.9. A precisão desse equipamento, segundo seu manual, é de $1^{\circ} \mathrm{C}$.

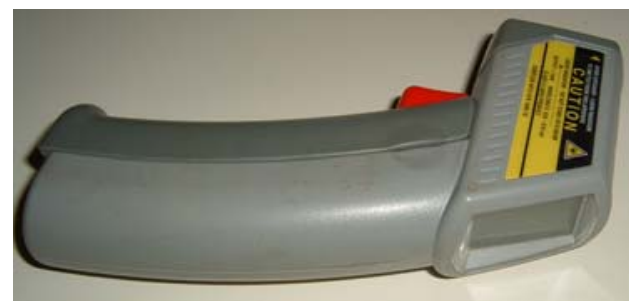

Figura 5.9 - Detalhe do termômetro digital a laser.

Foram instrumentados vinte pilares, tendo sido avaliado o comprimento entre dois pontos de referências fixados no concreto por meio de resina epóxi. As medidas foram efetuadas em duas faces paralelas de cada pilar. As 
observações foram realizadas no período compreendido entre os dias 06/09 a 17/10/2002. A Figura 5.10 apresenta a localização, em planta, dos pilares e suas respectivas faces instrumentadas.

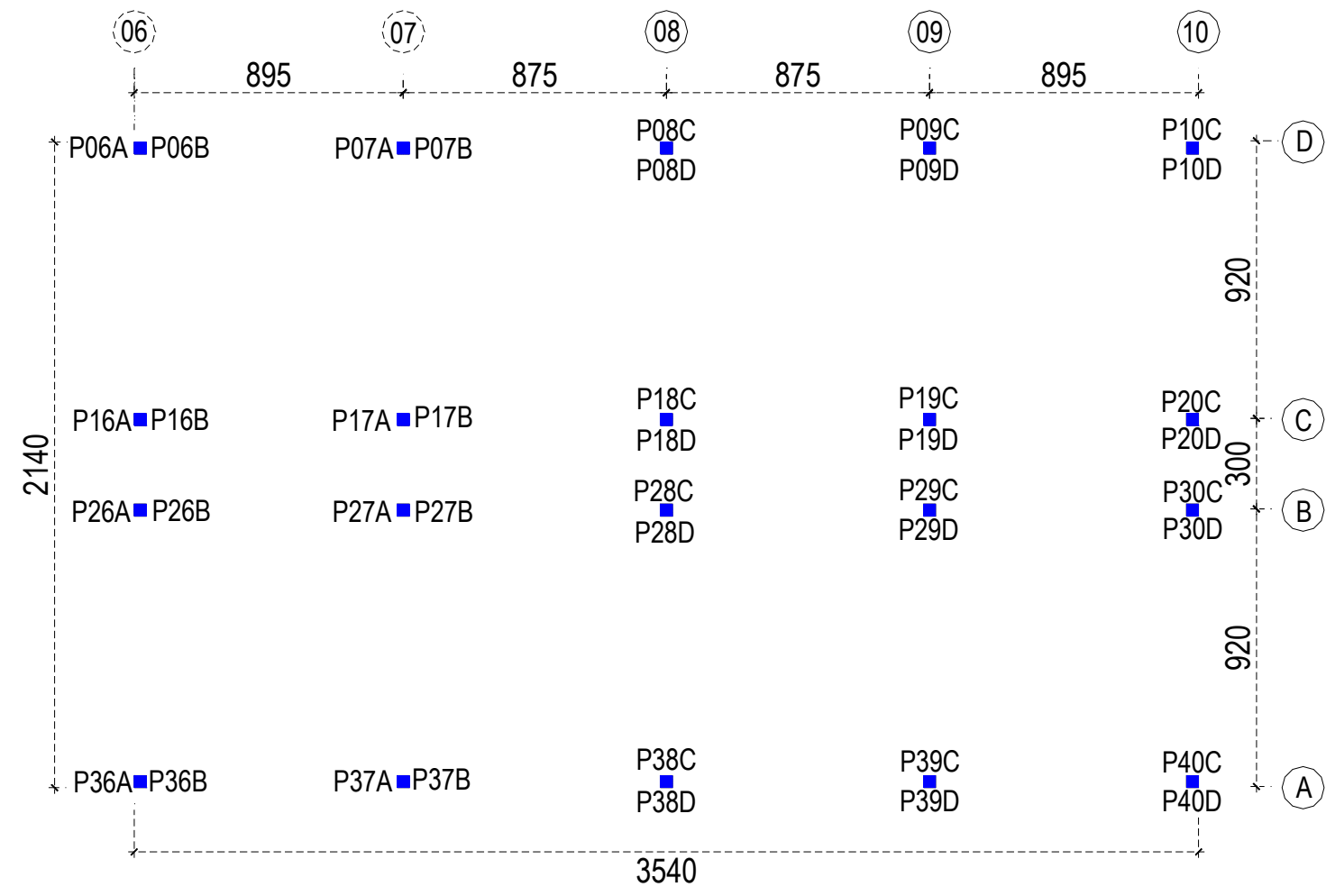

Figura 5.10 - Planta de localização dos pontos de medida de deformação nos pilares.

5.2.5 Ensaios de validação em laboratório.

Antes do uso do extensômetro mecânico em campo, foi realizada uma seqüência de ensaios em laboratório, simulando as condições de carregamento de um pilar de concreto armado, de modo a aferir a confiabilidade do sistema proposto. Os principais resultados desses são a seguir apresentados e encontram-se publicados em Russo Neto et al. (2002).

Para a realização dos ensaios de validação do instrumento foram confeccionados três pilares quadrados de concreto armado ( $f_{c k}$ de $25 \mathrm{MPa}$ ), com $15 \mathrm{~cm}$ de lado e $180 \mathrm{~cm}$ de comprimento. Um pórtico de reação, com altura livre total de $3 \mathrm{~m}$ e capacidade para $1.000 \mathrm{kN}$, foi especialmente construído para a realização dos testes. 
O sistema de aplicação e medida da carga foi o usualmente empregado em provas de carga estática, composto de célula de carga, macaco hidráulico e rótula.

Para cada pilar foi realizado um conjunto de três ensaios, envolvendo 10 estágios de carga até uma tensão normal máxima de aproximadamente $6 \mathrm{MPa}$ (tensão de trabalho usual em pilares de estruturas de concreto armado) e 4 estágios de descarga, até o total descarregamento. Em cada etapa foi medido (pelo menos três vezes) o comprimento nas quatro faces do pilar.

Adicionalmente, foi montado um pórtico plano transversal ao pórtico de reação, composto por dois dos três pilares anteriormente descritos, solidarizados por uma viga metálica sobre a qual era aplicada, no meio do vão, a solicitação dos ensaios. Estágios de carga e descarga com igual nível de solicitação no pilar foram aplicados, sendo os encurtamentos ou alongamentos medidos em todas as faces. A figura a seguir ilustra a montagem executada para a realização desses ensaios.

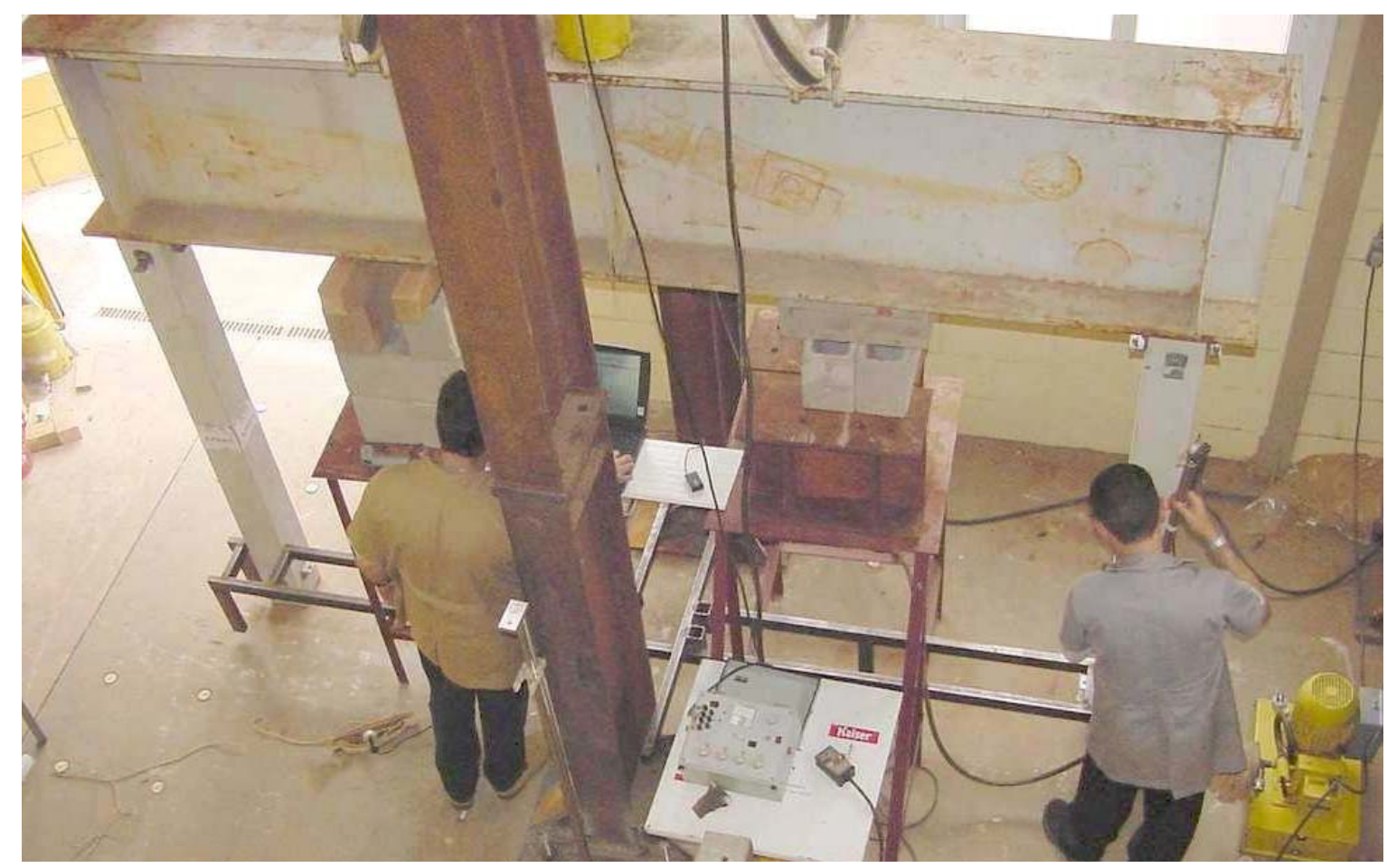

Figura 5.11 - Ensaio em laboratório.

O gráfico da Figura 5.12 apresenta o resultado típico da relação tensão aplicada $\mathrm{x}$ deformação medida, para um pilar ensaiado isoladamente. Os demais ensaios apresentam comportamento similar. Pode-se observar nessa 
figura que a excentricidade inicial do sistema de aplicação de carga, devido à rugosidade natural na interface de contato pilar - apoio, introduz comportamento diferenciado entre carregamento e descarregamento, das medidas em faces opostas paralelas, que diferem entre si. Nota-se na Figura 5.12 que, para um mesmo nível de deformação, a variação da tensão aferida pode ser da ordem de $1 \mathrm{MPa}$.

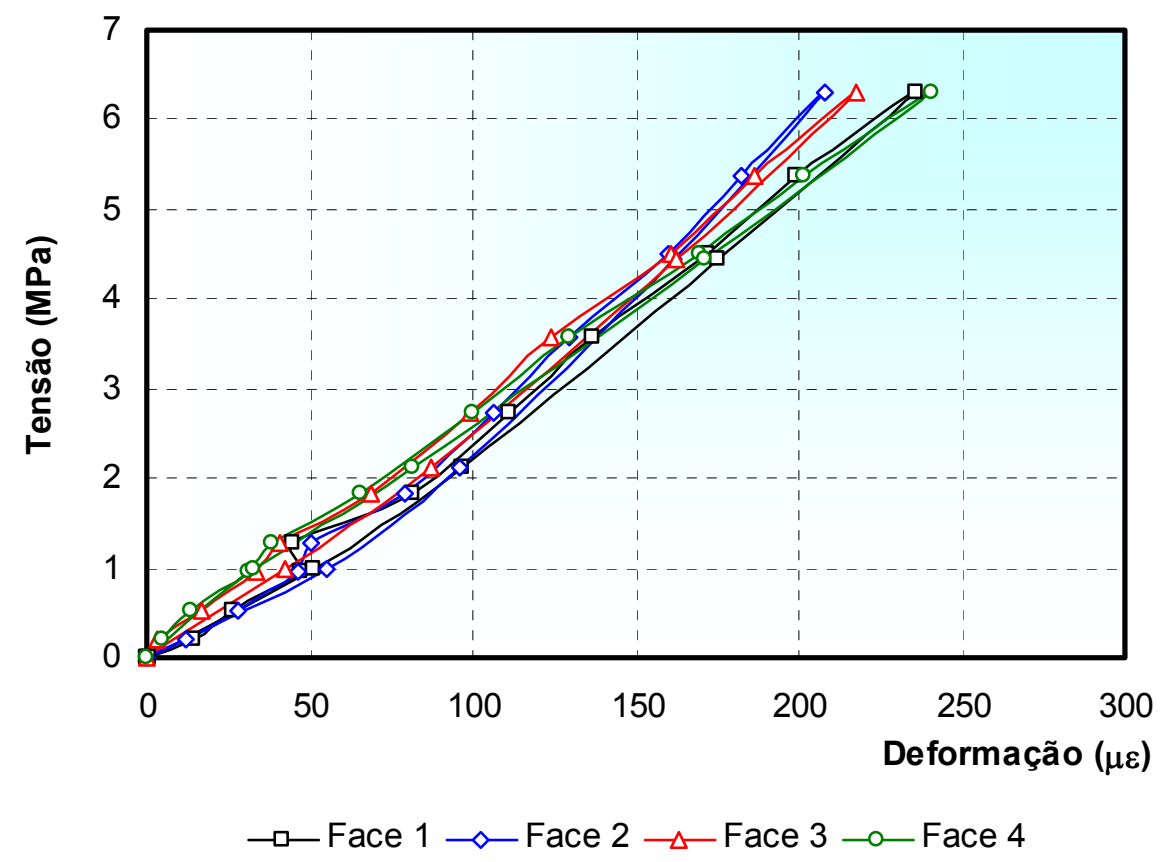

Figura 5.12 - Ensaio de pilar isolado - pilar 2, ensaio 1.

Essa dispersão, inaceitável, pode ser minimizada em se considerarndo apenas os estágios de carregamento e estabelecendo uma regressão linear para a média das observações efetuadas entre faces paralelas, a qual é apresentada no gráfico a seguir.

A Tabela 5.1 apresenta os resultados da regressão linear entre tensão aplicada e deformação média entre faces paralelas dos pilares para os ensaios realizados, expresso em termos de módulo de elasticidade do pilar. 


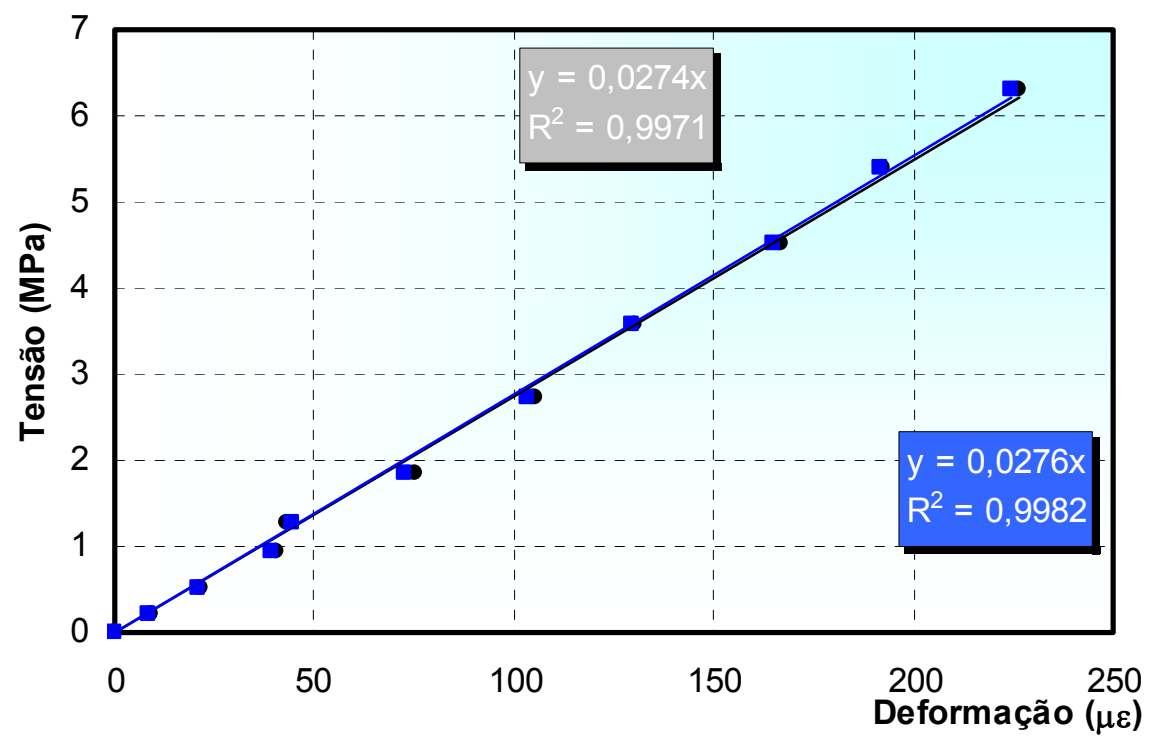

- Média 1 e 3 - Média 2 e 4

— Linear (Média 1 e 3) __ Linear (Média 2 e 4)

Figura 5.13 - Regressão linear, pilar isolado, média faces paralelas - pilar 1 ensaio 2.

Tabela 5.1 - Resumo dos ensaios de pilar isolado.

\begin{tabular}{cccccc}
\hline Pilar & Ensaio & \multicolumn{2}{c}{ Faces $1-3$} & \multicolumn{2}{c}{ Face $2-4$} \\
& & $\mathrm{E}_{\mathrm{ca}}$ & $\mathrm{R}^{2}$ & $\mathrm{E}_{\mathrm{ca}}$ & $\mathrm{R}^{2}$ \\
\hline \multirow{3}{*}{1} & 1 & 27,5 & 99,6 & 27,6 & 99,5 \\
& 2 & 27,4 & 99,7 & 27,6 & 99,8 \\
& 3 & 26,3 & 99,6 & 26,5 & 99,6 \\
& 1 & 29,8 & 99,9 & 30,5 & 99,9 \\
2 & 2 & 30,7 & 99,6 & 30,7 & 99,5 \\
& 3 & 29,5 & 99,9 & 30,3 & 99,9 \\
& 1 & 33,2 & 99,7 & 33,7 & 98,0 \\
3 & 2 & 33,7 & 99,8 & 33,2 & 99,8 \\
& 3 & 34,0 & 99,8 & 33,7 & 99,7 \\
\hline
\end{tabular}

Os resultados apresentados na tabela acima mostram que, embora todos os pilares tenham sido executados simultaneamente, com igual traço de concreto e submetidos a um processo de adensamento e cura idêntico, esses apresentam uma variabilidade do módulo, mais acentuada entre pilares (em torno de $8 \%$ ) e menos acentuada entre ensaios (inferior a $2 \%$ ).

Esses resultados indicam que o parâmetro do módulo de elasticidade não é característica apenas do material que o originou, mas sim do sistema que ele compõe. 
Para os ensaios realizados, nos quais se utilizou uma montagem de pórtico com medida simultânea das variações de comprimento em dois pilares, os ensaios conduziram aos resultados típicos, conforme os dados no gráfico da Figura 5.14.

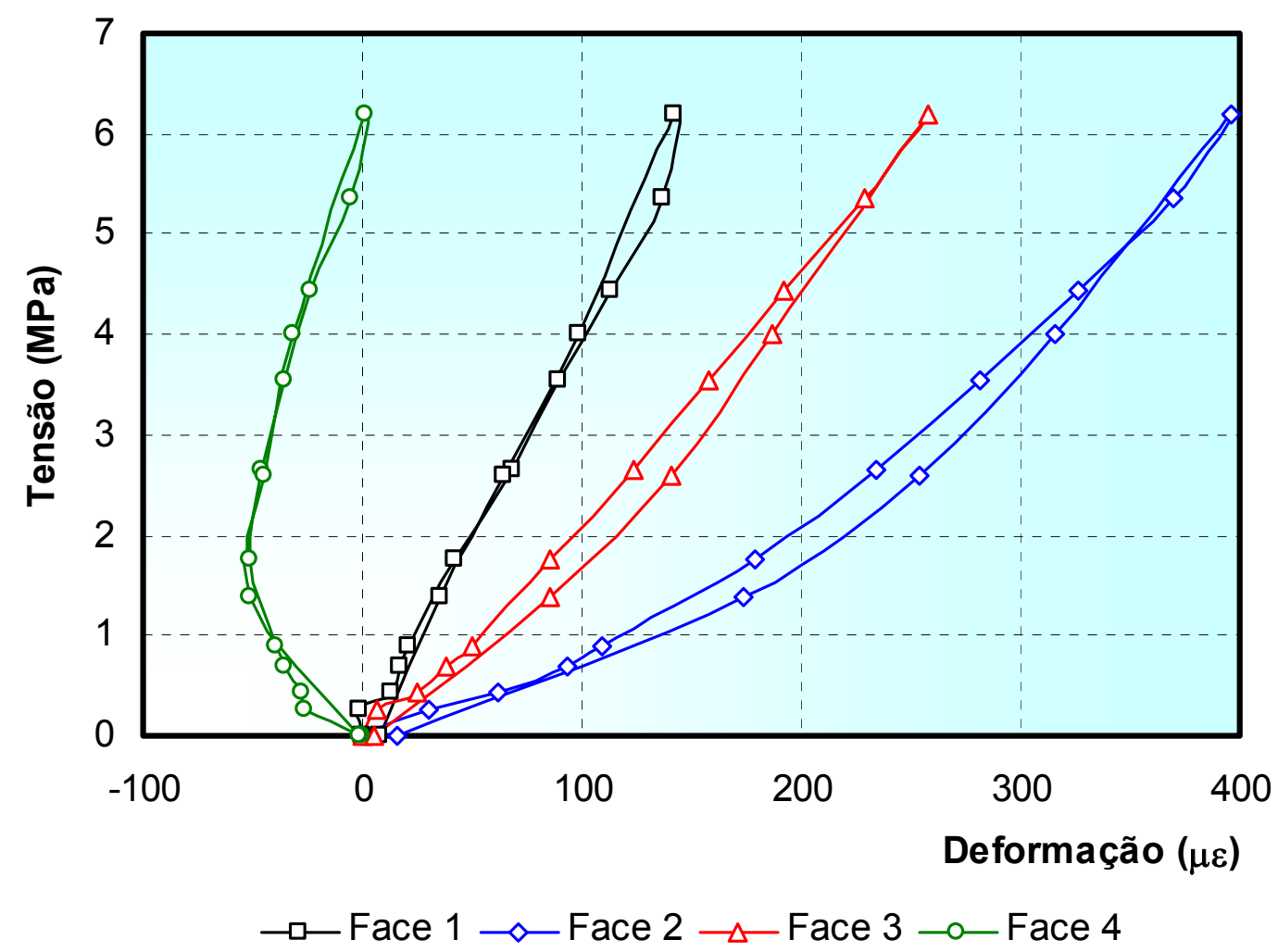

Figura 5.14 - Ensaio de montagem em pórtico - pilar 1, ensaio 3.

Um aspecto interessante a ser observado é que uma das faces foi tracionada durante a realização do ensaio. Essa condição é devida à rotação da viga metálica que transmitia a carga aos pilares, no contato entre viga e pilar.

Também para essa condição de ensaio, procedeu-se à regressão linear entre os valores de tensão aplicada e deformação medida média entre faces paralelas, os quais apresentam resultados típicos como os da Figura 5.15. 


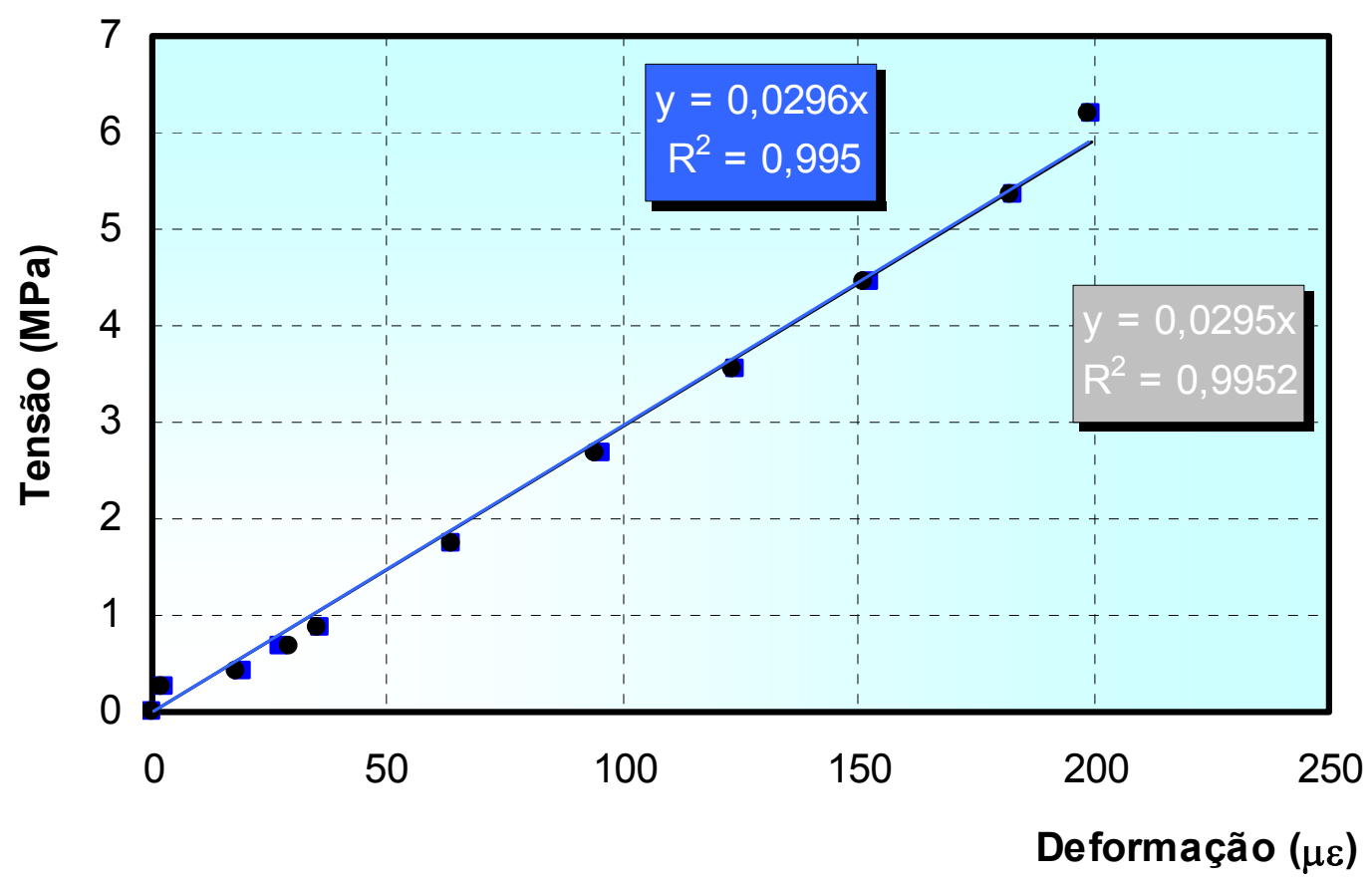

- Média 1 e 3

- Média 2 e 4

Linear (Média 1 e 3) — Linear (Média 2 e 4)

Figura 5.15 - Regressão linear, montagem em pórtico, média faces paralelas - pilar 1, ensaio 3.

Os resultados dos ensaios realizados com montagem em pórtico encontram-se sumarizados na Tabela 5.2.

\begin{tabular}{cccccc}
\multicolumn{2}{c}{ Tabela $5.2-$ Resumo dos ensaios de montagem em pórtico } \\
\multicolumn{2}{c}{ Ensaio } & Pilar & \multicolumn{2}{c}{ Face $1-3$} & \multicolumn{2}{c}{ Face $2-4$} \\
& & $\mathrm{E}_{\mathrm{ca}}$ & $\mathrm{R}^{2}$ & $\mathrm{E}_{\mathrm{ca}}$ & $\mathrm{R}^{2}$ \\
\hline 1 & 1 & 31,7 & 99,9 & 31,3 & 99,8 \\
& 2 & 31,8 & 99,7 & 31,7 & 99,7 \\
2 & 1 & 29,5 & 99,5 & 30,1 & 99,8 \\
& 2 & 31,0 & 99,6 & 30,3 & 99,7 \\
3 & 1 & 29,5 & 99,5 & 29,6 & 99,5 \\
& 2 & 31,9 & 99,9 & 31,8 & 99,6 \\
\hline
\end{tabular}

O conjunto de ensaios leva à conclusão que o equipamento proposto permite a avaliação indireta da solicitação normal em pilares de concreto armado, com precisão adequada para o nível de tensões envolvido em uma estrutura em concreto armado convencional. Os efeitos da flexão podem ser 
minimizados caso as medidas de deformação sejam efetuadas em faces paralelas.

Destaca-se para o leitor que tais ensaios foram realizados em laboratório, sendo o tempo necessário para aplicação de um ciclo de carregamento e descarregamento da ordem de uma hora. Nessas condições, não foram observados os efeitos de temperatura e fluência sobre a peça de concreto armado. A consideração desses, além da retração, são tratados a seguir.

5.2.6 Procedimentos adotados durante as medidas de campo.

Cada conjunto de medidas iniciava-se com as leituras na base de referência padrão. Em cada pilar era inicialmente efetuada a medida da temperatura nas quatro faces, em uma posição aproximada do ponto médio da localização da instrumentação (cerca de 1,0 m acima da superfície do terreno). Antes da leitura com o extensômetro mecânico, procedia-se à limpeza das cantoneiras com pano seco, para a remoção de poeira. Em cada face instrumentada eram feitas três leituras sucessivas com a instalação e remoção do extensômetro de haste. De modo geral, essas três leituras apresentaram-se dentro de uma faixa de variação máxima de $5 \mu \mathrm{m}$. 


\section{COMPORTAMENTO DA SUPERESTUTURA}

Neste capítulo são apresentados e interpretados os resultados das observações de campo referentes ao comportamento dos pilares do pavimento térreo. As medidas de variação de comprimento, efetuadas em duas faces opostas dos pilares, são expostas sob a forma de deformação específica. Essas medidas, após correção dos efeitos de temperatura, flexão, fluência e retração, permitem a avaliação das cargas nos pilares. $O$ valor da solicitação normal, fornecido a partir da instrumentação, é então comparado com o fornecido pelo cálculo estrutural.

\subsection{OBSERVAÇÕES DE DEFORMAÇÕES NOS PILARES.}

Foram instrumentados vinte pilares, tendo sido avaliado o comprimento entre dois pontos de referências fixados no concreto por meio de resina epóxi. As medidas foram efetuadas em duas faces paralelas de cada pilar. A variação do comprimento entre os dois pontos de referência permite avaliar a deformação que ocorre no elemento estrutural. As observações foram realizadas no período compreendido entre os dias 06/09 a 17/10/2002. A Figura 6.1 apresenta a localização em planta dos pilares e suas respectivas faces instrumentadas.

\subsubsection{Evolução das deformações com o tempo.}

Conforme apresentado no capítulo 3, item 3.4, o comportamento do concreto armado do pilar, no tocante às suas deformações, $\left(\varepsilon_{c}\right)$ sofre influência das seguintes componentes:

a) instantânea, solicitação normal $\left(\varepsilon_{\mathrm{ci}}\right)$;

b) flexão $\left(\varepsilon_{\mathrm{cm}}\right)$; 
c) temperatura $\left(\varepsilon_{c \mathrm{~T}}\right)$;

d) fluência $\left(\varepsilon_{\mathrm{cc}}\right)$;

e) retração $\left(\varepsilon_{\mathrm{cs}}\right)$.

O conjunto de gráficos das Figuras 6.2 a 6.21 apresenta a evolução com o tempo das medidas efetuadas e das componentes de deformações calculadas. Cada conjunto de seis gráficos refere-se ao comportamento de um único pilar.

O par de gráficos na parte superior apresenta, para as duas faces paralelas em que a medida foi efetuada, a influência da temperatura no comportamento do elemento da estrutural. A linha contínua preta apresenta os valores das deformações medidas $\left(\varepsilon_{c}\right)$. A linha contínua vermelha corresponde à evolução com o tempo da deformação corrigida do efeito da temperatura $\left(\varepsilon_{c}\right.$ $\varepsilon_{\mathrm{CT} T}$.

Os dois gráficos centrais apresentam, para as duas faces paralelas monitoradas, os efeitos da fluência e retração avaliados de acordo com o CEB-FIP 90. A linha preta apresenta a evolução da parcela de deformação devida à fluência $\left(\varepsilon_{c c}\right)$ e a azul, a parcela devida à retração $\left(\varepsilon_{c s}\right)$. Caso esses dois efeitos sejam subtraídos dos valores de deformações corrigidos da temperatura, pode-se determinar o valor da parcela de deformação "elástica" ou "instantânea" $\left(\varepsilon_{\mathrm{ci}}\right)$, conforme apresentado pela linha em vermelho. Um aspecto a ser ressaltado é que as deformações por fluência em um mesmo pilar podem não ser de igual valor para as duas faces, embora as devidas à retração devam obrigatoriamente ser iguais.

Os gráficos da porção inferior apresentam o efeito da flexão $\left(\varepsilon_{\mathrm{cm}}\right)$ no comportamento do elemento, sendo que no gráfico situado à esquerda foi considerado apenas o efeito da temperatura $\left(\varepsilon_{c}-\varepsilon_{c T}\right)$ e no da direita além da temperatura, leva-se em consideração o efeito da fluência e retração $\left(\varepsilon_{c}-\varepsilon_{c c}-\right.$ $\left.\varepsilon_{\mathrm{CS}}-\varepsilon_{\mathrm{CT}}\right)$. 


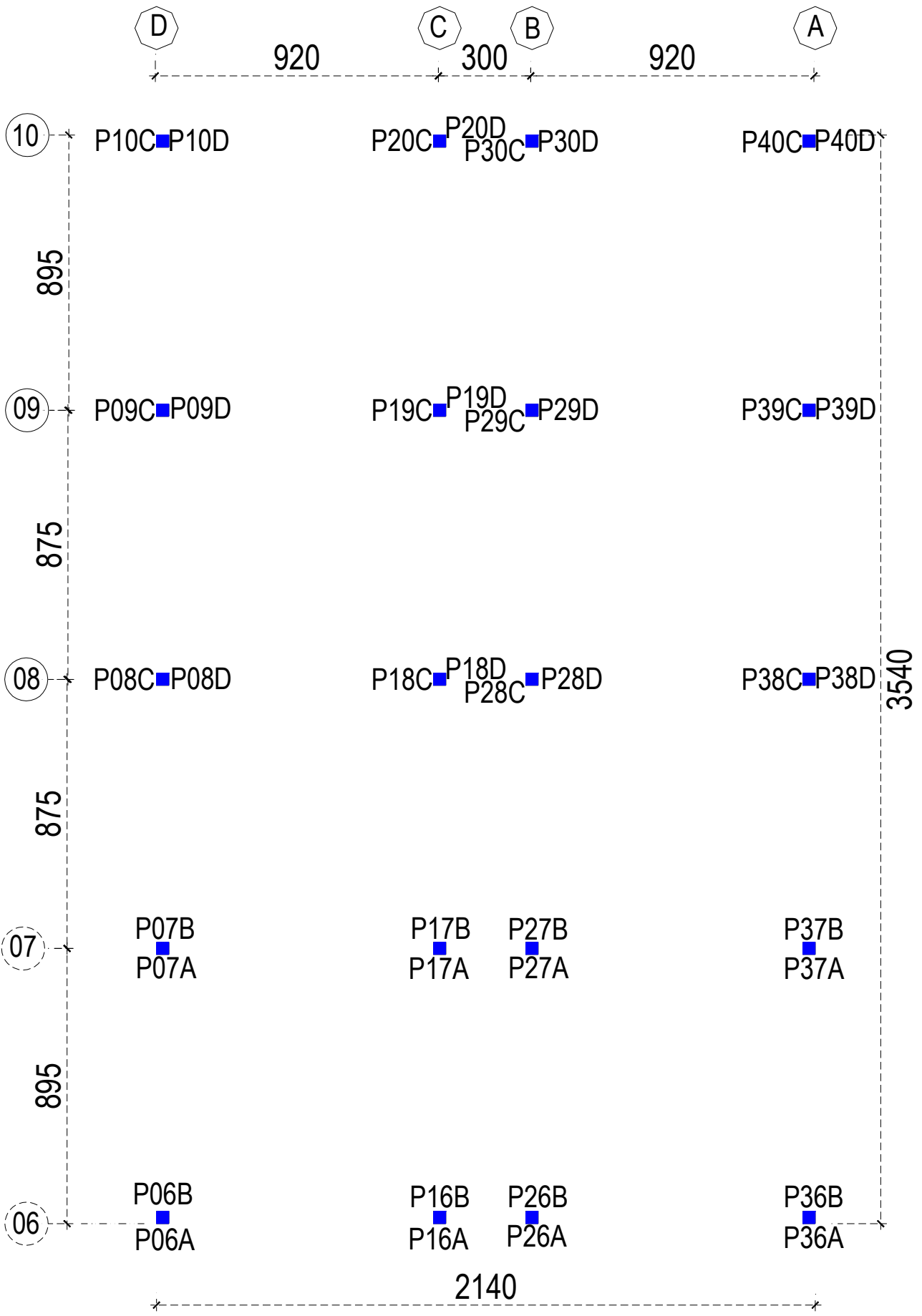

Figura 6.1 - Planta de localização dos pontos de medida de deformação nos pilares. 
Pilar 36 face $A$

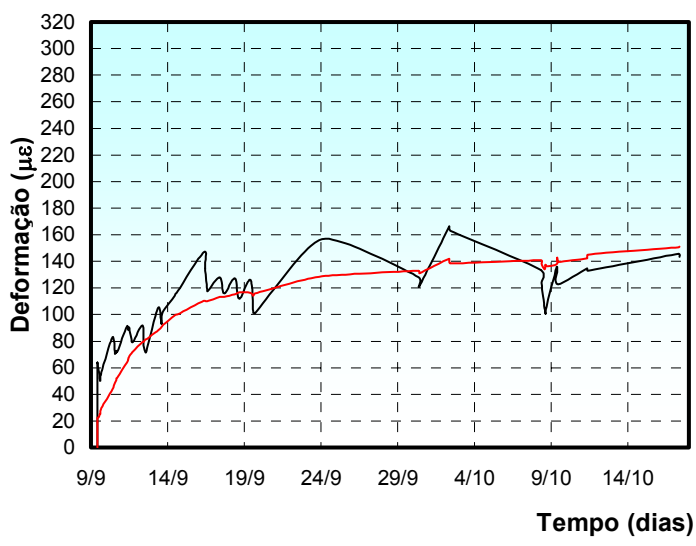

— Medido —Correção temperatura

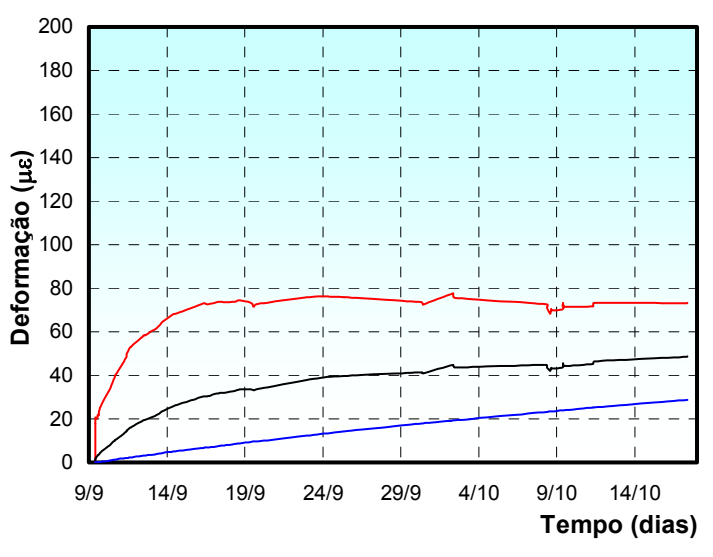

— Elástico — Fluência — Retração

b) Reologia
Pilar 36 face B

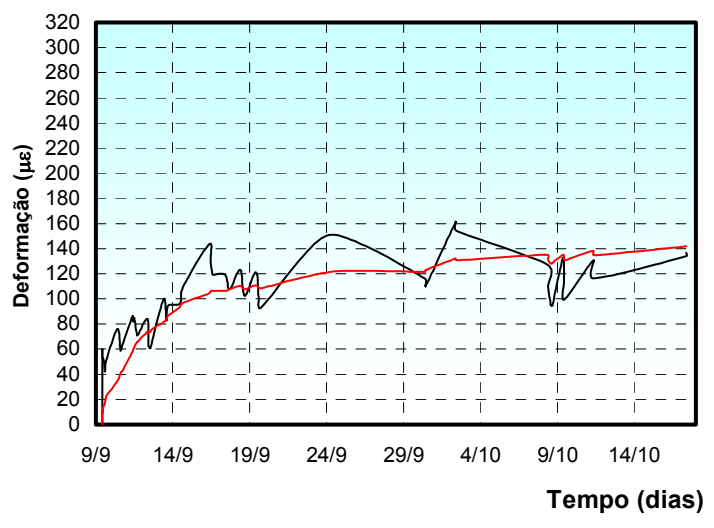

— Medido — Correção temperatura

a) Temperatura

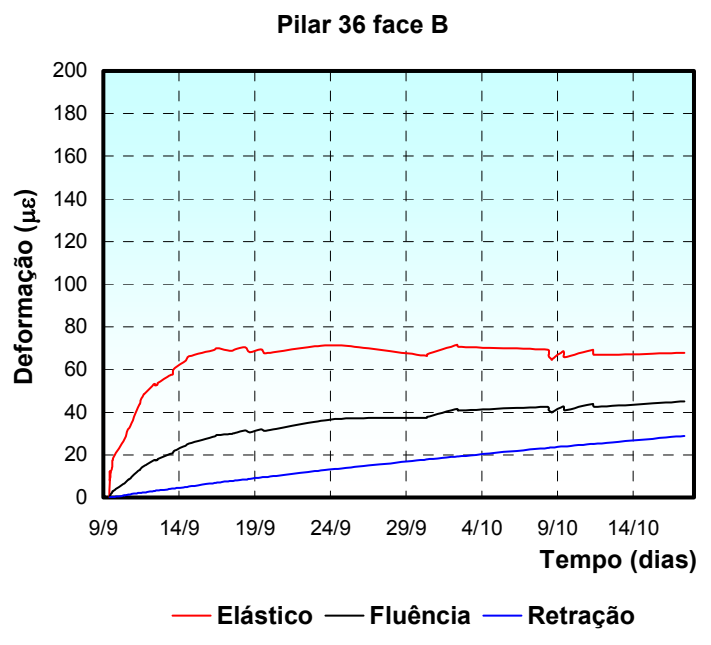

Pilar 36
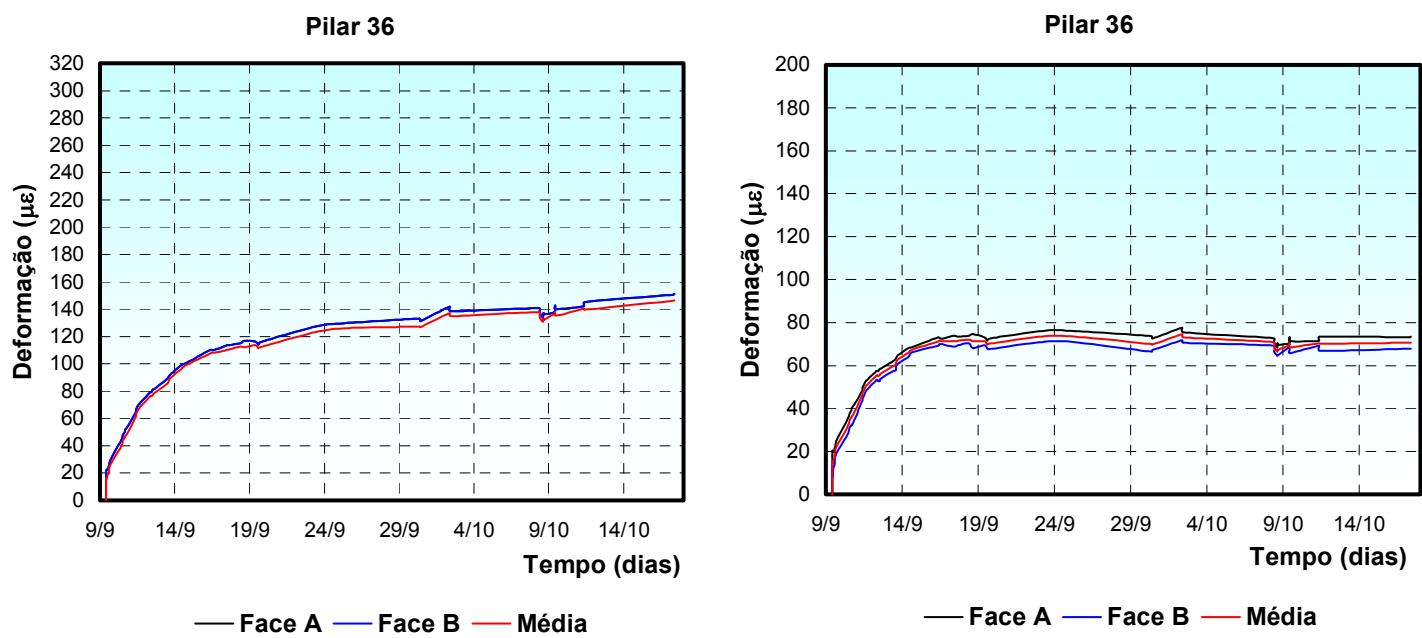

c) Flexão

Figura 6.2 - Curvas tempo deformação pilar 36. 

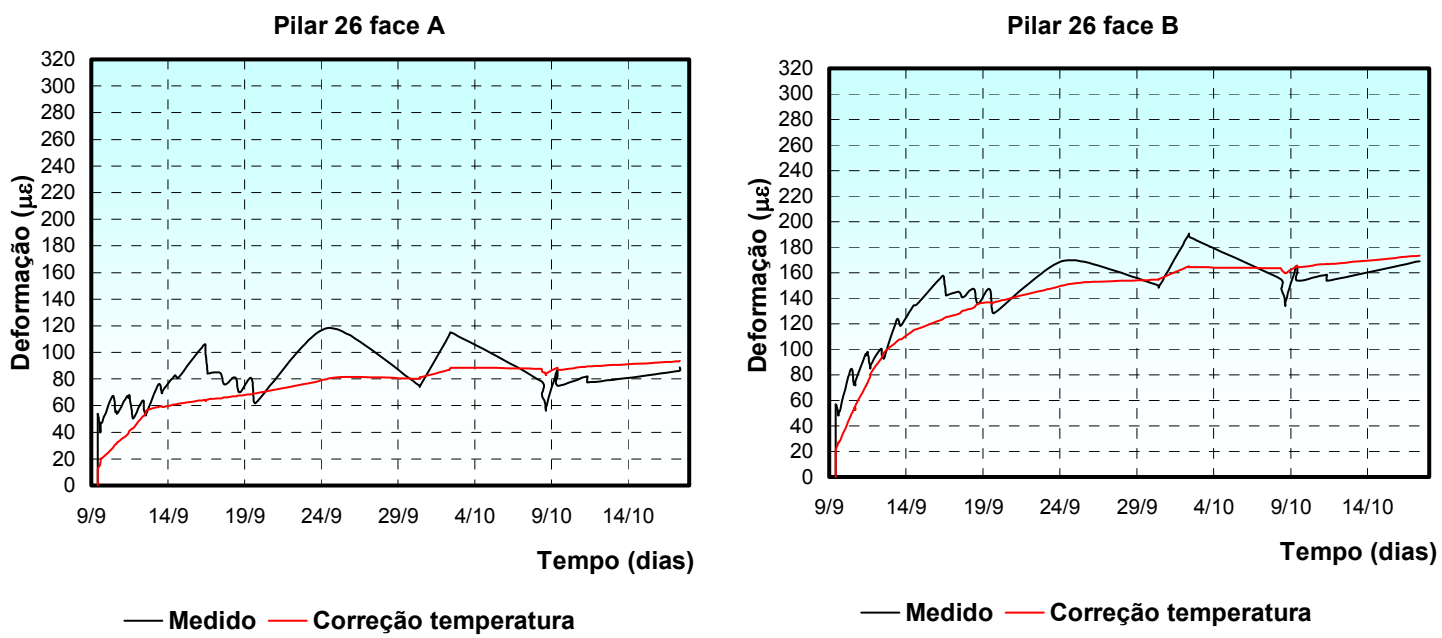

a) Temperatura
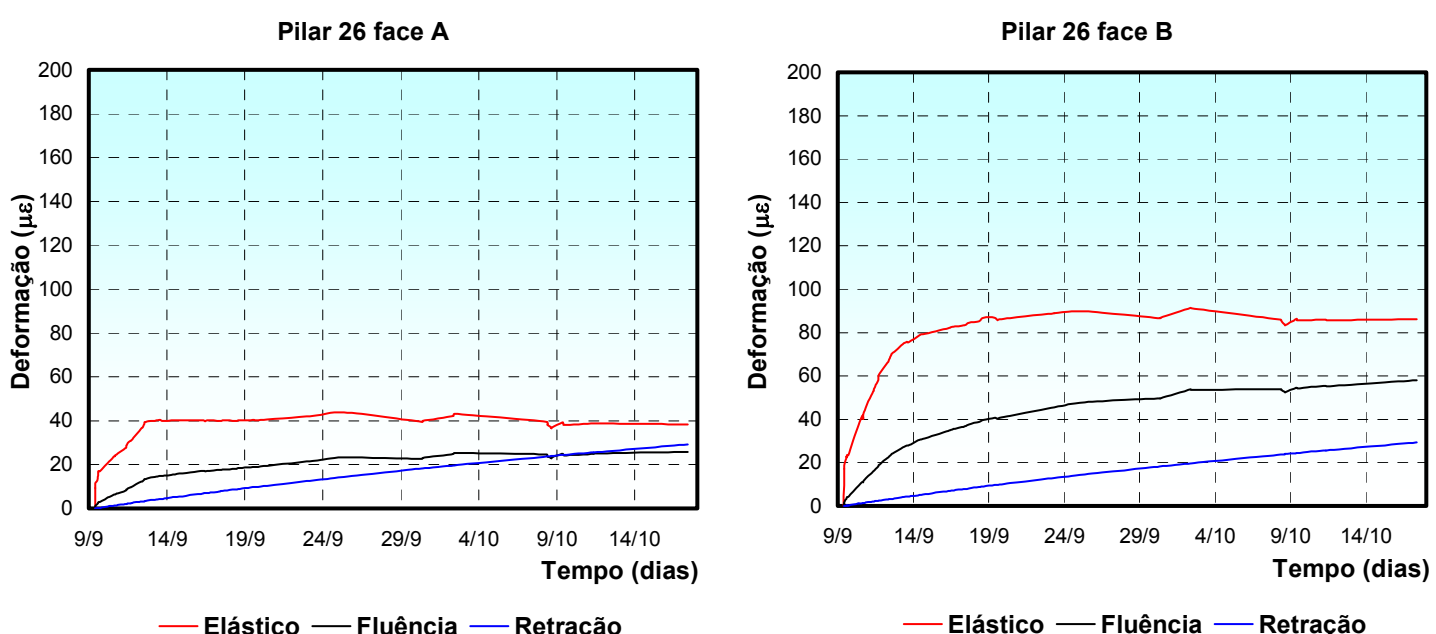

b) Reologia
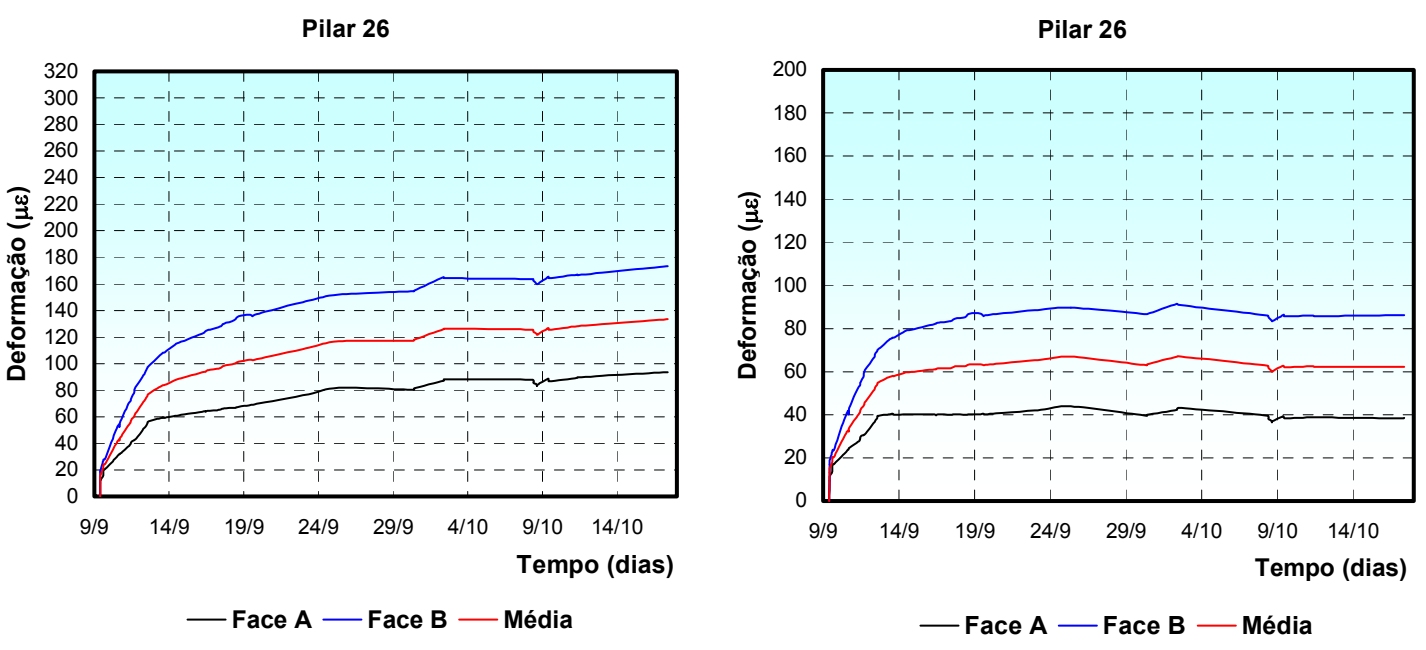

c) Flexão

Figura 6.3 - Curvas tempo deformação Pilar 26. 


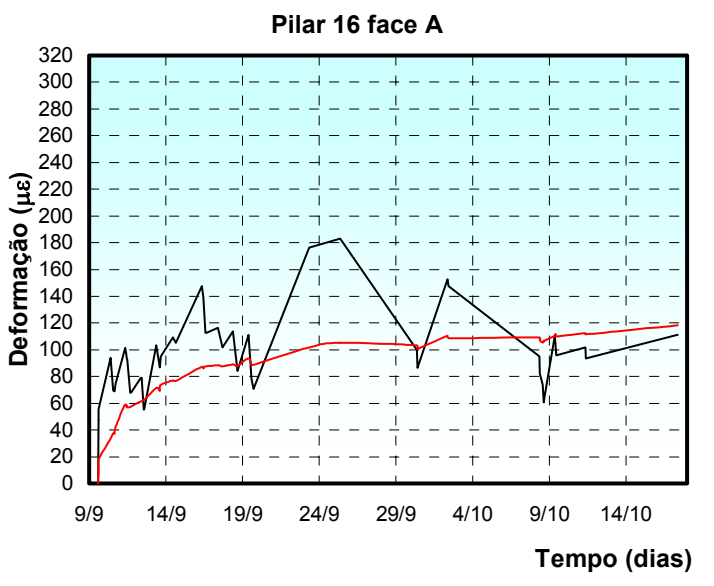

— Medido —Correção temperatura

a) Temperatura

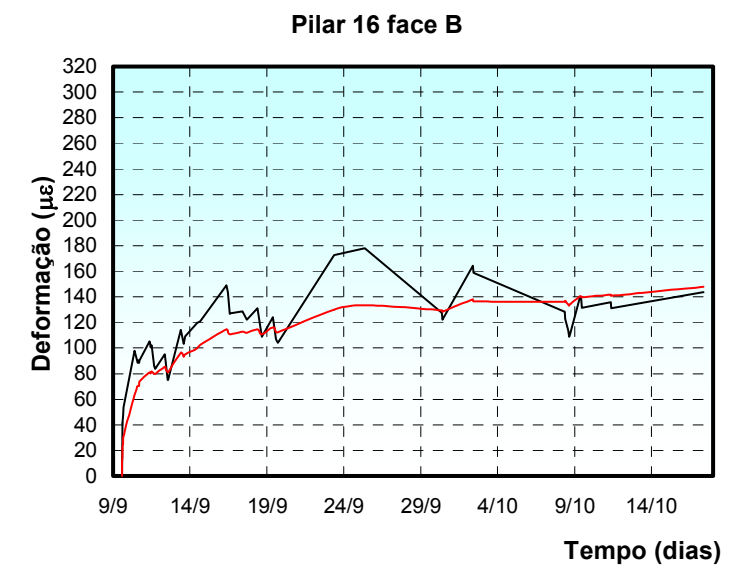

— Medido —Correção temperatura
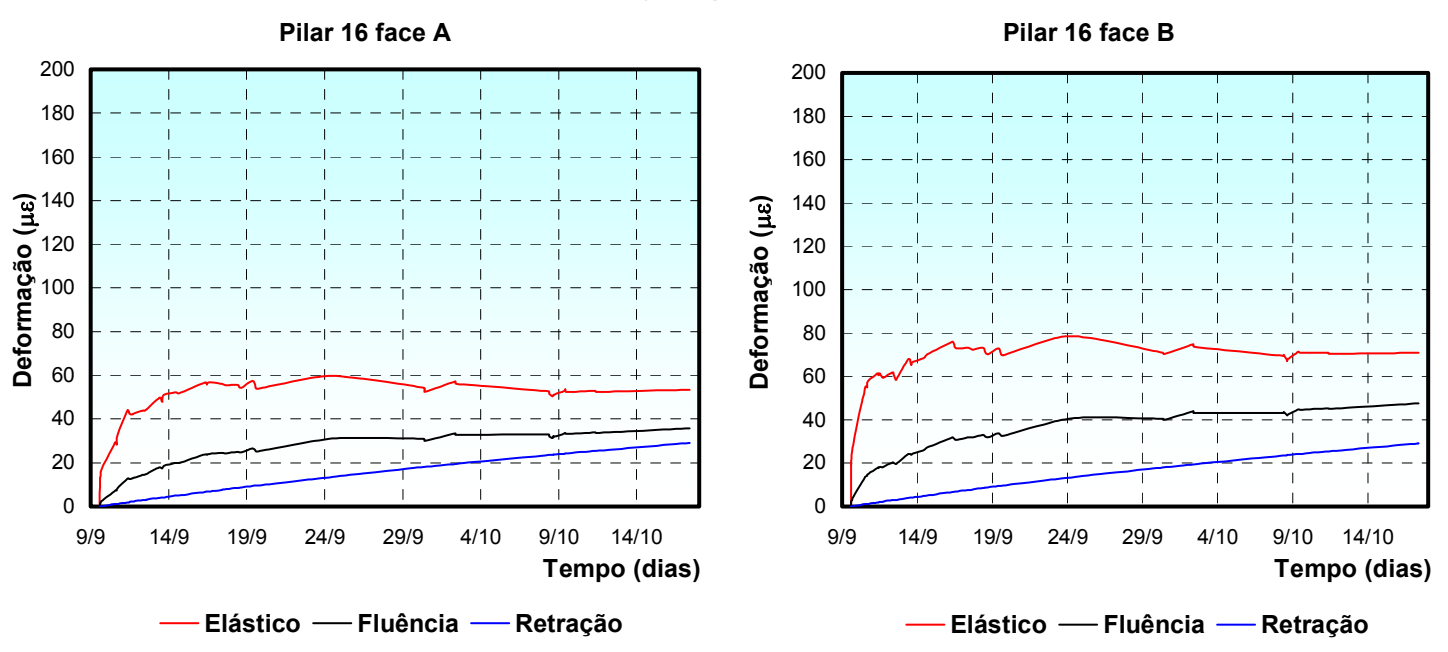

b) Reologia
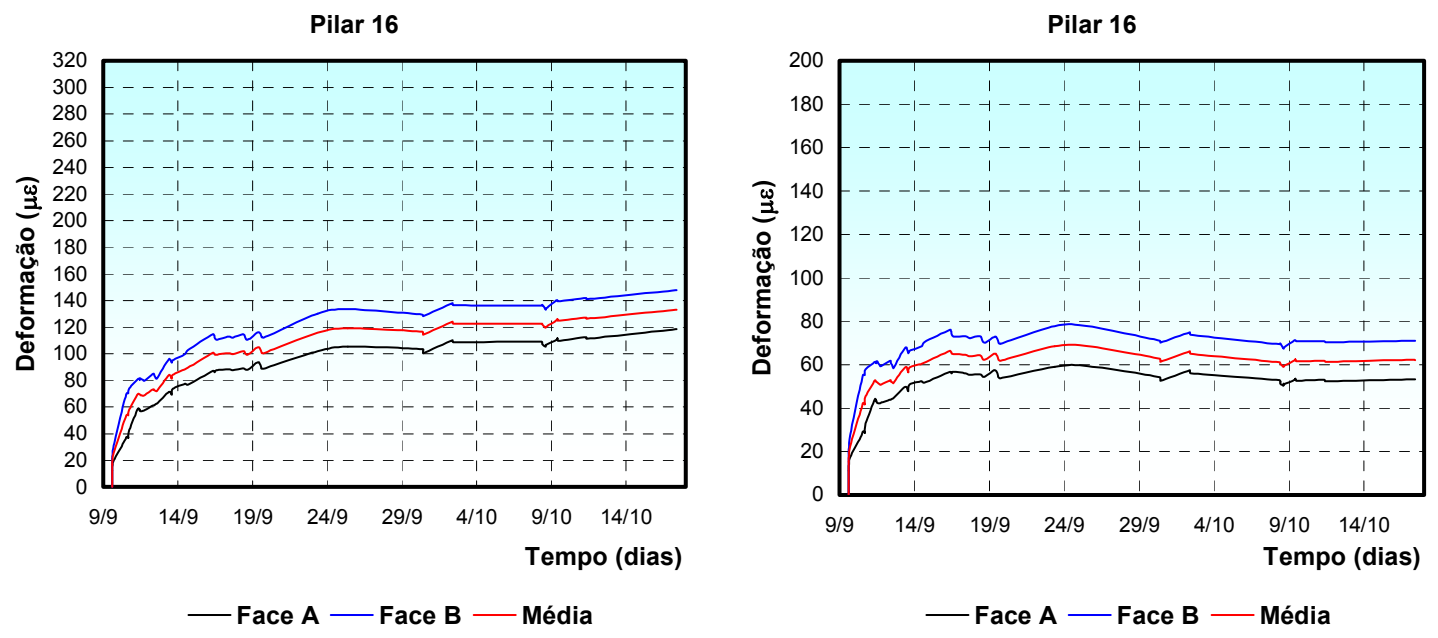

c) Flexão

Figura 6.4 - Curvas tempo deformação pilar 16. 

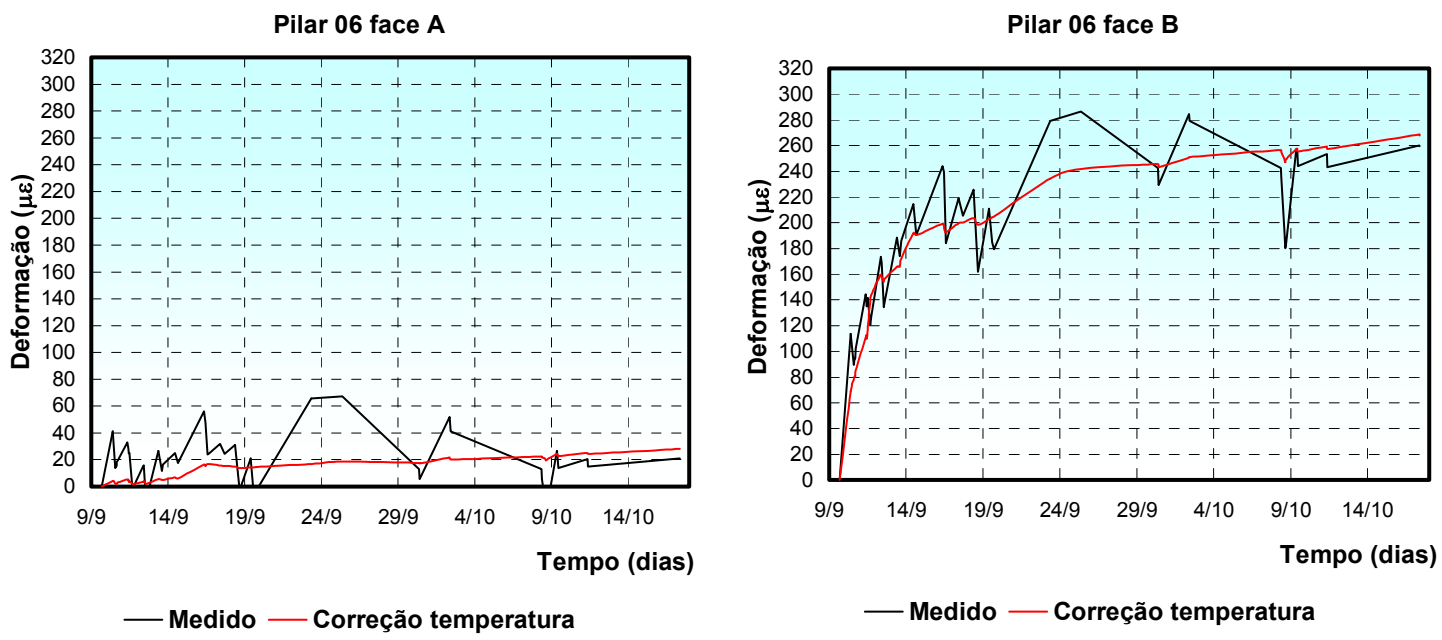

a) Temperatura
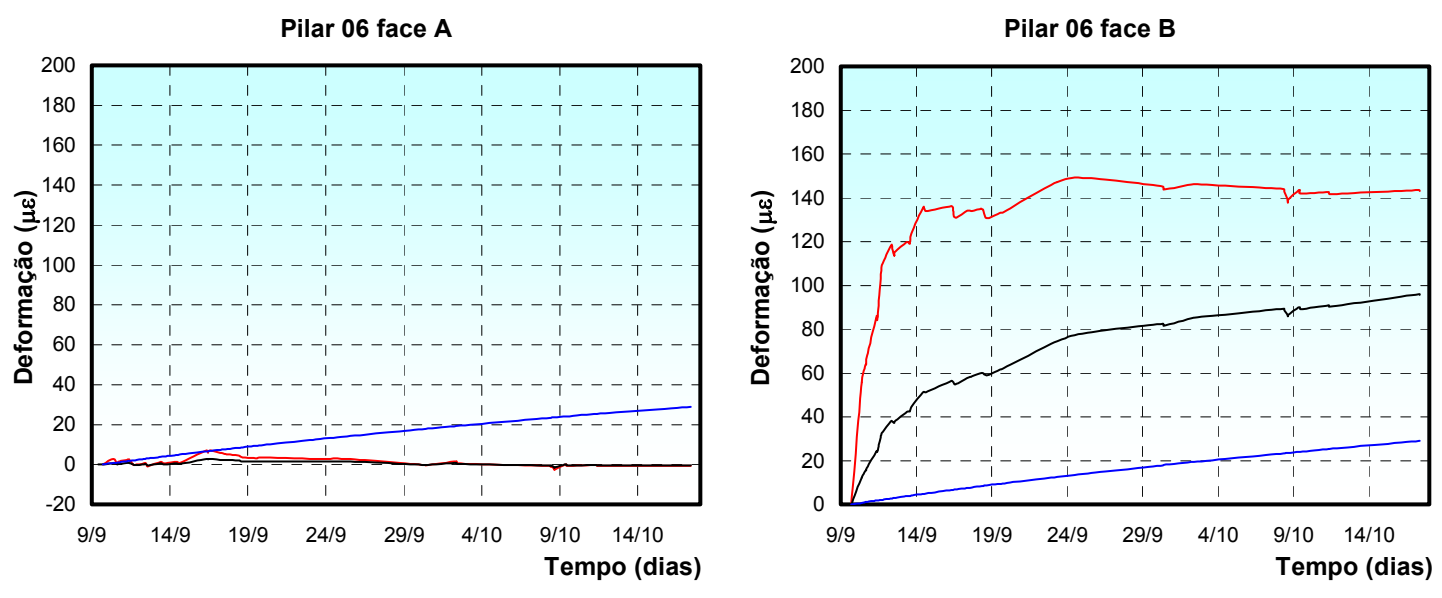

—Elástico — Fluência — Retração

b) Reologia

— Elástico — Fluência — Retração
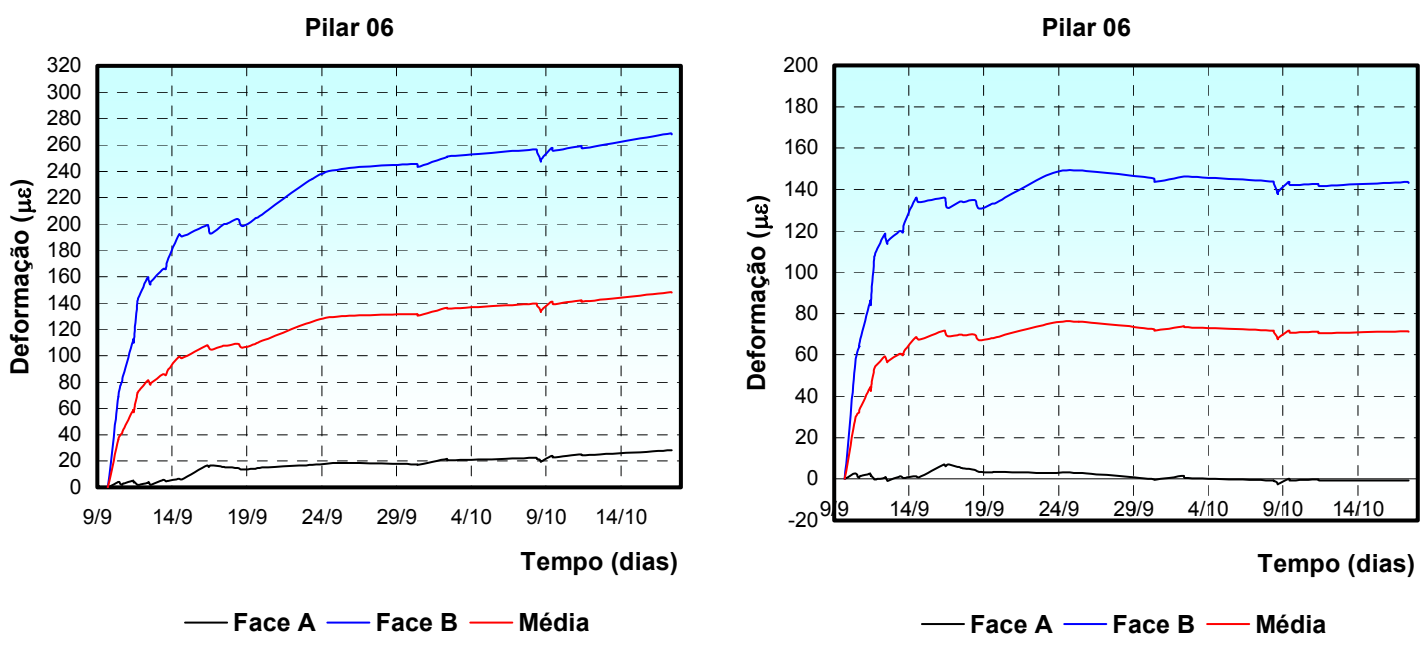

c) Flexão

Figura 6.5 - Curvas tempo deformação pilar 06. 

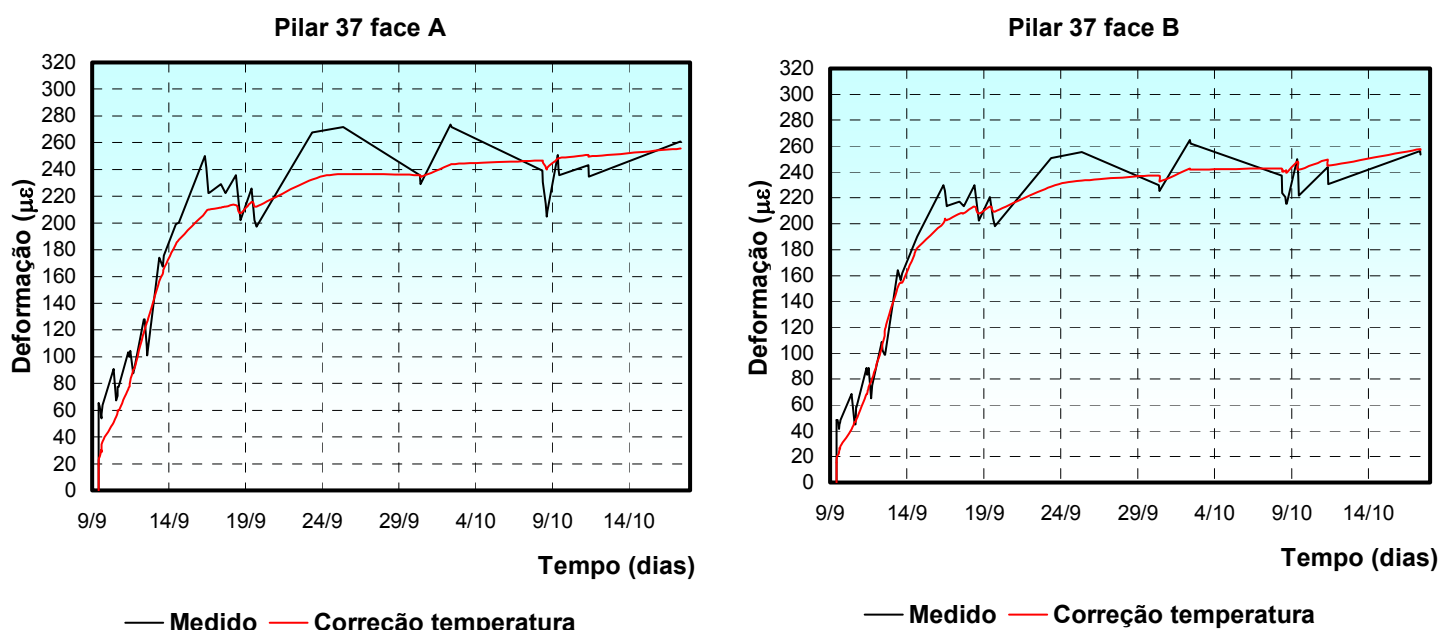

— Medido —Correção temperatura

a) Temperatura
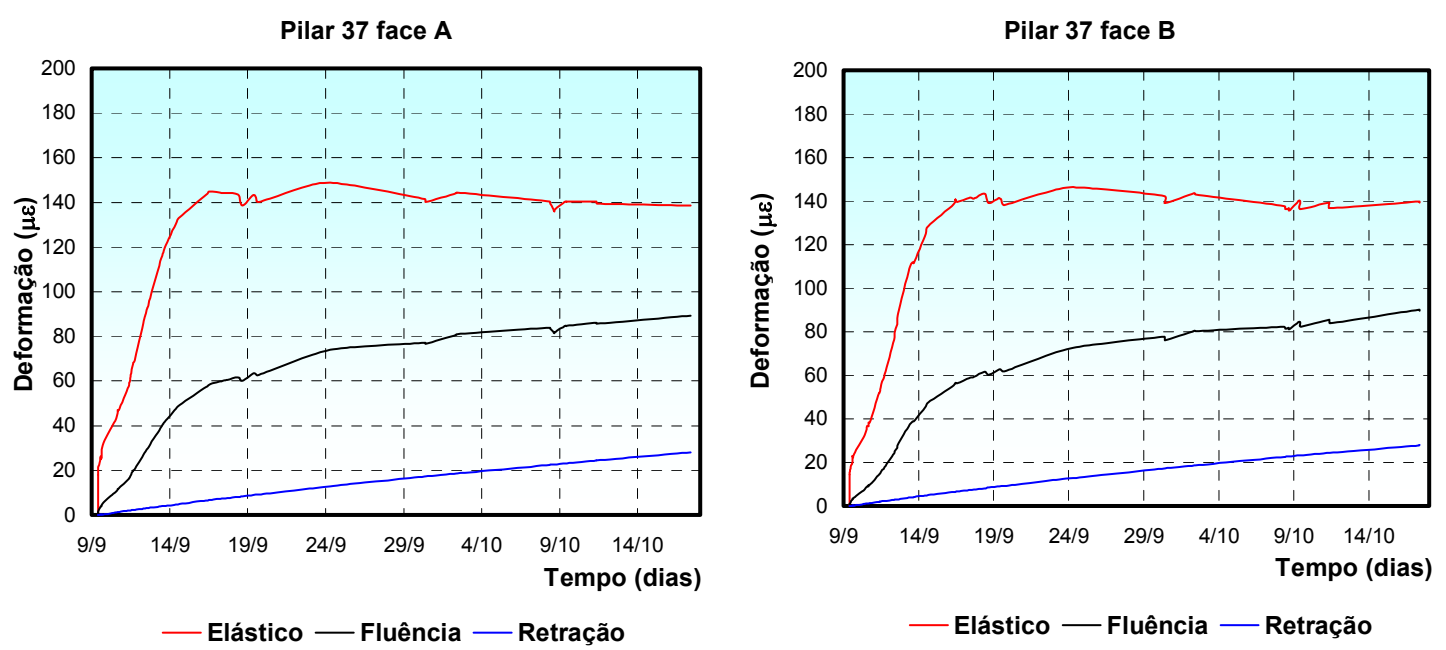

b) Reologia
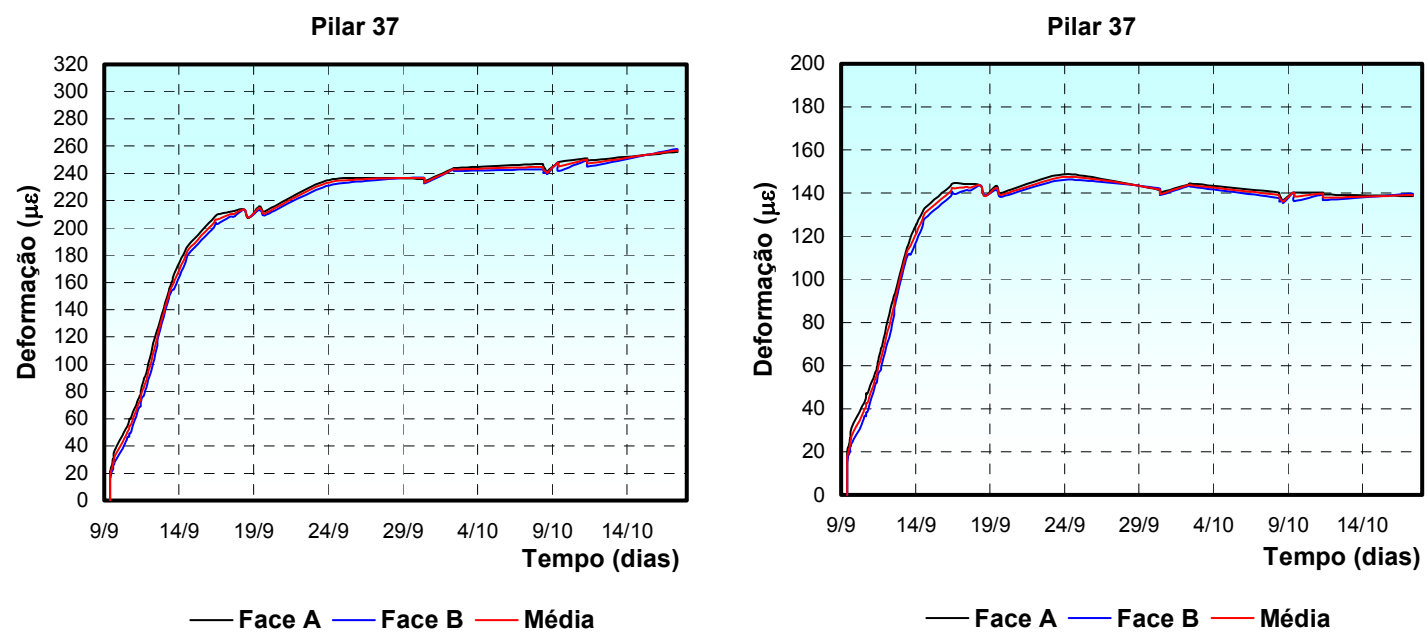

c) Flexão

Figura 6.6 - Curvas tempo deformação pilar 37. 

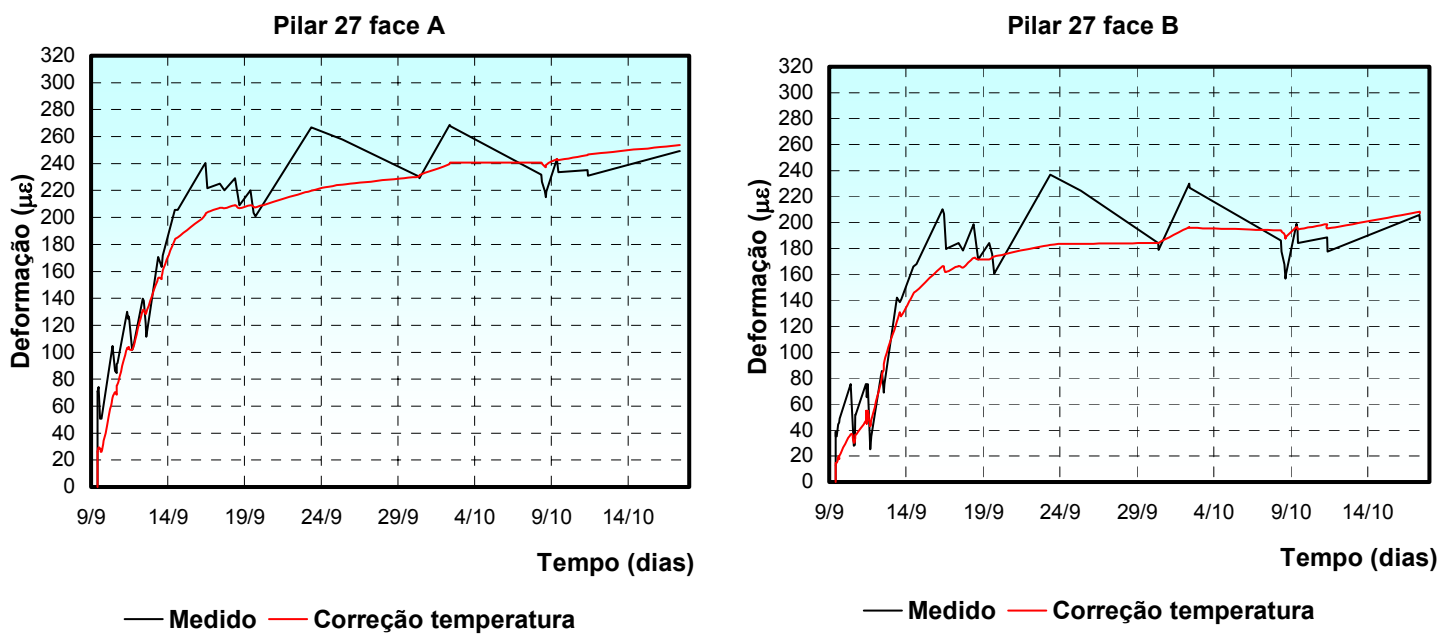

a) Temperatura
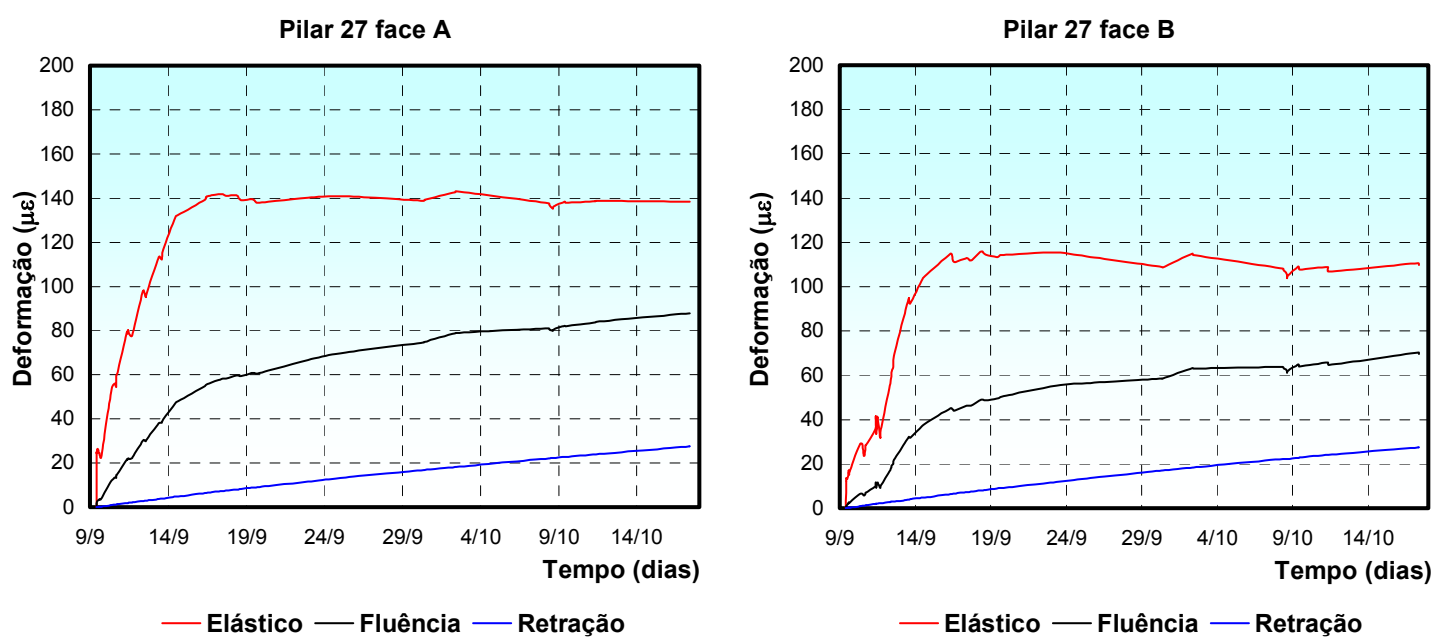

b) Reologia
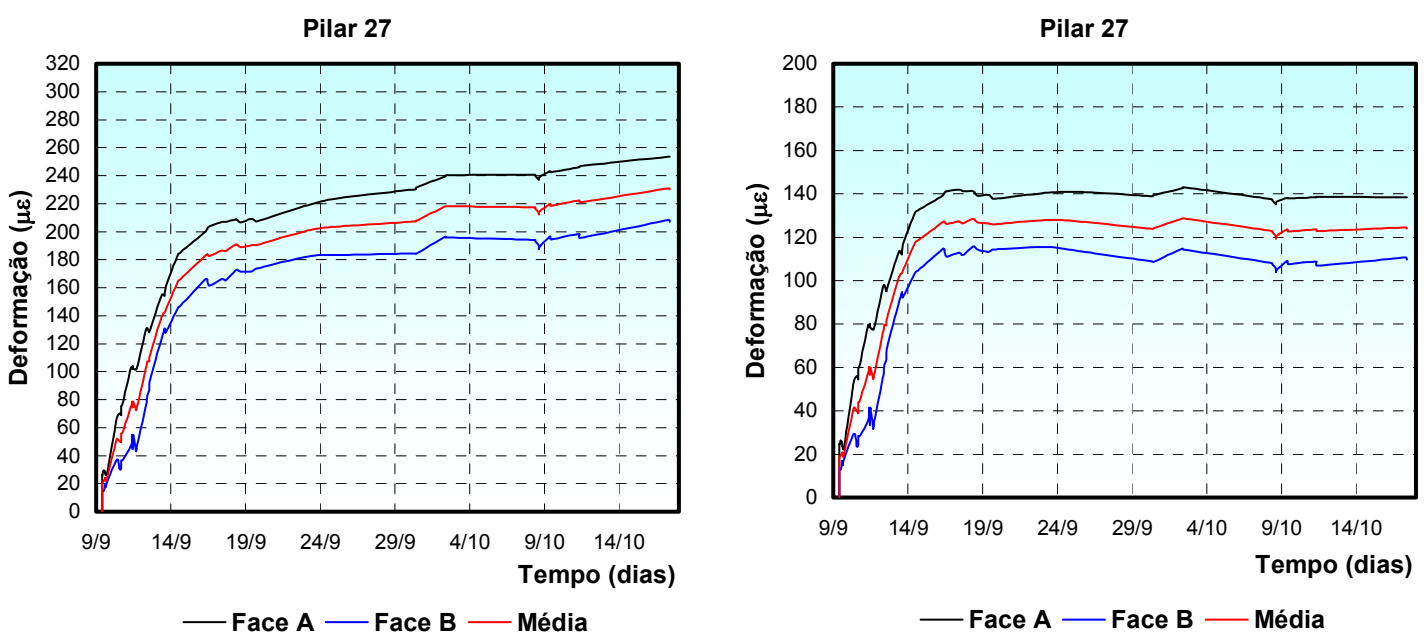

c) Flexão

Figura 6.7 - Curvas tempo deformação pilar 27. 


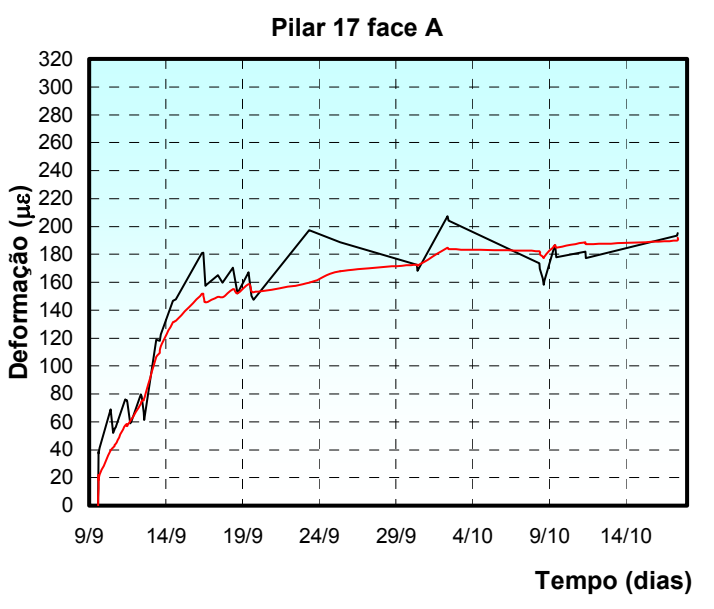

— Medido —Correção temperatura

a) Temperatura
Pilar 17 face $B$

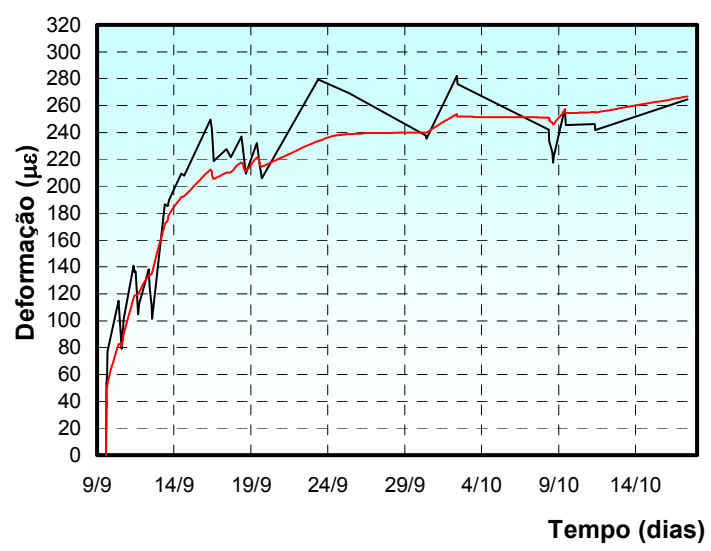

— Medido —Correção temperatura
Pilar 17 face $A$

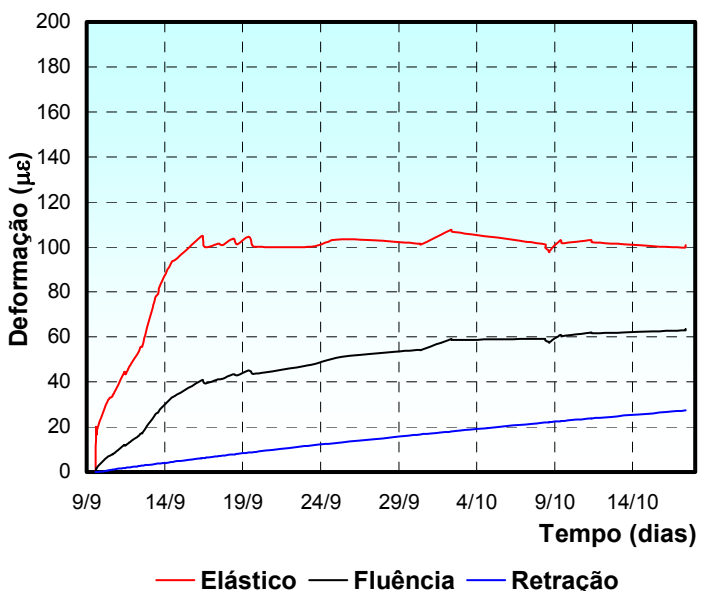

b) Reologia

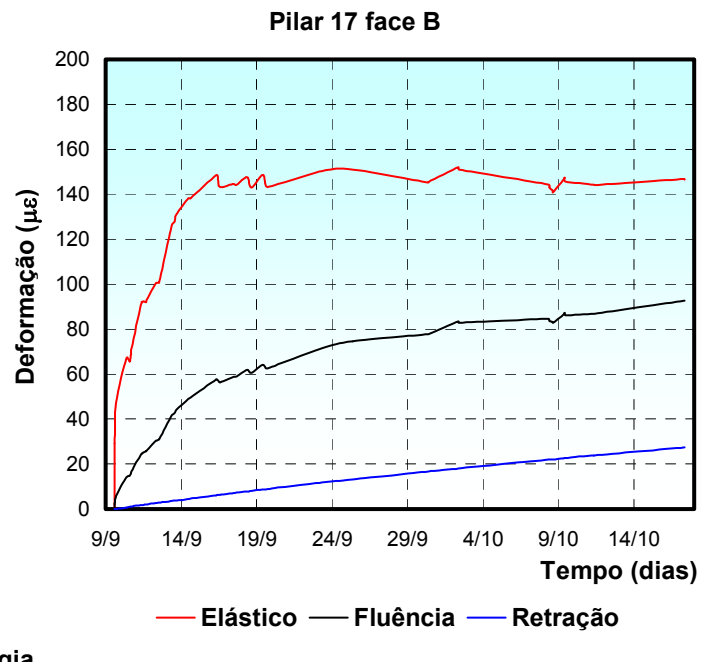

Pilar 17

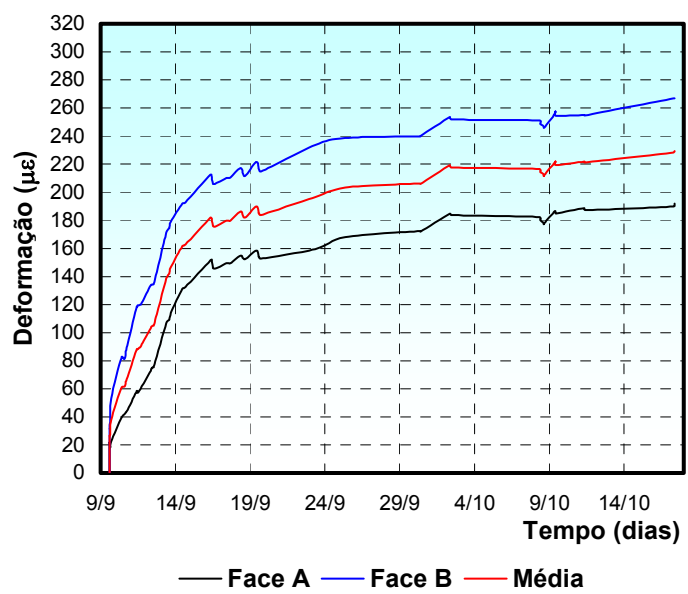

Pilar 17

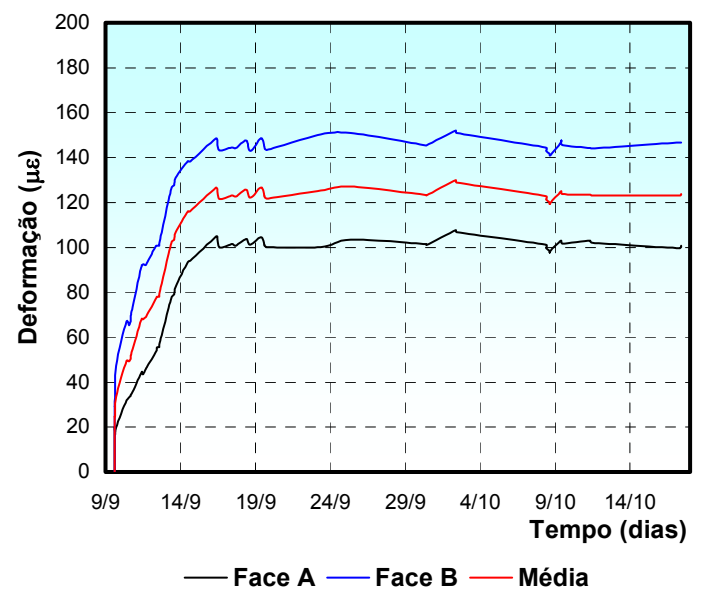

c) Flexão

Figura 6.8 - Curvas tempo deformação pilar 17. 

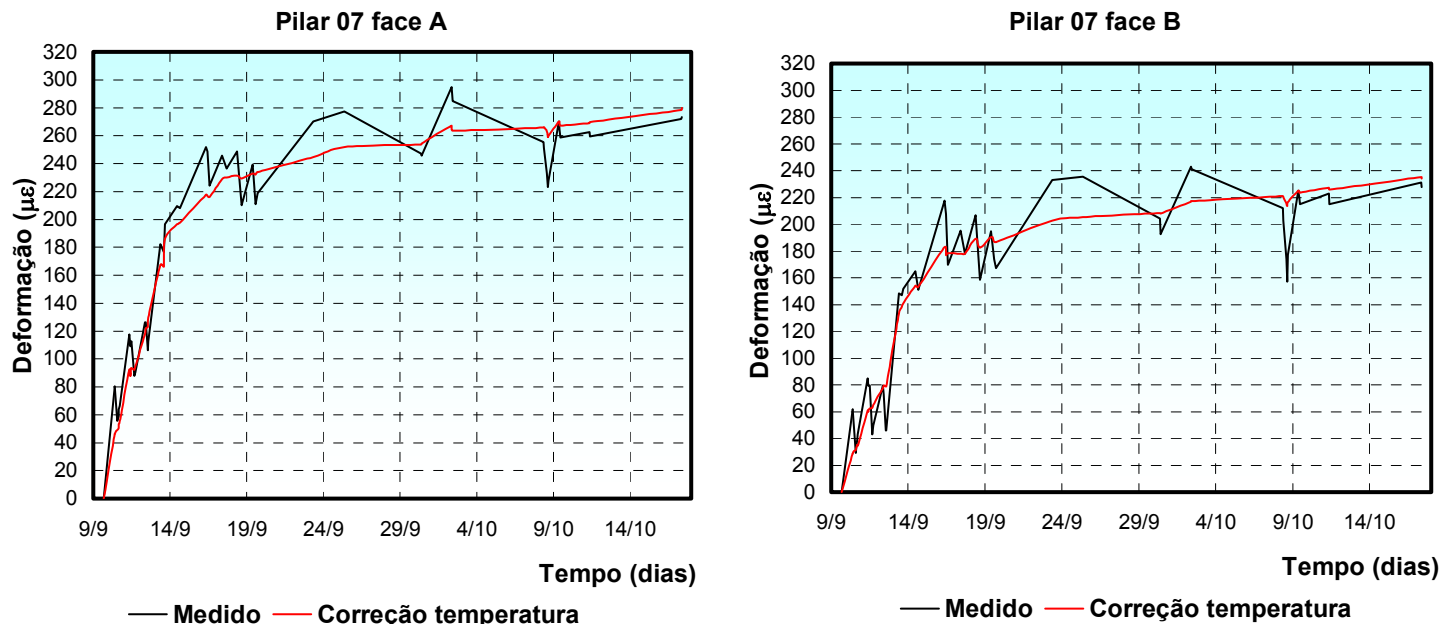

a) Temperatura
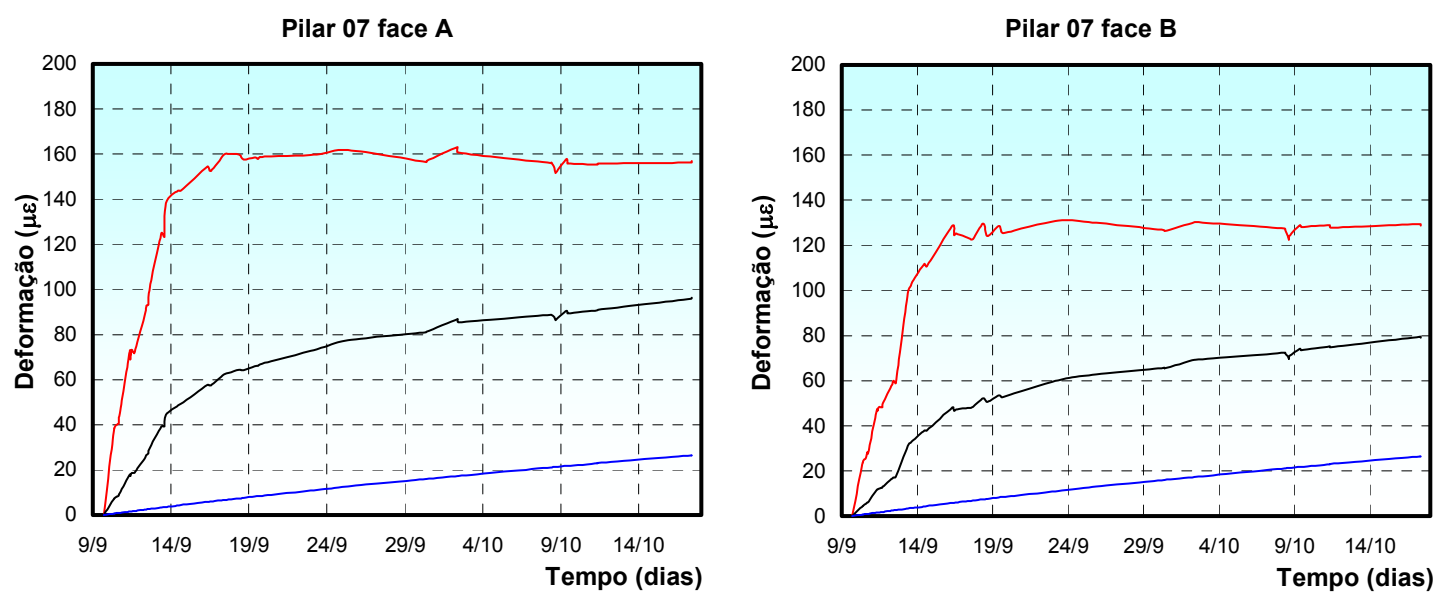

—Elástico — Fluência — Retração

b) Reologia
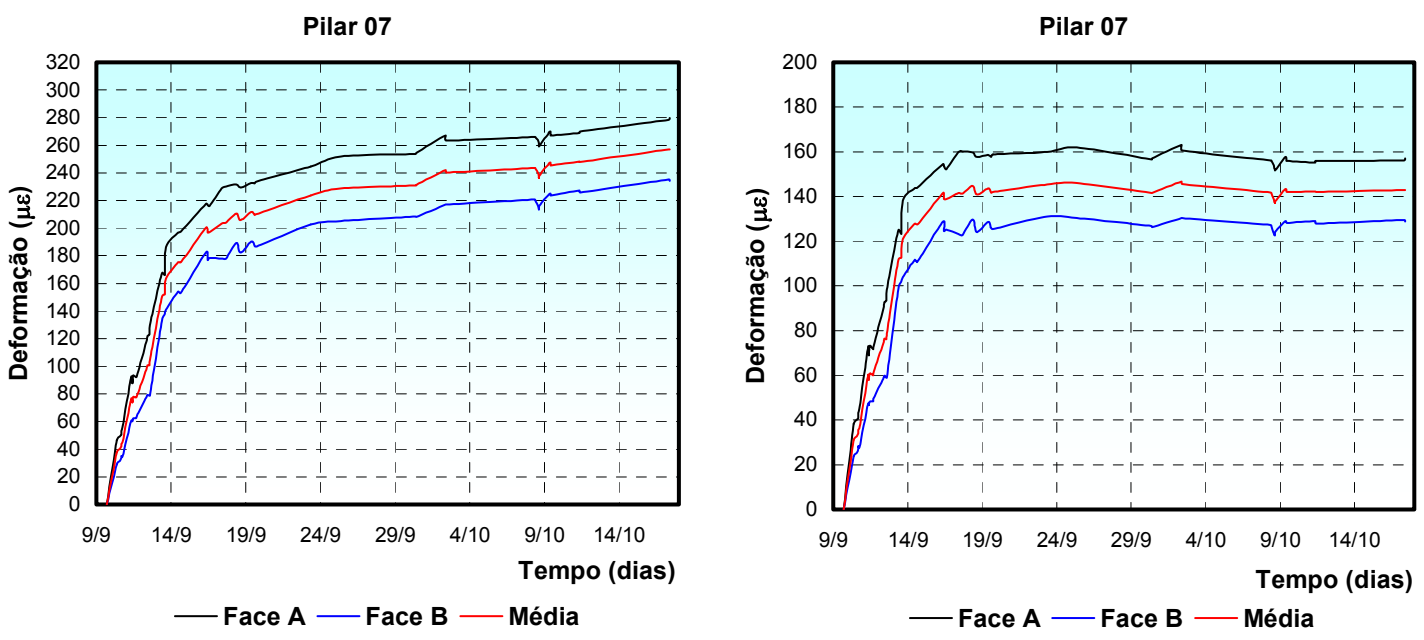

c) Flexão

Figura 6.9 - Curvas tempo deformação pilar 07. 


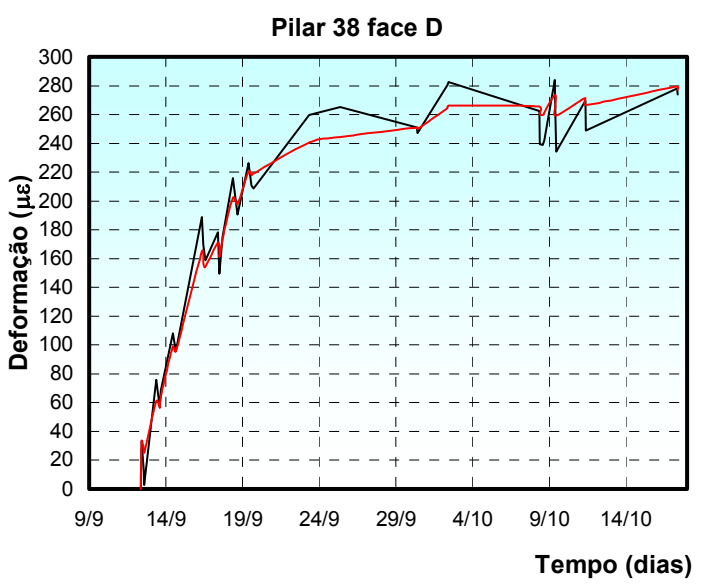

— Medido —Correção temperatura

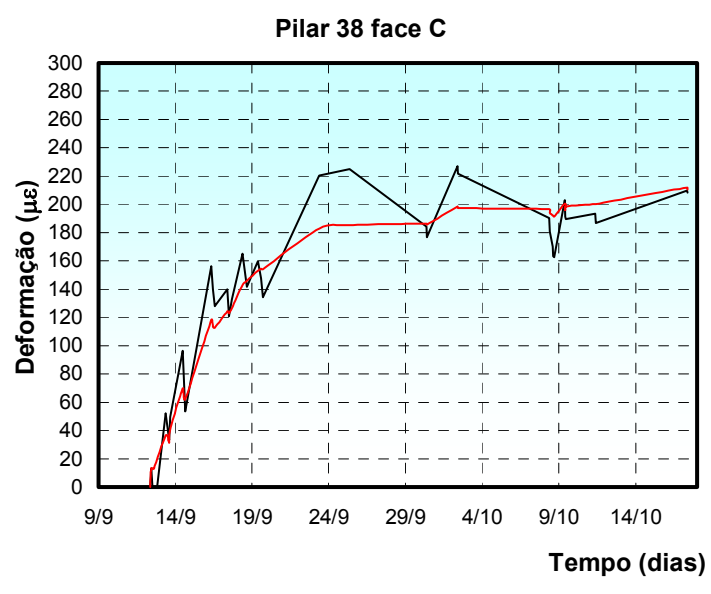

— Medido —Correção temperatura

a) Temperatura
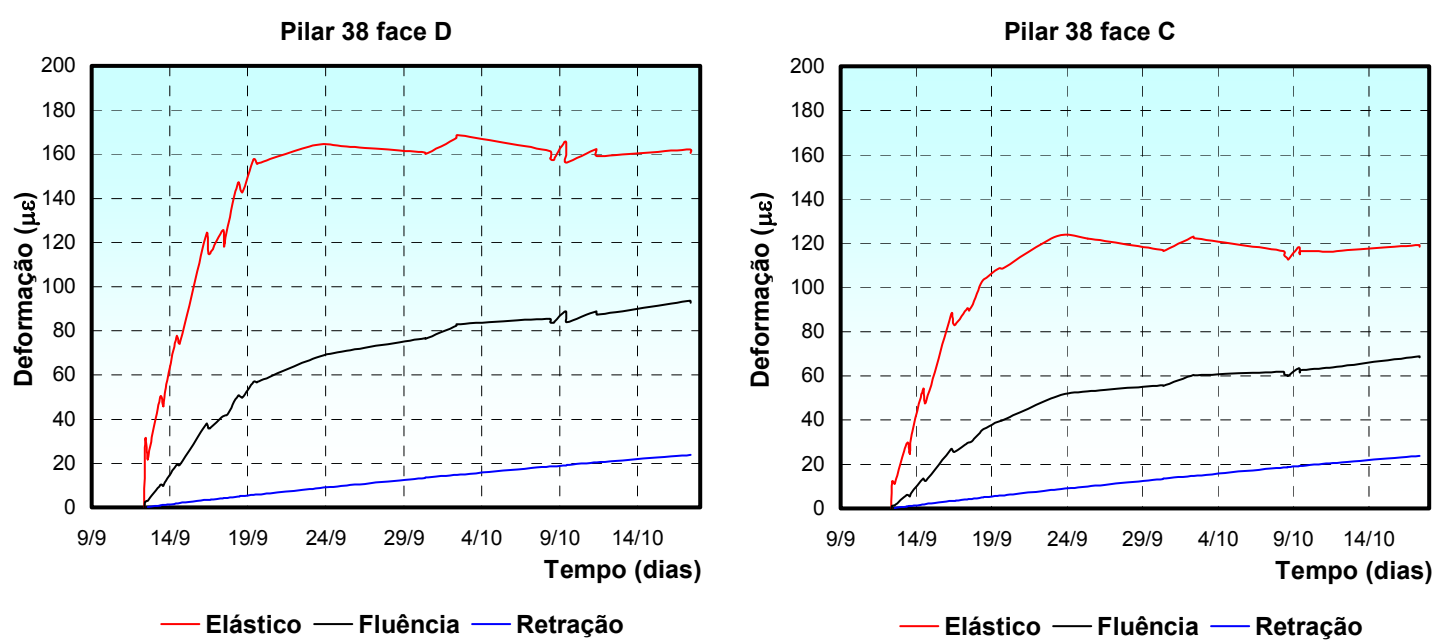

b) Reologia
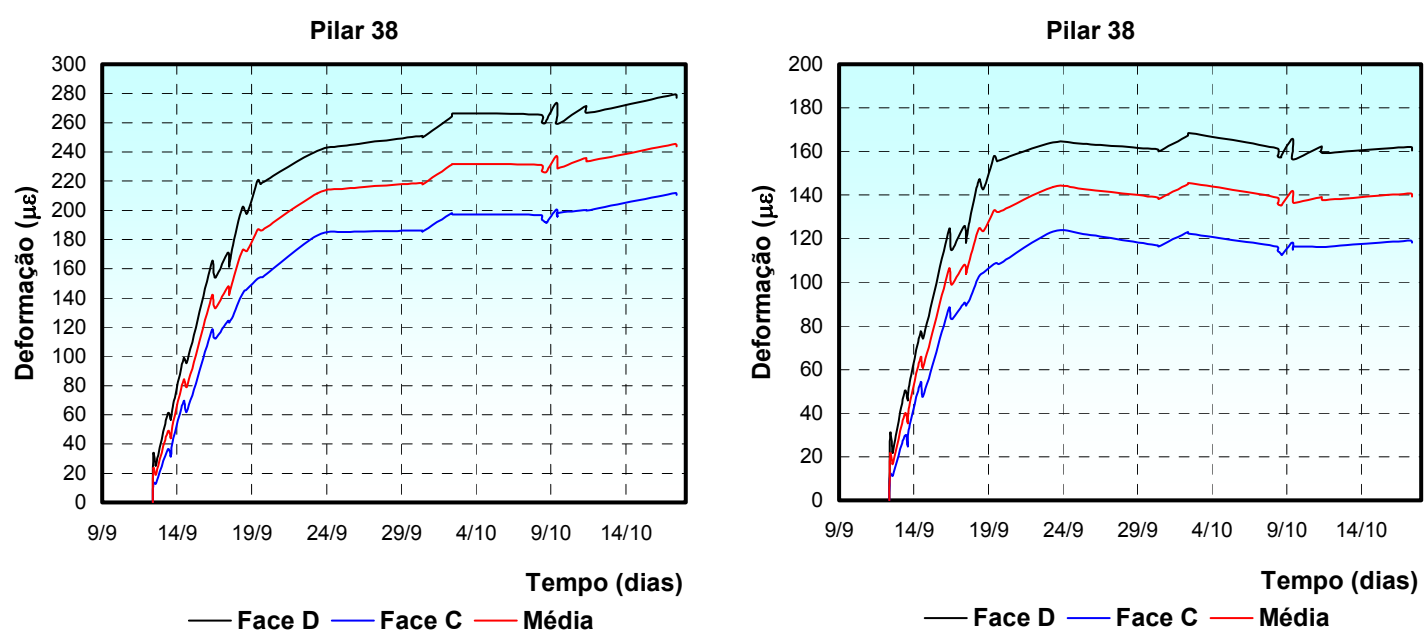

c) Flexão

Figura 6.10 - Curvas tempo deformação pilar 38. 

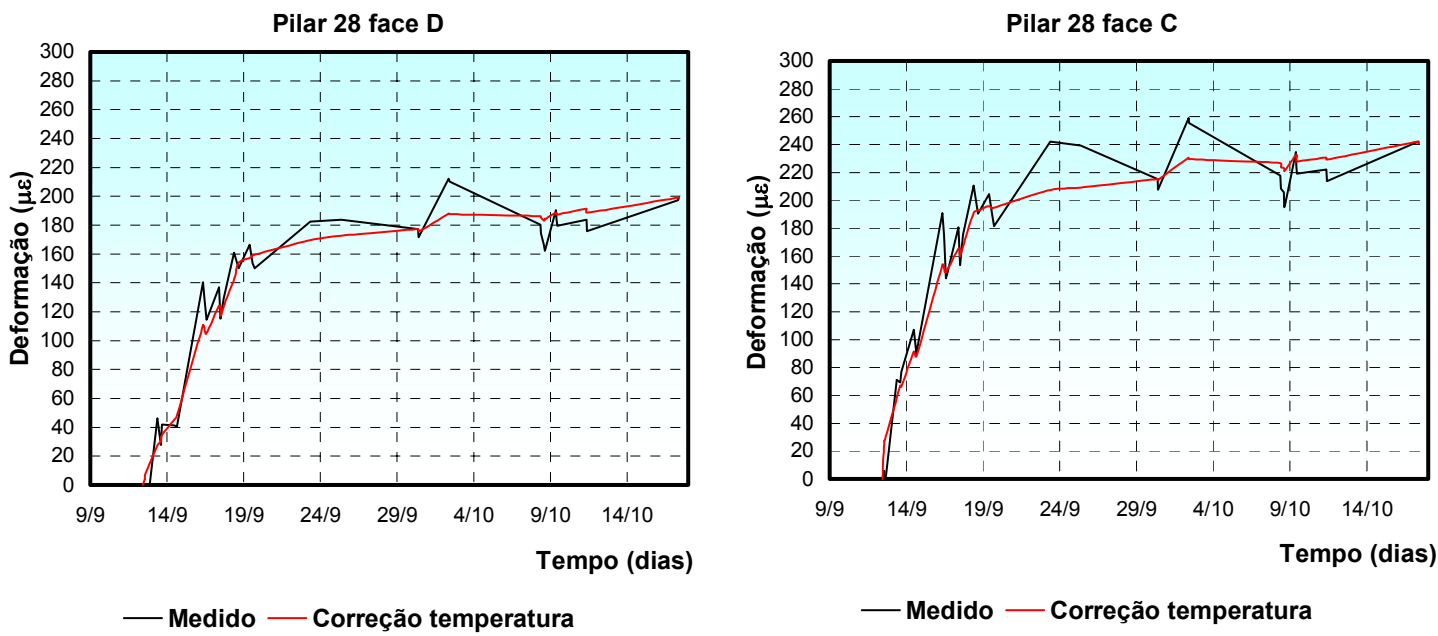

a) Temperatura
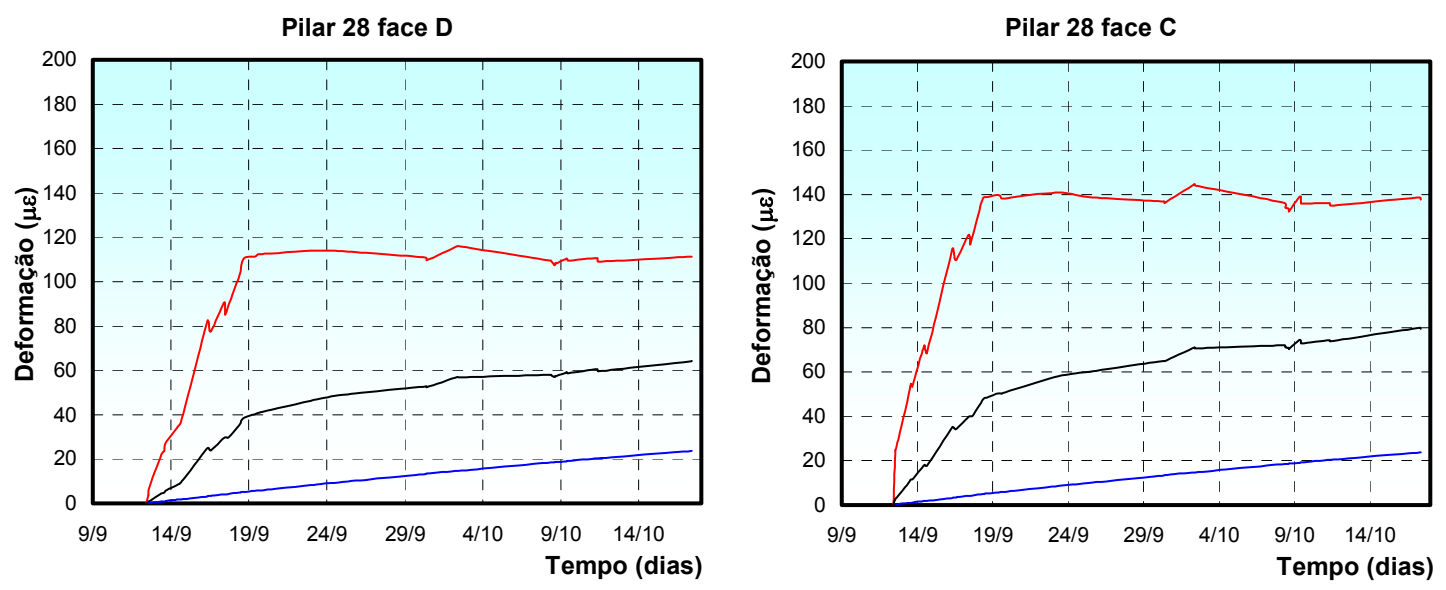

—Elástico — Fluência — Retração

b) Reologia
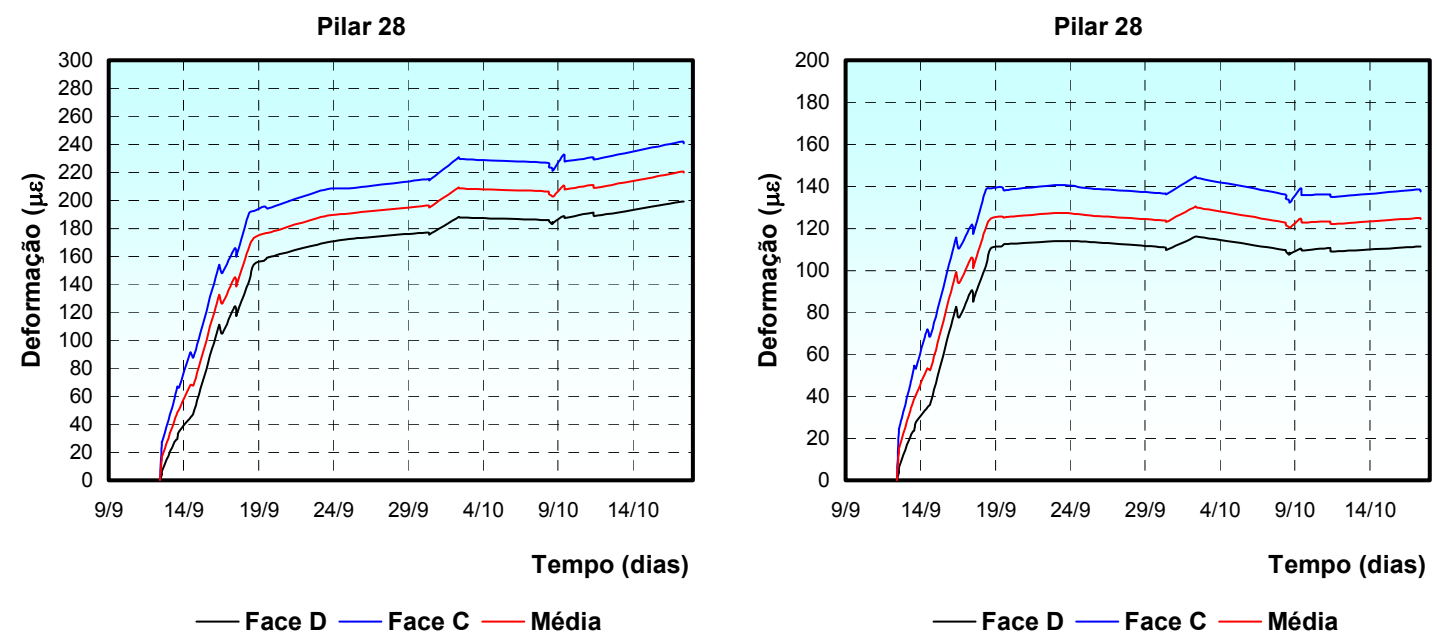

c) Flexão

Figura 6.11 - Curvas tempo deformação pilar 28. 

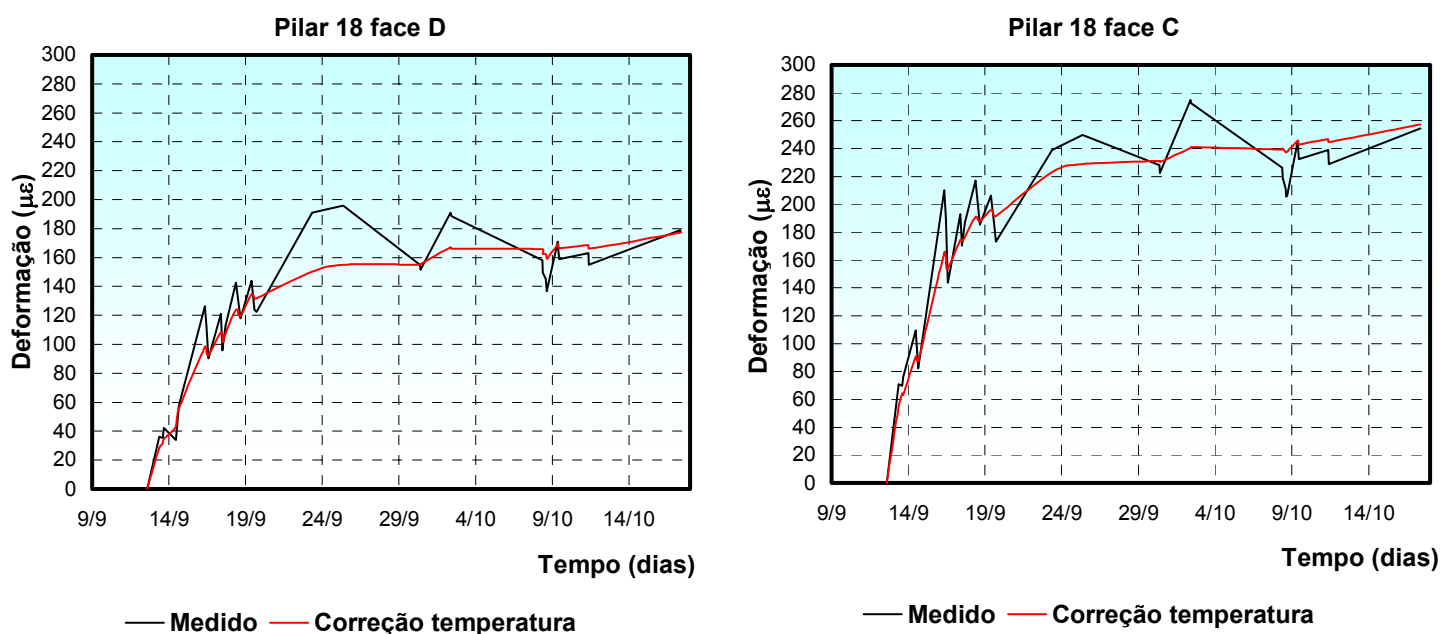

a) Temperatura
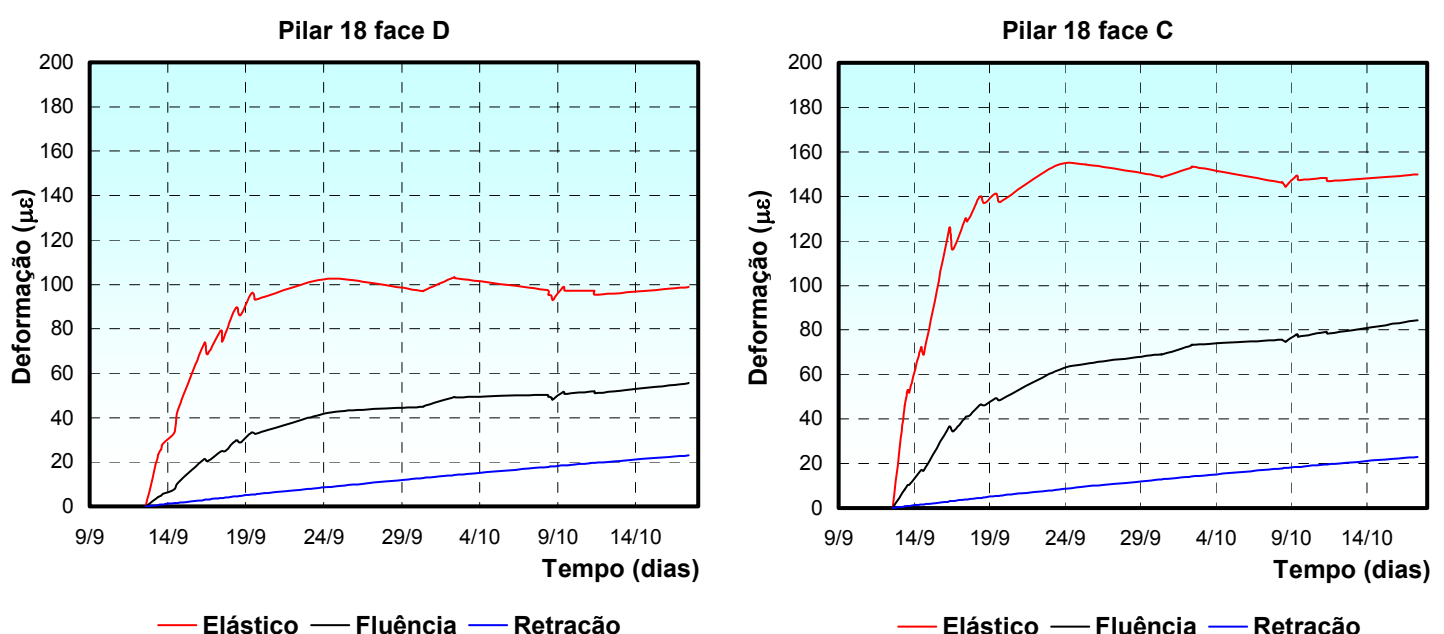

—Elástico — Fluência — Retração

b) Reologia
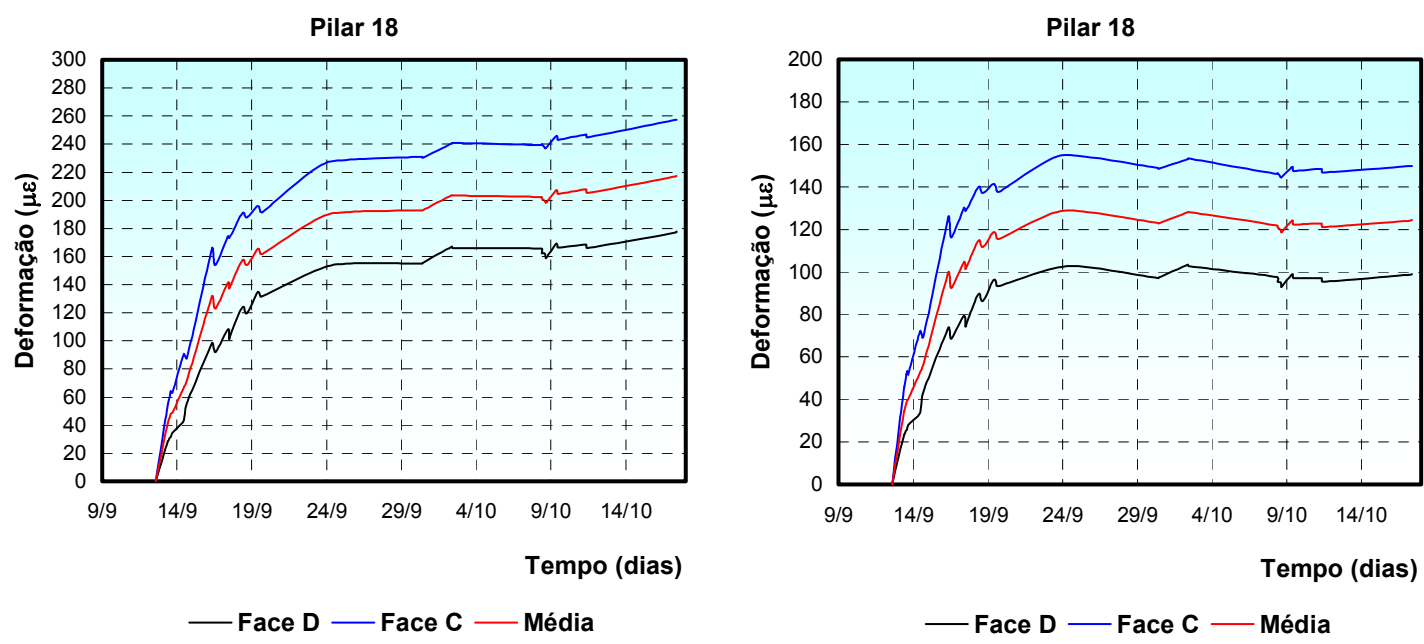

c) Flexão

Figura 6.12 - Curvas tempo deformação pilar 18. 

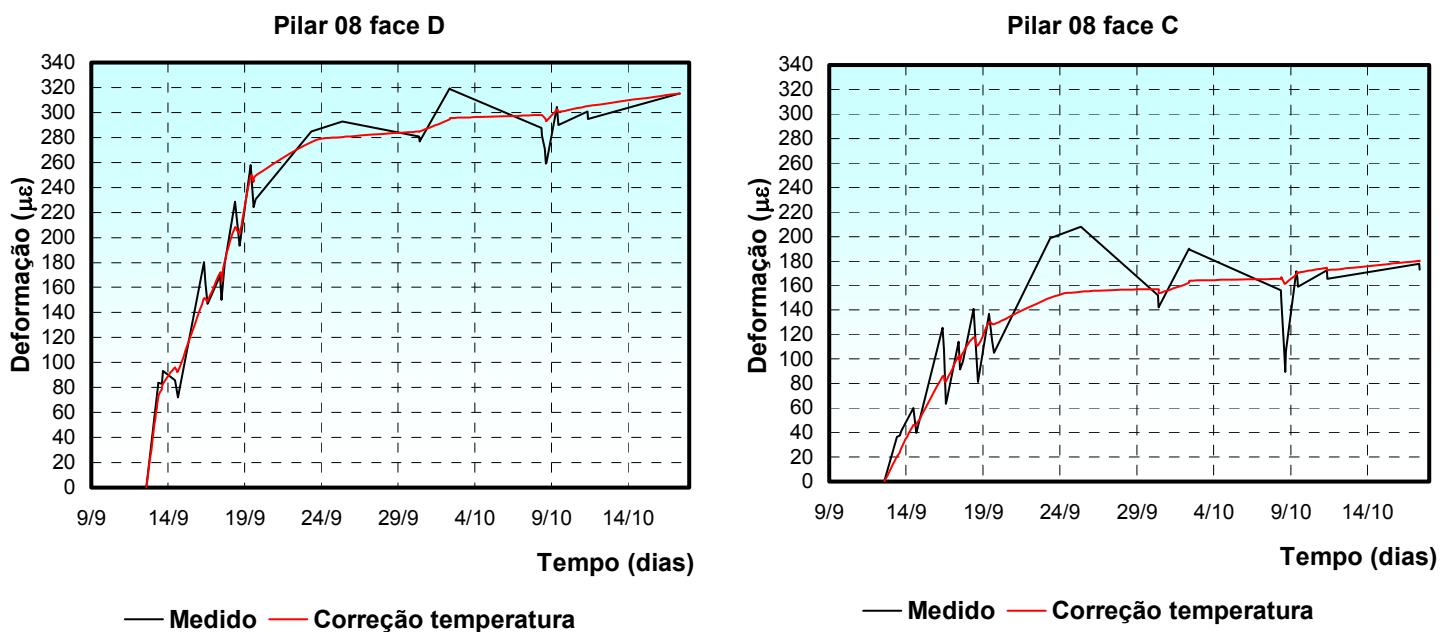

a) Temperatura
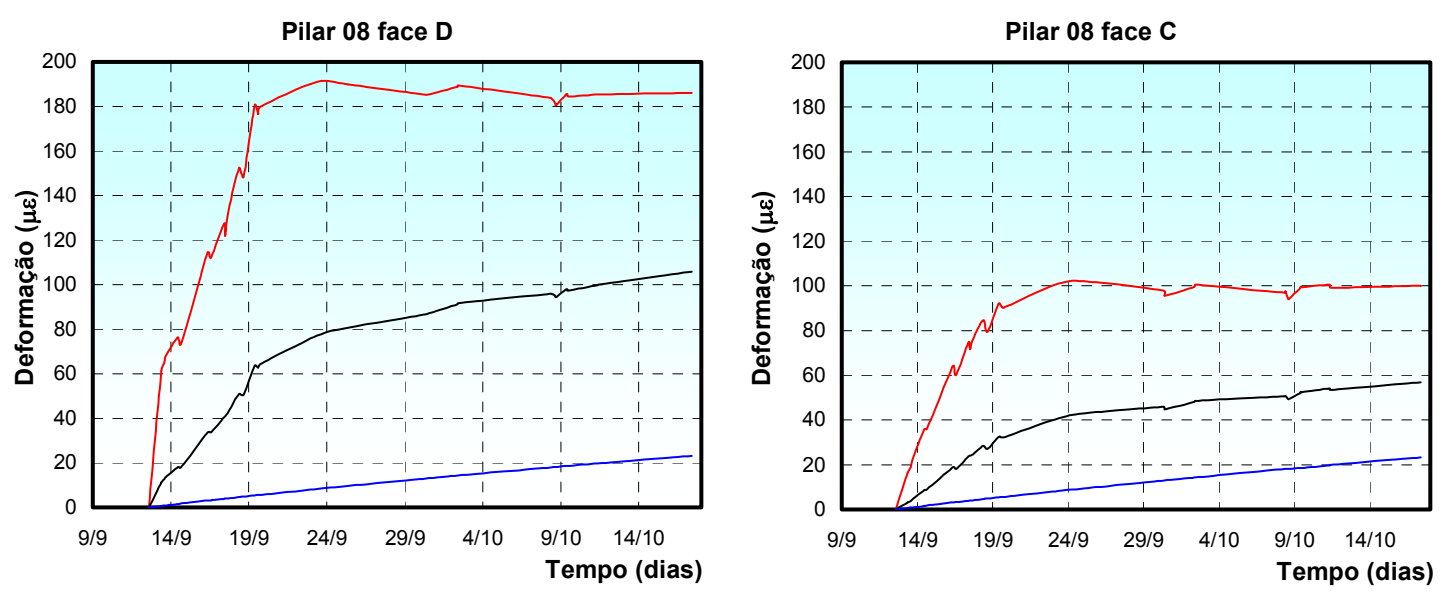

—Elástico — Fluência — Retração

b) Reologia
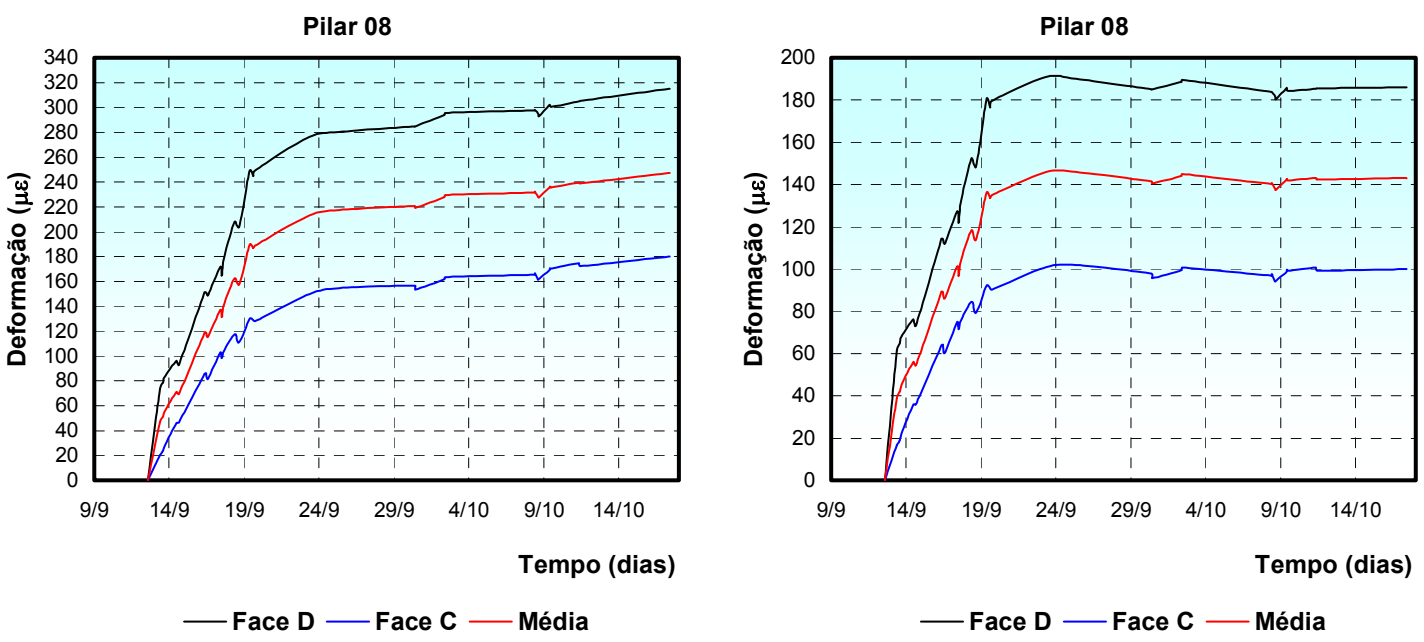

c) Flexão

Figura 6.13 - Curvas tempo deformação pilar 08. 
Pilar 39 face D

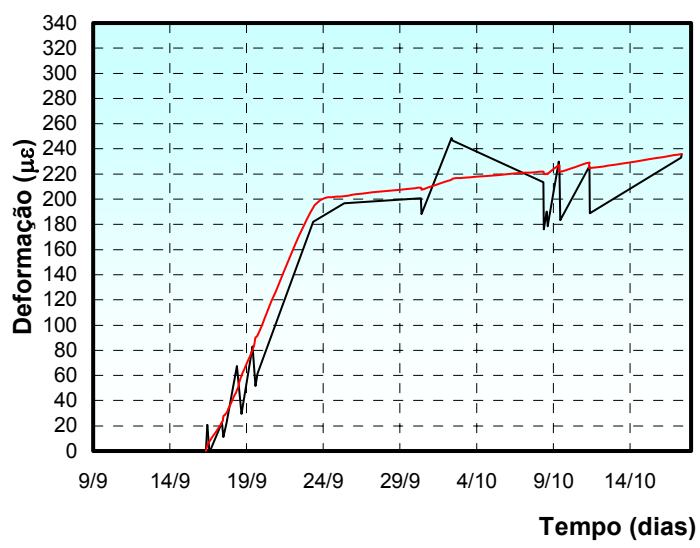

— Medido —Correção temperatura

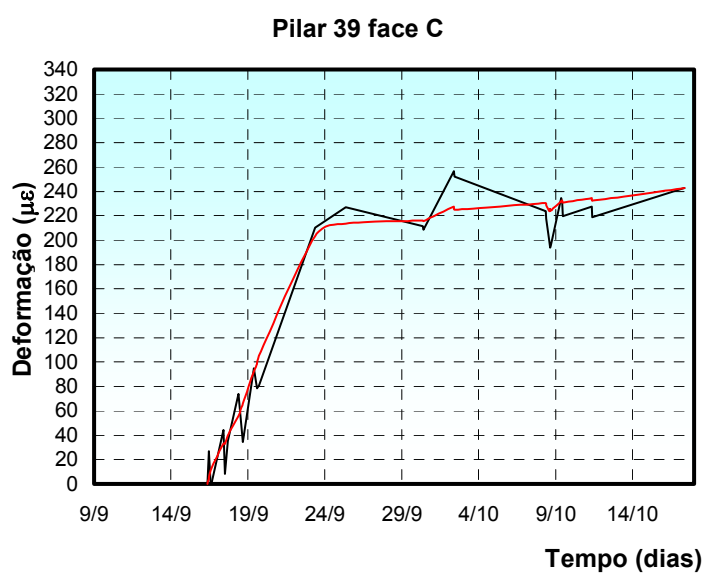

— Medido — Correção temperatura

a) Temperatura

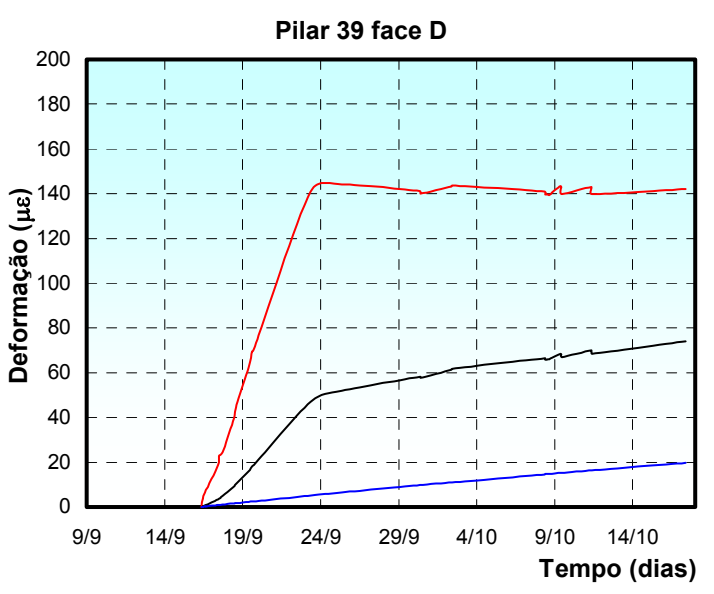

— Elástico — Fluência — Retração

b) Reologia

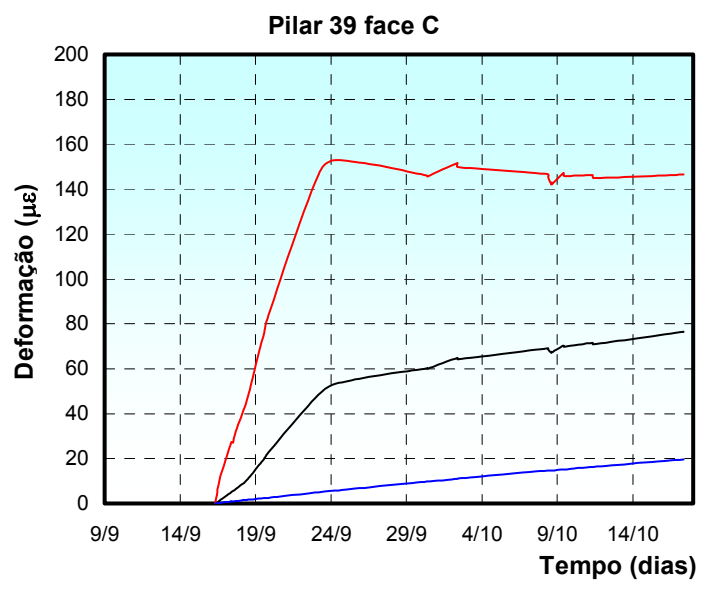

—Elástico — Fluência — Retração

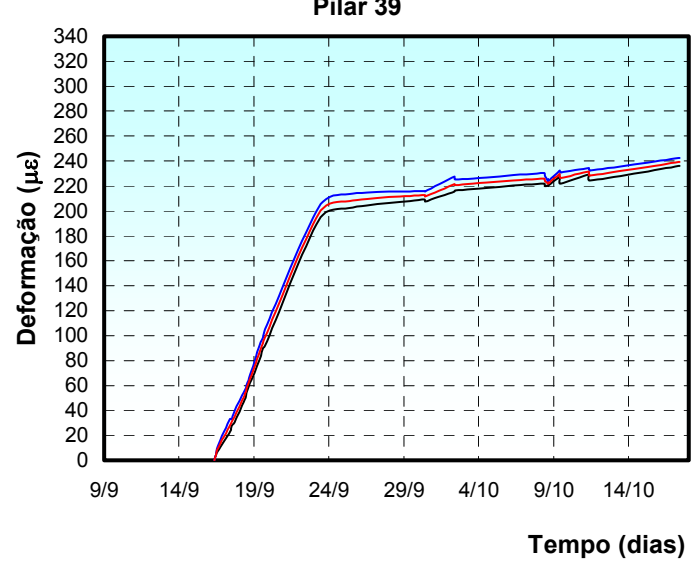

— Face D — Face C — Média
Pilar 39

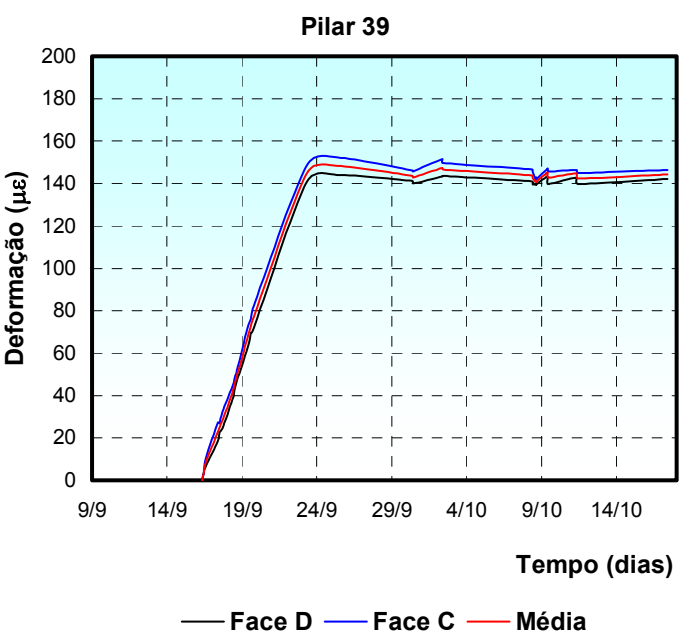

— Face D — Face C — Média

Figura 6.14 - Curvas tempo deformação pilar 39. 

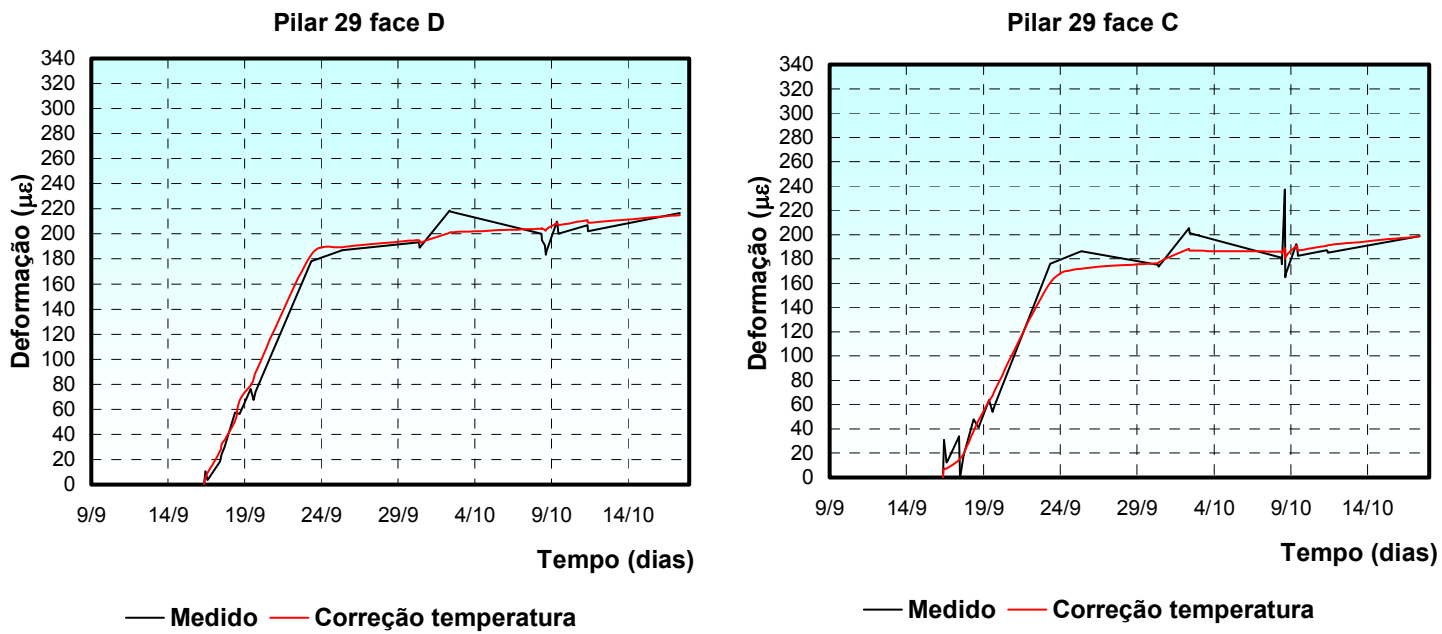

a) Temperatura
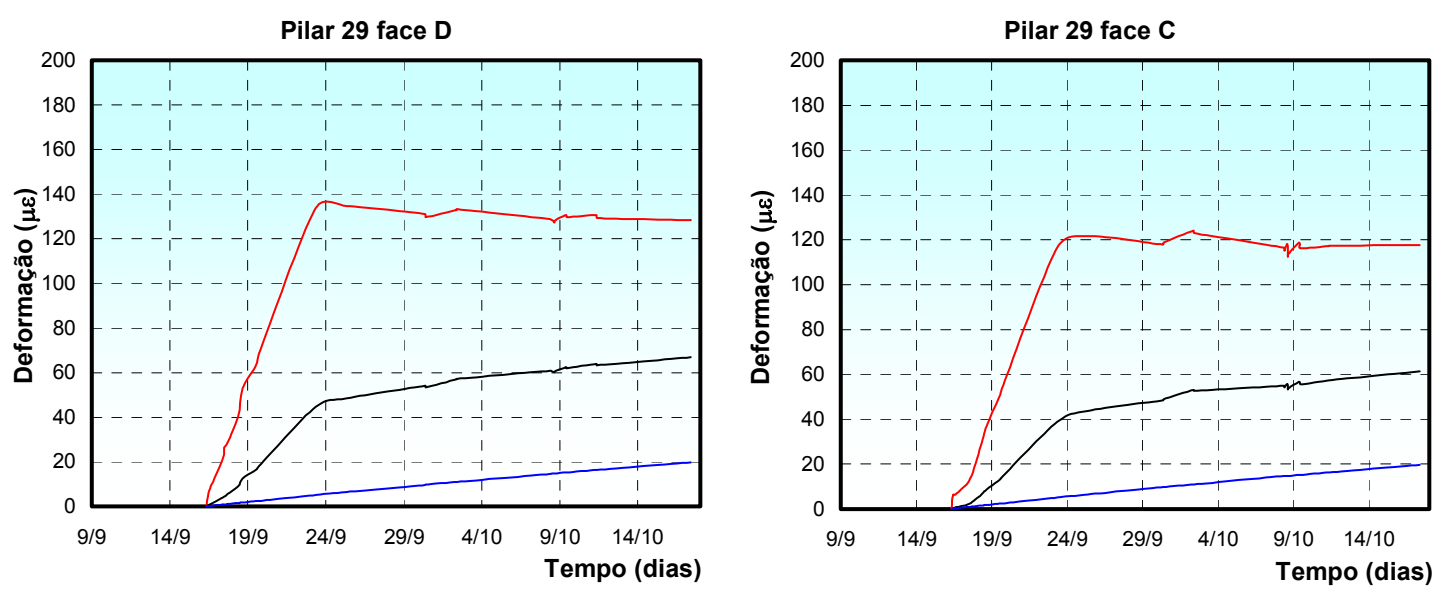

—Elástico — Fluência — Retração

b) Reologia
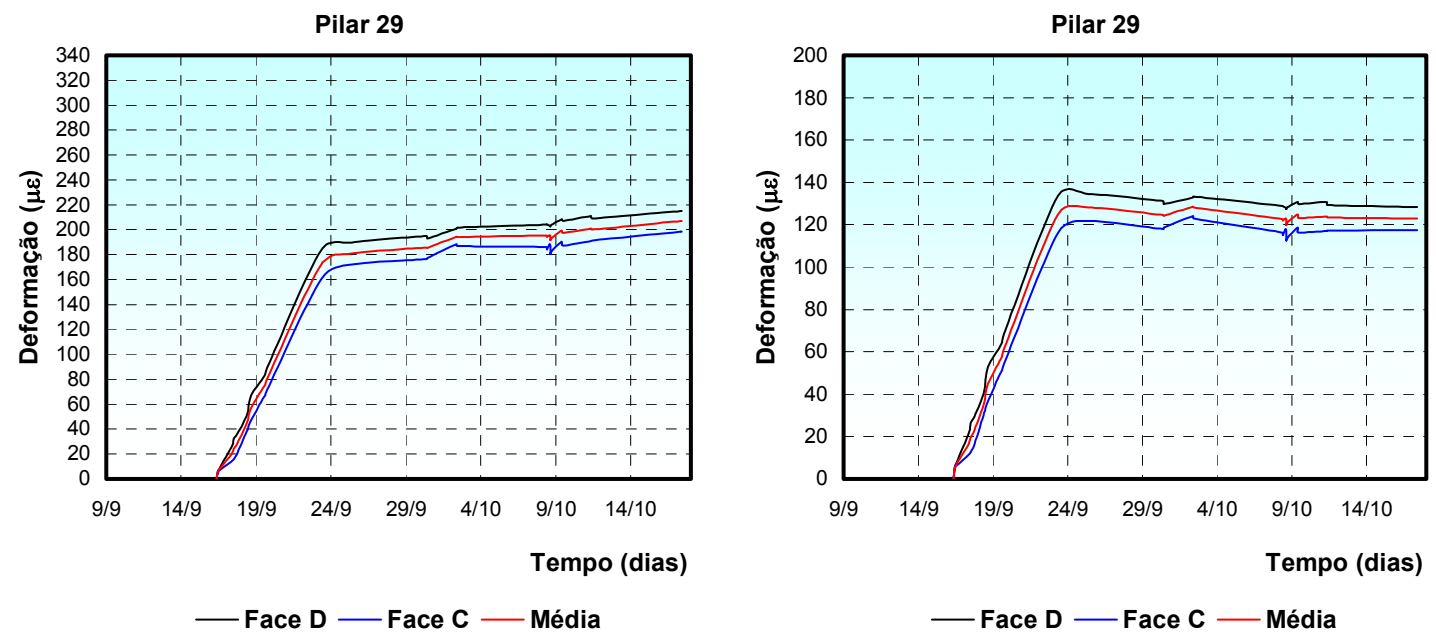

c) Flexão

Figura 6.15 - Curvas tempo deformação pilar 29. 


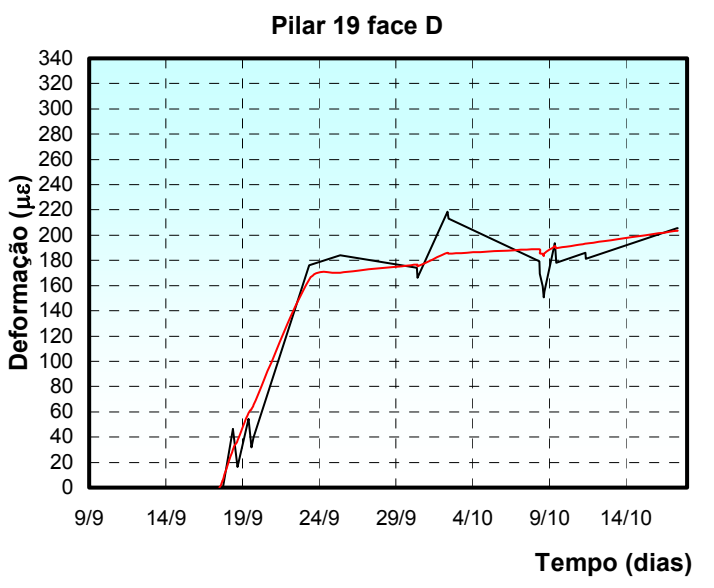

— Medido —Correção temperatura

a) Temperatura

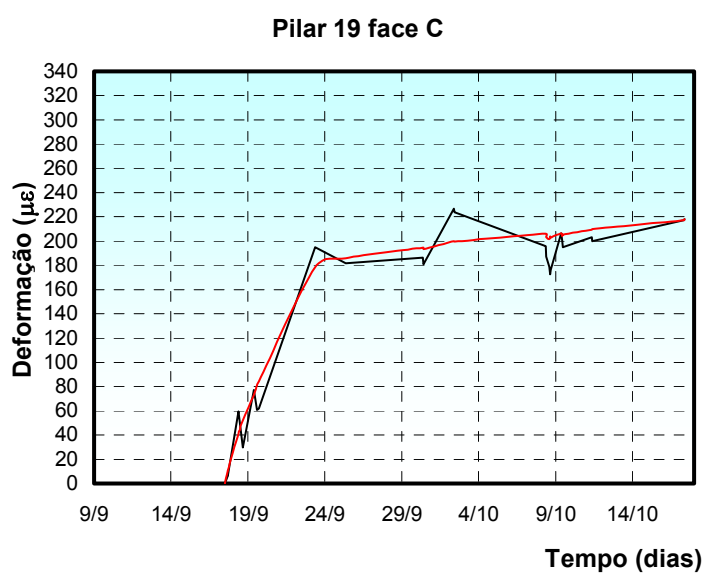

— Medido — Correção temperatura
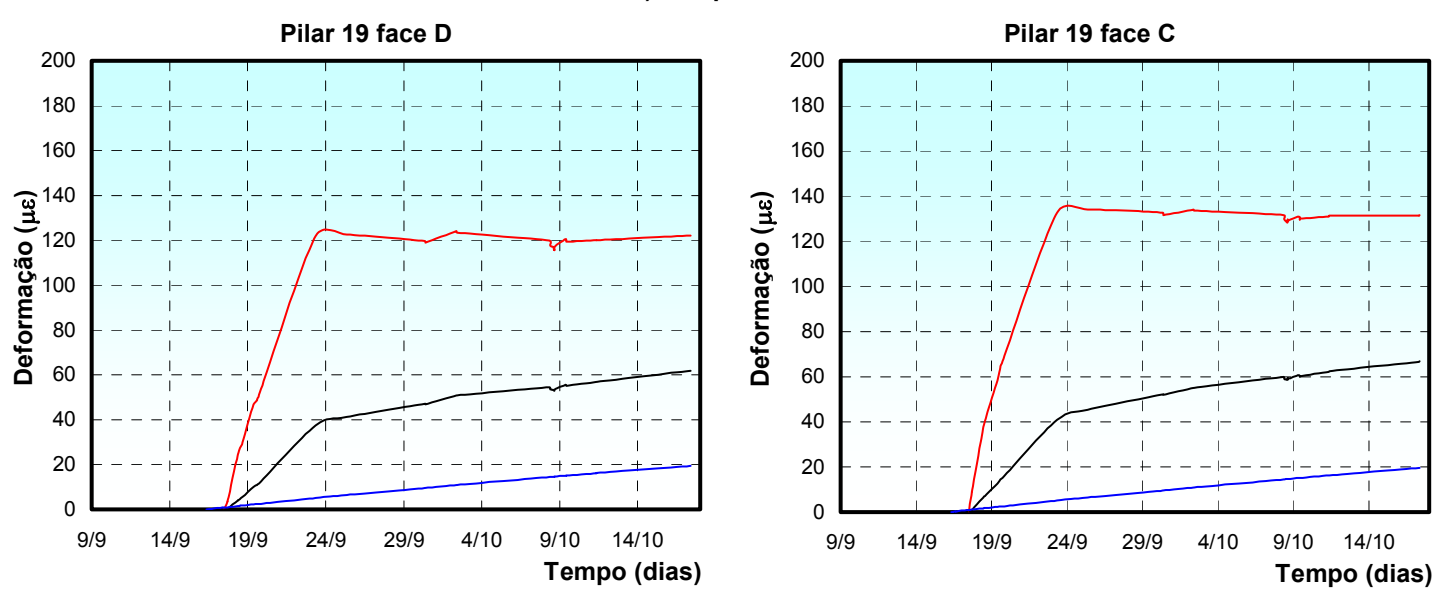

— Elástico — Fluência — Retração

b) Reologia
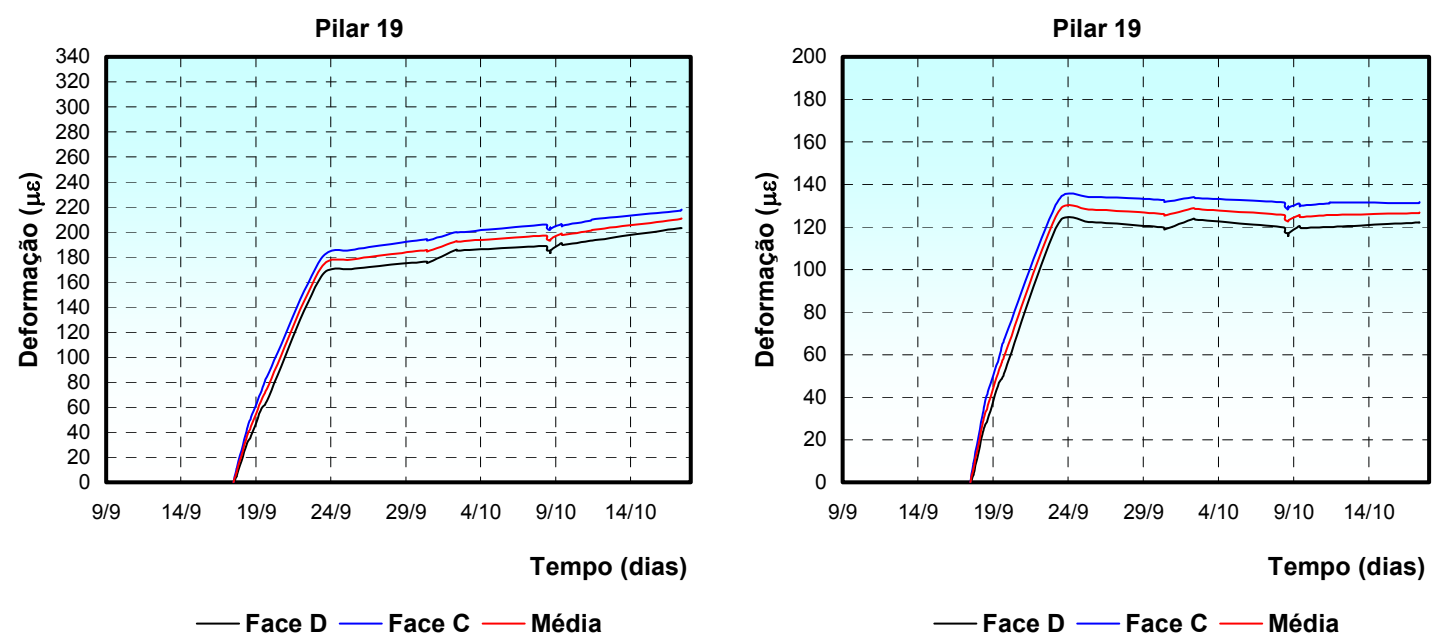

c) Flexão

Figura 6.16 - Curvas tempo deformação pilar 19. 

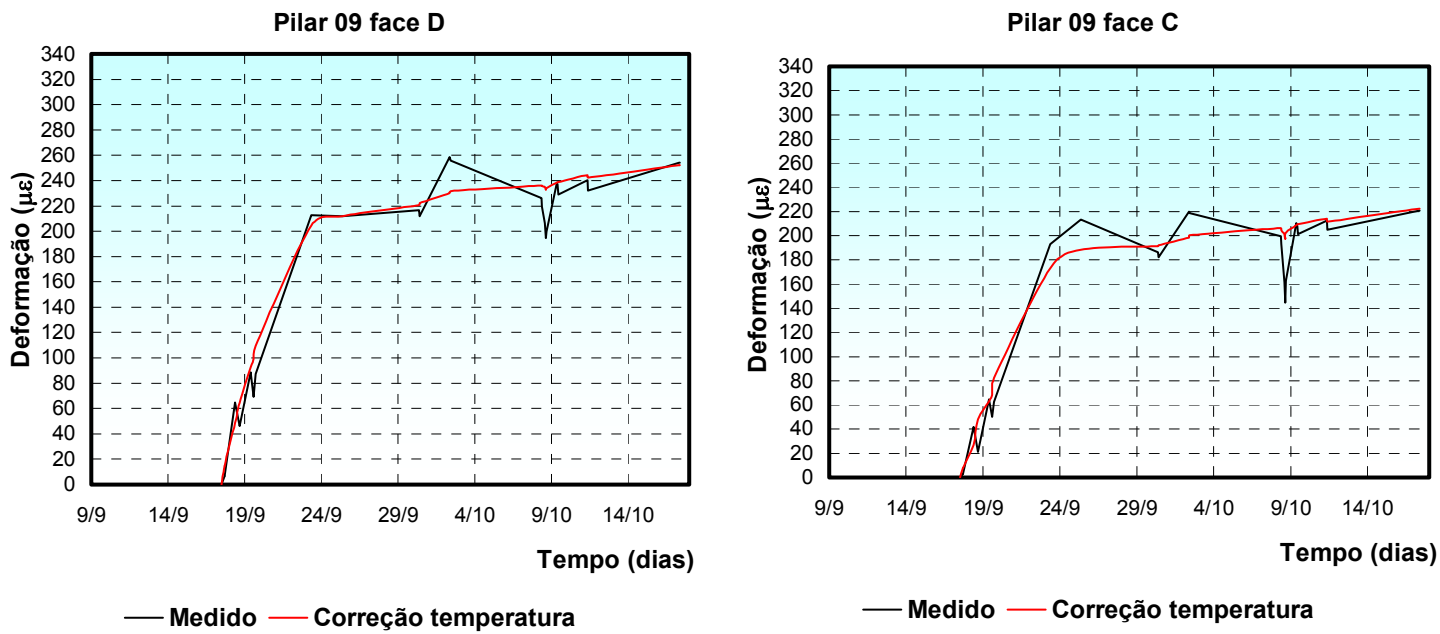

a) Temperatura
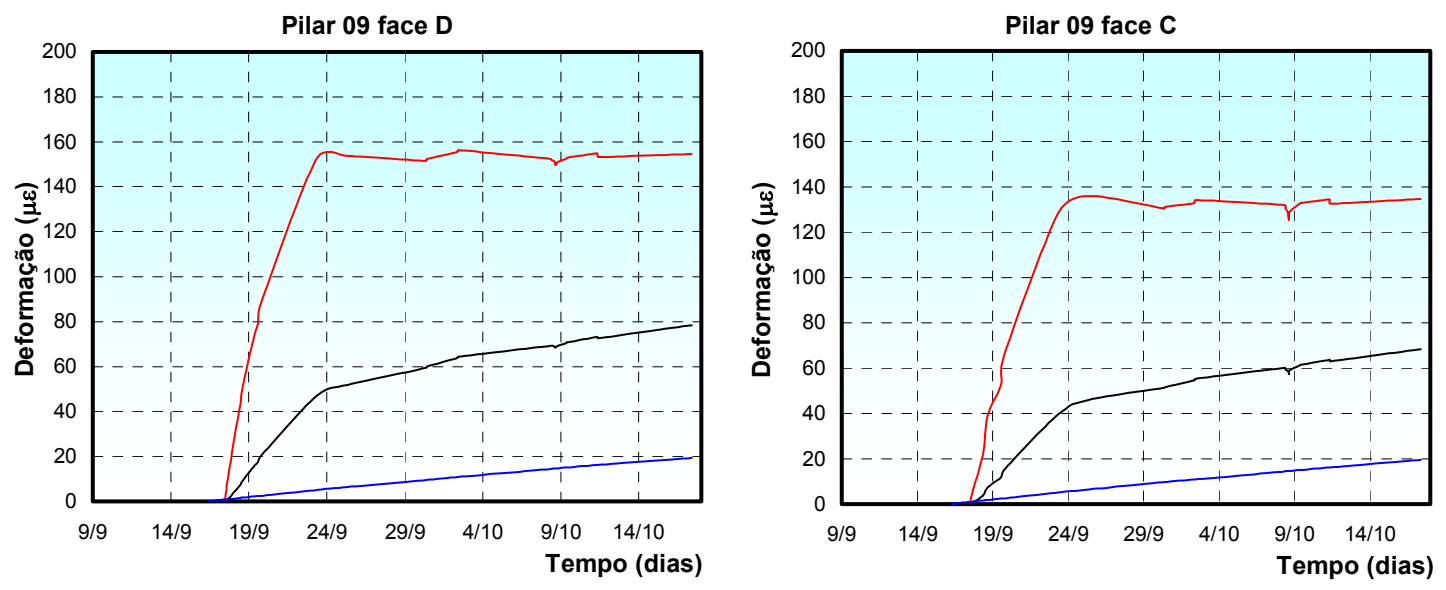

—Elástico — Fluência — Retração

b) Reologia
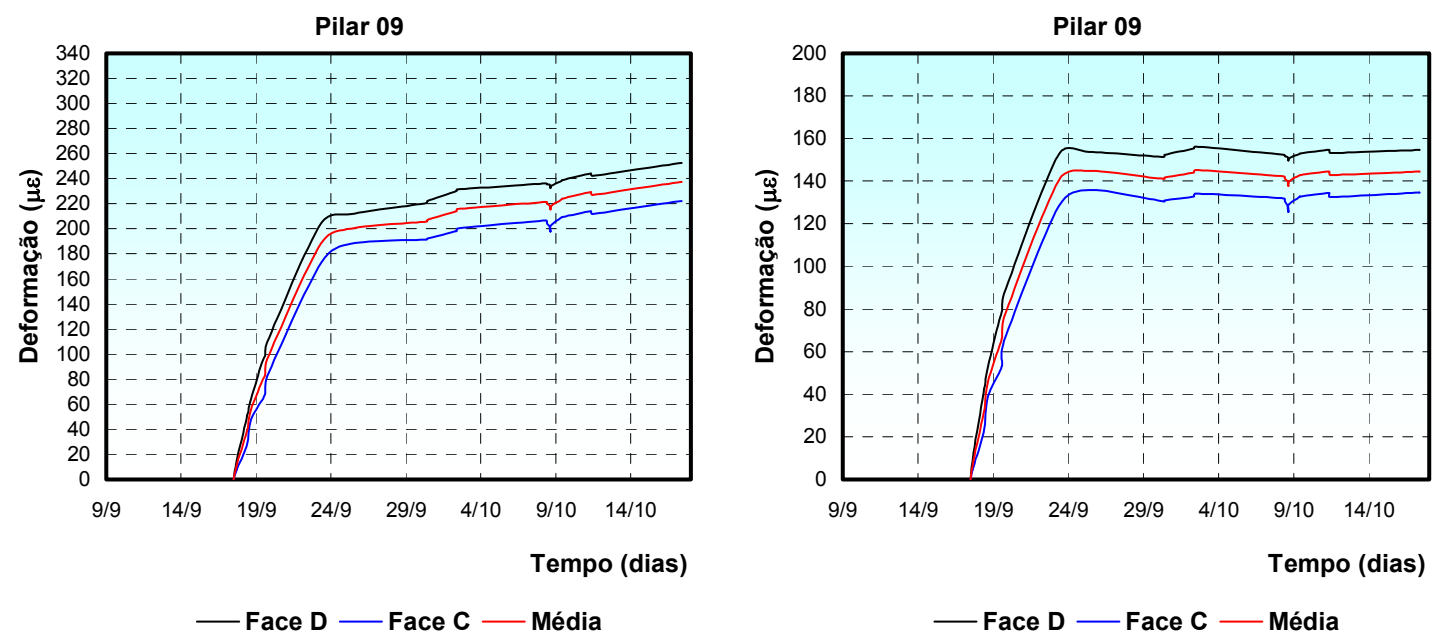

c) Flexão

Figura 6.17 - Curvas tempo deformação pilar 09. 


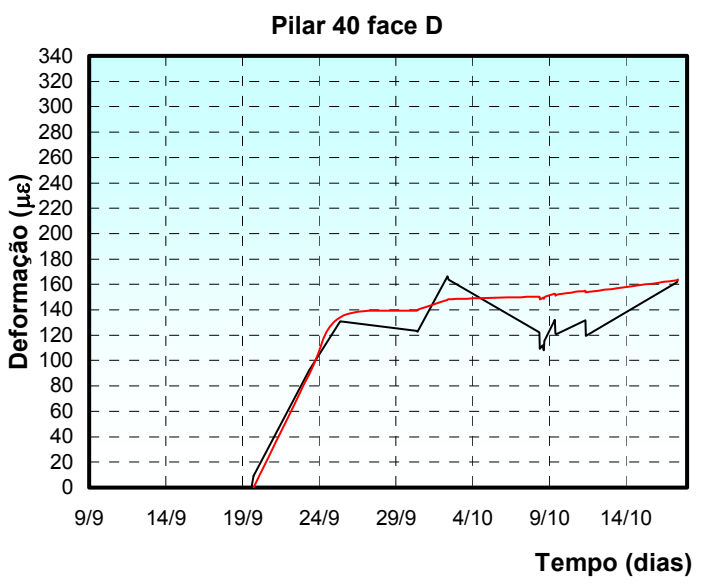

— Medido —Correção temperatura

a) Temperatura

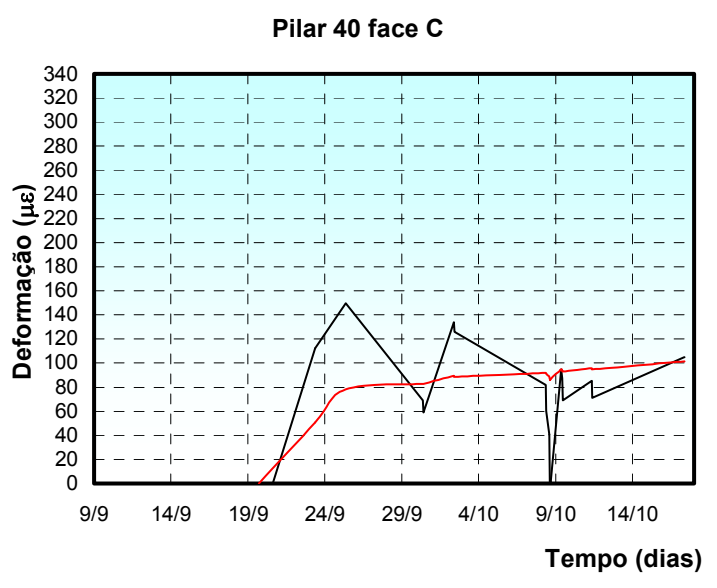

— Medido —Correção temperatura
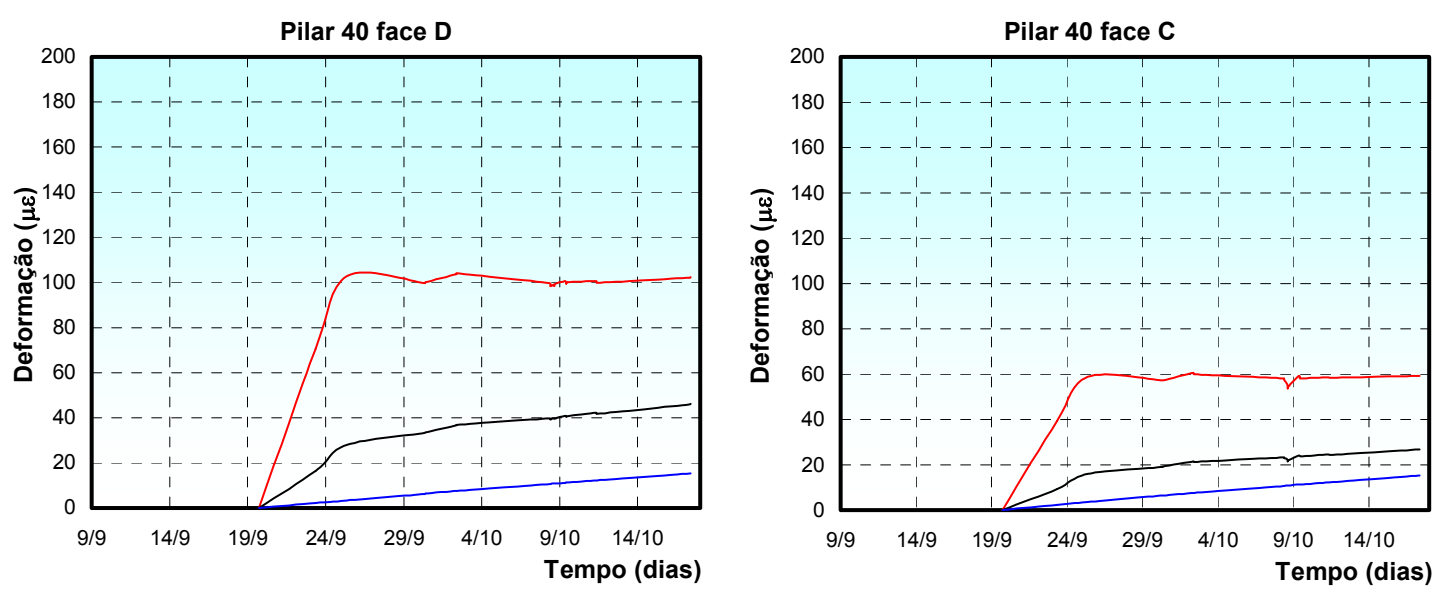

—Elástico — Fluência — Retração

b) Reologia
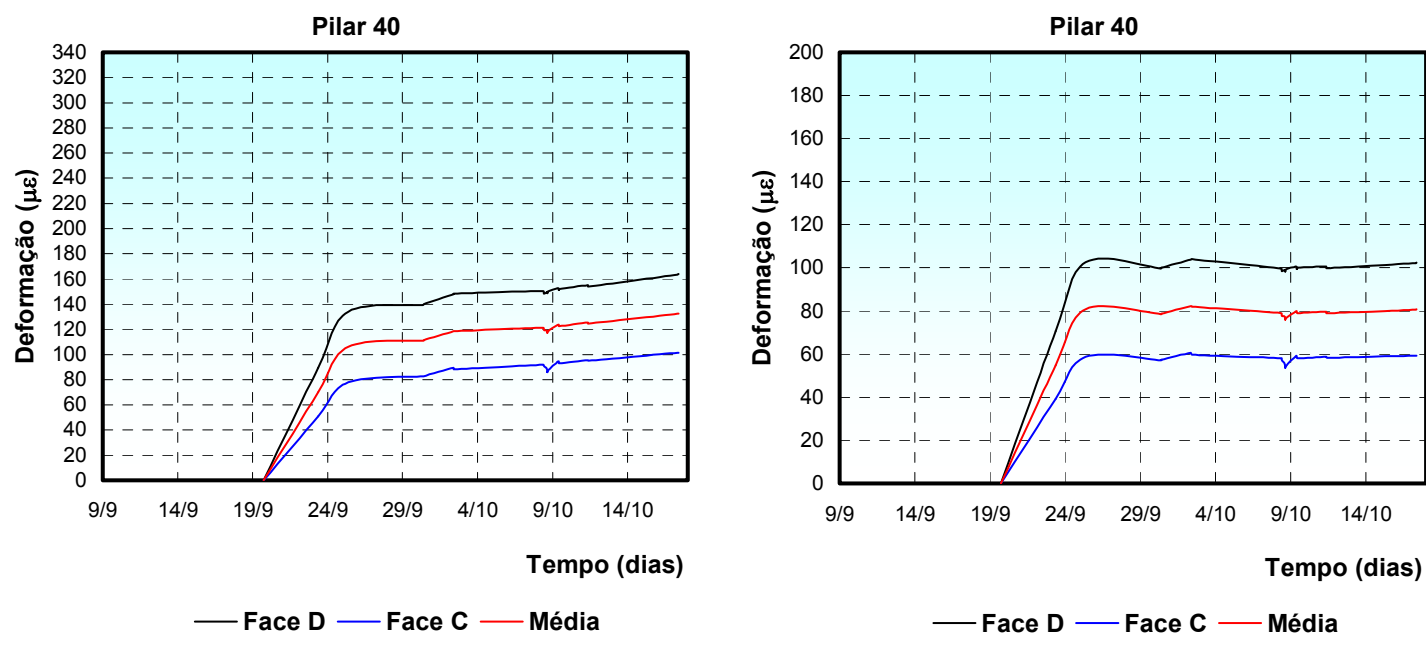

c) Flexão

Figura 6.18 - Curvas tempo deformação pilar 40. 

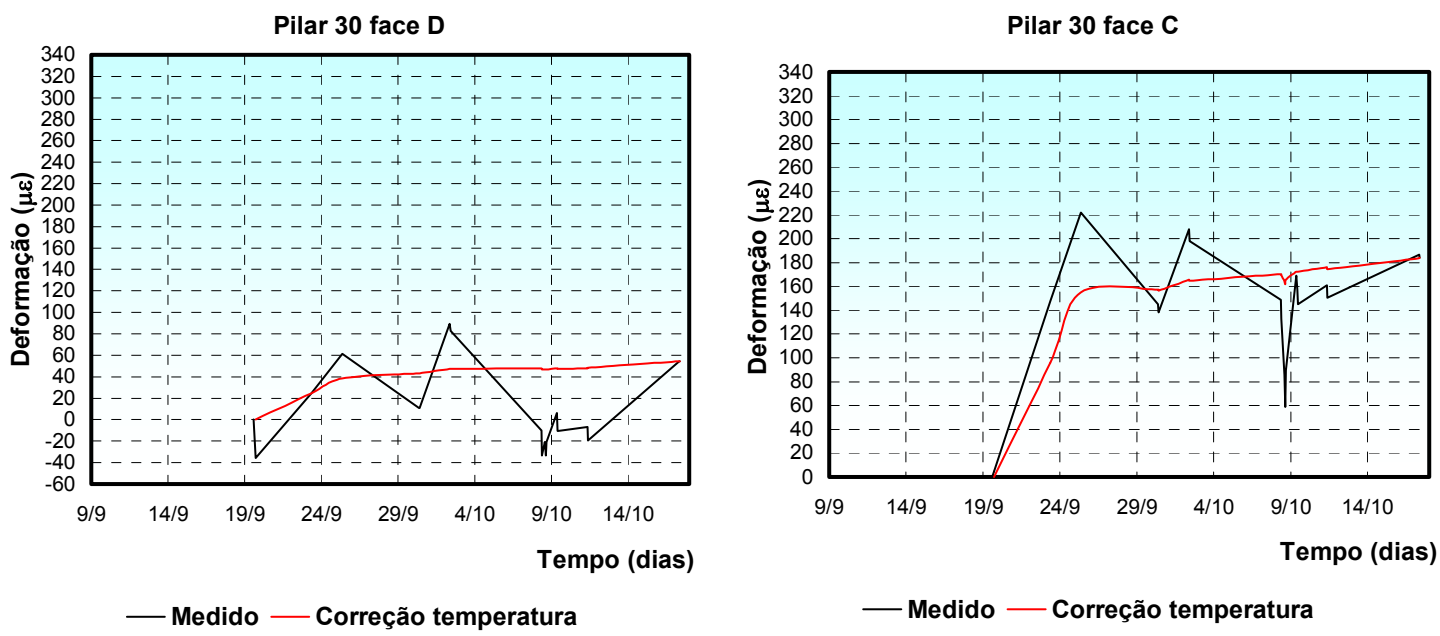

a) Temperatura
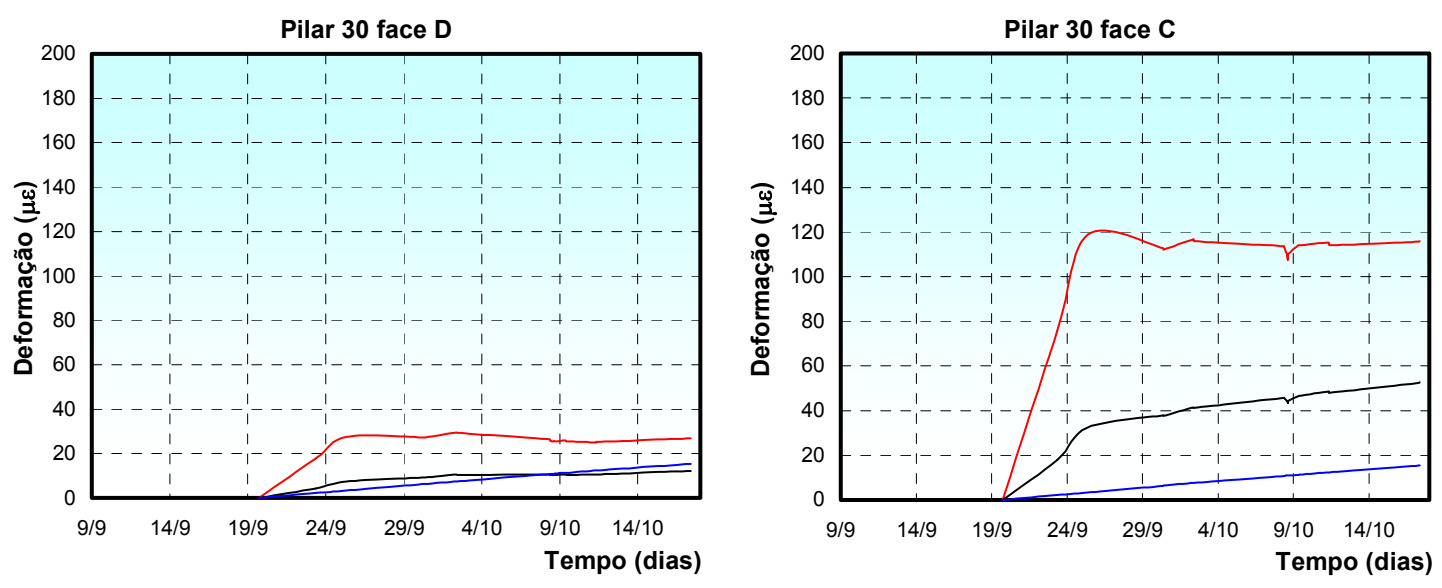

—Elástico — Fluência — Retração

—Elástico — Fluência — Retração

b) Reologia
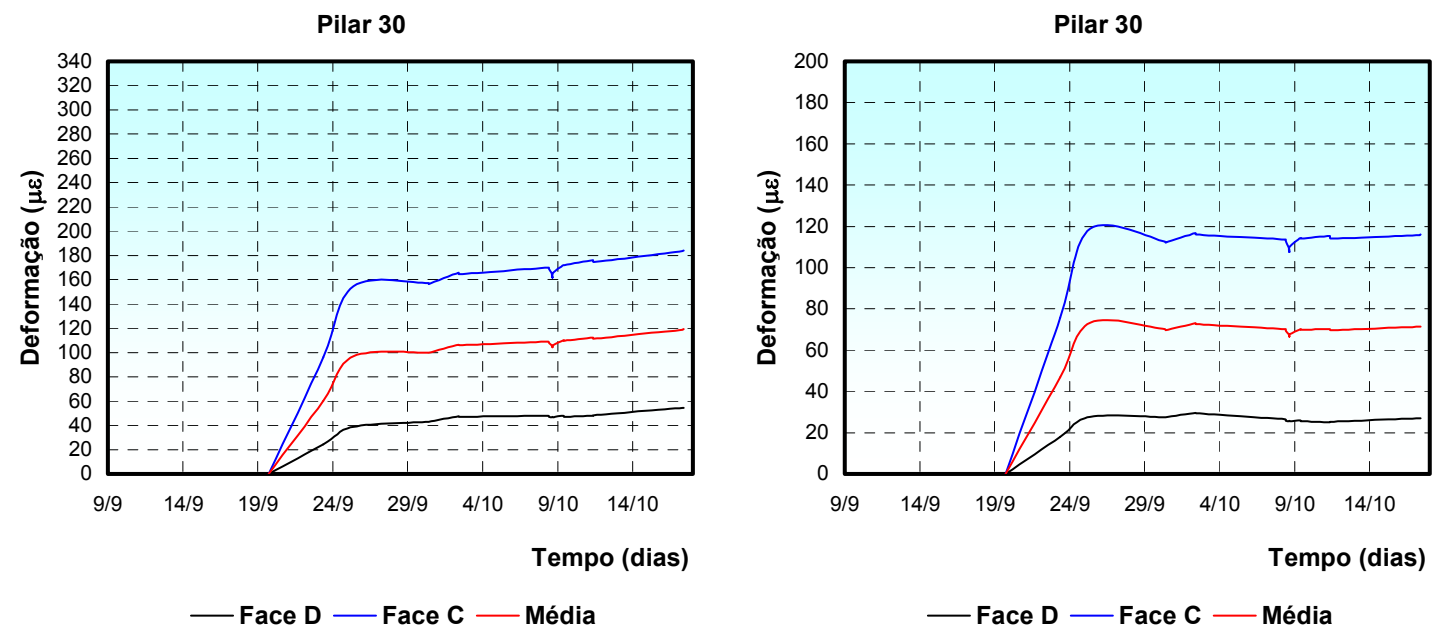

c) Flexão

Figura 6.19 - Curvas tempo deformação pilar 30. 


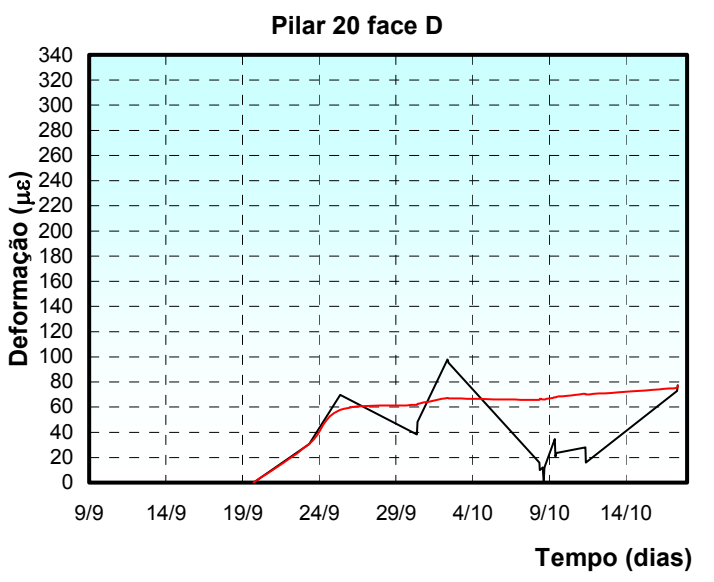

— Medido —Correção temperatura

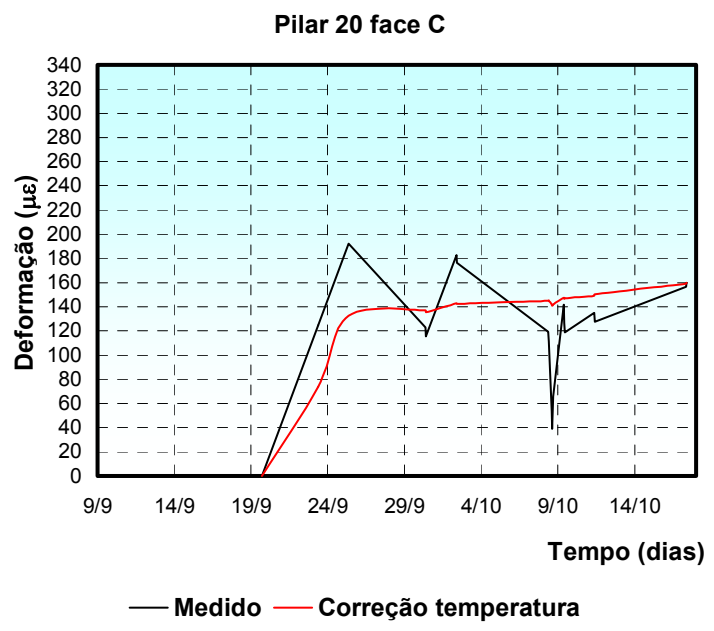

a) Temperatura
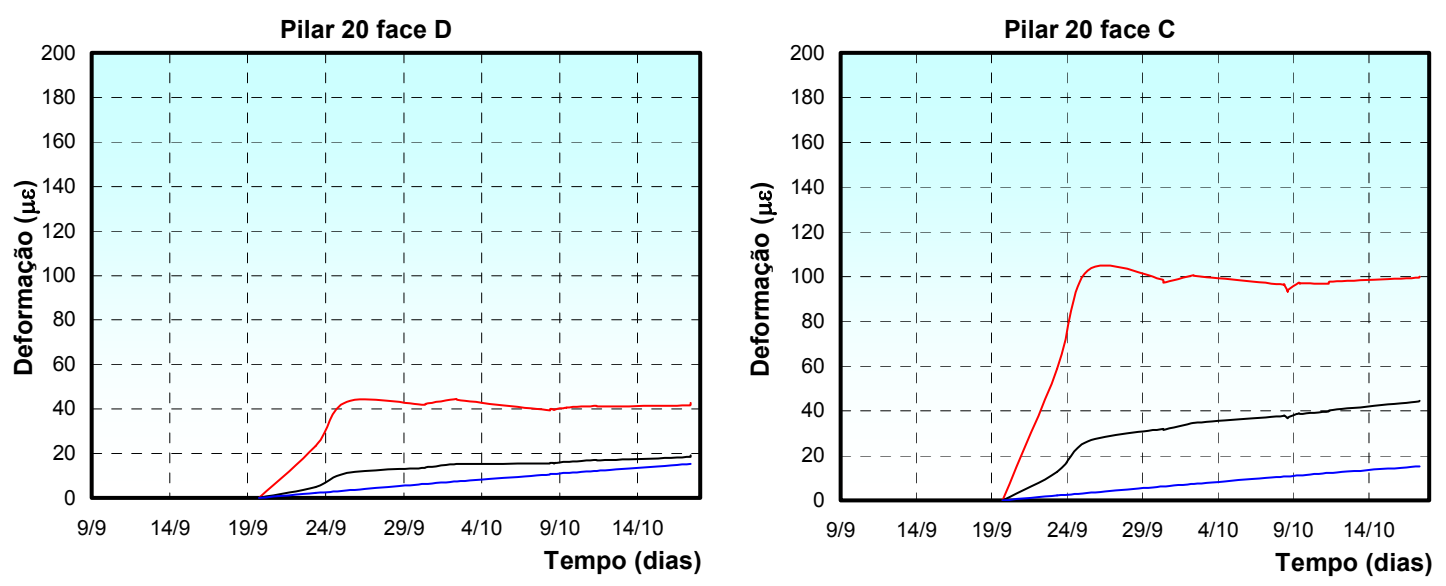

— Elástico — Fluência — Retração

—Elástico — Fluência — Retração

b) Reologia
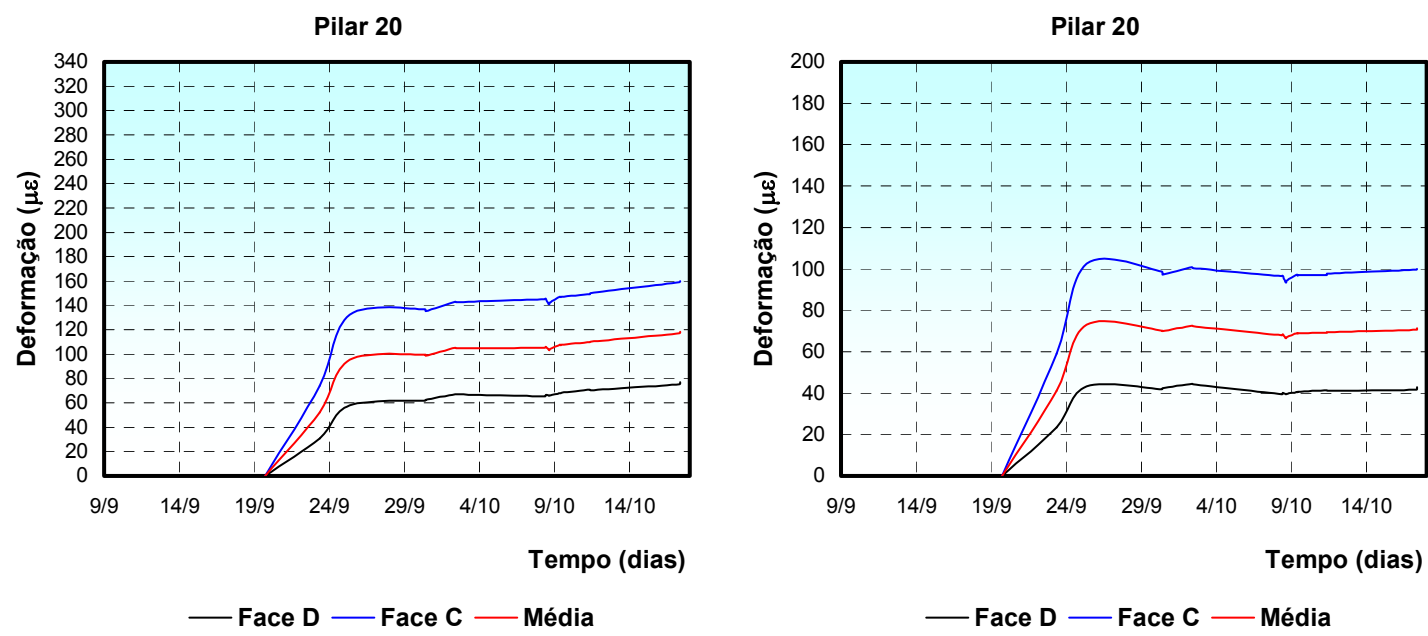

c) Flexão

Figura 6.20 - Curvas tempo deformação pilar 20. 
Pilar 10 face D

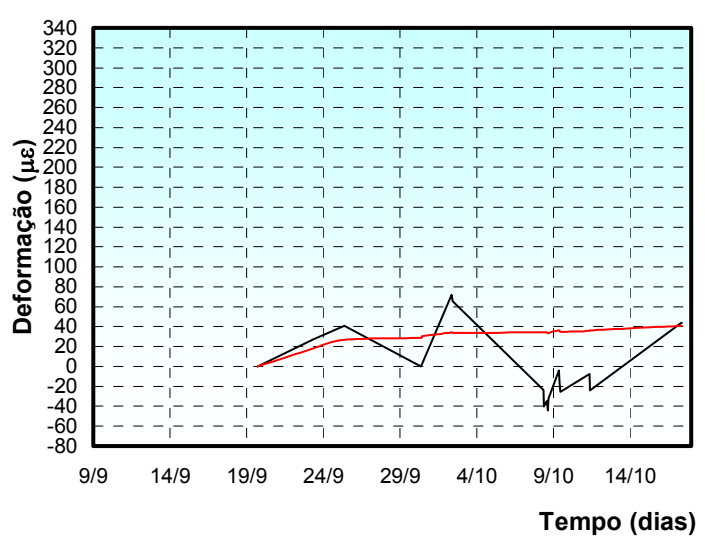

— Medido —Correção temperatura

a) Temperatura
Pilar 10 face $\mathrm{C}$

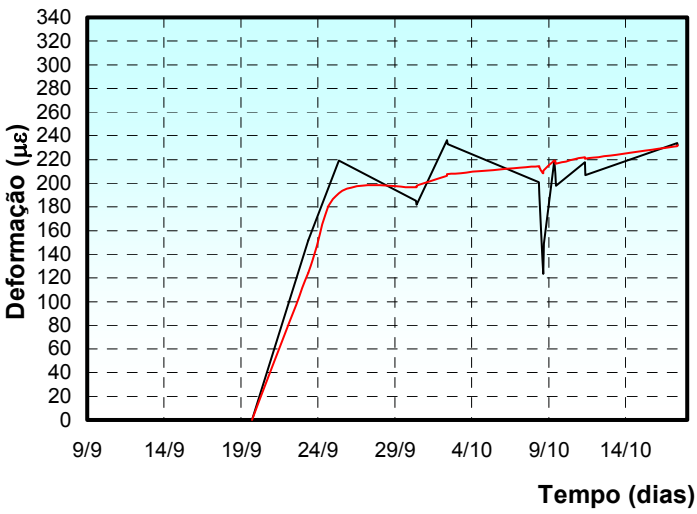

— Medido — Correção temperatura

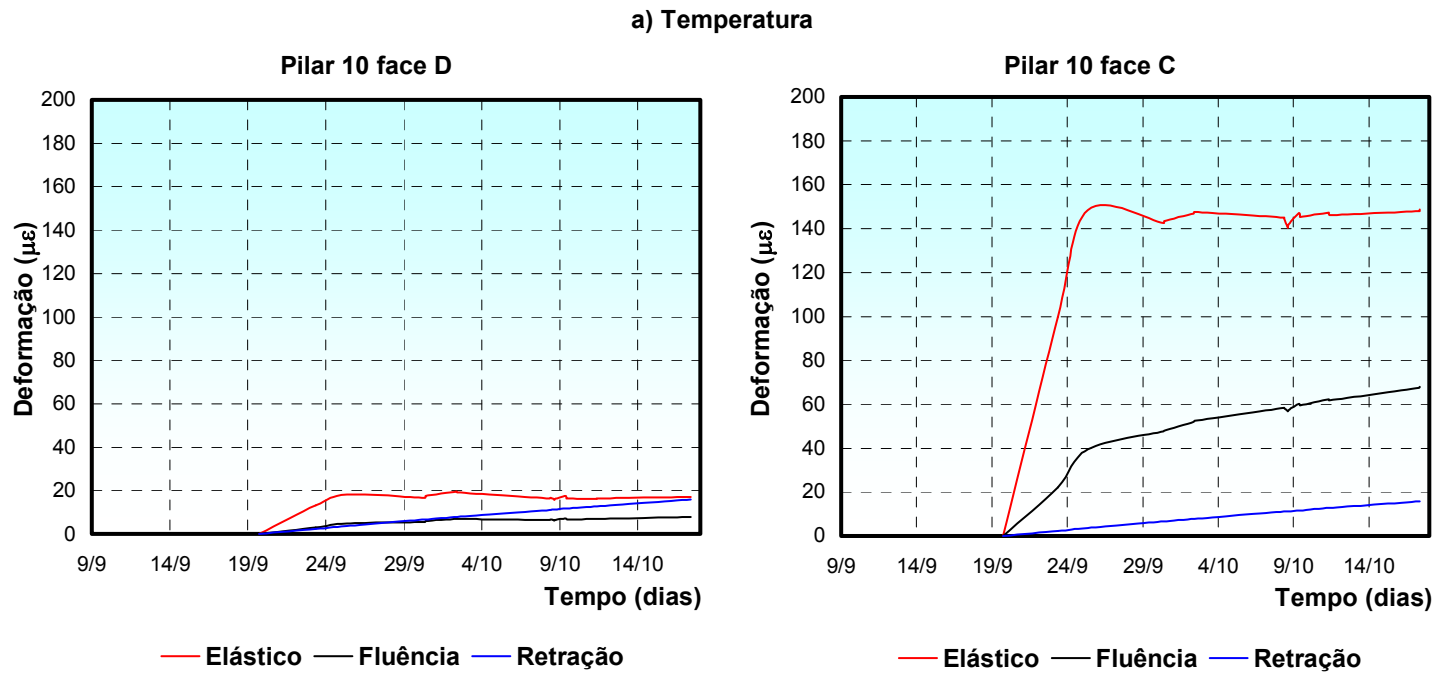

b) Reologia
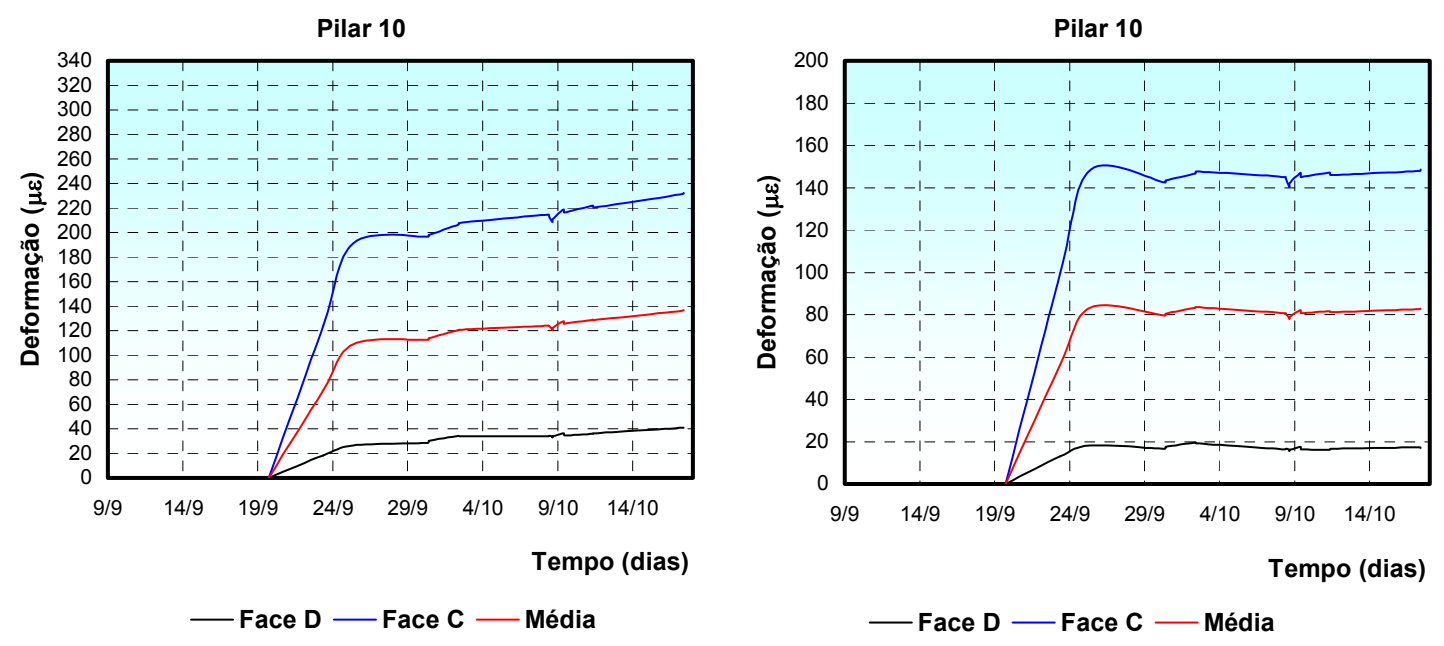

c) Flexão

Figura 6.21 - Curvas tempo deformação pilar 10. 
6.1.2 Considerações sobre a flexão observada.

São analisadas, a seguir, as diferenças entre as medidas efetuadas nas duas faces do pilar, indicadas pela instrumentação, as quais são devidas principalmente a efeitos da flexo-compressão atuante nos pilares. Essa análise poderia ser mais precisa caso tivessem sido efetuadas medidas nas quatro faces dos pilares. O propósito dessa análise é avaliar o valor da excentricidade da solicitação normal correspondente aos valores indicados pela instrumentação.

A expressão geral da flexo-compressão com um plano de simetria é:

$$
\sigma=\frac{P}{A} \pm \frac{M \times y}{I}
$$

onde:

$\sigma$ - tensão normal em um ponto situado a uma distância y do baricentro da seção;

P - solicitação normal;

A - área da seção transversal do pilar;

$\mathrm{M}$ - momento fletor atuante;

I - momento de inércia.

Para o caso em questão de seção transversal quadrada de lado (a) e para a posição da instrumentação situada na face, a expressão torna-se:

$$
\sigma_{\text {min }}=\frac{P}{A}-\frac{M \times \frac{a}{2}}{\frac{a^{4}}{12}}=\frac{P}{A}-\frac{M \times 6}{a^{3}}
$$

O momento fletor (M) pode ser expresso pelo produto da solicitação normal $(P)$ com a excentricidade $(e)$, assim,

$$
\sigma_{\min }=\frac{P}{A}-\frac{P \times e \times 6}{A \times a}=\frac{P}{A}\left(1-\frac{6 \times e}{a}\right)
$$


A relação (P/A) representa a tensão normal média $\left(\sigma_{\text {med }}\right)$ na seção. Assim:

$$
\sigma_{\text {min }}=\sigma_{\text {med }}\left(1-\frac{6 \times e}{a}\right) \quad \frac{\sigma_{\min }}{\sigma_{\text {med }}}=\left(1-\frac{6 \times e}{a}\right) \quad e=\frac{a}{6}\left(1-\frac{\sigma_{\text {min }}}{\sigma_{\text {med }}}\right)
$$

Admitindo proporcionalidade linear entre tensão e deformação, conforme Lei de Hooke, segundo um módulo de elasticidade do concreto armado $E_{c a}$, temos:

$$
\sigma=E_{c a} \times \varepsilon
$$

Assim, pode-se escrever:

$$
e=\frac{a}{6}\left(1-\frac{\varepsilon_{\min }}{\varepsilon_{\text {med }}}\right)
$$

Dessa forma, a excentricidade da solicitação normal foi avaliada para todos os pilares monitorados, estando os resultados apresentados na Tabela 6.1.

Tabela 6.1 - Avaliação da excentricidade (e) da solicitação normal, valores em $\mathrm{cm}$.

\begin{tabular}{ccccccccc}
\hline Pilar & $\begin{array}{c}\mathrm{e} \\
(\mathrm{cm})\end{array}$ & Direção & Pilar & $\begin{array}{c}\mathrm{e} \\
(\mathrm{cm})\end{array}$ & Direção & Pilar & $\begin{array}{c}\mathrm{e} \\
(\mathrm{cm})\end{array}$ & Direção \\
\hline 36 & 0,2 & $\mathrm{AB}$ & 37 & 0,03 & $\mathrm{AB}$ & 38 & 1,1 & $\mathrm{CD}$ \\
26 & 2,5 & $\mathrm{AB}$ & 27 & 0,8 & $\mathrm{AB}$ & 28 & 0,7 & $\mathrm{CD}$ \\
16 & 0,9 & $\mathrm{AB}$ & 17 & 1,2 & $\mathrm{AB}$ & 18 & 1,4 & $\mathrm{CD}$ \\
06 & 6,7 & $\mathrm{AB}$ & 07 & 0,7 & $\mathrm{AB}$ & 08 & 2,1 & $\mathrm{CD}$ \\
\hline
\end{tabular}

\begin{tabular}{cccccc}
\hline Pilar & $\begin{array}{c}\mathrm{e} \\
(\mathrm{cm})\end{array}$ & Direção & Pilar & $\begin{array}{c}\mathrm{e} \\
(\mathrm{cm})\end{array}$ & Direção \\
\hline 39 & 0,1 & $\mathrm{CD}$ & 40 & 1,8 & $\mathrm{CD}$ \\
29 & 0,3 & $\mathrm{CD}$ & 30 & 4,2 & $\mathrm{CD}$ \\
19 & 0,3 & $\mathrm{CD}$ & 20 & 2,7 & $\mathrm{CD}$ \\
09 & 0,5 & $\mathrm{CD}$ & 10 & 5,3 & $\mathrm{CD}$ \\
\hline
\end{tabular}

Pode-se observar, na Tabela 6.1 , que os valores determinados são muito pequenos e podem ser, em primeira aproximação, atribuídos a 
peculiaridades e imprecisões de alinhamento na montagem dos elementos prémoldados. Cabem alguns comentários sobre os pilares 06, 30, 20 e 10 que apresentam maiores valores. Note-se que esses elementos encontram-se nas extremidades da estrutura e neles os efeitos de flexão nas duas direções são mais acentuados.

6.1.3 Deformações sob carga constante - fluência e retração da superestrutura.

Os valores das deformações medidas, corrigidas dos efeitos de temperatura e flexão, foram plotados, distinguindo-se as etapas de carregamento e de carga constante. Nos gráficos das Figuras 6.22 a 6.26, a linha preta mostra a evolução das deformações médias com o tempo no período de carregamento, enquanto que os pontos em vermelho indicam as deformações médias sob carga constante. A linha vermelha corresponde à curva de ajuste da regressão logarítmica dos valores observados sob carga constante. Nesses gráficos também se apresenta o valor da equação da regressão, bem como o valor do coeficiente de correlação.
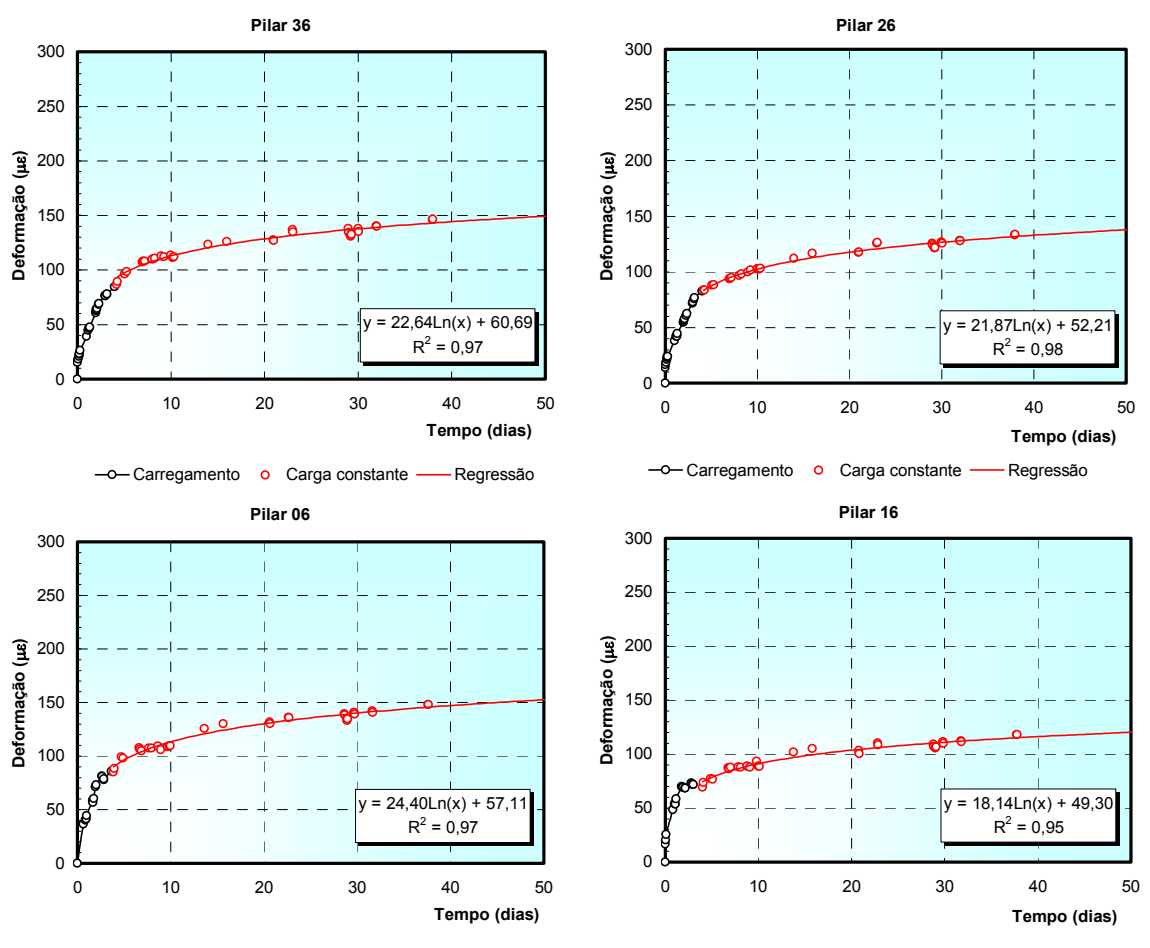

$\multimap$ Carregamento $\circ$ Carga constante — Regressão

$\multimap-$ Carregamento $\circ$ Carga constante — Regressão

Figura 6.22 - Curvas tempo deformação pilares do eixo 06. 

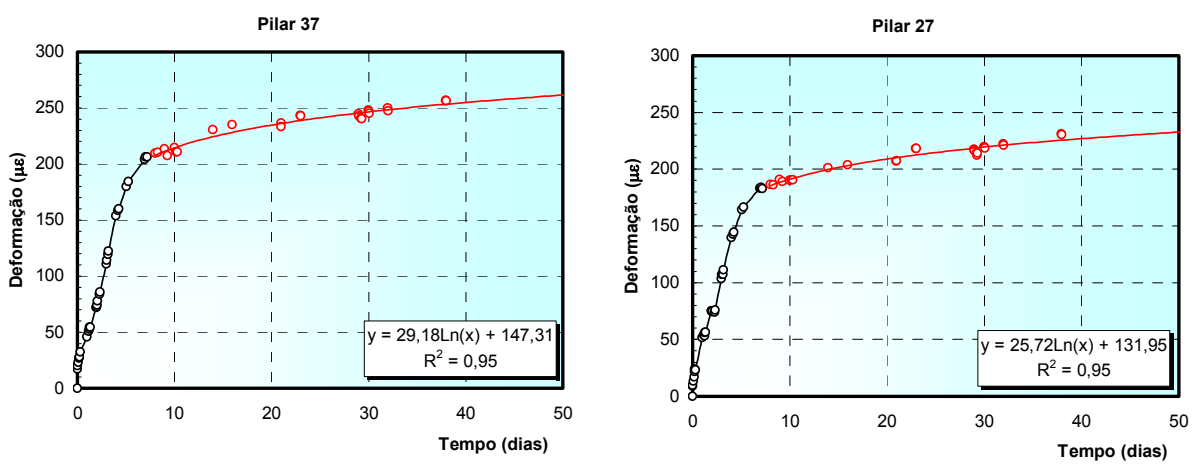

- - Carregamento $\circ$ Carga constante — Regressão

Pilar 17

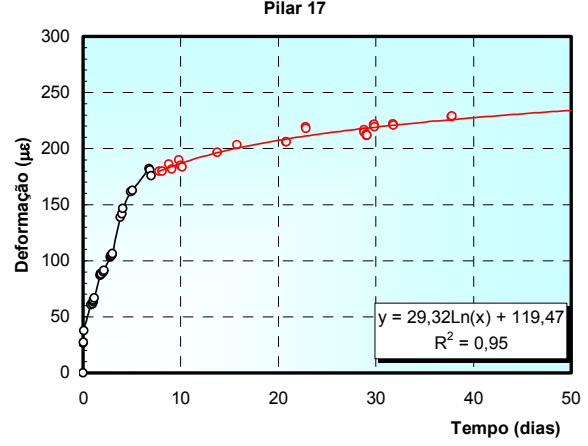

$\multimap$ - Carregamento $\circ$ Carga constante — Regressão

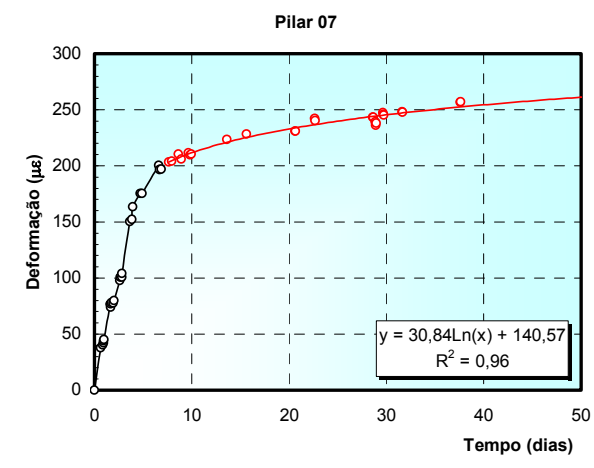

- — Carregamento ○ Carga constante — Regressão

Figura 6.23 - Curvas tempo deformação pilares do eixo 07.
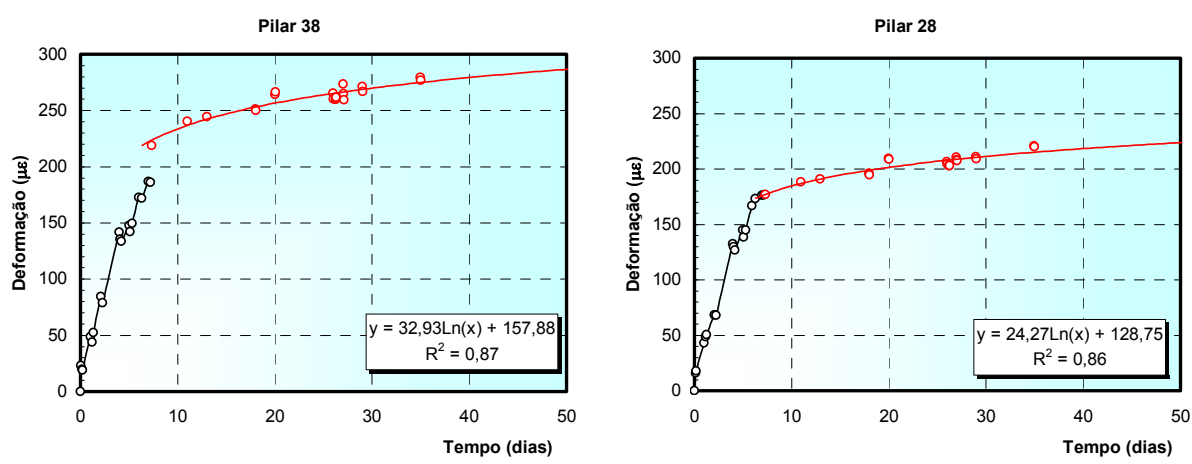

- - Carregamento $\circ$ Carga constante — Regressão - - Carregamento $\circ$ Carga constante — Regressão
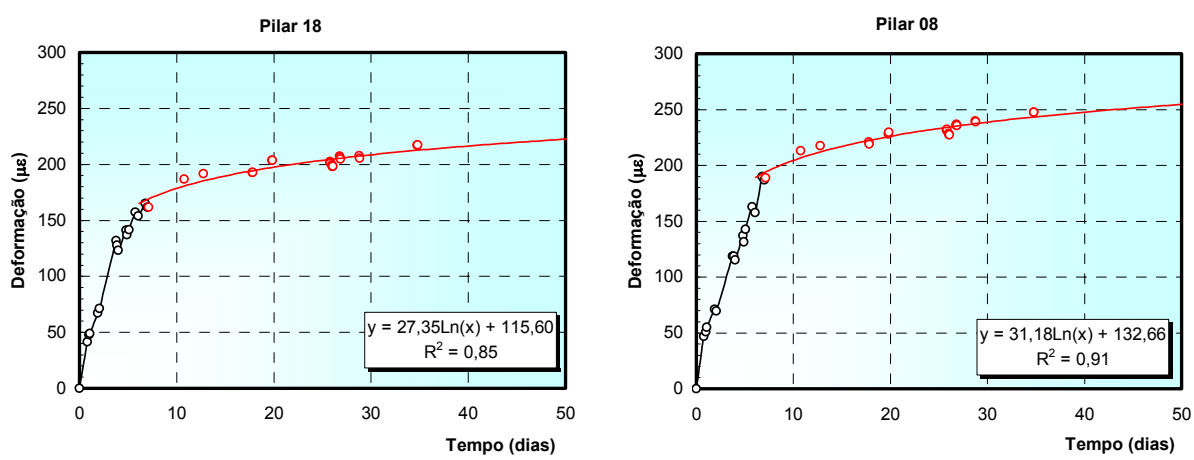

- - Carregamento ○ Carga constante — Regressão

- - Carregamento $\circ$ Carga constante — Regressão

Figura 6.24 - Curvas tempo deformação pilares do eixo 08. 

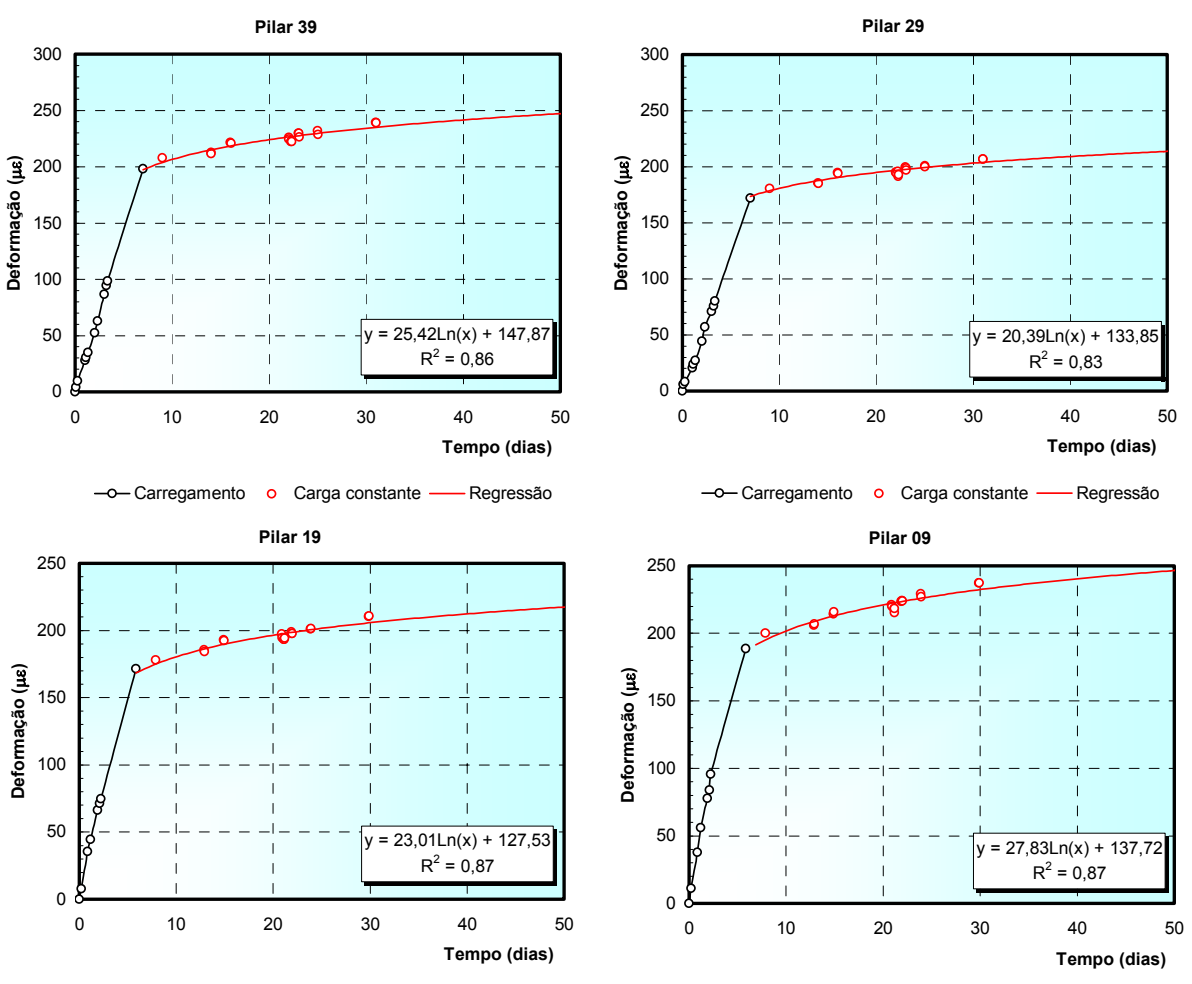

- - Carregamento ○ Carga constante — Regressão

$\multimap$ Carregamento ○ Carga constante — Regressão

Figura 6.25 - Curvas tempo deformação pilares do eixo 09.
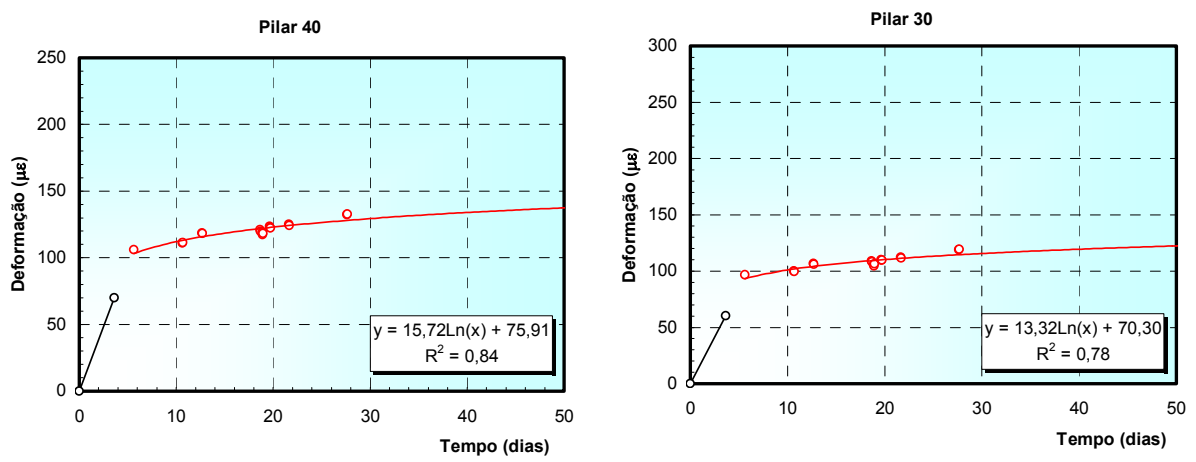

- - Carregamento ○ Carga constante — Regressão

-C Carregamento ○ Carga constante — Regressão
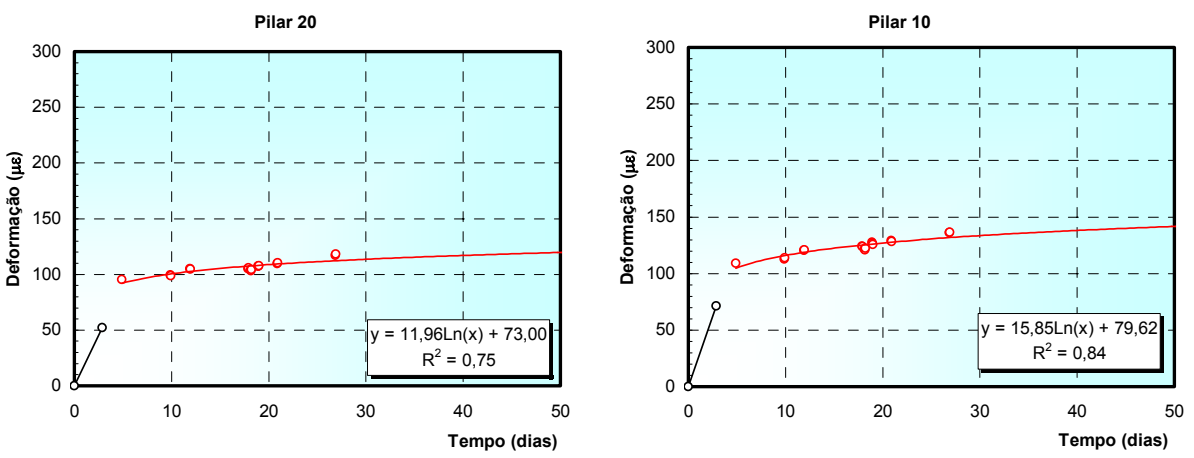

- - Carregamento ○ Carga constante — Regressão

- - Carregamento $\circ$ Carga constante - Regressão

Figura 6.26 - Curvas tempo deformação pilares do eixo 10. 
Os resultados da regressão aplicada aos valores observados durante o período de carga constante são sumarizados na Tabela 6.2. Nessa são apresentados o valor do coeficiente angular da regressão logarítmica em função do logaritmo natural ( $\varepsilon_{\alpha-}$ expresso em $\left.\mu \varepsilon / \log t\right)$, o qual é convertido em termos de deslocamento absoluto (encurtamento $s_{\alpha}$ - expresso em $\mathrm{mm} / \log \mathrm{t}$ ).

Tal procedimento tem por objetivo estabelecer um parâmetro, que permita a comparação da taxa de deslocamentos sob carga constante da superestrutura $\left(s_{\alpha}\right)$ com aquela que será determinada no próximo capítulo para a infra-estrutura, no caso corresponde à variável $\left(\mathrm{c}_{\alpha}\right)$.

O conjunto de dados apresenta esse coeficiente variável entre 0,113 $\mathrm{mm} / \log \mathrm{t}$ (pilar 38) e 0,041 mm/ log t (pilar 20), tendo como valor médio 0,081 $\mathrm{mm} / \log$ t. O desvio padrão dos valores determinados é igual a 0,020 mm/ log t correspondendo a um coeficiente de variação igual a $25 \%$. A correlação obtida entre a deformação e o logaritmo do tempo é boa, conforme expresso pelo coeficiente de correlação $\left(R^{2}\right)$, sendo feita exceção aos pilares 30 e 20, os quais apresentaram valor desse coeficiente inferiores a $80 \%$.

Tabela 6.2 - Regressão logarítmica deformação/deslocamento x tempo período de carga constante.

\begin{tabular}{lccccccccccc}
\hline Pilar & $\begin{array}{c}\varepsilon_{\alpha} \\
\mu \varepsilon / \log \mathrm{t}\end{array}$ & $\begin{array}{c}\mathrm{S}_{\alpha} \\
\mathrm{mm} / \log \mathrm{t}\end{array}$ & $\begin{array}{c}\mathrm{R}^{2} \\
\%\end{array}$ & Pilar & $\begin{array}{c}\varepsilon_{\alpha} \\
\mu \varepsilon / \log \mathrm{t}\end{array}$ & $\begin{array}{c}\mathrm{S}_{\alpha} \\
\mathrm{mm} / \log \mathrm{t}\end{array}$ & $\begin{array}{c}\mathrm{R}^{2} \\
\%\end{array}$ & Pilar & $\begin{array}{c}\varepsilon_{\alpha} \\
\mu \varepsilon / \log \mathrm{t}\end{array}$ & $\begin{array}{c}\mathrm{S}_{\alpha} \\
\mathrm{mm} / \log \mathrm{t}\end{array}$ & $\mathrm{R}^{2}$ \\
\hline 36 & 52 & 0,078 & 97 & 37 & 67 & 0,100 & 95 & 38 & 76 & 0,113 & 87 \\
26 & 50 & 0,075 & 98 & 27 & 59 & 0,088 & 95 & 28 & 56 & 0,083 & 86 \\
16 & 42 & 0,062 & 95 & 17 & 68 & 0,101 & 95 & 18 & 63 & 0,094 & 85 \\
06 & 56 & 0,084 & 97 & 07 & 71 & 0,106 & 96 & 08 & 72 & 0,107 & 91 \\
\hline Média & 50 & 0,075 & & & 66 & 0,099 & & 67 & 0,099 & \\
CV & $10 \%$ & $10 \%$ & & & $7 \%$ & $7 \%$ & & $12 \%$ & $12 \%$ & \\
\hline
\end{tabular}

\begin{tabular}{|c|c|c|c|c|c|c|c|}
\hline Pilar & $\begin{array}{c}\varepsilon_{\alpha} \\
\mu \varepsilon / \log t\end{array}$ & $\begin{array}{c}\mathbf{S}_{\alpha} \\
\mathrm{mm} / \log \mathrm{t}\end{array}$ & $\begin{array}{c}\mathrm{R}^{2} \\
\%\end{array}$ & Pilar & $\begin{array}{c}\varepsilon_{\alpha} \\
\mu \varepsilon / \log \mathrm{t}\end{array}$ & $\begin{array}{c}\mathrm{S}_{\alpha} \\
\mathrm{mm} / \log \mathrm{t}\end{array}$ & $\begin{array}{l}\mathrm{R}^{2} \\
\%\end{array}$ \\
\hline 39 & 59 & 0,087 & 86 & 40 & 36 & 0,054 & 84 \\
\hline 29 & 47 & 0,070 & 83 & 30 & 31 & 0,046 & 78 \\
\hline 19 & 53 & 0,079 & 87 & 20 & 28 & 0,041 & 75 \\
\hline 09 & 64 & 0,095 & 87 & 10 & 36 & 0,054 & 84 \\
\hline Média & 56 & 0,083 & & & 33 & 0,049 & \\
\hline CV & $11 \%$ & $11 \%$ & & & $12 \%$ & $12 \%$ & \\
\hline
\end{tabular}




\subsection{AVALIAÇÃO DA SOLICITAÇÃO NORMAL NOS PILARES.}

As deformações medidas podem permitir a avaliação da solicitação normal dos pilares, desde que seja conhecido o módulo de elasticidade do concreto. Para o nível de deformação observado, a hipótese de um módulo de elasticidade linear, conforme a Lei de Hooke, é razoável. A fim de obter uma boa estimativa desse módulo, adotou-se o seguinte procedimento: uma vez conhecido o valor total do carregamento aplicado, que para o caso em estudo envolveu apenas ações verticais externas devidas ao peso próprio dos elementos pré-moldados, o módulo de elasticidade médio $\left(E_{\mathrm{cm}}\right)$ do conjunto de pilares em concreto armado é expresso por:

$$
E_{c m}=\frac{\sum P_{i}}{\sum \varepsilon_{i} \times A_{i}}
$$

onde:

$\Sigma \mathrm{P}_{\mathrm{i}}$ - somatório das cargas aplicadas,

$\Sigma \varepsilon_{i}$ - somatório das deformações médias observadas,

$A_{i}$ - área da seção transversal do pilar.

Essa expressão foi aplicada ao conjunto de observações realizada, adotando-se peso específico para as peças de concreto armado pré-molado de $25 \mathrm{kN} / \mathrm{m}^{3}$, obtendo-se o gráfico da Figura 6.27. A regressão linear desses valores conduz à seguinte expressão:

$$
\sum P_{i}=5,72 \times \sum \varepsilon_{i}
$$




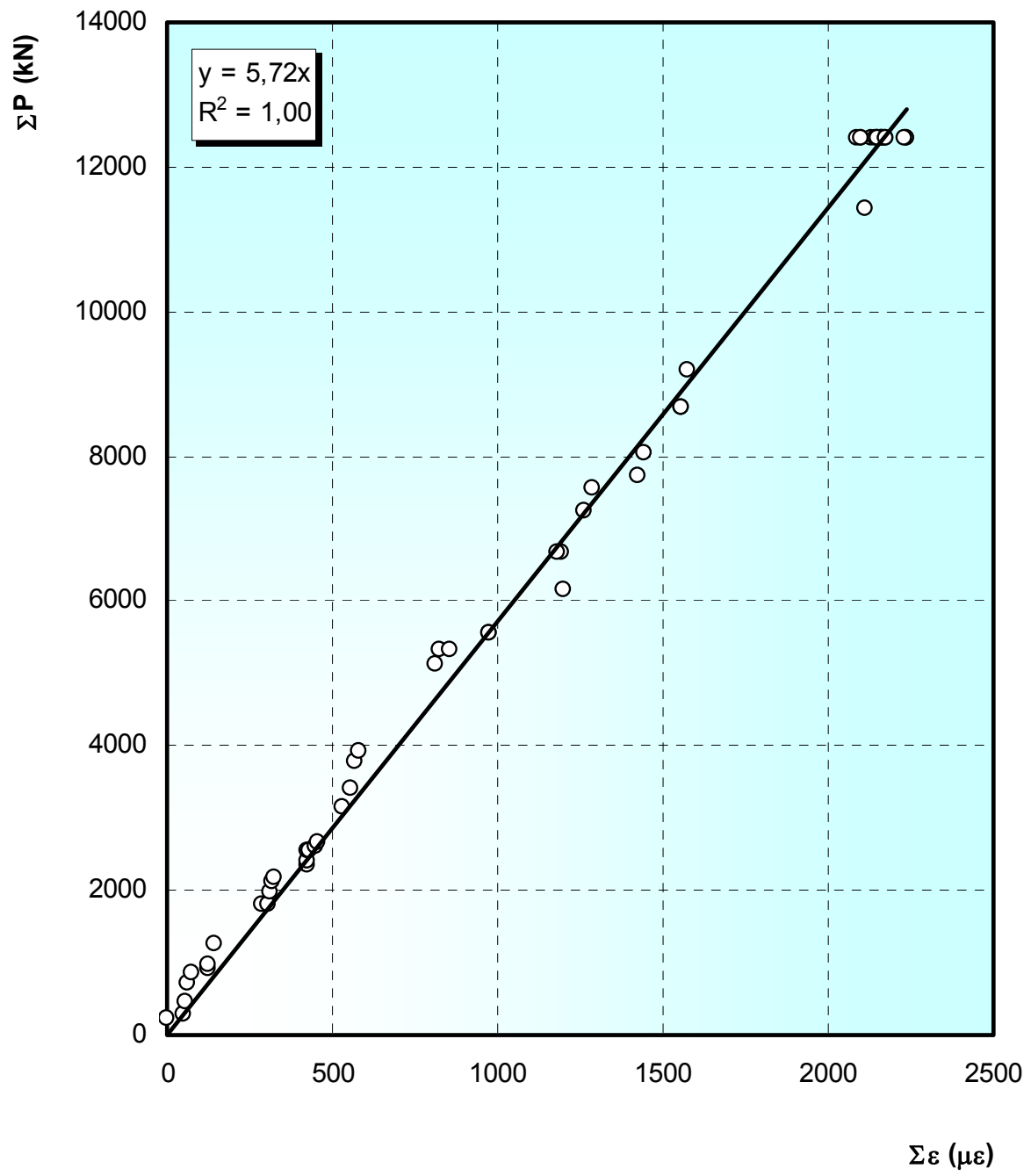

Figura 6.27 - Carga aplicada x somatório das deformações medidas.

a qual corresponde a um módulo de elasticidade médio para os pilares em concreto armado, igual a:

$$
E_{\text {cam }}=\frac{\sum P_{i}}{\sum \varepsilon_{i} \times A_{i}}=\frac{5,72}{0,4^{2}}=35,8 \mathrm{GPa}
$$

A partir do valor do módulo de elasticidade médio, a solicitação normal em um pilar qualquer pode ser expressa por:

$$
\begin{aligned}
& \sigma=E \times \varepsilon \\
& P=E \times \varepsilon \times A \\
& P_{i}=E_{c m} \times \varepsilon_{i} \times A_{i}=\frac{\sum P_{i}}{\sum \varepsilon_{i} \times A_{i}} \times \varepsilon_{i} \times A_{i}
\end{aligned}
$$


Para a condição de obra em estudo, todos os pilares são de igual seção transversal; pode-se escrever que a solicitação normal em um pilar genérico é igual a:

$$
P_{i}=\frac{\sum P_{i}}{\sum \varepsilon_{i}} \times \varepsilon_{i}
$$

Esse procedimento foi aplicado ao conjunto de medidas efetuadas, determinando-se a solicitação normal e a tensão normal em cada pilar. Os gráficos das Figuras 6.28 a 6.32 apresentam a relação tensão deformação para os vinte pilares monitorados.

Pilar 36

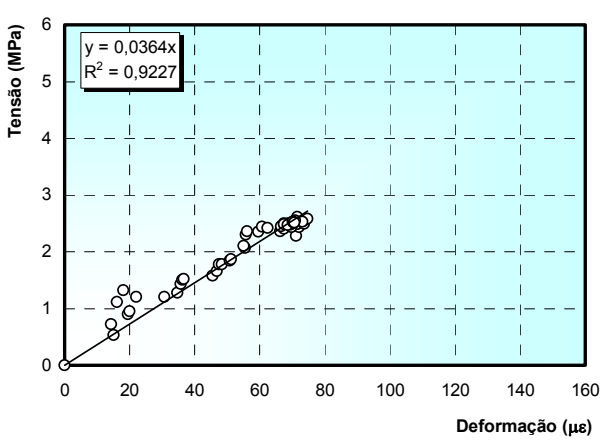

Pilar 16

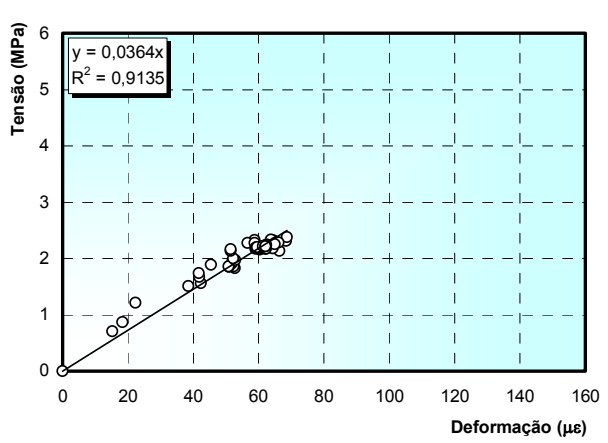

Pilar 26

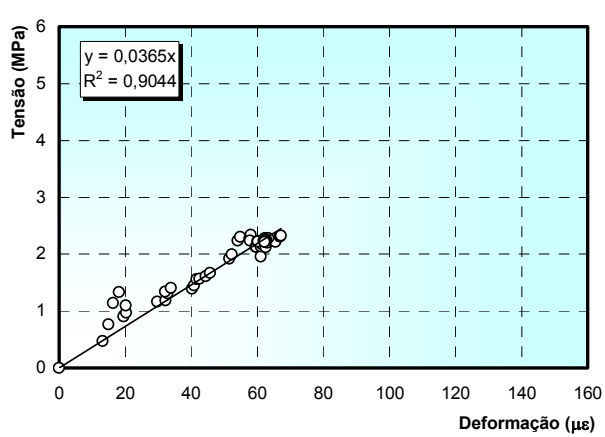

Pilar 06

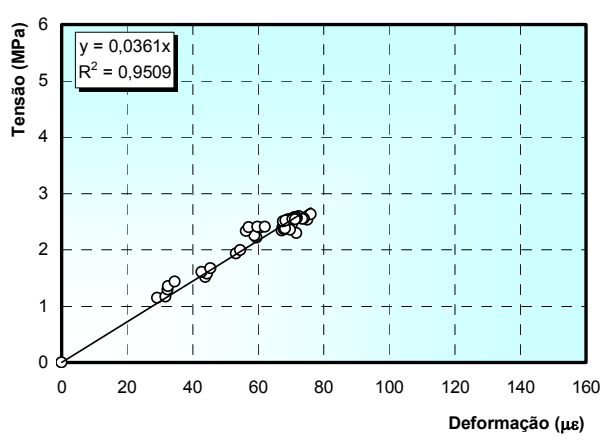

Figura 6.28 - Relação tensão deformação dos pilares do eixo 06. 
Pilar 37

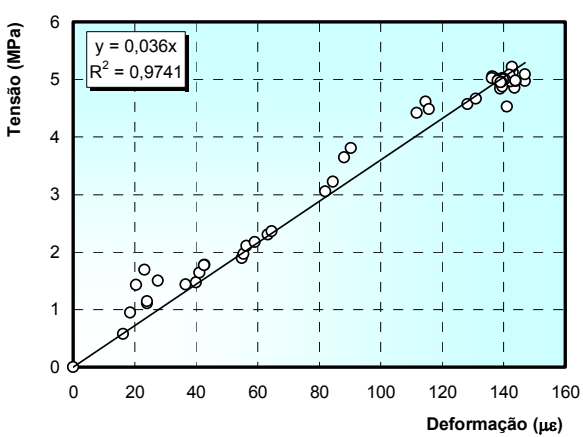

Pilar 17

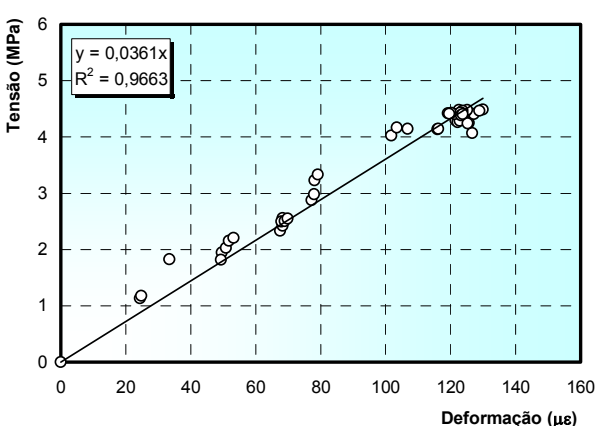

Pilar 27

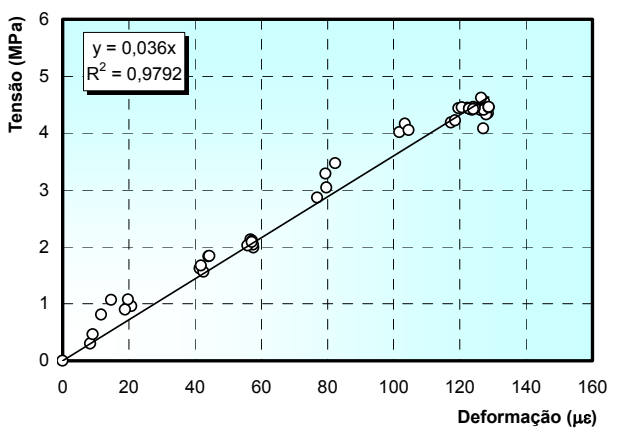

Pilar 07

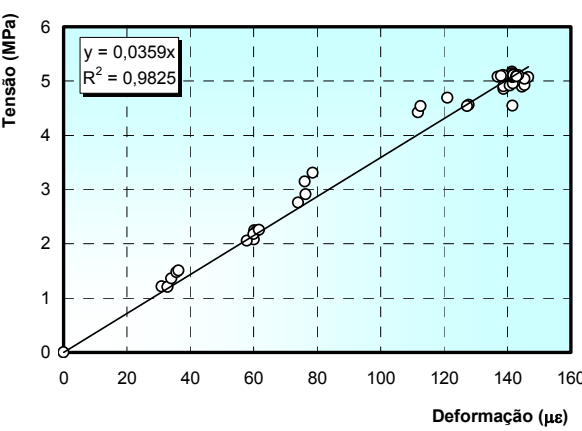

Figura 6.29 - Relação tensão deformação dos pilares do eixo 07.

Pilar 38

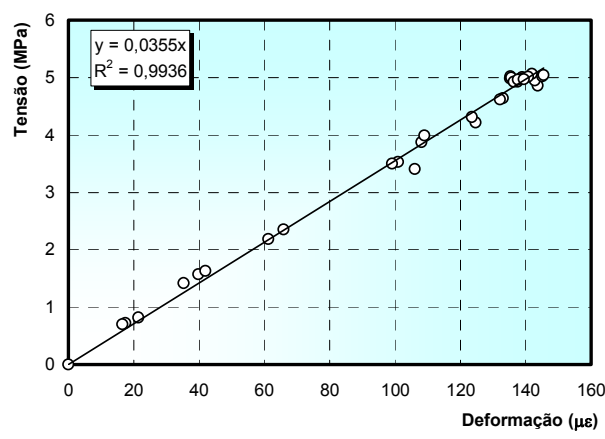

Pilar 18

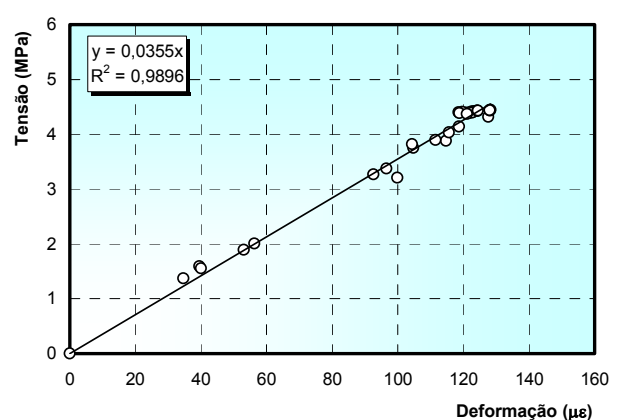

Pilar 28

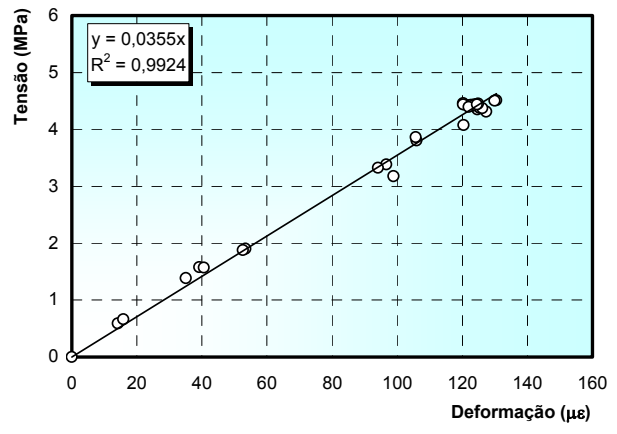

Pilar 08

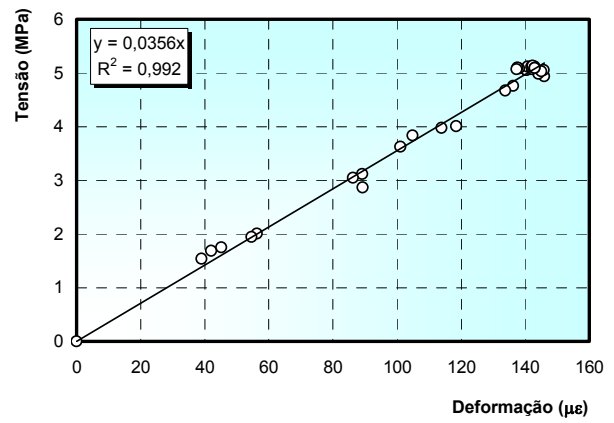

Figura 6.30 - Relação tensão deformação dos pilares do eixo 08. 
Pilar 39

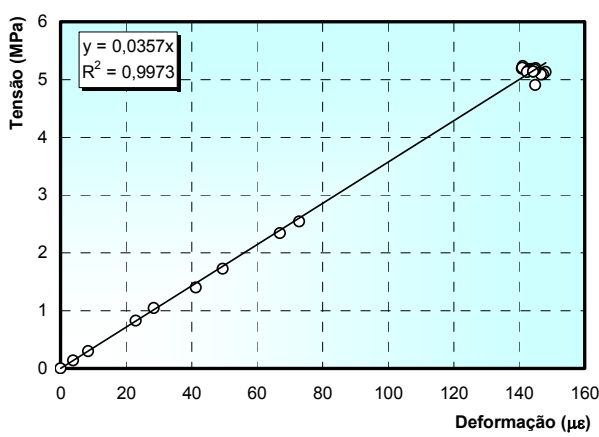

Pilar 19

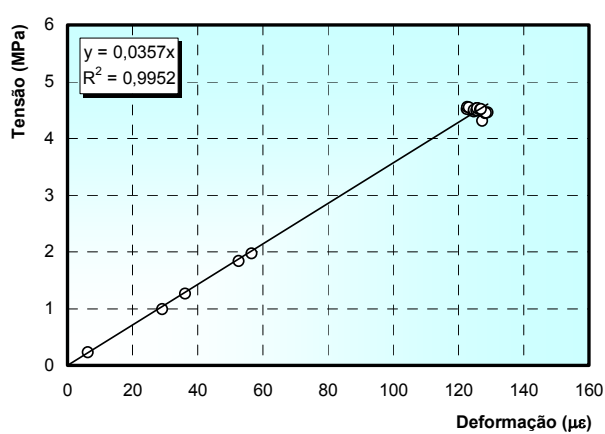

Pilar 29

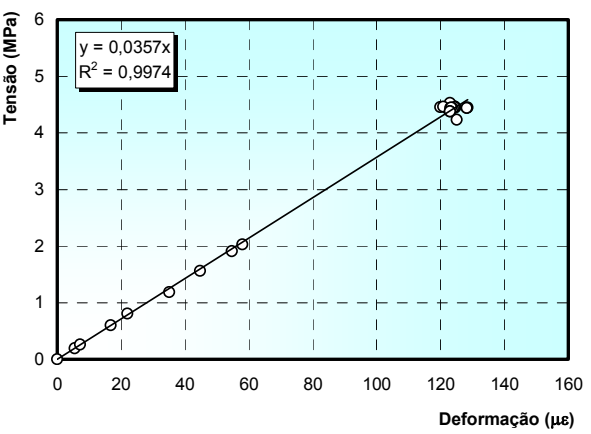

Pilar 09

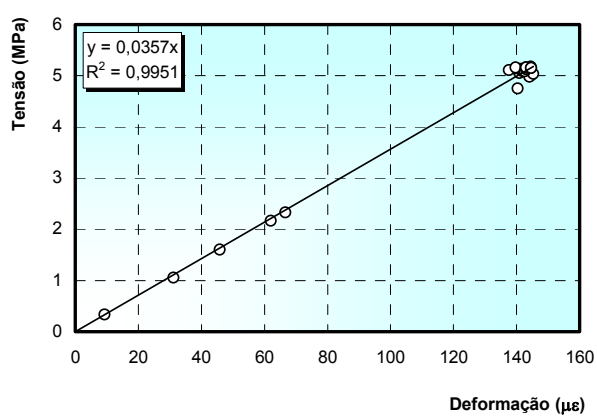

Figura 6.31 - Relação tensão deformação dos pilares do eixo 09.
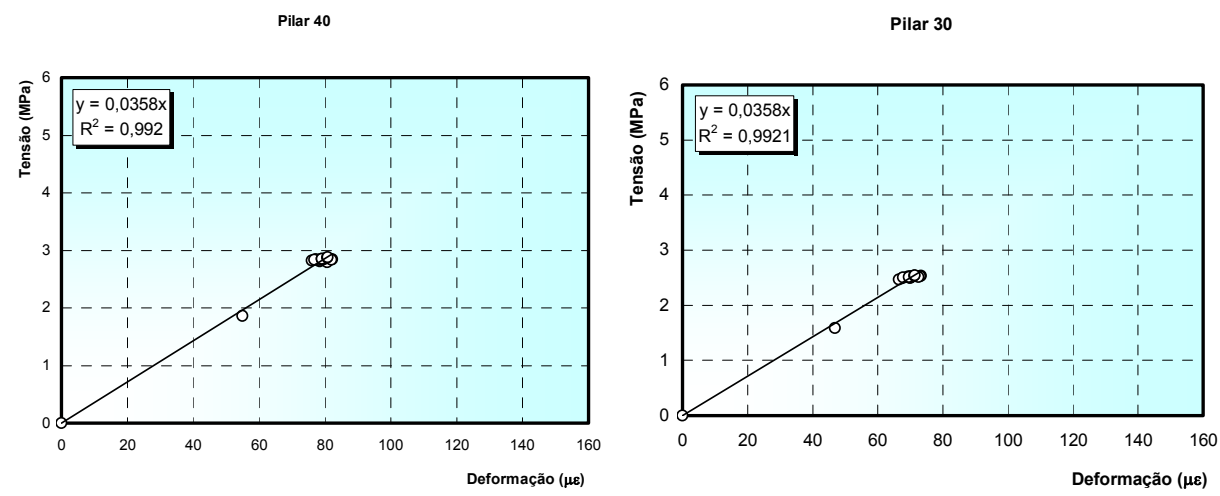

Pilar 20

Pilar 10
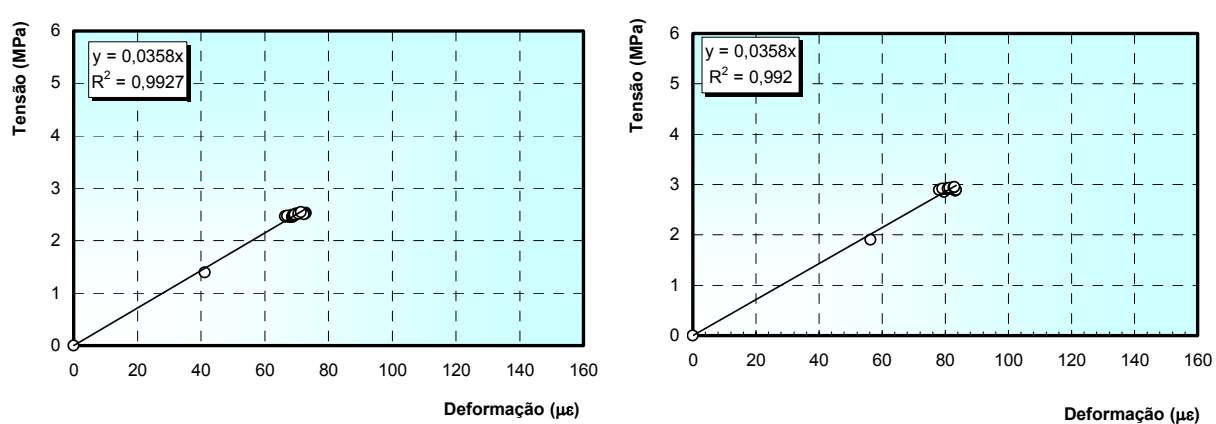

Figura 6.32 - Relação tensão deformação dos pilares do eixo 10. 
A Tabela 6.3 sumariza os resultados da relação tensão deformação determinada pela regressão linear, a qual conduz a um módulo de elasticidade do concreto armado.

Tabela 6.3 - Relação tensão deformação no concreto armado dos pilares.

\begin{tabular}{lcccccccccccccc}
\hline Pilar & $\begin{array}{c}E_{c a} \\
(\mathrm{GPa})\end{array}$ & $R^{2}$ & Pilar & $\begin{array}{c}\mathrm{E}_{\mathrm{ca}} \\
(\mathrm{GPa})\end{array}$ & $\mathrm{R}^{2}$ & Pilar & $\begin{array}{c}\mathrm{E}_{\mathrm{ca}} \\
(\mathrm{GPa})\end{array}$ & $\mathrm{R}^{2}$ & Pilar & $\mathrm{E}_{\mathrm{ca}}$ & $\mathrm{R}^{2}$ & Pilar & $\begin{array}{c}\mathrm{E}_{\mathrm{ca}} \\
(\mathrm{GPa})\end{array}$ & $\mathrm{R}^{2}$ \\
\hline 36 & 36,4 & 92 & 37 & 36,0 & 97 & 38 & 35,5 & 99 & 39 & 35,7 & 100 & 40 & 35,8 & 99 \\
26 & 36,5 & 90 & 27 & 36,0 & 98 & 28 & 35,5 & 99 & 29 & 35,7 & 100 & 30 & 35,8 & 99 \\
16 & 36,4 & 91 & 17 & 36,1 & 97 & 18 & 35,5 & 99 & 19 & 35,7 & 100 & 20 & 35,8 & 99 \\
06 & 36,1 & 95 & 07 & 35,9 & 98 & 08 & 35,6 & 99 & 09 & 35,7 & 100 & 10 & 35,8 & 99 \\
\hline
\end{tabular}

Verifica-se, nessa tabela, que os valores do módulo de elasticidade apresentam-se variáveis entre 36,4 GPa e 35,8 GPa, sendo a correlação da regressão linear boa. Esse parâmetro indica que o procedimento adotado para a avaliação indireta da solicitação normal nos pilares é adequado.

Cumpre salientar que os valores de módulo de elasticidade, anteriormente determinados, referem-se aos pilares em concreto armado $\left(E_{c a}\right)$. De modo a comparar o valor obtido através da instrumentação com valores estabelecidos para o concreto simples $\left(E_{c}\right)$, por meio de códigos e normas, lançou-se mão da seção homogenizada do pilar conforme expresso a seguir:

$$
E_{c a} \times A_{c a}=E_{c} \times A_{c}+E_{s} \times A_{s}
$$

onde:

$\mathrm{E}_{\mathrm{s}}$ - módulo de elasticidade do aço, adotado igual a $210 \mathrm{GPa}$, $\mathrm{A}_{\mathrm{s}}$ - área da armadura do pilar.

Por meio da expressão (6.8), o módulo de elasticidade do concreto simples é expresso por:

$$
E_{c}=\frac{E_{c a} \times A_{c a}-E_{s} \times A_{s}}{A_{c}}
$$

A Tabela 6.4 apresenta informações sobre a armadura longitudinal de cada pilar, e o valor do módulo de elasticidade do concreto simples, conforme apresentado acima. 
Tabela 6.4 - Avaliação do módulo de elasticidade concreto simples.

\begin{tabular}{lccccccc}
\hline Pilar & Armadura & $\begin{array}{c}\mathrm{E}_{\mathrm{ca}} \\
(\mathrm{GPa})\end{array}$ & $\begin{array}{c}\mathrm{E}_{\mathrm{c}} \\
(\mathrm{GPa})\end{array}$ & Pilar & Armadura & $\begin{array}{c}\mathrm{E}_{\mathrm{ca}} \\
(\mathrm{GPa})\end{array}$ & $\begin{array}{c}\mathrm{E}_{\mathrm{c}} \\
(\mathrm{GPa})\end{array}$ \\
\hline 36 & $20 \phi 25$ & 36,4 & 25,1 & 37 & $16 \phi 20$ & 36,0 & 30,4 \\
26 & $20 \phi 25$ & 36,5 & 25,2 & 27 & $12 \phi 20+4 \phi 25$ & 36,0 & 29,5 \\
16 & $20 \phi 25$ & 36,4 & 25,1 & 17 & $12 \phi 20+4 \phi 25$ & 36,1 & 29,6 \\
06 & $16 \phi 20$ & 36,1 & 30,5 & 07 & $16 \phi 20$ & 35,9 & 30,3 \\
\hline
\end{tabular}

\begin{tabular}{llcccccc}
\hline Pilar & Armadura & $\begin{array}{c}\mathrm{E}_{\mathrm{ca}} \\
(\mathrm{GPa})\end{array}$ & $\begin{array}{c}\mathrm{E}_{\mathrm{c}} \\
(\mathrm{GPa})\end{array}$ & Pilar & Armadura & $\begin{array}{c}\mathrm{E}_{\mathrm{ca}} \\
(\mathrm{GPa})\end{array}$ & $\begin{array}{c}\mathrm{E}_{\mathrm{c}} \\
(\mathrm{GPa})\end{array}$ \\
\hline 38 & $16 \phi 20$ & 35,5 & 29,8 & 39 & $16 \phi 20$ & 35,7 & 30,0 \\
28 & $12 \phi 20+4 \phi 25$ & 35,5 & 29,0 & 29 & $12 \phi 20+4 \phi 25$ & 35,7 & 29,2 \\
18 & $12 \phi 20+4 \phi 25$ & 35,5 & 29,0 & 19 & $12 \phi 20+4 \phi 25$ & 35,7 & 29,2 \\
08 & $16 \phi 20$ & 35,6 & 29,9 & 09 & $16 \phi 20$ & 35,7 & 30,0 \\
\hline
\end{tabular}

\begin{tabular}{cccc}
\hline Pilar & Armadura & $\begin{array}{c}\mathrm{E}_{\mathrm{ca}} \\
(\mathrm{GPa})\end{array}$ & $\begin{array}{c}\mathrm{E}_{\mathrm{c}} \\
(\mathrm{GPa})\end{array}$ \\
\hline 40 & $16 \phi 20$ & 35,8 & 30,1 \\
30 & $20 \phi 20$ & 35,8 & 28,7 \\
20 & $20 \phi 20$ & 35,8 & 28,7 \\
10 & $16 \phi 20$ & 35,8 & 30,1 \\
\hline
\end{tabular}

Os valores acima apresentados mostram que o módulo de elasticidade do concreto simples apresentou-se variável entre 30,5 e 25,1 GPa, tendo como média o valor de 29,0 GPa e um coeficiente de variação igual a 5,9\%. Essa variabilidade é de igual ordem de grandeza da variabilidade dos ensaios de compressão simples aos 28 dias, realizados em corpos de prova cilíndricos, sendo essa igual a $5,7 \%$.

Segundo a Norma Brasileira 6118 ABNT (2001), o módulo de elasticidade tangente inicial do concreto é dado pela expressão:

$$
E_{c}=5600 \times f_{c k}^{1 / 2}=5600 \times \sqrt{35,7}=33,5 \mathrm{GPa}
$$

Essa mesma Norma estabelece que o módulo de elasticidade secante deve ser tomado igual a $85 \%$ do valor do módulo tangente, o que conduz a um valor igual a $28,4 \mathrm{GPa}$.

O código ACI 318 (2002) recomenda o uso da expressão:

$$
E_{c}=4730 \sqrt{f_{c k}}=4730 \times \sqrt{35,7}=28,3 \mathrm{GPa}
$$


O código CEB FIP-90 indica para o módulo secante a expressão:

$$
E_{c}=8500 \times \sqrt[3]{f_{c k}+8}=8500 \times \sqrt[3]{35,7+8}=29,9 G P a
$$

Verifica-se que os valores determinados pela instrumentação são similares aos fornecidos pelas expressões dadas pelos códigos e normas para o módulo de elasticidade secante.

Os valores da solicitação normal, aferidos indiretamente, foram comparados com o resultado do cálculo estrutural convencional, modelando-se a estrutura em estudo como pórtico espacial, por meio de software específico (SAP 2000). Os carregamentos foram aplicados como carga uniformemente distribuída em elementos de barras, equivalente ao peso próprio de cada peça pré-moldada. Foram selecionados os seguintes momentos da execução da estrutura para modelagem:
a) 10/09 - montagem parcial eixos 6 a 7;
b) 11/09 - eixos 6 a 7 quase concluídos;
c) 13/09 - montagem dos elementos entre os eixos 7 e 8;
d) 14/09 - fase final da montagem entre eixos 7 e 8;
e) 19/09 - concluída montagem até o eixo 9;
f) 23/09 - montagem da estrutura pré-moldada concluída.

As Figuras 6.33 a 6.38 ilustram a modelagem e o estágio da obra em cada um desses momentos. 


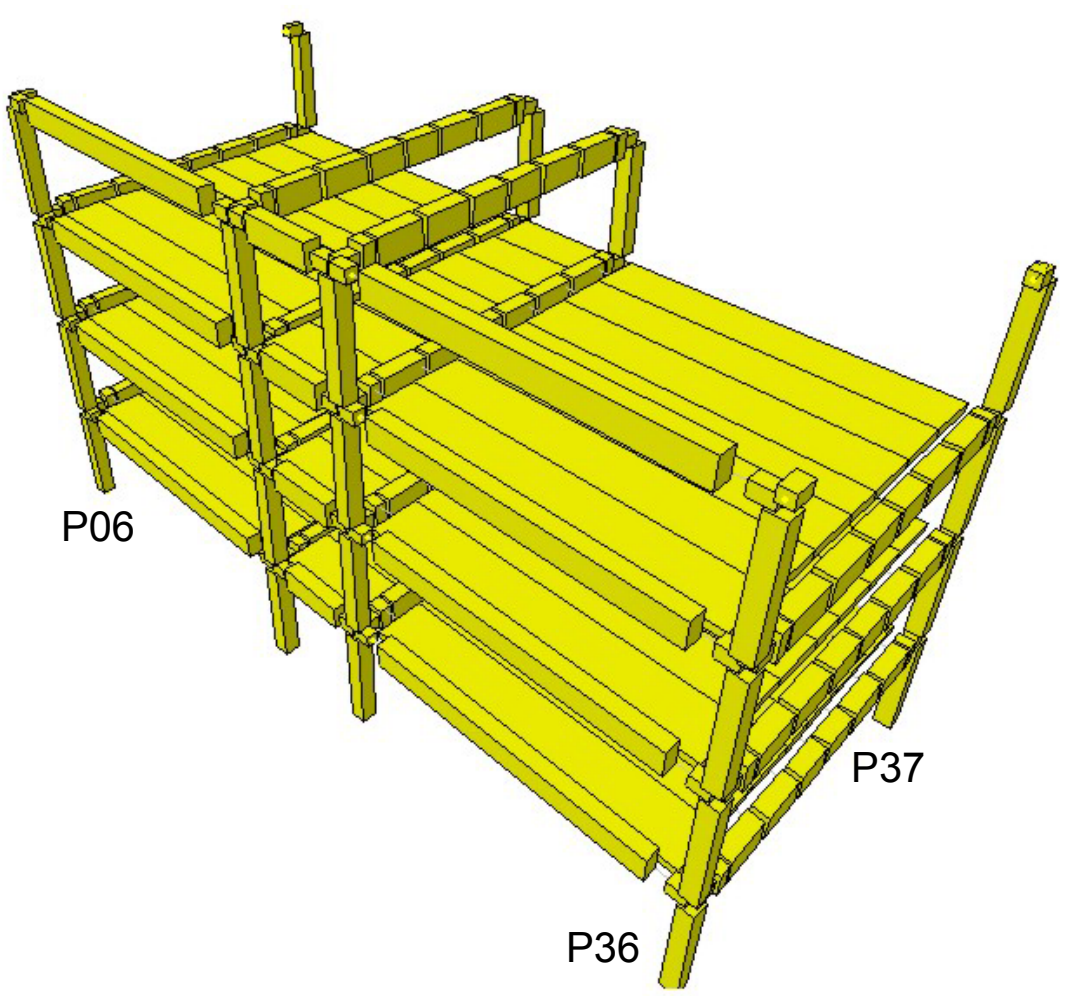

Figura 6.33 - Montagem parcial dos eixos 6 a 7 (10/09).

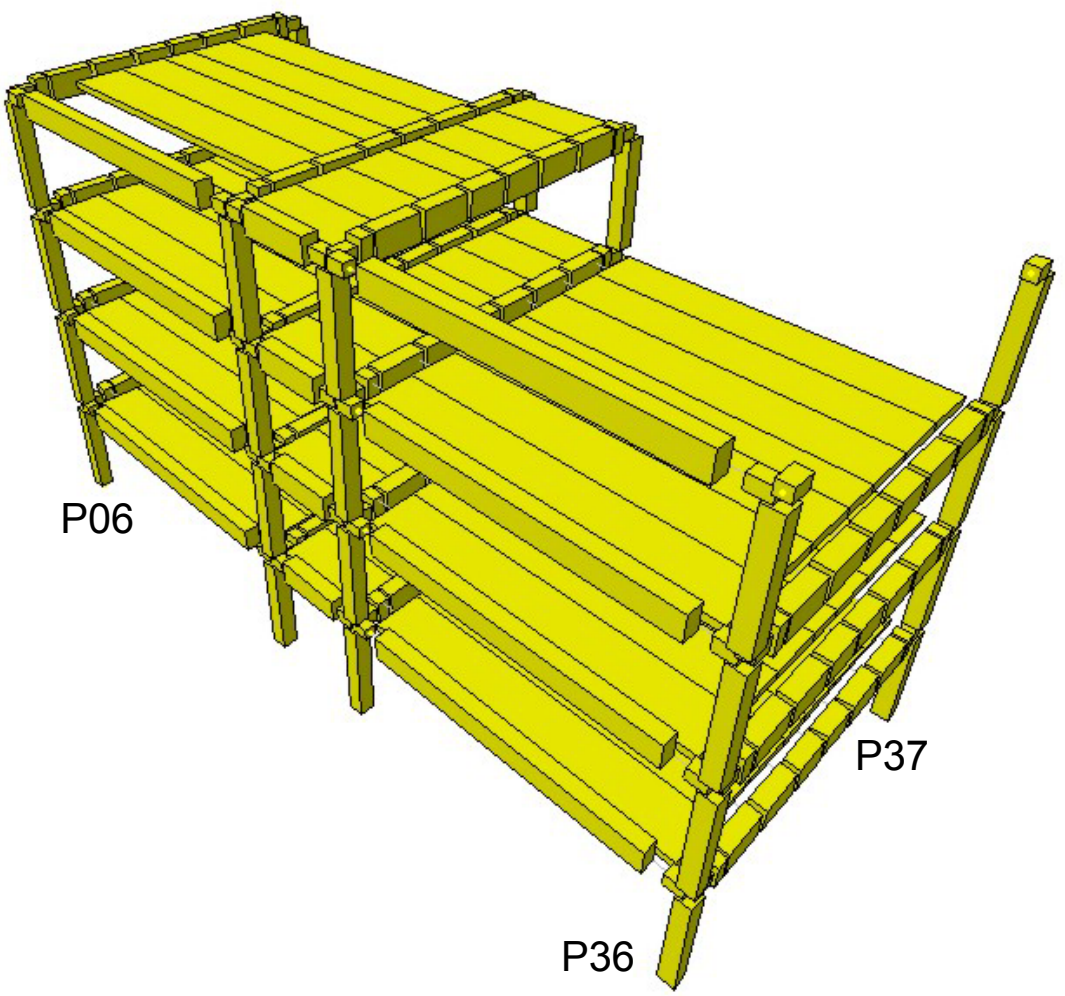

Figura 6.34 - Eixos 6 a 7 quase concluídos (11/09). 


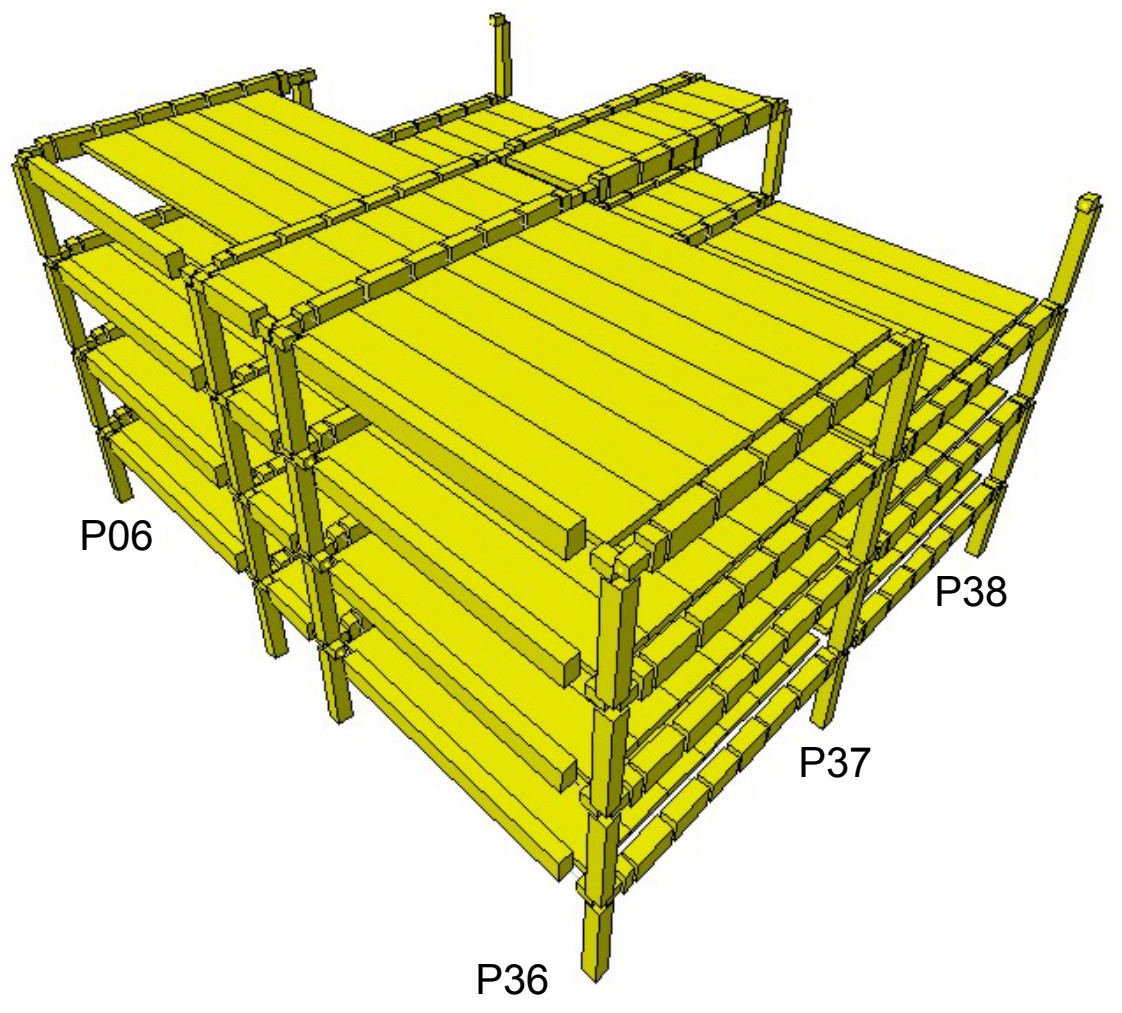

Figura 6.35 - Montagem dos elementos entre os eixos 7 e 8 (13/09).

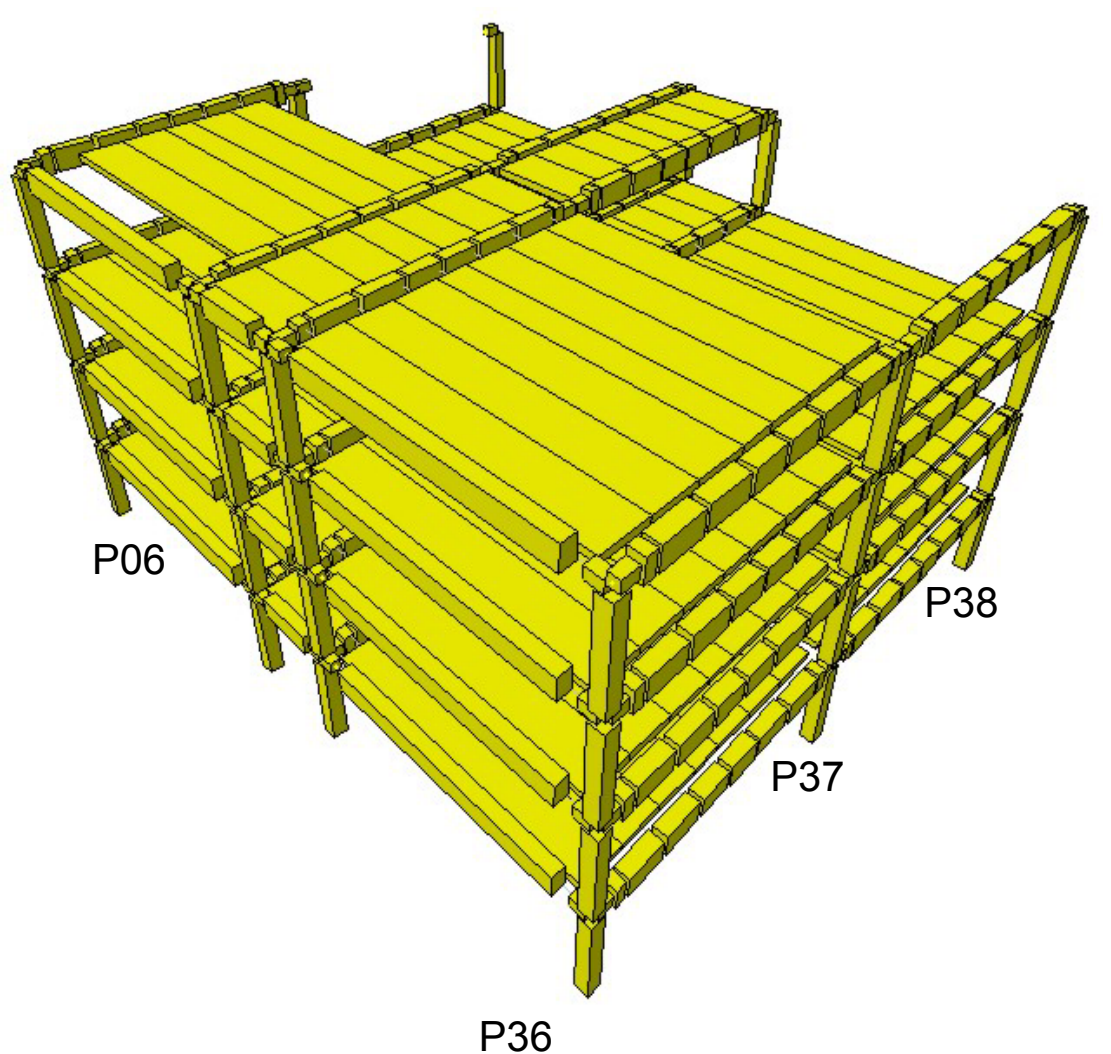

Figura 6.36 - Fase final da montagem entre os eixos 7 e 8 (14/09). 


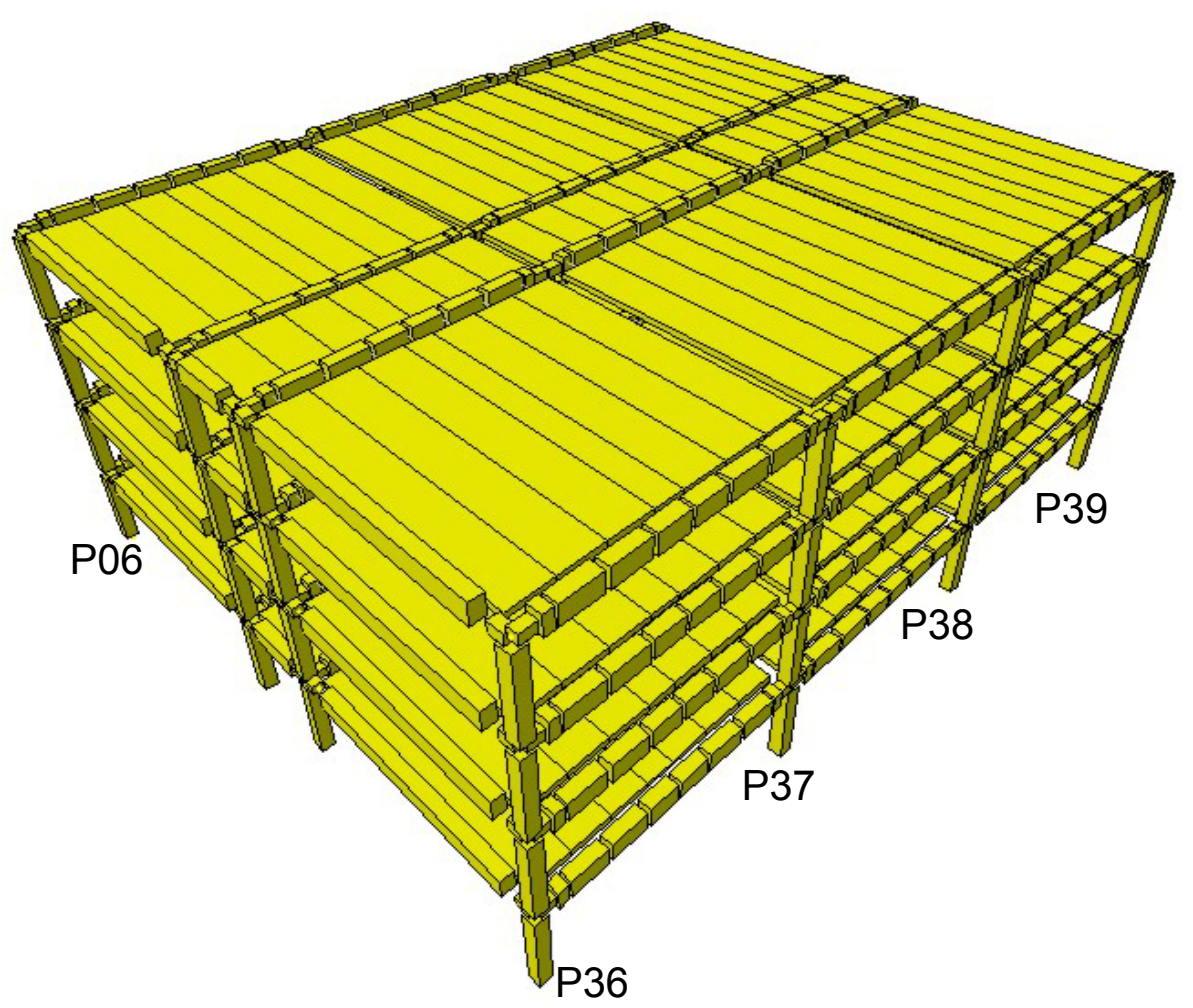

Figura 6.37 - Montagem concluída até o eixo 9 (19/09).

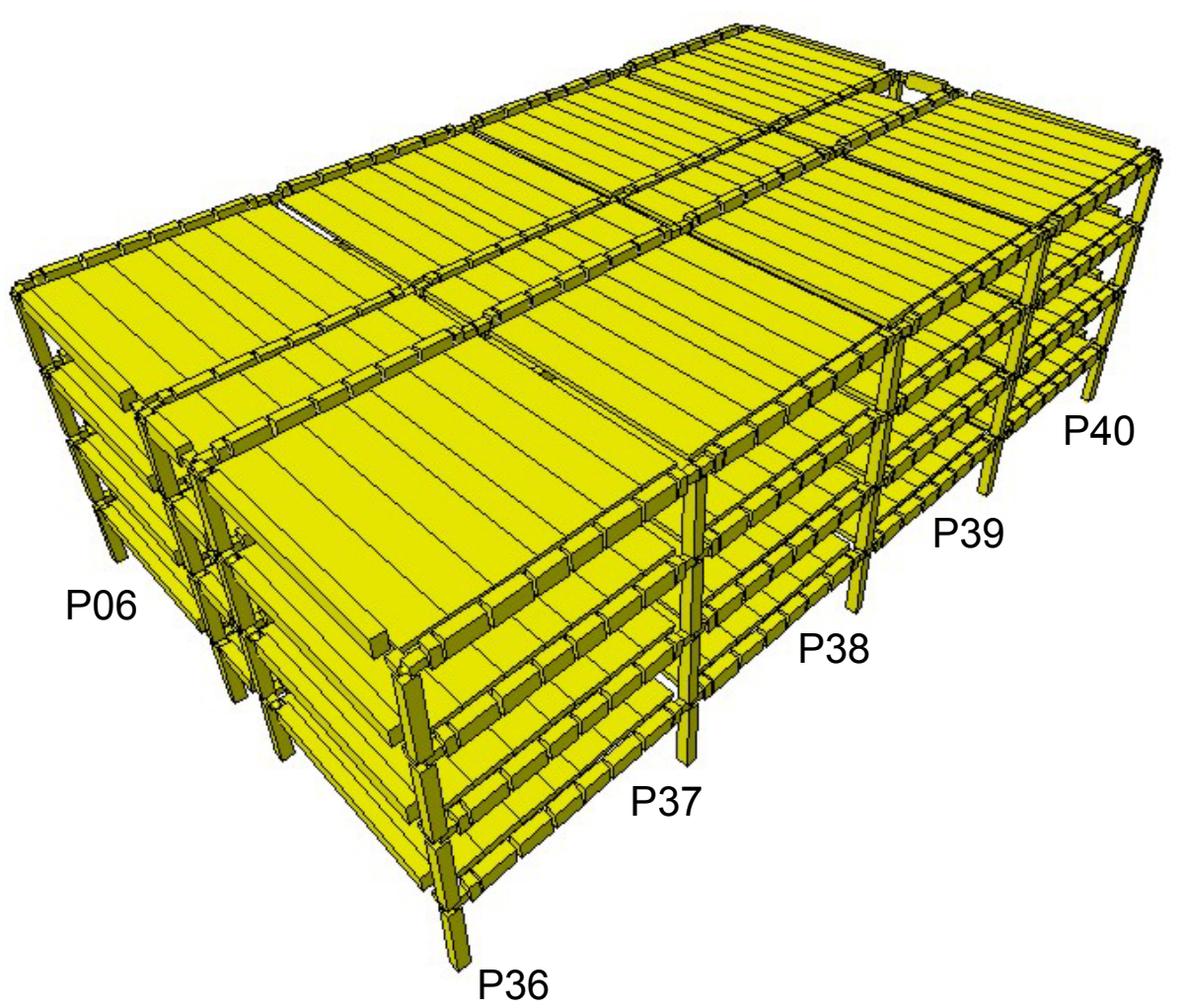

Figura 6.38 - Montagem da estrutura pré-moldada concluída (23/09). 
Para efeito de verificação de cálculo, foram comparados os valores da somatória das reações de apoio nos pilares, fornecida pelo programa de análise estrutural $\left(\Sigma \mathrm{R}_{\mathrm{i}}\right)$ com o valor total do carregamento aplicado, o qual é igual à somatória das solicitações normais nos pilares $\left(\Sigma \mathrm{P}_{\mathrm{i}}\right)$, avaliadas pela instrumentação.

Tabela 6.5 - Comparativo cálculo estrutural x valores obtidos pela instrumentação.

\begin{tabular}{llll}
\hline Data & $\begin{array}{l}\Sigma \mathrm{R}_{\mathrm{i}} \\
(\mathrm{kN})\end{array}$ & $\begin{array}{l}\Sigma \mathrm{P}_{\mathrm{i}} \\
(\mathrm{kN})\end{array}$ & $\begin{array}{l}\Delta \\
(\%)\end{array}$ \\
\hline $10 / 09$ & 2118 & 2109 & $-0,4$ \\
$11 / 09$ & 2676 & 2663 & $-0,5$ \\
$13 / 09$ & 5169 & 5135 & $-0,7$ \\
$14 / 09$ & 5585 & 5551 & $-0,6$ \\
$19 / 09$ & 9181 & 9199 & 0,2 \\
$23 / 09$ & 12446 & 12384 & $-0,5$ \\
\hline
\end{tabular}

Nos gráficos das Figuras 6.39 a 6.43 apresenta-se comparação ao longo do tempo entre os valores de solicitação normal nos pilares aferidos indiretamente pela instrumentação com os fornecidos pelo programa de cálculo estrutural.
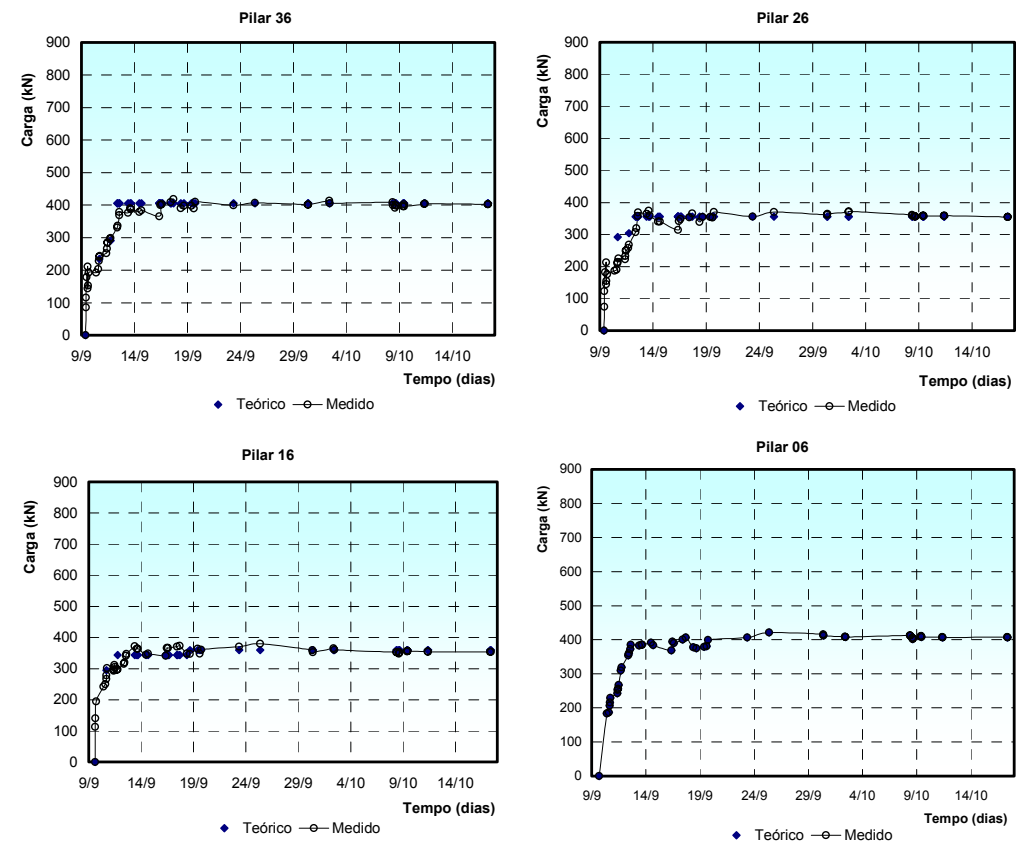

Figura 6.39 - Solicitação normal - comparativo medido x cálculo estrutural - pilares do eixo 06. 

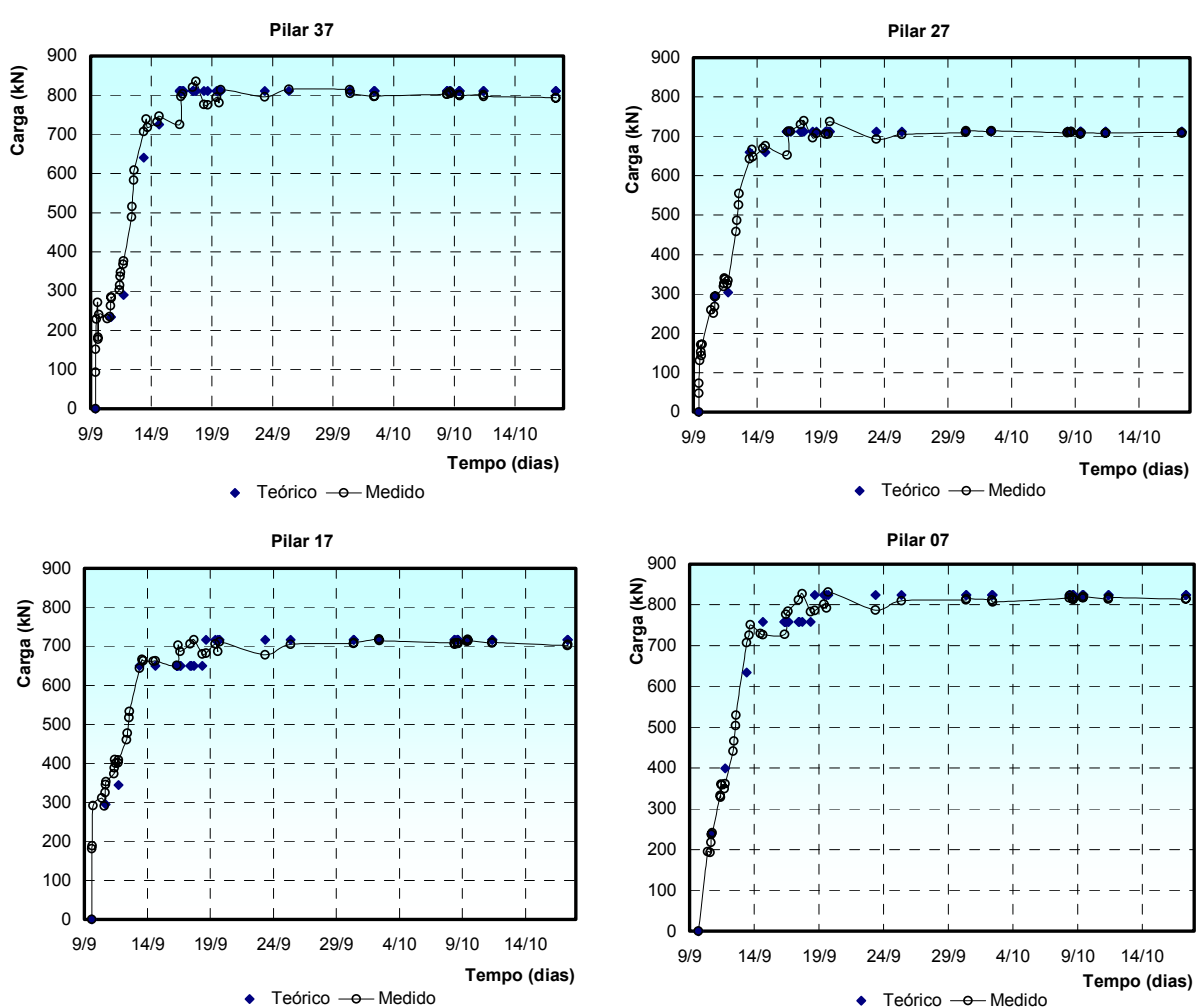

Figura 6.40 - Solicitação normal - comparativo medido x cálculo estrutural - pilares do eixo 07.
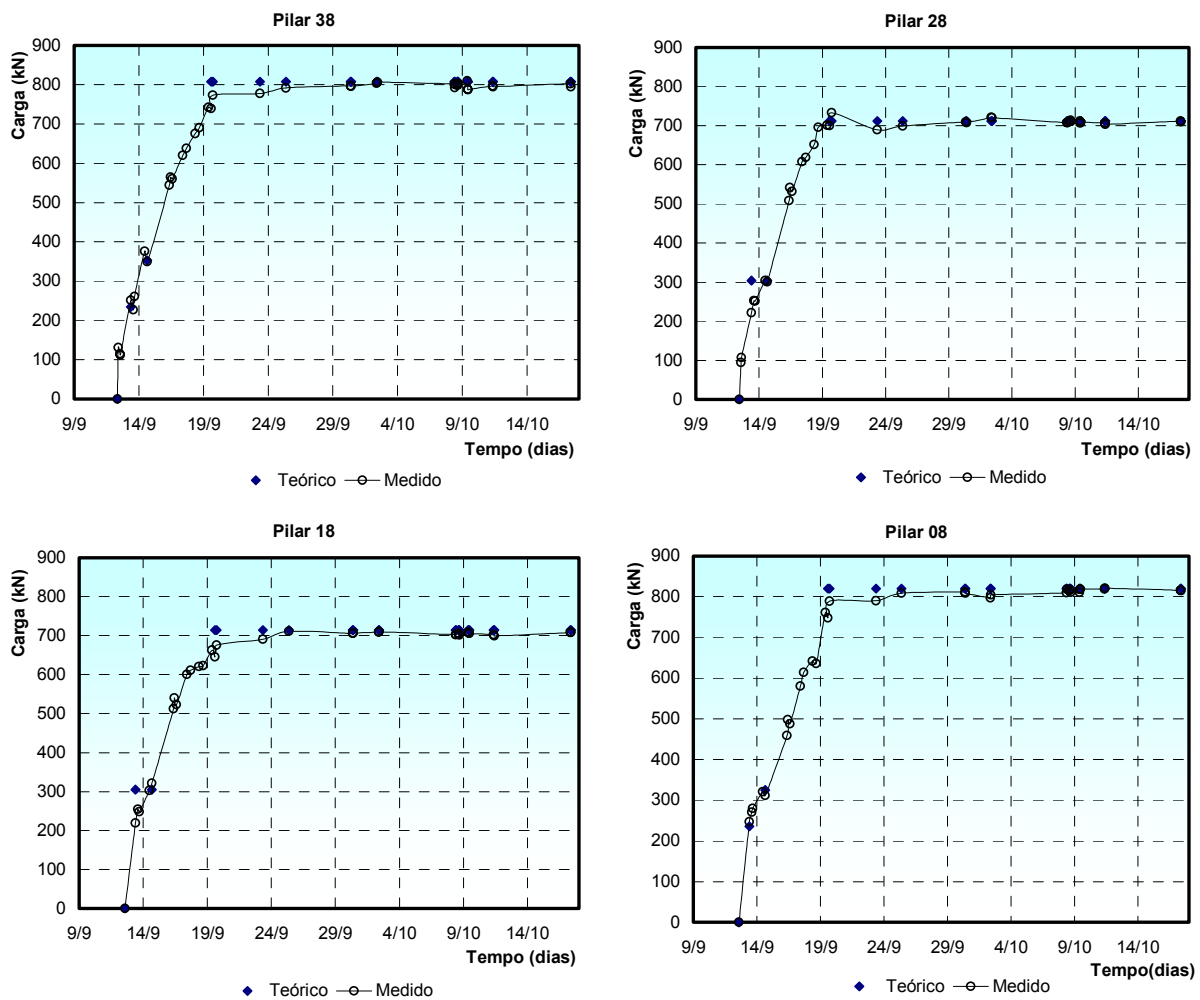

Figura 6.41 - Solicitação normal - comparativo medido x cálculo estrutural - pilares do eixo 08. 

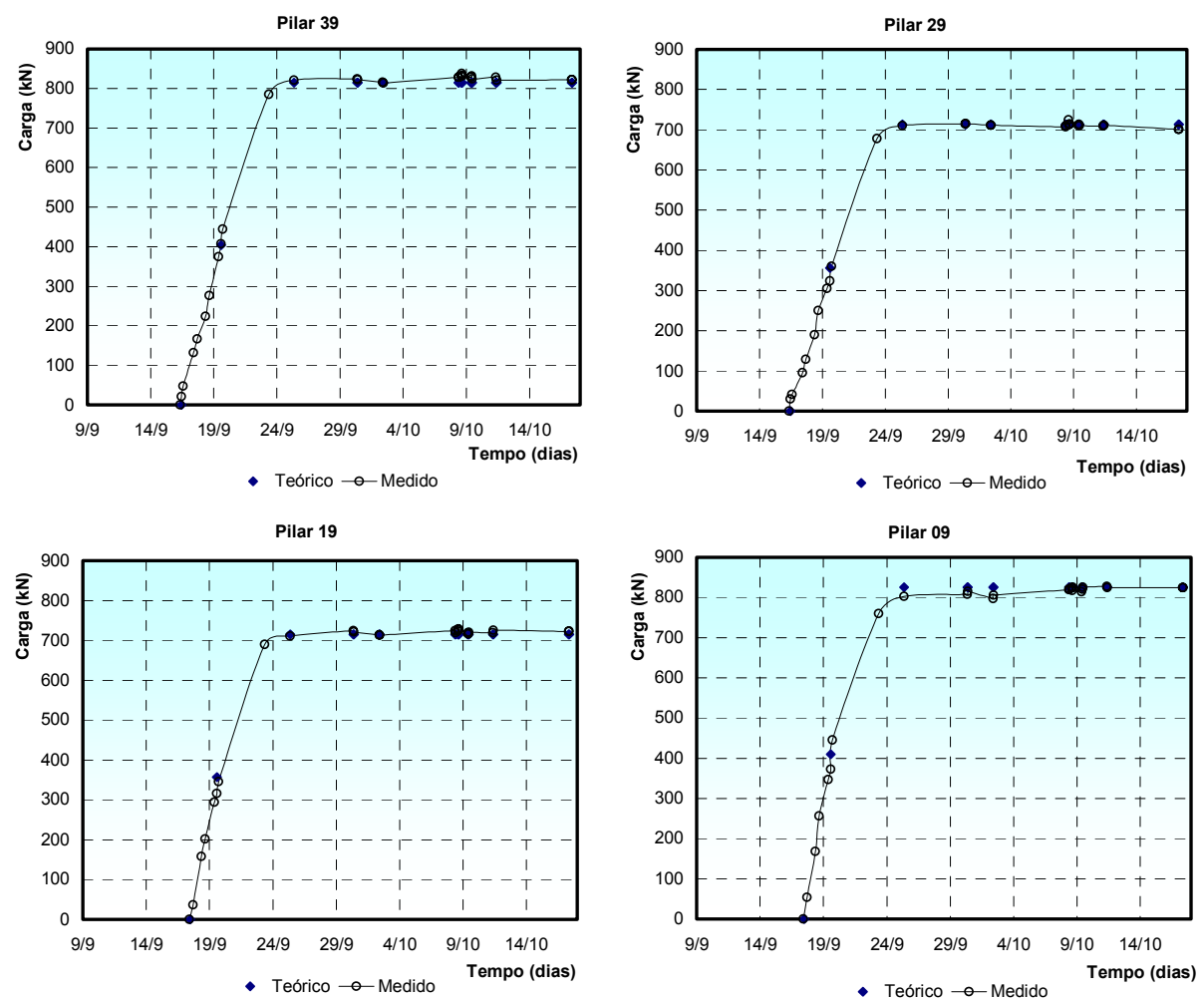

Figura 6.42 - Solicitação normal - comparativo medido x cálculo estrutural - pilares do eixo 09.
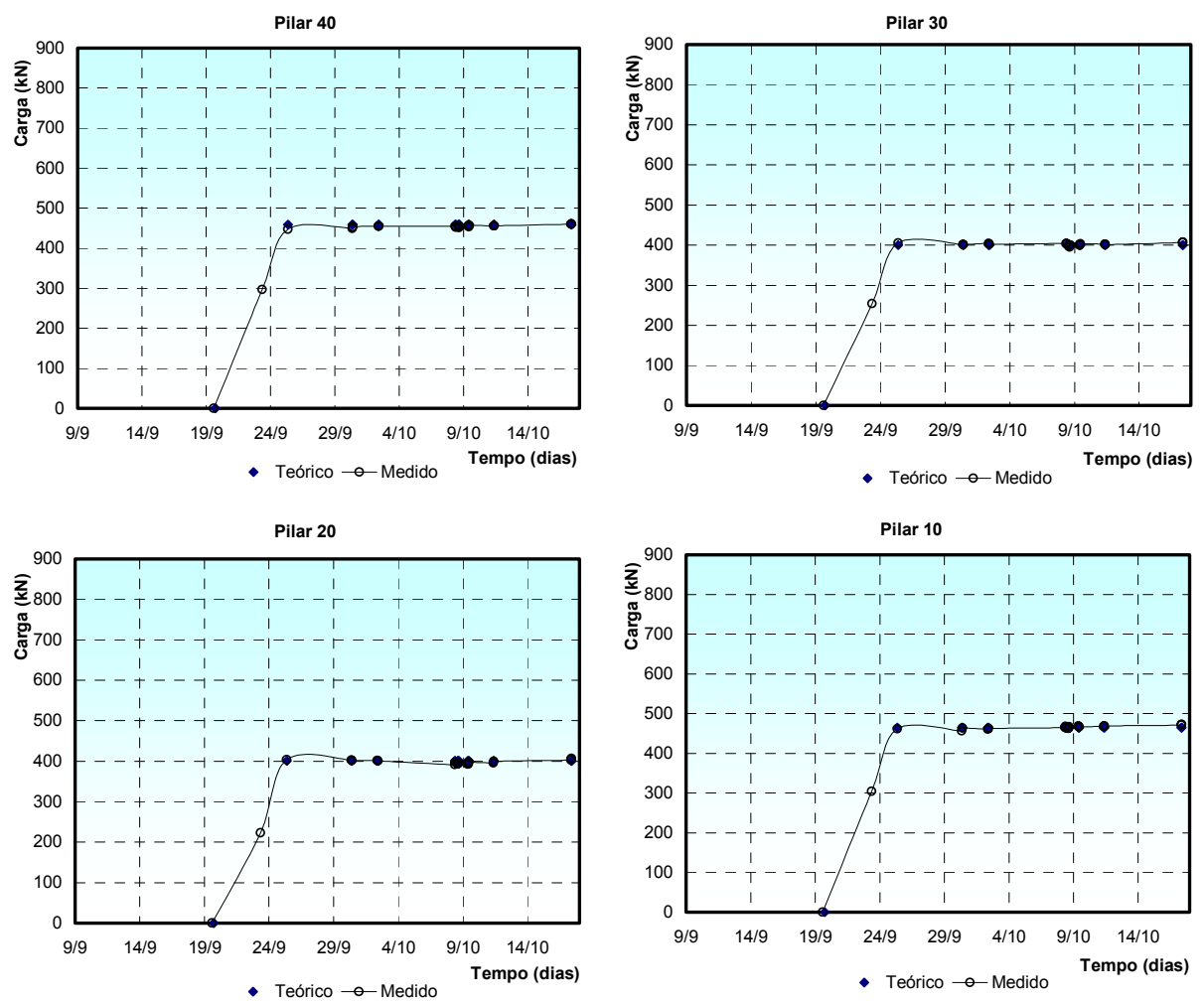

Figura 6.43 - Solicitação normal - comparativo medido x cálculo estrutural - pilares do eixo10. 
Nesses gráficos é possível verificar uma boa concordância entre os valores fornecidos pelo cálculo estrutural e os medidos. A Tabela 6.6 apresenta comparação entre os valores fornecidos pelo cálculo estrutural e o valor médio medido no período de 25/09 a 17/10, situação essa que corresponde ao final do carregamento da estrutura.

Tabela 6.6 - Comparativo entre a solicitação normal nos pilares cálculo estrutural x medido carga final máxima.

\begin{tabular}{|c|c|c|c|c|c|c|c|c|c|c|c|}
\hline Dilar & $\begin{array}{c}\mathrm{P}_{\mathrm{i}} \\
\text { calc. } \\
(\mathrm{kN})\end{array}$ & $\begin{array}{c}\mathrm{P}_{\mathrm{i}} \\
\text { med. } \\
(\mathrm{kN})\end{array}$ & & Pilar & $\begin{array}{c}\mathrm{P}_{\mathrm{i}} \\
\text { calc. } \\
\text { (kN) }\end{array}$ & $\begin{array}{c}\mathrm{P}_{\mathrm{i}} \\
\text { med. } \\
(\mathrm{kN})\end{array}$ & & Pila & $\begin{array}{c}\mathrm{P}_{\mathrm{i}} \\
\text { calc. } \\
\text { (kN) }\end{array}$ & $\begin{array}{c}P_{i} \\
\text { med. } \\
(k N)\end{array}$ & \\
\hline 36 & 406 & 402 & $-0,9$ & 37 & 810 & 802 & $-1,0$ & 3 & 808 & 798 & $-1,3$ \\
\hline 26 & 356 & 360 & 1,2 & 27 & 712 & 709 & 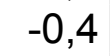 & 2 & 712 & 10 & -0 \\
\hline 16 & 360 & 357 & $-0,9$ & 17 & 717 & 709 & $-1,1$ & 1 & 714 & 706 & $-1,2$ \\
\hline 06 & 414 & 409 & $-1,2$ & 07 & 825 & 815 & $-1,2$ & 08 & 820 & 813 & $-0,9$ \\
\hline
\end{tabular}

\begin{tabular}{lccccccc}
\hline Pilar & $\begin{array}{c}\mathrm{P}_{\mathrm{i}} \\
\text { calc. }\end{array}$ & $\begin{array}{c}\mathrm{P}_{\mathrm{i}} \\
\text { med. }\end{array}$ & $\Delta$ & Pilar & $\begin{array}{c}\mathrm{P}_{\mathrm{i}} \\
\text { calc. }\end{array}$ & $\begin{array}{c}\mathrm{P}_{\mathrm{i}} \\
\text { med. }\end{array}$ & $\Delta$ \\
& $(\mathrm{kN})$ & $(\mathrm{kN})$ & $(\%)$ & & $\begin{array}{c}(\mathrm{kN}) \\
(\mathrm{kN})\end{array}$ & $(\%)$ \\
\hline 39 & 815 & 825 & 1,3 & 40 & 459 & 455 & $-1,0$ \\
29 & 713 & 711 & $-0,3$ & 30 & 400 & 402 & 0,5 \\
19 & 715 & 720 & 0,8 & 20 & 400 & 398 & $-0,5$ \\
09 & 826 & 817 & $-1,0$ & 10 & 464 & 465 & 0,3 \\
\hline
\end{tabular}

Também cabe salientar um aspecto interessante relativo à metodologia aplicada, que diz respeito à variabilidade das deformações medidas em comparação com a variabilidade das cargas aferidas indiretamente. A Tabela 6.7 apresenta o valor do coeficiente de variação das deformações médias medidas e das solicitações normais nos pilares, avaliados no período de "crgas constantes" da obra (25/09 a 17/10).

Pode-se verificar nessa tabela que a variabilidade das solicitações normais é menor que a variabilidade das deformações medidas médias. Esse comportamento pode ser atribuído a erros ou imprecisões presentes nas medidas de deformações, que são comuns a todos os pilares em uma determinada data, os quais são eliminados ao se aplicar a metodologia. 
Tabela 6.7 - Comparativo do coeficiente de variação (\%) deformação média medida $x$ solicitação normal.

\begin{tabular}{lcccccccccccccc}
\hline Pilar & $\varepsilon_{\mathrm{i}}$ & $\mathrm{P}_{\mathrm{i}}$ & Pilar & $\varepsilon_{\mathrm{i}}$ & $\mathrm{P}_{\mathrm{i}}$ & Pilar & $\varepsilon_{\mathrm{i}}$ & $\mathrm{P}_{\mathrm{i}}$ & Pilar & $\varepsilon_{\mathrm{i}}$ & $\mathrm{P}_{\mathrm{i}}$ & Pilar & $\varepsilon_{\mathrm{i}}$ & $\mathrm{P}_{\mathrm{i}}$ \\
\hline 36 & 3,0 & 1,2 & 37 & 2,0 & 0,7 & 38 & 2,2 & 0,7 & 39 & 1,5 & 0,7 & 40 & 2,1 & 0,7 \\
26 & 3,3 & 1,5 & 27 & 2,0 & 0,4 & 28 & 2,3 & 0,8 & 29 & 1,9 & 0,7 & 30 & 2,5 & 0,7 \\
16 & 3,8 & 2,0 & 17 & 2,3 & 0,6 & 18 & 2,4 & 0,5 & 19 & 1,5 & 0,7 & 20 & 2,8 & 1,1 \\
06 & 2,7 & 1,1 & 07 & 1,8 & 0,5 & 08 & 1,7 & 0,7 & 09 & 1,5 & 1,1 & 10 & 2,0 & 0,9 \\
\hline
\end{tabular}




\section{COMPORTAMENTO DA FUNDAÇÃO}

Neste capítulo são apresentados e interpretados os resultados das observações de campo referentes às medidas de recalque efetuadas em posição próxima à base dos pilares. Na seqüência, tendo em vista o conjunto de informações coletadas, o comportamento carga $x$ recalque observado em cada ponto de medida é analisado.

\subsection{OBSERVAÇÕES DE RECALQUE.}

Foram efetuadas medidas em 20 pilares no período compreendido entre os dias 06/09 a 17/10/2002. A montagem da estrutura aconteceu entre os dias 06 e 23/09. As observações foram iniciadas desde o momento do posicionamento de cada pilar em sua base (início do carregamento), até a conclusão da etapa da montagem da estrutura pré-moldada (23/09).

Após a conclusão da montagem, seguiu-se um período de 24 dias, no qual não foi aplicado carregamento adicional à estrutura. Esse período é neste trabalho, denominado "carga constante" ou "repouso".

A Figura 7.1 apresenta a localização, em planta, dos pontos de observação, a posição da referência de nível profunda ("bench-mark") e do local onde foi posicionado o nível ótico. Também é indicada nessa figura a face do pilar em que foi realizada a medida, a qual é representada por uma letra ( $A$, $B, C$ ou D), acrescentada ao final da designação do pilar. 


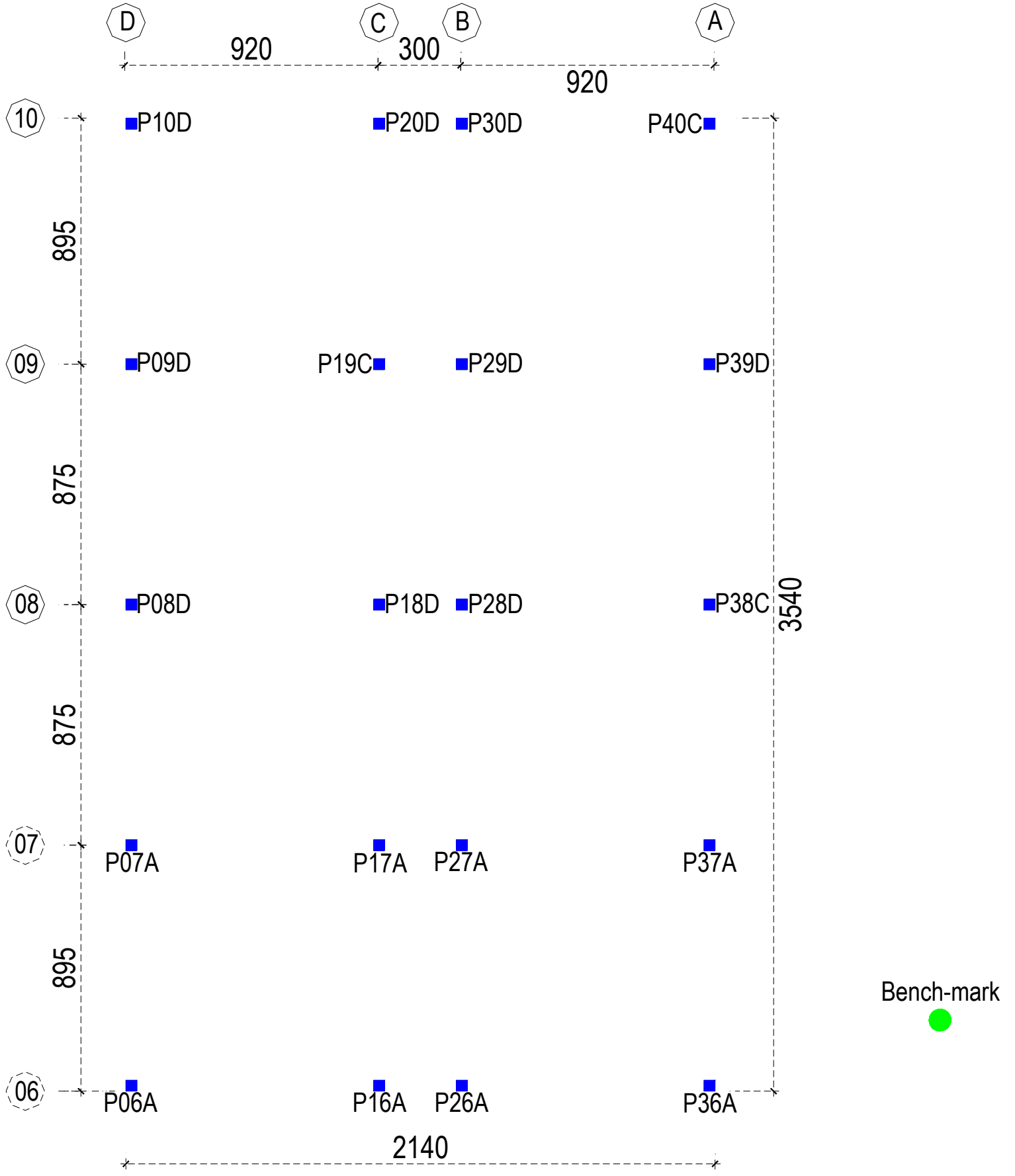

Nível ótico

Figura 7.1 - Planta de localização dos pontos de monitoramento dos recalques. 
7.1.1 Evolução dos recalques com o tempo.

As leituras de campo foram transformadas em cotas, as quais foram convertidas em recalques. As curvas que apresentam a evolução dos recalques ao longo do tempo são mostradas nos gráficos das Figuras 7.2 a 7.10.

Tempo (dias)

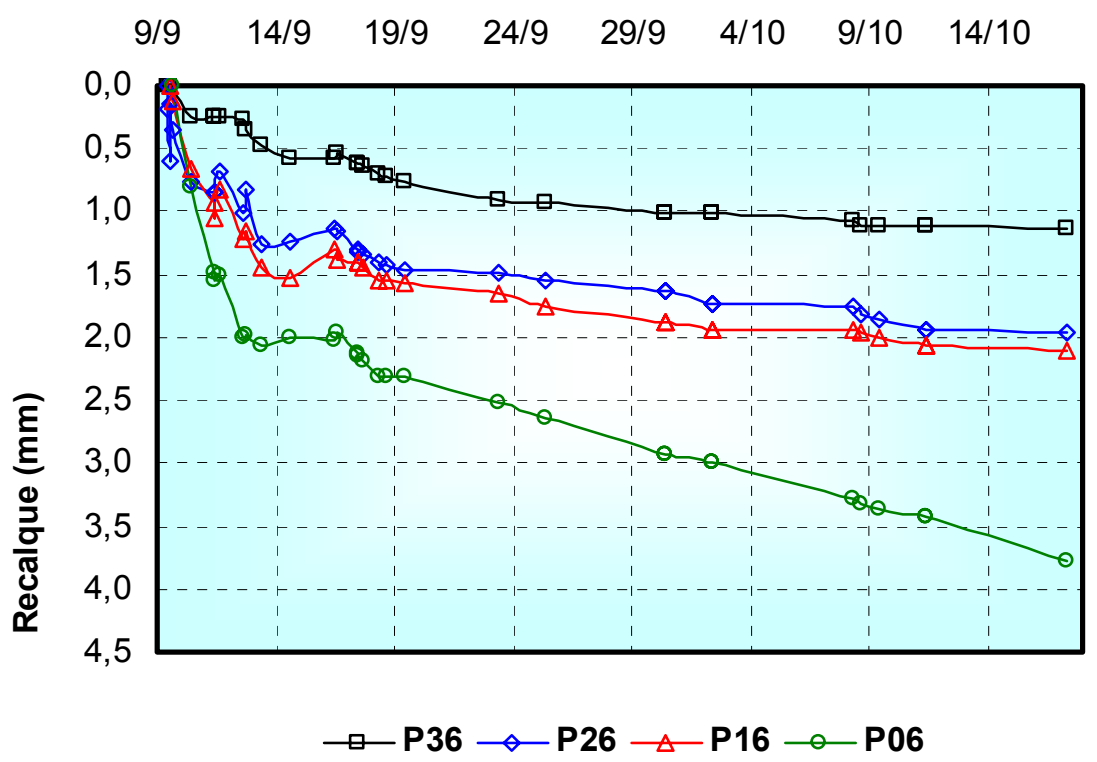

Figura 7.2 - Curvas tempo x recalque, pilares do eixo 6 .

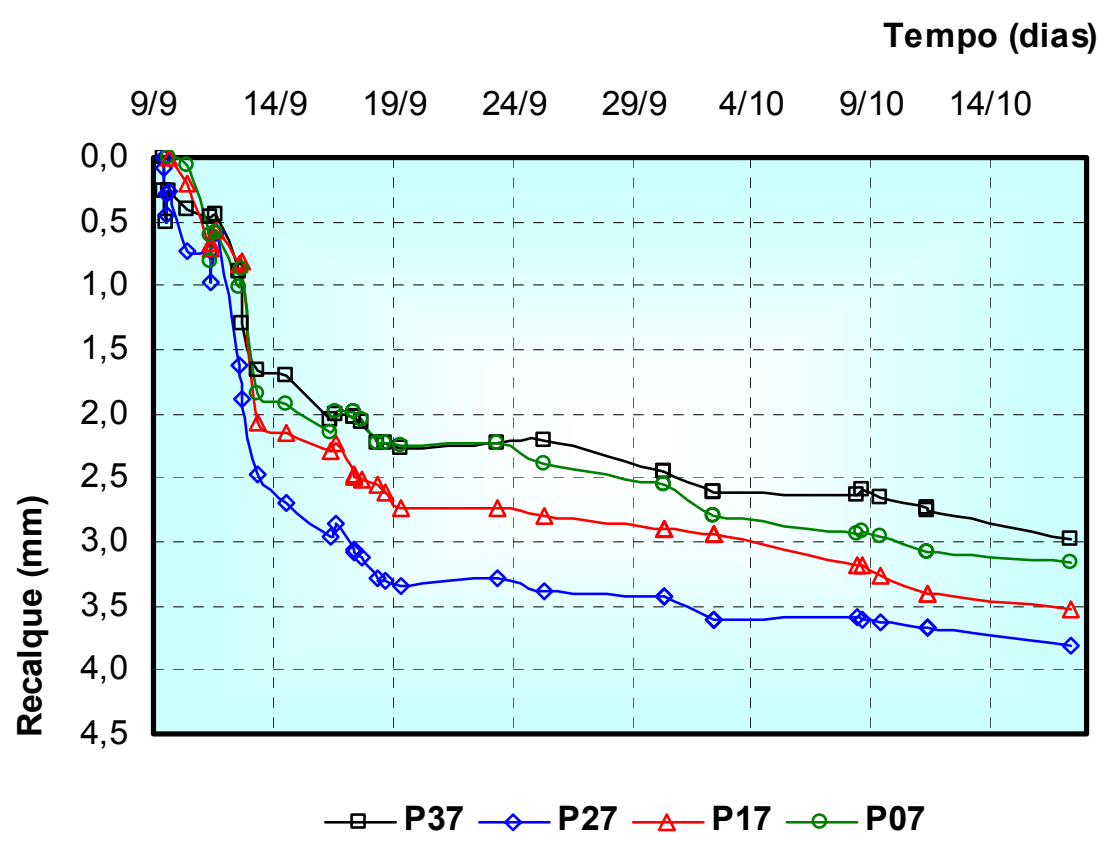

Figura 7.3 - Curvas tempo x recalque, pilares do eixo 7. 
Tempo (dias)

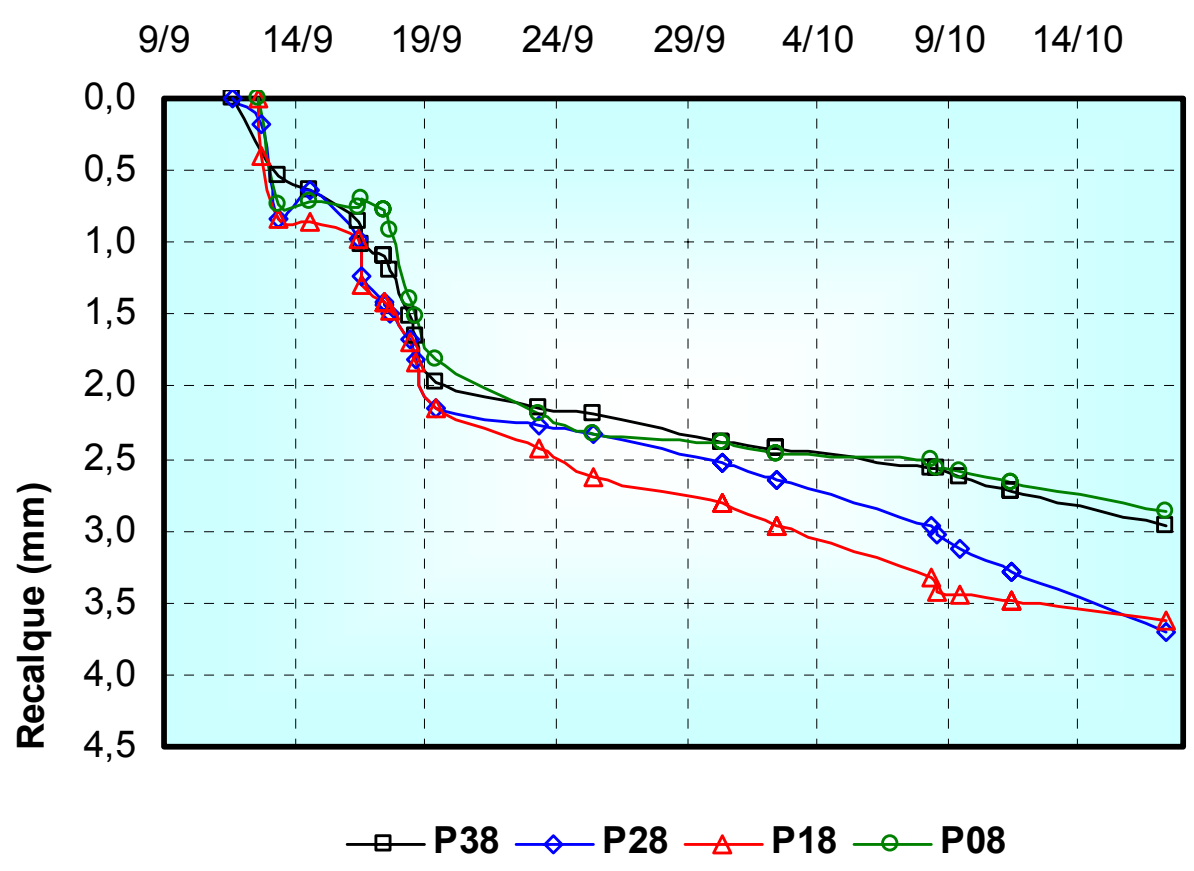

Figura 7.4 - Curvas tempo x recalque, pilares do eixo 8.

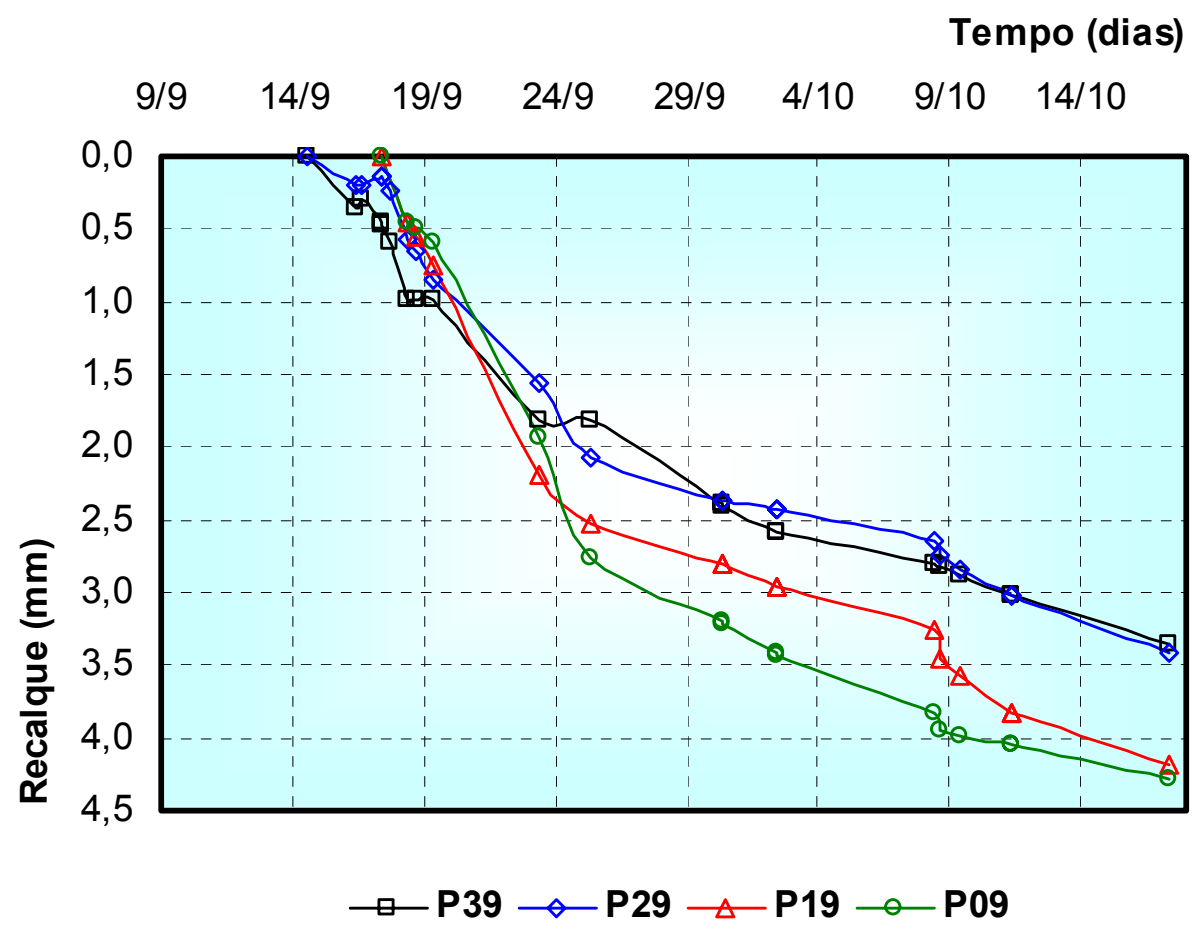

Figura 7.5 - Curvas tempo x recalque, pilares do eixo 9. 
Tempo(dias)

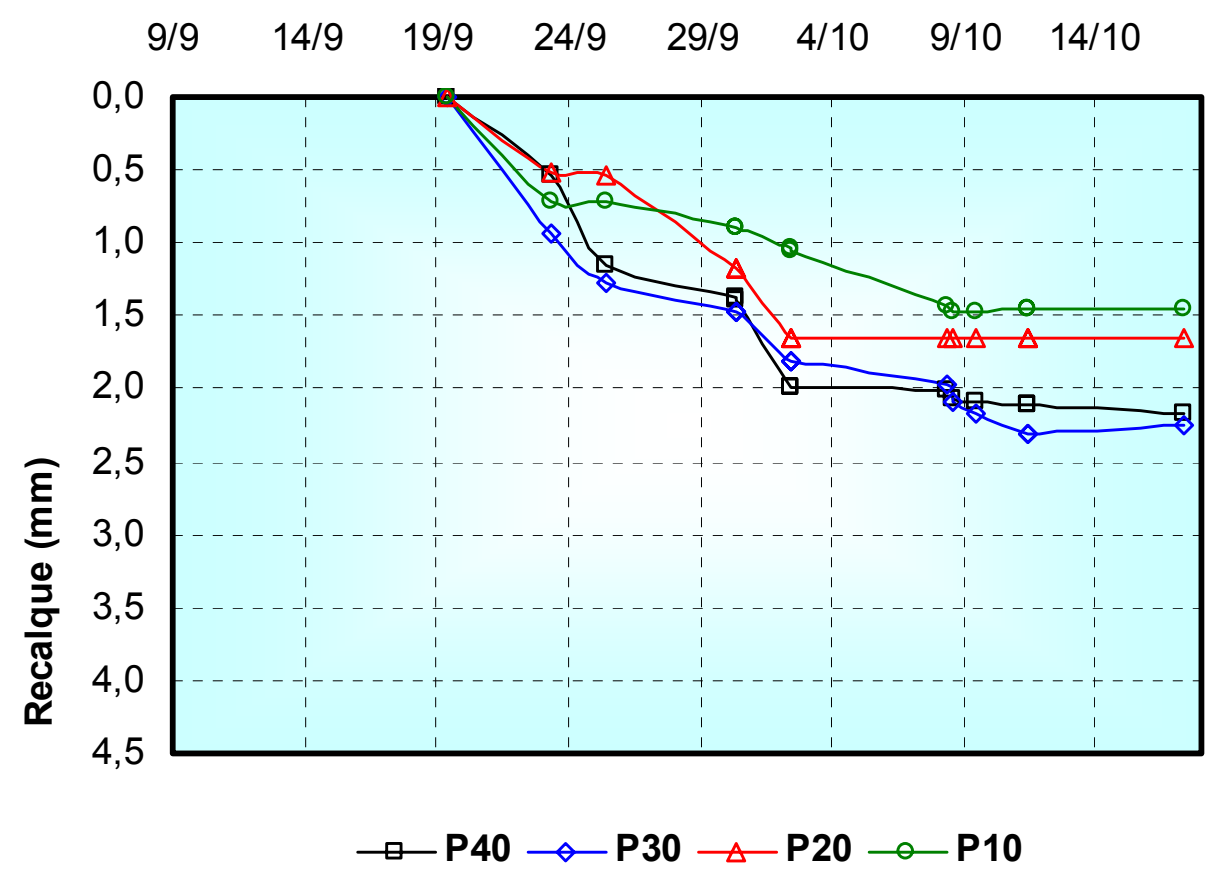

Figura 7.6 - Curvas tempo x recalque, pilares do eixo 10.

Tempo (dias)

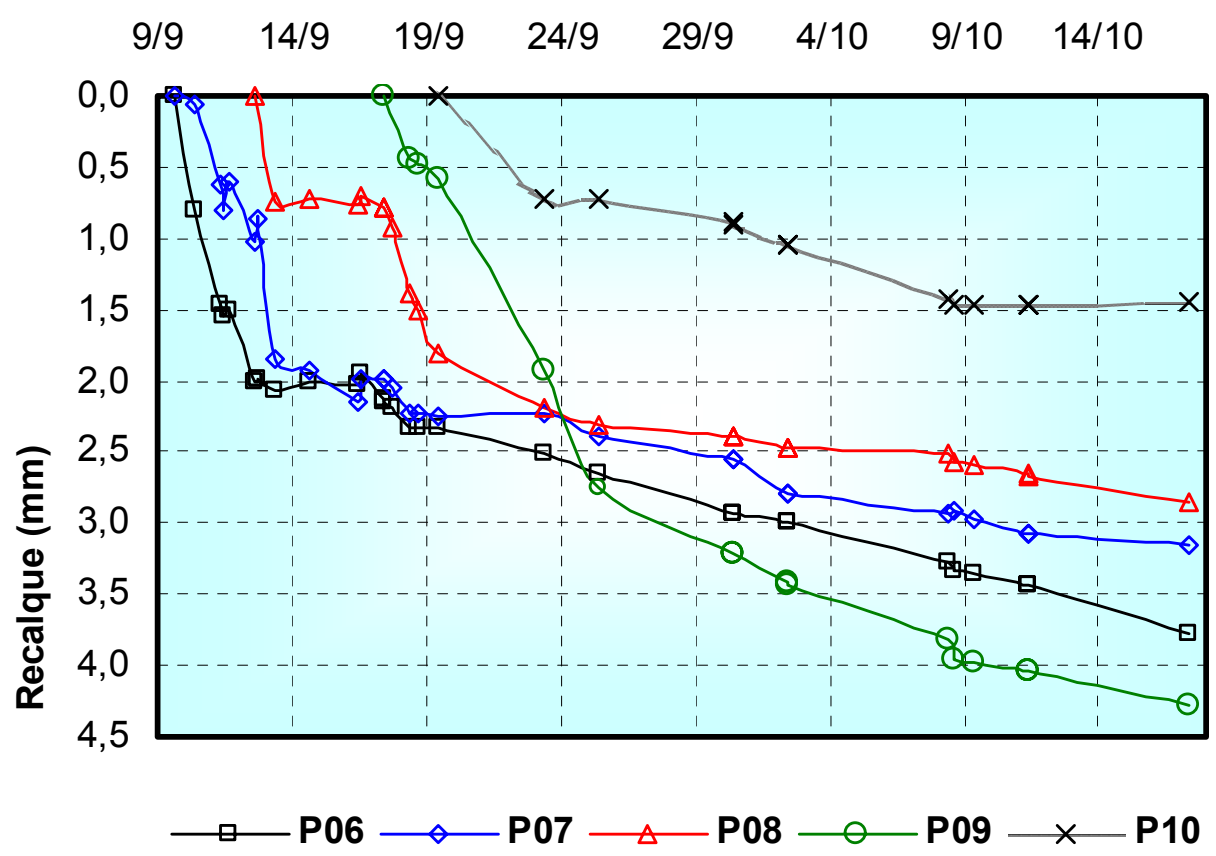

Figura 7.7 - Curvas tempo x recalque, pilares eixo A. 
Tempo (dias)

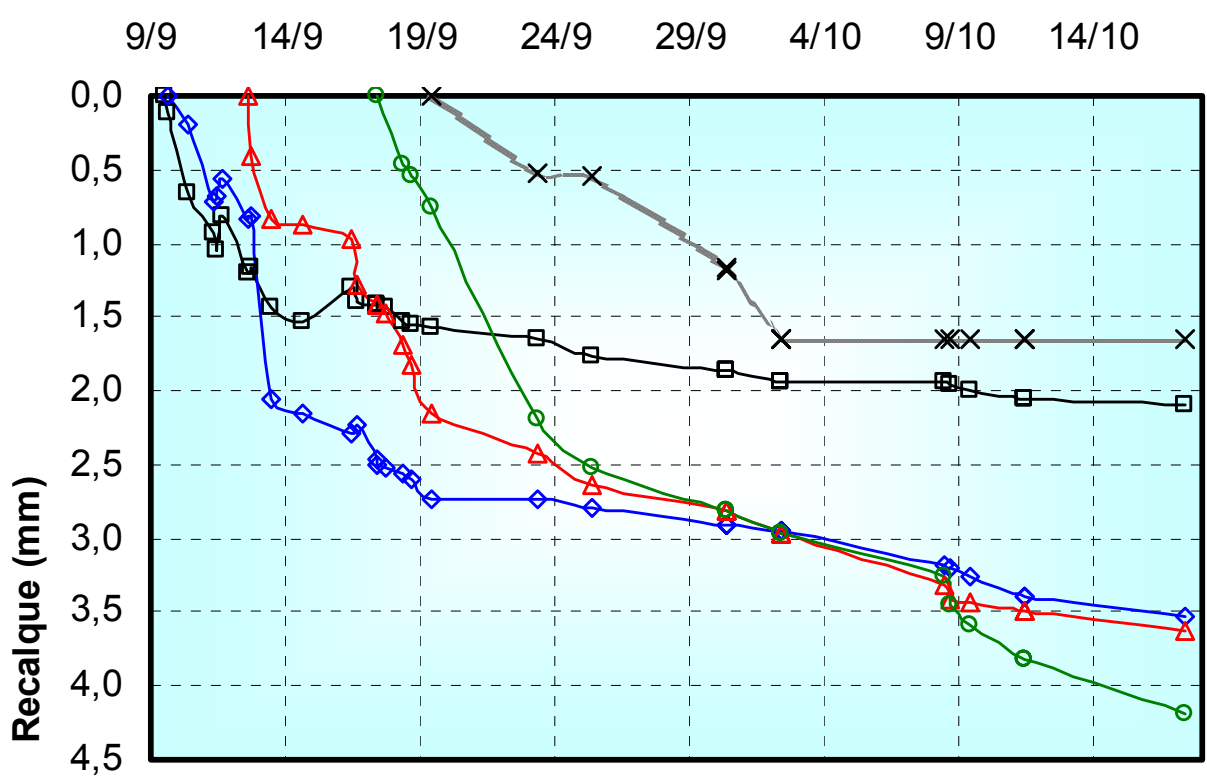

$\longrightarrow \mathrm{P} 16 \multimap \mathrm{P} 17 \longrightarrow \triangle \mathrm{P} 18 \longrightarrow \mathrm{Q}-\mathrm{P} 19 \longrightarrow \mathrm{P} 20$

Figura 7.8 - Curvas tempo x recalque, pilares eixo $B$.

Tempo (dias)

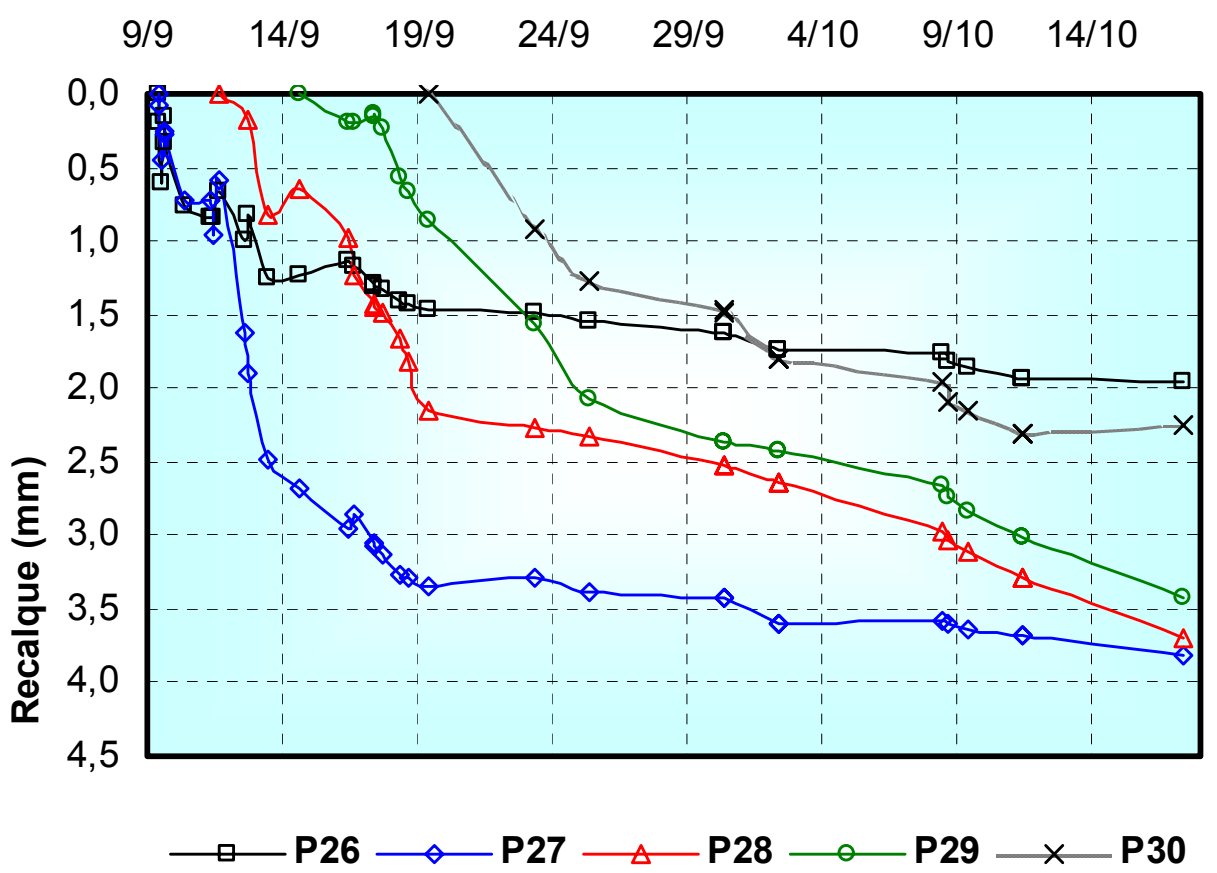

Figura 7.9 - Curvas tempo x recalque, pilares eixo $C$. 


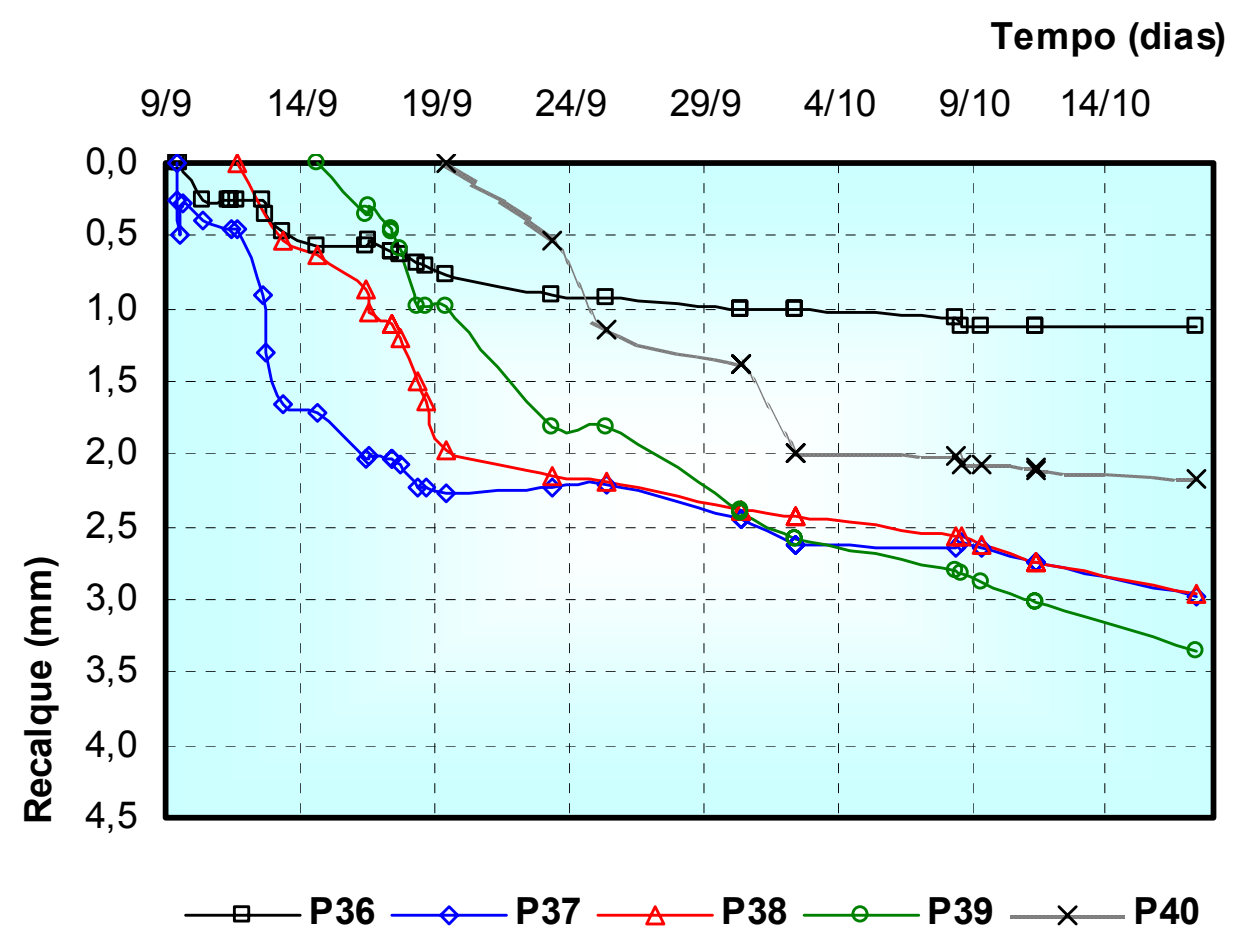

Figura 7.10 - Curvas tempo x recalque, pilares eixo $D$.

A Tabela 7.1 apresenta os valores do máximo recalque medido em $17 / 10\left(\delta_{\text {máx }}\right)$ em cada ponto de observação. Os resultados são agrupados de acordo com a sua disposição em planta, sendo os pilares dos eixos 06 e 10 situados nas extremidades do local do estudo. Justifica-se esse agrupamento por serem esses pontos submetidos a uma história de carregamento e a um nível de tensão praticamente idêntico. Para cada conjunto de quatro pilares apresenta-se o valor médio do recalque, bem como o coeficiente de variação (CV) do conjunto respectivo.

Tabela 7.1 - Máximo recalque observado.

\begin{tabular}{llllllllll}
\hline Pilar & $\begin{array}{l}\delta_{\text {máx }} \\
(\mathrm{mm})\end{array}$ & Pilar & $\begin{array}{l}\delta_{\text {máx }} \\
(\mathrm{mm})\end{array}$ & Pilar & $\begin{array}{l}\delta_{\text {máx }} \\
(\mathrm{mm})\end{array}$ & Pilar & $\begin{array}{l}\delta_{\text {máx }} \\
(\mathrm{mm})\end{array}$ & Pilar & $\delta_{\text {máx }}$ \\
$(\mathrm{mm})$
\end{tabular}

Verifica-se na Tabela 7.1 que o maior recalque foi observado no pilar 09, com magnitude de 4,3 mm, e o menor ocorreu no pilar $36 \mathrm{com} \mathrm{1,1} \mathrm{mm.} \mathrm{O} \mathrm{valor}$ 
médio das medidas é de 2,9 mm. Também é possível verificar que a maior variabilidade dos deslocamentos verticais nas bases dos pilares ocorre nos pilares extremos (eixos 06 e 10), enquanto nos pilares centrais apresenta-se uma menor variabilidade, a qual se situa entre 9 e 11\%, com recalques médios entre 3,3 a $3,8 \mathrm{~mm}$.

\subsubsection{Disposição dos recalques em planta.}

A disposição em planta e a evolução com o tempo dos recalques têm sua visualização facilitada pela representação gráfica das curvas de igual recalque (iso-recalques ou bacia de recalques), as quais são apresentadas nas Figuras 7.11 a 7.20. Nessas figuras também é indicada a posição dos pontos em que as medidas foram efetuadas (pilares). Cabe salientar que a evolução da obra ocorre da esquerda para a direita, sendo os pilares inicialmente carregados os dos eixos 06 e 07 . A seqüência construtiva adotada para o local do estudo era que uma nova linha de pilares somente era carregada depois da conclusão do módulo anterior, fato esse devido à necessidade de acesso para o guindaste de montagem da estrutura pré-moldada.

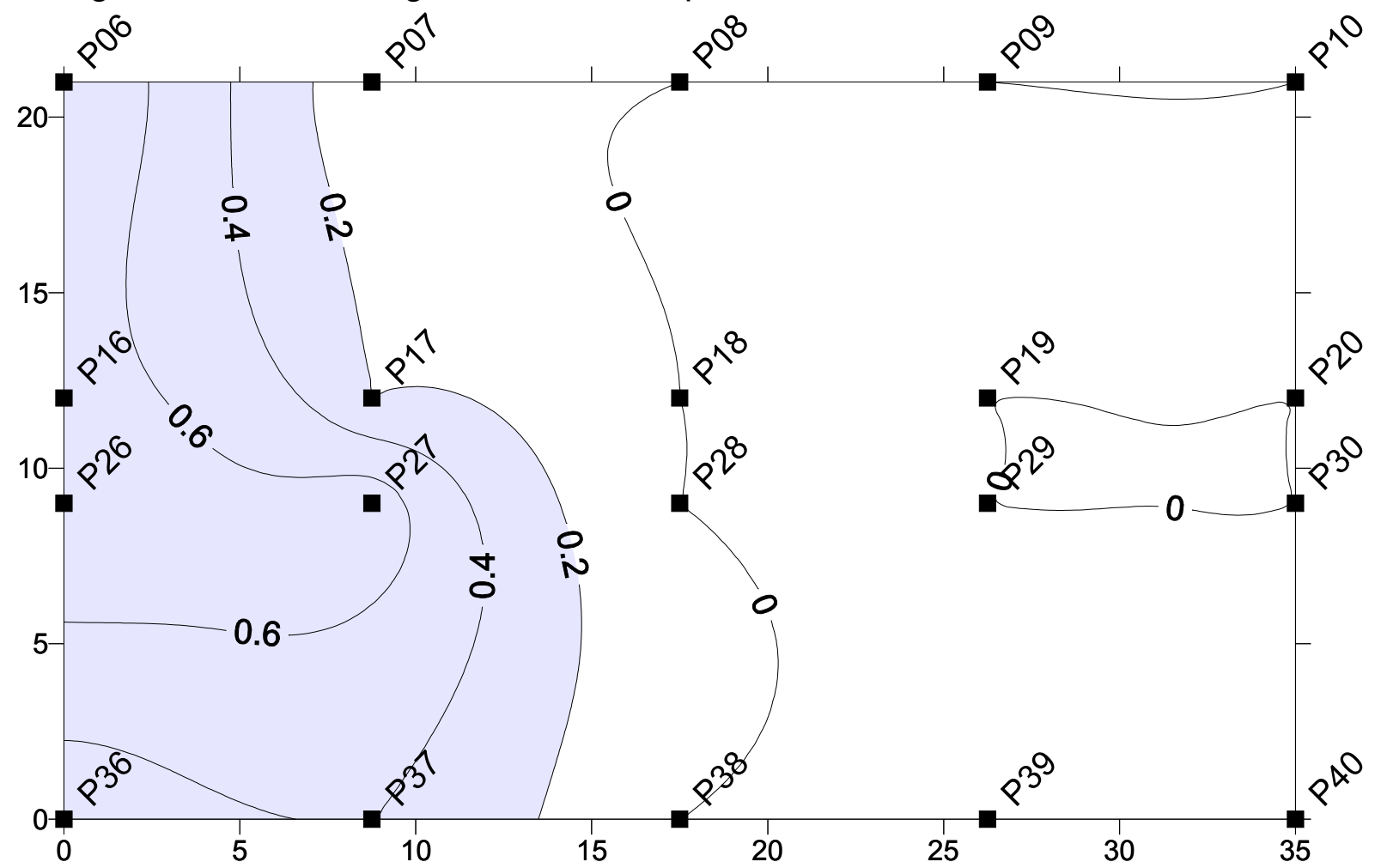

Figura 7.11 - Bacia de recalques em 10/09. 


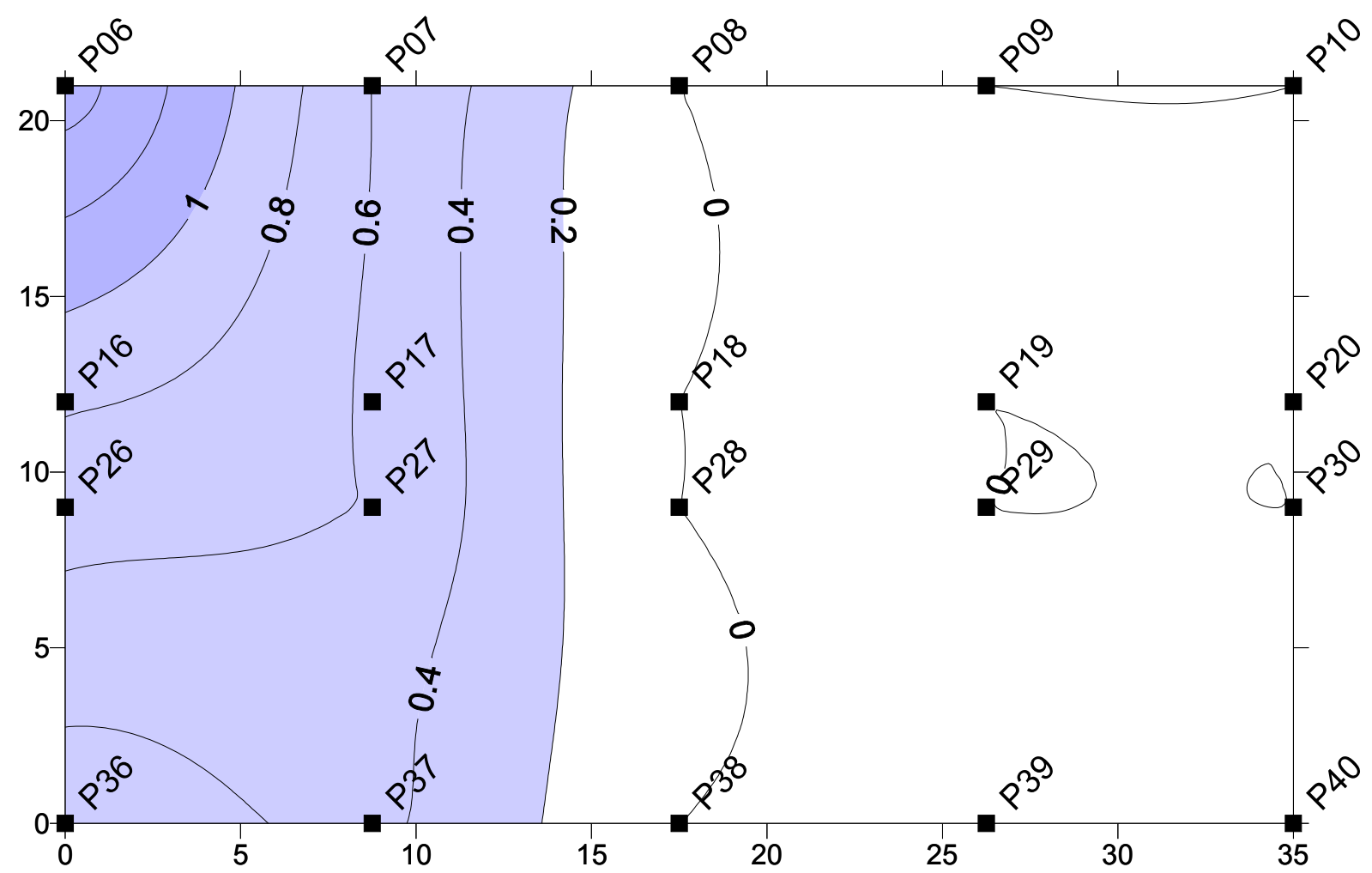

Figura 7.12 - Bacia de recalques em 11/09.

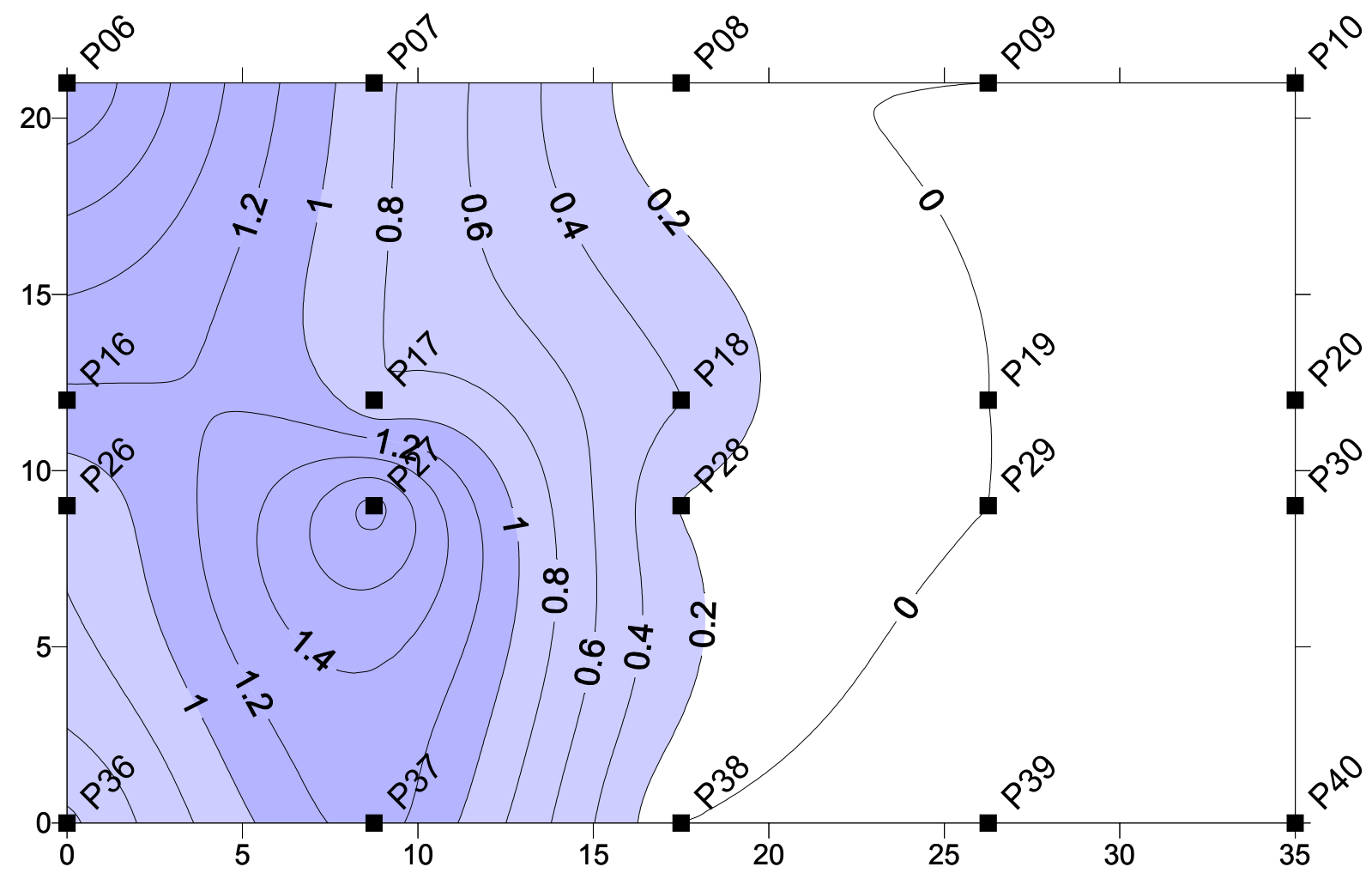

Figura 7.13 - Bacia de recalques em 12/09. 


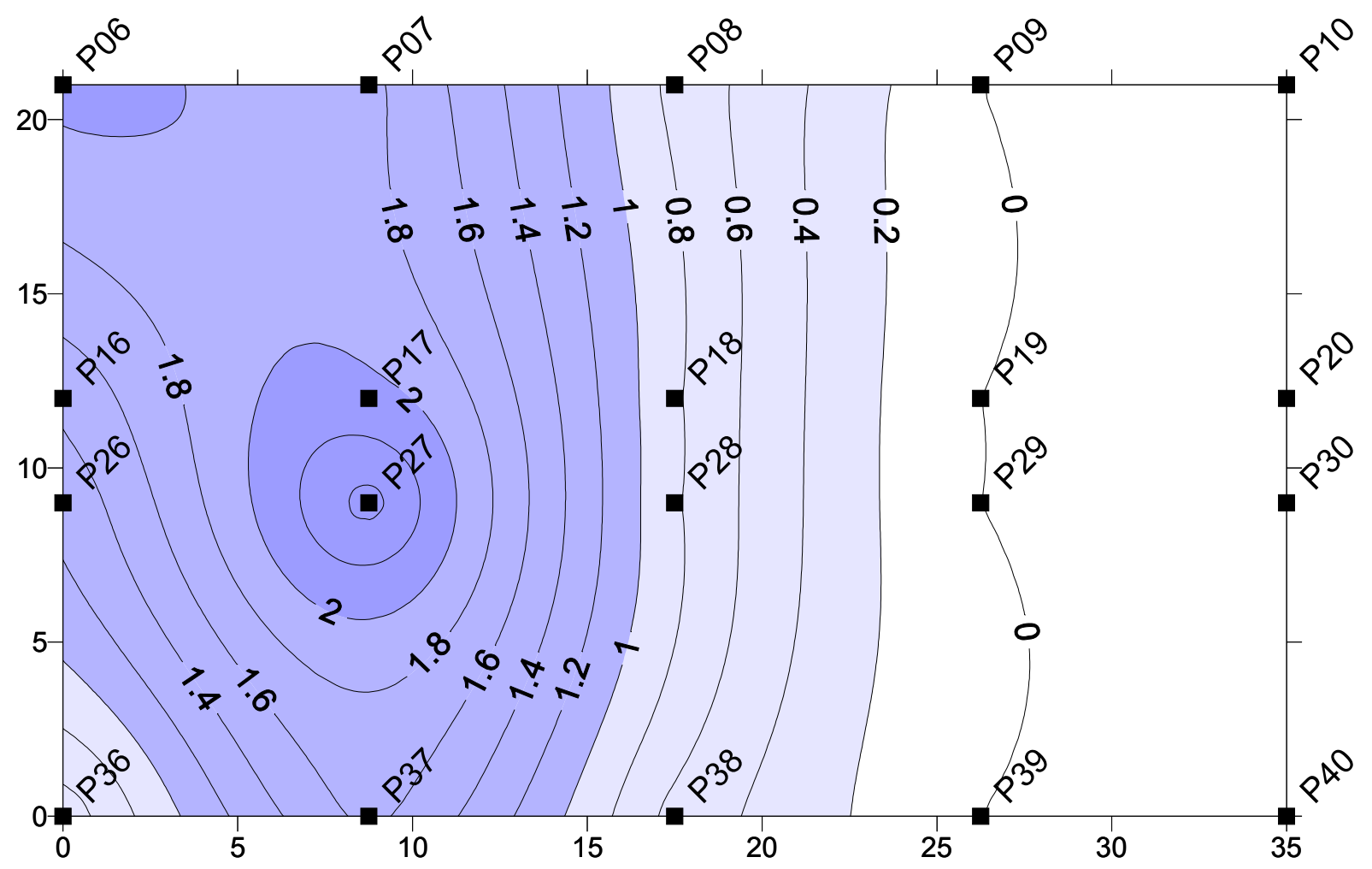

Figura 7.14 - Bacia de recalques em 13/09.

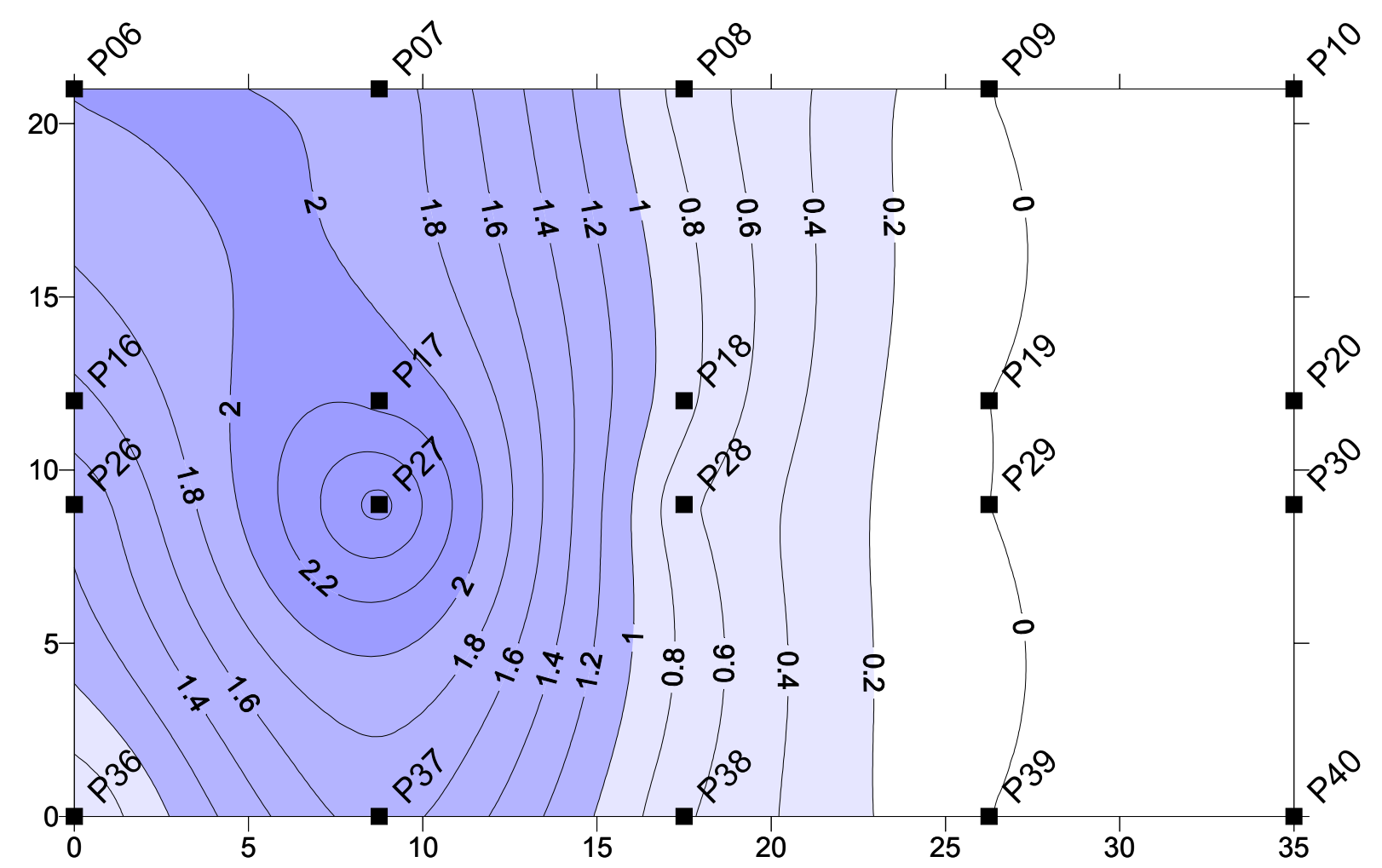

Figura 7.15 - Bacia de recalques em 14/09. 


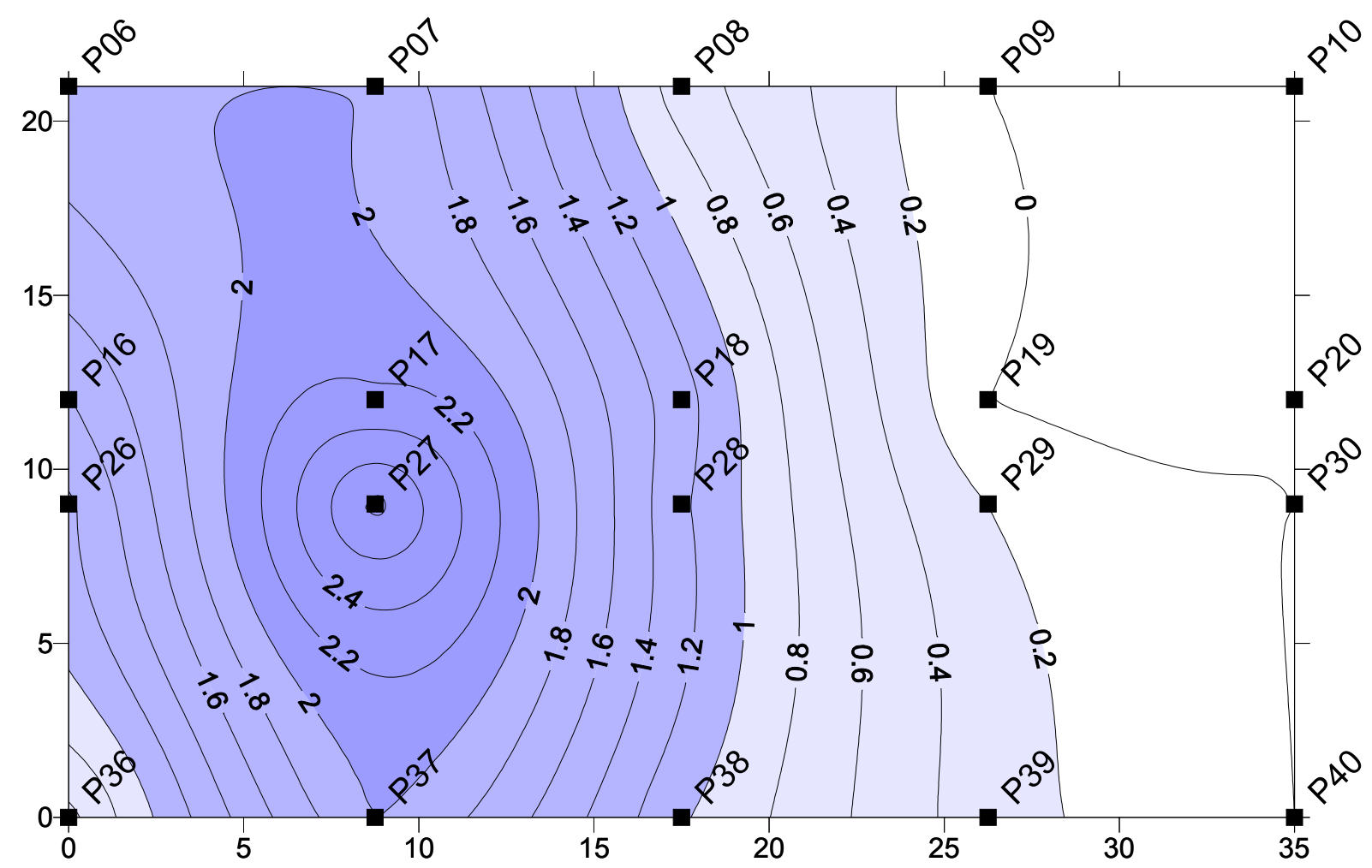

Figura 7.16 - Bacia de recalques em 16/09.

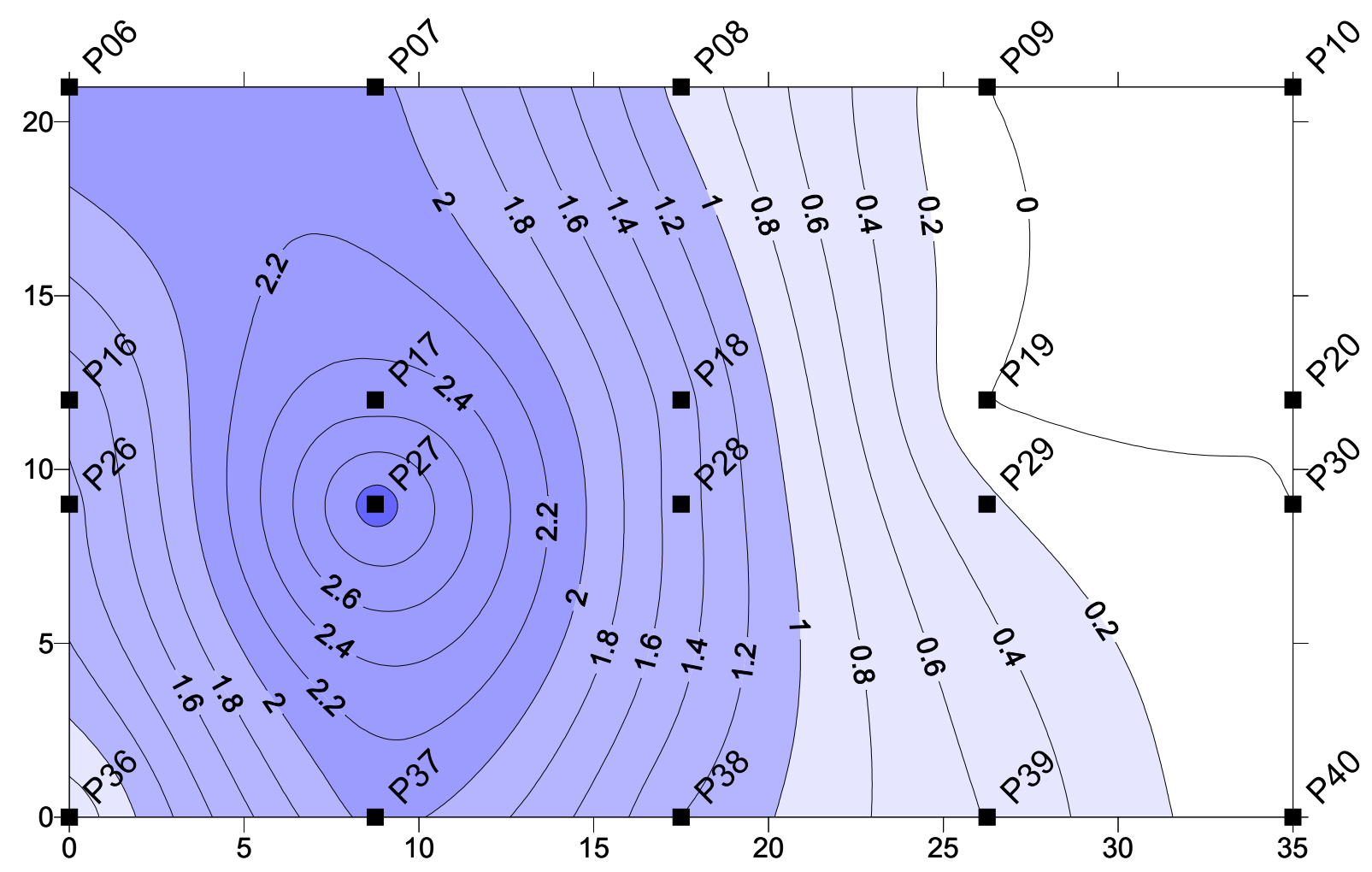

Figura 7.17 - Bacia de recalques em 17/09. 


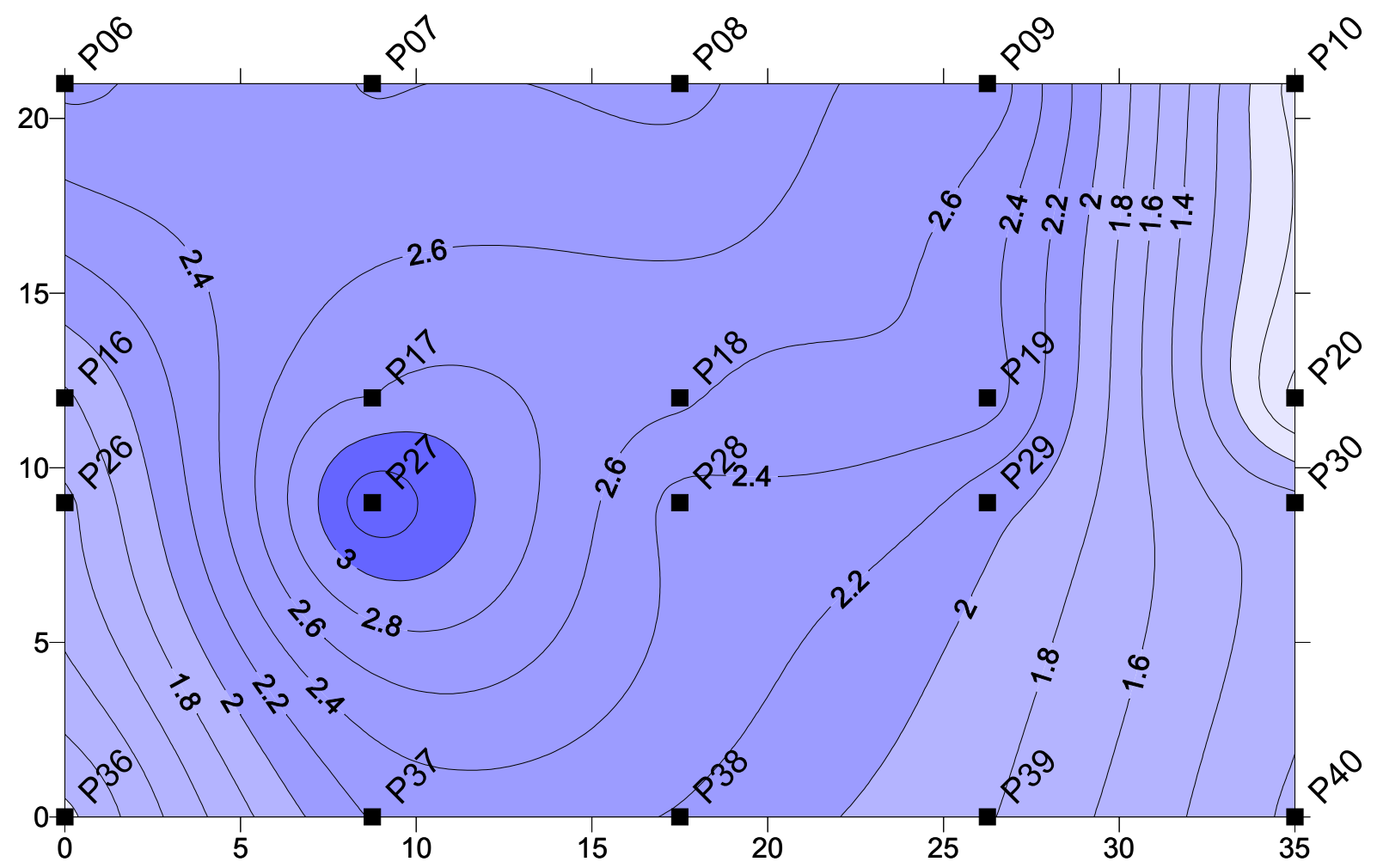

Figura 7.18 - Bacia de recalques em 25/09.

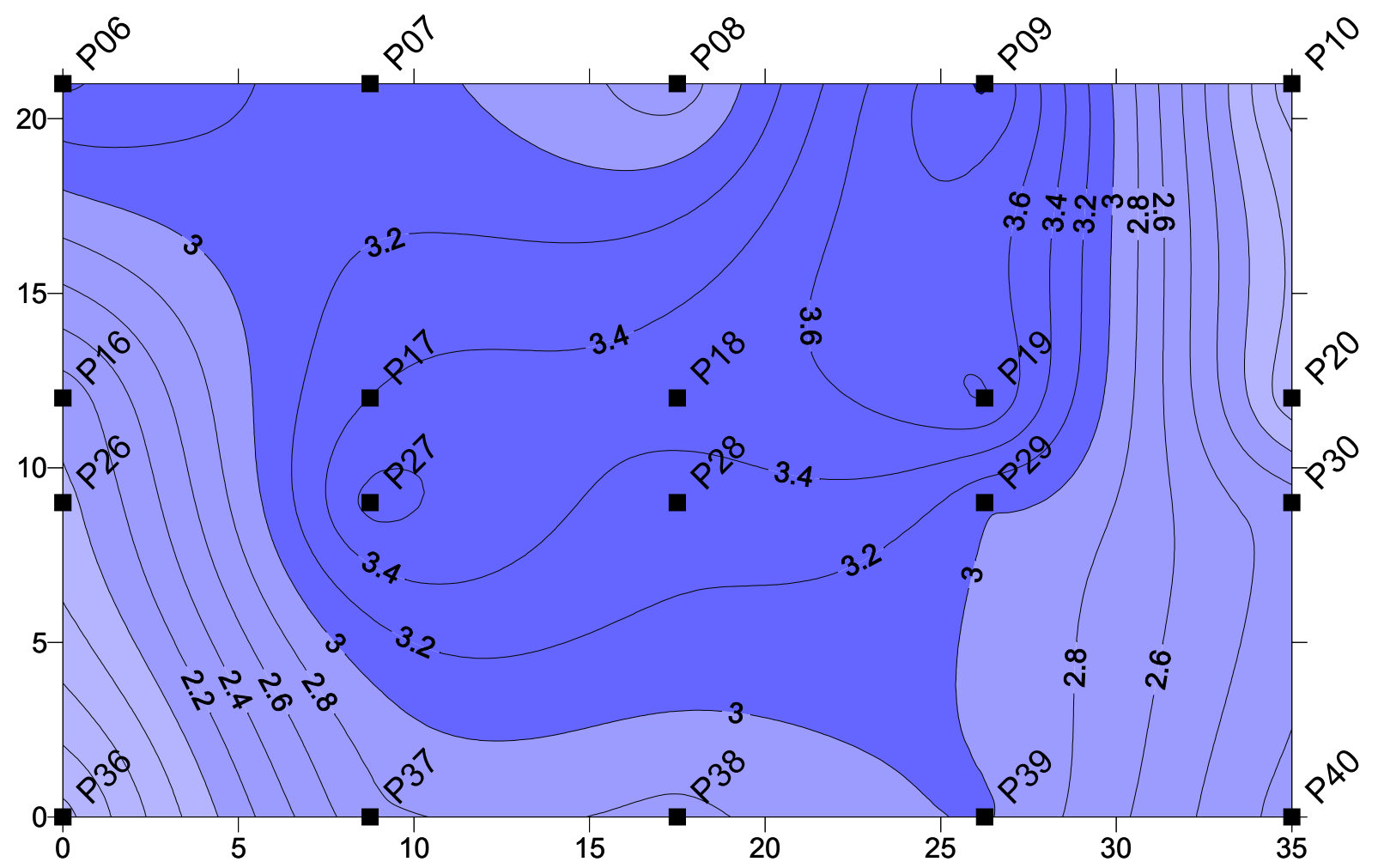

Figura 7.19 - Bacia de recalques em 11/10. 


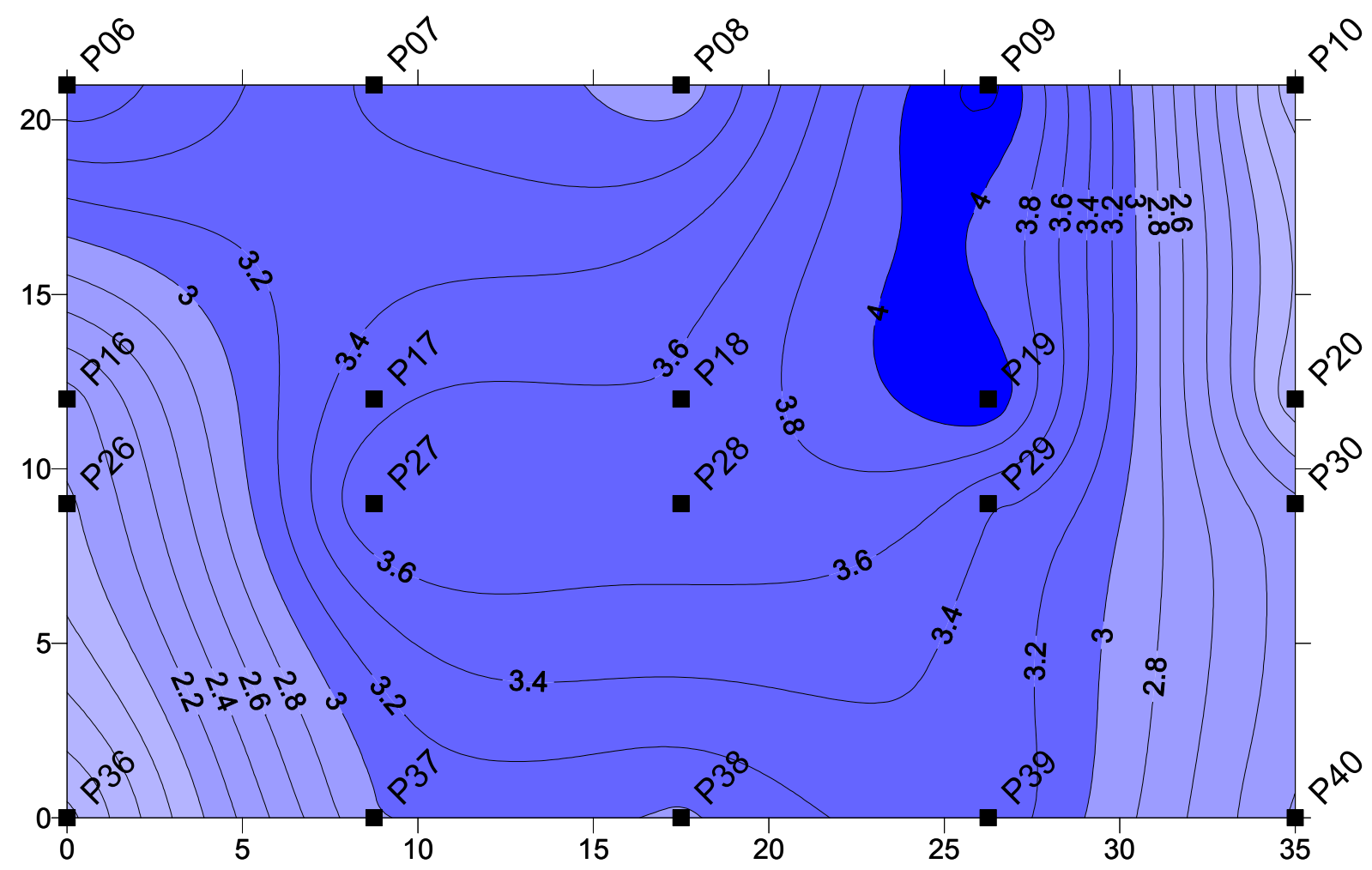

Figura 7.20 - Bacia de recalques em 17/10 (máximo recalque observado).

Também de modo a facilitar a visualização dos recalques, são apresentados nas Figuras 7.21 a 7.29 os gráficos da deformada de recalques para as datas de 11/09, 18/09, 25/09 e 17/10 (máximo recalque observado).

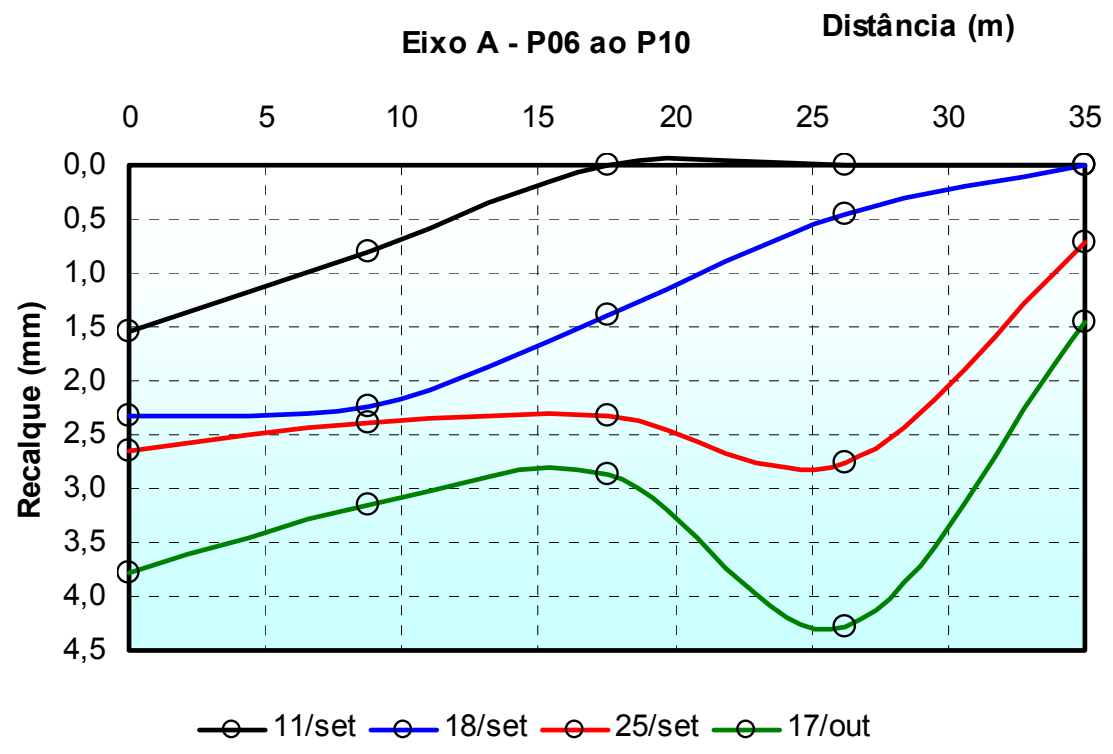

Figura 7.21 - Deformada de recalques, pilares 06 a 10. 
Eixo B - P16 ao P20 Distância (m)

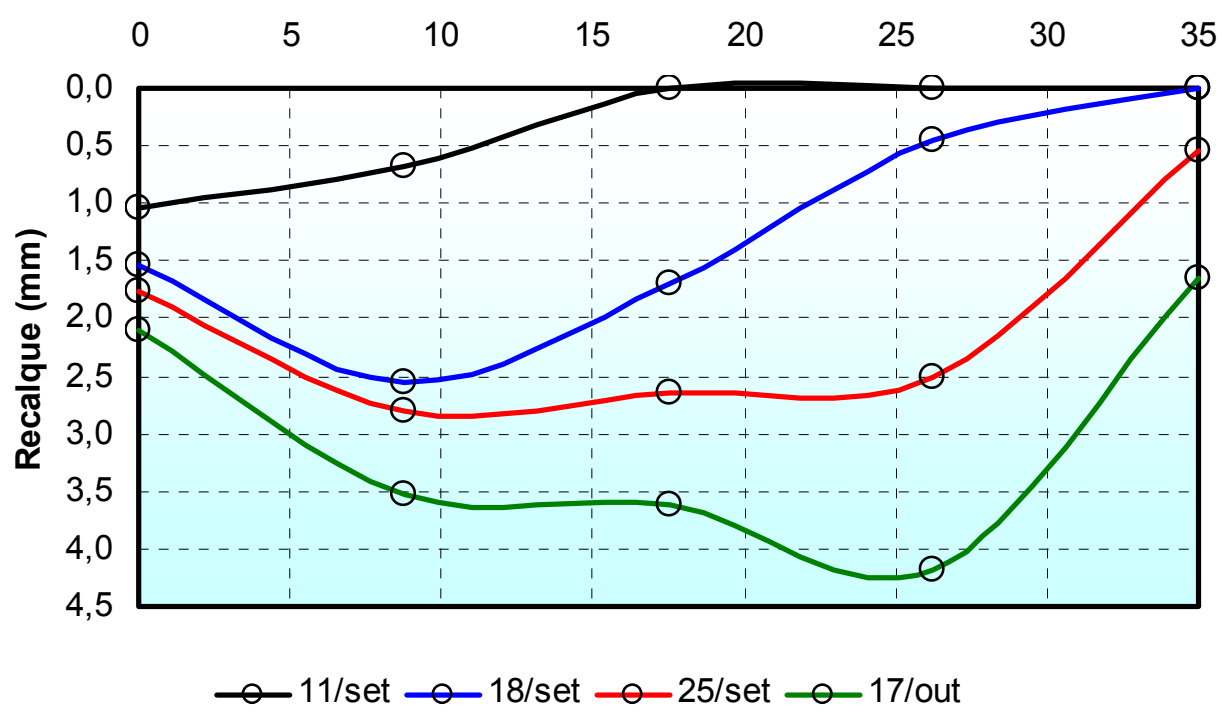

Figura 7.22 - Deformada de recalques, pilares 16 a 20.

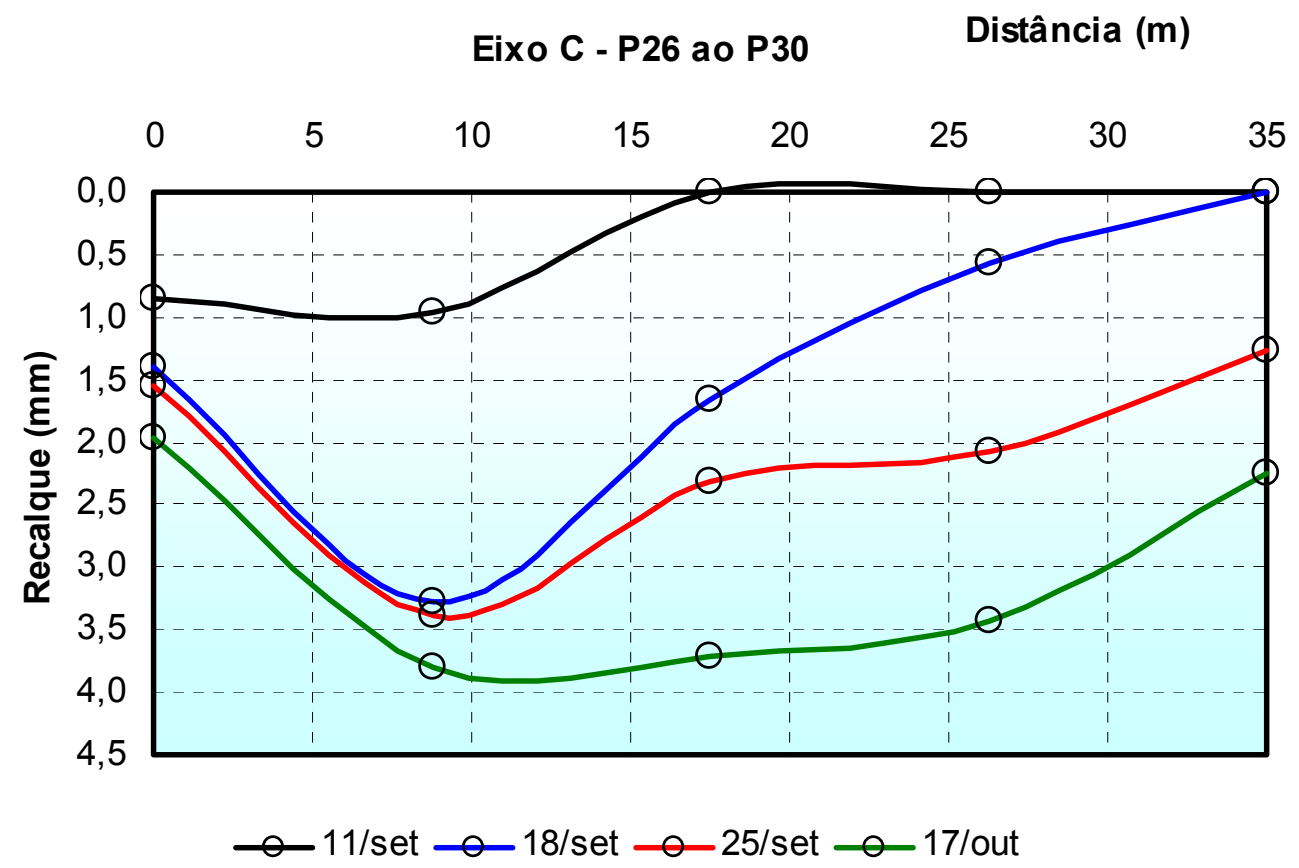

Figura 7.23 - Deformada de recalques, pilares 26 a 30. 


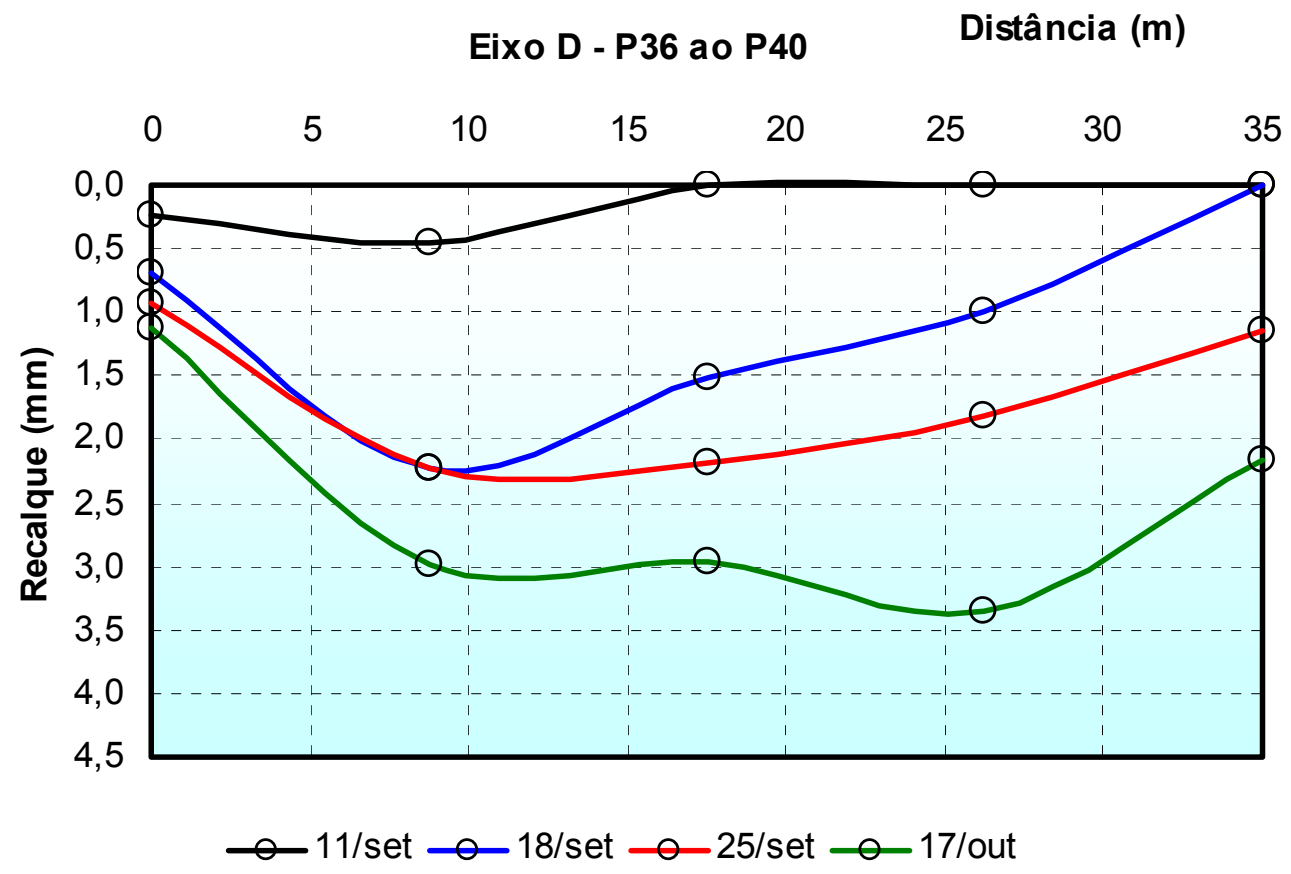

Figura 7.24 - Deformada de recalques, pilares 36 a 40.

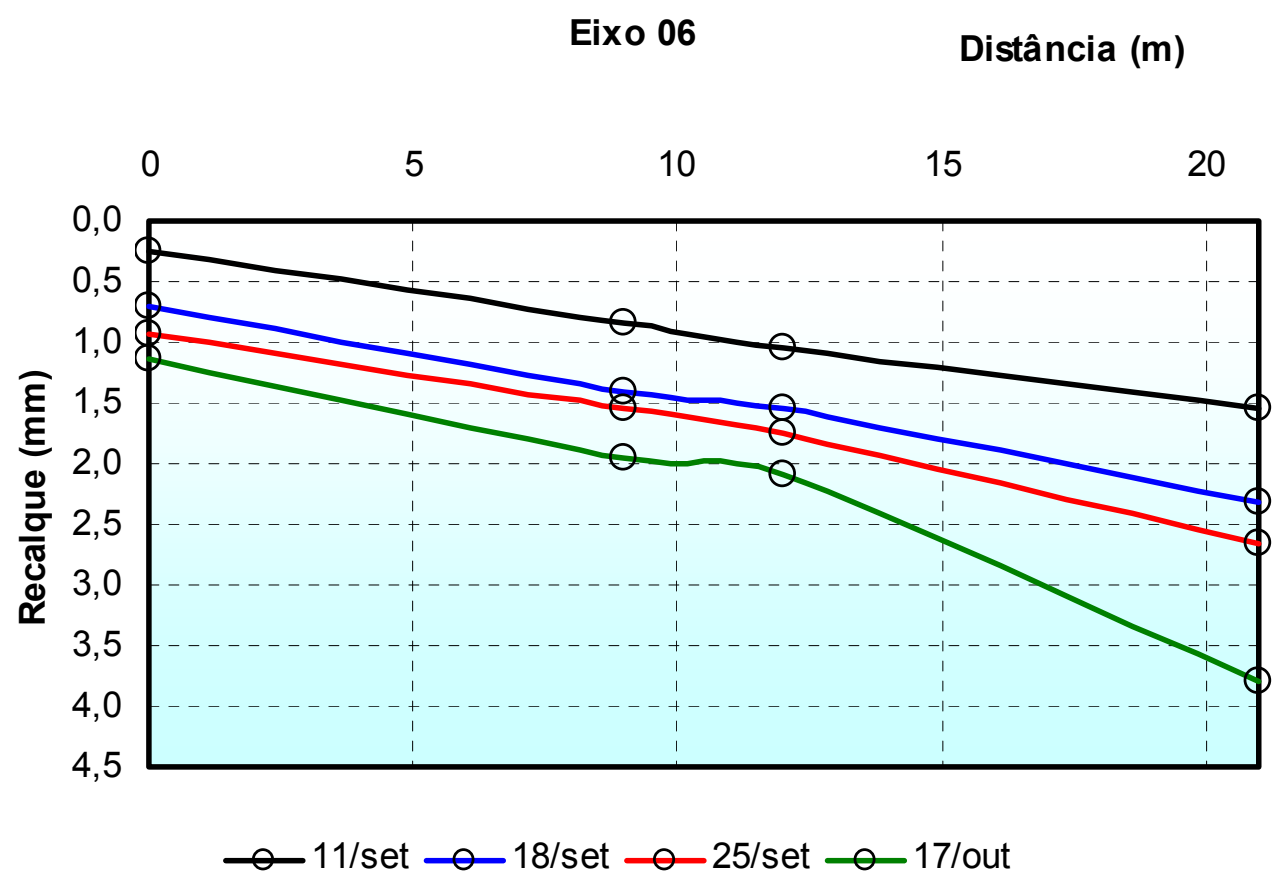

Figura 7.25 - Deformada de recalques pilares, do eixo 6. 


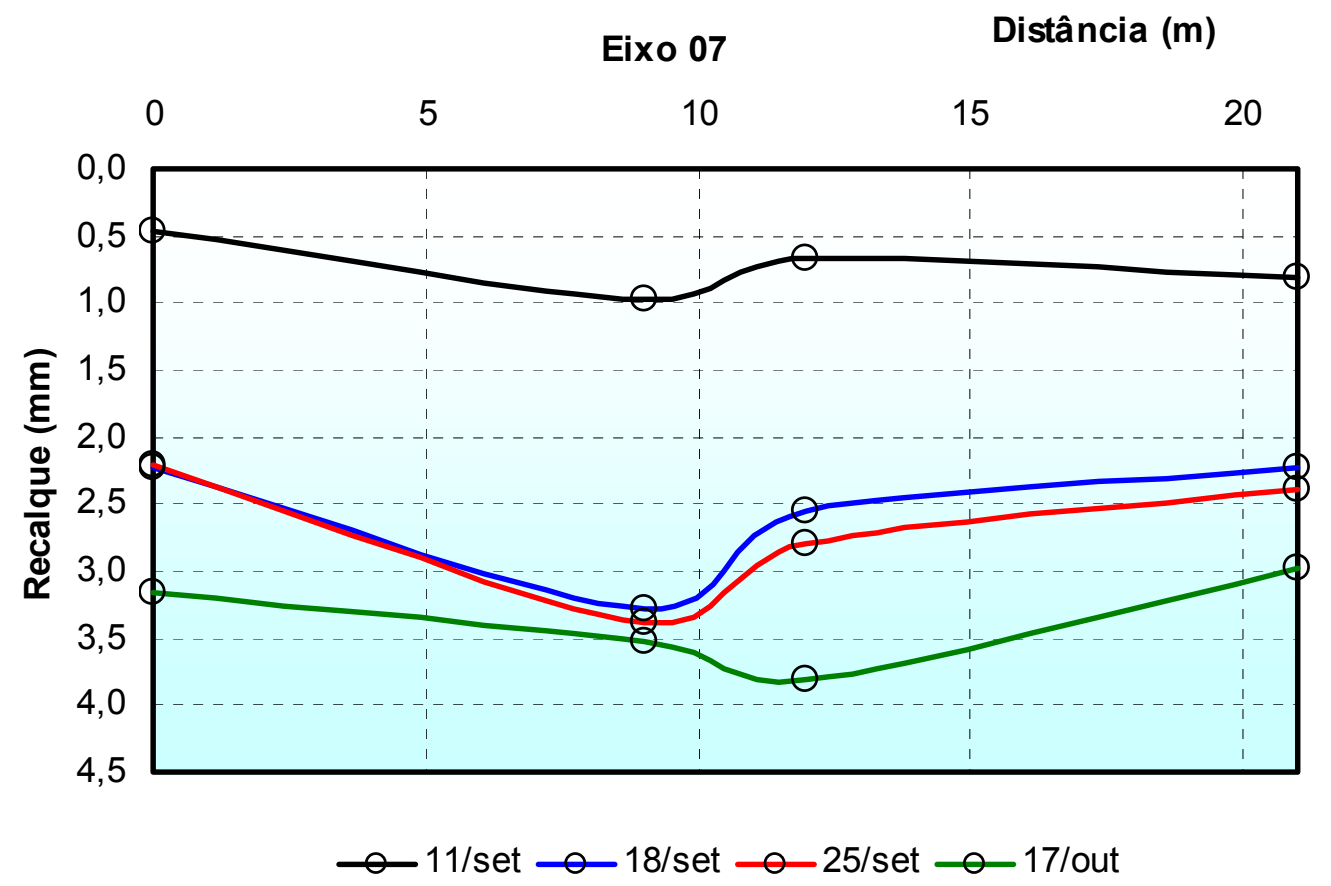

Figura 7.26 - Deformada de recalques, pilares do eixo 7.

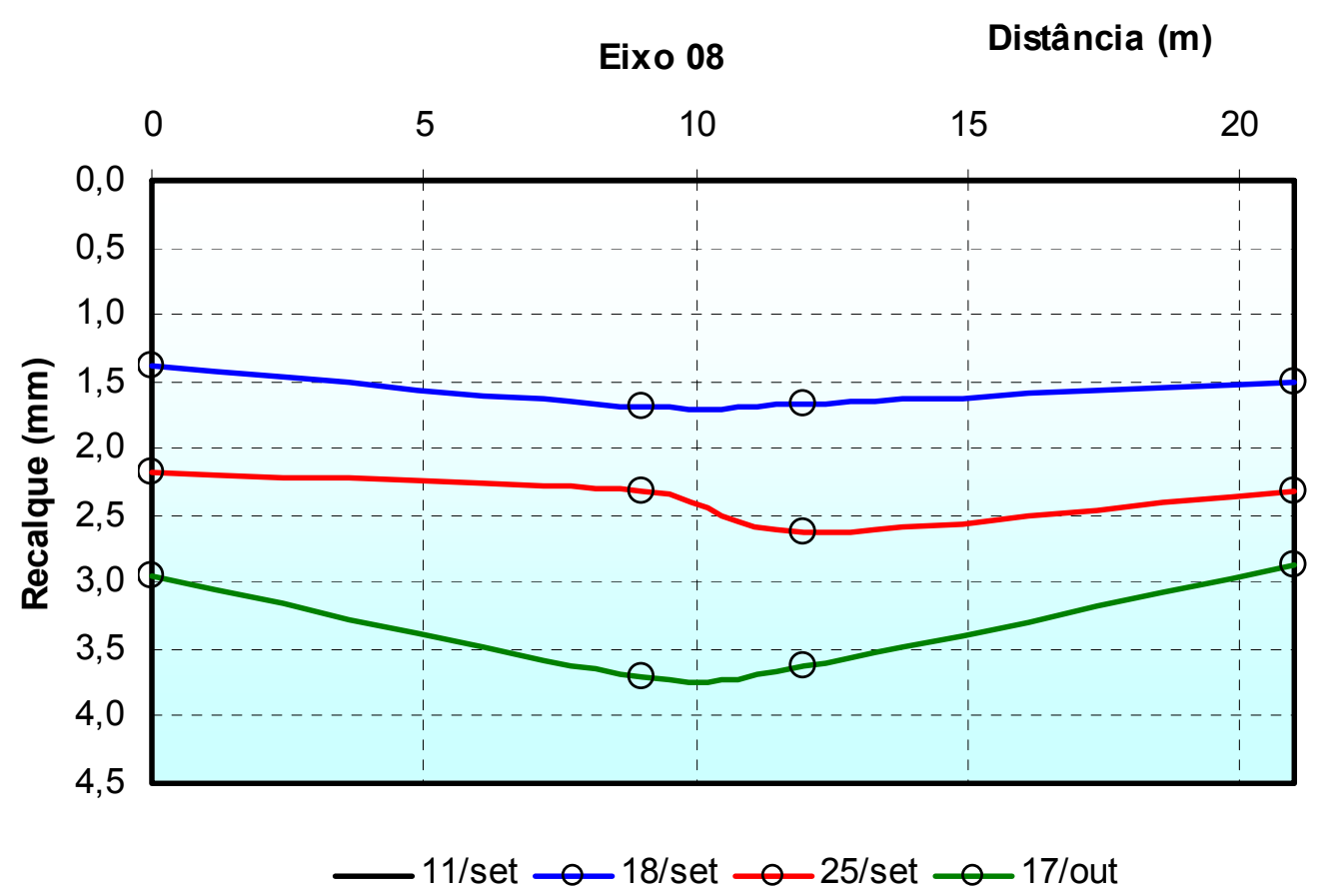

Figura 7.27 - Deformada de recalques, pilares do eixo 8. 


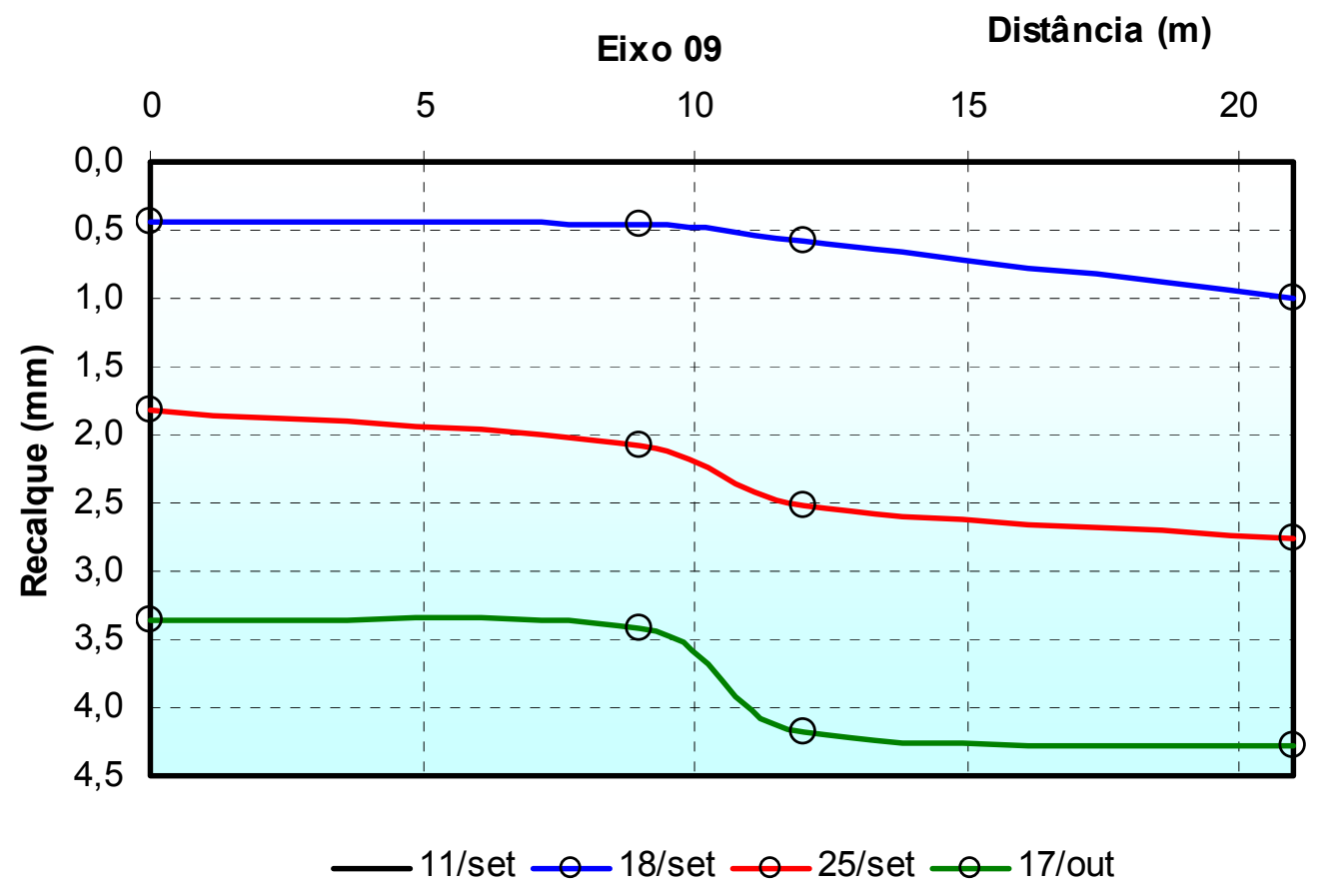

Figura 7.28 - Deformada de recalques, pilares do eixo 9.

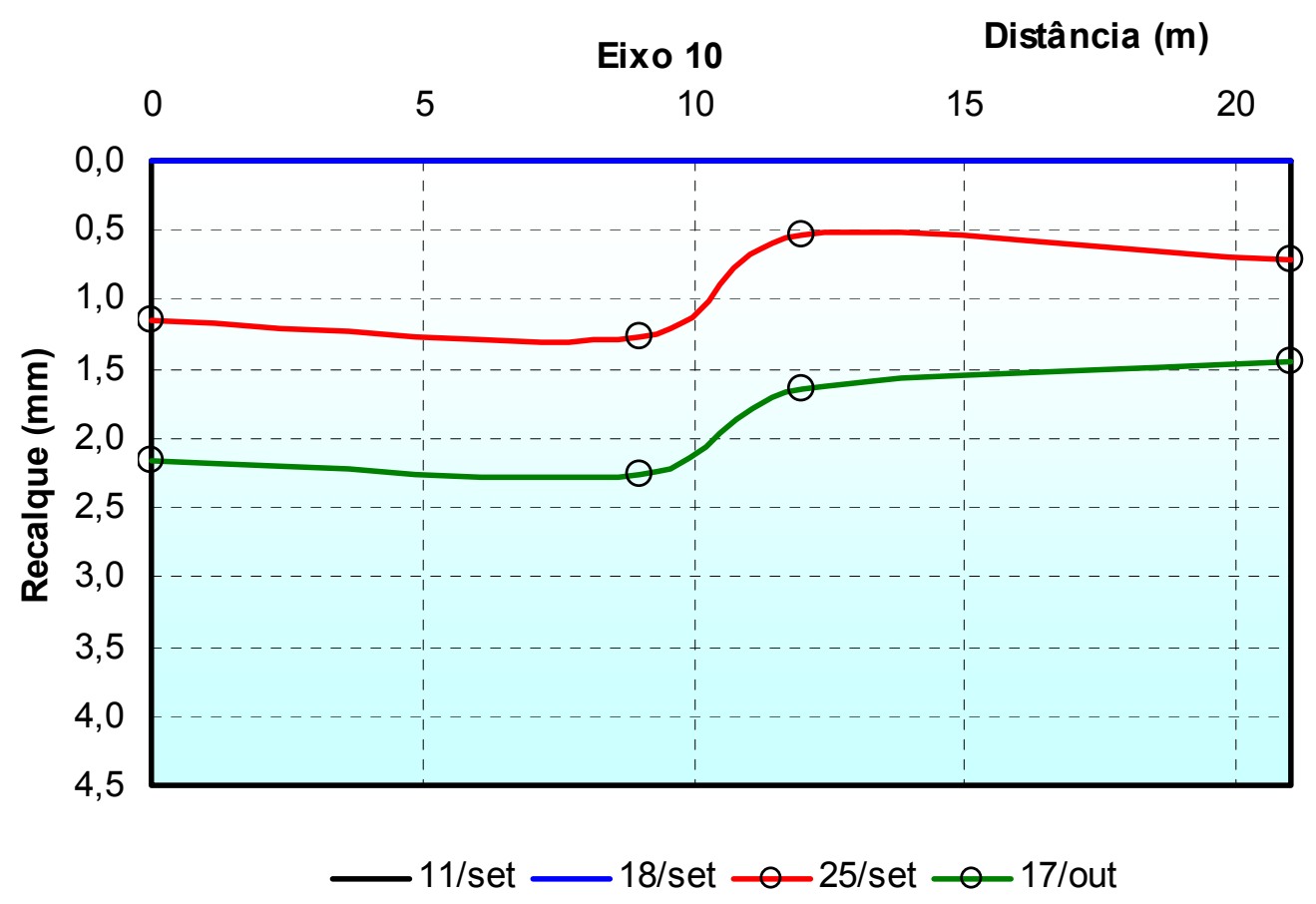

Figura 7.29 - Deformada de recalques pilares, do eixo 10. 
7.1.3 Recalques sob carga constante - fluência da fundação.

A evolução dos recalques com o tempo é a seguir apresentada em gráficos, Figuras 7.30 a 7.34, nos quais são discretizados dois períodos distintos (carregamento e carga constante). Em linha preta e marcadores circulares pretos, é apresentado o comportamento de cada ponto de medida durante o período de carregamento. Marcadores circulares em vermelho indicam observações dos recalques sob carregamento constante no pilar. A linha vermelha contínua apresenta a curva de regressão logarítmica pelo método dos mínimos quadrados para o período de carregamento constante. Também é apresentada, em cada gráfico, a equação da regressão para o período de carga constante, bem como o coeficiente de correlação $\left(R^{2}\right)$ desse ajuste.
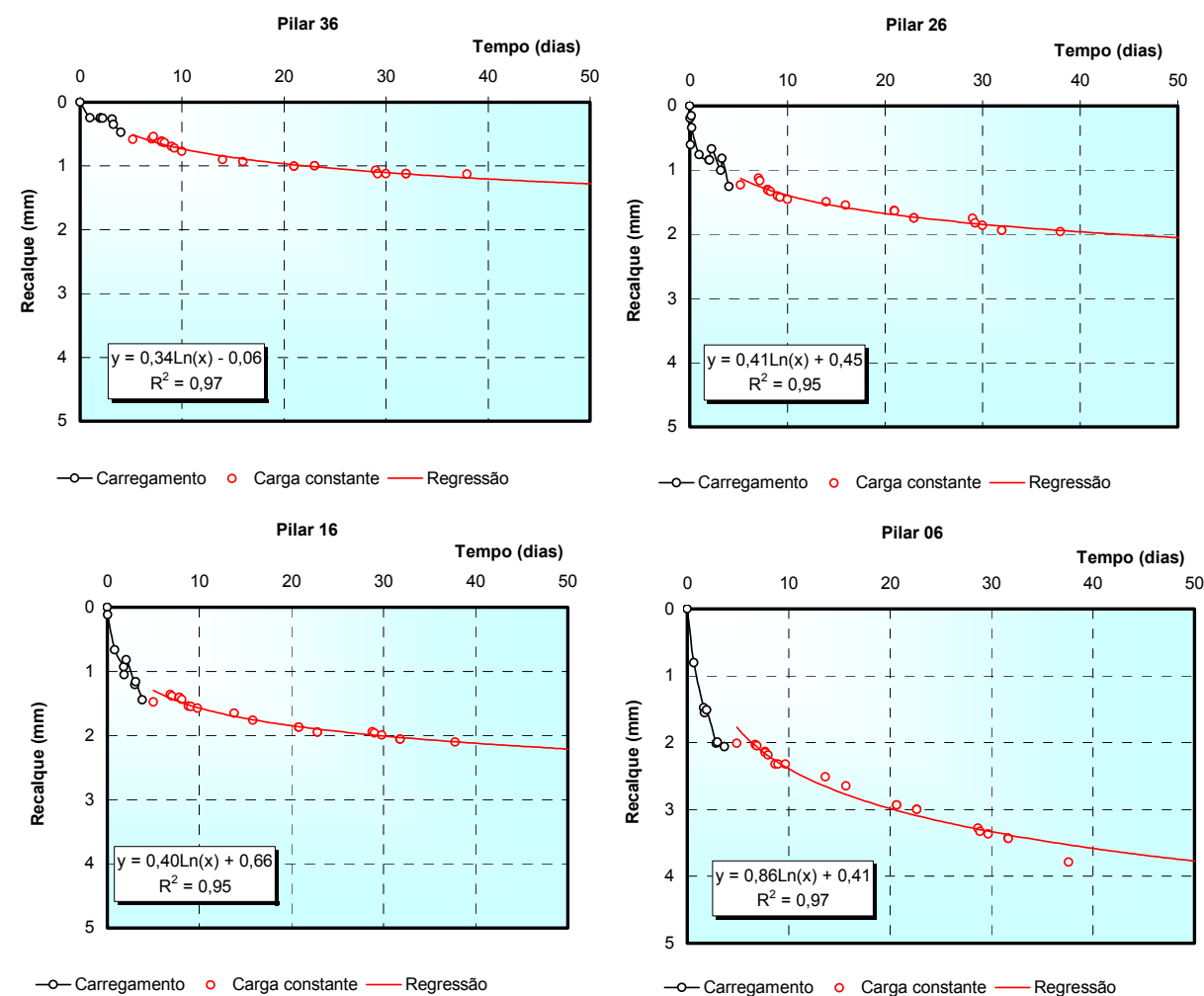

Figura 7.30 - Curva tempo recalque - pilares do eixo 06. 

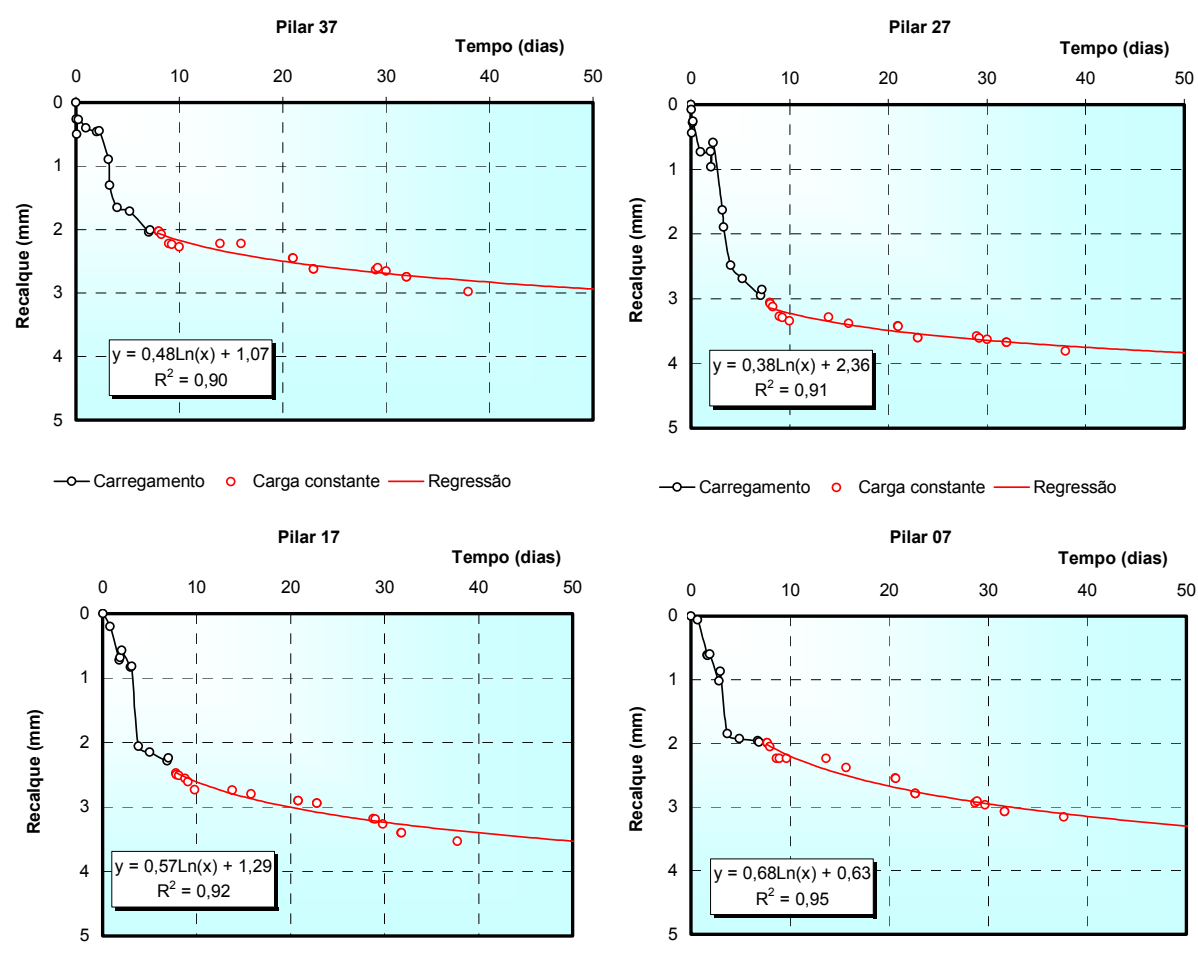

$\multimap$ Carregamento $\circ$ Carga constante — Regressão

$\multimap$ Carregamento $\circ$ Carga constante — Regressão

Figura 7.31 - Curva tempo recalque - pilares do eixo 07.
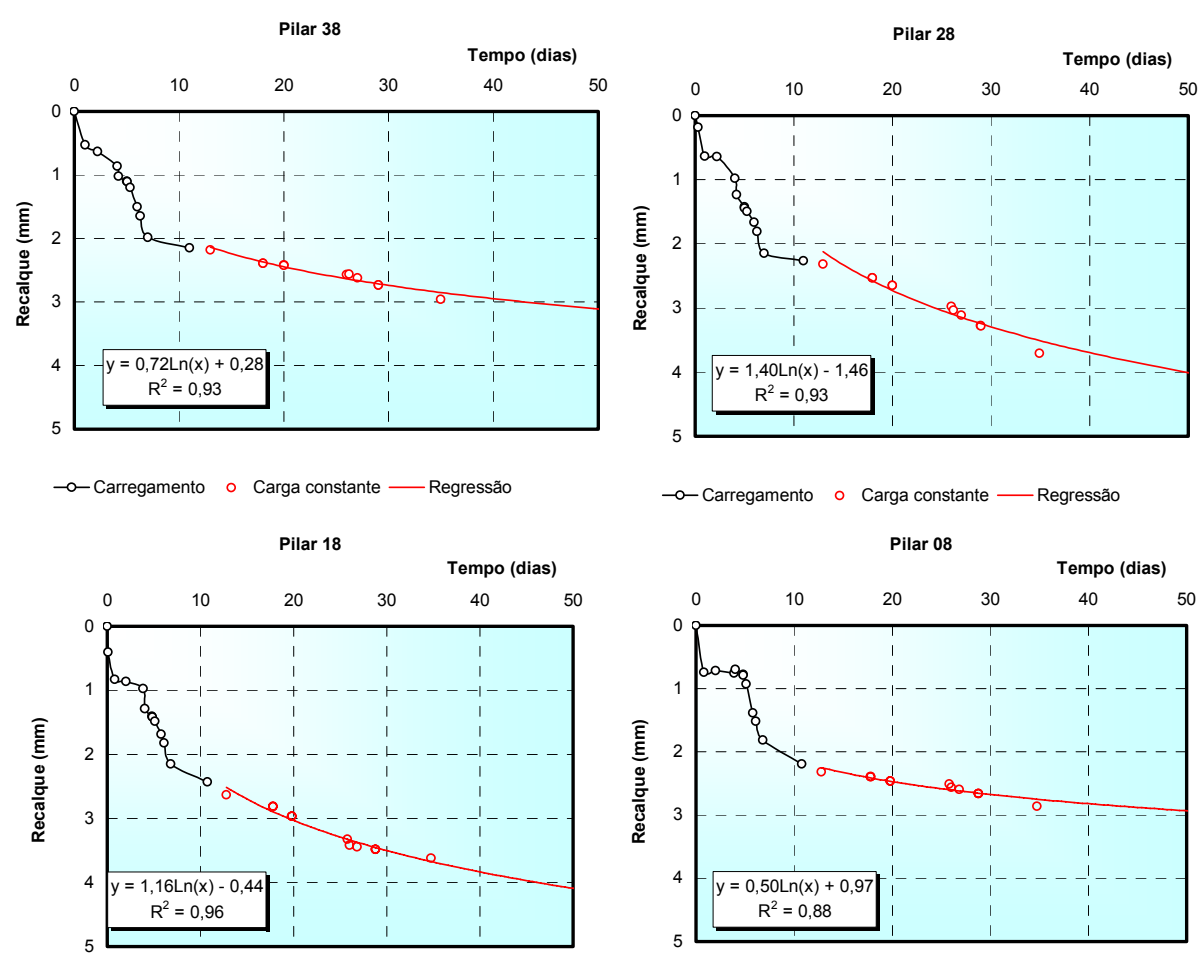

- - Carregamento ○ Carga constante — Regressão

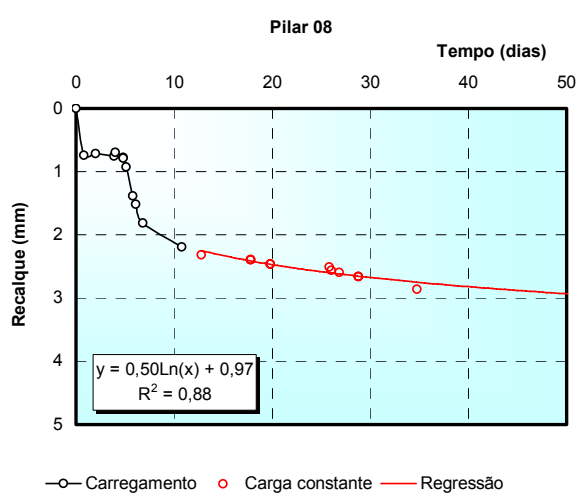

Figura 7.32 - Curva tempo recalque - pilares do eixo 08. 

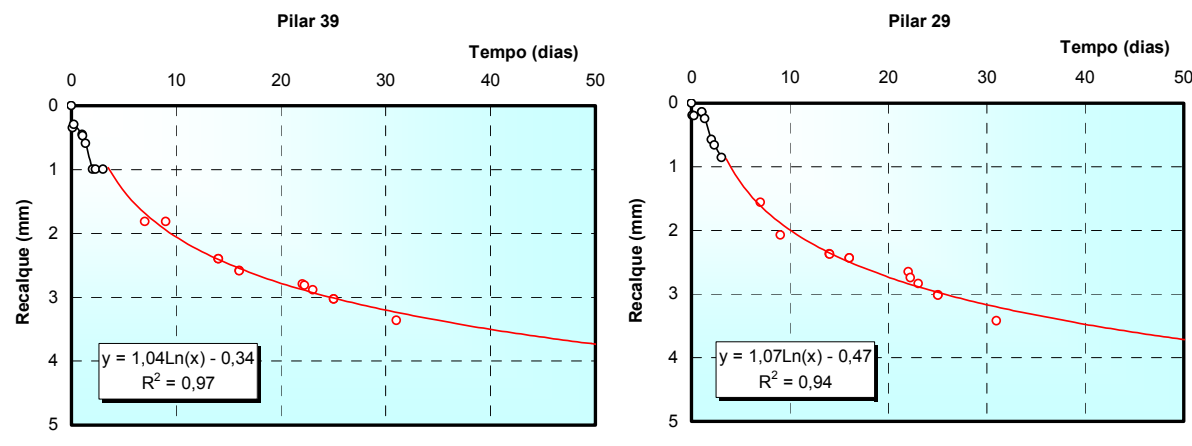

- - Carregamento ○ Carga constante — Regressão

- C Carregamento ○ Carga constante — Regressão
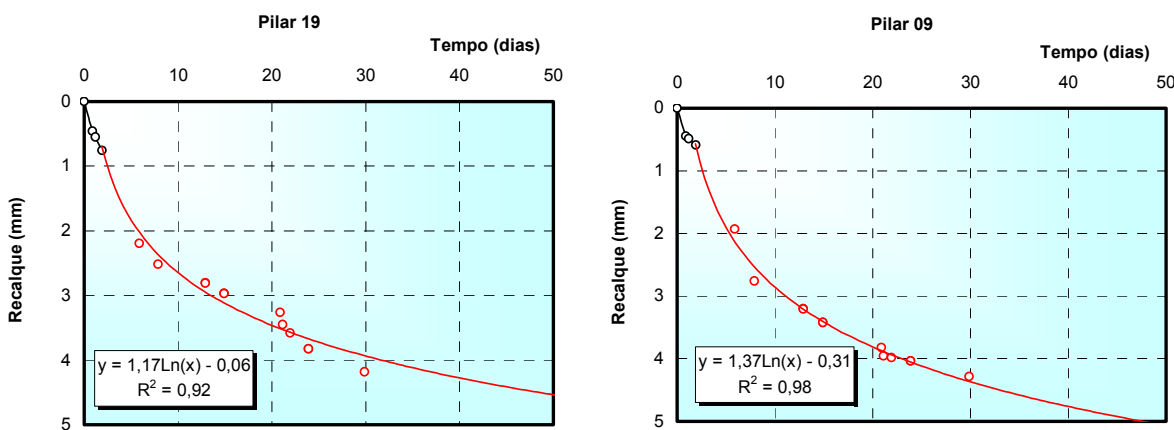

$\multimap$ Carregamento $\circ$ Carga constante — Regressão

- - Carregamento ○ Carga constante — Regressão

Figura 7.33 - Curva tempo recalque pilares do eixo 09.
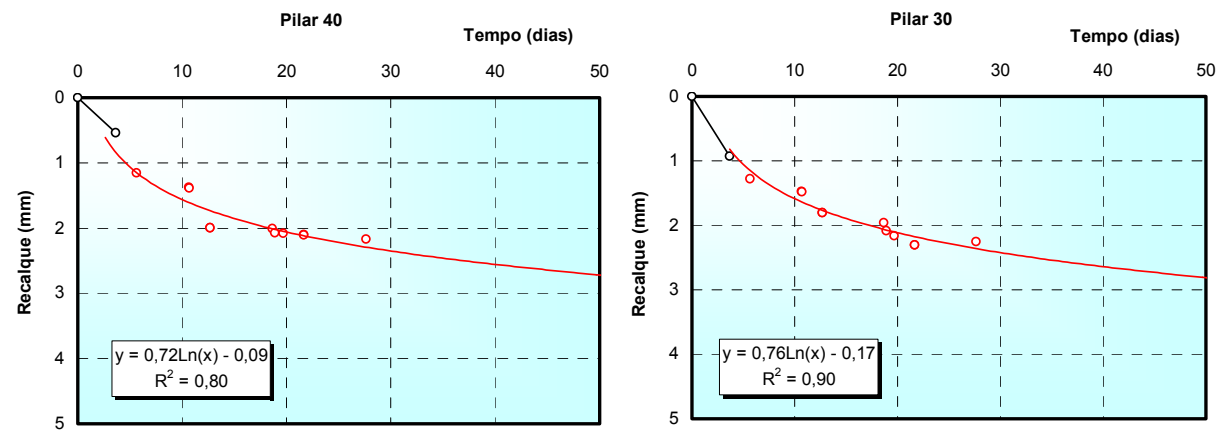

○-Carregamento ○ Carga constante — Regressão

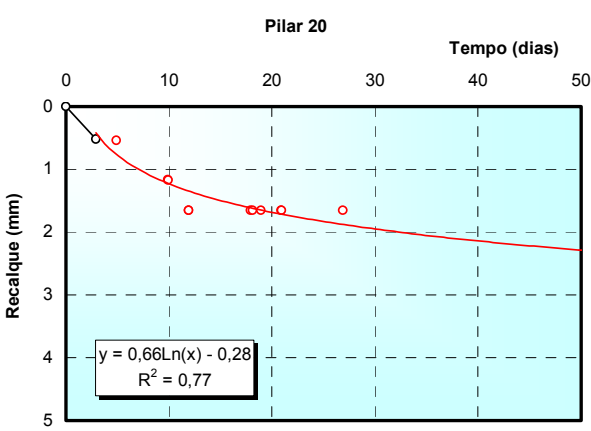

$\multimap$ Carregamento $\circ$ Carga constante — Regressão

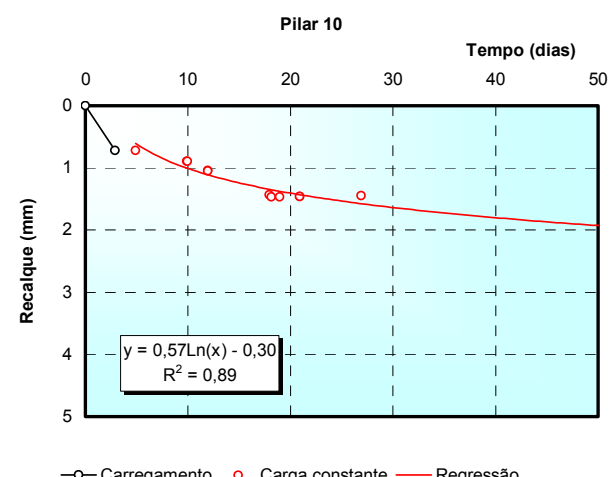

- - Carregamento $\circ$ Carga constante - Regressão

- C Carregamento $\circ$ Carga constante — Regressão

Figura 7.34 - Curva tempo recalque - pilares do eixo 10. 
Essa seqüência de gráficos mostra a presença de recalques crescentes com o tempo, após a conclusão do carregamento do ponto em questão. Uma parcela desses deslocamentos pode ser creditada a efeito do carregamento de outras porções da obra (efeito de grupo), mas essa é de pequena magnitude conforme será verificado nas retroanálises efetuadas, as quais serão apresentadas no capítulo seguinte. Tal comportamento pode ser atribuído aos seguintes fatores, os quais provavelmente atuam em conjunto:

a) deformação lenta, fluência ou "creep" do concreto das estacas;

b) desenvolvimento de atrito negativo nas camadas superficiais de argila mole;

c) dissipação de poro pressões no estrato silto-arenoso devido à aplicação das cargas pela estrutura;

d) desenvolvimento de "creep" no estrato silto-arenoso.

Pode-se verificar naqueles gráficos que há relação linear entre o recalque e o logaritmo do tempo, a qual é analisada na Tabela 7.2. Nessa tabela são apresentados os coeficientes angulares da regressão em função do logaritmo do tempo $\left(\mathrm{c}_{\alpha}\right)$, bem como o valor do coeficiente de correlação. As correlações mais fracas se dão nos dados dos pilares 40 e 20 e podem ser atribuídas a um menor período de observação de comportamento, no período de carga constante.

Tabela 7.2 - Regressão logarítmica recalque x tempo, período de carga constante.

\begin{tabular}{|c|c|c|c|c|c|c|c|c|}
\hline Pilar & $\begin{array}{c}\mathrm{C}_{\alpha} \\
\mathrm{mm} / \log \mathrm{t}\end{array}$ & $\begin{array}{l}\mathrm{R}^{2} \\
\%\end{array}$ & Pilar & \multicolumn{2}{|c|}{$\begin{array}{c}\mathrm{C}_{\alpha} \\
\mathrm{mm} / \log \mathrm{t}\end{array}$} & $\begin{array}{l}\mathrm{R}^{2} \\
\%\end{array}$ & Pilar & $\mathrm{mm}$ \\
\hline 36 & 0,8 & 97 & 37 & & 1,1 & 90 & 38 & \\
\hline 26 & 0,9 & 95 & 27 & & 0,9 & 91 & 28 & \\
\hline 16 & 0,9 & 95 & 17 & & 1,3 & 92 & 18 & \\
\hline 06 & 2,0 & 97 & 07 & & 1,6 & 95 & 08 & \\
\hline Média & 1,16 & & & & 21 & & & \\
\hline $\mathrm{CV}$ & $41 \%$ & & & & $1 \%$ & & & \\
\hline & Pilar & $\mathrm{mm}$ & $\begin{array}{l}\mathrm{C}_{\alpha} \\
\mathrm{l} / \log \mathrm{t}\end{array}$ & $\begin{array}{l}\mathrm{R}^{2} \\
\% \\
\end{array}$ & Pilar & & $\begin{array}{l}\mathrm{c}_{\alpha} \\
\mathrm{n} / \log \mathrm{t}\end{array}$ & $\begin{array}{l}\mathrm{R}^{2} \\
\% \\
\end{array}$ \\
\hline & 39 & & 2,6 & 97 & 40 & & 1,7 & 80 \\
\hline & 29 & & 2,4 & 94 & 30 & & 2,1 & 90 \\
\hline & 19 & & 3,0 & 92 & 20 & & 0,9 & 77 \\
\hline & 09 & & 3,2 & 98 & 10 & & 1,6 & 89 \\
\hline & Média & & 68 & & & & 1,56 & \\
\hline & $\mathrm{CV}$ & & $1 \%$ & & & & $11 \%$ & \\
\hline
\end{tabular}


Os valores acima mostram valores de $c_{\alpha}$, variáveis entre $3,2 \mathrm{~mm} / \log \mathrm{t}$ (pilar 09) e 0,8 mm/log t (pilar 36), sendo o valor médio igual a $1,8 \mathrm{~mm} / \log \mathrm{t}$, tendo desvio padrão igual a $0,7 \mathrm{~mm} / \log \mathrm{t}$, o qual corresponde a um coeficiente de variação igual a $43 \%$.

Comparando-se o valor do coeficiente $\left(\mathrm{c}_{\alpha}\right)$ determinado para a infraestrutura (média igual a $1,3 \mathrm{~mm} / \log \mathrm{t}$ ) com aqueles determinados para a superestrutura $\left(s_{\alpha}-\right.$ média igual a $0,081 \mathrm{~mm} / \log \mathrm{t}$ ), tem-se uma relação igual a 16 , indicando que os deslocamento sob carga constante da infra-estrutura são superiores aos da superestrutura.

A regressão linear realizada anteriormente é uma expressão do tipo:

$$
\delta_{f}=\delta_{\text {final }}+c_{\alpha} \times \log (t)
$$

sendo:

$\delta_{\text {final }}$ - recalque no momento da aplicação da carga máxima, $\delta_{f}$ - recalque em um tempo $t$ após a aplicação da carga máxima.

A derivada desse recalque em relação ao tempo, fornece a velocidade de recalques $(v)$ dada pela expressão

$$
v=\frac{d \delta_{f}}{d t}=\frac{c_{\alpha} \times \log (e)}{t}
$$

A partir dessa expressão é possível avaliar a variação da velocidade de recalque com o tempo. Teoricamente, os recalques irão cessar quando a aceleração torna-se nula, mas de acordo com a expressão acima isso só acontece a tempo infinito. O gráfico da Figura 7.35 apresenta a variação da velocidade de recalques com o tempo, para os extremos do intervalo de valores de $\left(c_{\alpha}\right)$ anteriormente determinados e para o valor central. 


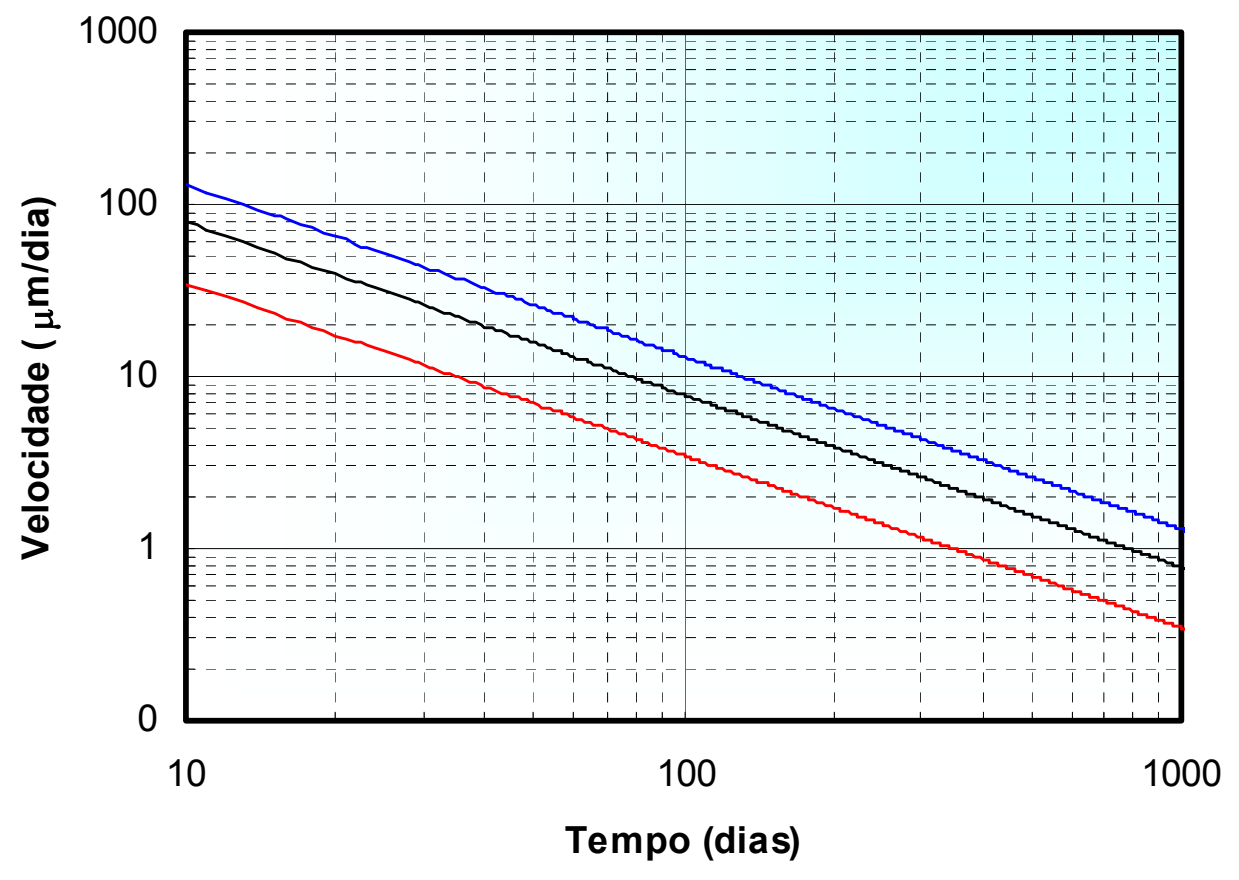

$-3,2 \mathrm{~mm} / \log \mathrm{t}-1,8 \mathrm{~mm} / \log \mathrm{t}-0,8 \mathrm{~mm} / \log \mathrm{t}$

Figura 7.35 -Variação da velocidade de recalque com o tempo, sob carga constante.

Verifica-se, no gráfico anterior, que a velocidade de recalque torna-se inferior a $10 \mu \mathrm{m} / \mathrm{dia}$ em um tempo aproximado entre um mês e quatro meses. A tabela a seguir apresenta o tempo a partir do qual as velocidades de recalque tornam-se inferiores a 50, 25, 10, 5 e $1 \mu \mathrm{m} /$ dia para os valores de $c_{\alpha}$ máximo, mínimo e médio, anteriormente determinados.

Pode-se estabelecer um critério para definir a estabilização dos recalques, seja $5 \mu \mathrm{m} / \mathrm{dia}$. Assim, conforme os dados da tabela tem-se que para o limite superior de $c_{\alpha}$ igual a $3,2 \mathrm{~mm} / \log \mathrm{t}$, em um tempo igual a 278 dias, obtêm-se velocidades inferiores a esse valor.

Tabela 7.3 - Tempo (dias) para atingir determinada velocidade de recalques.

\begin{tabular}{crrr}
$\mathrm{V}$ & \multicolumn{3}{c}{$\mathrm{C}_{\alpha}$} \\
$(\mu \mathrm{m} / \mathrm{dia})$ & \multicolumn{2}{c}{$(\mathrm{mm} / \log \mathrm{t})$} \\
& 0,8 & 1,8 & 3,2 \\
\hline 50 & 7 & 16 & 28 \\
25 & 14 & 31 & 56 \\
10 & 35 & 78 & 139 \\
5 & 69 & 156 & 278 \\
1 & 347 & 782 & 1390 \\
\hline
\end{tabular}




\subsection{RELAÇÃO CARGA RECALQUE.}

Tendo em vista que as informações coletadas por esse estudo experimental permitiram a medida simultânea, desde o início da construção, da carga e do recalque em vinte pilares contíguos, desenvolve-se a seguir análise do comportamento carga x recalque observado, adotando-se um modelo linear ou modelo Hookeano, caracterizado por uma constante de mola ou coeficiente de rigidez de mola.

Os gráficos das Figuras 7.36 a 7.39 apresentam a evolução com o tempo dos recalques e da solicitação normal nos pilares.

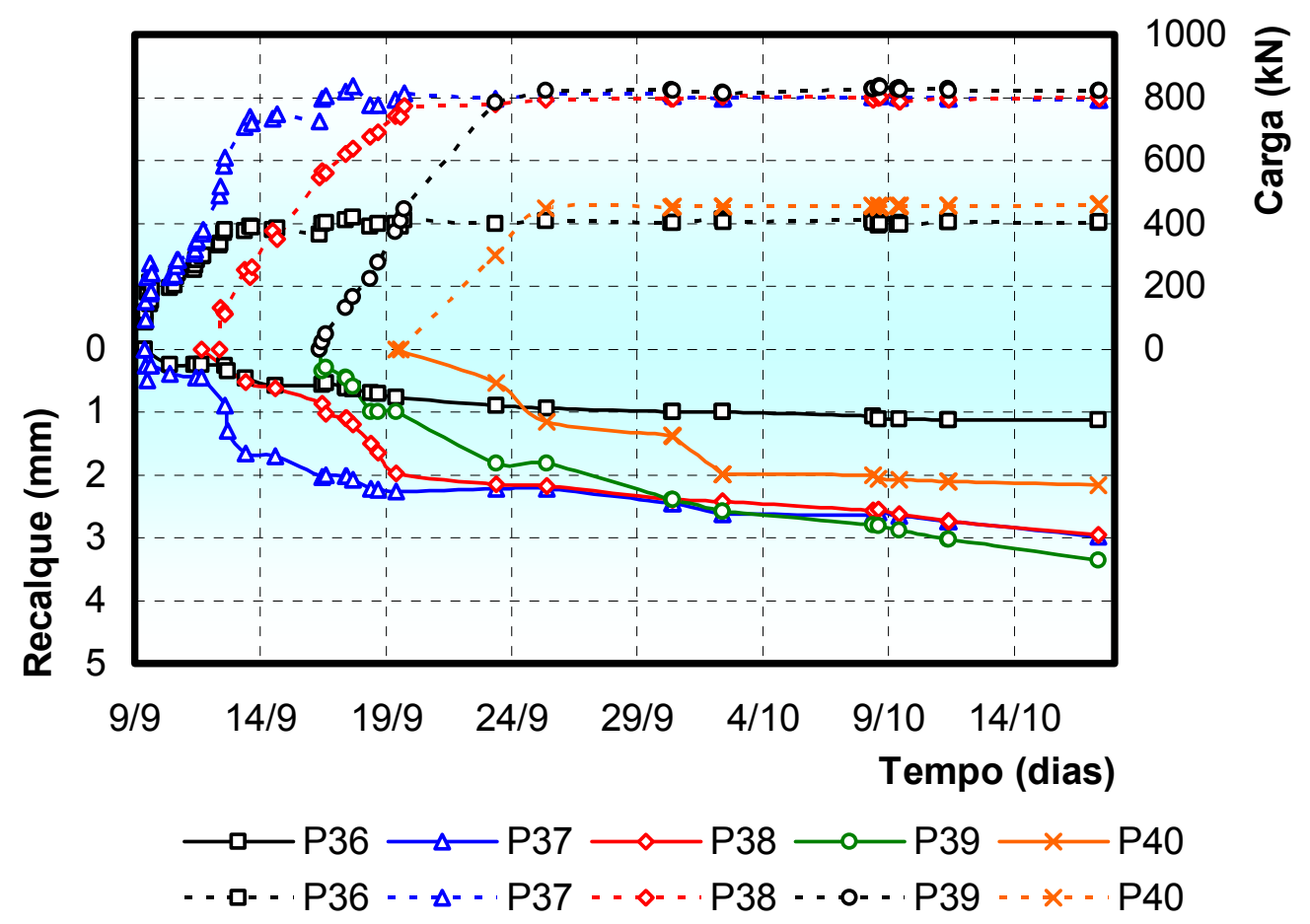

Figura 7.36 - Curvas tempo x carga e recalque, pilares do eixo $A$. 


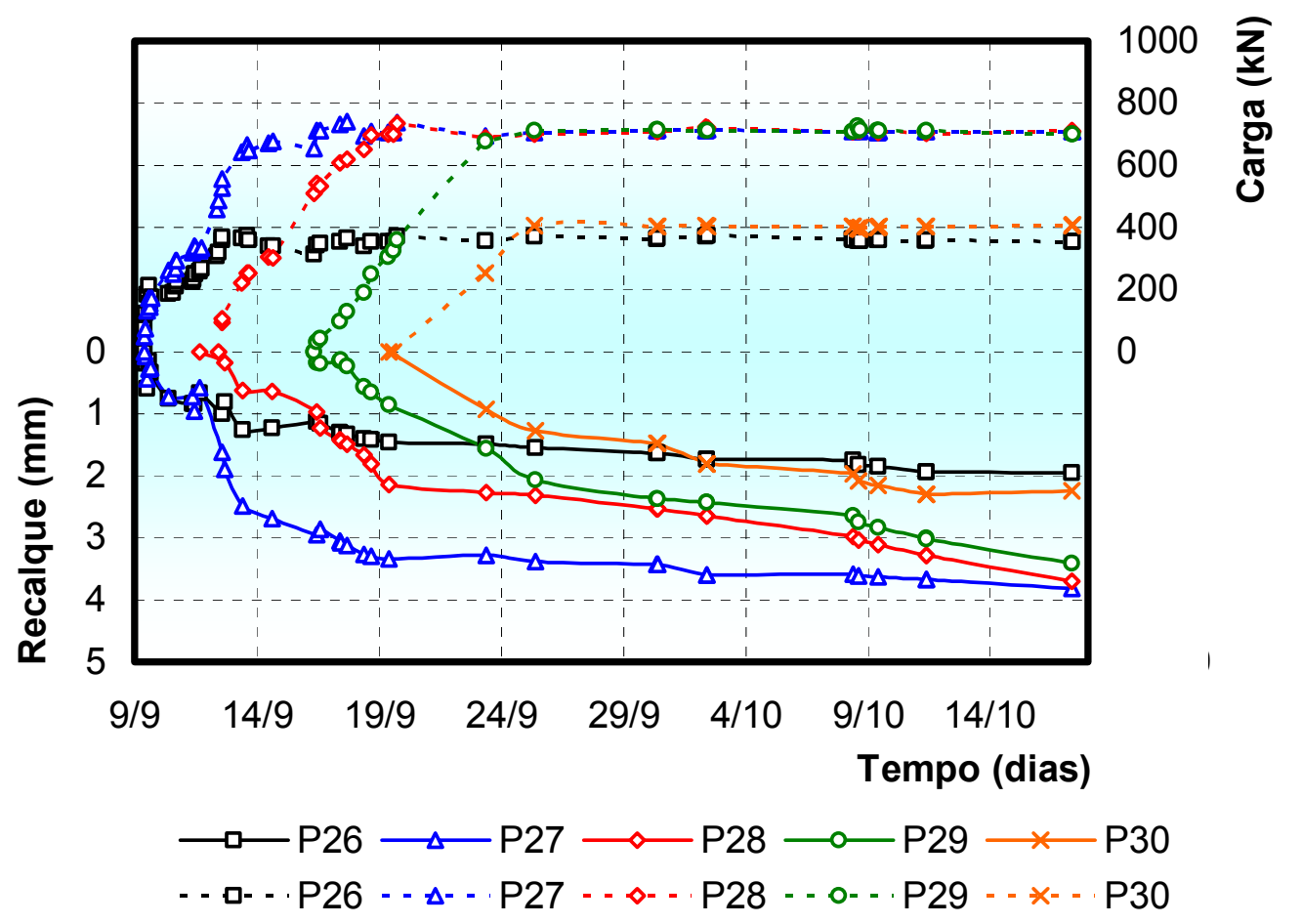

Figura 7.37 - Curvas tempo x carga e recalque, pilares do eixo $B$.

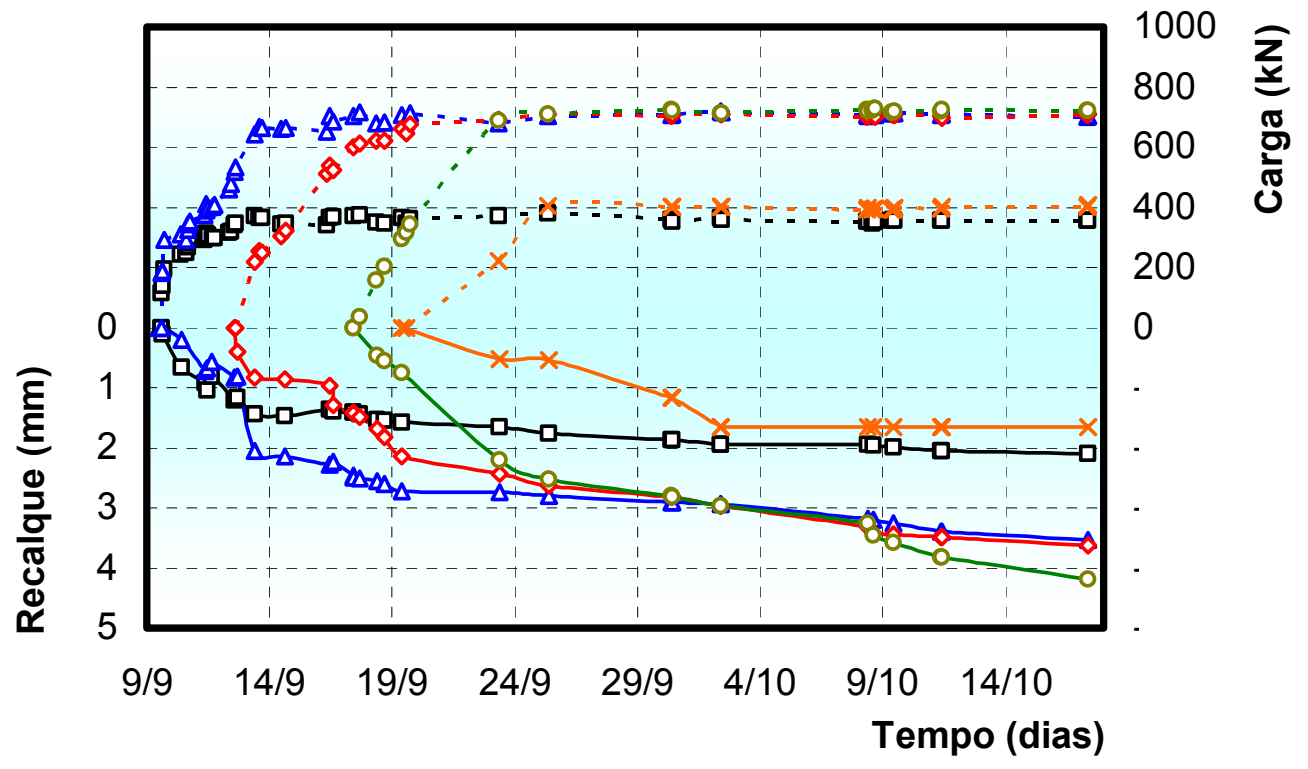

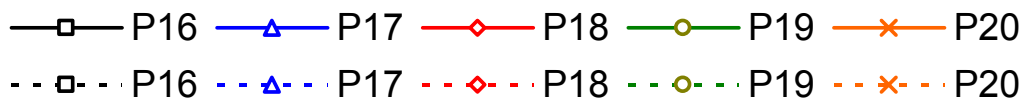

Figura 7.38 - Curvas tempo $x$ carga e recalque, pilares do eixo $C$. 


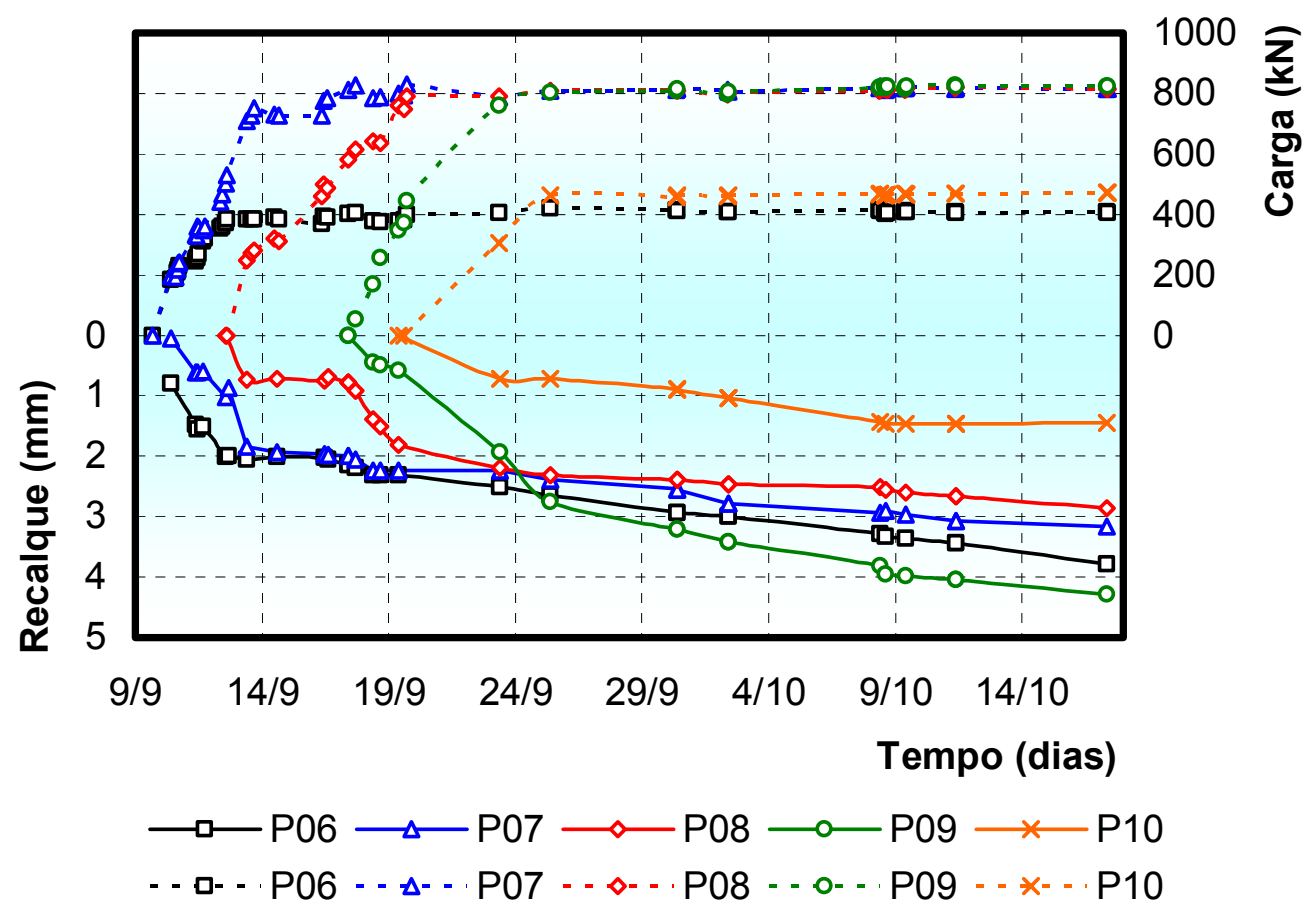

Figura 7.39 - Curvas tempo x carga e recalque, pilares do eixo $D$.

A Tabela 7.4 apresenta um resumo, contendo informações sobre características geométricas dos elementos de fundação (número de estacas no bloco, dimensão da seção transversal e comprimento médio), valores medidos e calculados de carga nos pilares $\left(P_{\text {med }}\right.$ e $\left.P_{\text {calc }}\right)$ e recalque $\left(\delta_{\text {final }}\right.$ - recalque no momento da aplicação da carga máxima no pilar, $\delta_{\text {máx }}$ - máximo recalque observado). Adicionalmente, é apresentado o valor do coeficiente de mola $\left(k_{\text {mola }}\right)$ correspondente à relação entre a carga total medida no pilar e o recalque determinado no momento da aplicação dessa carga. Cabe salientar que o valor do recalque no momento da aplicação da máxima carga ao pilar não corresponde a uma igual data para todos os pilares, e que esses valores não foram efetivamente medidos e sim determinados por interpolação dos gráficos acima. 
Tabela 7.4 - Características geométricas do grupo de estacas, resumo dos valores medidos e coeficiente de mola.

\begin{tabular}{|c|c|c|c|c|c|c|c|c|}
\hline Pilar & $\mathrm{N}^{\circ}$ & $\begin{array}{c}a \\
(\mathrm{~cm})\end{array}$ & $\begin{array}{c}\mathrm{L} \\
(\mathrm{m})\end{array}$ & $\begin{array}{l}P_{\text {med }} \\
(\mathrm{kN})\end{array}$ & $\begin{array}{l}P_{\text {calc }} \\
(\mathrm{kN})\end{array}$ & $\begin{array}{r}\delta_{\text {final }} \\
(\mathrm{mm})\end{array}$ & $\begin{array}{c}\delta_{\max } \\
(\mathrm{mm})\end{array}$ & $\begin{array}{c}k_{\text {mola }} \\
(\mathrm{kN} / \mathrm{mm}\end{array}$ \\
\hline 06 & 4 & 35 & 8 & 402 & 414 & 2,0 & 3,8 & 201 \\
\hline 16 & 8 & 32 & 8 & 361 & 360 & 1,6 & 2,1 & 226 \\
\hline 26 & 6 & 35 & 8 & 360 & 356 & 1,3 & 2,0 & 277 \\
\hline 36 & 8 & 35 & 7 & 402 & 406 & 0,6 & 1,1 & 670 \\
\hline
\end{tabular}

\begin{tabular}{ccccccccc}
\hline Pilar & $\mathrm{N}^{\circ}$ & $\begin{array}{c}\mathrm{a} \\
(\mathrm{cm})\end{array}$ & $\begin{array}{c}\mathrm{L} \\
(\mathrm{m})\end{array}$ & $\begin{array}{c}\mathrm{P}_{\text {med }} \\
(\mathrm{kN})\end{array}$ & $\mathrm{P}_{\text {calc }}$ & $\delta_{\text {final }}$ & $\delta_{\max }$ & $\mathrm{k}_{\text {mola }}$ \\
$(\mathrm{mm})$ & $(\mathrm{mm})$ & $(\mathrm{kN} / \mathrm{mm})$ \\
\hline 07 & 6 & 32 & 9 & 815 & 825 & 2,2 & 3,2 & 370 \\
17 & 5 & 35 & 8 & 709 & 717 & 2,6 & 3,5 & 273 \\
27 & 5 & 35 & 8 & 709 & 712 & 3,2 & 3,8 & 222 \\
37 & 4 & 35 & 8 & 802 & 810 & 2,2 & 3,0 & 365 \\
\hline
\end{tabular}

\begin{tabular}{ccccccccc}
\hline Pilar & $\mathrm{N}^{\circ}$ & $\begin{array}{c}\mathrm{a} \\
(\mathrm{cm})\end{array}$ & $\begin{array}{c}\mathrm{L} \\
(\mathrm{m})\end{array}$ & $\begin{array}{c}\mathrm{P}_{\text {med }} \\
(\mathrm{kN})\end{array}$ & $\begin{array}{c}\mathrm{P}_{\text {calc }} \\
(\mathrm{kN})\end{array}$ & $\begin{array}{c}\delta_{\text {final }} \\
(\mathrm{mm})\end{array}$ & $\begin{array}{c}\delta_{\max } \\
(\mathrm{mm})\end{array}$ & $\begin{array}{c}\mathrm{k}_{\text {mola }} \\
(\mathrm{kN} / \mathrm{mm})\end{array}$ \\
\hline 08 & 4 & 35 & 8 & 813 & 820 & 2,2 & 2,9 & 370 \\
18 & 5 & 35 & 8 & 706 & 714 & 2,5 & 3,6 & 282 \\
28 & 5 & 35 & 8 & 710 & 712 & 2,3 & 3,7 & 309 \\
38 & 4 & 35 & 8 & 798 & 808 & 2,2 & 3,0 & 363 \\
\hline
\end{tabular}

\begin{tabular}{|c|c|c|c|c|c|c|c|c|}
\hline Pilar & $\mathrm{N}^{0}$ & $\begin{array}{c}\mathrm{a} \\
(\mathrm{cm})\end{array}$ & $\begin{array}{l}\mathrm{L} \\
(\mathrm{m})\end{array}$ & $\begin{array}{l}P_{\text {med }} \\
(\mathrm{kN})\end{array}$ & $\begin{array}{l}P_{\text {calc }} \\
(k N)\end{array}$ & $\begin{array}{r}\delta_{\text {final }} \\
(\mathrm{mm})\end{array}$ & $\begin{array}{c}\delta_{\max } \\
(\mathrm{mm})\end{array}$ & $\begin{array}{c}\mathrm{k}_{\text {mola }} \\
(\mathrm{kN} / \mathrm{mm})\end{array}$ \\
\hline 09 & 4 & 35 & 8 & 817 & 826 & 2,8 & 4,3 & 292 \\
\hline 19 & 5 & 35 & 8 & 720 & 715 & 2,5 & 4,2 & 288 \\
\hline 29 & 5 & 35 & 8 & 711 & 713 & 1,8 & 3,4 & 395 \\
\hline 39 & 4 & 35 & 10 & 825 & 815 & 1,8 & 3,4 & 458 \\
\hline
\end{tabular}

\begin{tabular}{ccccccccc}
\hline Pilar & $\mathrm{N}^{\circ}$ & $\begin{array}{c}\mathrm{a} \\
(\mathrm{cm})\end{array}$ & $\begin{array}{c}\mathrm{L} \\
(\mathrm{m})\end{array}$ & $\begin{array}{c}\mathrm{P}_{\text {med }} \\
(\mathrm{kN})\end{array}$ & $\mathrm{P}_{\text {calc }}$ \\
$(\mathrm{kN})$ & $\begin{array}{c}\delta_{\text {final }} \\
(\mathrm{mm})\end{array}$ & $\begin{array}{c}\delta_{\max } \\
(\mathrm{mm})\end{array}$ & $\begin{array}{c}\mathrm{k}_{\text {mola }} \\
(\mathrm{kN} / \mathrm{mm})\end{array}$ \\
\hline 10 & 4 & 35 & 8 & 465 & 464 & 0,7 & 1,5 & 664 \\
20 & 5 & 35 & 8 & 398 & 400 & 0,6 & 1,7 & 663 \\
30 & 4 & 35 & 9 & 402 & 400 & 1,3 & 2,3 & 309 \\
40 & 4 & 35 & 9 & 455 & 459 & 1,2 & 2,2 & 379 \\
\hline
\end{tabular}

Verifica-se, nessas tabelas, que o coeficiente de mola, determinado a partir das medidas efetuadas pela relação entre a carga máxima aplicada e o recalque no momento da aplicação dessa carga, apresenta-se variável entre 670 e $201 \mathrm{kN} / \mathrm{mm}$, tendo valor central igual a $369 \mathrm{kN} / \mathrm{mm}$ e desvio padrão de 
$143 \mathrm{kN} / \mathrm{mm}$, correspondente a um coeficiente de variação igual a 39\%. Para um intervalo de confiabilidade de $\pm 5 \%$, o valor do coeficiente de mola pode ser tomado variando entre 604 e $134 \mathrm{kN} / \mathrm{mm}$.

Caso sejam excluídos dessa análise os pilares das extremidades (eixos 06 e 10), os quais estão submetidos a um menor nível de solicitação, esse parâmetro varia entre 458 e $222 \mathrm{kN} / \mathrm{mm}$, tendo média igual a $332 \mathrm{kN} / \mathrm{mm}$, desvio padrão igual a $63 \mathrm{kN} / \mathrm{mm}$ e coeficiente de variação de $19 \%$. Nesse caso, o coeficiente de mola para um intervalo de confiabilidade de $\pm 5 \%$ varia entre 436 e $228 \mathrm{kN} / \mathrm{mm}$.

A Figura 7.40 apresenta a visualização da distribuição, em planta, dos coeficientes de mola determinados para os pilares monitorados. Pode-se observar nessa figura pontos onde foi constatada maior rigidez da fundação, a saber, pilares 36, 10 e 20.

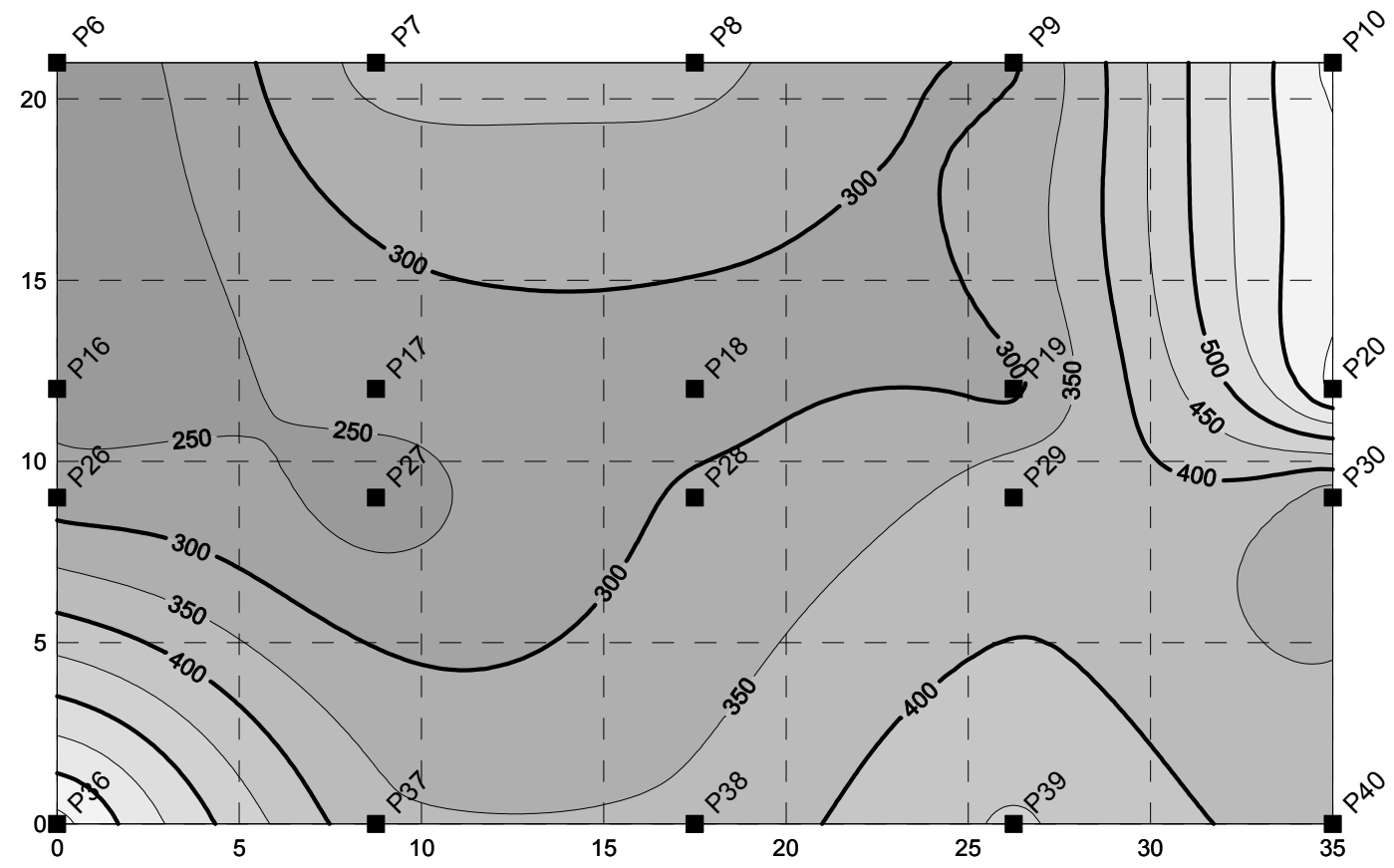

Figura 7.40 - Curvas de igual coeficiente de mola.

O coeficiente de mola foi também determinado a partir da relação entre o valor da solicitação normal nos pilares e dos recalques determinados durante o período de montagem da estrutura pré-moldada.

Os dados referentes aos pilares do eixo 10 não são incluídos nessa apresentação, pois apresentam apenas um único ponto de medida durante a fase de carregamento. 
Os gráficos das Figuras 7.41 a 7.44 apresentam a relação entre a carga e o recalque para o conjunto de pilares monitorados. Esses gráficos contêm resultado de regressão linear para a relação em questão.

A Tabela 7.5 resume os valores determinados pela regressão.
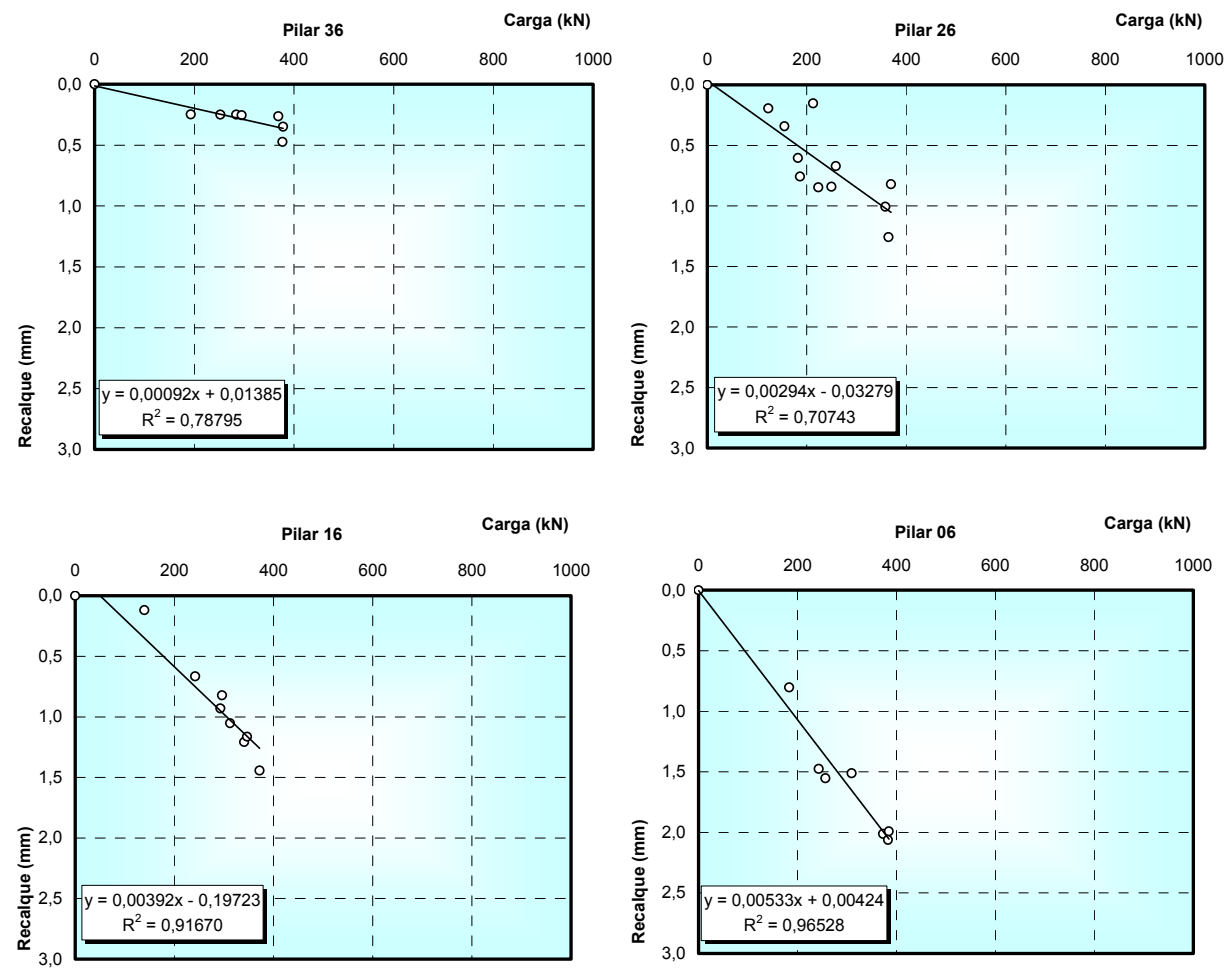

Figura 7.41 - Relação carga recalque, pilares do eixo 06.
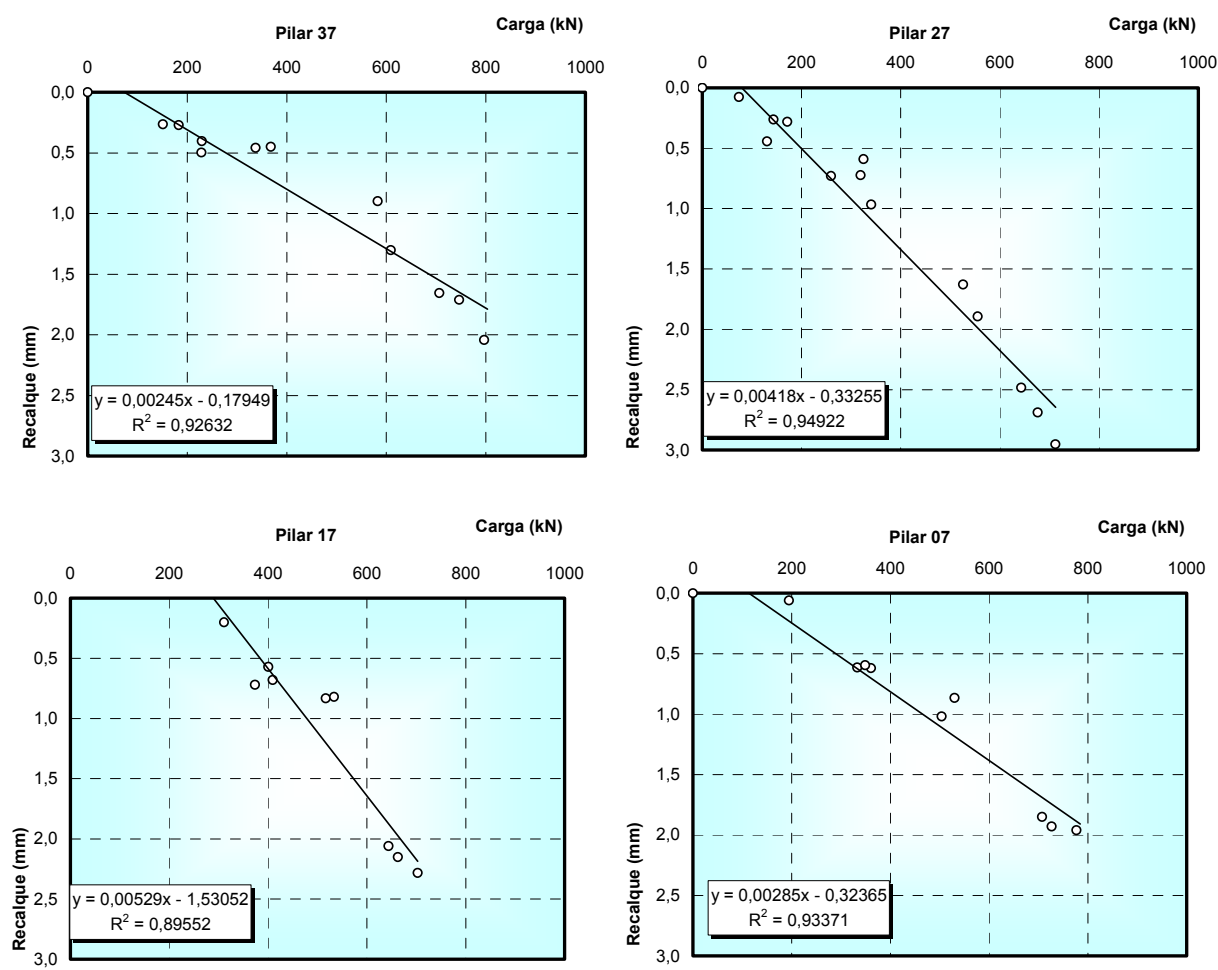

rıgura 1.42 - Kelaçao carga recaıque, pılares ao eıxo Uı. 

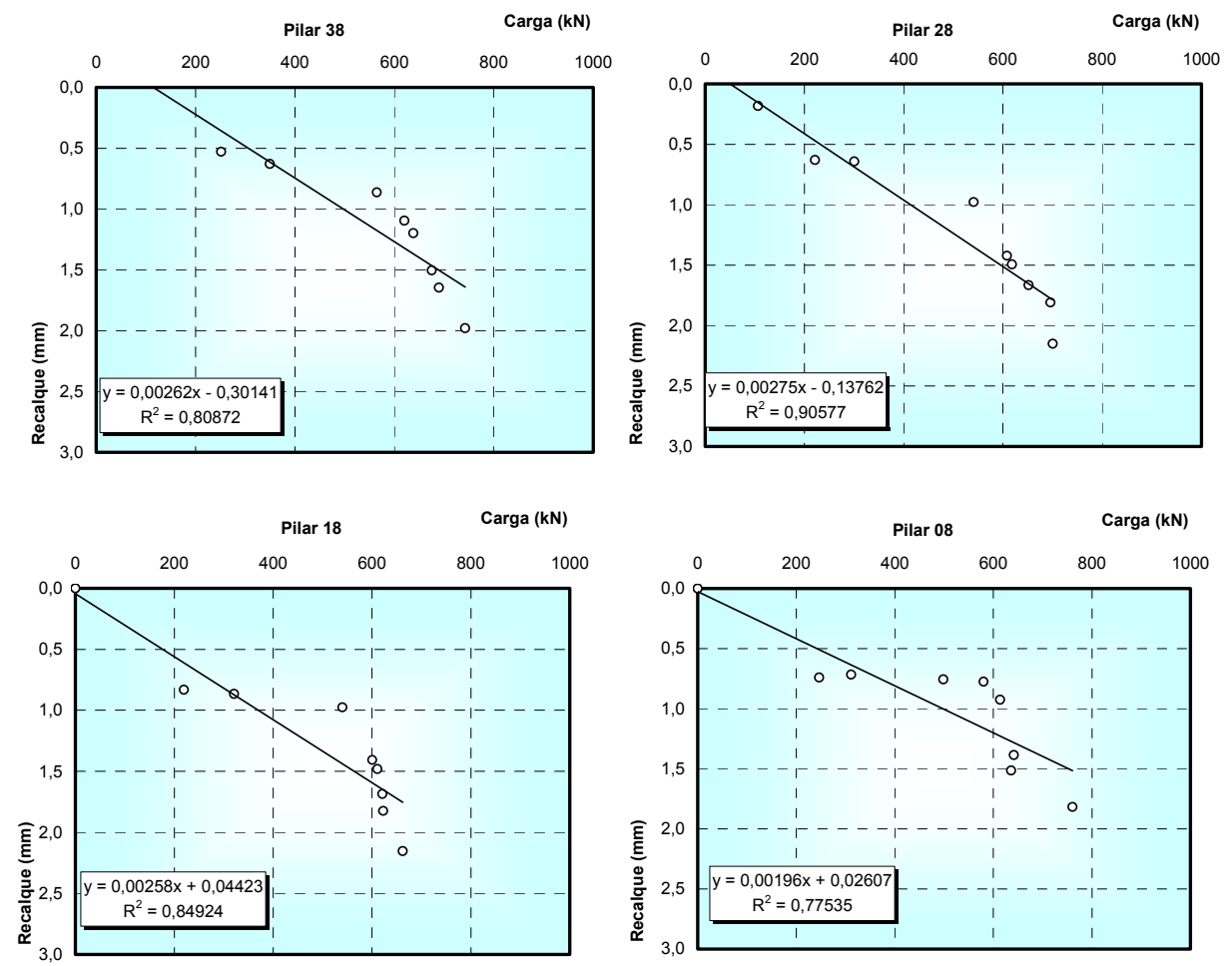

Figura 7.43 - Relação carga recalque, pilares do eixo 08.
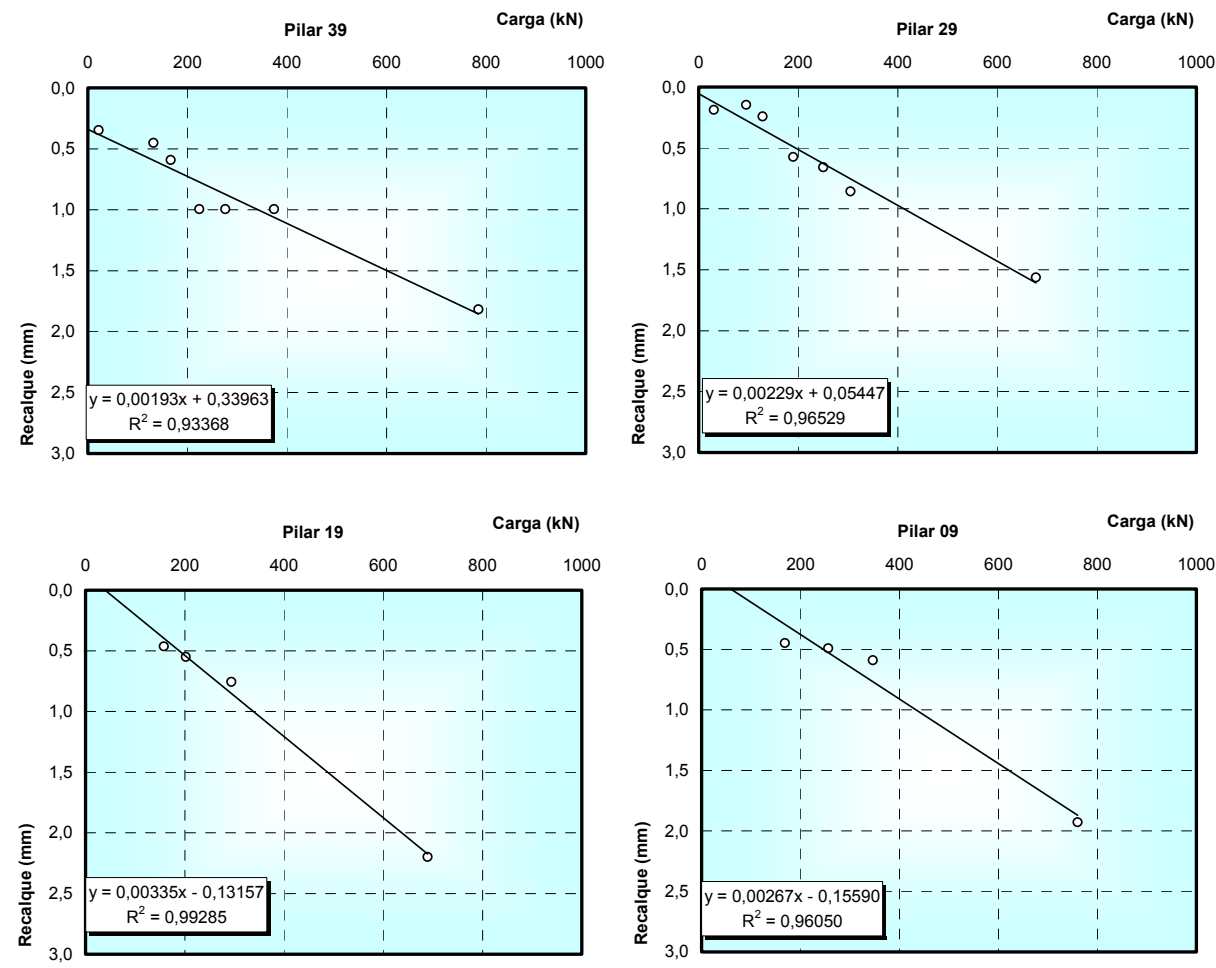

Figura 7.44 - Relação carga recalque, pilares do eixo 09. 
Tabela 7.5 - Relação carga recalque - regressão linear.

\begin{tabular}{|c|c|c|c|c|c|c|c|c|c|c|c|}
\hline Pilar & $\begin{array}{c}k_{\text {mola }} \\
(\mathrm{kN} / \mathrm{mm})\end{array}$ & $\begin{array}{l}\mathrm{R}^{2} \\
(\%)\end{array}$ & Pilar & $\begin{array}{c}\mathrm{k}_{\mathrm{mola}} \\
(\mathrm{kN} / \mathrm{mm})\end{array}$ & $\begin{array}{l}\mathrm{R}^{2} \\
(\%)\end{array}$ & Pilar & $\begin{array}{c}\mathrm{k}_{\mathrm{mola}} \\
(\mathrm{kN} / \mathrm{mm})\end{array}$ & $\begin{array}{l}R^{2} \\
(\%)\end{array}$ & Pilar & $\begin{array}{c}\mathrm{k}_{\text {mola }} \\
(\mathrm{kN} / \mathrm{mm})\end{array}$ & $\begin{array}{l}R^{2} \\
(\%)\end{array}$ \\
\hline 36 & 1087 & 79 & 37 & 408 & 93 & 38 & 382 & 81 & 39 & 518 & 93 \\
\hline 26 & 340 & 71 & 27 & 239 & 95 & 28 & 364 & 91 & 29 & 437 & 97 \\
\hline 16 & 255 & 92 & 17 & 189 & 90 & 18 & 388 & 85 & 19 & 299 & 99 \\
\hline 06 & 188 & 97 & 07 & 351 & 93 & 08 & 510 & 78 & 09 & 375 & 96 \\
\hline Méd & 467 & & & 297 & & & 411 & & & 407 & \\
\hline CV & $77 \%$ & & & $29 \%$ & & & $14 \%$ & & & $20 \%$ & \\
\hline
\end{tabular}

Pode-se verificar, na tabela acima, que apenas nos pilares 36 e 26 o coeficiente de correlação é inferior a $80 \%$. Também se constata que o pilar 36 apresenta uma rigidez elevada em relação aos demais, enquanto os pilares 06 e 17 mostram-se mais flexíveis que o restante do conjunto. Eliminando-se esses valores extremos, verifica-se que o coeficiente de mola varia entre 518 e $239 \mathrm{kN} / \mathrm{mm}$, tendo valor central igual a $374 \mathrm{kN} / \mathrm{mm}$, desvio padrão de 81 $\mathrm{kN} / \mathrm{mm}$ correspondendo a um coeficiente de variação igual a $22 \%$.

De maneira análoga ao anteriormente apresentado, a Figura 7.45 apresenta curvas de igual coeficiente de mola determinados através de regressão linear entre os valores de carga e recalque medidos.

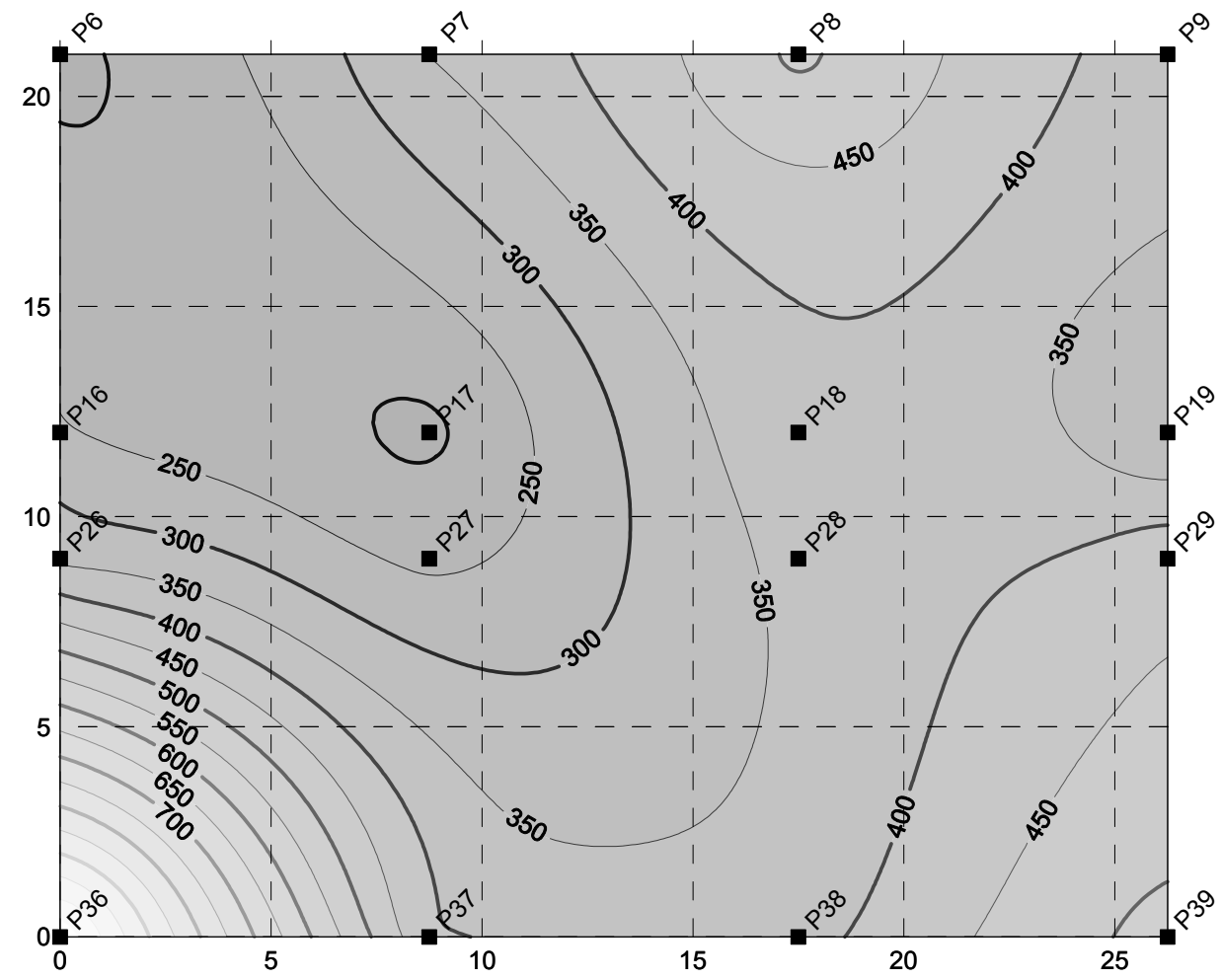

Figura 7.45 - Curvas de igual coeficiente de mola. 


\section{RETROANÁLISE}

\subsection{INTRODUÇÃO.}

A previsão de recalques de uma estrutura ainda continua sendo tema instigante no campo da Engenharia de Fundações. Independente do modelo a ser adotado para realizar essa previsão, o aspecto fundamental a ser definido é a deformabilidade do maciço de solo.

Pretende-se, neste capítulo, estabelecer propriedades de deformabilidade do maciço de solo, partindo-se dos dados coletados no estudo de caso em questão.

Duas retroanálises foram desenvolvidas, sendo que a diferença fundamental entre elas é devida à posição da superfície resistente adotada.

A primeira é de certo modo similar à previsão classe $A$ da classificação proposta por Lambe (1973), na qual a estimativa é realizada com as informações existentes na fase de projeto, antes da execução da obra. Essa será denominada, neste trabalho, de retroanálise $A$.

A segunda corresponde ao tipo de previsão classe C1 (ou, conforme Lambe denomina, autópsia) a qual é realizada após a execução da obra. Sendo conhecidos os resultados do comportamento da mesma, e será identificada como retroanálise $\mathrm{C} 1$.

\subsection{METODOLOGIA.}

Os dados coletados durante a campanha de campo serão a seguir analisados, sob o enfoque da interação solo estrutura originalmente proposto por Chamecki (1954) e conforme roteiro recomendado por Aoki e Cintra (2003). A superestrutura é modelada por meio de pórtico espacial isostático, apoiado em molas representativas das fundações por estacas. No cálculo das molas, foi 
utilizada a integração numérica da solução de Mindlin para a modelagem do efeito de grupo do sistema formado pelas estacas e pelo maciço de solo.

As ações de competência do engenheiro estrutural (determinação da "carga nos pilares") foram desenvolvidas com auxílio de software específico de análise estrutural (SAP2000).

A superestrutura, composta de elementos de concreto armado prémoldado de tipo pilares, vigas, lajes e painéis, foi modelada por meio de elementos de barras. Adicionalmente, modelou-se o bloco de coroamento das estacas por meio de elementos de placa (tipo "shell"), os quais se apóiam em molas com rigidez apenas na direção vertical, sendo elas posicionadas no local correspondente a cada uma das estacas da obra. A opção de permitir movimentação apenas na direção vertical deve-se ao fato de que o carregamento é predominantemente vertical, e os deslocamentos advindos dele também terão essa direção como principal. A Figura 8.1 apresenta representação gráfica em três dimensões da superestrutura, conforme modelado.

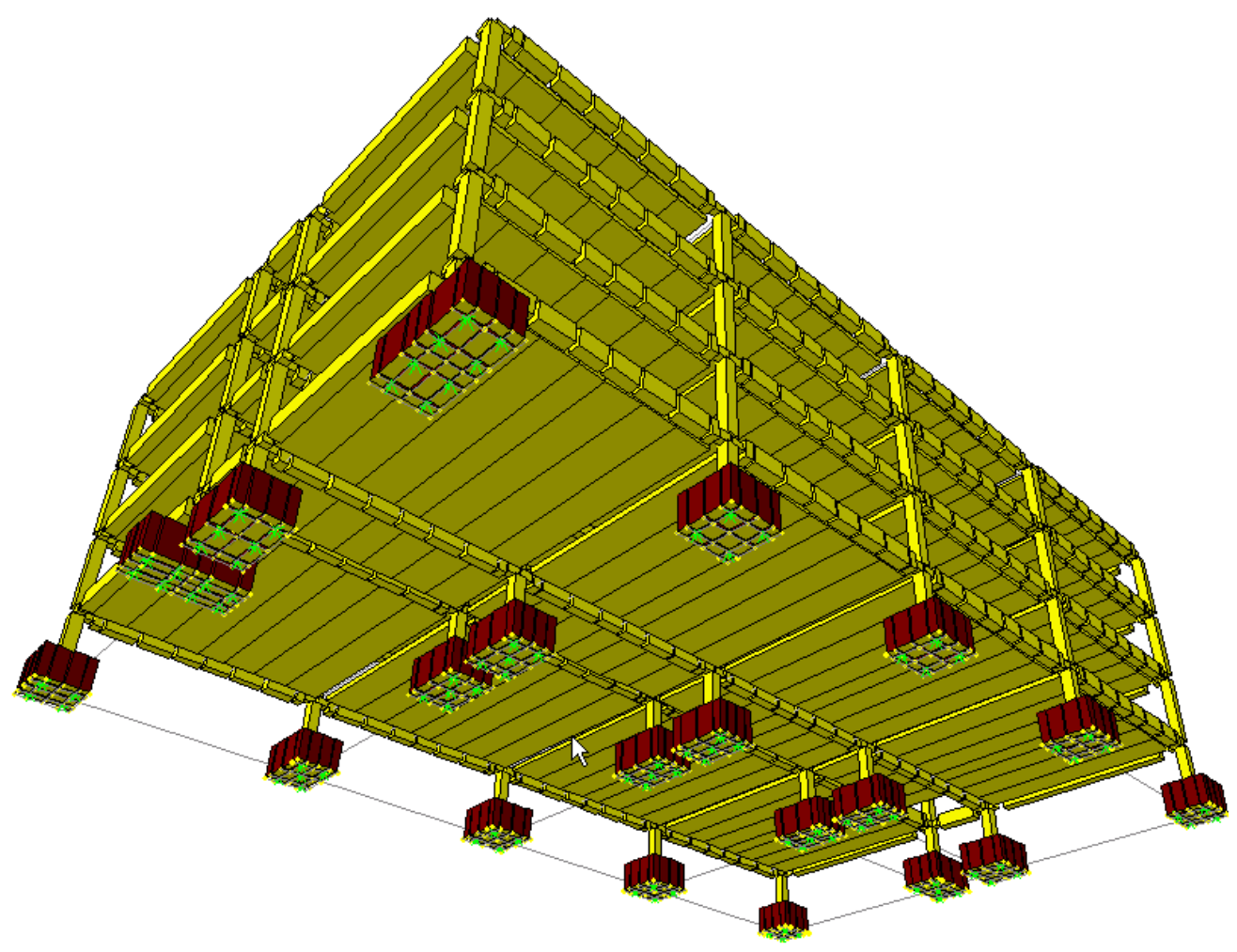

Figura 8.1 - Modelagem da superestrutura, vista inferior. 
As ações de competência do engenheiro de fundações (determinação da "bacia de recalques") foram desenvolvidas com auxílio de software específico para determinação de deslocamentos verticais em maciços de solos, denominado SOILDEF 3.0. Esse programa é baseado na proposição feita por Aoki e Lopes (1975) e envolve a integração numérica da solução de Mindlin (1936) para o cálculo de deslocamentos verticais em maciços de solos, quando submetidos a carregamentos concentrados verticais. Como essa solução é restrita ao caso de meios homogêneos, encontra-se implementada no programa a proposição de Steinbrenner (1934) para a consideração de maciço estratificado. Como resultado final, o programa fornece o deslocamento vertical da ponta de cada estaca.

Conforme proposto por Vésic (1975), para determinação do deslocamento do topo da estaca $\left(\delta_{\mathrm{t}}\right)$, aos resultados do programa SOILDEF 3.0 $\left(\delta_{s}\right)$ deslocamento do maciço de solo na posição da ponta da estaca são acrescentados os deslocamentos verticais devidos ao encurtamento do concreto das estacas $\left(\delta_{\mathrm{p}}\right)$.

O diagrama de esforço normal em cada estaca foi calculado pelo método Aoki e Velloso (1975).

A integração entre as duas "especialidades" foi efetuada por meio da utilização de uma planilha eletrônica que a cada iteração, recalculava os dados necessários de cada software para a próxima etapa. O detalhamento dos dados, procedimentos e critérios adotados para a elaboração das análises são descritos a seguir.

\subsubsection{Superestrutura.}

A modelagem da superestrutura foi bastante facilitada, tendo em vista que os elementos envolvidos eram pré-moldados de concreto. Essa solução de engenharia faz com que as características geométricas das peças sejam conhecidas e bem definidas. O objetivo principal dessa modelagem é determinar o valor da solicitação normal nos pilares e da força normal atuante nas molas que apóiam o bloco. 
As ações externas nessa etapa de construção são unicamente verticais, envolvendo apenas aquelas devidas ao peso próprio do concreto armado prémoldado, o qual foi considerado igual a $25 \mathrm{kN} / \mathrm{m}^{3}$.

A montagem dos elementos pré-fabricados, que foi levada a efeito no presente estudo, envolve uma estrutura isostática, pois os elementos tipo laje eram simplesmente apoiados nos tipo viga, os quais se apóiam nos pilares em consoles. $\mathrm{O}$ contato entre a viga e o console do pilar se dava por meio de uma placa de neoprene. A discretização dessas peças foi feita por meio de elementos de barras. A Figura 8.2 mostra uma visualização tridimensional dessa discretização, dada pelo programa utilizado.

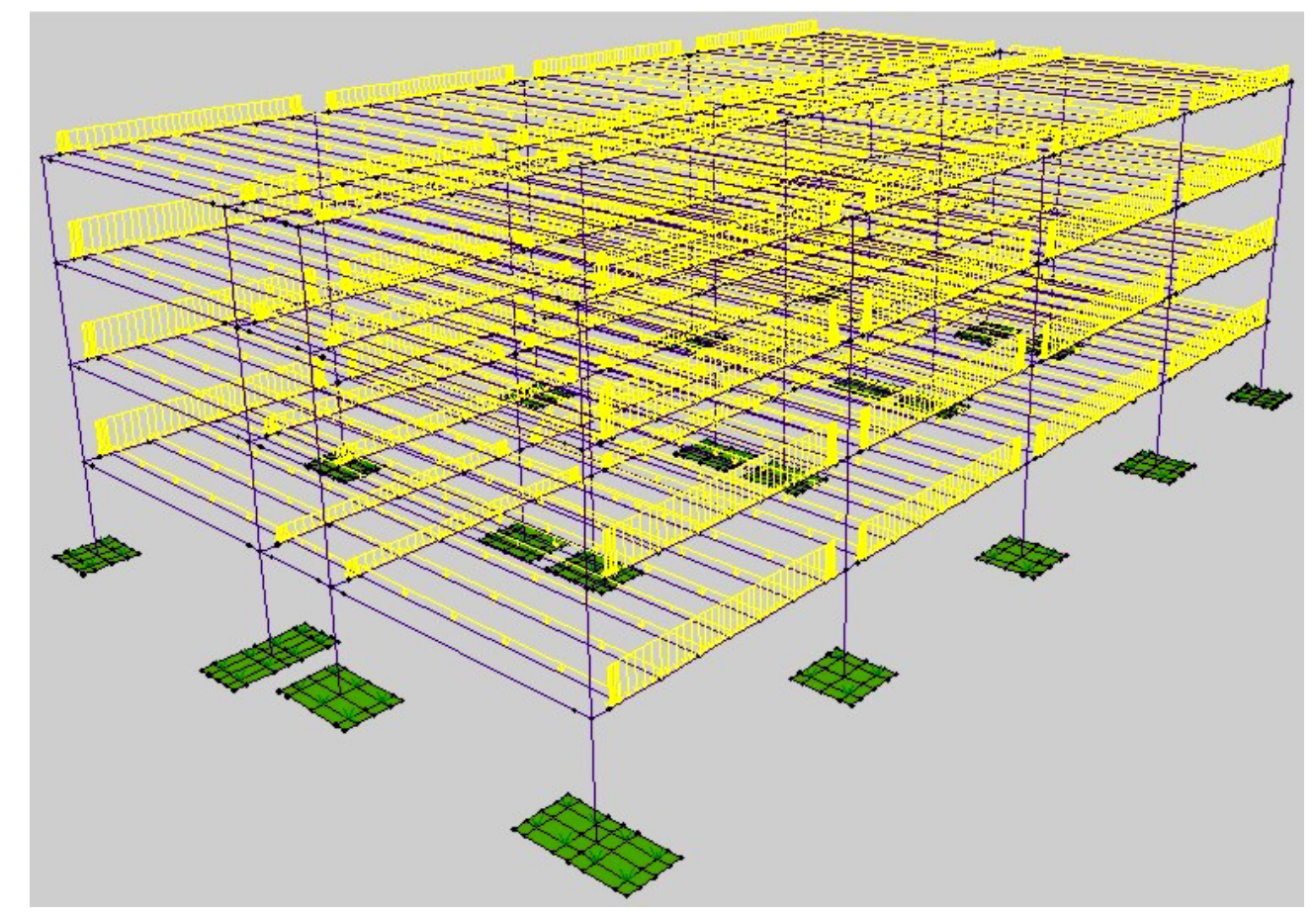

Figura 8.2 - Discretização da superestrutura por meio de elementos de barra e placa.

Nesta análise considerou-se que o bloco de coroamento das estacas fazia parte integrante da superestrutura, o qual se apoiava em molas nas posições respectivas das estacas. Estes foram executados com concreto moldados no local utilizando-se concreto usinado. Todos esses elementos foram executados com altura de 1,3 m. A modelagem dos blocos foi efetuada utilizando-se elementos de placa tipo "shell". 


\subsubsection{Maciço de solo.}

O problema da interação solo estrutura apresenta um elevado grau de hiperestaticidade, tendo em vista que o número de pontos de contato no maciço é infinito, segundo Costa Nunes (1977). Uma das formas de se levantar essa indeterminação é a determinação do sistema geotécnico fundamental, o qual consiste em determinar, na ruptura, as parcelas de atrito lateral e de resistência de ponta do elemento de fundação. Para a determinação dessas parcelas utilizou-se o método de previsão de capacidade de carga de fundações profundas, proposto Aoki e Velloso (1975), o qual pode ser expresso pela equação:

$$
P=P_{L}+P_{P}=\sum_{i} \frac{\alpha_{i} \times k_{i} \times N_{i}}{F_{2}} \times A_{L i}+\frac{k \times N_{P}}{F_{1}} \times A_{P}
$$

onde:

$\mathrm{P}$ - resistência do sistema estaca solo;

$P_{L}$ - resistência por atrito lateral;

$\mathrm{P}_{\mathrm{P}}$ - resistência de ponta;

$\alpha$ e $\mathrm{k}$ - coeficientes tabelados que dependem da textura do solo;

$F_{1}$ e $F_{2}$ - coeficientes que levam em conta o grau de alteração promovido no solo devido à instalação do elemento de fundação. Para o caso de estacas pré-moldadas $\mathrm{F}_{1}=1,75$ e $\mathrm{F}_{2}=3,5$.

$N_{i}$ e $N_{P}$ - valor do número de golpes SPT ao longo do fuste da estaca e na ponta da estaca, respectivamente.

$A_{L}$ - área da superfície lateral.

$A_{P}$ - área da ponta.

O resultado do método de previsão da capacidade de carga, no tocante à parcela de atrito lateral, aplicado aos dados da sondagem SP-06 e para uma estaca pré-moldada de seção quadrada de lado $35 \mathrm{~cm}$, é apresentado na Tabela 8.1. 
Tabela 8.1 - Determinação do atrito lateral, método Aoki Velloso, sondagem SP-06.

\begin{tabular}{ccccccccc}
\hline $\begin{array}{c}\text { Prof } \\
(\mathrm{m})\end{array}$ & $\begin{array}{c}\text { Cota } \\
(\mathrm{m})\end{array}$ & $\mathrm{N}_{\mathrm{SPT}}$ & $\begin{array}{c}\mathrm{k} \\
(\mathrm{kPa})\end{array}$ & $\begin{array}{c}\alpha \\
(\%)\end{array}$ & $\begin{array}{c}\mathrm{r}_{\mathrm{L}} \\
(\mathrm{kPa})\end{array}$ & $\begin{array}{c}\Delta \mathrm{L} \\
(\mathrm{m})\end{array}$ & $\begin{array}{c}\text { Local } \\
(\mathrm{kN})\end{array}$ & $\begin{array}{c}\mathrm{PL}_{\mathrm{L}} \\
(\mathrm{kN})\end{array}$ \\
\hline 0,0 & 884,5 & 0 & 200 & 6,0 & 0,0 & 0,0 & 0,0 & 0,0 \\
1,0 & 883,5 & 2 & 200 & 6,0 & 6,9 & 1,0 & 9,6 & 9,6 \\
2,0 & 882,5 & 2 & 200 & 6,0 & 6,9 & 1,0 & 9,6 & 19,2 \\
3,0 & 881,5 & 2 & 200 & 6,0 & 6,9 & 1,0 & 9,6 & 28,8 \\
4,0 & 880,5 & 3 & 200 & 6,0 & 10,3 & 1,0 & 14,4 & 43,2 \\
4,6 & 879,9 & 3 & 200 & 6,0 & 10,3 & 0,6 & 8,6 & 51,8 \\
5,0 & 879,5 & 15 & 800 & 2,0 & 68,6 & 0,4 & 38,4 & 90,2 \\
5,8 & 878,7 & 15 & 800 & 2,0 & 68,6 & 0,8 & 76,8 & 167,0 \\
6,0 & 878,5 & 5 & 230 & 3,4 & 11,2 & 0,2 & 3,1 & 170,2 \\
7,0 & 877,5 & 9 & 230 & 3,4 & 20,1 & 1,0 & 28,2 & 198,3 \\
8,0 & 876,5 & 20 & 550 & 2,2 & 69,1 & 1,0 & 96,8 & 295,1 \\
9,0 & 875,5 & 41 & 550 & 2,2 & 141,7 & 1,0 & 198,4 & 493,6 \\
\hline
\end{tabular}

Outra informação do maciço de solos necessária para a determinação do deslocamento da ponta das estacas é aquela referente ao módulo de deformabilidade $\left(E_{s}\right)$ do solo, sendo a determinação dele um dos objetivos principais da presente análise. Neste trabalho, considera-se que esse parâmetro pode ser aferido indiretamente, por meio de correlação com a resistência de ponta $\left(q_{c}\right)$ do ensaio de penetração de cone (CPT), dada pela expressão:

$$
E_{s}=\eta \times q_{c}
$$

Cabe ressaltar que, na proposta apresentada por Vésic (1975), apenas as camadas abaixo da ponta das estacas estão envolvidas nesse processo. Assim sendo, neste trabalho, apenas a camada silto-arenosa de origem residual, na qual a ponta das estacas se apóia, foi detalhada, ignorando-se as características de deformabilidade dos estratos acima dela.

$O$ ensaio de cone elétrico fornece, a cada $2 \mathrm{~cm}$, dados do solo. De modo a diminuir a quantidade de informações para cada ensaio o valor de $\left(q_{c}\right)$ foi tomado pelo seu valor médio a cada $50 \mathrm{~cm}$, a partir da cota $+879,5 \mathrm{~m}$ (aproximadamente cota do topo do solo residual). 


\subsubsection{Processo iterativo.}

A partir de todas estas informações, procedeu-se a um processo iterativo de modo a realizar a análise da interação solo estrutura, a qual é descrita a seguir. O processo é concluído quando são atendidas simultaneamente duas condições:

a) o valor do recalque médio calculado é igual ao valor do recalque médio medido, para o conjunto de vinte pilares em questão (para retroanálise $A$ ); o deslocamento vertical da base de cada pilar é igual ao recalque medido (para retroanálise $\mathrm{C} 1$ );

b) a diferença do valor da solicitação normal nas estacas entre iterações sucessivas for inferior a $1 \mathrm{kN}$.

1) Considerando molas de igual rigidez $\left(k_{\text {mola }}\right)$ para as estacas de um dado pilar, executa-se o programa de análise estrutural (SAP2000) determinando-se o deslocamento vertical $\left(\delta_{\mathrm{i}}\right)$ da base do pilar (contato entre o pilar e o topo do bloco de coroamento das estacas) e a solicitação normal $\left(\mathrm{N}_{\mathrm{i}}\right)$ em cada estaca.

2) Compara-se o valor da solicitação normal entre iterações $\left(\mathrm{N}_{\mathrm{i}}, \mathrm{N}_{\mathrm{i}-1}\right)$.

3) Compara-se o recalque médio medido com o valor médio calculado para retroanálise A. Compara-se o valor do deslocamento vertical $\left(\delta_{\mathrm{i}}\right)$ da base do pilar com o valor do recalque medido $\left(\delta_{\text {med }}\right)$, para a retroanálise $\mathrm{C} 1$. Ajusta-se a relação $E / q_{c}$ proporcionalmente ao valor da relação entre o recalque calculado e o medido.

4) Com o valor de $\mathrm{N}_{\mathrm{i}}$ determina-se, a partir do sistema geotécnico fundamental, o diagrama de transferência de carga ao longo do fuste de cada estaca e as parcelas de atrito local nos trechos discretizados.

5) O diagrama de transferência de carga permite calcular o encurtamento elástico $\left(\delta_{\mathrm{p}}\right)$ do concreto armado do fuste de cada estaca.

6) A partir dos dados de atrito local, geometria do estaqueamento e de distribuição do módulo de deformabilidade, executa-se o programa SOILDEF 3.0, obtendo-se o deslocamento vertical do solo na posição da ponta das estacas $\left(\delta_{\mathrm{s}}\right)$. 
7) Determina-se o deslocamento do topo da estaca $\left(\delta_{t}\right)$, somando-se as parcelas de deslocamento da ponta $\left(\delta_{\mathrm{s}}\right)$ ao encurtamento elástico do fuste $\left(\delta_{\mathrm{p}}\right)$.

8) Calcula-se um novo coeficiente de mola $\left(k_{\text {mola }}\right)$ considerando $o$ deslocamento do topo da estaca.

9) Retorna-se ao item 1), repetindo o processo até que as duas condições sejam satisfeitas.

\subsection{RESULTADOS.}

Como a etapa de construção em que foram feitas as observações referese a uma estrutura isostática, o resultado da análise não mostrou distribuição de solicitações na superestrutura. $O$ efeito da interação solo estrutura foi verificado na distribuição de solicitação normal entre estacas de um mesmo bloco. O cálculo estrutural convencional, sem a consideração da interação, conduz a uma distribuição "uniforme" da solicitação normal entre estacas de um mesmo bloco, enquanto que, conforme será visto a seguir, há redistribuição de esforços entre estacas de um mesmo bloco, fato esse devido ao efeito de grupo.

\subsubsection{Retroanálise A.}

Realizou-se processo iterativo anteriormente descrito, considerando-se as informações disponíveis antes da execução da obra. A condicionante previamente estabelecida foi a de iguais recalques médios medidos e previstos.

Ao final da convergência do processo iterativo, a relação entre módulo de deformabilidade do solo e resistência à penetração de ponta do cone para essa condição foi determinada igual a:

$$
E_{s} / q_{c}=1,2
$$

Essa relação conduz à distribuição em profundidade do módulo, conforme apresentado na Tabela 8.2 e no gráfico da Figura 8.3. 
Tabela 8.2 - Variação de $E_{s}$ com a profundidade - retroanálise $A$.

\begin{tabular}{ccc}
\hline $\begin{array}{c}\text { Profundidade } \\
(\mathrm{m})\end{array}$ & $\begin{array}{c}\mathrm{q}_{\mathrm{c}} \\
(\mathrm{MPa})\end{array}$ & $\begin{array}{c}\mathrm{E}_{\mathrm{s}} \\
(\mathrm{MPa})\end{array}$ \\
\hline 5,0 & 3,9 & 47,3 \\
5,5 & 1,6 & 18,7 \\
6,0 & 2,2 & 26,2 \\
6,5 & 3,0 & 36,6 \\
7,0 & 3,5 & 42,5 \\
7,5 & 3,4 & 41,3 \\
8,0 & 7,5 & 90,3 \\
8,5 & 7,0 & 84,5 \\
9,0 & 6,3 & 76,0 \\
9,5 & 10,1 & 121,7 \\
10,0 & 10,7 & 128,3 \\
10,5 & 11,3 & 136,2 \\
11,0 & 13,7 & 164,3 \\
\hline
\end{tabular}

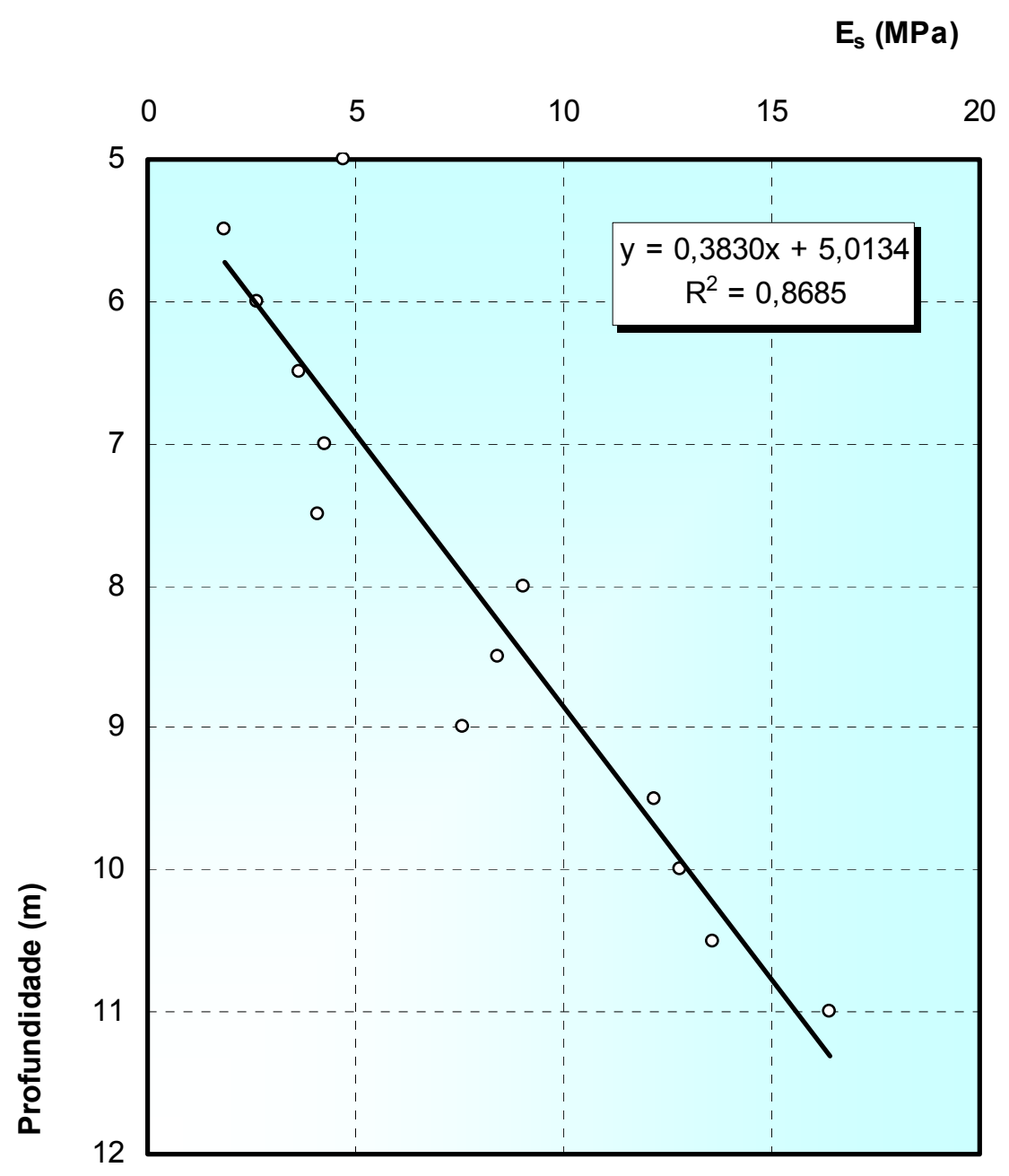

Figura 8.3 - Variação de $E_{s}$ com a profundidade. 
Na Figura 8.3 está indicada, por meio de linha contínua, a regressão linear entre a profundidade e o módulo de deformabilidade, a qual conduz a um coeficiente de correlação de $87 \%$. A expressão do tipo solo de Gibson, e que relaciona essas duas quantidades, é dada a seguir:

$$
E_{s}=2,61 \times z-13,089 \quad(M P a)
$$

Uma vez definido o módulo de deformabilidade do solo $\left(E_{s}\right)$, é possível calcular o módulo de deformabilidade transversal ou modulo de cisalhamento do solo $\left(G_{s}\right)$ pela expressão fornecida pela teoria da elasticidade. Ver por exemplo Timoshenko e Godier (1970)

$$
G_{s}=\frac{E_{s}}{2(1+v)}
$$

sendo:

$v$ - coeficiente de Poisson do solo, considerado igual a 0,3.

Robertson (1990) apresenta correlações entre o módulo de cisalhamento inicial tangente $\left(G_{0}\right)$ com a resistência à penetração de ponta do cone $\left(q_{c}\right)$, dada por:

$G_{0}=800 \sqrt[3]{q_{c} \sigma_{v}^{\prime} p_{a}} \quad$ limite superior: solos cimentados.

$G_{0}=280 \sqrt[3]{q_{c} \sigma_{v}^{\prime} p_{a}} \quad$ limite inferior: solos cimentados.

limite superior: solos não cimentados.

$G_{0}=110 \sqrt[3]{q_{c} \sigma_{v}^{\prime} p_{a}} \quad$ limite inferior: solos não cimentados.

onde:

$\sigma_{v}$ - tensão efetiva vertical;

$p_{a}-$ pressão atmosférica.

Aplicando-se as equações (8.5) e (8.8), adotando o limite inferior dessa aos solos cimentados aos valores apresentados na tabela 8.2, é possível 
determinar os valores do módulo de deformabilidade (tanto secante como inicial tangente) para as condições do presente estudo e estabelecer um comparativo entre eles. A Tabela 8.3 apresenta esses resultados.

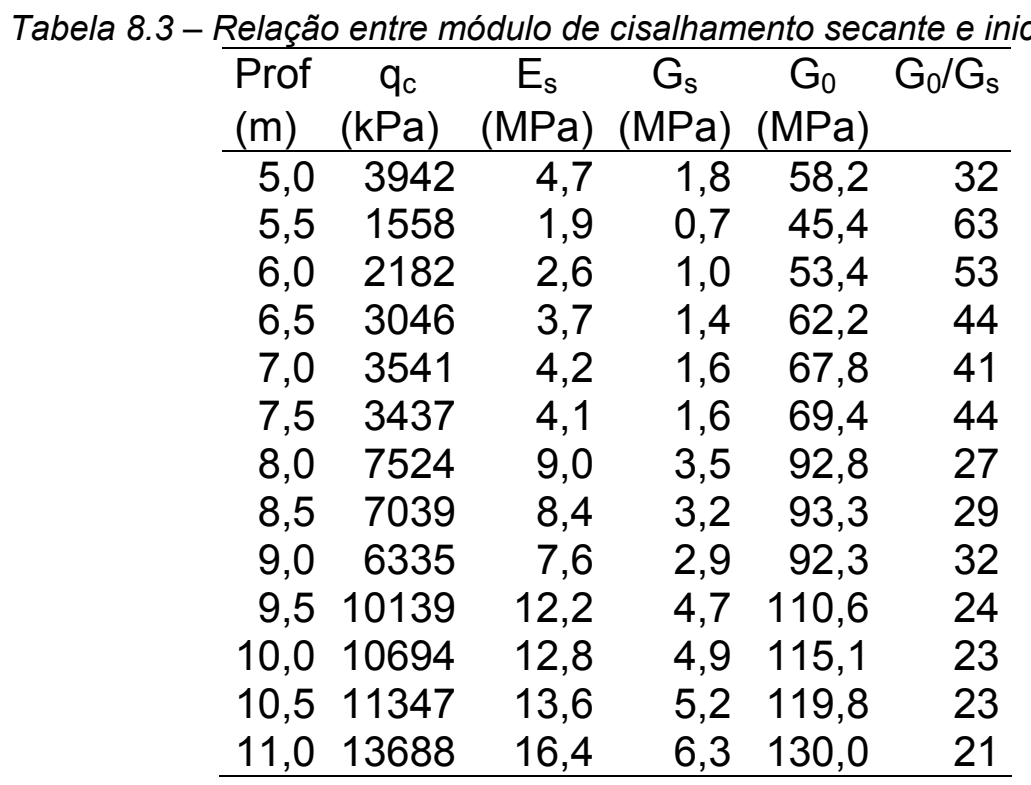

A relação $\left(G_{s} / G_{0}\right)$ determinada na tabela acima, indica que, para o nível de tensão ou de deformação imposto pela condição de obra analisada, o módulo de deformabilidade transversal secante, determinado pela retroanálise, corresponde a uma relação variável entre 21 e 63 vezes o valor do módulo de cisalhamento inicial tangente, fornecido pela correlação existente na literatura específica.

Os principais resultados da análise da interação solo estrutura efetuada são apresentados na Tabela 8.4. Nela constam as seguintes informações: a designação do pilar, a identificação de cada estaca, o comprimento $(L)$ previsto em projeto, o encurtamento elástico da estaca $\left(\delta_{\mathrm{p}}\right)$, o deslocamento do maciço de solo na ponta da estaca $\left(\delta_{\mathrm{s}}\right)$, o deslocamento do topo da estaca $\left(\delta_{\mathrm{t}}\right)$, a constante de mola de cada estaca $\left(k_{\mathrm{mola}}\right)$, o deslocamento vertical da base do pilar fornecido pelo programa de análise estrutural $\left(\delta_{\text {calc }}\right)$, o valor do recalque fornecido pela instrumentação $\left(\delta_{\text {med }}\right)$ e a solicitação normal no topo de cada estaca $\left(\mathrm{N}_{\mathrm{i}}\right)$. 
Tabela 8.4-Resultados da análise interação solo estrutura - retroanálise A.

\begin{tabular}{|c|c|c|c|c|c|c|c|c|c|}
\hline Pilar & Estaca & $\begin{array}{c}\mathrm{L} \\
(\mathrm{m})\end{array}$ & $\begin{array}{c}\delta_{\mathrm{p}} \\
(\mathrm{mm})\end{array}$ & $\begin{array}{c}\delta_{\mathrm{s}} \\
(\mathrm{mm})\end{array}$ & $\begin{array}{c}\delta_{\mathrm{t}} \\
(\mathrm{mm})\end{array}$ & $\begin{array}{c}\mathrm{k}_{\text {mola }} \\
(\mathrm{kN} / \mathrm{m})\end{array}$ & $\begin{array}{c}\delta_{\text {calc }} \\
(\mathrm{mm})\end{array}$ & $\begin{array}{c}\delta_{\text {med }} \\
(\mathrm{mm})\end{array}$ & $\begin{array}{c}\mathrm{N}_{\mathrm{i}} \\
(\mathrm{kN})\end{array}$ \\
\hline \multirow{8}{*}{ P36 } & E252 & 7,5 & 0,05 & 0,65 & 0,70 & 84133 & \multirow{8}{*}{0,72} & \multirow{8}{*}{0,60} & 59 \\
\hline & E253 & 7,5 & 0,03 & 0,67 & 0,70 & 63597 & & & 45 \\
\hline & E254 & 7,5 & 0,04 & 0,67 & 0,70 & 67417 & & & 48 \\
\hline & E255 & 7,5 & 0,02 & 0,69 & 0,71 & 48155 & & & 34 \\
\hline & E256 & 7,5 & 0,04 & 0,66 & 0,70 & 70037 & & & 49 \\
\hline & E257 & 7,5 & 0,02 & 0,68 & 0,71 & 53124 & & & 37 \\
\hline & E258 & 7,5 & 0,07 & 0,62 & 0,70 & 103215 & & & 72 \\
\hline & E259 & 7,5 & 0,06 & 0,64 & 0,70 & 89035 & & & 62 \\
\hline \multirow{6}{*}{ P26 } & E176 & 7 & 0,04 & 1,46 & 1,50 & 35308 & \multirow{6}{*}{1,51} & \multirow{6}{*}{1,30} & 53 \\
\hline & E177 & 7 & 0,03 & 1,48 & 1,51 & 26654 & & & 40 \\
\hline & E178 & 7 & 0,05 & 1,46 & 1,50 & 36474 & & & 55 \\
\hline & E179 & 7 & 0,03 & 1,48 & 1,51 & 28373 & & & 43 \\
\hline & E180 & 7 & 0,10 & 1,40 & 1,50 & 59604 & & & 89 \\
\hline & E181 & 7 & 0,08 & 1,42 & 1,50 & 50708 & & & 76 \\
\hline \multirow{8}{*}{ P16 } & E112 & 7 & 0,12 & 1,32 & 1,44 & 58421 & \multirow{8}{*}{1,46} & \multirow{8}{*}{1,60} & 84 \\
\hline & E113 & 7 & 0,05 & 1,40 & 1,45 & 33203 & & & 48 \\
\hline & E114 & 7 & 0,04 & 1,40 & 1,45 & 31876 & & & 46 \\
\hline & E115 & 7 & 0,08 & 1,36 & 1,44 & 44252 & & & 64 \\
\hline & E116 & 7 & 0,06 & 1,38 & 1,44 & 36547 & & & 53 \\
\hline & E117 & 7 & 0,01 & 1,47 & 1,47 & 12117 & & & 18 \\
\hline & E118 & 7 & 0,01 & 1,47 & 1,48 & 10996 & & & 16 \\
\hline & E119 & 7 & 0,02 & 1,42 & 1,44 & 21584 & & & 31 \\
\hline \multirow{4}{*}{ P06 } & E029 & 7 & 0,14 & 1,48 & 1,62 & 68095 & \multirow{4}{*}{1,63} & \multirow{4}{*}{2,00} & 110 \\
\hline & E030 & 7 & 0,14 & 1,48 & 1,62 & 67824 & & & 110 \\
\hline & E031 & 7 & 0,12 & 1,50 & 1,62 & 60922 & & & 99 \\
\hline & E032 & 7 & 0,11 & 1,50 & 1,62 & 59468 & & & 96 \\
\hline Pilar & Estaca & $\begin{array}{c}\mathrm{L} \\
(\mathrm{m})\end{array}$ & $\begin{array}{c}\delta_{\mathrm{p}} \\
(\mathrm{mm})\end{array}$ & $\begin{array}{c}\delta_{\mathrm{s}} \\
(\mathrm{mm})\end{array}$ & $\begin{array}{c}\delta_{\mathrm{t}} \\
(\mathrm{mm})\end{array}$ & $\begin{array}{c}\mathrm{k}_{\text {mola }} \\
(\mathrm{kN} / \mathrm{m})\end{array}$ & $\begin{array}{c}\delta_{\text {calc }} \\
(\mathrm{mm})\end{array}$ & $\begin{array}{c}\delta_{\text {med }} \\
(\mathrm{mm})\end{array}$ & $\begin{array}{c}\mathrm{N}_{\mathrm{i}} \\
(\mathrm{kN})\end{array}$ \\
\hline \multirow{4}{*}{ P37 } & E261 & 8 & 0,31 & 1,71 & 2,02 & 99773 & \multirow{4}{*}{2,05} & \multirow{4}{*}{2,20} & 202 \\
\hline & E262 & 8 & 0,32 & 1,71 & 2,02 & 100532 & & & 203 \\
\hline & E263 & 8 & 0,31 & 1,71 & 2,02 & 99799 & & & 202 \\
\hline & E264 & 8 & 0,32 & 1,71 & 2,02 & 100539 & & & 203 \\
\hline \multirow{5}{*}{ P27 } & E183 & 7,5 & 0,15 & 2,46 & 2,61 & 45733 & & & 119 \\
\hline & E184 & 7,5 & 0,17 & 2,44 & 2,61 & 48350 & & & 126 \\
\hline & E185 & 7,5 & 0,13 & 2,50 & 2,63 & 40550 & 2,63 & 3,20 & 107 \\
\hline & E186 & 7,5 & 0,26 & 2,34 & 2,60 & 68419 & & & 178 \\
\hline & E187 & 7,5 & 0,27 & 2,34 & 2,60 & 69748 & & & 182 \\
\hline & E121 & 7,5 & 0,27 & 2,34 & 2,62 & 69917 & & & 183 \\
\hline & E122 & 7,5 & 0,28 & 2,33 & 2,61 & 71 & & & 187 \\
\hline P17 & E123 & 7,5 & 0,12 & 2,53 & 2,64 & 37458 & 2,64 & 2,60 & 99 \\
\hline & E124 & 7,5 & 0,16 & 2,46 & 2,62 & 46046 & & & 121 \\
\hline & E125 & 7,5 & & 2,45 & & & & & 127 \\
\hline & E034 & 7 & 0,28 & 3,28 & 3,56 & 450 & & & 160 \\
\hline & E035 & 7 & 0,29 & 3,27 & 3,56 & 45741 & & & 163 \\
\hline $\mathrm{P} 07$ & E036 & 7 & 0,12 & 3,45 & 3,57 & 24054 & & 22 & 86 \\
\hline ror & E036A & 7 & 0,15 & 3,41 & 3,56 & & 3,59 & ¿, ८U & 102 \\
\hline & E037 & 7 & 0,27 & 3,29 & 3,56 & 43853 & & & 156 \\
\hline & E038 & 7 & 0,27 & 3,28 & 3,56 & 44342 & & & 158 \\
\hline Pilar & Estaca & $\begin{array}{c}\mathrm{L} \\
(\mathrm{m})\end{array}$ & $\begin{array}{c}\delta_{\mathrm{p}} \\
(\mathrm{mm})\end{array}$ & $\begin{array}{c}\delta_{\mathrm{s}} \\
(\mathrm{mm})\end{array}$ & $\begin{array}{c}\delta_{\mathrm{t}} \\
(\mathrm{mm})\end{array}$ & $\begin{array}{c}\mathrm{k}_{\text {mola }} \\
(\mathrm{kN} / \mathrm{m})\end{array}$ & $\begin{array}{c}\delta_{\text {calc }} \\
(\mathrm{mm})\end{array}$ & $\begin{array}{c}\delta_{\text {med }} \\
(\mathrm{mm})\end{array}$ & $\begin{array}{c}\mathrm{N}_{\mathrm{i}} \\
(\mathrm{kN})\end{array}$ \\
\hline & E266 & 8 & 0,31 & 1,73 & 2,04 & 98218 & & & 201 \\
\hline & E267 & 8 & 0,32 & 1,73 & 2,04 & 99276 & & & 203 \\
\hline$r$ & E268 & 8 & 0,31 & 1,73 & 2,04 & 98346 & 2,07 & 0 & 201 \\
\hline & E269 & 8 & 0,32 & 1,73 & 2,04 & 99384 & & & 203 \\
\hline P28 & E189 & 8 & 0,14 & 1,99 & 2,13 & 52522 & 2,15 & 2,30 & 112 \\
\hline & E190 & 8 & 0,16 & 1,97 & 2,13 & 56895 & & & 121 \\
\hline & E191 & 8 & 0,16 & 1,99 & 2,15 & 55867 & & & 120 \\
\hline
\end{tabular}




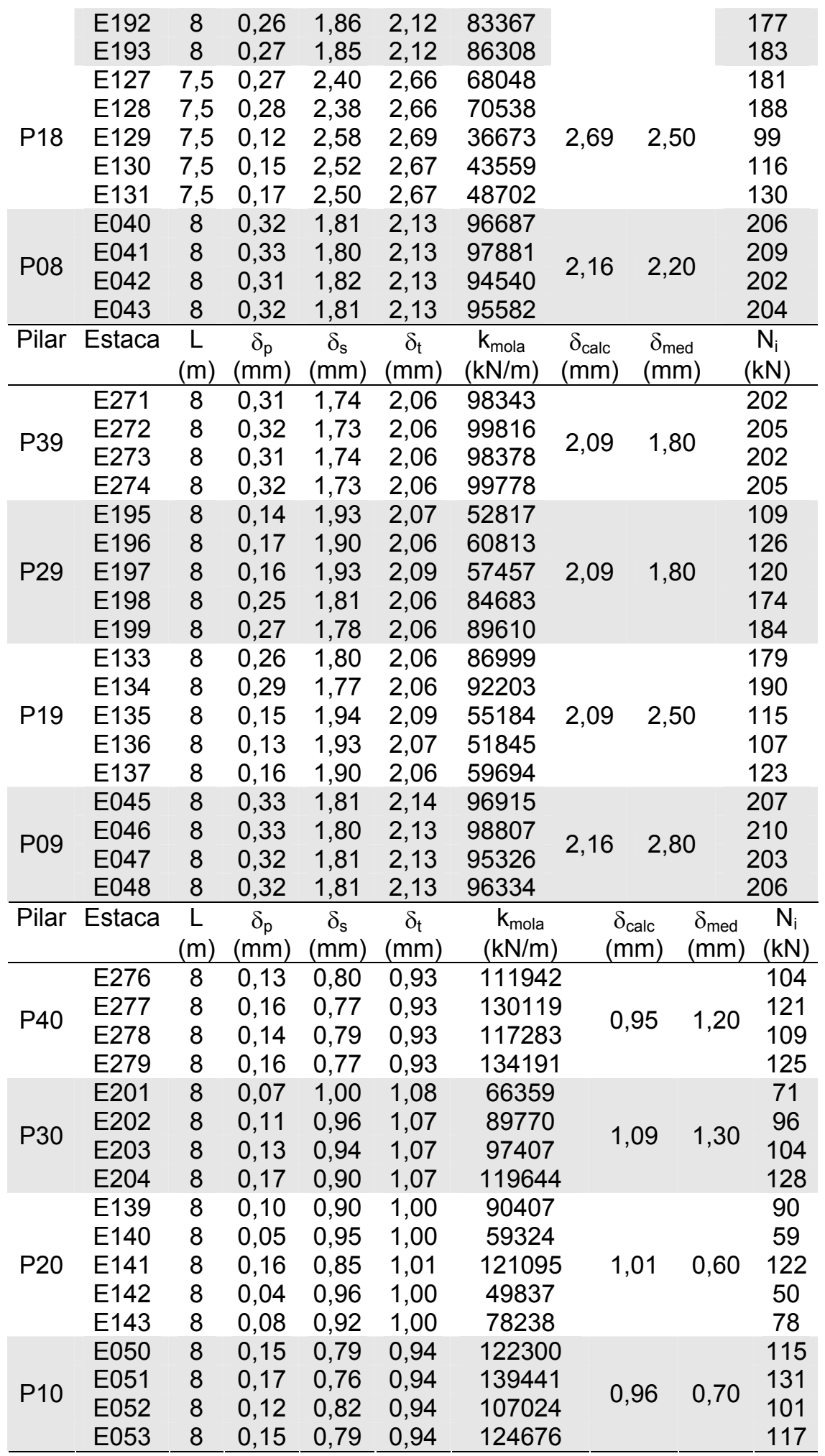

Os valores dos recalques determinados nessa análise são comparados aos valores medidos na Tabela 8.5. 
Tabela 8.5 - Comparativo entre recalques medidos e calculados - retroanálise A.

\begin{tabular}{lccc}
\hline RECALQUE & & Calculado & Medido \\
\hline Máximo & $(\mathrm{mm})$ & 3,59 & 3,20 \\
Mínimo & $(\mathrm{mm})$ & 0,72 & 0,60 \\
Médio & $(\mathrm{mm})$ & 1,89 & 1,88 \\
CV & $(\%)$ & 37 & 38 \\
\hline
\end{tabular}

Também de modo a confrontar os valores calculados com aqueles medidos, apresentam-se nas Figuras 8.4 a 8.12 gráficos da deformada de recalques.

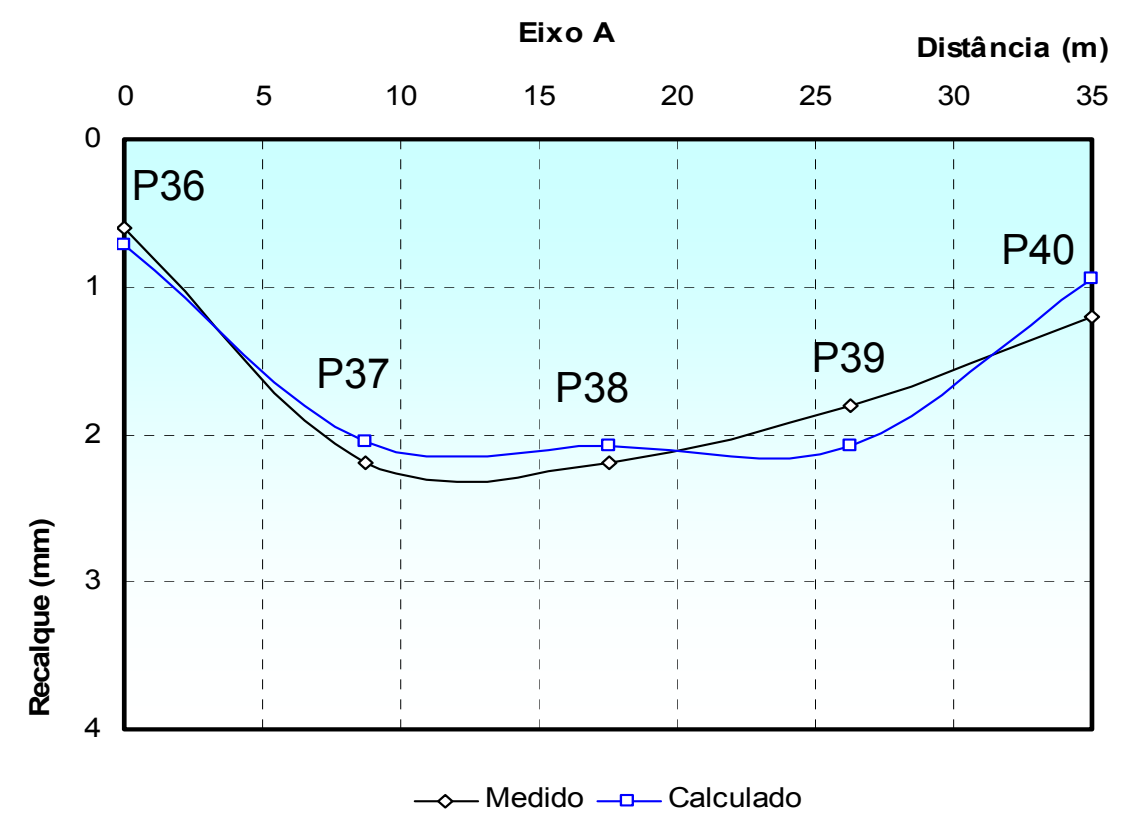

Figura 8.4 - Deformada de recalques eixo A - pilar 36 a 40.

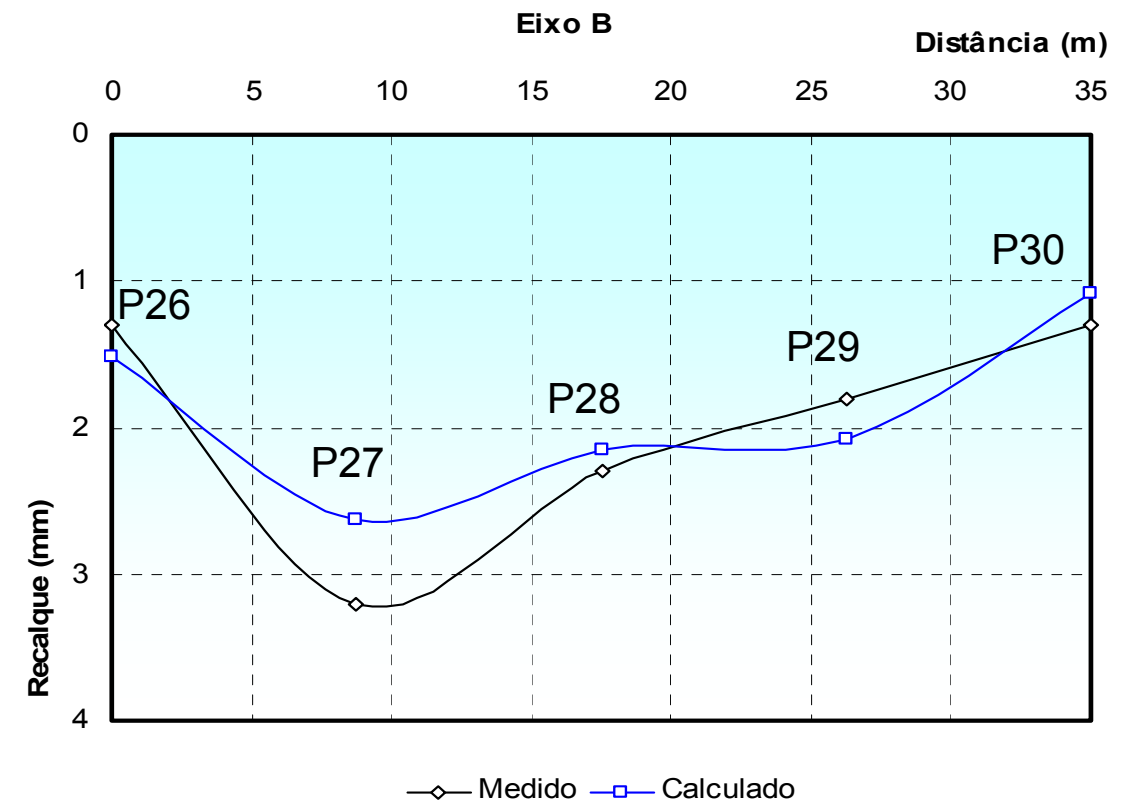

Figura 8.5 - Deformada de recalques eixo B - pilar 26 a 30. 


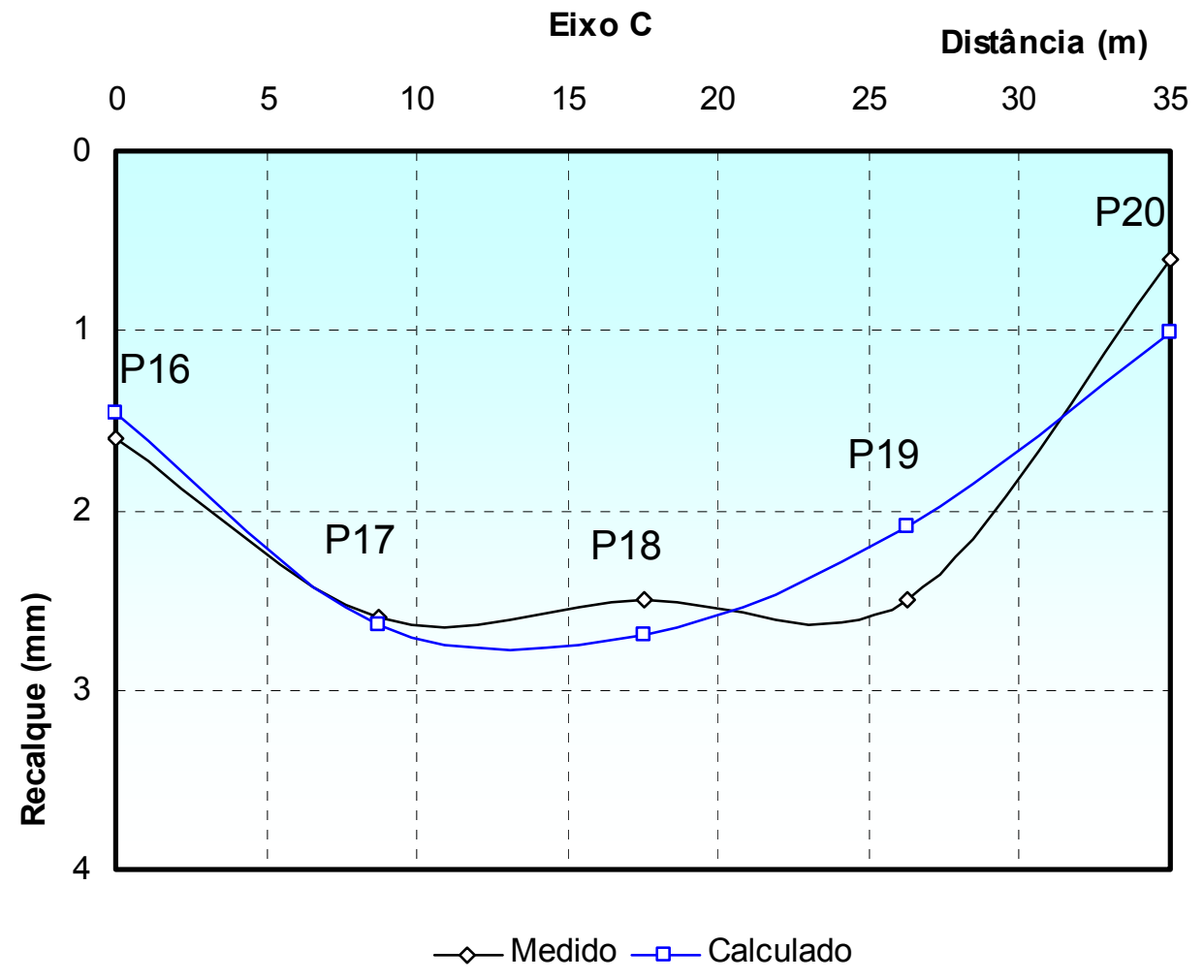

Figura 8.6 - Deformada de recalques eixo C - pilar 16 a 20.

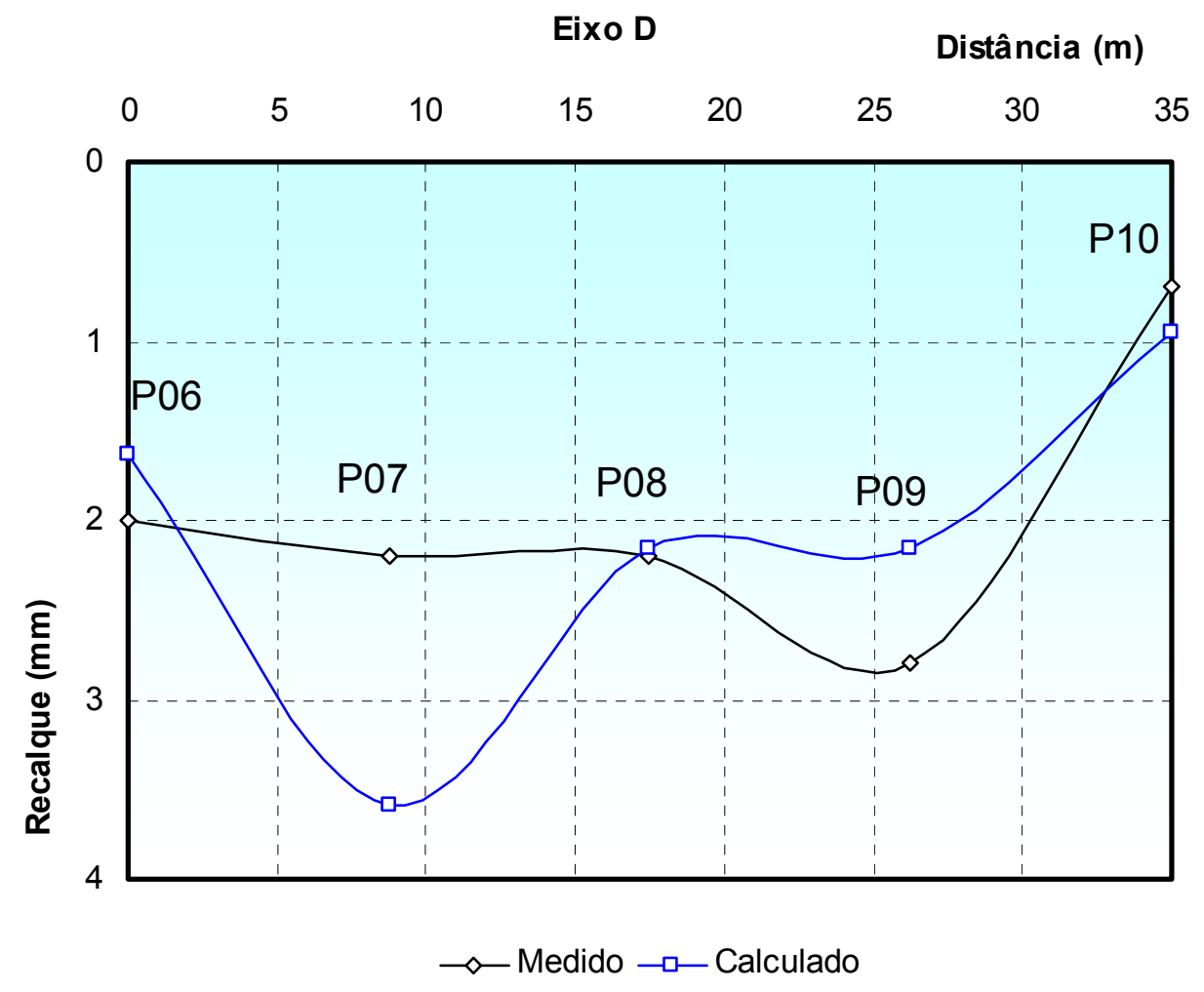

Figura 8.7 - Deformada de recalques eixo D - pilar 06 a 10. 


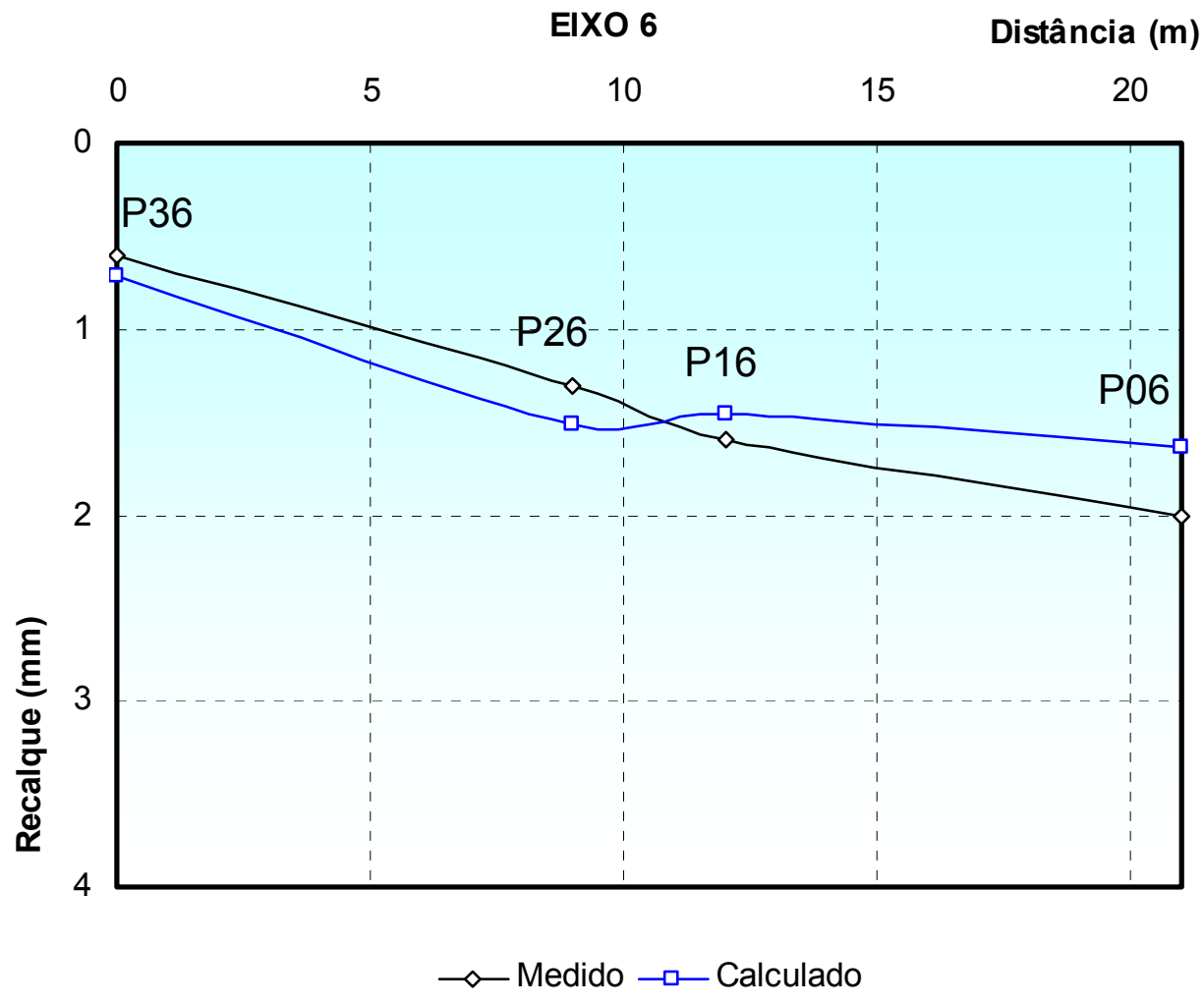

Figura 8.8-Deformada de recalques eixo 6.

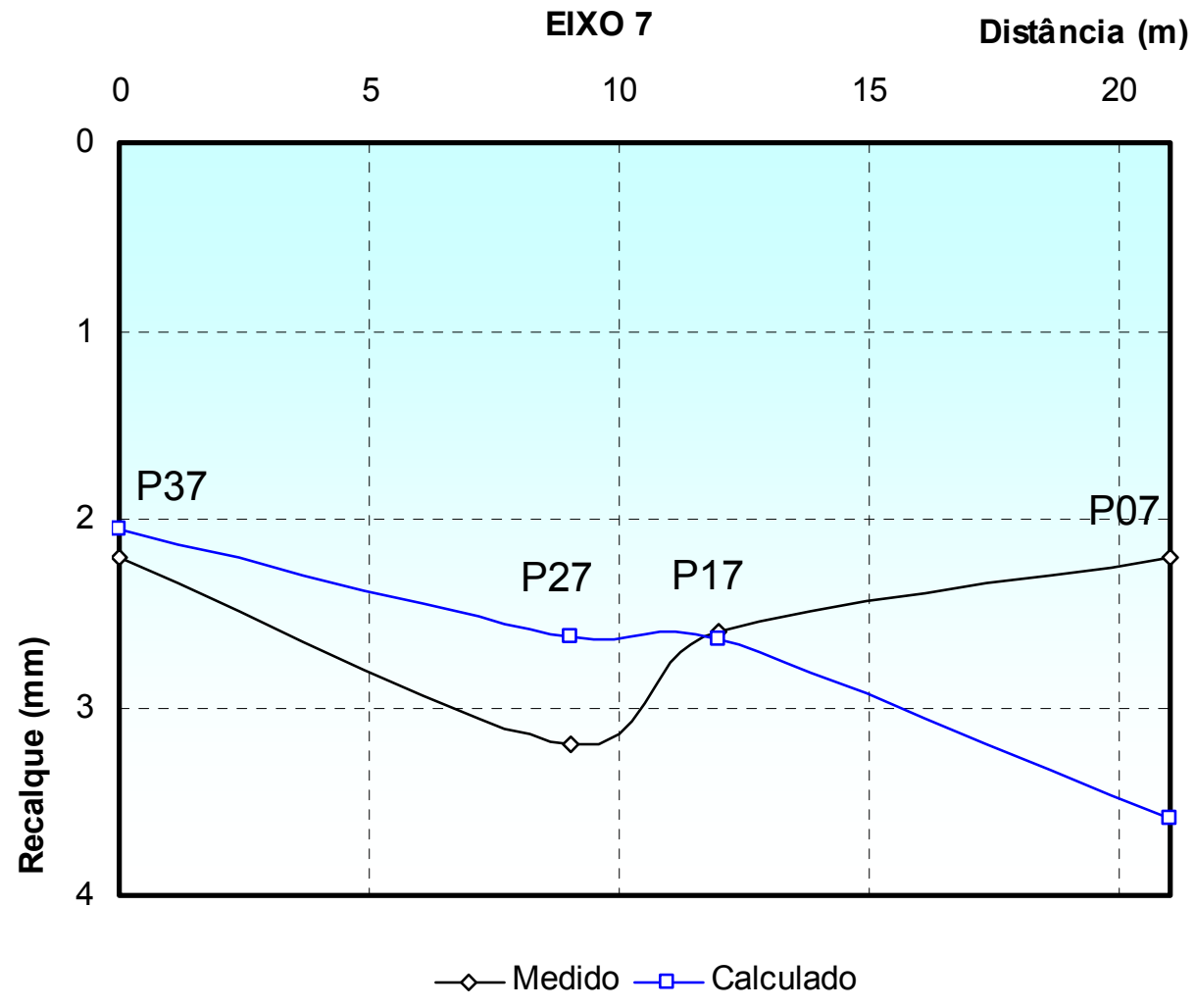

Figura 8.9 -Deformada de recalques eixo 7. 


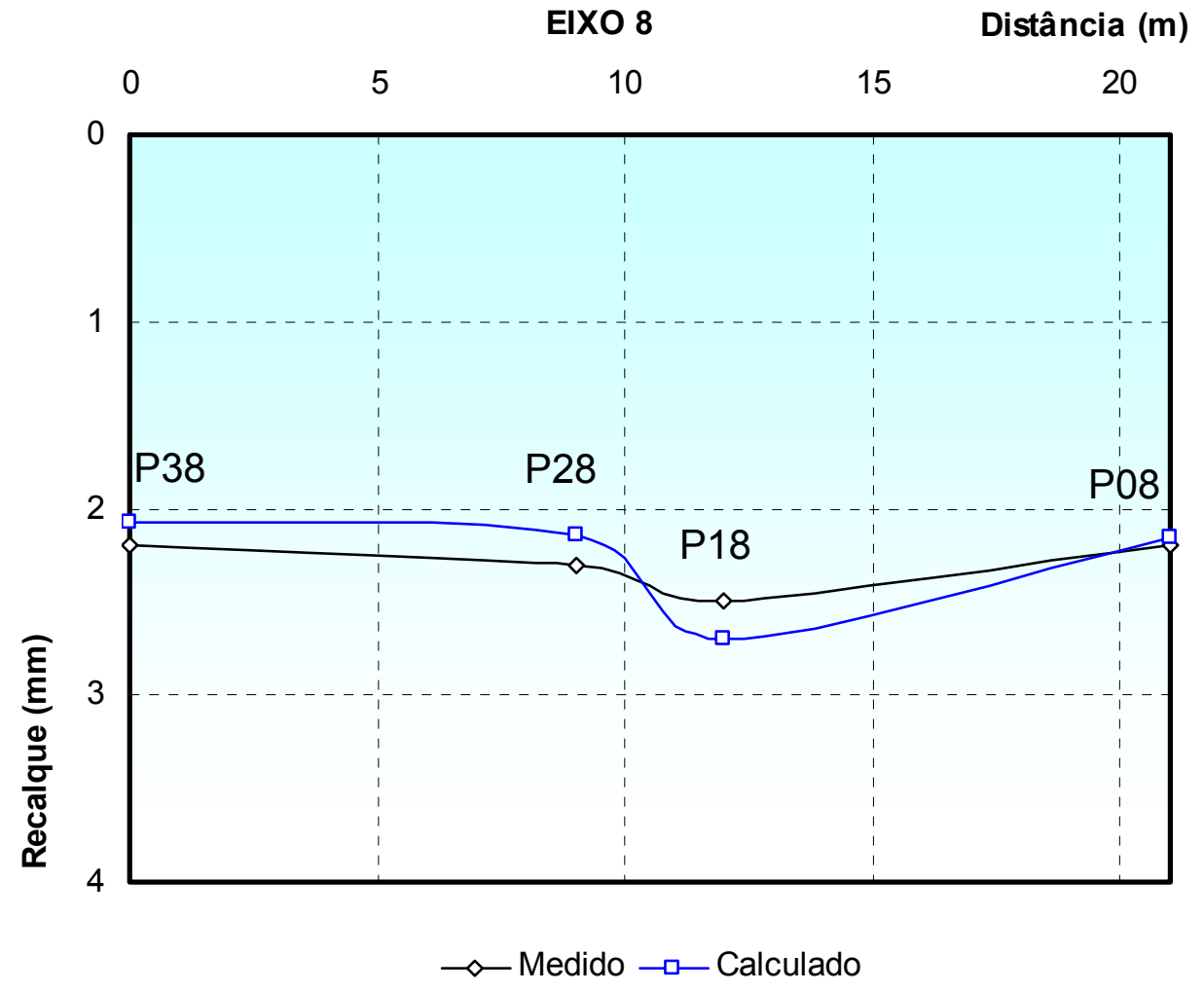

Figura 8.10 - Deformada de recalques eixo 8.

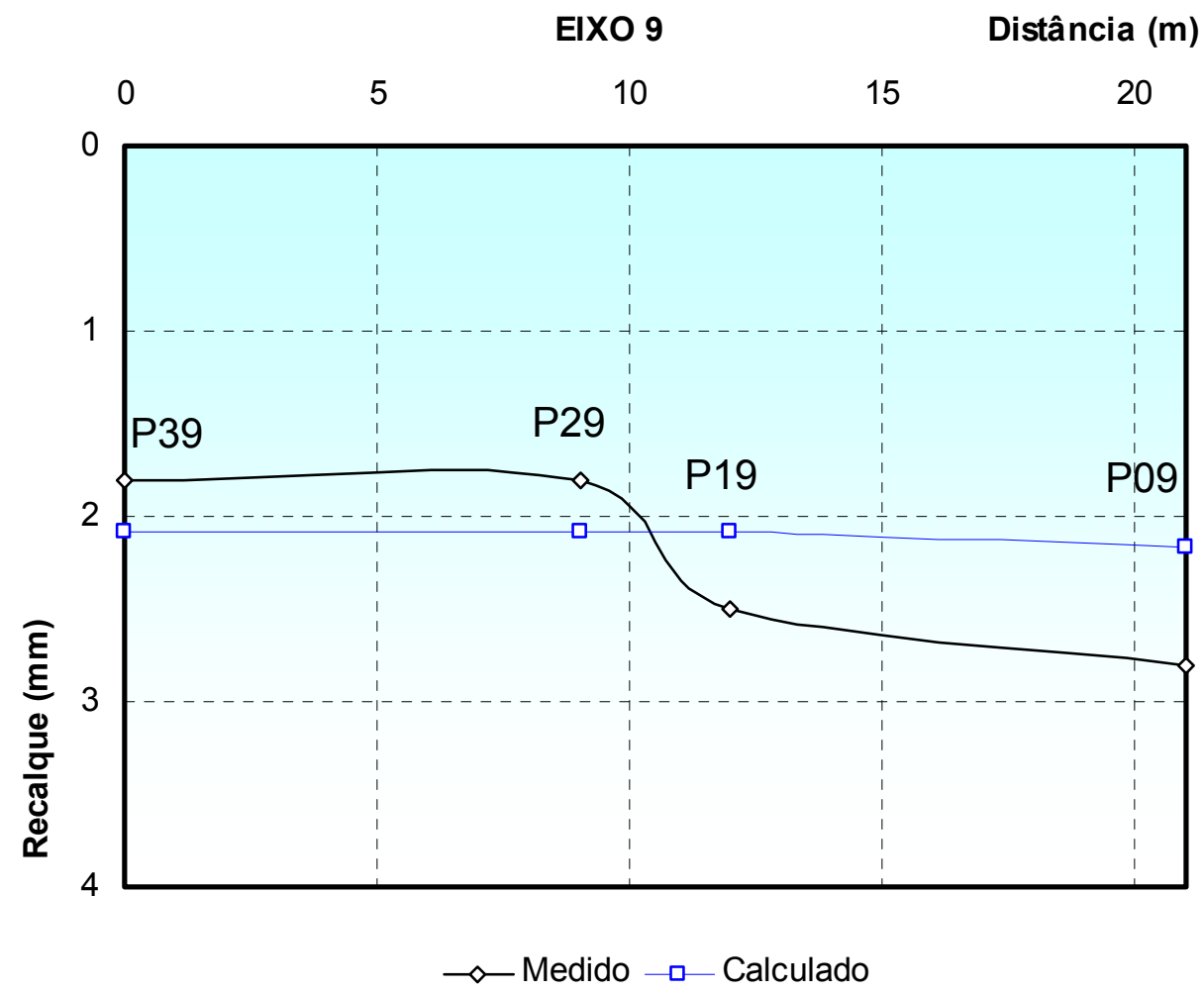

Figura 8.11-Deformada de recalques eixo 9. 


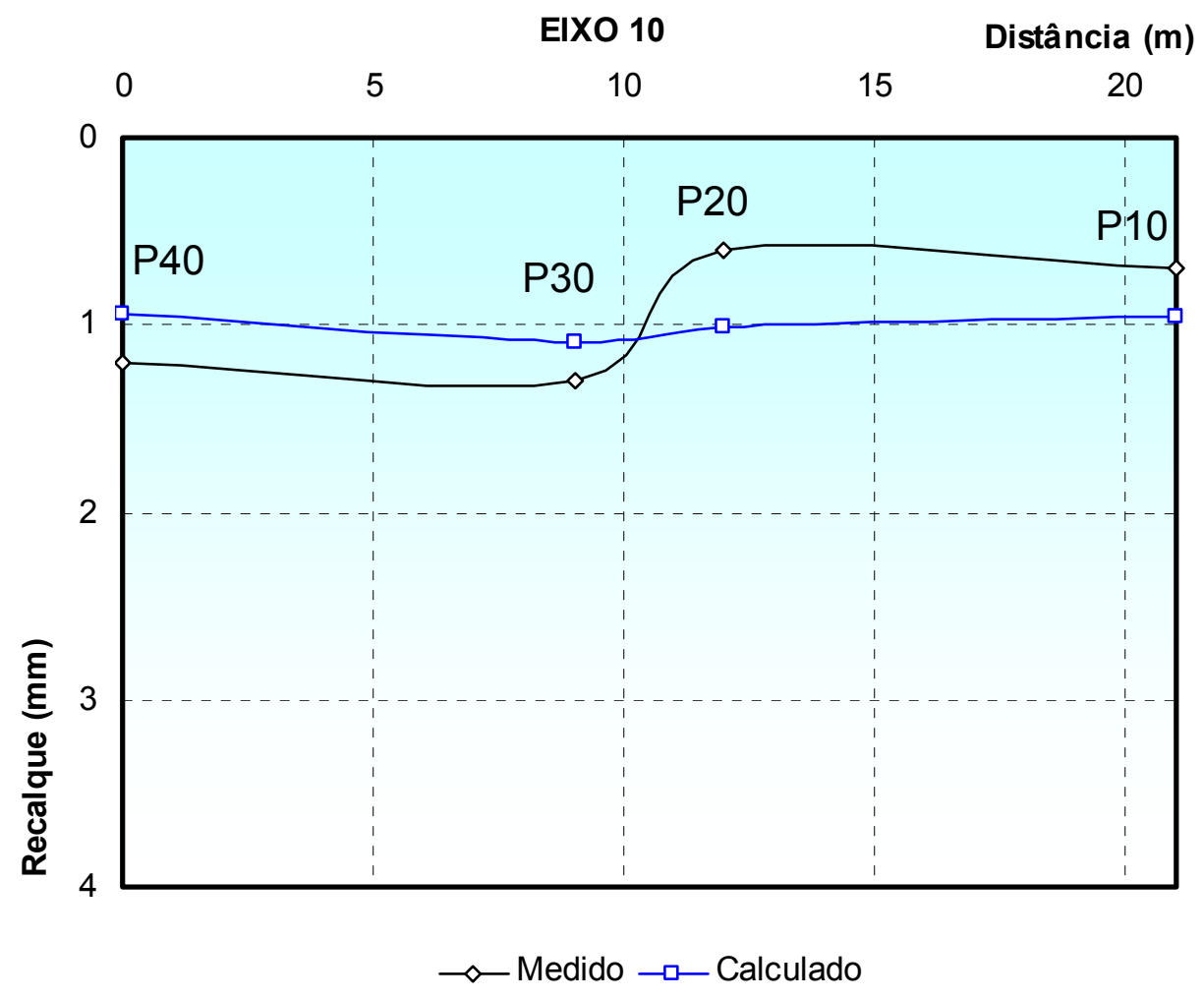

Figura 8.12 - Deformada de recalques eixo 10.

Esses resultados mostram a concordância entre os valores dos recalques resultantes da modelagem, com as medidas de campo. Destacam-se os resultados dos pilares 07 e 20 , nos quais verifica-se uma diferença mais acentuada (da ordem de 65\%), enquanto que nos pilares $17,38,28,18$ e 08 essa diferença é inferior a 10\%.

Os gráficos das Figuras 8.13 a 8.17 apresentam a variação da distribuição da solicitação normal com a profundidade, conforme resultados da análise da interação solo estrutura, nos quais se constata redistribuição de esforços entre estacas de um mesmo bloco devidos ao efeito de grupo de estacas.

Nesses gráficos, em linha tracejada preta, é apresentado o valor fornecido pelo cálculo convencional de distribuição de esforços entre estacas submetidas a carregamento exclusivamente vertical, que é uniforme em todos os elementos do bloco. Verifica-se nesses gráficos que, no caso de grupo de estacas correspondente aos pilares externos (compostos por grupo de quatro estacas), essa redistribuição é de pouca significância (pilares $06,37,38,08$, 39, 09 e 40), ao passo que para o caso de pilares centrais (eixos B e C da obra) a redistribuição é significativa. 

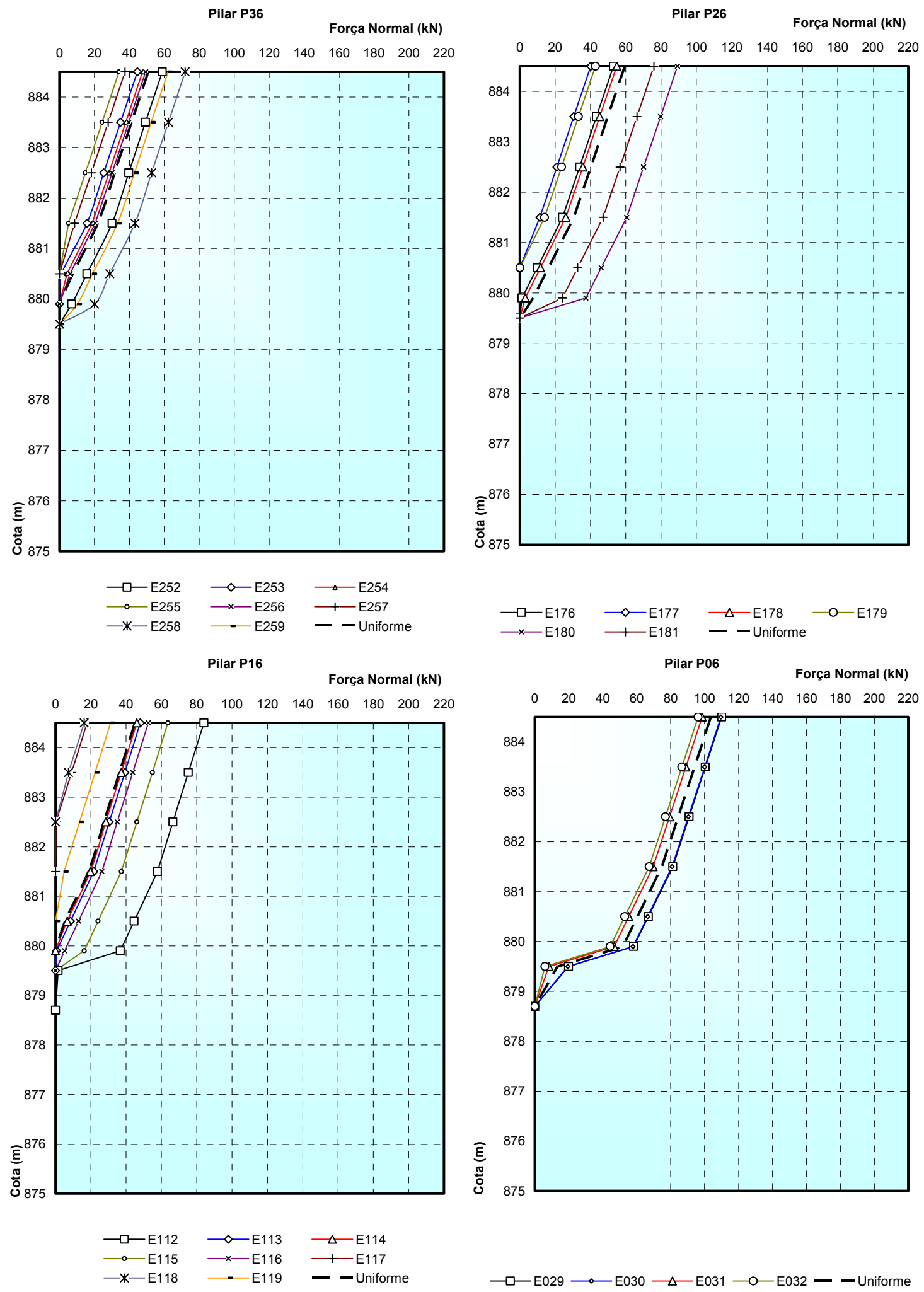

Figura 8.13 - Diagrama de solicitação normal nas estacas - pilares do eixo 6. 

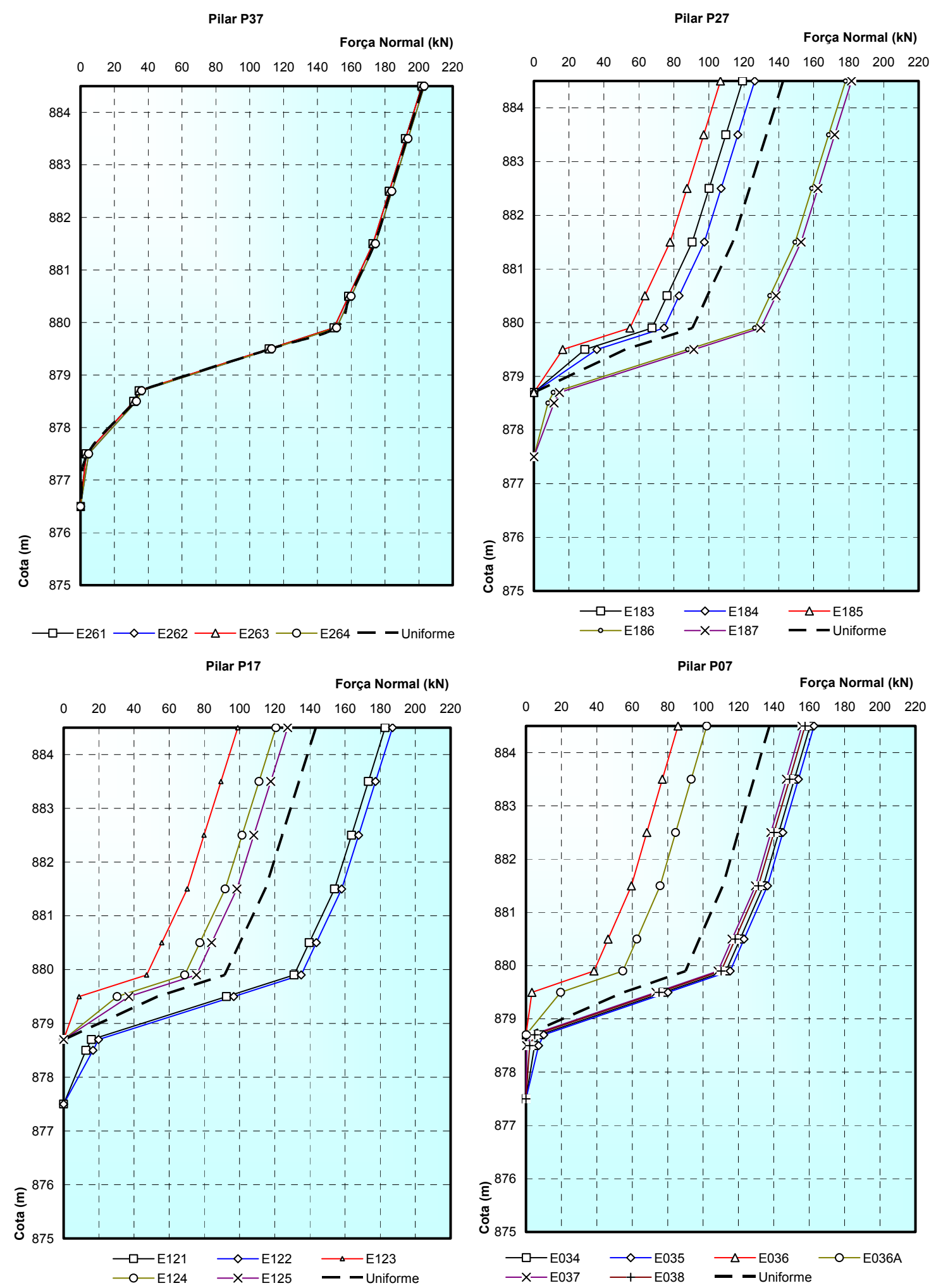

Figura 8.14 - Diagrama de solicitação normal nas estacas - pilares do eixo 7. 

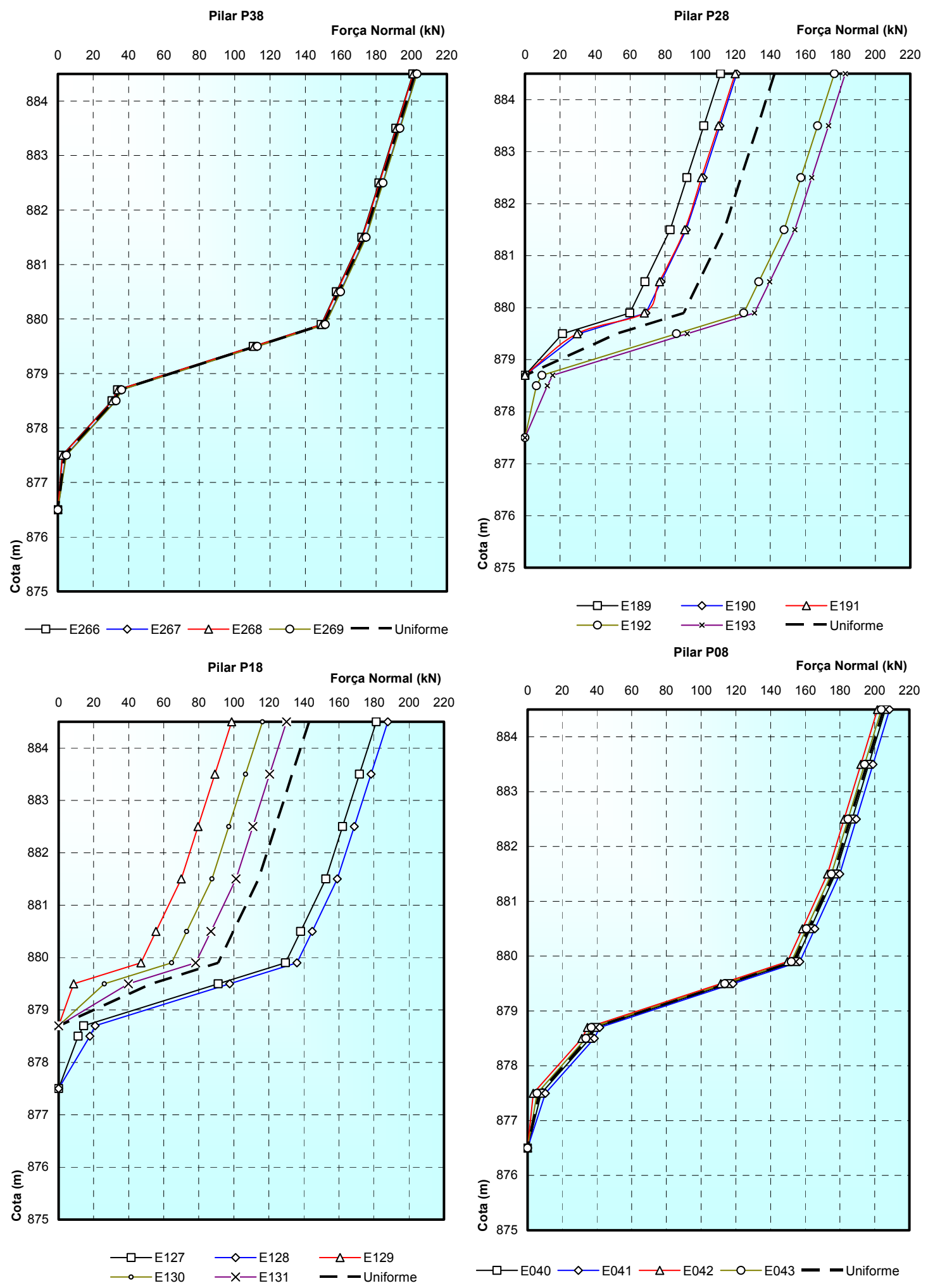

Figura 8.15 - Diagrama de solicitação normal nas estacas - pilares do eixo 8. 

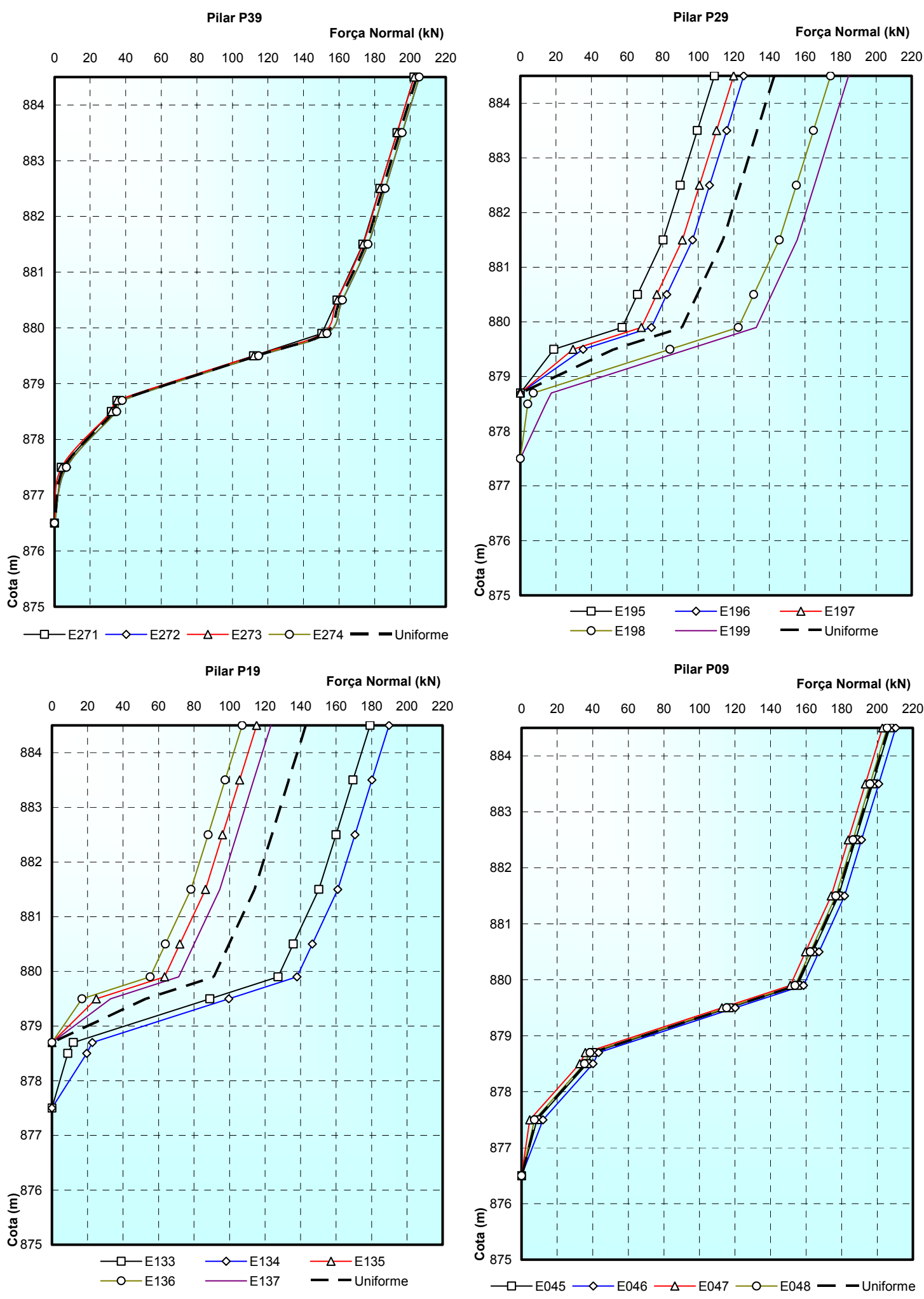

Figura 8.16 - Diagrama de solicitação normal nas estacas - pilares do eixo 9. 

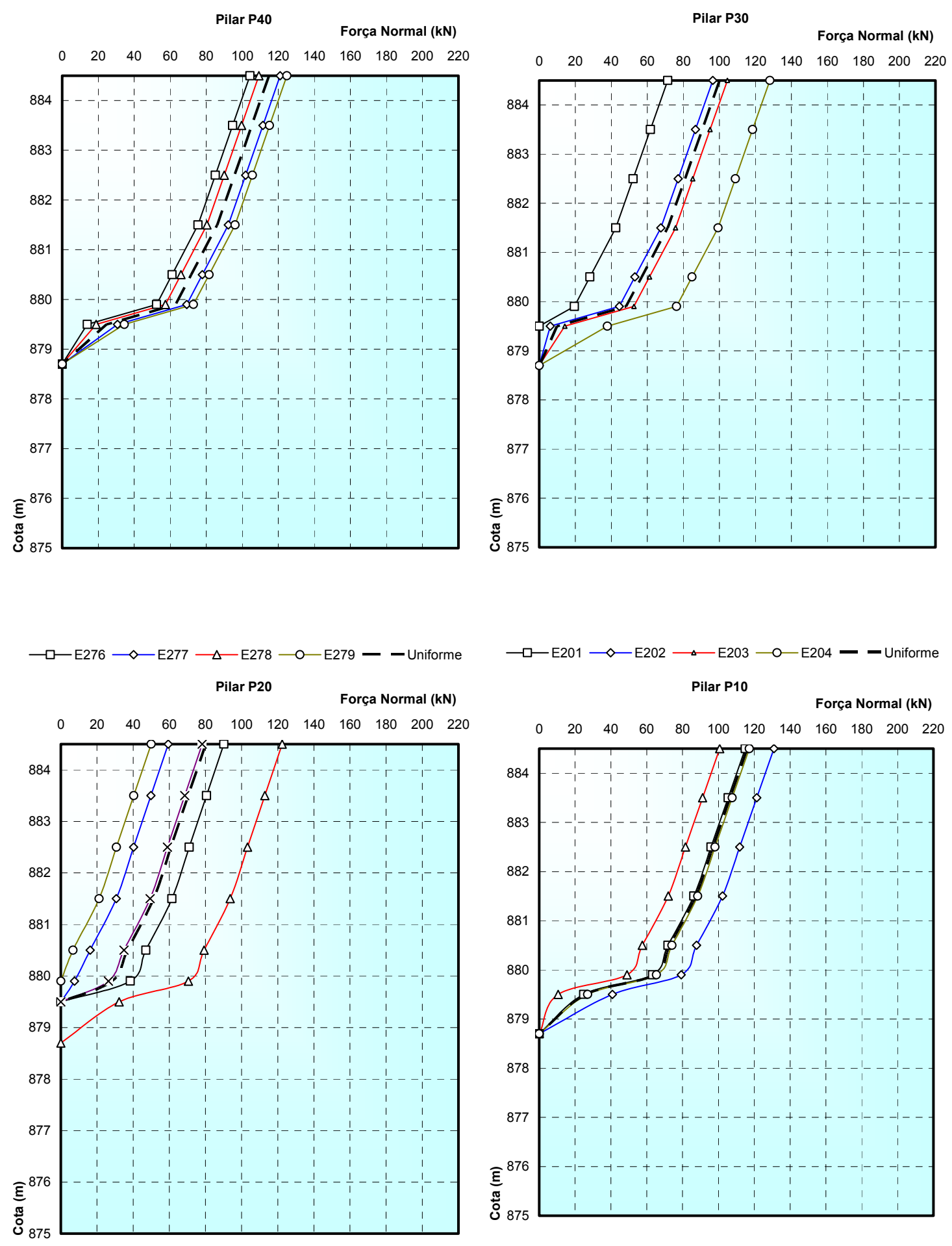

$$
\begin{array}{lll}
\longrightarrow \square-E 139 & \multimap-E 140 & \square-E 141 \\
-0-E 142 & \rightarrow x-E 143 \quad-- \text { Uniforme }
\end{array}
$$

$$
\longrightarrow \text { E050 ひ-E051 } \triangle \text { E052 O-E053 - -Uniforme }
$$

Figura 8.17 - Diagrama de solicitação normal nas estacas - pilares do eixo 10. 
Em todos os elementos envolvidos não se verifica a mobilização da resistência de ponta para o nível de solicitação dessa análise.

De forma a quantificar o efeito de grupo, foi avaliado o fator de recalque $\left(R_{\mathrm{s}}\right)$ para as estacas dos pilares dos eixos 7 e 8 . A etapa (6) do processo iterativo anteriormente descrito (determinação do deslocamento da ponta da estaca pelo programa SOILDEF 3.0) foi novamente repetida, considerando agora o efeito de cada estaca isoladamente. Ao valor determinado pelo programa, foi acrescido o encurtamento elástico correspondente. $\mathrm{O}$ deslocamento do topo determinado para as duas condições (grupo e isolada) e do fator de recalque $\left(R_{s}\right)$ correspondente, são apresentados na tabela 8.6.

Tabela 8.6 - Efeito de grupo - fator de recalque $\left(R_{s}\right)$, eixos 7 e 8.

\begin{tabular}{|c|c|c|c|c|c|c|c|c|c|}
\hline Pilar & Estaca & $\begin{array}{c}\delta_{\mathrm{g}} \\
(\mathrm{mm})\end{array}$ & $\begin{array}{c}\delta_{\mathrm{i}} \\
(\mathrm{mm})\end{array}$ & $\mathrm{R}_{\mathrm{s}}$ & Pilar & Estaca & $\begin{array}{c}\delta_{\mathrm{g}} \\
(\mathrm{mm})\end{array}$ & $\begin{array}{c}\delta_{\mathrm{i}} \\
(\mathrm{mm})\end{array}$ & $\mathrm{R}_{\mathrm{s}}$ \\
\hline \multirow{6}{*}{ P07 } & E034 & 3,56 & 1,28 & 2,8 & \multirow{6}{*}{$P$} & E121 & 2,62 & 0,84 & 3,1 \\
\hline & E035 & 3,56 & 1,37 & 2,6 & & E122 & 2,61 & 0,89 & 2,9 \\
\hline & E036 & 3,57 & 0,42 & 8,4 & & E123 & 2,64 & 0,32 & 8,3 \\
\hline & E036A & 3,56 & 0,58 & 6,2 & & E124 & 2,62 & 0,43 & 6,1 \\
\hline & E037 & 3,56 & 1,11 & 3,2 & & E125 & 2,62 & 0,47 & 5,6 \\
\hline & 038 & 3,56 & 1,18 & 3,0 & & & & & \\
\hline Média & & & & 4,5 & & & & & 5,2 \\
\hline
\end{tabular}

\begin{tabular}{|c|c|c|c|c|c|c|c|c|c|}
\hline Pilar & Estaca & $\begin{array}{c}\delta_{\mathrm{g}} \\
(\mathrm{mm})\end{array}$ & $\begin{array}{c}\delta_{\mathrm{i}} \\
(\mathrm{mm})\end{array}$ & $\mathrm{R}_{\mathrm{s}}$ & Pilar & Estaca & $\begin{array}{c}\delta_{\mathrm{g}} \\
(\mathrm{mm})\end{array}$ & $\begin{array}{c}\delta_{\mathrm{i}} \\
(\mathrm{mm})\end{array}$ & $\mathrm{R}_{\mathrm{s}}$ \\
\hline \multirow{5}{*}{ P27 } & E183 & 2,61 & 0,43 & 6,1 & & E261 & 2,02 & 0,84 & 2,41 \\
\hline & E184 & 2,61 & 0,46 & 5,7 & \multirow{4}{*}{ P37 } & E262 & 2,02 & 0,87 & 2,32 \\
\hline & E185 & 2,63 & 0,36 & 7,3 & & E263 & 2,02 & 0,84 & 2,41 \\
\hline & E186 & 2,60 & 0,79 & 3,3 & & E264 & 2,02 & 0,87 & 2,32 \\
\hline & E187 & 2,60 & 0,83 & 3,1 & & & & & \\
\hline Médi & & & & 5,1 & & & & & 2,4 \\
\hline
\end{tabular}

\begin{tabular}{llllllllll}
\hline Pilar & Estaca & $\begin{array}{l}\delta_{\mathrm{g}} \\
(\mathrm{mm})\end{array}$ & $\begin{array}{l}\delta_{\mathrm{i}} \\
(\mathrm{mm})\end{array}$ & $\mathrm{R}_{\mathrm{s}}$ & Pilar Estaca & $\begin{array}{l}\delta_{\mathrm{g}} \\
(\mathrm{mm})\end{array}$ & $\begin{array}{l}\delta_{\mathrm{i}} \\
(\mathrm{mm})\end{array}$ & $\mathrm{R}_{\mathrm{s}}$ \\
\hline \multirow{6}{*}{ P08 } & $\mathrm{E} 040$ & 2,13 & 0,94 & 2,3 & & $\mathrm{E} 127$ & 2,66 & 0,82 & 3,2 \\
& $\mathrm{E} 041$ & 2,13 & 0,99 & 2,2 & $\mathrm{E} 128$ & 2,66 & 0,90 & 3,0 \\
& $\mathrm{E} 042$ & 2,13 & 0,84 & 2,6 & $\mathrm{P} 18$ & $\mathrm{E} 129$ & 2,69 & 0,32 & 8,5 \\
& $\mathrm{E} 043$ & 2,13 & 0,89 & 2,4 & & $\mathrm{E} 130$ & 2,67 & 0,41 & 6,5 \\
& & & & & & $\mathrm{E} 131$ & 2,67 & 0,48 & 5,5 \\
\hline Média & & \multicolumn{3}{c}{2,3} & & & & 5,3 \\
\hline
\end{tabular}




\begin{tabular}{|c|c|c|c|c|c|c|c|c|c|}
\hline Pilar & Estaca & $\begin{array}{c}\delta_{\mathrm{g}} \\
(\mathrm{mm})\end{array}$ & $\begin{array}{c}\delta_{\mathrm{i}} \\
(\mathrm{mm})\end{array}$ & $\mathrm{R}_{\mathrm{s}}$ & Pilar & Estaca & $\begin{array}{c}\delta_{\mathrm{g}} \\
(\mathrm{mm})\end{array}$ & $\begin{array}{c}\delta_{\mathrm{i}} \\
(\mathrm{mm})\end{array}$ & $\mathrm{R}_{\mathrm{s}}$ \\
\hline & E189 & 1,99 & 0,32 & 6,7 & & E266 & 2,04 & 0,82 & 2,5 \\
\hline & $\mathrm{E}$ & 1,97 & 0,35 & 6,0 & & $E$ & 2,04 & 0,87 & 2 \\
\hline \multirow[t]{3}{*}{ P28 } & E1s & 1,99 & 0 & 6,1 & P38 & E2 & 2,04 & 0,82 & 2,5 \\
\hline & $E$ & 1,8 & 0,61 & 3,5 & & E269 & 2,04 & 0,87 & 2,4 \\
\hline & $\mathrm{E}$ & 1,85 & 0,65 & 3,2 & & & & & \\
\hline éd & & & & 5,1 & & & & & 2,4 \\
\hline
\end{tabular}

Os valores acima indicam, que para as estacas do pilares centrais (P17, $\mathrm{P} 27, \mathrm{P} 18$ e P28) o fator de recalque é superior a 5 , enquanto que os pilares externos (P37, P08 e P38) esse fator é reduzido à metade, excetuando-se o caso do pilar externo (P07) o qual é formado por grupo de 6 estacas. Verificase um efeito marcante de grupo de estacas de grupo de pilares, onde os elementos do centro da obra devido à sua proximidade apresentam um maior fator de recalque.

Assim sendo, o nível de deformação imposto pelo conjunto de estacas pode ser, em termos médios, cinco vezes ao de uma estaca isolada e portanto, a extrapolação do comportamento de uma estaca isolada (caso de prova de carga estática) para o comportamento da fundação irá conduzir a erro considerável.

O erro decorrente dessa extrapolação deverá ser ainda maior, pois a relação tensão deformação esperada para esse nível de deformação deve ser não linear, implicando em um menor módulo de deformabilidade para o caso do grupo que para a estaca isolada.

A Figura 8.18 pretende propiciar uma visualização da distribuição da solicitação normal no topo das estacas, conforme determinado pela análise de interação solo estrutura, a qual mostra um baixo nível de tensão (média igual a 1,05 MPa) e diferentes solicitações em estacas de um mesmo grupo. A posição de cada estaca encontra-se indicada na figura por meio de marcadores quadrados.

Como decorrência dessa distribuição, os coeficientes de mola para cada estaca são distintos. A Figura 8.19 apresenta curvas de igual coeficiente de mola, sendo esses variáveis entre $139.441 \mathrm{KN} / \mathrm{m}$ (estaca 051 do pilar 10) e $10.996 \mathrm{kN} / \mathrm{m}$ (estaca 118 do pilar 16), tendo valor central de $71.881 \mathrm{kN} / \mathrm{m}$ e 
coeficiente de variação igual a $41 \%$. Essa variabilidade é devida, em parte, à geotecnia do local e em parte ao sistema envolvido.

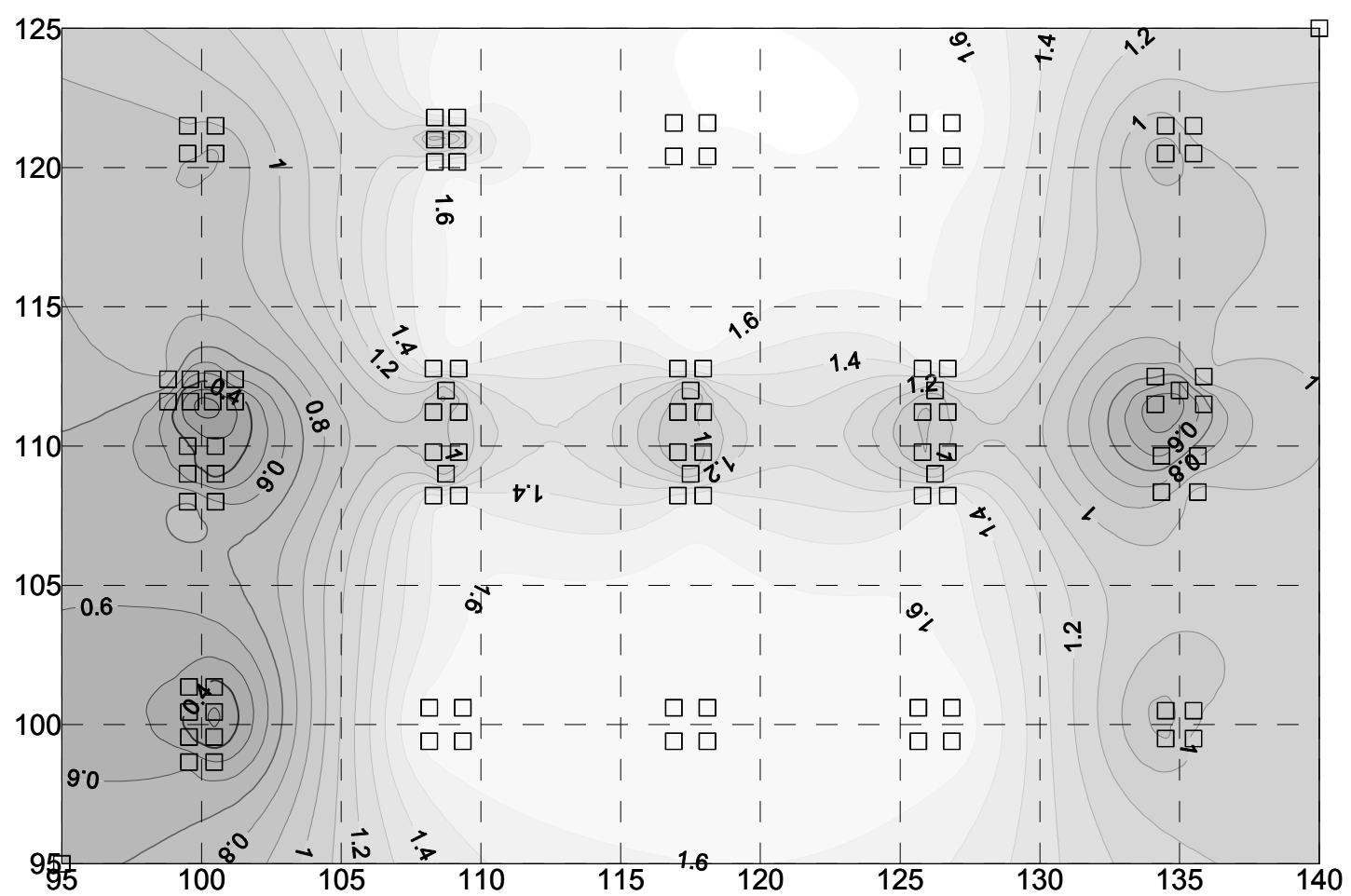

Figura 8.18 - Curvas de igual solicitação no topo das estacas (valores em MPa).

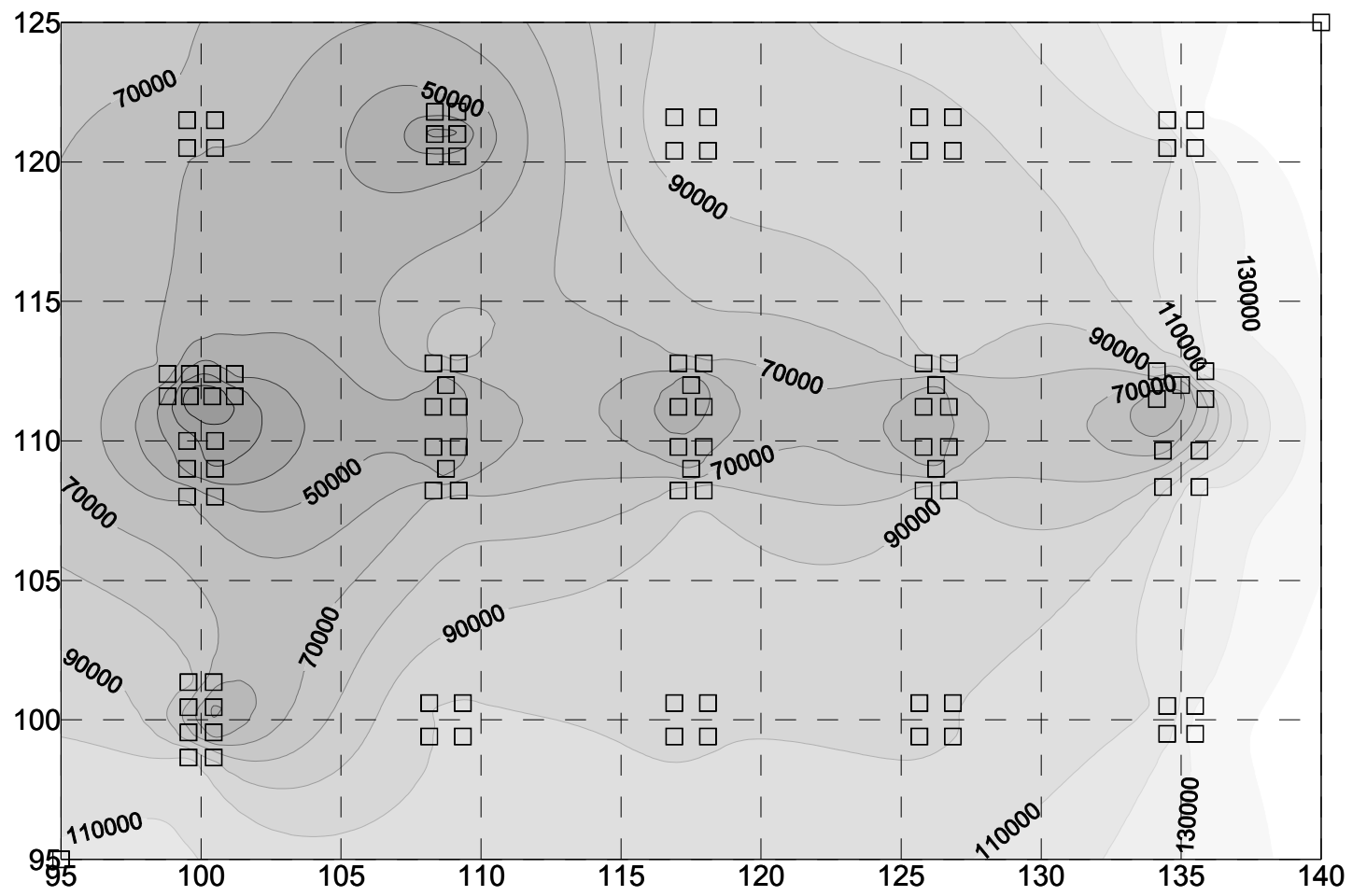

Figura 8.19 - Curvas de igual coeficiente de mola (valores em kN/m). 
Tendo em vista as informações disponíveis, conhecimento de carga e recalques dos pilares e definição da deformabilidade do maciço de solo, analisa-se a seguir o nível de solicitação do maciço de solo das camadas imediatamente acima e abaixo da ponta das estacas, especificamente o estrato silto-arenoso de solo residual, o qual, em linhas gerais, situa-se entre as profundidades de 5 a $11 \mathrm{~m}$.

Para realização dessa análise também foi utilizado o programa SOILDEF 3.0 para determinar o deslocamento do maciço de solo em 150 pontos, distribuídos em planta e nas profundidades de 5 a $11 \mathrm{~m}$ tomados a cada metro. Assim sendo, com as condições finais determinadas pela retroanálise $A$ (deformabilidade do solo e distribuição da solicitação normal ao longo das 99 estacas), calculou-se o deslocamento em cada um dos pontos $\left(\delta_{z i}\right)$ nas diferentes profundidades selecionadas.

A deformação média do maciço $\left(\varepsilon_{z i}\right)$ entre duas profundidades consecutivas de uma mesma vertical pode ser, então, calculada pela expressão a seguir, que permite avaliar o nível de deformação do maciço para as condições específicas do presente estudo:

$$
\varepsilon_{z i}=\frac{\delta_{z i+1}-\delta_{z i}}{1 \text { metro }}
$$

As Figuras 8.20 a 8.23 apresentam curvas de igual deformação específica (valores em $\mathrm{m} \varepsilon$ ) nas profundidades médias entre as profundidades selecionadas.

Uma outra forma de visualizar o nível de deformação do maciço é dada nas Figuras 8.24 a 8.27, as quais apresentam, para os eixos A, B, C e D da obra, curvas de igual deformação ao longo da profundidade. 


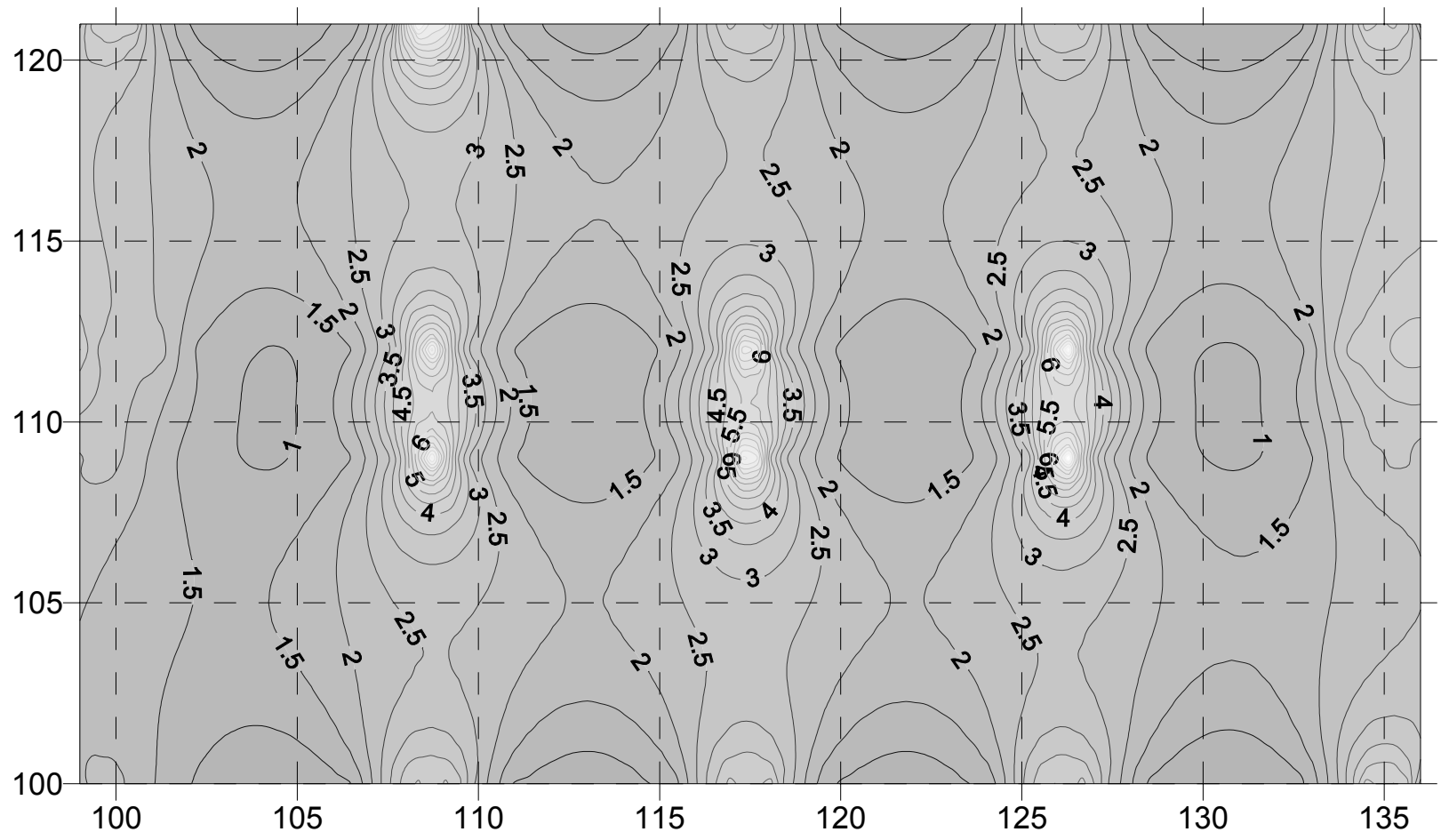

Figura 8.20 - Curvas de igual deformação - profundidade 5,5 $\mathrm{m}$ (valores em $\mathrm{m \varepsilon}$ ).

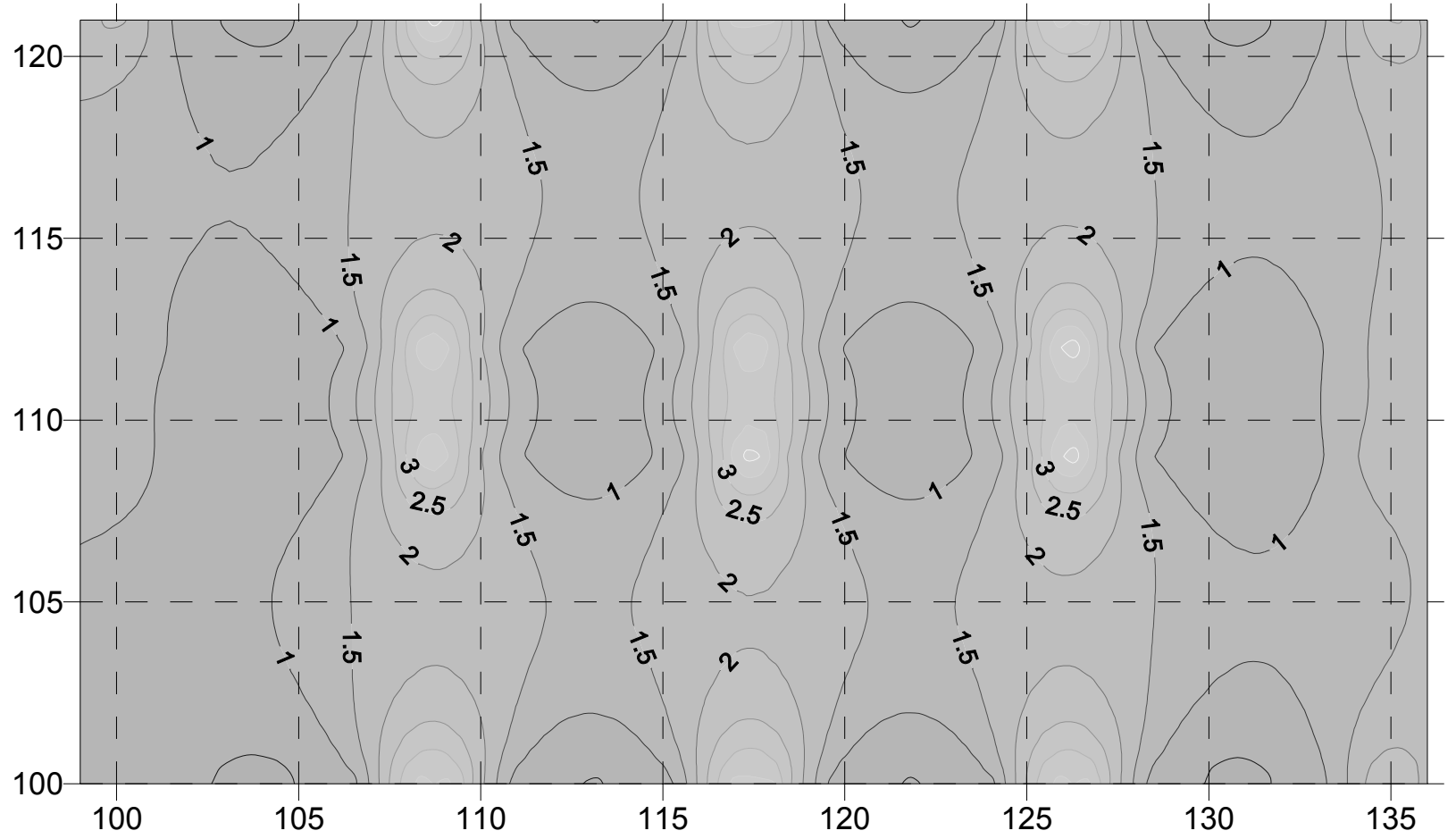

Figura 8.21 - Curvas de igual deformação - profundidade 6,5 $\mathrm{m}$ (valores em $\mathrm{m \varepsilon}$ ). 


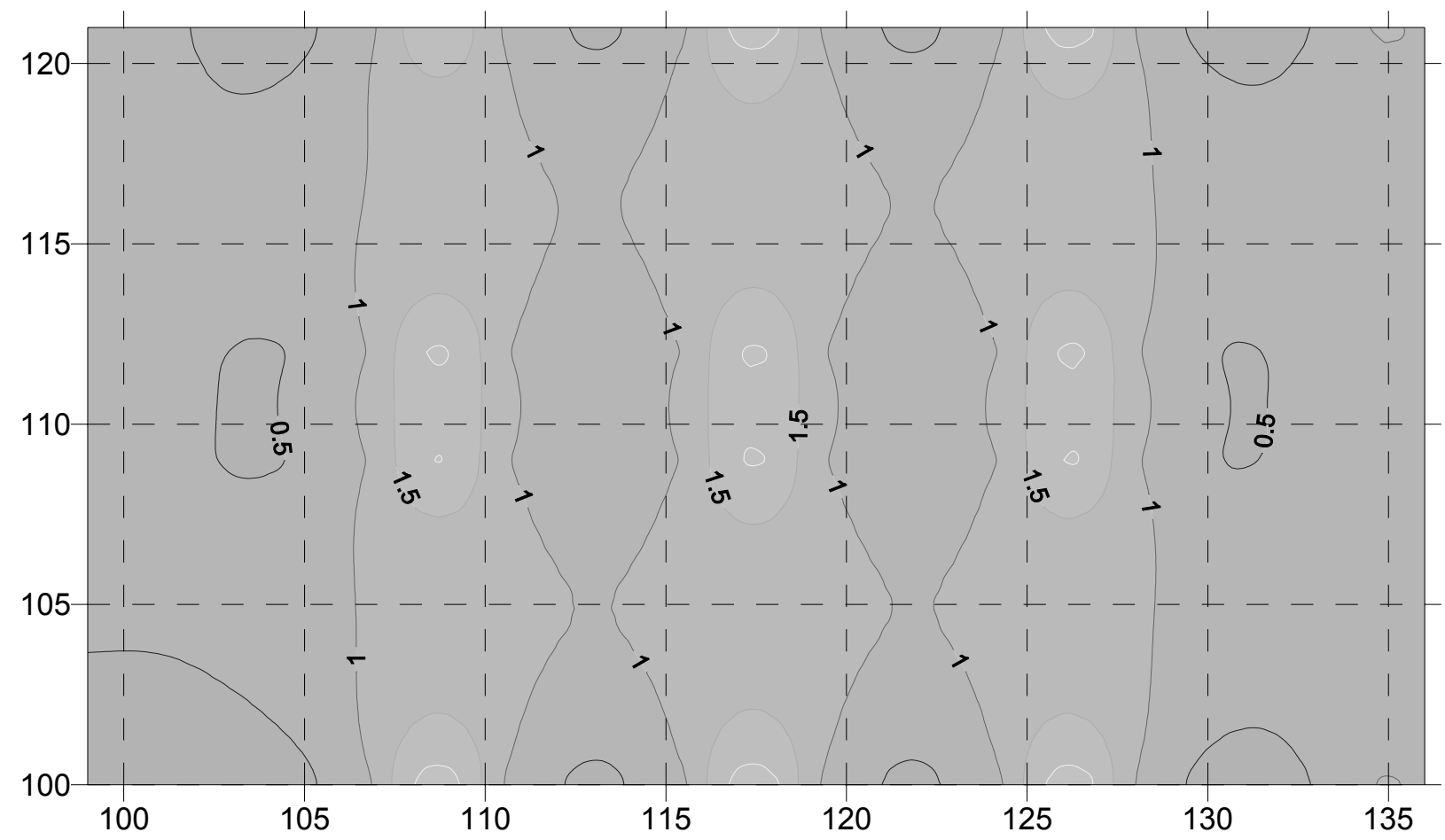

Figura 8.22 - Curvas de igual deformação - profundidade 7,5 $\mathrm{m}$ (valores em me).

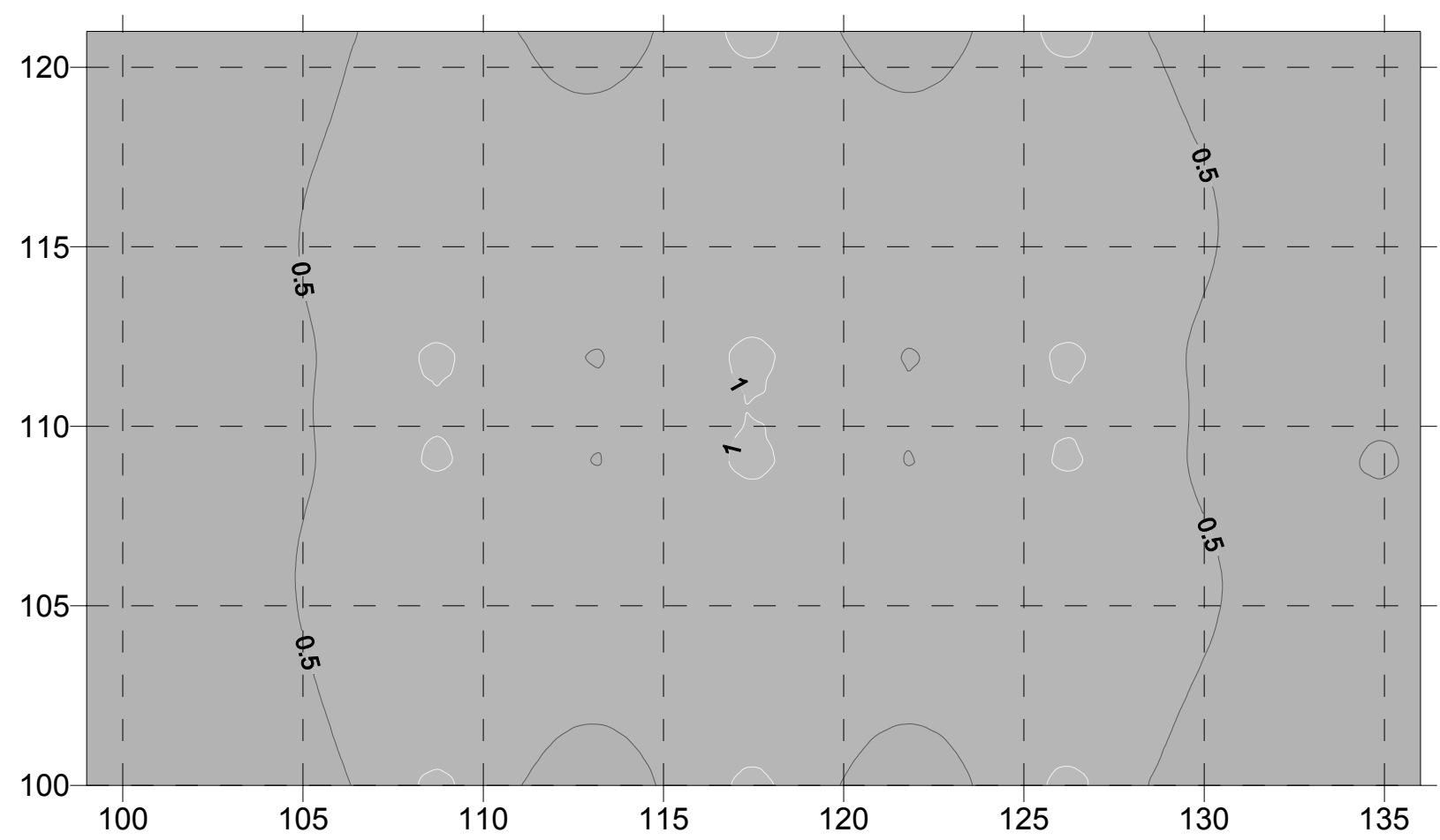

Figura 8.23 - Curvas de igual deformação - profundidade $8,5 \mathrm{~m}$ (valores em $\mathrm{m \varepsilon}$ ). 


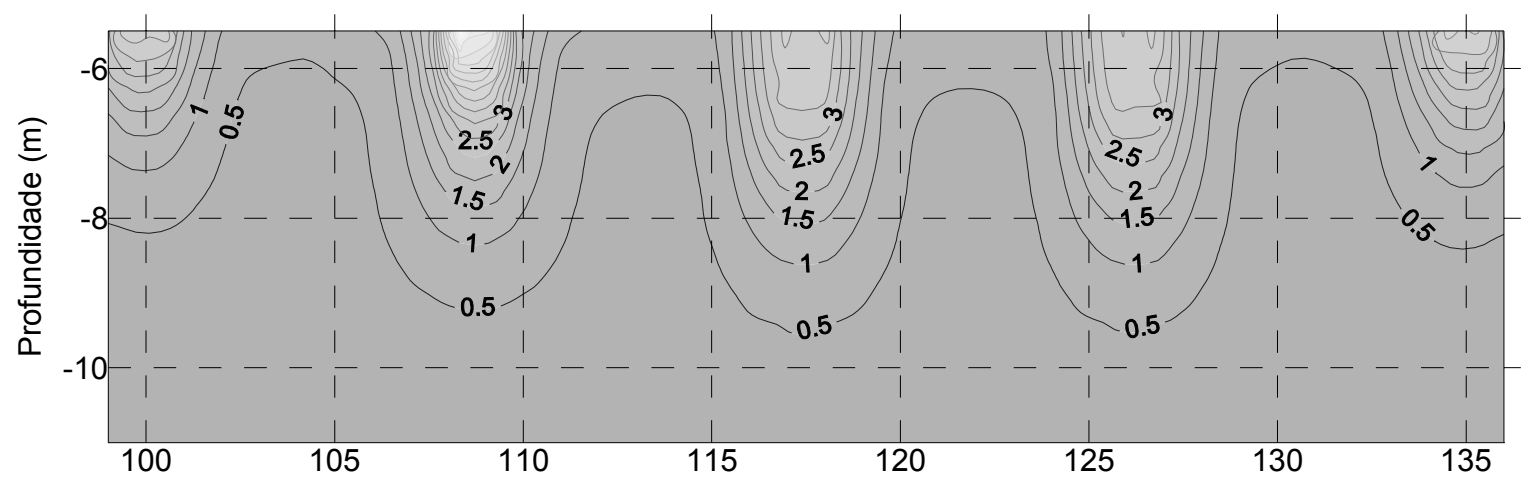

Figura 8.24 - Curvas de igual deformação - eixo A (valores em $m \varepsilon$ ).

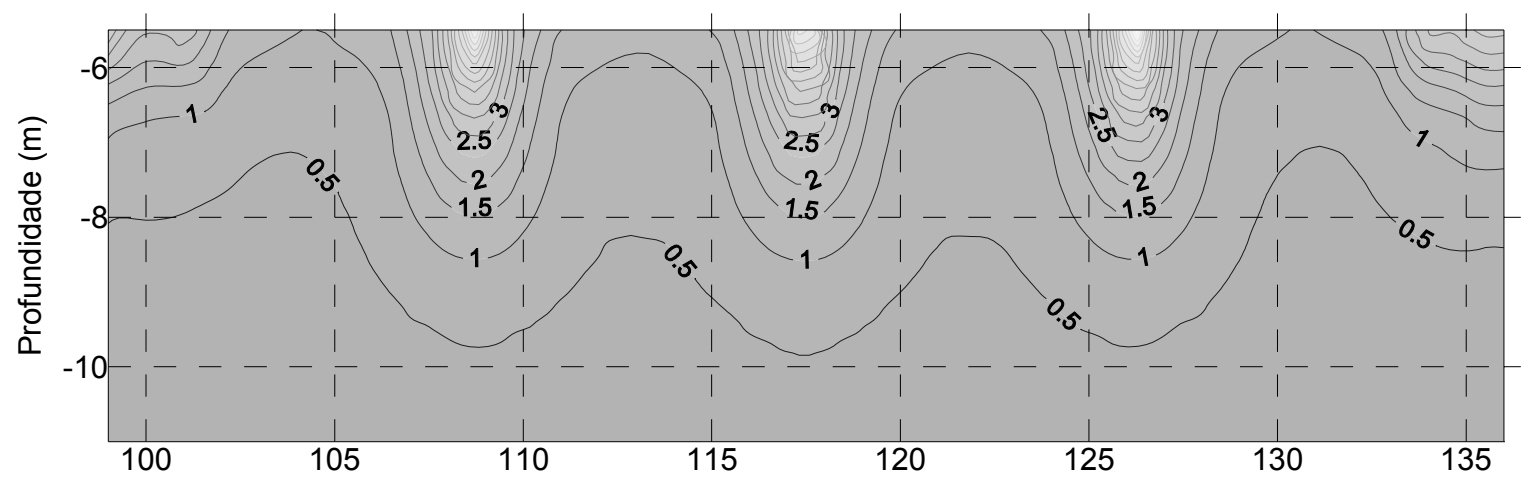

Figura 8.25 - Curvas de igual deformação - eixo B (valores em $m \varepsilon$ ).

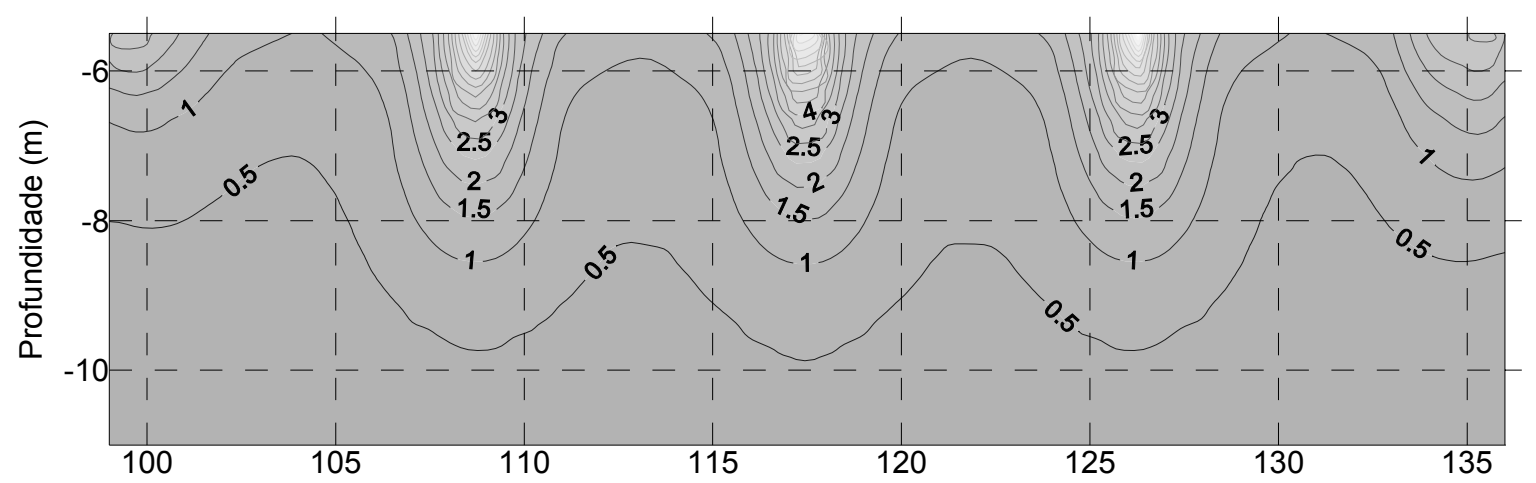

Figura 8.26 - Curvas de igual deformação - eixo C (valores em me).

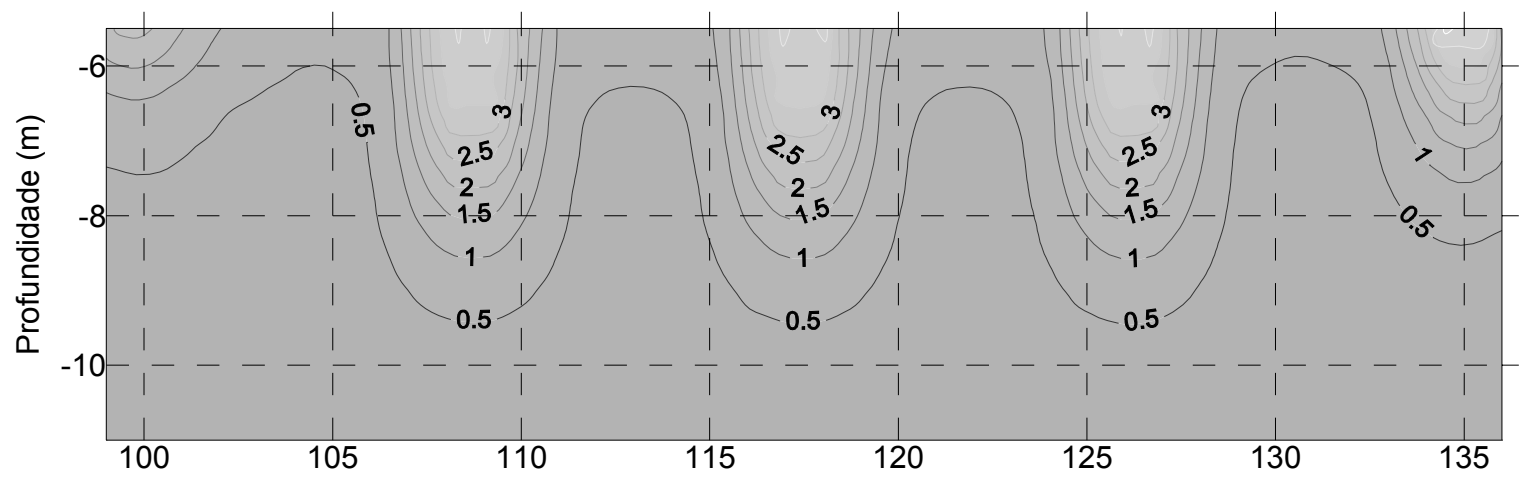

Figura 8.27 - Curvas de igual deformação - eixo $D$ (valores em $\mathrm{m} \varepsilon$ ). 
Verifica-se nessas representações gráficas que as deformações na região da ponta das estacas (profundidades entre 7 e $8 \mathrm{~m}$ ) apresentam um valor máximo da ordem de $3 \mathrm{m \varepsilon}$ ou 0,3\%. Correa et al. (2004) apresentam tabela, a qual é reproduzida a seguir, na qual são apresentados aspectos importantes relacionados com o nível de deformação. Uma seta vermelha indica o nível de deformação máximo determinado no presente estudo, na região da ponta das estacas.

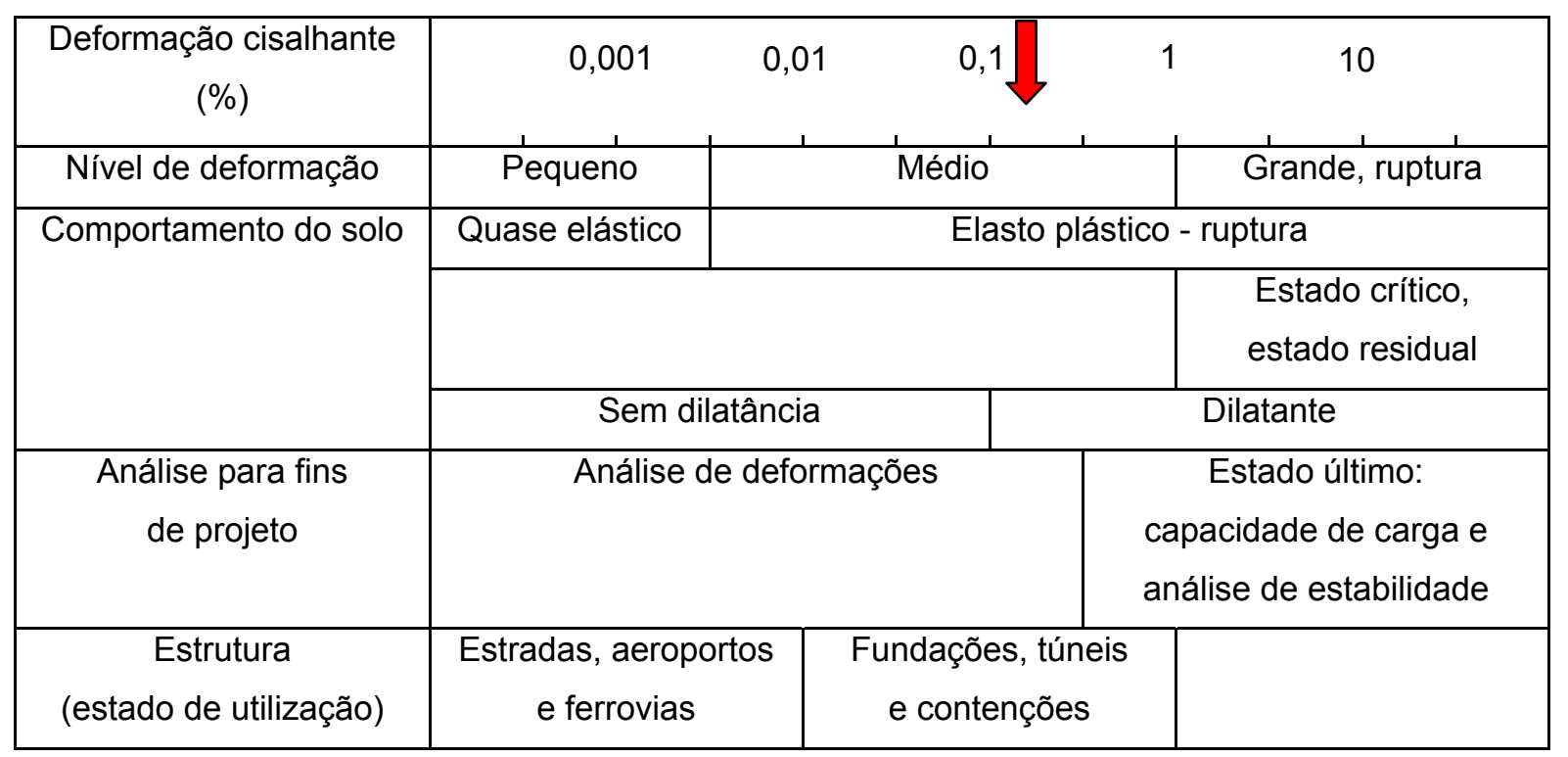

Tabela 8.7 - Aspectos importantes relacionados com o nível de deformação, in Correa et al. (2004).

Segundo essa classificação, as deformações na região da ponta das estacas não podem ser consideradas pequenas e são classificadas de médias, muito embora os recalques medidos sejam pequenos. O comportamento esperado para o solo é elasto-plástico, não dilatante. $O$ autor antecipadamente previa esse comportamento para o caso de fundações sob condições de utilização.

Uma vez conhecido o estado de deformação do maciço, os acréscimos de tensão $\left(\sigma_{z i}\right)$, promovidos pela etapa da obra de que trata esse trabalho, pode então ser determinado, aplicando-se Lei de Hooke dada pela expressão:

$$
\sigma_{z i}=E_{s z i} \times \varepsilon_{z i}
$$


As figuras 8.28 a 8.36 tratam, de modo similar ao anteriormente realizado, da distribuição desses acréscimos de tensão no maciço de solo. Os valores indicados nessas representações são expressos em kPa.

Esse conjunto de gráficos permite verificar que o nível de tensões ou de deformações no solo imediatamente abaixo da ponta das estacas é de pequena magnitude, valor máximo da ordem de $10 \mathrm{kPa}$.

Também é possível nitidamente visualizar nessas figuras o efeito de grupo de estacas, sendo a posição delas omitidas nas representações, de modo a tornar a visualização mais clara ao leitor.

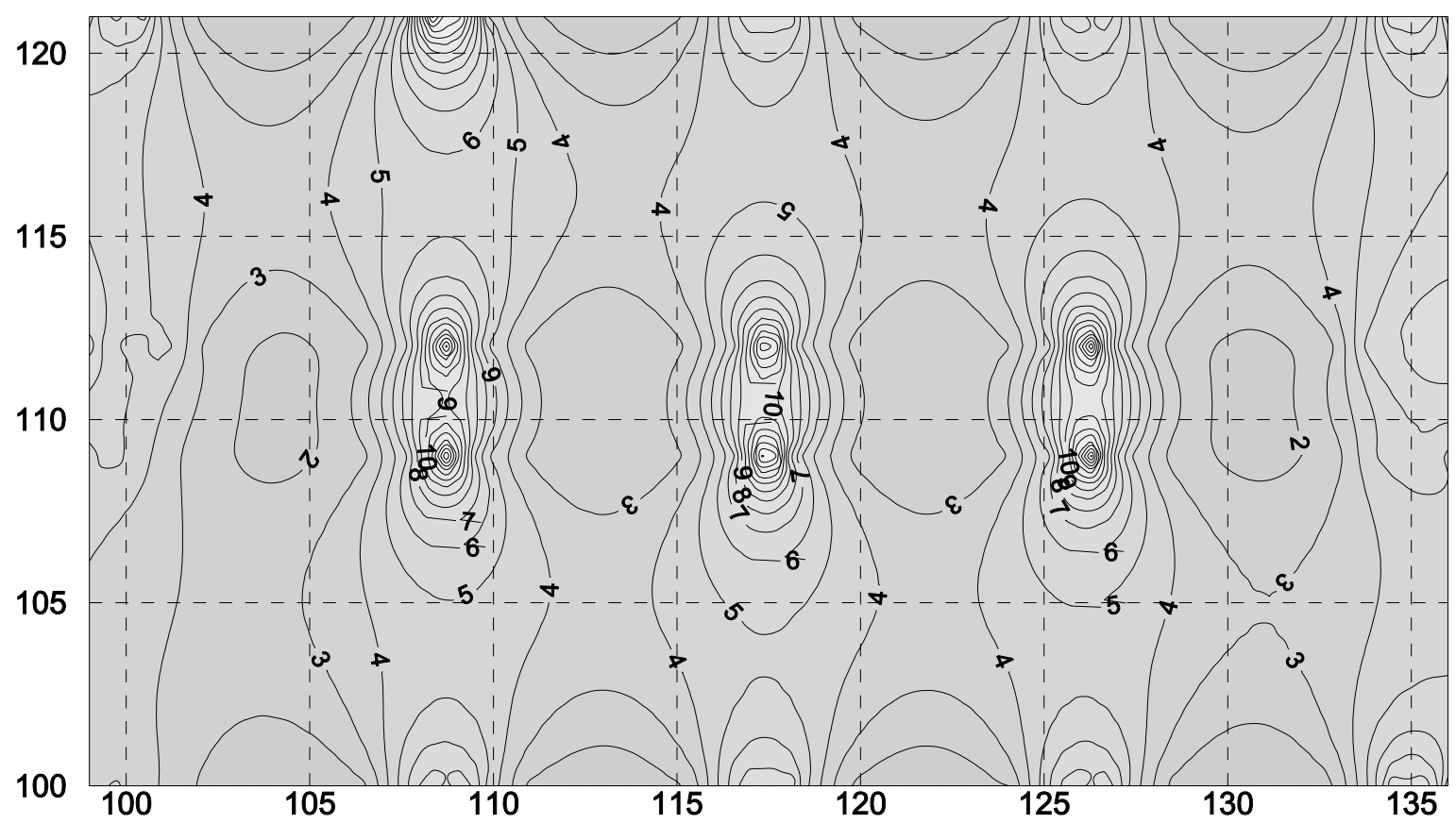

Figura 8.28 - Curvas de igual acréscimo de tensão - profundidade 5,5 m (valores em $\mathrm{kPa}$ ). 


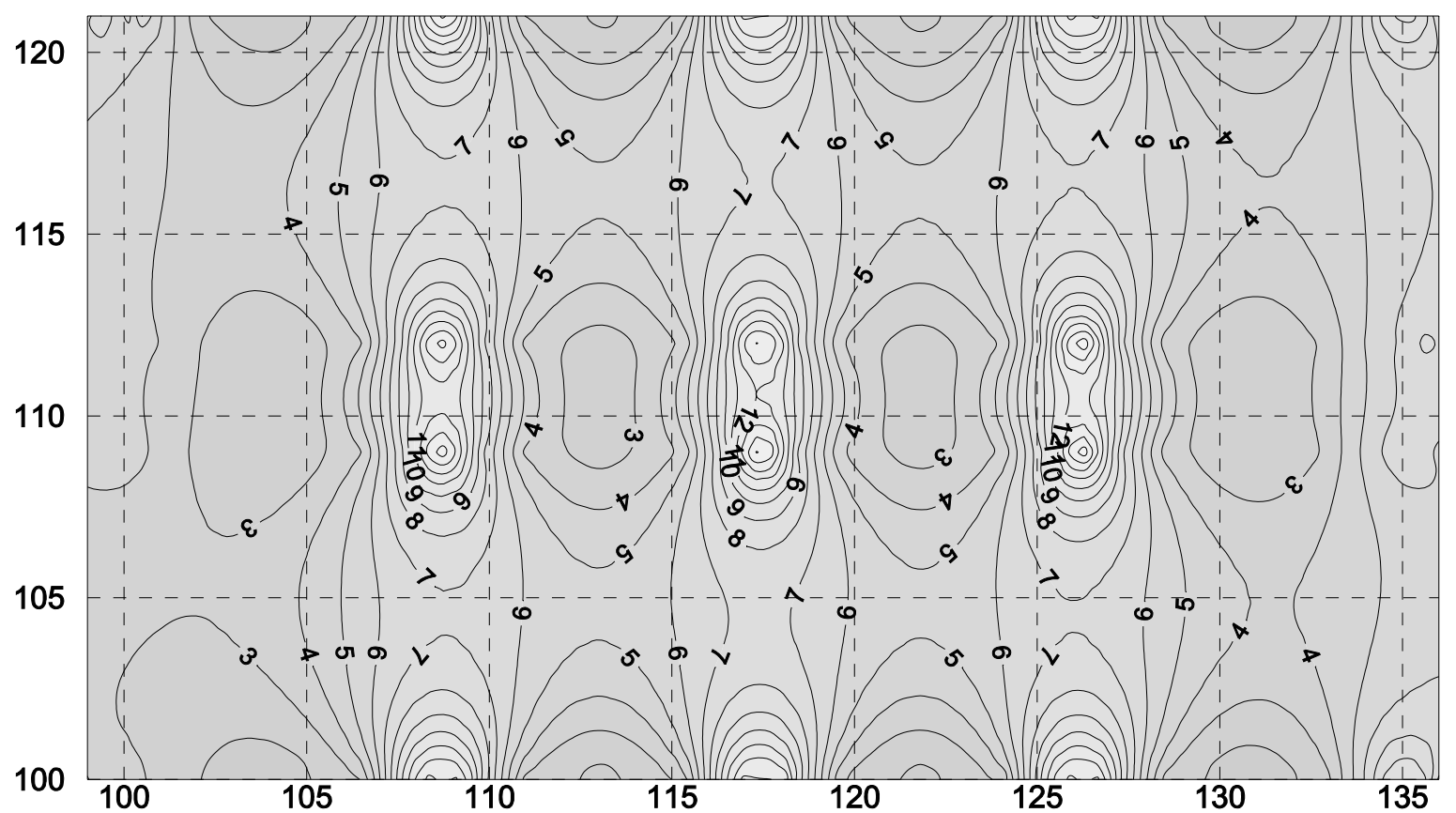

Figura 8.29-Curvas de igual acréscimo de tensão - profundidade 6,5 m (valores em kPa).

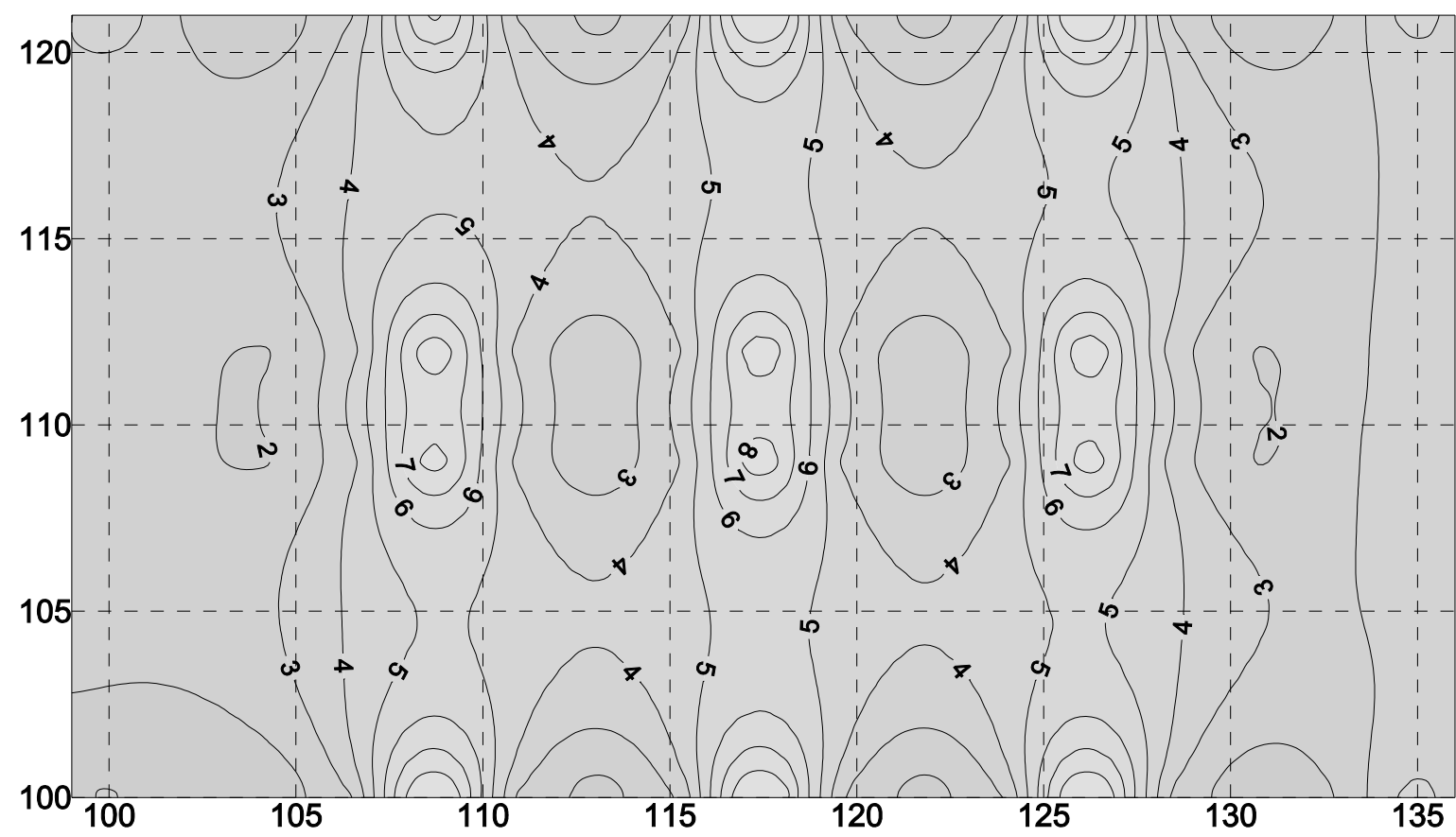

Figura 8.30 - Curvas de igual acréscimo de tensão - profundidade 7,5 m (valores em kPa). 


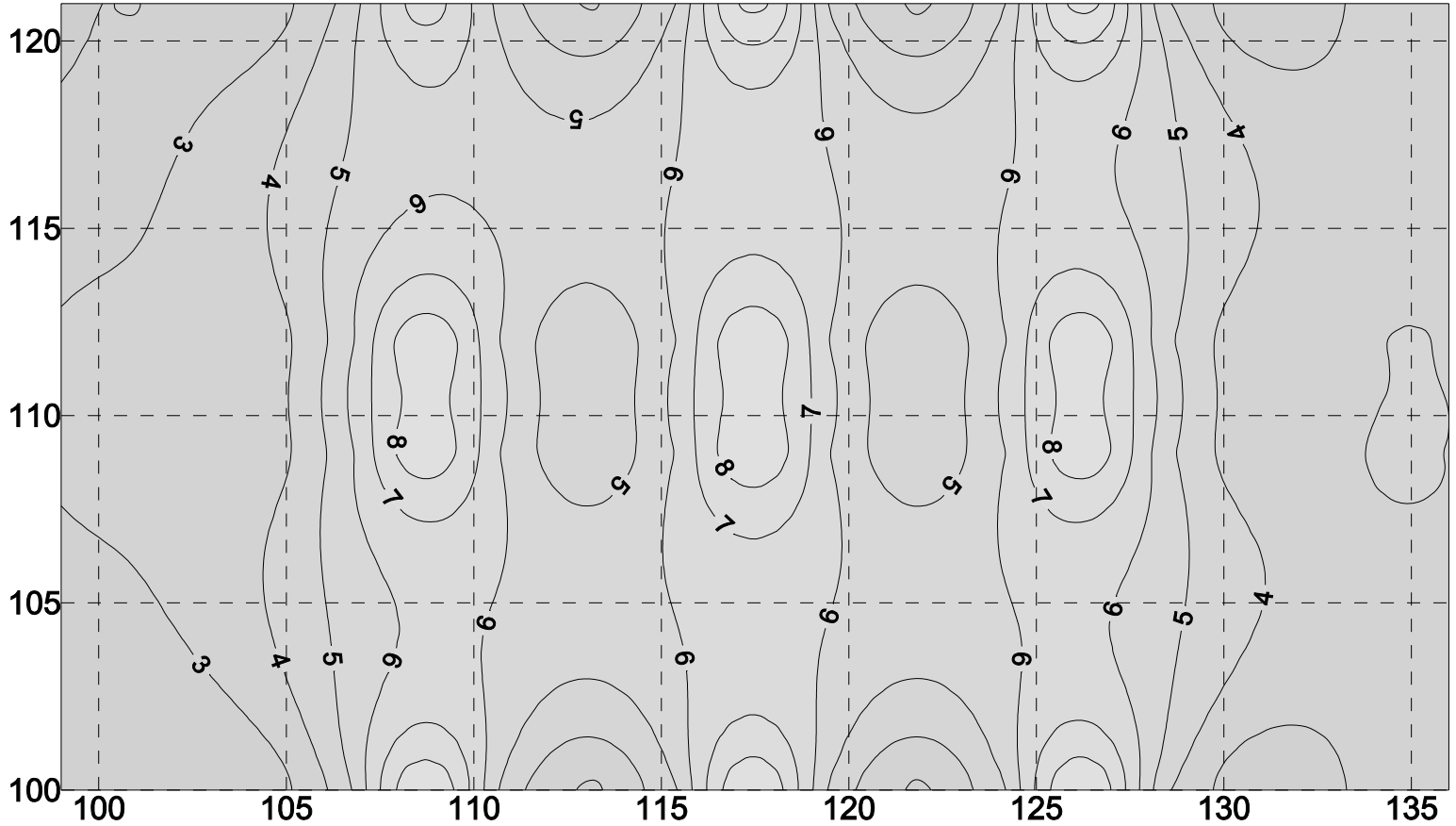

Figura 8.31 - Curvas de igual acréscimo de tensão - profundidade $8,5 \mathrm{~m}$ (valores em $\mathrm{kPa}$ ).

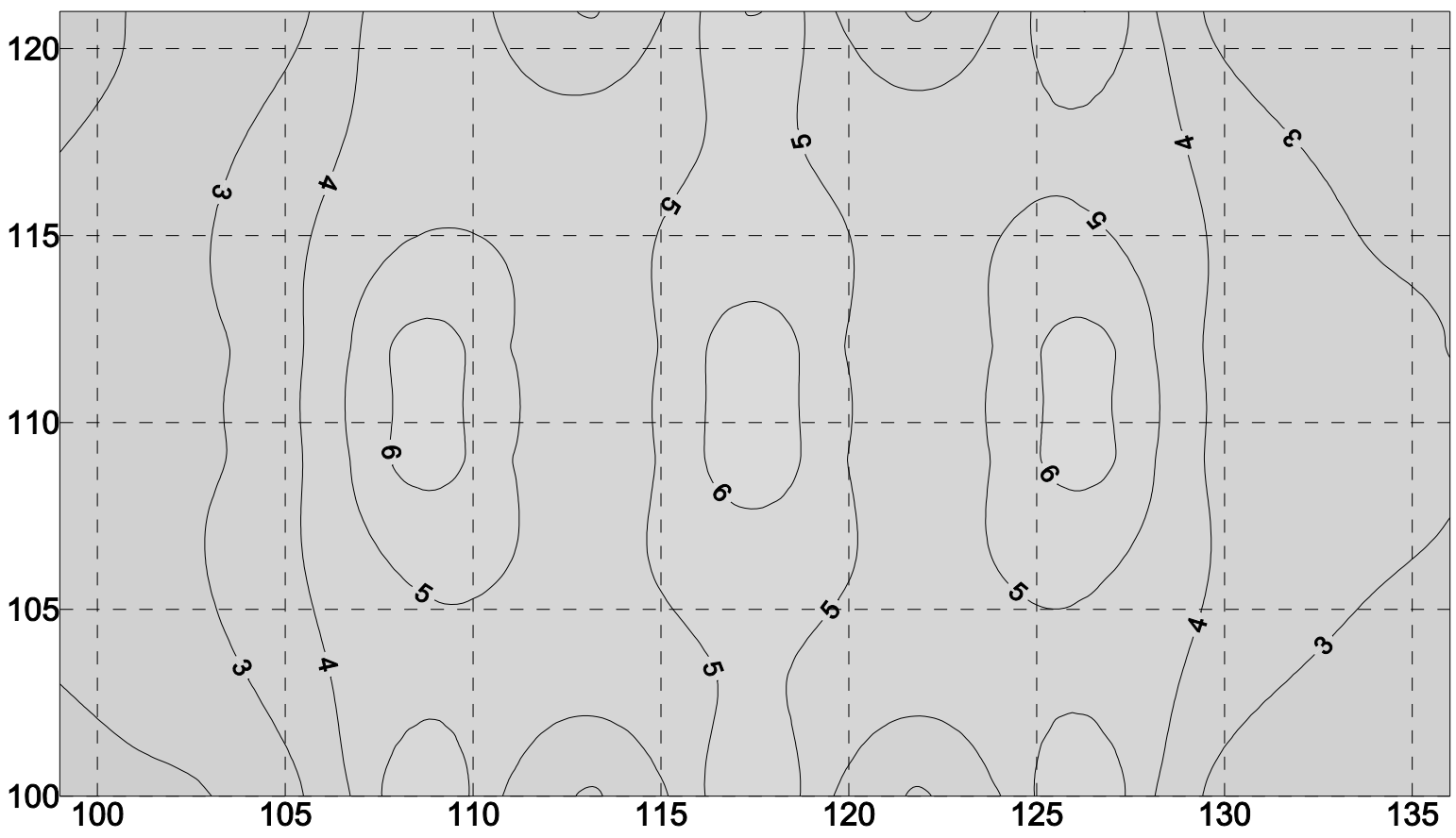

Figura 8.32 - Curvas de igual acréscimo de tensão - profundidade 9,5 m (valores em kPa). 


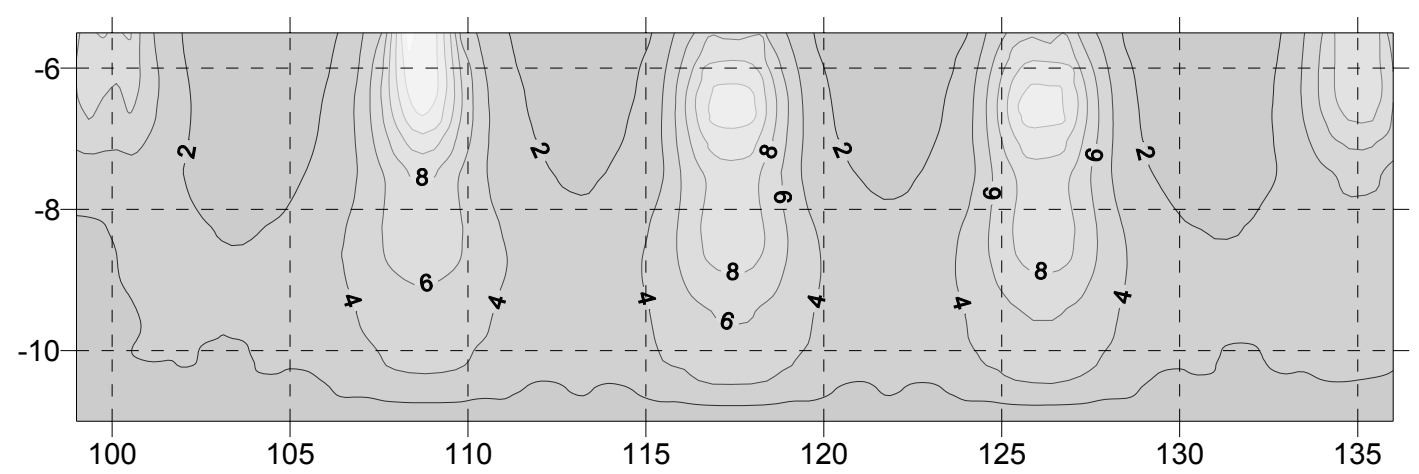

Figura 8.33 - Curvas de igual acréscimo de tensão - eixo A (valores em kPa).

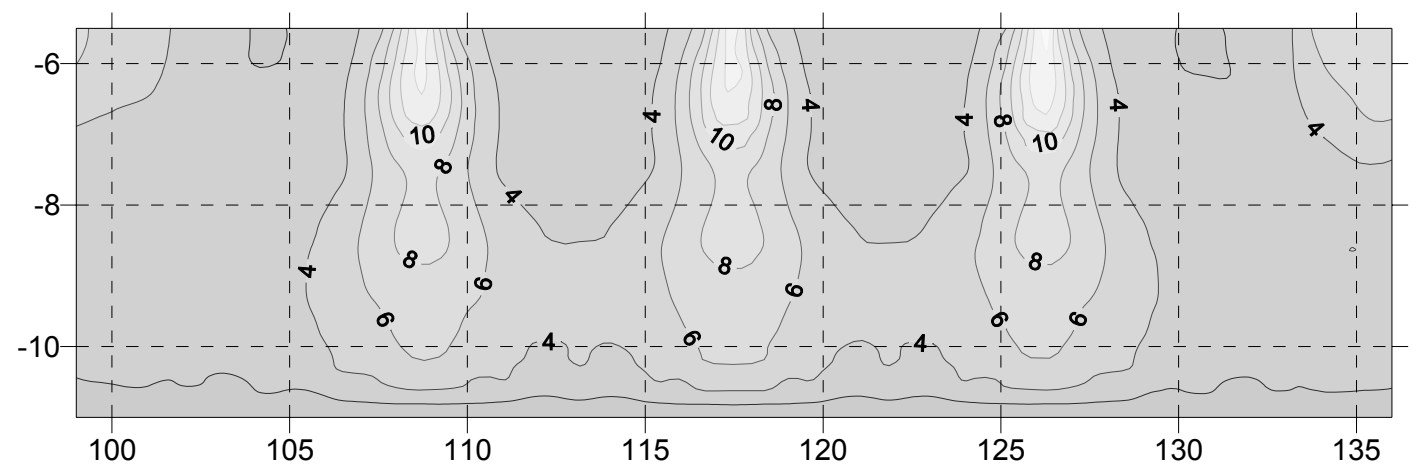

Figura 8.34 - Curvas de igual acréscimo de tensão - eixo B (valores em kPa).

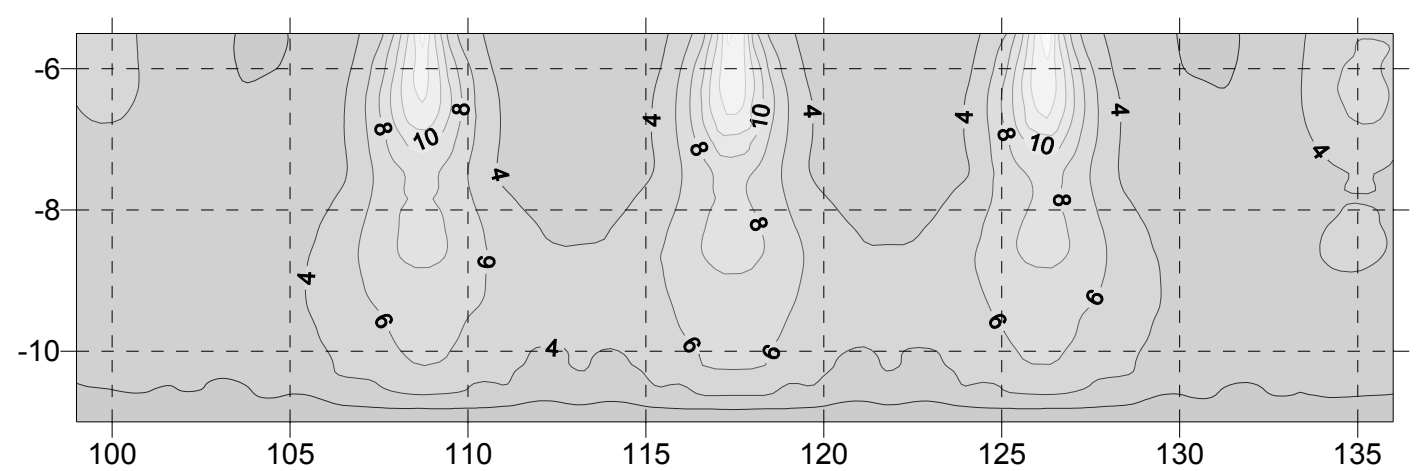

Figura 8.35 - Curvas de igual acréscimo de tensão - eixo C (valores em kPa).

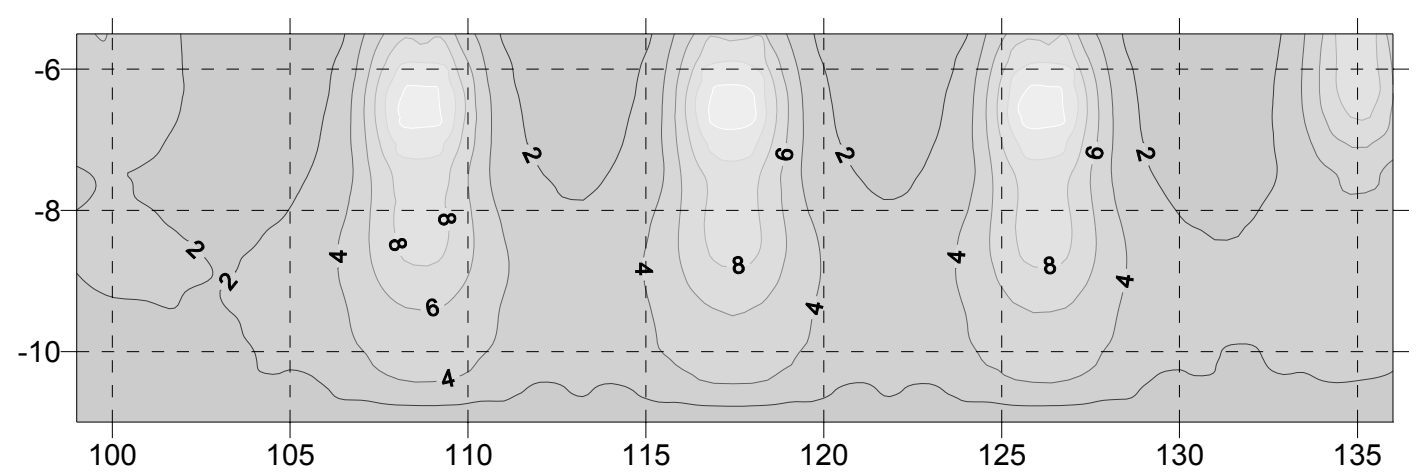

Figura 8.36 - Curvas de igual acréscimo de tensão - eixo D (valores em kPa). 


\subsubsection{Retroanálise C1.}

Nessa análise, visando a tentar reproduzir a variabilidade da geotecnia local, determinou-se, na vertical de cada pilar, uma "sondagem interpolada" (fictícia) SPT e CPT obtidas por meio de interpolação por krigagem a partir dos dados originais (seis verticais SPT e quatro CPT). Assim sendo, para cada um dos vinte pilares deste estudo foi determinado para aquela posição uma sondagem SPT e um ensaio CPT.

Conforme exposto em 8.2.3, procedeu-se ao processo iterativo de análise da interação solo estrutura, sendo que nessa etapa procurou-se definir a condição de reprodução dos valores de recalques medidos.

Ao final do processo, obteve-se, para a posição da vertical de cada pilar, uma relação $\left(E_{s} / q_{c}\right)$ variável entre os limites de 3,15 (pilar 36) e 0,36 (pilares 30 e 40), apresentado valor médio igual a 1,13 (similar ao determinado na análise anterior), desvio padrão de 0,67, correspondendo a um coeficiente de variação de $59 \%$. Essa variabilidade conduz a valores do módulo de deformabilidade variáveis entre limites extremos da ordem de 10 vezes.

A Figura 8.37 apresenta as curvas de valor de igual relação $\left(E_{s} / q_{c}\right)$, determinadas pela análise. Nessa encontram-se indicadas, por meio de marcadores quadrados, a posição de cada estaca.

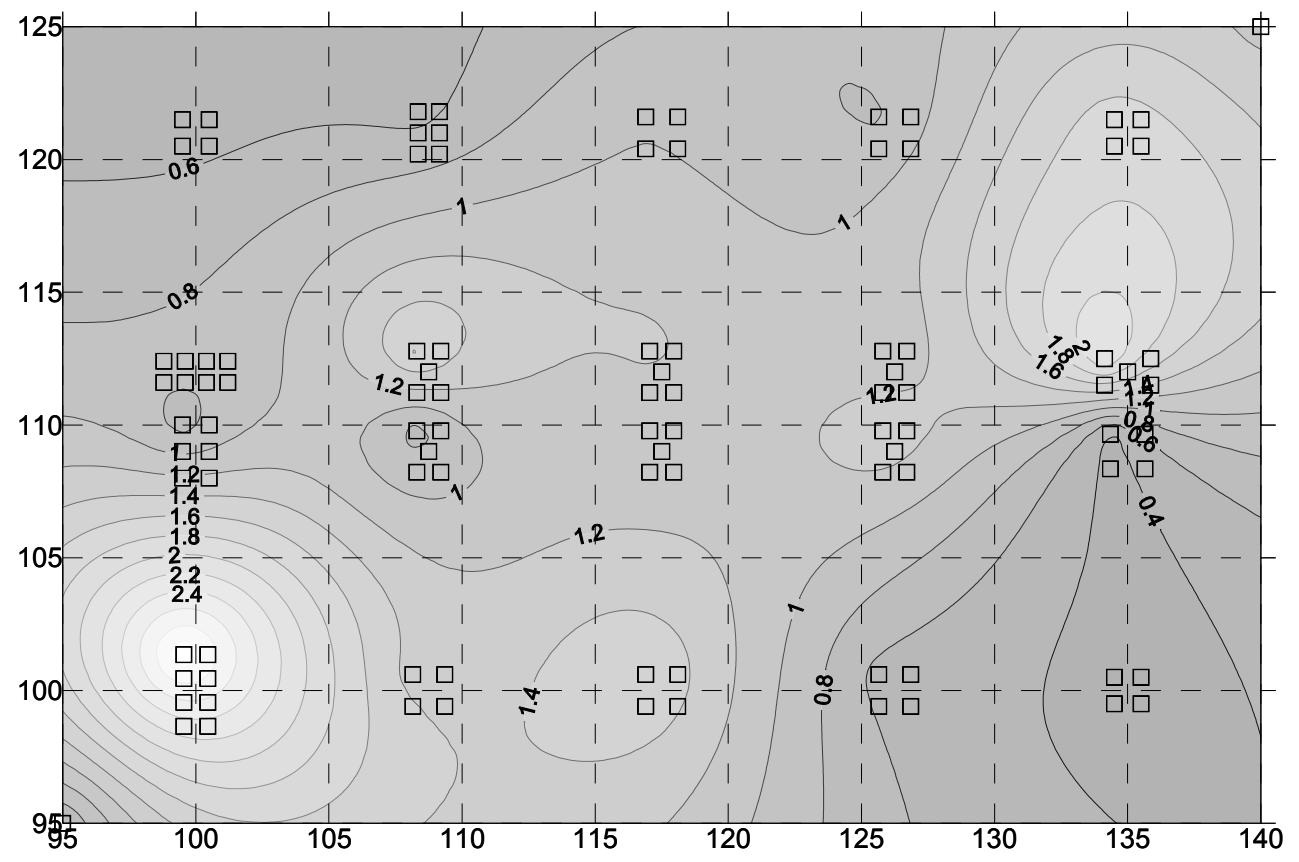

Figura 8.37 - Curvas de igual relação E/q. 
A distribuição em profundidade do módulo de deformabilidade para os limites extremos da relação $\left(E_{s} / q_{c}\right)$ determinada é apresentada na Tabela 8.8 e no gráfico da Figura 8.38.

Tabela 8.8 - Valores limite superior e inferior de $E_{s}$ - retroanálise $C 1$.

\begin{tabular}{ccc}
\hline $\begin{array}{c}\text { Profundidade } \\
(\mathrm{m})\end{array}$ & $\begin{array}{c}\mathrm{E}_{\mathrm{smáx}} \\
(\mathrm{MPa})\end{array}$ & $\begin{array}{c}\mathrm{E}_{\mathrm{smin}} \\
(\mathrm{MPa})\end{array}$ \\
\hline 5,0 & 12,4 & 1,4 \\
5,5 & 4,9 & 0,6 \\
6,0 & 6,9 & 0,8 \\
6,5 & 9,6 & 1,1 \\
7,0 & 11,2 & 1,3 \\
7,5 & 10,8 & 1,2 \\
8,0 & 23,7 & 2,7 \\
8,5 & 22,2 & 2,5 \\
9,0 & 20,0 & 2,3 \\
9,5 & 31,9 & 3,6 \\
10,0 & 33,7 & 3,8 \\
10,5 & 35,7 & 4,1 \\
11,0 & 43,1 & 4,9 \\
\hline
\end{tabular}

$E_{s}(M P a)$

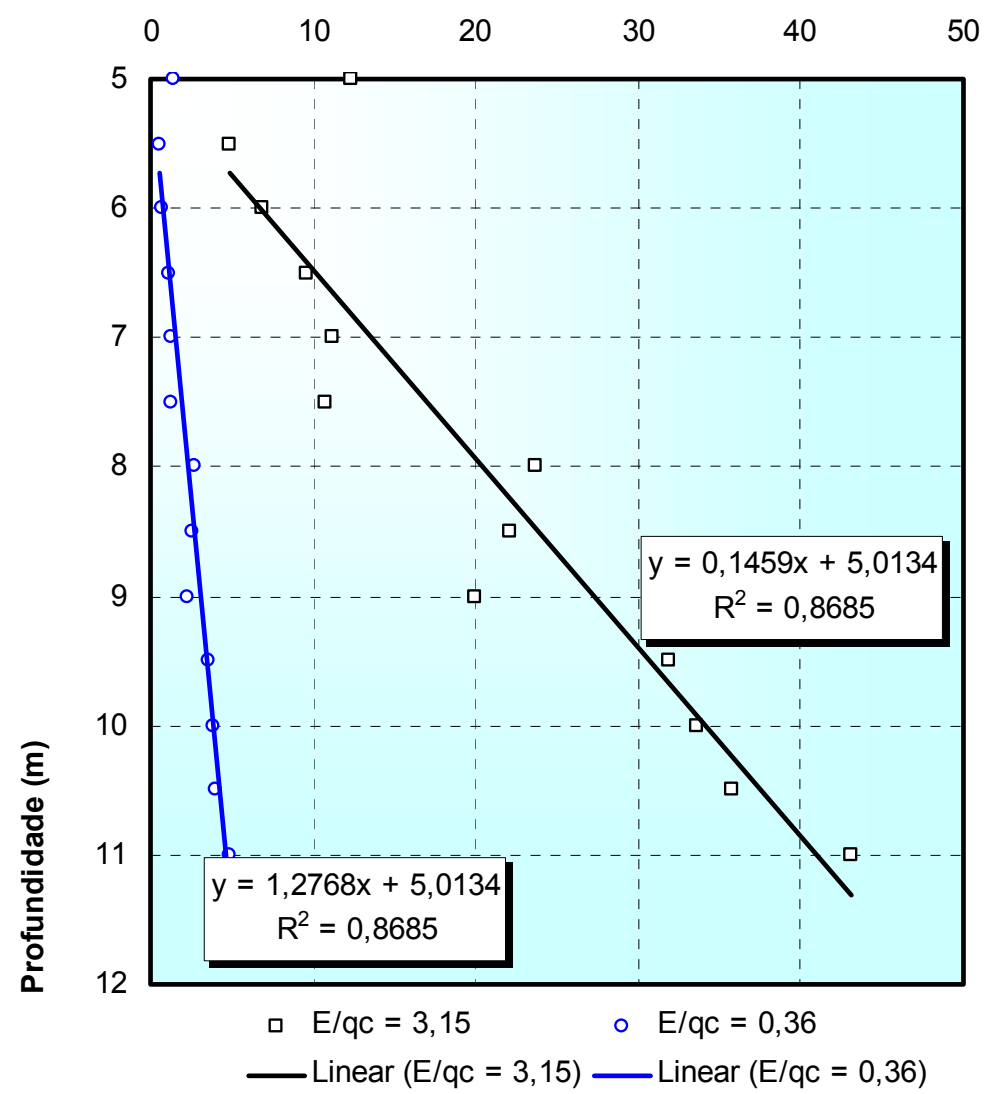

Figura 8.38 - Variação do módulo de deformabilidade do solo $\left(E_{s}\right)$ com a profundidade retroanálise $\mathrm{C1}$. 
As regressões lineares, apresentadas na Figura 8.39, conduzem às seguintes expressões, que relacionam o módulo de deformabilidade do solo com a profundidade dada por:

$$
\begin{aligned}
& E_{s}=6,853 \times z-34,357(M P a) \Rightarrow E / q_{c}=3,15 \\
& E_{s}=0,783 \times z-3,926(M P a) \Rightarrow E / q_{c}=0,36
\end{aligned}
$$

Os principais resultados da presente análise encontram-se apresentados na tabela 8.9 .

\begin{tabular}{|c|c|c|c|c|c|c|c|c|}
\hline Pilar & Estaca & $\begin{array}{l}\mathrm{L} \\
(\mathrm{m})\end{array}$ & $\begin{array}{c}\delta_{\mathrm{p}} \\
(\mathrm{mm})\end{array}$ & $\begin{array}{c}\delta_{\mathrm{s}} \\
(\mathrm{mm})\end{array}$ & $\begin{array}{c}\delta_{\mathrm{t}} \\
(\mathrm{mm})\end{array}$ & $\begin{array}{c}\mathrm{k}_{\text {mola }} \\
(\mathrm{kN} / \mathrm{m})\end{array}$ & $\begin{array}{c}\mathrm{N}_{\mathrm{i}} \\
(\mathrm{kN})\end{array}$ & $E_{s} / q_{c}$ \\
\hline \multirow{8}{*}{36} & E252 & 7,2 & 0,14 & 0,44 & 0,58 & 194590 & 112 & \multirow{8}{*}{3,15} \\
\hline & E253 & 7,3 & 0,17 & 0,41 & 0,58 & 221857 & 128 & \\
\hline & E254 & 6,7 & 0,00 & 0,60 & 0,60 & 732 & 0 & \\
\hline & E255 & 6,5 & 0,00 & 0,70 & 0,70 & 3 & 0 & \\
\hline & E256 & 6,0 & 0,00 & 0,75 & 0,75 & 1 & 0 & \\
\hline & E257 & 5,0 & 0,00 & 1,19 & 1,19 & 0 & 0 & \\
\hline & E258 & 6,7 & 0,11 & 0,47 & 0,58 & 164677 & 96 & \\
\hline & E259 & 6,5 & 0,07 & 0,51 & 0,58 & 119271 & 70 & \\
\hline \multirow{6}{*}{26} & E176 & 8,3 & 0,07 & 1,23 & 1,30 & 54107 & 70 & \multirow{6}{*}{0,73} \\
\hline & E177 & 8,4 & 0,07 & 1,23 & 1,30 & 51264 & 67 & \\
\hline & E178 & 8,0 & 0,01 & 1,33 & 1,34 & 16485 & 22 & \\
\hline & E179 & 8,3 & 0,09 & 1,21 & 1,30 & 62435 & 81 & \\
\hline & E180 & 7,7 & 0,00 & 1,37 & 1,37 & 7587 & 10 & \\
\hline & E181 & 8,2 & 0,13 & 1,16 & 1,29 & 81576 & 106 & \\
\hline \multirow{8}{*}{16} & E112 & 7,2 & 0,00 & 1,78 & 1,78 & 636 & 1 & \multirow{8}{*}{0,86} \\
\hline & E113 & 7,6 & 0,00 & 1,79 & 1,79 & 1440 & 3 & \\
\hline & E114 & 8,5 & 0,38 & 1,22 & 1,60 & 124142 & 199 & \\
\hline & E115 & 6,8 & 0,00 & 2,95 & 2,95 & 0 & 0 & \\
\hline & E116 & 7,4 & 0,01 & 1,61 & 1,62 & 12199 & 20 & \\
\hline & E117 & 8,0 & 0,16 & 1,44 & 1,60 & 64538 & 103 & \\
\hline & E118 & 8,0 & 0,03 & 1,59 & 1,61 & 21328 & 34 & \\
\hline & E119 & 7,0 & 0,00 & 2,57 & 2,57 & 0 & 0 & \\
\hline \multirow{4}{*}{06} & E029 & 8,7 & 0,38 & 1,59 & 1,97 & 116703 & 230 & \multirow{4}{*}{0,51} \\
\hline & E030 & 7,0 & 0,00 & 3,58 & 3,58 & 0 & 0 & \\
\hline & E031 & 8,5 & 0,28 & 1,70 & 1,97 & 93662 & 185 & \\
\hline & E032 & 7,0 & 0,00 & 3,61 & 3,61 & 0 & 0 & \\
\hline Pilar & Estaca & $\begin{array}{c}\mathrm{L} \\
(\mathrm{m})\end{array}$ & $\begin{array}{c}\delta_{\mathrm{p}} \\
(\mathrm{mm})\end{array}$ & $\begin{array}{c}\delta_{\mathrm{s}} \\
(\mathrm{mm})\end{array}$ & $\begin{array}{c}\delta_{\mathrm{t}} \\
(\mathrm{mm})\end{array}$ & $\begin{array}{c}\mathrm{k}_{\text {mola }} \\
(\mathrm{kN} / \mathrm{m})\end{array}$ & $\begin{array}{c}\mathrm{N}_{\mathrm{i}} \\
(\mathrm{kN})\end{array}$ & $\mathrm{E}_{\mathrm{s}} / \mathrm{q}_{\mathrm{c}}$ \\
\hline \multirow{4}{*}{37} & E261 & 7,5 & 0,28 & 1,90 & 2,18 & 86026 & 188 & \multirow{4}{*}{1,33} \\
\hline & E262 & 7,9 & 0,35 & 1,84 & 2,18 & 98841 & 216 & \\
\hline & E263 & 7,5 & 0,28 & 1,91 & 2,18 & 84741 & 185 & \\
\hline & E264 & 8,0 & 0,36 & 1,82 & 2,18 & 101333 & 221 & \\
\hline \multirow{5}{*}{27} & E183 & 8,5 & 0,30 & 2,89 & 3,19 & 61398 & 196 & \multirow{5}{*}{0,73} \\
\hline & E184 & 8,4 & 0,26 & 2,93 & 3,19 & 56222 & 180 & \\
\hline & E185 & 8,6 & 0,44 & 2,78 & 3,22 & 78794 & 254 & \\
\hline & E186 & 8,0 & 0,09 & 3,14 & 3,23 & 24851 & 80,2 & \\
\hline & E187 & 7,6 & 0,00 & 3,59 & 3,59 & 719 & 3 & \\
\hline 17 & E121 & 7,9 & 0,40 & 2,19 & 2,60 & 92177 & 239 & 1,64 \\
\hline
\end{tabular}

Tabela 8.9 - Resultados análise interação solo estrutura - retroanálise C1. 


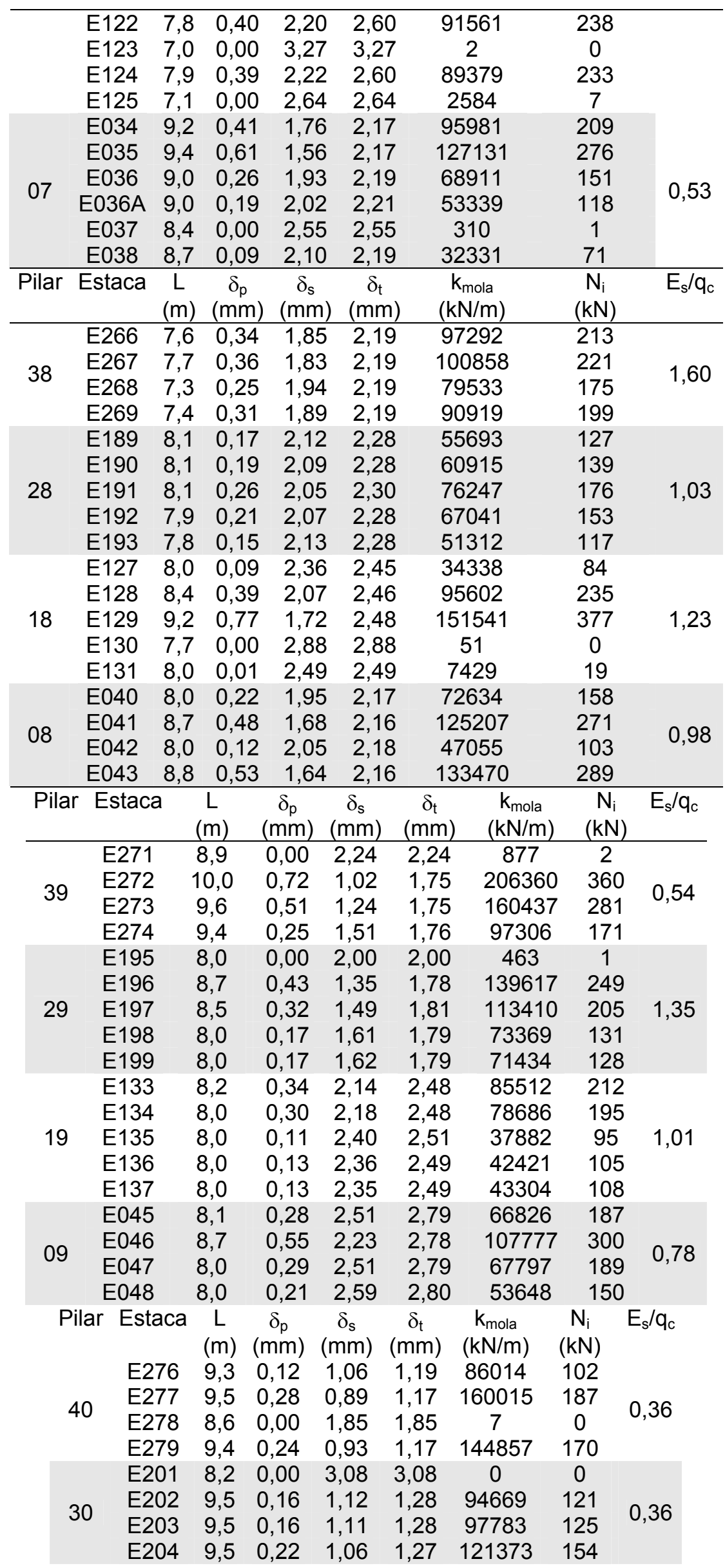




\begin{tabular}{ccccccccc} 
& E139 & 8,5 & 0,20 & 0,38 & 0,58 & 246944 & 143 & \\
& E140 & 8,0 & 0,01 & 0,54 & 0,55 & 47067 & 26 & \\
20 & E141 & 8,0 & 0,13 & 0,47 & 0,60 & 172545 & 103 & 2,20 \\
& E142 & 8,0 & 0,00 & 0,54 & 0,55 & 23265 & 13 & \\
& E143 & 8,3 & 0,15 & 0,44 & 0,58 & 197723 & 115 & \\
& E050 & 8,5 & 0,24 & 0,42 & 0,66 & 252688 & 168 & \\
10 & E051 & 8,0 & 0,10 & 0,57 & 0,66 & 130560 & 87 & 1,70 \\
& E052 & 8,0 & 0,01 & 0,62 & 0,63 & 47290 & 30 & 1,70 \\
& E053 & 8,6 & 0,27 & 0,40 & 0,66 & 272178 & 180 & \\
\hline
\end{tabular}

As premissas adotadas nas análises de igual condição geotécnica para a vertical de cada pilar e estacas de diferente comprimento em um mesmo bloco implicam em diferente deslocamento do topo das estacas, o que gera diferentes coeficientes de mola. Como o bloco de coroamento modelado comporta-se como "elemento rígido", impondo igual deslocamento a todas as estacas de um mesmo bloco, a compatibilização ocorre com a redistribuição de solicitação normal nas estacas. Como regra geral, estacas mais compridas terão menor deslocamento do topo, maior coeficiente de mola e estarão submetidas às maiores solicitações normais.

Os gráficos das Figuras 8.39 a 8.43 apresentam a variação com a profundidade da solicitação normal nas estacas. Ressalta-se que em nenhum dos elementos foi verificada a mobilização da resistência de ponta das estacas para o nível de solicitações envolvido pela montagem da estrutura em concreto pré-moldada.

A comparação entre esse conjunto de gráficos e aquele determinado na retroanálise $A$ mostra que os efeitos de redistribuição de esforços é mais acentuado para o caso $\mathrm{C} 1$ onde em um mesmo bloco apresentam-se estacas de comprimento diferente.

Na seqüência, apresenta-se na Figura 8.44, curvas de distribuição da solicitação normal no topo das estacas, valores expressos em MPa. Verifica-se nessa figura que a simetria apresentada no gráfico similar da previsão Classe $\mathrm{A}$ quase não é verificada.

Posteriormente, na Figura 8.45 são apresentadas curvas de igual coeficiente de mola nas estacas. 

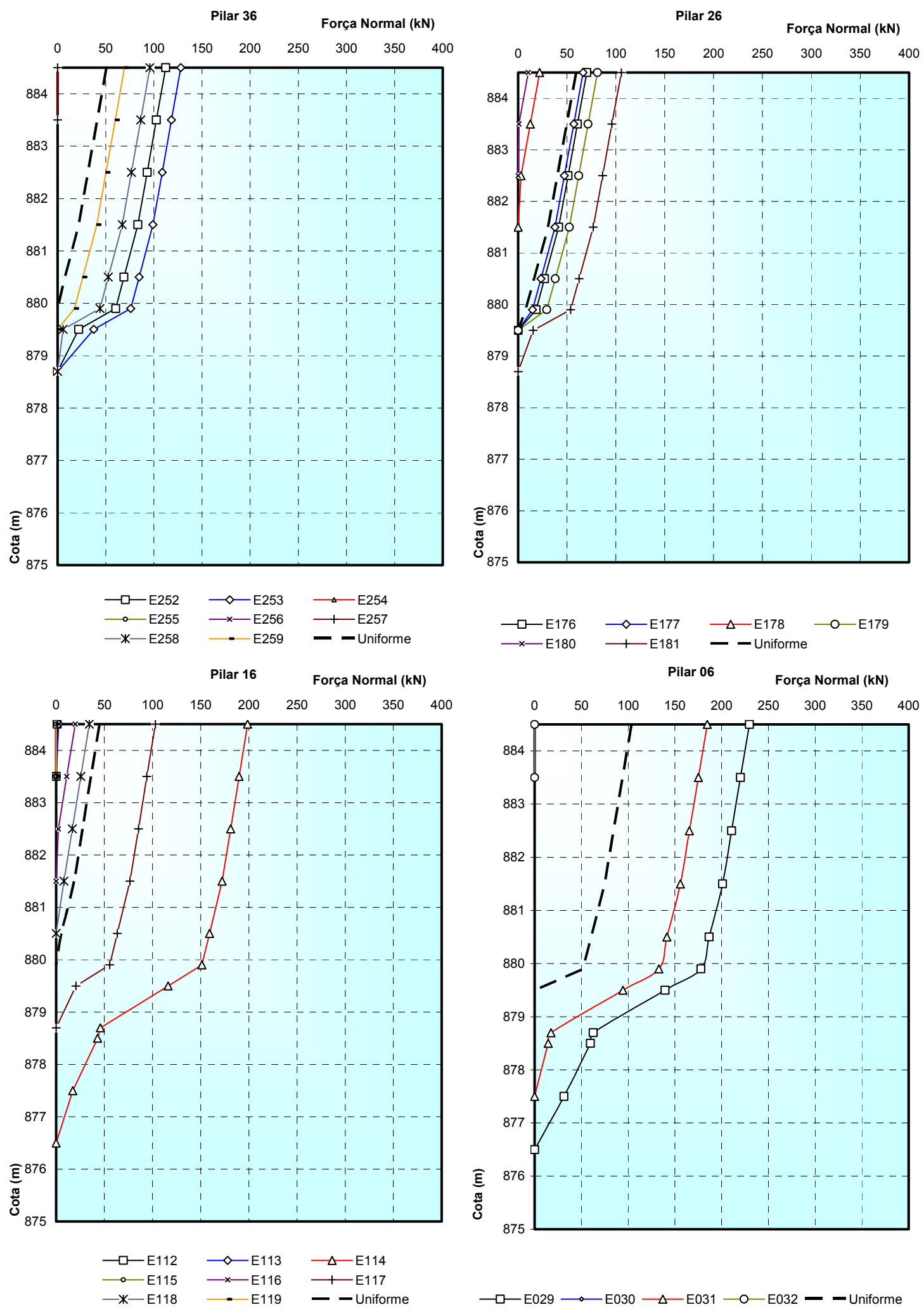

Figura 8.39 - Diagrama de solicitação normal nas estacas - pilares do eixo 6. 

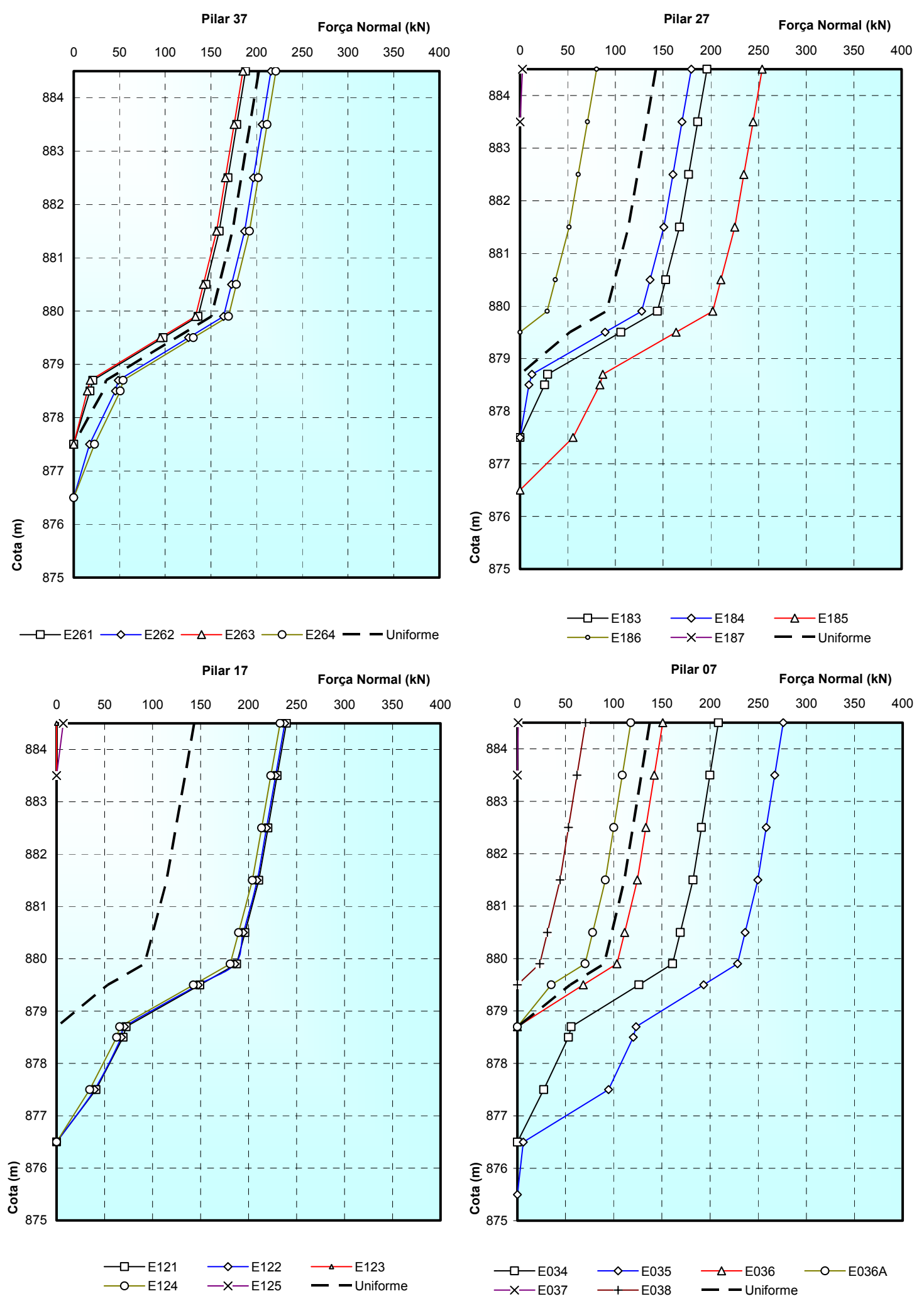

Figura 8.40 - Diagrama de solicitação normal nas estacas - pilares do eixo 7. 

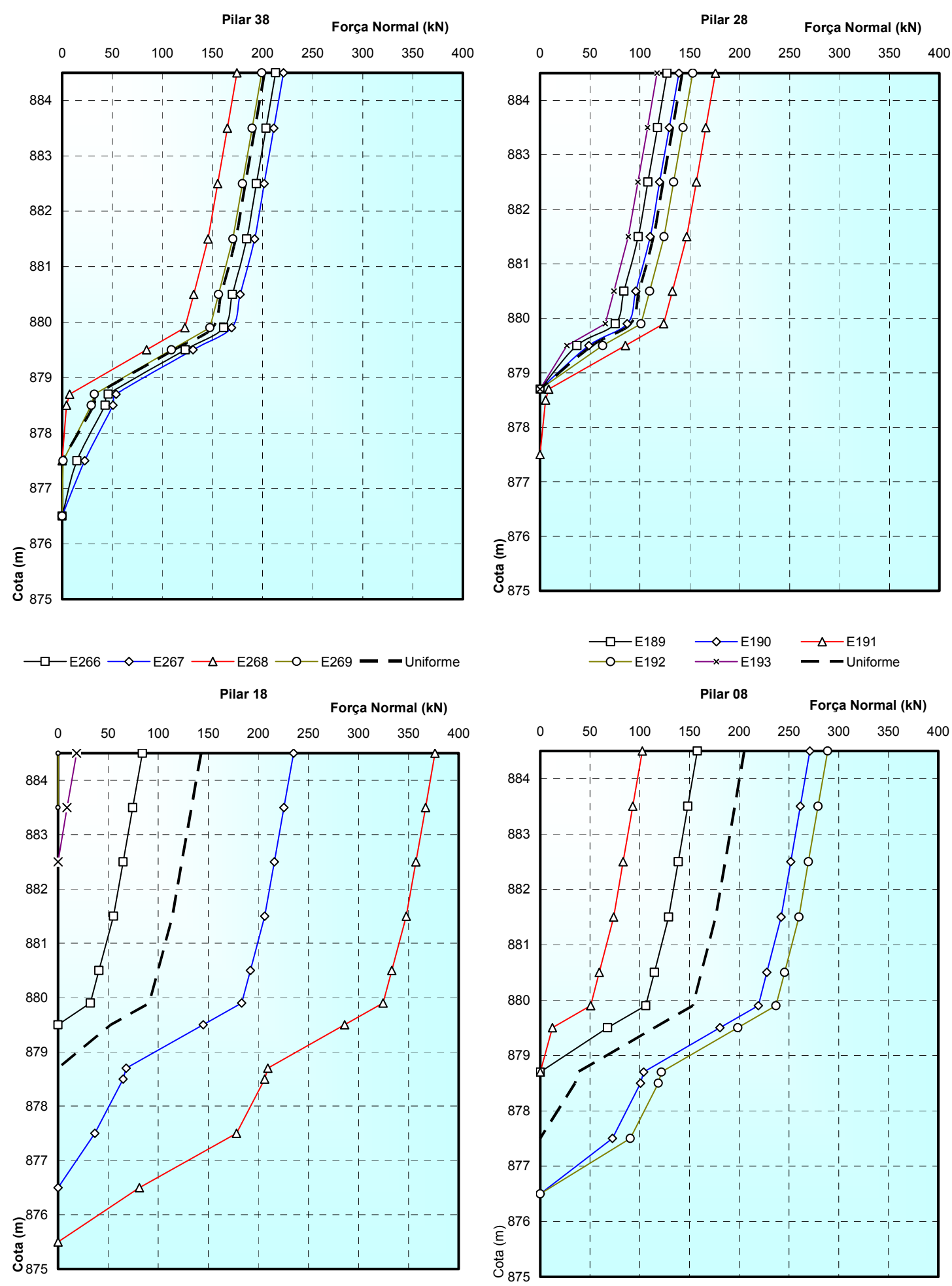

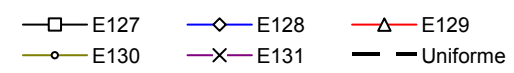

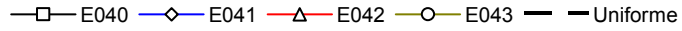

Figura 8.41 - Diagrama de solicitação normal nas estacas - pilares do eixo 8. 

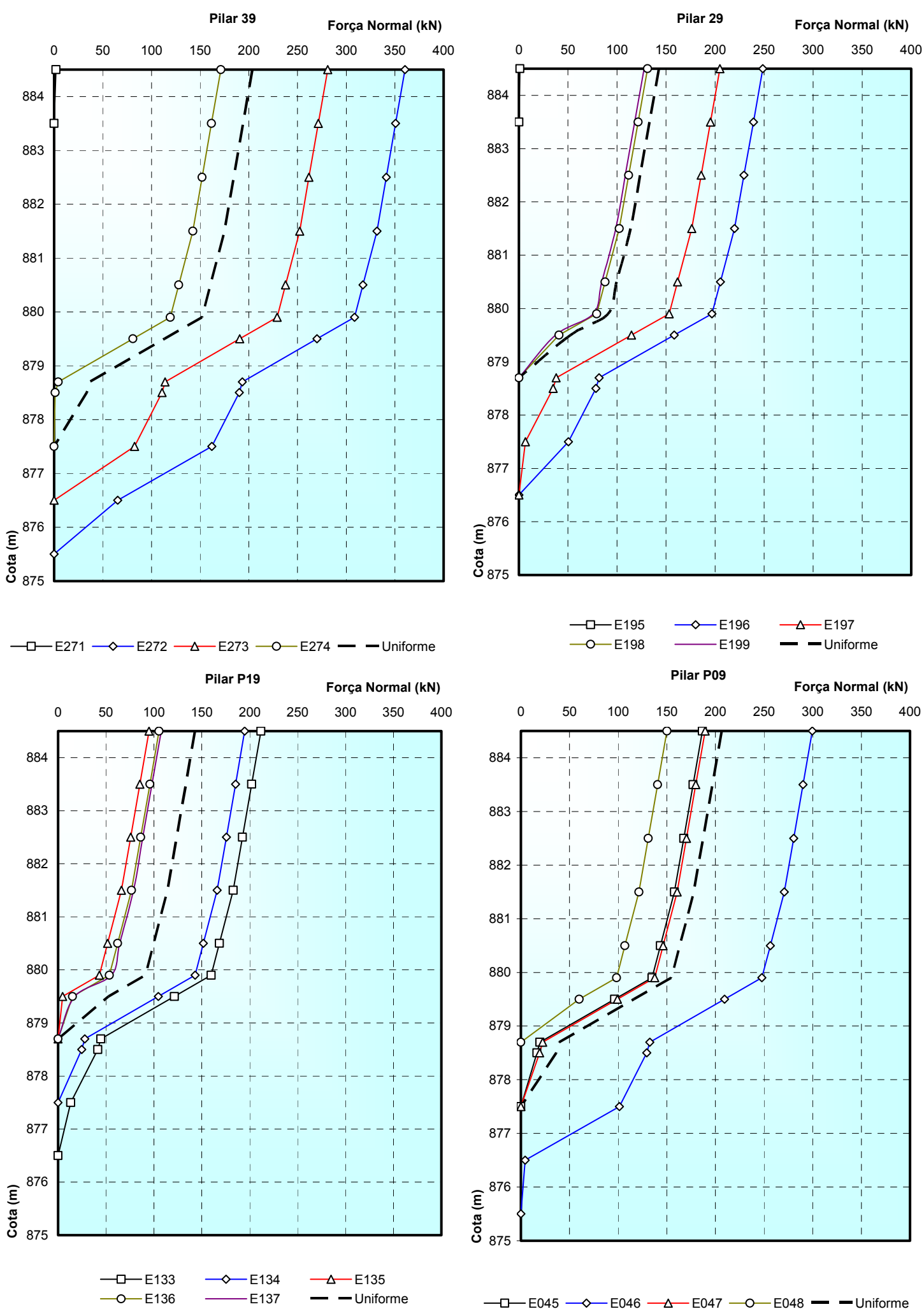

Figura 8.42 - Diagrama de solicitação normal nas estacas - pilares do eixo 9. 

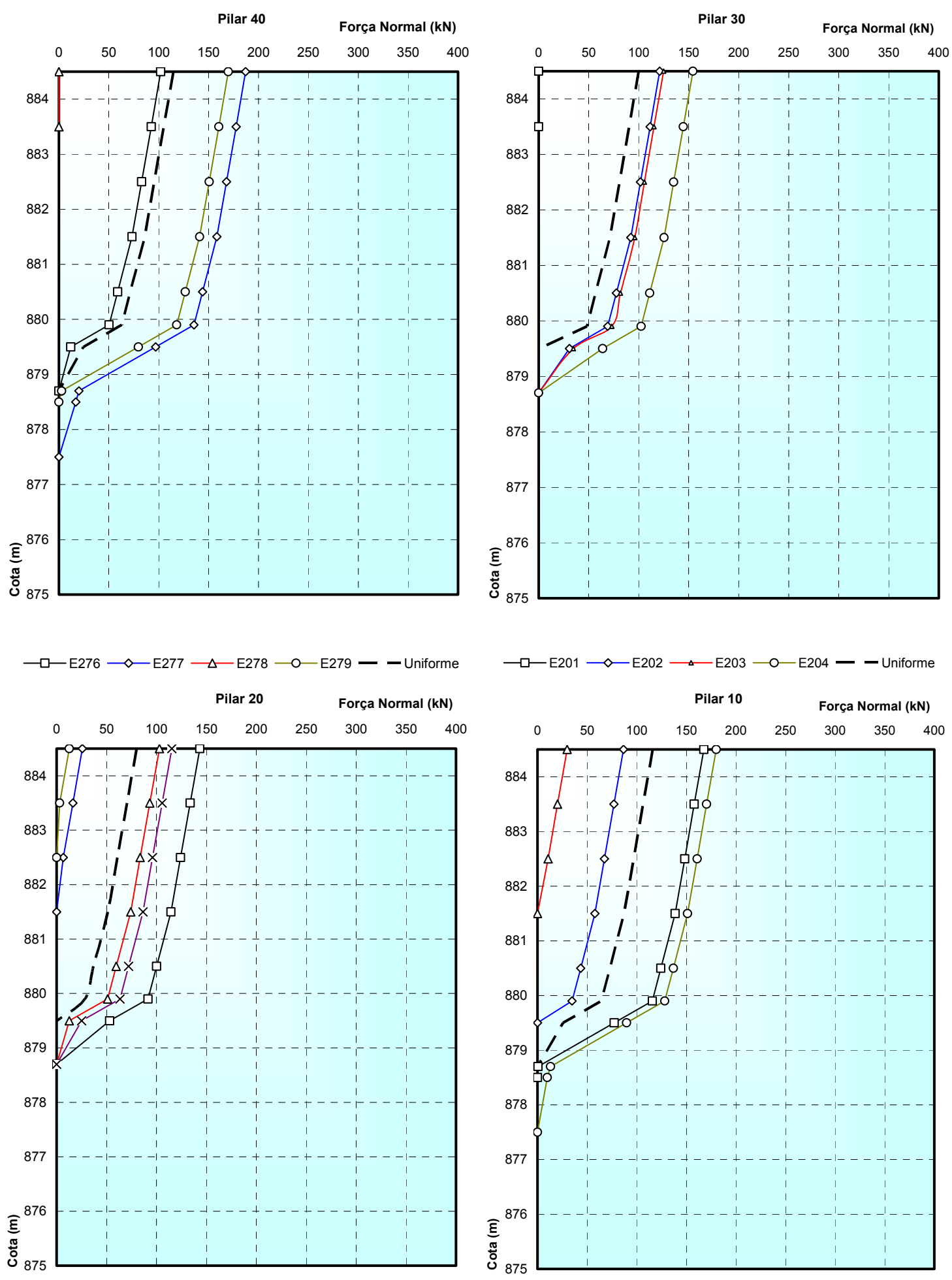

$$
\begin{array}{lll}
\longrightarrow-E 139 & \sim \text { E140 } & - \text { E141 } \\
-0-E 142 & \longrightarrow-\mathrm{E} 143 & -- \text { Uniforme }
\end{array}
$$$$
\multimap \square-E 050 \multimap-E 051 \multimap \Delta \text { E052 O-E053 - -Uniforme }
$$

Figura 8.43 - Diagrama de solicitação normal nas estacas - pilares do eixo 10. 


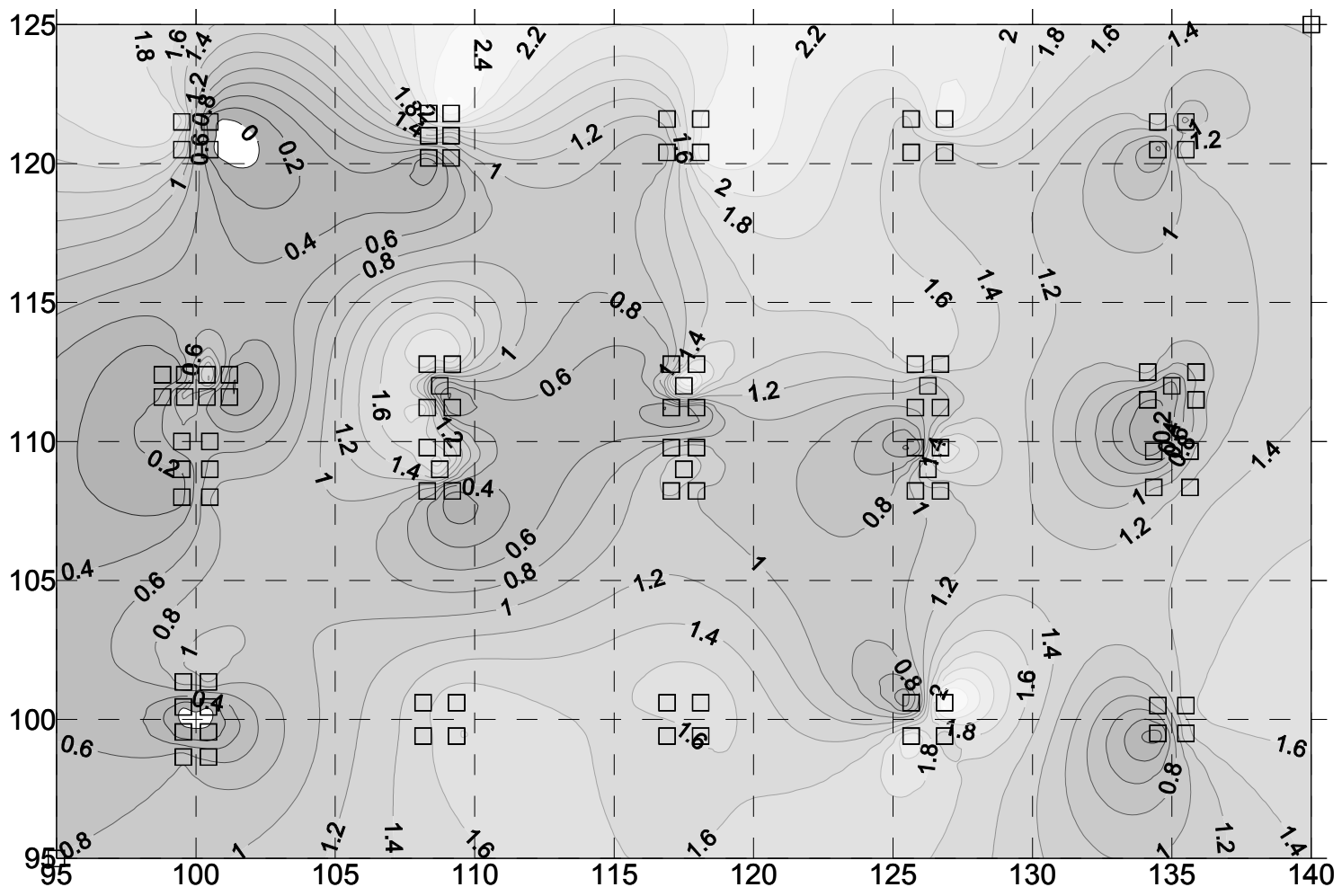

Figura 8.44 - Curvas de igual solicitação no topo das estacas (valores em MPa).

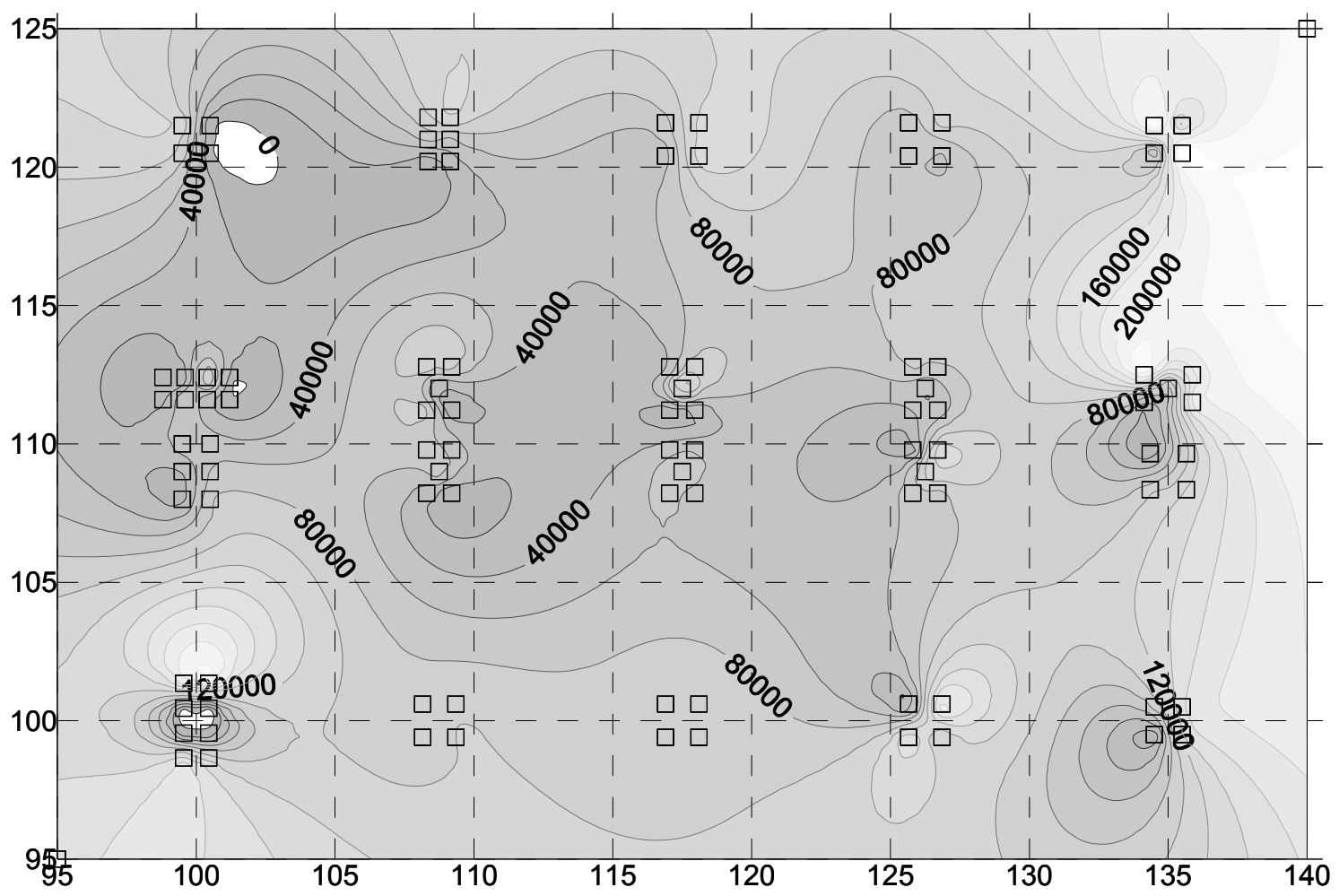

Figura 8.45 - Curvas de igual coeficiente de mola das estacas (valores em kN/m). 
Respectivamente aos valores dos coeficientes de mola, verifica-se valores varáveis entre 0 e $272178 \mathrm{kN} / \mathrm{m}$, sendo a média desses valores igual a $76214 \mathrm{kN} / \mathrm{m}$ (similar ao valor médio retroanálise A $71.881 \mathrm{kN} / \mathrm{m}$ ), com coeficiente de variação de $82 \%$. 


\section{CONCLUSÕES}

O trabalho apresentado teve por objetivo observar, interpretar e analisar o comportamento de uma obra de engenharia em escala natural, sob condições normais de execução.

Essas observações envolveram a medida de deslocamentos verticais na base dos pilares (recalque da fundação), em conjunto com a medida indireta da solicitação normal nesses elementos (carga nos pilares). A partir dessa condição de contorno conhecida, procedeu-se a análise do comportamento dessa estrutura sob o enfoque da interação solo-estrutura.

A obra de engenharia em questão envolveu a montagem de uma estrutura isostática pré-moldada de concreto armado, apoiada em fundações profunda do tipo estaca cravada, tendo sido efetuadas observações em vinte pilares dessa obra.

No período de observações, foram medidos recalques máximos variáveis entre 1,1 e 4,3 $\mathrm{mm}$. Também se verificou desenvolvimento de recalques crescentes com o tempo, sugerindo fluência da fundação profunda. As taxas de deslocamento nessas condições apresentaram-se variáveis entre 0,8 e 3,2 mm/log t. A velocidade de recalque deverá ser inferior a $10 \mu \mathrm{m} / \mathrm{dia}$ em um período aproximado de 120 dias, para os valores máximos de taxa de deslocamento.

O equipamento especialmente desenvolvido para esse trabalho, denominado extensômetro mecânico removível, permite determinar a solicitação normal em pilares, desde que possam ser avaliados os efeitos de temperatura, fluência, retração e flexão a que a peça estrutural está submetida. Verificou-se que fatores ambientais, principalmente temperatura, apresentam influência nas medidas efetuadas. 
A metodologia utilizada para determinação da carga no pilar que considerou os efeitos de temperatura, retração, fluência e flexão, conduziu a resultados concordantes com os fornecidos pelo cálculo estrutural.

O modelo reológico de avaliação da retração e fluência do CEB-FIP 90 mostrou-se adequado para as condições encontradas na obra deste estudo.

As taxas de deformação sob carga constante da superestrutura (média 0,081 mm/log t), quando comparadas às da fundação (média 1,8 mm/log t), são em média dezesseis vezes superiores, indicando que o comportamento da obra de engenharia é, em primeira ordem, comandado pela fundação.

As observações indicam deslocamentos e deformações crescentes sob carga constante, isto é, fluência dos sistemas envolvidos, e portanto, mostram que o comportamento visco-elástico deve ser considerado em análises de interação solo estrutura.

O conjunto de dados conduz a relação carga recalque variável entre 201 e 670 kN/mm para o conjunto dos vinte pilares monitorados; assim sendo, não é possível definir um único coeficiente de mola a ser adotado para todos os apoios em análises de interação solo estrutura.

As retroanálises efetuadas conduziram a módulos de deformabilidade do estrato silto arenoso, variáveis espacialmente mostrando tendência de crescimento linear com a profundidade. Os valores determinados apresentamse entre 0,6 e 43,1 MPa, com um valor médio da relação com a resistência a penetração de ponta do cone $\left(E_{s} / q_{c}\right)$ da ordem de 1,2.

O módulo de deformabilidade transversal $\left(G_{s}\right)$ fornecido pela retroanálise é em média trinta vezes superior ao valor do módulo de deformabilidade inicial tangente $\left(\mathrm{G}_{0}\right)$, determinado por correlações com a resistência à penetração de ponta do cone, disponíveis na literatura.

Também é constatado nas análises que a solicitação normal nas estacas depende da definição da superfície resistente, do efeito de grupo de estacas de um mesmo pilar e do efeito de grupo de estacas de um grupo de pilares.

As premissas adotadas nas análises de igual condição geotécnica para a vertical de cada pilar e estacas de diferente comprimento em um mesmo bloco implicam em diferente deslocamento do topo das estacas, o que gera diferentes coeficientes de mola. Como o bloco de coroamento modelado comporta-se como "elemento rígido", impondo igual deslocamento a todas as 
estacas de um mesmo bloco, a compatibilização ocorre com a redistribuição de solicitação normal nas estacas. Como regra geral, estacas mais compridas terão menor deslocamento do topo, maior coeficiente de mola e estarão submetidas às maiores solicitações normais.

Embora os recalques medidos possam ser considerados de pequena magnitude (da ordem máxima de $4 \mathrm{~mm}$ ), as deformações no maciço de solo, na posição da ponta das estacas (da ordem de $1 \mathrm{~m} \varepsilon$ ) não podem ser consideradas pequenas. A literatura específica as classifica como médias deformações.

\section{SUGESTÕES PARA PESQUISAS FUTURAS}

Conforme exortado por inúmeros autores, a observações de obras de engenharia em escala natural sob as condições impostas pelo meio ambiente e pelos processos executivos, continua sendo um campo de pesquisa a ser explorado.

O presente trabalho tratou de apenas uma etapa executiva, de um caso particular de obra de engenharia, de uma determinada solução de fundação em uma dada Formação Geológica. Novos estudos experimentais, similares ao aqui apresentado, devem ser levados a termo, envolvendo as inúmeras condições existentes nas obras correntes de engenharia.

O autor ressalta que a realização de um programa de pesquisa limitado, como o apresentado neste trabalho, envolveu recursos financeiros, muitas vezes não disponíveis, os quais deverão ser previamente orçados e disponibilizados. Desde que possam ser garantidos esses recursos, recomenda-se a utilização de instrumentação eletrônica, hoje disponível, com sistema de aquisição de dados automático.

No caso da utilização de extensômetros mecânicos, recomenda-se o monitoramento das deformações nas quatro faces dos pilares e a utilização de um elemento de referência, similar ao que está sendo observado, não submetido a carregamento, o qual permitirá avaliar apenas os efeitos ambientais e os efeitos da reologia no sistema em questão. 
Os dados aqui coletados podem ser retroanalisados segundo outros modelos de análise, por exemplo, Poulos, Randolph, elementos finitos e elementos de contorno, permitindo uma comparação entre eles.

A consideração do comportamento visco-elástico dos materiais e sistemas envolvidos devem ser incluídos nessas análises. 


\section{REFERÊNCIAS}

ABNT (1983). NBR 8036 Programação de sondagens de simples reconhecimento dos solos para fundações de edifícios, Rio de Janeiro, 1983.

ABNT (1985). NBR 9061 Segurança de escavação a céu aberto, Rio de Janeiro, 1985.

ABNT (1993). NBR 12815 Concreto endurecido - Determinação do coeficiente de dilatação térmica, Rio de Janeiro, 1993.

ABNT (1996). NBR 6122 Projeto e execução de fundações. Rio de Janeiro, 1996.

ABNT (2001). NBR6118 Projeto e execução de obras de concreto armado. Rio de Janeiro, 2001.

$\mathrm{ACl}$ (2002). Building code requirements for structural concrete (ACI 318-02) and Commentary (ACl 318R-02), Farmington Hills Michigan, 2002.

AGI (1991). Deformation on soils and displacements os structures. Proceedings of the $10^{\text {th }}$ Eurpean Conference on Soil Mechanics and Foundation Engineering. Florence, Italy.

ALONSO, U. R. (1995). Previsão e controle das Fundações, Editora Edgard Blucher Ltda., São Paulo, p. 142.

ÁVILA, IGOR ADOLFO DE (2001). Análise do comportamento de estacas metálicas cravadas na Bacia de Taubaté através de provas de carga dinâmica de energia crescente. 87 p. Dissertação (Mestrado em Geotecnia), Escola de Engenharia de São Carlos, Universidade de São Paulo, São Carlos. 2001.

AOKI, N.; VELLOSO, D. A. (1975). An approximate method to estimate the bearing capacity of piles, Proceedings, $5^{\text {th. }}$ Pan American CSMFE, Buenos Aires, vol. 1, pp. 367-376.

AOKI, N.; LOPES, F. R. (1975). Estimating stresses and settlements due to deep foundations by the Theory of Elasticity, Proceedings, $5^{\text {th. }}$ Pan American CSMFE, Buenos Aires, vol. 1, pp. 377-386. 
AOKI, N. (1985). Peculiarities of in situ behaviour of tropical lateritic and saprolitic soils in their natural conditions: building foundations. First International Conference on Geomechanics in Tropical Lateritic and Saprolitic Soils, Brasilia, 1985, vol. 4, p. 36.

AOKI, N. (1989). Discussion to Session 14, Proceedings, $12^{\text {th. }}$ ICSMFE, Rio de Janeiro, vol. 5, pp. 2963-2966.

AOKI, N. (1997). Aspectos geotécnicos da interação estrutura - maciço de solos, XXVIII Jornadas Sul Americanas de Engenharia Estrutural, vol.1, São Carlos, pp. VII - XX.

AOKI, N. (2002). Novo conceito de carga admissível de fundação profunda baseado em probabilidade de ruína. II Simpósio de Prática de Engenharia Geotécnica da Região Sul - GEOSUL 2002, ABMS-NRPRSC, Joinvile/SC, p. $131-140$.

AOKI, N.; CINTRA, J. C. A (1999). Carga admissível em fundações profundas. São Carlos : EESC-USP, 1999, p. 61.

AOKI, N.; CINTRA, J. C. A (2003). Notas de aula disciplina SGS-404 Fundações, EEESC - Departamento de Geotecnia, EESC, USP, São Carlos.

BALECH, JEAN (2000). Análise de transferência de carga de estacas cravadas em argila mole a partir de provas de carga dinâmica de energia crescente. 153 p. Dissertação (Mestrado em Geotecnia), Escola de Engenharia de São Carlos, Universidade de São Paulo. 2000.

BAGUELIN, F.; BUSTAMENTE, M.; FRANK, R.;JEZEQUEL, J. F. (1975). La capacite portant dês pieux. Annales de I'Institut Technique du Bâtiment et des Travaux Publics. Supl. 330, Série SF/116, pp. 1 - 22.

BASE, G. D. (1955). Further notes on DEMEC, a demountable mechanical strain gage for concrete structures. Magazine Concrete Research (Cement and Concrete Association), London, vol. 7, no 19, mar., pp. 35-38.

BGS (1974) - Settlements of Structures, Pentech Press, London, p. 811.

BORESI, A. P.; SCHMIDT, R. J.; SIDEBOTTOM, O. M. (1993). Advanced Mechanics of Materials. John Willey \& Sons Inc. $5^{\text {th }}$ ed., New York, p. 656.

CASTRO, N. (1987). Função fluência do concreto obtida por ensaio direto de relaxação. Tese de Doutorado, COPPE, UFRJ, Rio de janeiro, p. 195.

CHAMECKI, S. (1954). Consideração da Rigidez da Estrutura no Cálculo dos Recalques da Fundação, Separata dos Anais do I Congresso Brasileiro de Mecânica dos Solos - Volume I, Porto Alegre, RS, pp. 35 - 80.

CEB-FIP (1990). Comitê Euro-International du Beton, 1990, Model Code, Design Code, Thomas Telford. 
COOKE, R.W. (1974). The settlement of friction pile foundations. Proceedings, Conference on Tall Buildings, Kuala Lumpur, pp. 7-19.

CORDING, E.; HENDRON, J. A.; HANSMIRE, W. H.; MAHAR, J. W.; MAC PHERSON, H. H..; JONES, R. A.; O ROURKE, T.D. (1975). Methods for geotechnical observations and instrumentation in tunneling. Rep. No. UILU-E 75 2022, Department of Civil Engineering, University of Illinois, Urbana, IL.

CORREIA, A. G.; VIANA DA FONSECA, A.; GAMBIN, M. (2004). Routine and advanced analysis of mechanical in situ tests. Results on saprolitic soils from granite more or less mixed in Portugal. Proceedings ISC-2 on Geotechnical and Geophysical Site Caracterization, Viana da Fonseca \& Mayne (eds.), Millpress, Roterdam, p. 75 - 95.

COSTA NUNES, A. J. DA (1977). Panorama e perspectivas da prospecção do subsolo. $1^{\circ}$ Simpósio da Associação Brasileira de Mecânica dos Solos - Núcleo Nordeste, Recife.

DANZIGER, F. A. B.; BARATA, F. E.; SANTA MARIA, P. E.; DANZIGER, B. R.; CRISPEL, F. A. (1997). Measurement of settlements and strains on buildings from the beginning of construction, Proceedings, $14^{\text {th }}$. ICSMFE, Hamburg, pp. $787-788$.

DANZIGER, B. R.; DANZIGER, F. A. B.; CRISPEL, F. A. (2000). A medida de recalque desde o início da construção como um indicador da interação solo estrutura. Simpósio Interação Estrutura-Solo em Edifícios, EESC, Departamento de Geotecnia, São Carlos, SP, em CD-ROM.

DÉCOURT, L.; QUARESMA, A. R. (1978). Capacidade de carga de estacas a partir de valores de SPT, Anais, VI CBMSEF, Rio de Janeiro, vol. 1, pp. 45 -53.

DE MELLO, V. F. B. (2003). Rates of consolidation settlements affecting acceptable building performances. Jubilee Volume in celebration of the $75^{\text {th }}$ Anniversary of K. Terzaghi's Erdbaumechank, $60^{\text {th }}$ birthday of O. Univ. Prof. Dr. Heinz Brandl. Vienna Technical University, $2^{\text {nd }}$ edition, vol 5., pp. $995-113$.

DUNNICLIFF, J. (1993). Geotechnical Instrumentation for Monitoring Field Performance, John Wiley \& Sons, Inc., New York, 577 p.

FLEMING, W. G.; WELMAN, A. J.; RANDOLPH, M. F.; ELSON, W. K. (1985). Piling Engineering. Surrey University Press.

FONTE, A. O. C.; PONTES FILHO, I.; JUCÁ, J. F. T. (1994). Interação solo estrutura em edifícios altos, Anais, X COBRAMSEG, vol. 1, pp. 239 - 246.

FRANCISCO, G. M. (2004). Estudo dos efeitos do tempo em estacas de fundação em solos argilosos. Tese de Doutorado, COPPE, UFRJ, Rio de Janeiro, p. 213. 
FRANK, R. (1974). Etude théorique du comportment des pieux sous charge verticale, introduction de la dilatance. DR-Eng. Thesis, Université de Paris VI (Pierre et Marie Curie Université).

GIBSON, R.E. (1967) Some results concerning displacements and stresses in a non-homogeneous elastic half-space, Geotechnique, 17, pp. 58-67.

GOLDER, H. Q. (1971). The allowable Settlement of Structures, Proceedings $4^{\text {th }}$ Pan American Conference on Soil Mechanics and Foundation Engineering, San Juan, Puerto Rico, June 1971, pp. 171 - 187.

GONÇALVES, J. C. (2004). Avaliação da influência dos recalques das fundações na variação das cargas dos pilares de um edifício. Dissertação de Mestrado, COPPE, UFRJ, Rio de Janeiro, p. 104.

GOSHY, B. (1978). Soil-foundation-structure interaction. Journal of the Structural Division, ASCE, vol. 104, n ST5, pp. 749 - 761.

GUSMÃO FILHO, J. A. (1995). Contribuição à prática de fundações: a experiência do Recife, Tese para concurso de Professor Titular, UFPE, Recife, p. 251.

HACHICH W. ET AL. (1996). Fundações teoria e prática. Editora Pini, São Paulo, p. 751.

HERTZBERG, R.W. (1996). Deformation and fracture mechanics of engineering materials. $4^{\text {th }}$ ed, New York : J. Wiley \& Sons, 1996.

ISRM (1984). Suggested methods for surface monitoring of movements across discontinuities. ISRM, Comission on Standardization of Laboratory and Field Tests, Int. J. Rock Mech. \& Min. Sci. Geomech. Abstr., Vol. 21, No 5, pp. 265276.

IWAMOTO, R. K. (2000). Alguns aspectos dos efeitos da interação soloestrutura em edifícios de múltiplos andares com fundação profunda. 140 p. Dissertação (Mestrado em Estruturas), Escola de Engenharia de São Carlos, Universidade de São Paulo.

JORDÃO, D. R. (2003). Estabilidade global de edifícios sobre fundações profundas, considerando a interação estrutura - solo. Dissertação (Mestrado em Geotecnia), Escola de Engenharia de São Carlos, Universidade de São Paulo, p. 142.

KATZENBACH, R.; ARSLAN, U.; GUTWALD. J.; HOLZHAUSER, J. (1997). Soil-structure-interaction of the $300 \mathrm{~m}$ high Commezbank tower in Frankfurt am Main. Measurements ans numerical studies. Proceedings $14^{\text {th }}$ ICSMFE, Hamburg, pp. $1081-1084$.

LAMBE, T. W. (1973). Predictions in soil engineering. $13^{\text {th }}$ Rankine Lecture. Géotechnique 23, No. 2, 149-202. 
LOBO, A. S.; FERREIRA, C. V.; ALBIERO, J. H. (1994). Comportamento de tubulões através da medida de recalques de um edifício, no interior de São Paulo, Anais X COBRAMSEF, vol. 1, Foz do Iguaçú.

MEYERHOF, G. G. (1959). Compaction of sands and bearing capacity of piles. Journal of Geotechnical Eng. Div., ASCE, 95 (SM1),pp. 189 - 207.

MEYERHOF, G.G. (1976). Bearing capacity and settlement of pile foundations. (Terzaghi Lecture), JGED, ASCE, vol. 102, nº GT3, pp. 197-228.

MINDLIN, R. D. (1936). Force at a point in the interior of a Semi-Infinite Solid. Physics $7: 5$, p. 195.

MORICE, P.B. AND BASE, G. D. (1953). The design and use of a demountable mechanical strain gauge for concrete structures. Magazine Concrete Research (Cement and Concrete Association), London, vol. 5, no. 13, August, pp. 37-42.

MOURA, A. R. L. U. DE (1995). Interação solo-estrutura em edifícios. Dissertação de Mestrado, UFPE, Recife, p. 135.

NUNES A. J. C.; SPINELLI, O. H.; NOVAES, J. L. M.,; SILVA S. R. B. (1980). Avaliação do comportamento de estacas pré-moldadas cravadas. $2^{\circ}$ Seminário Regional de Mecânica dos Solos e Engenharia de Fundações, ABMS, Núcleo Regional da Bahia, Salvador.

PINI (1997). Concretos: massa estrutural, projetado e compactado com rolo : ensaios e propriedades. Editora Pini, São Paulo, p. 932.

POULOS (1975). Settlements analysis of structural foundation systems, Proceedings, IV South - East Asian Conference on Soil Engineering, Kuala Lumpur, Malásia, Vol. IV, pp. $52-62$.

POULOS, H. G. (1993). Settlement prediction for bored pile groups. Proc. $2^{\text {nd }}$ Int. Seminar on Deep Foundations, Ghent. pp. $103-117$.

POULOS, H. G.; DAVIES, E. H. (1980). Pile foundations analysis and design. John Wiley and Sons, New York, 397p.

RANDOLPH, M. F. (1977). A theoretical study of the performance of piles. Ph.D. Thesis. University of Cambridge.

RANDOLPH, M. F.; WROTH, C. P. (1978). Analysis of deformation of vertically loaded piles. Journal of Geotechnical Engineering, ASCE, vol. 104. $n^{\circ}$ GT12, pp. 1465-1488.

RANDOLPH, M.F.; WROTH, C. P. (1979). An analysis of vertical deformation of pile groups. Geotechnique 29, n 4, pp. $423-439$. 
REIS, J. H. C. (2000). Interação solo-estrutura de grupo de edifícios com fundações superficiais em argila mole. 148 p. Dissertação (Mestrado em Geotecnia), Escola de Engenharia de São Carlos, Universidade de São Paulo.

ROBERTSON, P. K. (1990). Soil classification using the cone penetration test. Can. Geotech. J., 27(1): $151-158$.

RUSSO NETO, L. (1980). Aterro instrumentado a recalques sobre depósito mole turfoso na margem Oeste da Lagoa de Itaipu, RJ. Dissertação de Mestrado, PUC-Rio, 1980.

RUSSO NETO, L.; AOKI, N.; MENEGOTTO, M. L. (2002). Instrumento para medida de carga em pilares, XII COBRAMSEG, São Paulo.

SANTA MARIA, P. E. L. (1996). Fundamentos da viscoelasticidade linear. Notas de aula da disciplina Estudos Especiais em Engenharia Civil, COPPE/UFRJ.

SANTA MARIA, P. E. L.; SANTA MARIA, F. C. M.; SANTOS, A. B. (1999). Análise de vigas contínuas com apoio viscoelásticos e sua aplicação a problemas de interação solo-estrutura. Solos e Rochas, 22, (3): 170-193, Dezembro, 1999.

SILVEIRA, A. (1975). O papel da instrumentação em engenharia de solos e fundações. Simpósio sobre Instrumentação de Campo em Engenharia de Solos e Fundações. COPPE, UFRJ, Rio de Janeiro, Novembro, p. 17 - 25.

SKEMPTON, A. W. (1953). Discussion contribution: piles and pile foundations, settlement of pile foundations. Proc. $3^{\text {rd }}$ ICSMFE, Zurich, pp. 3 - 172.

STEINBRENNER, W. (1934).Tafeln sur Setzungberechnung. Die Strasse, vol. 1, p. 121.

TAKEYA, T. (2000). Notas de aula Análise Experimental de Estruturas. EESC, Departamento de Estruturas, São Carlos, p. 50.

TALAMINI, E. (2001). Caracterização geotécnica do subsolo de Curitiba para o planejamento de ocupação do espaço subterrâneo. Dissertação (Mestrado em Geotecnia), Escola de Engenharia de São Carlos, Universidade de São Paulo, p. 169.

TAYLOR, D.W. (1948). Fundamentals of soil mechanics. John Wiley \& Sons, New York.

TERZAGHI, K. (1936). A Mecânica dos Solos e a Engenharia de Fundações. Discurso inaugural do Congresso Internacional de Mecânica dos Solos e Engenharia de Fundações, Cambridge, Mass., in: Separata da Revista Politécnica $n^{\circ} 142$, Tradução elaborada pela Seção de Solos e Fundações do Instituto de Pesquisas Tecnológicas. 
TIMOSHENKO, S. P.; GODIER, J. N. (1970). Theory of elasticity. New York: Mc Graw Hill Inc., $3^{\text {rd }}$ edition.

VAUGHAN, P. R. (1975). The use of instrumentation in foundation engineering. Anais do Simpósio sobre Instrumentação de Campo em Engenharia de Solos e Fundações. COPPE/UFRJ, Rio de Janeiro, p. 451 - 461.

VAN IMPE, W. F. (1999). The behaviour of distinctive pile type under the same building. Int. Conf. on Deep Foundations, Honoring Lymon Reese, Geotechnical Special Publication (ASCE) no 88, Texas - Austin.

VELLOSO, D. A.; LOPES, F. R. (2002). Fundações - vol. 2, Fundações Profundas. COPPE/UFRJ, Rio de Janeiro, 2002, p. 472.

VESIC, A. S. (1969). Experiments with instrumented pile groups in sand. Proc. Conf. on Performance of Deep Foundations, ASTM, Spec. Tech. Publ. $n^{\circ} 444$, p. $177-222$.

VESIC, A. S. (1975). Principles of pile foundation design (Lecture 2), Boston Society of Civil Engineers Sections, ASCE, March - April, 1975, p. 46.

VESIC, A.S. (1977). Problems of development of a mathematical model to predict performance of a pile group. Working paper prepared for the Federal Highway Administration, Research Review Conference, p. 19.

VIGGIANI, C. (1997). Panel discussion: Somme comments on the analysis of piles rafts. Proceedings $14^{\text {th }}$ ICSMFE, Hamburg, pp. $2263-2264$. 